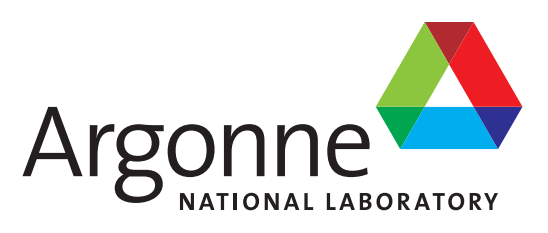

ANL/EVS/R-13/2

\title{
Impact of Future Climate Variability on ERCOT Thermoelectric Power Generation
}

In Support of Interconnection-Wide Transmission Planning

Environmental Science Division 
About Argonne National Laboratory

Argonne is a U.S. Department of Energy laboratory managed by UChicago Argonne, LLC under contract DE-AC02-06CH11357. The Laboratory's main facility is outside Chicago, at 9700 South Cass Avenue, Argonne, Illinois 60439. For information about Argonne and its pioneering science and technology programs, see www.anl.gov.

\section{Availability of This Report}

This report is available, at no cost, at http://www.osti.gov/bridge. It is also available on paper to the U.S. Department of Energy and its contractors, for a processing fee, from:

U.S. Department of Energy

Office of Scientific and Technical Information

P.O. Box 62

Oak Ridge, TN 37831-0062

phone (865) 576-8401

fax (865) 576-5728

reports@adonis.osti.gov

\section{Disclaimer}

This report was prepared as an account of work sponsored by an agency of the United States Government. Neither the United States Government nor any agency thereof, nor UChicago Argonne, LLC, nor any of their employees or officers, makes any warranty, express or implied, or assumes any legal liability or responsibility for the accuracy, completeness, or usefulness of any information, apparatus, product, or process disclosed, or represents that its use would not infringe privately owned rights. Reference herein to any specific commercial product, process, or service by trade name, trademark, manufacturer, or otherwise, does not necessarily constitute or imply its endorsement, recommendation, or favoring by the United States Government or any agency thereof. The views and opinions of document authors expressed herein do not necessarily state or reflect those of the United States Government or any agency thereof, Argonne National Laboratory, or UChicago Argonne, LLC. 


\section{Impact of Future Climate Variability on ERCOT Thermoelectric Power Generation}

In Support of Interconnection-Wide Transmission Planning

Lead Authors:

Y. Eugene Yan, Argonne National Laboratory

Vince C. Tidwell, Sandia National Laboratories

Carey W. King and Margaret A. Cook, The University of Texas at Austin

Contributing Authors:

Y.K. Demissie and C.B. Harto, Argonne National Laboratory

M.S. Wigmosta, A. Coleman, and T.K. Tesfa, Pacific Northwest National Laboratory

B.D. Moreland, C.M. Zemlick, and B.L. Roberts, Sandia National Laboratories

Sponsor: U.S. Department of Energy, Office of Electricity Delivery and Energy Reliability

Date: January 2013 


\title{
Impact of Future Climate Variability on ERCOT Thermoelectric Power Generation
}

\author{
A report based on work in the project: \\ Energy and Water in the Western and Texas Interconnects \\ Leading Organization: Sandia National Laboratories \\ With support from: \\ Argonne National Laboratory \\ Electric Power Research Institute \\ Idaho National Laboratory \\ National Renewable Energy Laboratory \\ Pacific Northwest National Laboratory \\ University of Texas \\ In response to DOE Call:
}

Technical Support for Interconnection-Level Electric Infrastructure Planning

RC-BM-2010

Area of Interest 3: Water/Energy Nexus 


\section{Table of Contents}

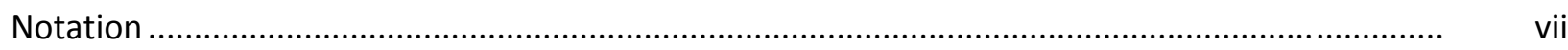

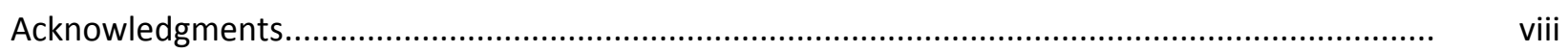

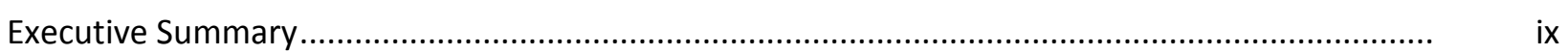

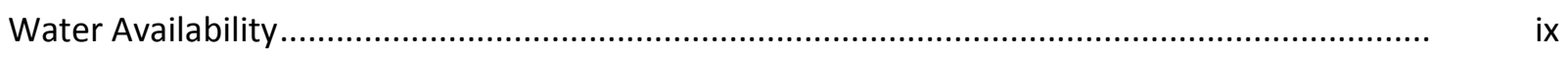

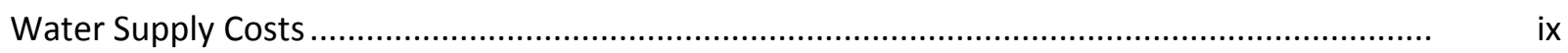

Potential Derating of Thermoelectric Cooling during Drought due to Lack of Water Supply ....... $\quad \mathrm{x}$

Potential Derating of Thermoelectric Cooling during Drought due to Effluent Discharge

Temperature Limits..................................................................................................

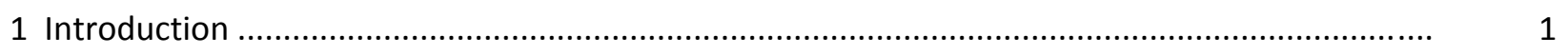

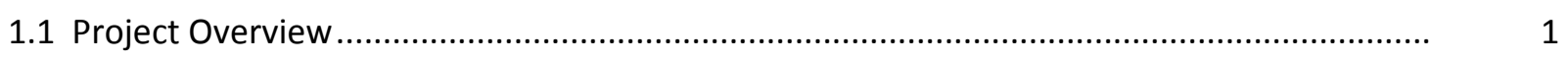

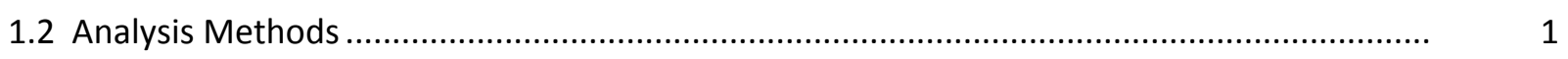

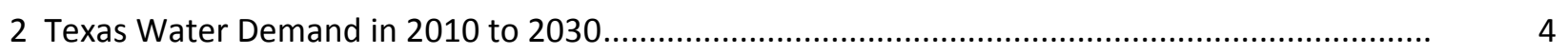

3 Climate Model Data Generation for Scenarios to 2030 ...............................................................

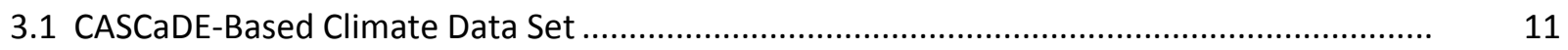

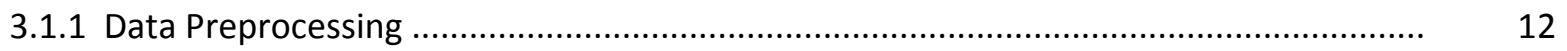

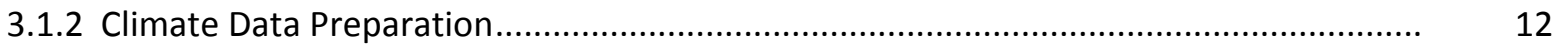

3.2 U.S. Bureau of Reclamation Climate Data Set.................................................................... 13

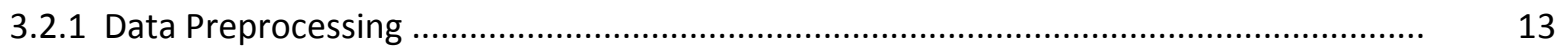

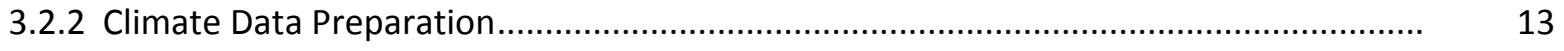

4 Hydrologic Model Description and Results of Drought Simulation ............................................ 14

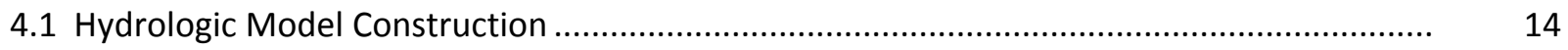

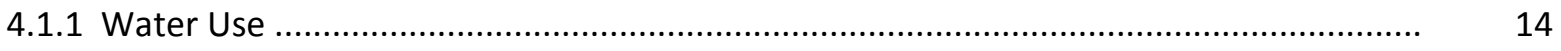

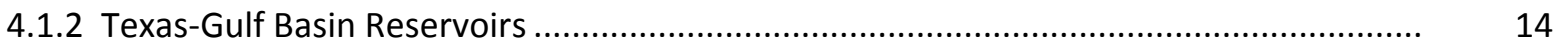

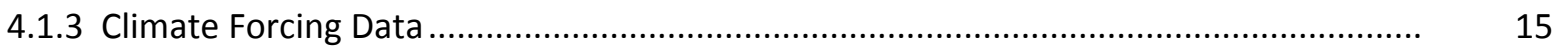

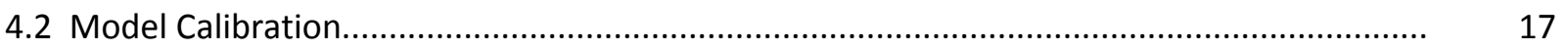

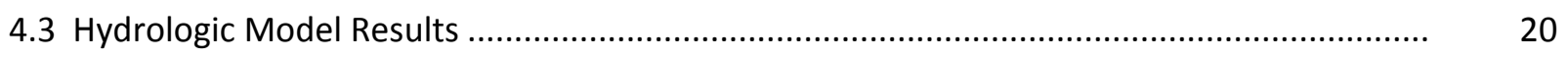

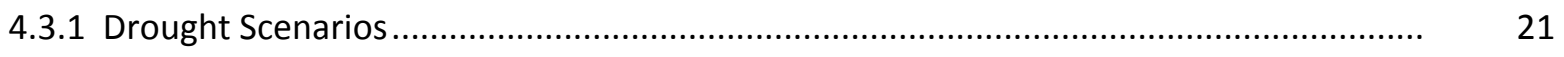

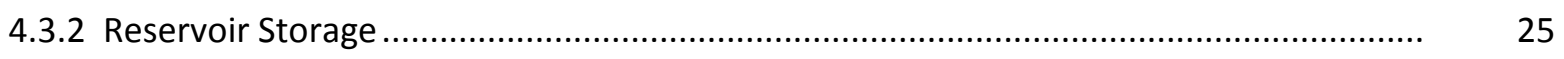

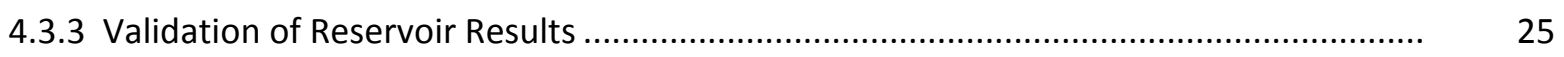

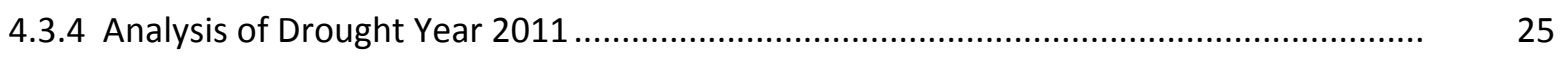

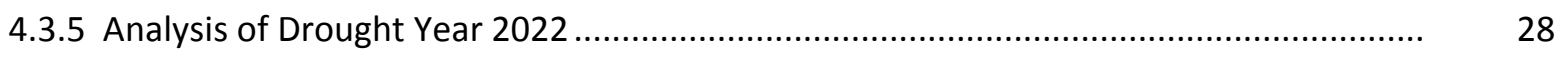

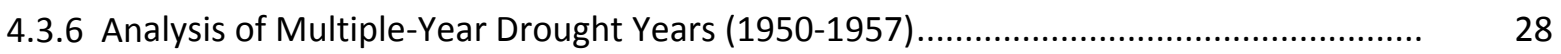




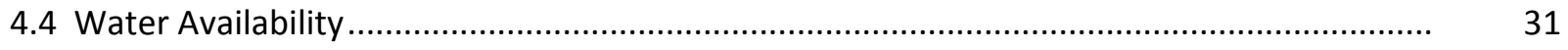

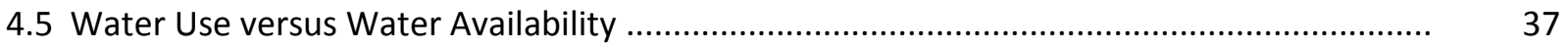

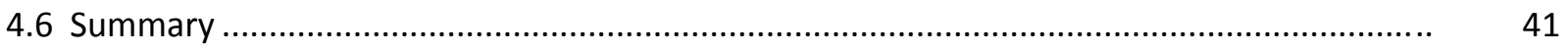

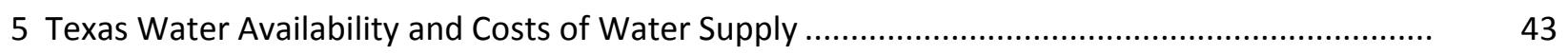

5.1 Competing Demands for Water Supplies.......................................................................

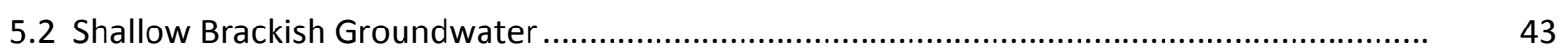

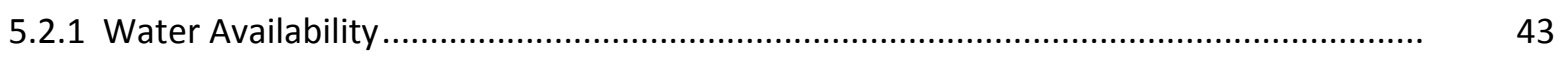

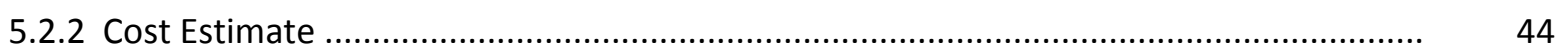

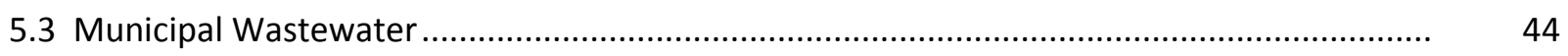

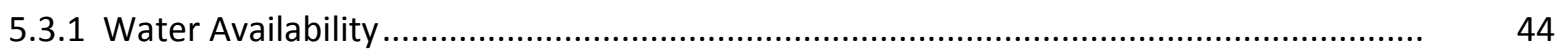

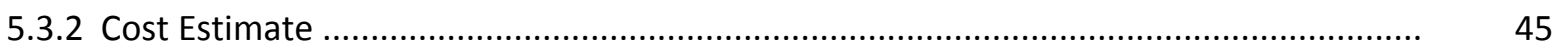

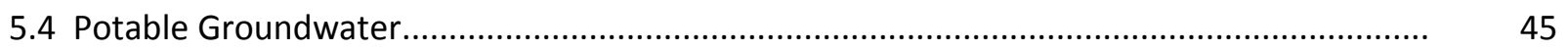

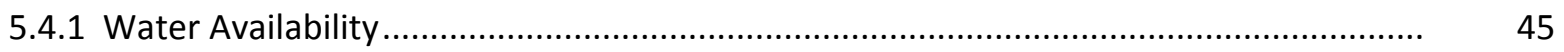

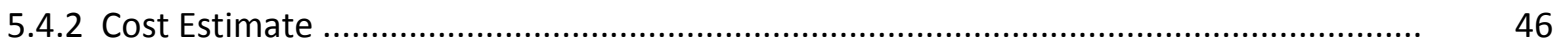

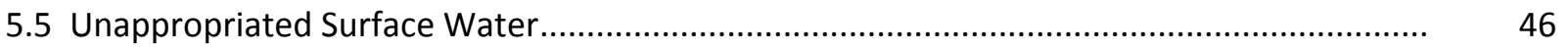

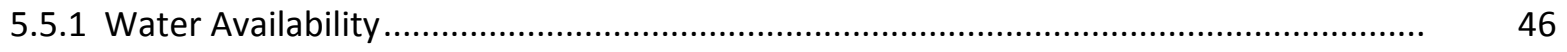

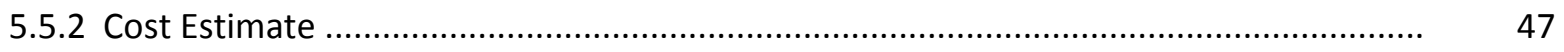

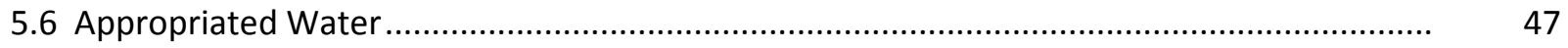

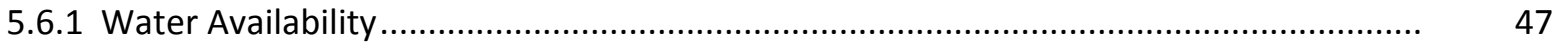

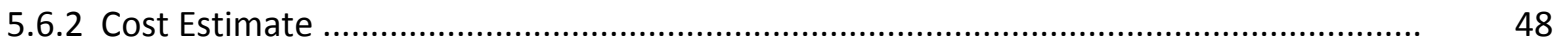

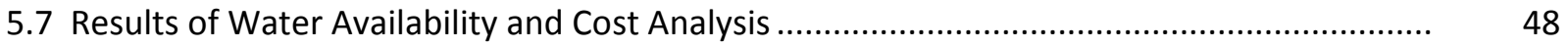

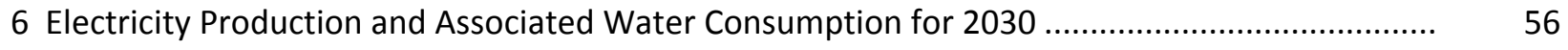

6.1 Wind Scenario (Baseline Water Consumption for Power Generation)................................. 56

6.2 No-Wind Scenario (Baseline Water Consumption for Power Generation)........................... 57

7 Assessment of Water-Related Risk to ERCOT Power Generation for 2030 Scenarios.................. 59

7.1 Power Plants at Risk of Curtailment due to Low Water Levels in Cooling Reservoirs ............ 59

7.2 Power Plants at Risk of Curtailment due to High Effluent Temperatures ............................. 64

7.3 Summary of Analysis of Drought and Future Climate Risk to ERCOT Power Plant

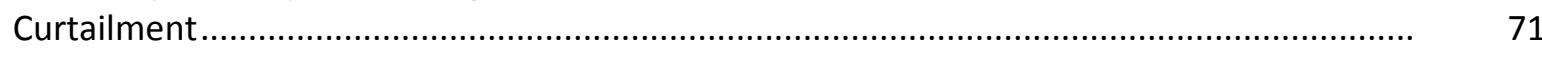

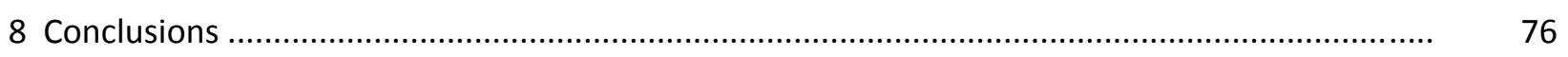

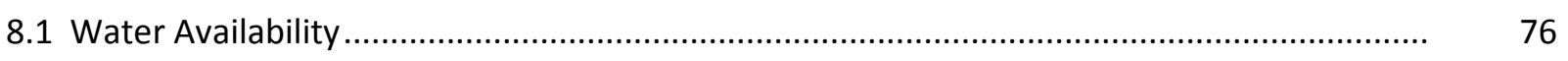

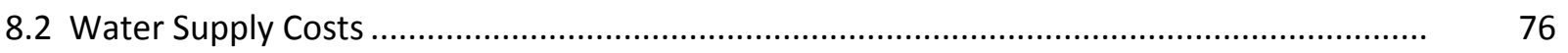

8.3 Potential Derating of Thermoelectric Cooling during Drought due to Lack of Water Supply

8.4 Potential Derating of Thermoelectric Cooling during Drought due to Effluent Discharge Temperature Limits. 


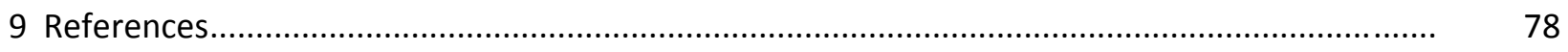

Appendix A: Historical data for Reservoirs and Cooling Ponds Associated with Power

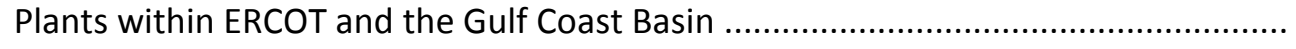

Appendix B: Regression Analysis Results for Estimates of Cooling Water Effluent Discharge Temperatures for Applicable Power Plants in ERCOT. 
This page intentionally left blank. 


\section{Notation}

$\begin{array}{ll}{ }^{\circ} \mathrm{C} & \text { degree(s) Celsius } \\ { }^{\circ} \mathrm{F} & \text { degree(s) Fahrenheit } \\ \text { ac-ft } & \text { acre-foot (feet) } \\ \text { BCSD } & \text { bias correction/spatial downscaling } \\ \text { Btu } & \text { British thermal unit(s) } \\ \text { CPS } & \text { CPS Energy } \\ \text { CWNS } & \text { Clean Watershed Needs Survey } \\ \text { ECHO } & \text { Enforcement and Compliance History Online } \\ \text { EIA } & \text { Energy Information Administration } \\ \text { EPA } & \text { U.S. Environmental Protection Agency } \\ \text { ERCOT } & \text { Electric Reliability Council of Texas } \\ \text { gal } & \text { gallon(s) } \\ \text { GCM } & \text { Global Circulation Model } \\ \text { GFDL } & \text { Geophysical Fluid Dynamics Laboratory } \\ \text { GHCN } & \text { Global Historical Climatology Network } \\ \text { GHG } & \text { greenhouse gas } \\ \text { h } & \text { hour } \\ \text { HUC } & \text { hydrologic unit code } \\ \text { in. } & \text { inch } \\ \text { IPCC } & \text { Intergovernmental Panel on Climate Change } \\ \text { km } & \text { kilometer(s) } \\ \text { kPa } & \text { kilopascal(s) } \\ \text { m } & \text { meter(s) } \\ \text { MGD } & \text { million gallons per day } \\ \text { mm } & \text { millimeter } \\ \text { MW } & \text { megawatt(s) } \\ \text { NCDC } & \text { National Climatic Data Centers } \\ \text { NETL } & \text { National Energy Technology Laboratory } \\ \text { NOAA } & \text { National Oceanic and Atmospheric Administration } \\ \text { O\&M } & \text { operation and maintenance } \\ \text { PCM } & \text { Parallel Climate Model } \\ \text { PCS } & \text { Permit Compliance System } \\ \text { QA/OC } & \text { quality assurance/quality control } \\ \text { RH } & \text { relative humidity } \\ \text { S } & \text { second(s) } \\ \text { SRES } & \text { Special Report on Emissions Scenarios } \\ \text { STP } & \text { South Texas Nuclear Project } \\ \text { SWAT } & \text { Soil and Water Assessment Tool } \\ \text { TDS } & \text { total dissolved solids } \\ \text { TWDB } & \text { Texas Water Development Board } \\ \text { USBoR } & \text { U.S. Bureau of Reclamation } \\ \text { USDA } & \text { U.S. Department of Agriculture } \\ & \text { U.S. Geological Survey } \\ \text { VIC } & \text { Vater Availability Models } \\ \text { WA } & \end{array}$




\section{Acknowledgments}

The authors would like to thank Doug Murray and Kevin Hanson at the Electric Reliability Council of Texas, Andrew Chastain-Howley at Black and Veatch, and Tom Iseman at the Western Governors Association for their invaluable guidance, feedback, and support for this assessment. We would like to thank Caitlin Callaghan, Ray Lopez, and Mathew Rosenbaum with the Department of Energy's Office of Electricity Delivery and Energy Reliability for sponsoring this work and for their guidance throughout this effort. We would also like to thank Ruben Solis and John Zhu at the Texas Water Development Board, Surface Water Resources, for providing reservoir data to improve our hydrologic modeling. Finally, we would like to thank Argonne colleagues John Gasper for helping to manage this effort; Karen Haugen for the thankless job of providing a thorough edit of this document; and Esther Bowen, Maja Kucharczyk, and Persephone Ma for collecting and managing large data sets with GIS and preparing figures for the report. 


\section{Impact of Future Climate Variability on ERCOT Thermal Electricity Generation}

\section{Executive Summary}

This report summarizes a study to determine the medium-term (through the year 2030) impacts of future climate and drought scenarios on electricity generation by the Electric Reliability Council of Texas (ERCOT). Because water in reservoirs is used to cool many steam cycle-based power plants, significantly low water levels can reduce the ability to cool power plants. This reduced cooling ability can come from physical supply limitations or environmental constraints (power plant effluent temperatures exceeding permitted limits).

The objective of this report is to inform ERCOT as to the potential water-related risks for power plant operations and possible future water supply (other than historical supply) for electricity generation. The approach projects future climate and water demands to determine stream flows, water storage in reservoirs, and power plant effluent temperatures. The results for historical and future water availability, demand, its cost, reservoir storage, and stream flow are reported for U.S. Geological Survey 8-digit hydrologic unit code (HUC8) water basins. The water and climate data are compared to power plant characteristics and past performance data to infer the likelihood that future summer power generation could be curtailed at a power plant. Beyond impacts on the existing fleet of power plants, this study also considers siting of future power plants to avoid regions of limited water availability.

The main findings from the study relate to four categories, as outlined below:

Water Availability

Water is projected to be available for ERCOT thermoelectric power plant operations until 2030. However, water for new development will likely need to come from sources other than unappropriated surface water. This conclusion largely means that future water supplies for thermoelectric power will be more expensive than historical supplies. Specifics are as follows:

- In general, very little unappropriated surface water is available for any use, including thermoelectric power.

- Water availability from appropriated surface water supplies, assumed as "low-value" agriculture, is limited. This appropriated water is present in quantities $>5,000 \mathrm{ac}-\mathrm{ft} / \mathrm{yr}$ in only a few HUC8 basins.

- Several HUC8 basins have wastewater, potable groundwater, and brackish groundwater availability at greater than $10,000 \mathrm{ac}-\mathrm{ft} / \mathrm{yr}$ (enough for a large power plant).

- A number of basins (14) with severely limited water supplies are targeted for siting of new electric power production.

Water Supply Costs

- The cheapest water supply (at $\$ 18 / \mathrm{ac}-\mathrm{ft}$ ) that has enough water (roughly $>5,000 \mathrm{ac}-\mathrm{ft} / \mathrm{yr}$ ) to supply wet cooling at a medium to large-sized thermal power plant is from low-value agriculture.

- Estimated costs for brackish water availability per HUC8 basin vary widely, from tens to thousands of dollars per acre-foot, with most in the range of $\$ 500-900 / a c-f t$ (or about $\$ 1.7-$ $2.7 / 1,000$ gal). This price for water is close to but below some estimates for the cost of water needed to incentivize the use of dry cooling systems at $>\$ 3 / 1,000$ gal. 


\section{Potential Derating of Thermoelectric Cooling during Drought due to Lack of Water Supply}

The project team constructed a model of the Texas-Gulf river basin by using the Soil and Water Assessment Tool (SWAT). This hydrologic model uses input of meteorological data (e.g., temperature, precipitation), together with water demands (e.g., municipal, agriculture, power plant operation), to estimate evapotranspiration, stream flow, and water storage in soil and reservoirs. The team used the reservoir storage information and two matrices based on water use versus water availability to assess the risk that power plants would not be able to take water into cooling systems. Specifics are as follows:

- Three drought scenarios were evaluated: (1) the recent drought in 2011, with the current level of water use; (2) a single-year drought in 2022, with the assumed water use level projected for 2030; and (3) a multiyear drought under 1950-1957 climate conditions, with the projected 2030 water use.

- The projected drought scenario in 2022 and the historical droughts in 2011 and 1954-1956 represent two different precipitation patterns in Texas-Gulf river basin. The projected 2022 drought is characterized by low precipitation ( $<25$ in.) in the eastern basin and moderate precipitation (25-30 in.) in the western basin, while the historical 2011 scenario shows extremely low precipitation (< 20 in.) in western basin and high precipitation ( $>30$ in.) in only the southeastern basin.

- Hydrologic modeling results indicate significant impact on water availability (water yield, stream flow, and reservoir storage) for single-year drought (2011 and 2022) and multiple-year drought (1950-1957).

- The model predictions for average and minimum monthly reservoir storage during the 2011 drought year were statistically validated, with coefficient of determination R2 $=0.81$ and 0.72 , respectively, for 22 of 37 reservoirs that provide water supply to 47 power plants.

- Using criteria based on observed ( $<50 \%$ storage) and predicted ( $<55 \%$ storage) reservoir data, we identified 15 low-storage reservoirs in 2011, 10 in 2022, and 20 in 1956 (the last year for the multiple-year drought). Among them, 4 reservoirs (Addicks Reservoir, Texana Lake, Martin Lake, and Smithers Lake) are under low-storage conditions in all three drought scenarios. The affected reservoirs, as predicted by the model, are located near Austin, Houston, and San Antonio, as well as south of Lubbock.

- Reservoir water storage declines gradually over the duration of the multiple-year drought, suggesting that the reservoirs can mitigate effects of water shortage during short-term drought but would be less effective in long-term drought.

- Analysis of available water intake levels for 9 power plants found that all would be able to take in cooling water, in spite of low reservoir water levels, in the three drought scenarios. Such an analysis is recommended for all reservoirs, especially low-storage reservoirs predicted for the drought scenarios, when water intake level data for other reservoirs with power plants become available.

- The different drought scenarios (2011, 2022, and 1950-1957) show different drought effects in terms of spatial distribution of water availability and reservoir storage reduction because of variations in the climate pattern.

- Vulnerable HUC8 basins, identified by two matrices on the basis of water use versus water availability in three drought scenarios, need to be evaluated carefully for future power plant siting to avoid the basins with high water demand and limited water availability. The predictions for the 1956 scenario (reflecting cumulative effects of long-term drought and increased water use for 2030) suggest more vulnerable HUC8 basins near Dallas, Houston, Austin, San Antonio, Brownsville, and Lubbock than do the predictions for the other scenarios. 
Potential Derating of Thermoelectric Cooling during Drought due to Effluent Discharge Temperature Limits

The assessment of ERCOT thermal power plant operations above Environmental Protection Agency (EPA) limits for effluent discharge temperatures indicated that a few power plants and a significant quantity of generation capacity have operated at or near these temperature limits in the past. In addition, due to anticipated warming from climate change (the major factor affecting effluent temperatures), ambient temperature can be expected to result in future derating potential (near $1,000,000 \mathrm{MW}$-h per summer month) being limited by cooling water effluent temperatures. However, although some power plants are projected to be exposed to curtailment because of these EPA temperature limits, we estimate that six times more electricity generation potential (roughly 6,000,000 MW-h per summer month) is available from other existing generators where power plants will not reach thermal effluent temperature limits. Specifics are as follows:

- The regression models derived for this study reasonably model average monthly effluent temperatures for most of the open-loop and recirculating cooling pond systems in ERCOT.

- The data on effluent water thermal discharges from power plants reveal that at least 2 power plants (Martin Lake, Coleto Creek) operated above their average temperature effluent discharge limits in 2007-2011.

- By 2030, up to 6 power plants could have effluent discharge thermally limiting their generation at roughly 20,000-200,000 MW-h per month, if they attempt to operate at 2011 capacity factors.

- By 2030, up to 13 power plants could have effluent discharge thermally limiting their generation at about $1,000,000 \mathrm{MW}$-h per month, if they attempt to operate at $100 \%$ summer capacity factors.

- Approximately $6,000,000 \mathrm{MW}$-h of electricity is available (up to $100 \%$ capacity factor in summer months) from thermal generators that would not be limited by effluent temperature limits. 
This page intentionally left blank. 


\section{Introduction}

\subsection{Project Overview}

In 2011 the Department of Energy's Office of Electricity embarked on a comprehensive program to assist our nation's three primary electric interconnections with long-term transmission planning. Given the growing concern over water resources in the western United States, the Electric Reliability Council of Texas (ERCOT) requested assistance with integrating water resource considerations into its broader electric transmission planning. The lead laboratory for this effort, Sandia National Laboratories, is supported by other national laboratories, a university, and an industrial research institute. Specific participants include Argonne National Laboratory, Idaho National Laboratory, the National Renewable Energy Laboratory, Pacific Northwest National Laboratory, the University of Texas, and the Electric Power Research Institute.

In 2011, the state of Texas experienced the worst single-year drought on record. This recent event raised questions as to how future droughts might impact ERCOT operations. This report summarizes a study to determine the medium-term (through the year 2030) impacts of future climate and drought scenarios on electricity generation in ERCOT. Drought can challenge power plant cooling systems through both physical supply limitations and environmental constraints (power plant effluent temperatures exceeding permitted limits). Beyond impacts to the existing fleet of power plants, this study also considers siting of future power plants to avoid regions of limited water availability.

\subsection{Analysis Methods}

In this report, data are collected or modeled to some extent for three geographic (or quasigeographic) regions (in decreasing order of areal coverage): the state of Texas, the region of ERCOT, and the Texas-Gulf river basin (2-digit Hydrologic Unit Code [HUC2] $=12$, as defined by the U.S. Geological Survey [USGS]) (Figure 1). The Texas-Gulf river basin includes combined drainage areas of a series of rivers that flow into the Gulf of Mexico. These multiple boundaries correspond to difficulties with translating available energy and water demand data to natural hydrologic features. Fortunately, the boundaries of the Texas-Gulf water basin and ERCOT largely match, making this study of water impacts for electrical interconnections in Texas relevant for the vast majority of the state.

The boundaries of ERCOT also include a portion of the Rio Grande basin (HUC2 $=13$ ), which covers the remaining portion of Texas to the west and along the Mexico border that lies outside the Texas-Gulf river basin. No attempt was made to model the Rio Grande, because much of the contributing watershed originates in Mexico. Both the available resources and the availability of data dictated that we not model the Rio Grande. 


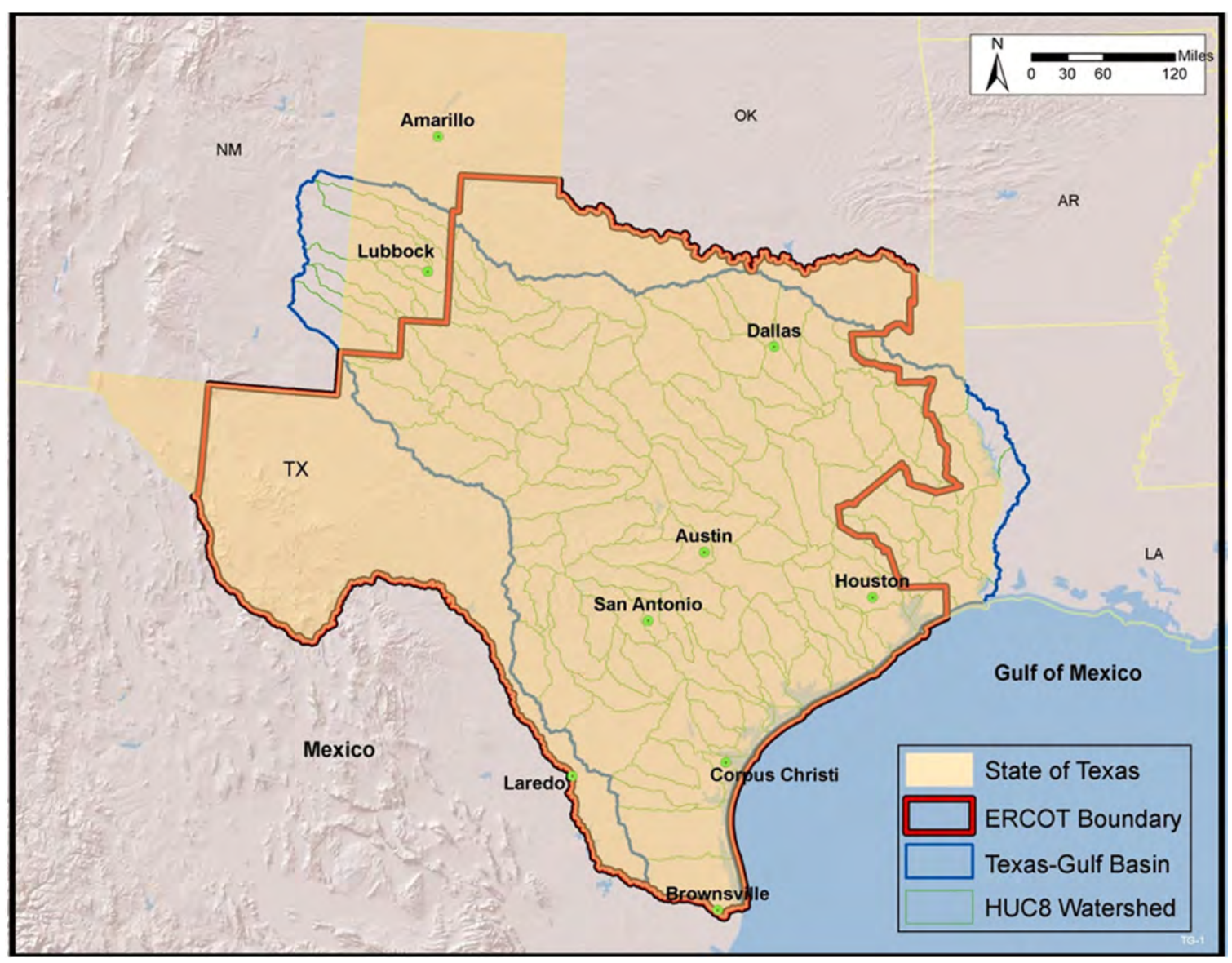

Figure 1. The boundary of the Texas-Gulf river basin $(H U C 2=12)$ relative to the Texas state boundary and the approximate boundary of the ERCOT electric grid.

Figure 2 and Figure 3 demonstrate the flow of information, research, and model results that inform this analysis of potential effects of future climate and drought scenarios on power generation in the region of ERCOT and the HUC2 Texas-Gulf $(H U C 2=12)$ river basin. This work involved the coordination of multiple research units at three national laboratories (Argonne, Pacific Northwest, and Sandia) and The University of Texas at Austin.

The major effort involved generating future climate predictions (e.g., precipitation, temperature, humidity) by using climate models. These global climate model results were scaled down to generate information for the Texas-Gulf region of interest. The downscaled climate data were then fed into a hydrologic model that predicted stream flow and reservoir storage levels per HUC8 basin. Using these estimated reservoir levels and climate data (e.g., air temperature, humidity) we then used power plant-specific information (as available) to determine whether power curtailment would be expected in the summer months. The two criteria for determining water-related thermoelectric generation curtailment are whether (1) reservoir/stream water levels fall below cooling water intake levels and (2) cooling water effluent temperatures reach environmental limits of the National Pollutant Discharge Elimination System permit for the facility.

Additional criteria for identifying vulnerable HUC8 basins were established by using two matrices on the basis of water uses versus water availability established for the scenarios. This analysis in conjunction with other modeling results could provide insights for future power plant siting to avoid potentially vulnerable water basins. 
Regional Scale to HUC-8 Basins

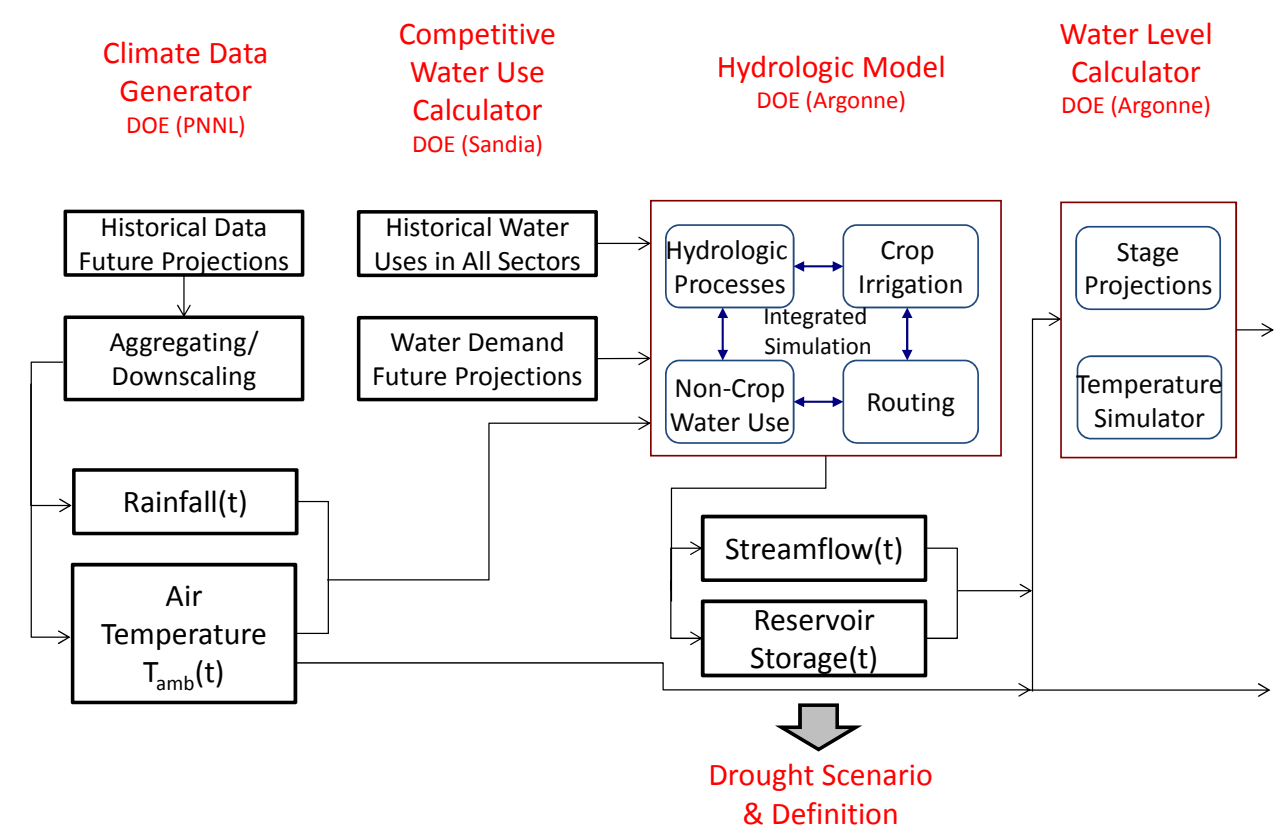

Figure 2. Downscaled climate projections from global climate models provide precipitation and temperature inputs to a hydrologic model that then estimates stream flow and water storage, while considering water demands from all sectors.

\section{Local Power Plants}

Water Level of Power

Plant cooling water

sources

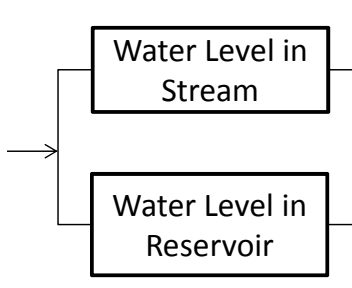

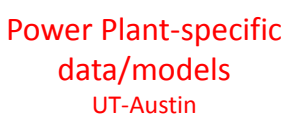

Power Plant-specific data/models

UT-Austin

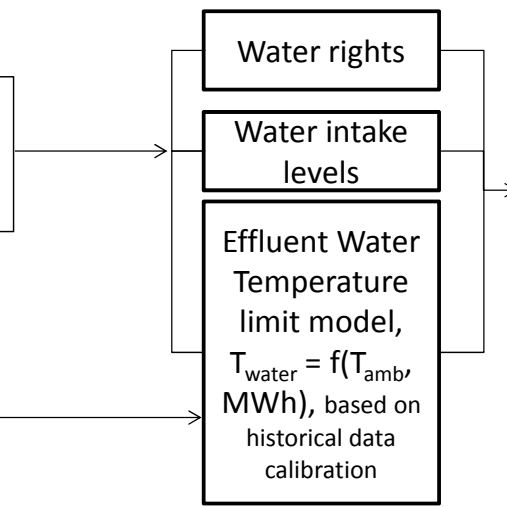

Power Plant output (Summer)

UT-Austin

Max. MWh each power plant (monthly)

Effluent Water Temperature at MWh (monthly)

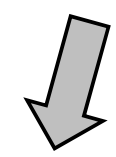

Determine if:

(i) water effluent temperature permit limits can reduce power generation,

(ii) intake levels constrain water intake, and therefore power generation

Figure 3. Hydrologic models estimate monthly average stream flow and water storage per HUC8 basin. These data are compared with power plant-specific parameters and models to determine if a given power plant in a HUC8 basin has a high probability of being forced to curtail power generation (if no changes are made to the power plant). 


\section{Texas Water Demand in 2010 to 2030}

Although this report focuses on creating information for informing electricity planning, the analysis considered the context of all water demands. The maps in Figures 4-16 illustrate the water demands for the state for different sectorial water demands, as given by values from the 2012 State Water Plan prepared by the Texas Water Development Board (TWDB 2012). For completeness, water demand data are presented for the entire state of Texas, including watersheds outside ERCOT in the Texas panhandle, as well as east and west Texas. The ERCOT boundary is given in each map for reference. Data for the Rio Grande basin $(\mathrm{HUC2}=13$ ) are given, in addition to the modeled Texas-Gulf region (HUC2 = 12). The Rio Grande basin, which is partially within ERCOT, includes much of the far western region of Texas and forms the border with Mexico.

\section{Current Total Consumptive Use}

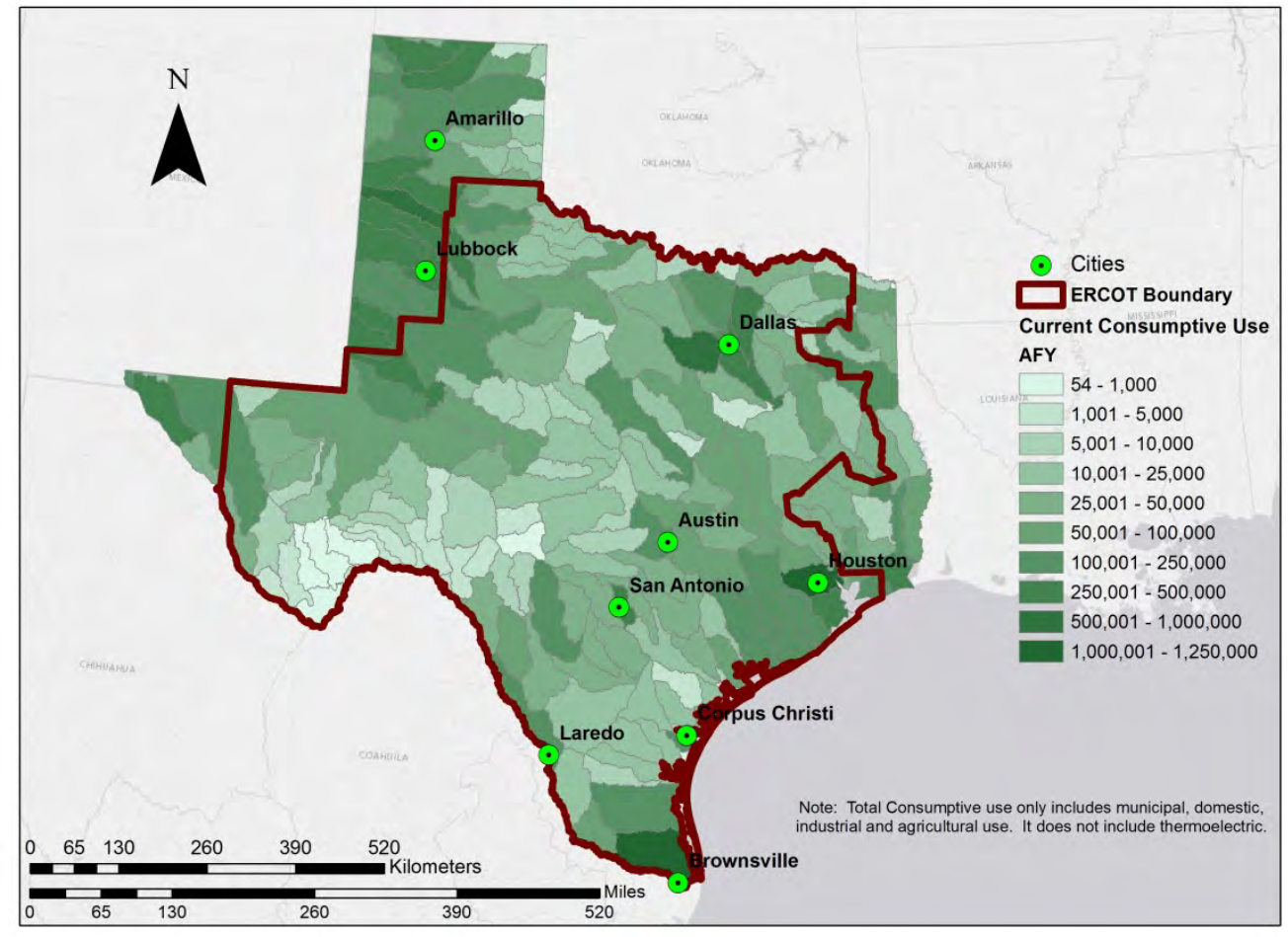

Figure 4. The total estimated Texas water consumption (demand from TWDB, not including steam-electric) in 2010 is $17,277,000 \mathrm{ac}-\mathrm{ft}$. 


\section{Total Consumptive Use}

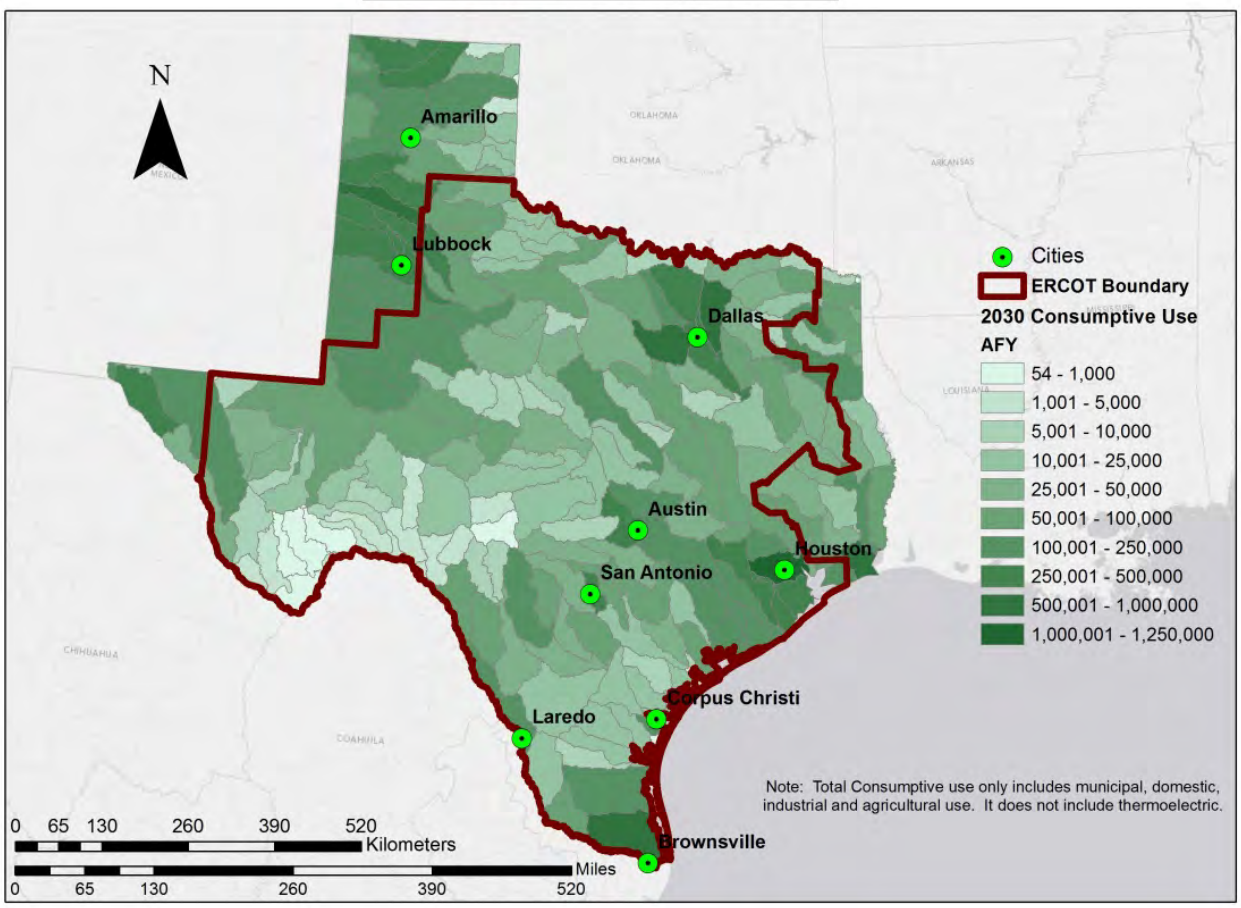

Figure 5. The total estimated Texas water consumption (demand from TWDB, not including steam-electric) in 2030 is $18,661,000 \mathrm{ac}-\mathrm{ft}$.

\section{Difference in Total Consumptive Use}

$\underline{2010-2030}$

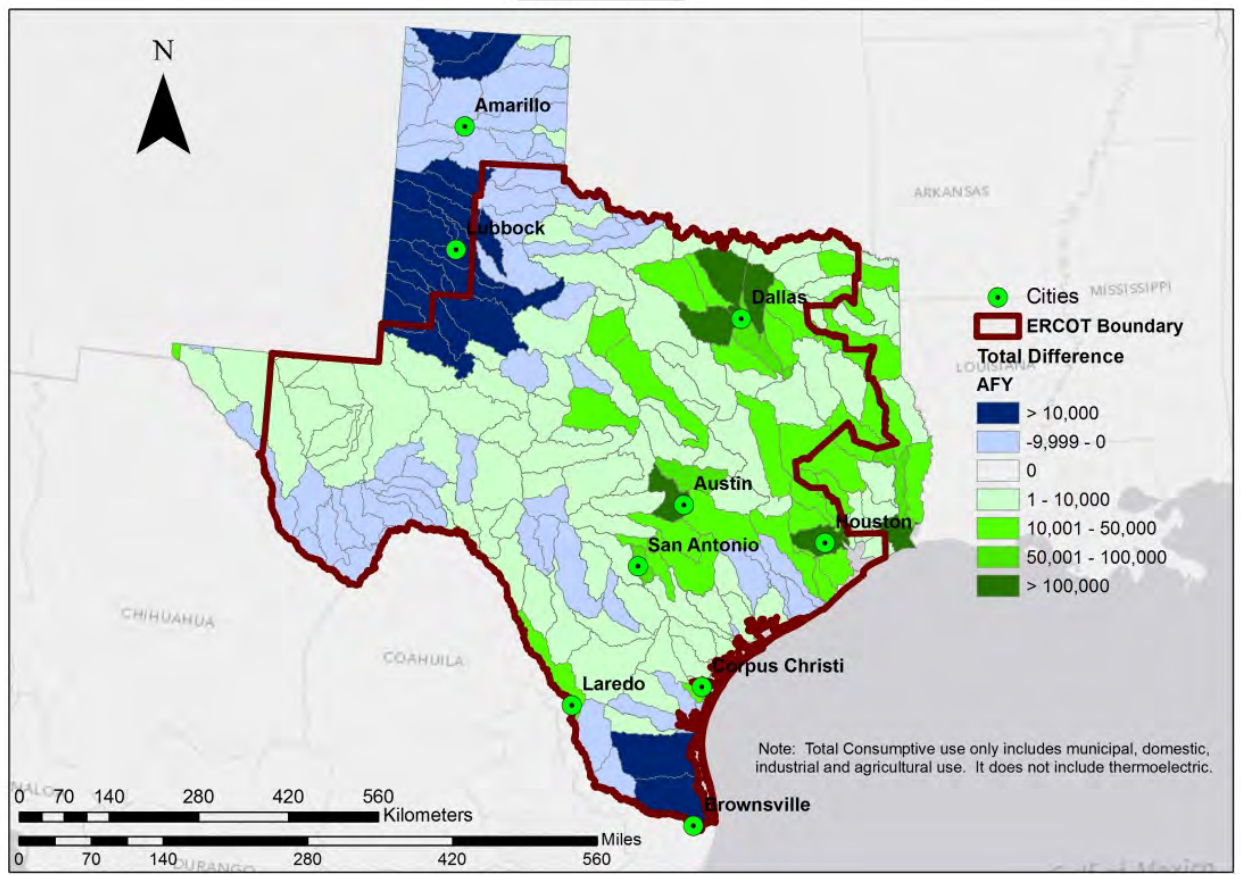

Figure 6. The difference in 2030 projected water demand versus the 2010 estimated water demand is primarily driven by increased municipal water demand and declining agricultural water demand. 


\section{Current Municipal and Domestic Consumptive Use}

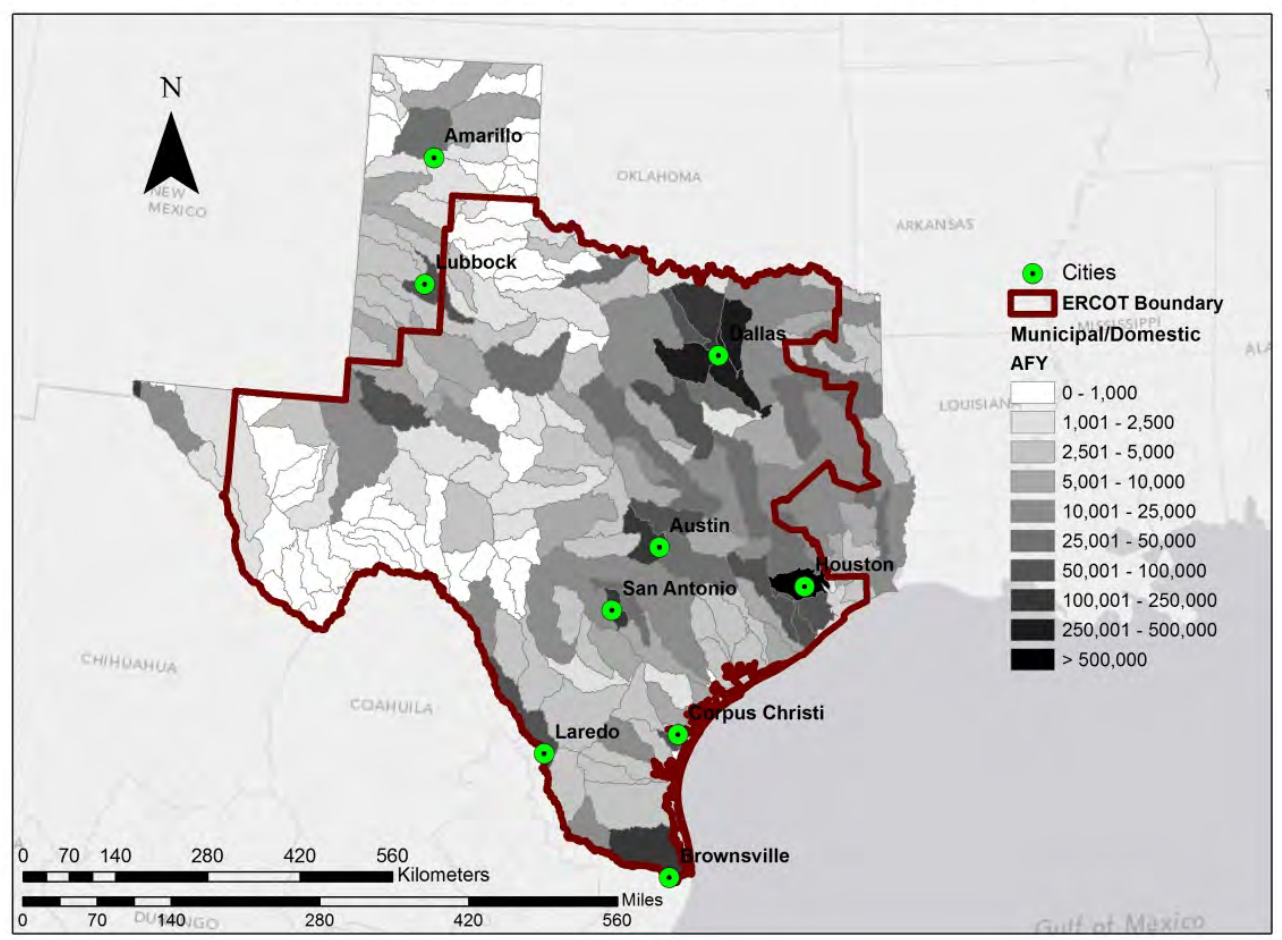

Figure 7. The estimated water consumption for Texas municipal demand in 2010 is $4,851,000$ ac-ft.

\section{Municipal and Domestic Consumptive Use}

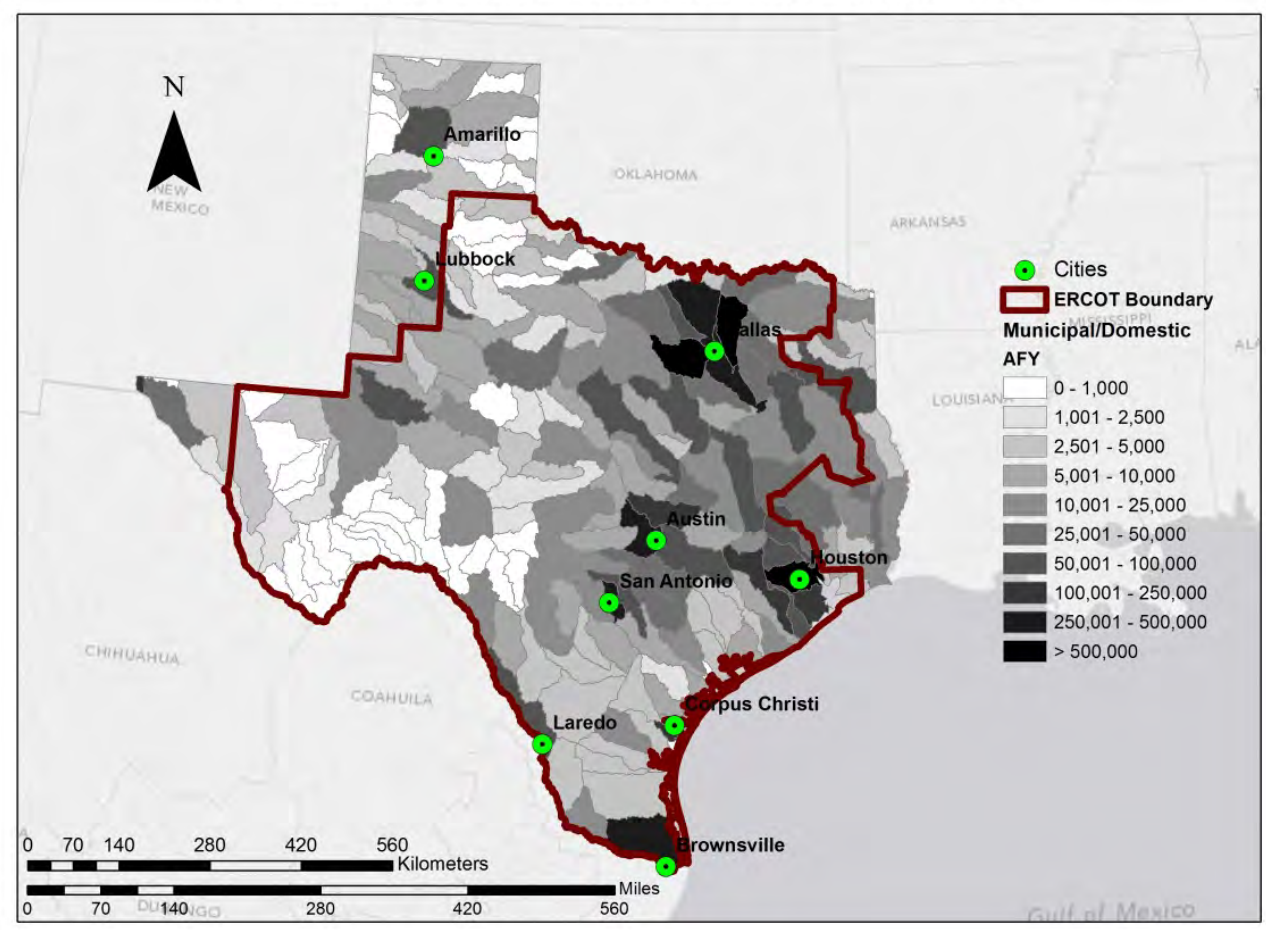

Figure 8. The estimated water consumption for Texas municipal demand in 2030 is $6,255,000$ ac-ft. 


\section{Difference in Municipal/Domestic Consumptive Use}

$\underline{2010-2030}$

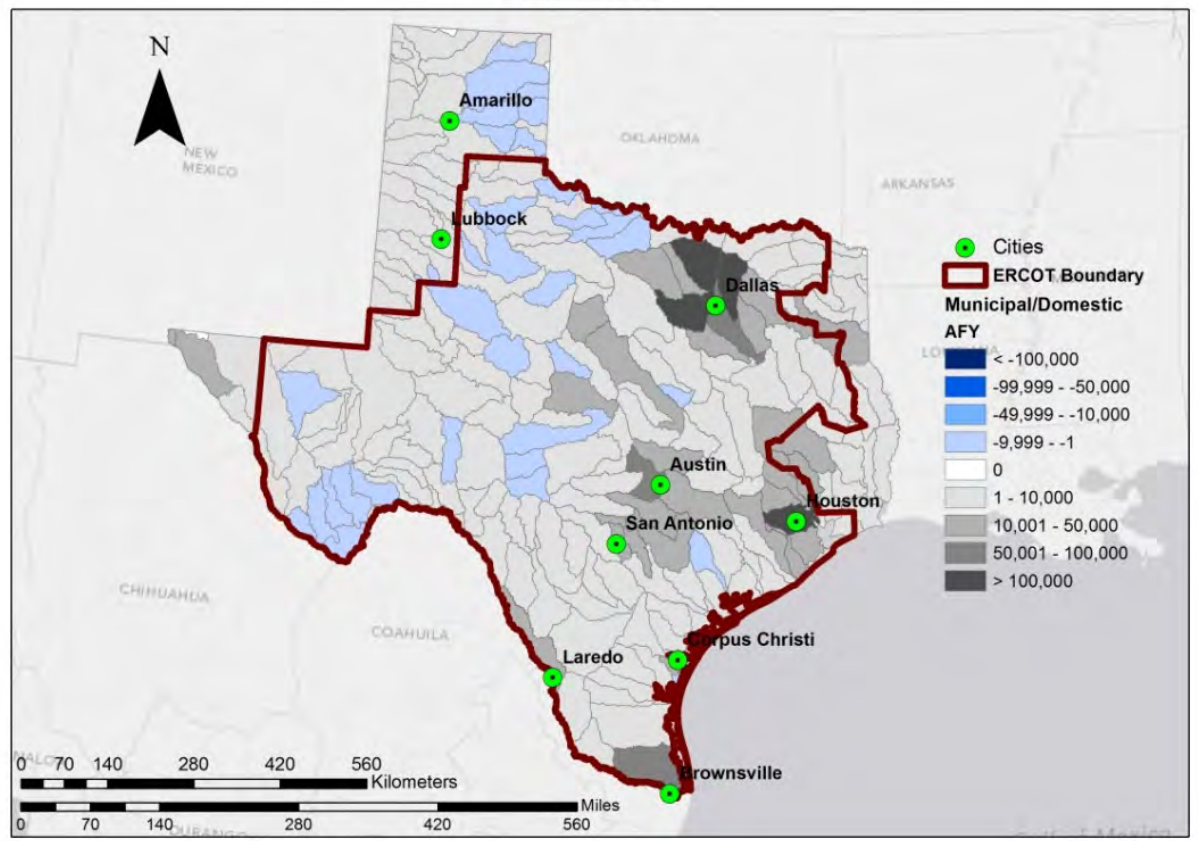

Figure 9. Changes in TWDB projected municipal demand from 2010 to 2030 feature increased demand in the major cities and slightly decreased demand in some western portions of the state.

\section{Current Agricultural Consumptive Use}

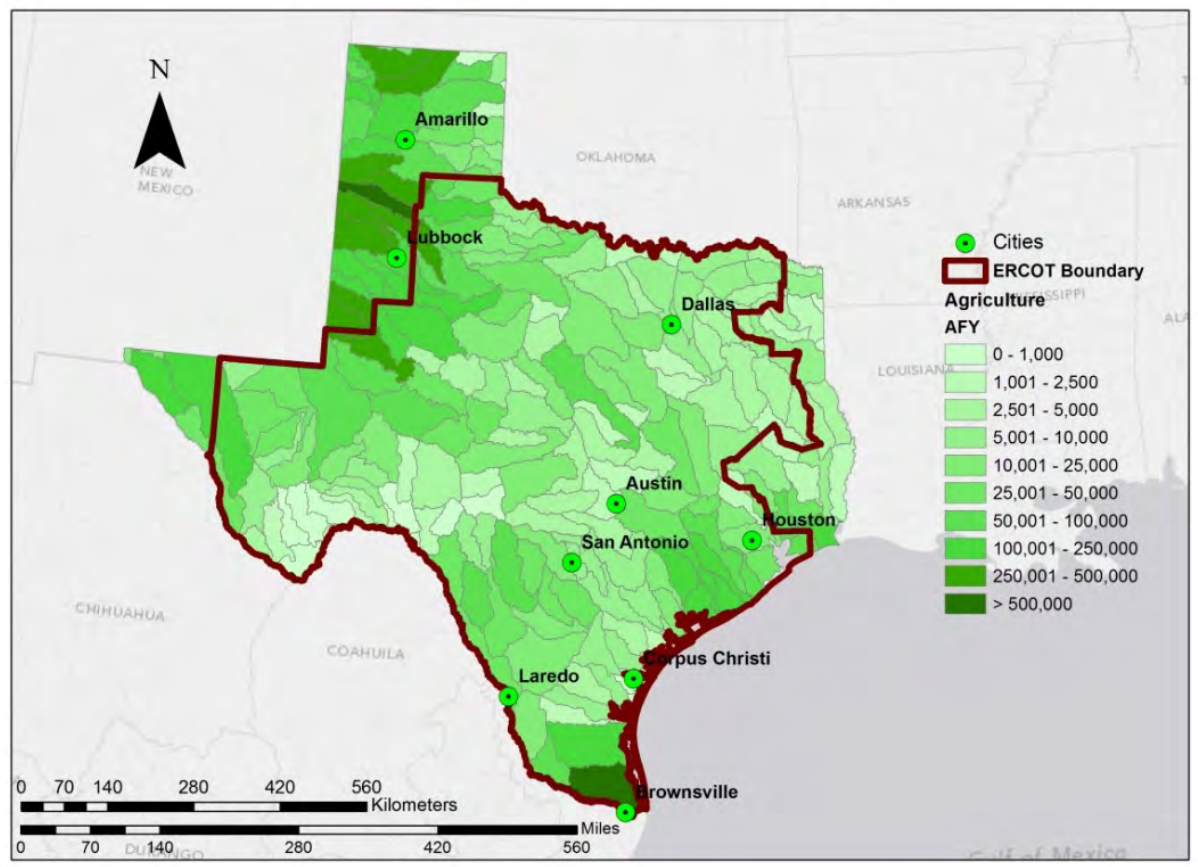

Figure 10. The estimated water consumption for Texas agricultural demand (irrigation and livestock) in 2010 is 10,403,000 ac- $\mathrm{ft}(10,080,000 \mathrm{ac}-\mathrm{ft}$ for irrigation and 323,000 ac-ft for livestock). 


\section{Agricultural Consumptive Use}

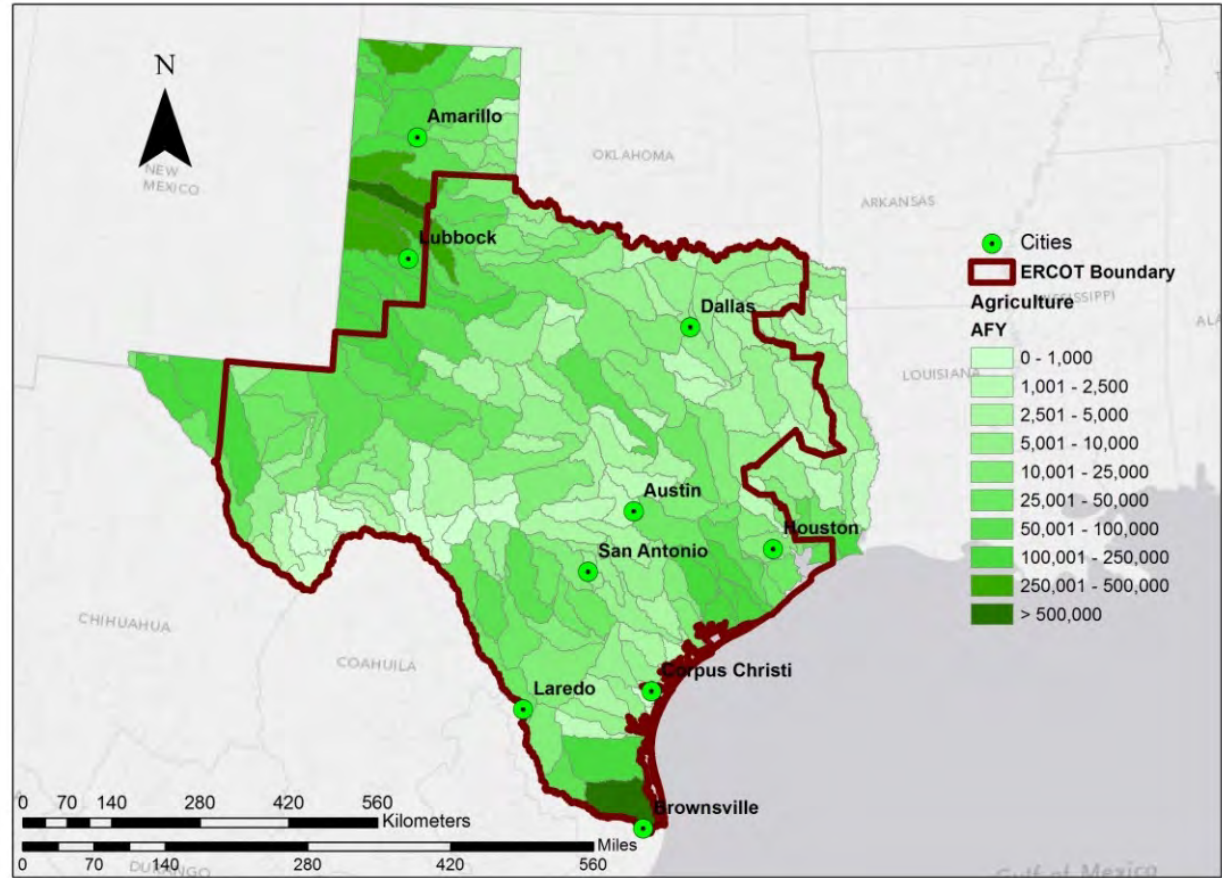

Figure 11. The estimated water consumption for Texas agricultural demand (irrigation and livestock) in 2030 is 9,643,000 ac-ft $(9,299,000$ ac-ft for irrigation and 344,000 ac-ft for livestock).

\section{Difference in Agricultural Consumptive Use}

2010-2030

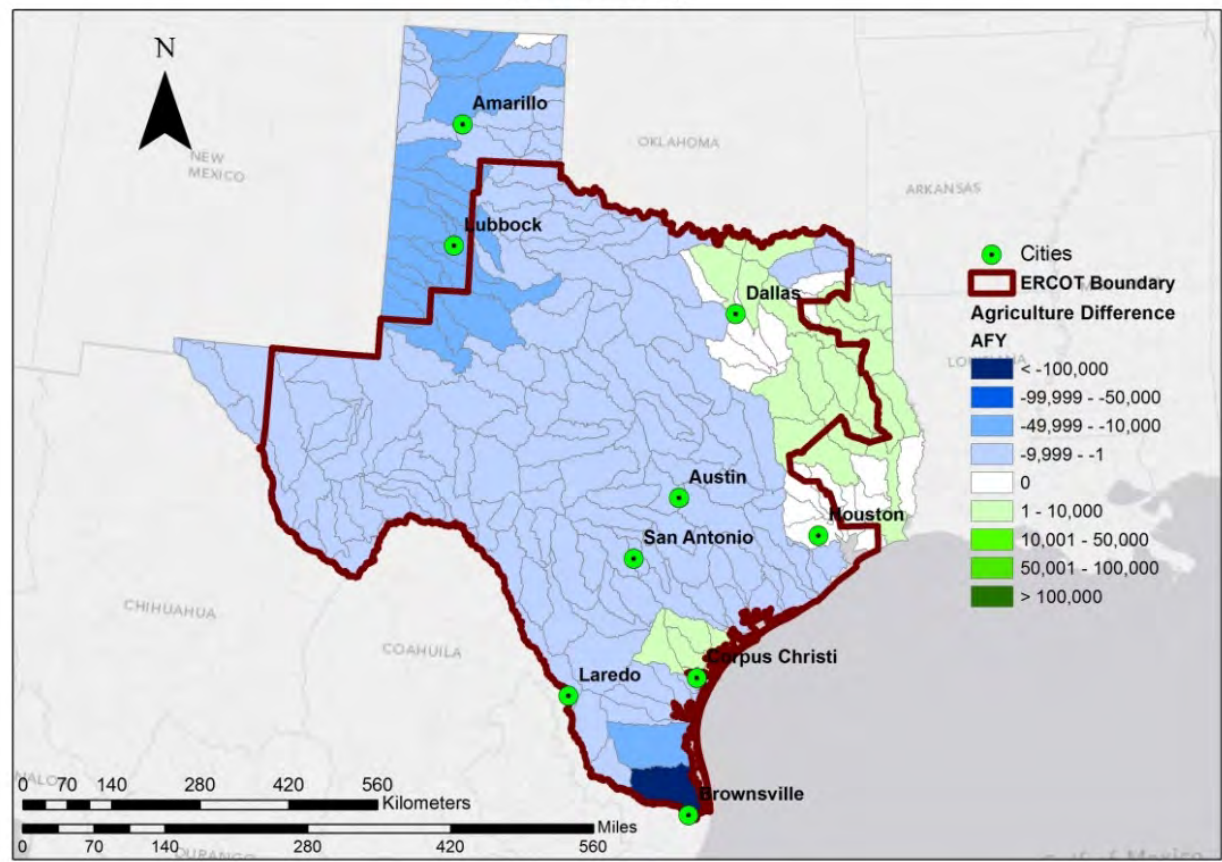

Figure 12. The TWDB projected changes in agricultural water demand from 2010 to 2030 assume more irrigated farming in east Texas and less irrigation in the panhandle and in southernmost Texas. 


\section{Current Industrial (Manufacturing) Consumptive Use}

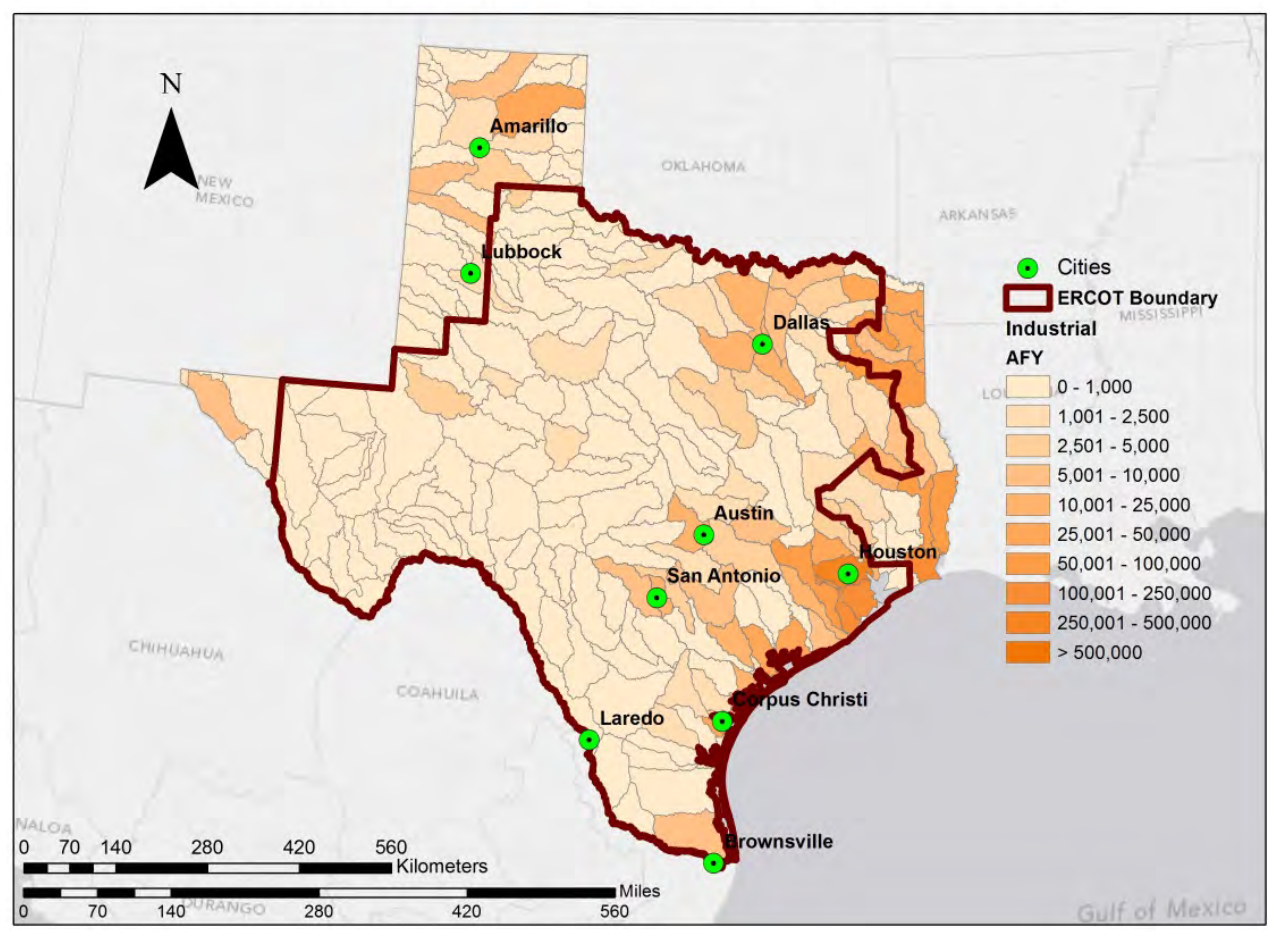

Figure 13. The estimated water consumption for Texas manufacturing demand in 2010 is $1,728,000 \mathrm{ac}-\mathrm{ft}$.

\section{Industrial (Manufacturing) Consumptive Use}

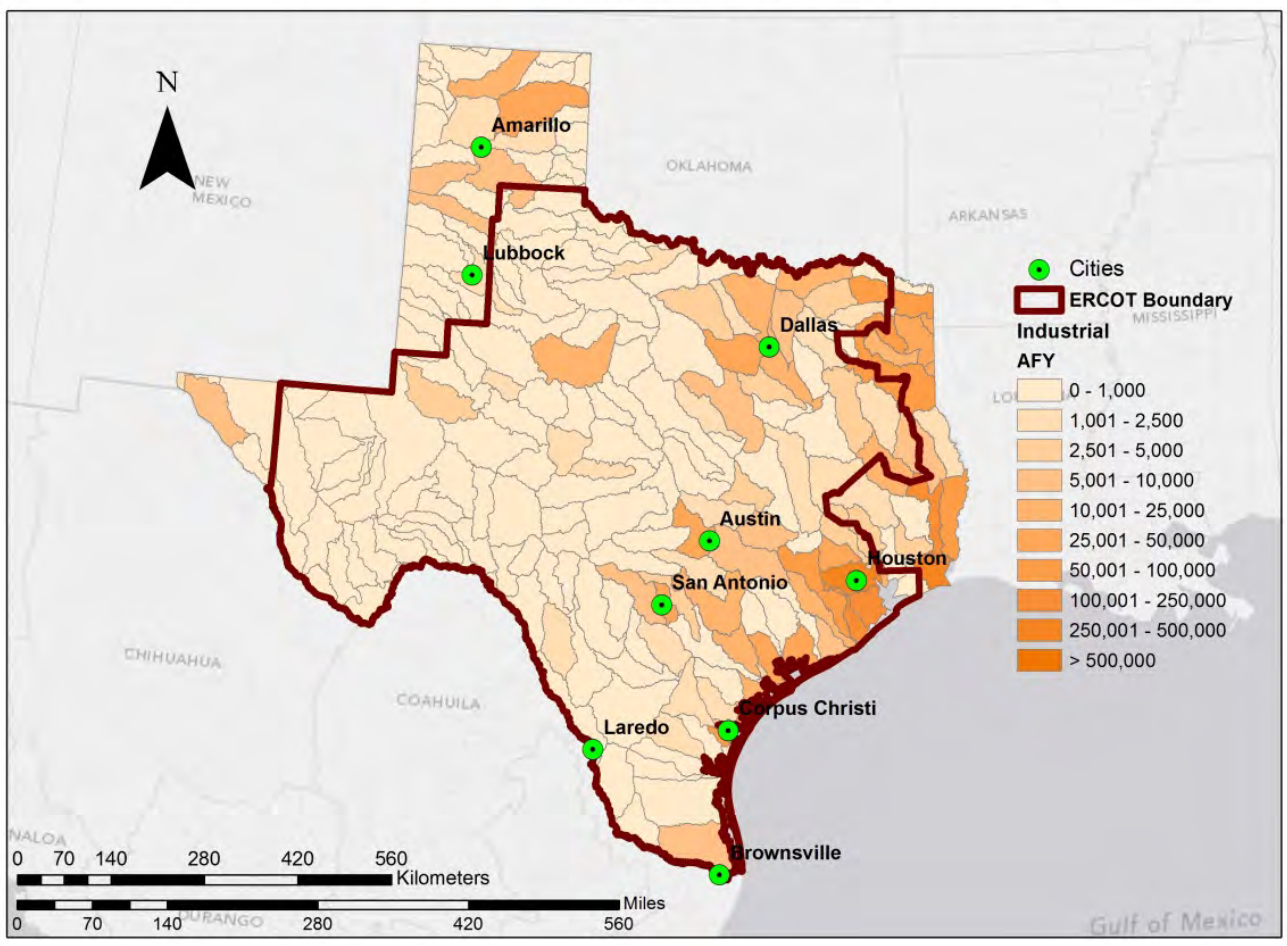

Figure 14. The estimated water consumption for Texas manufacturing demand in 2030 is $2,466,000$ ac-ft. 


\section{Current Mining Consumptive Use}

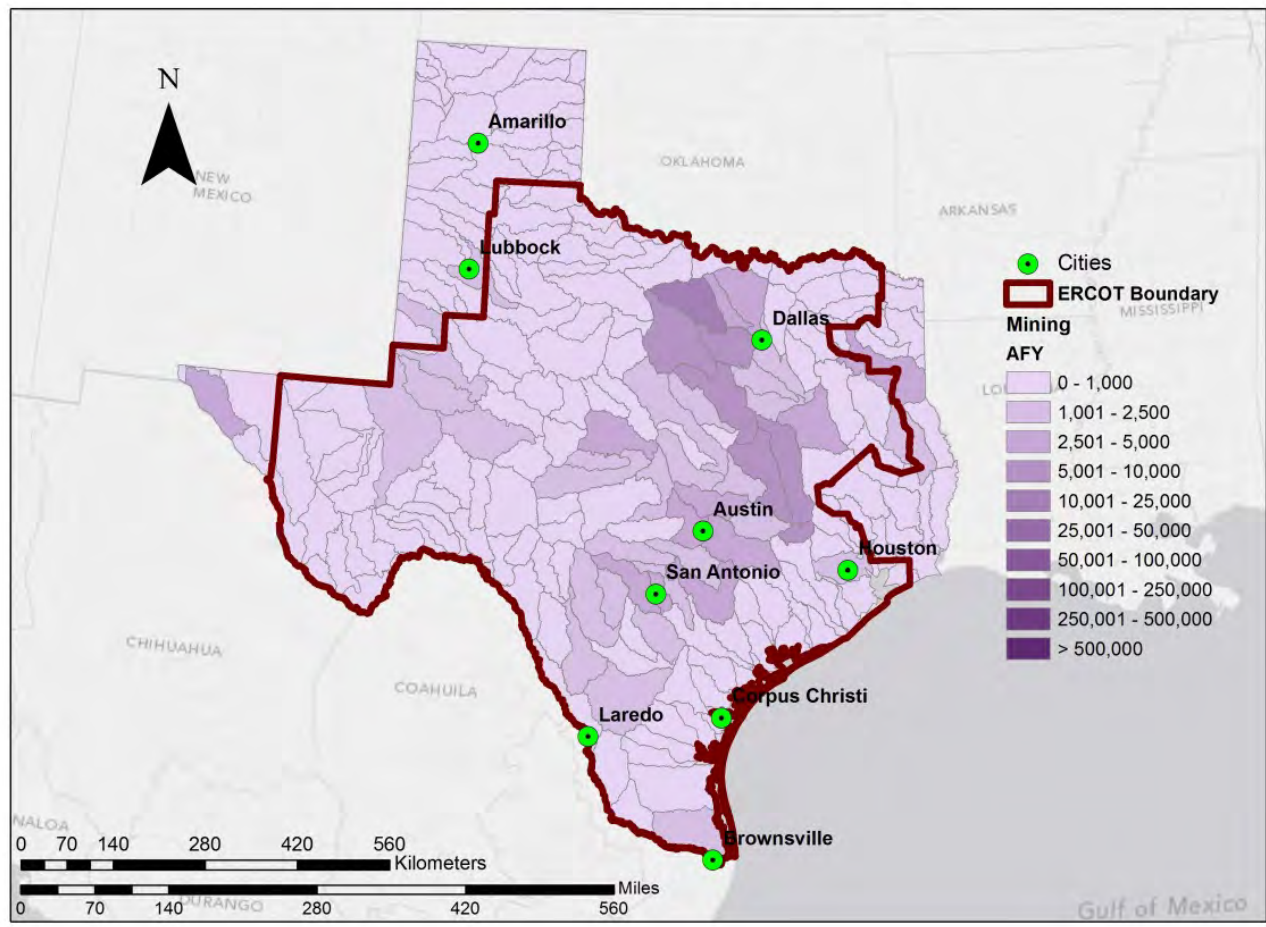

Figure 15. The estimated water consumption for Texas mining demand in 2010 is 296,000 ac-ft.

\section{Mining Consumptive Use}

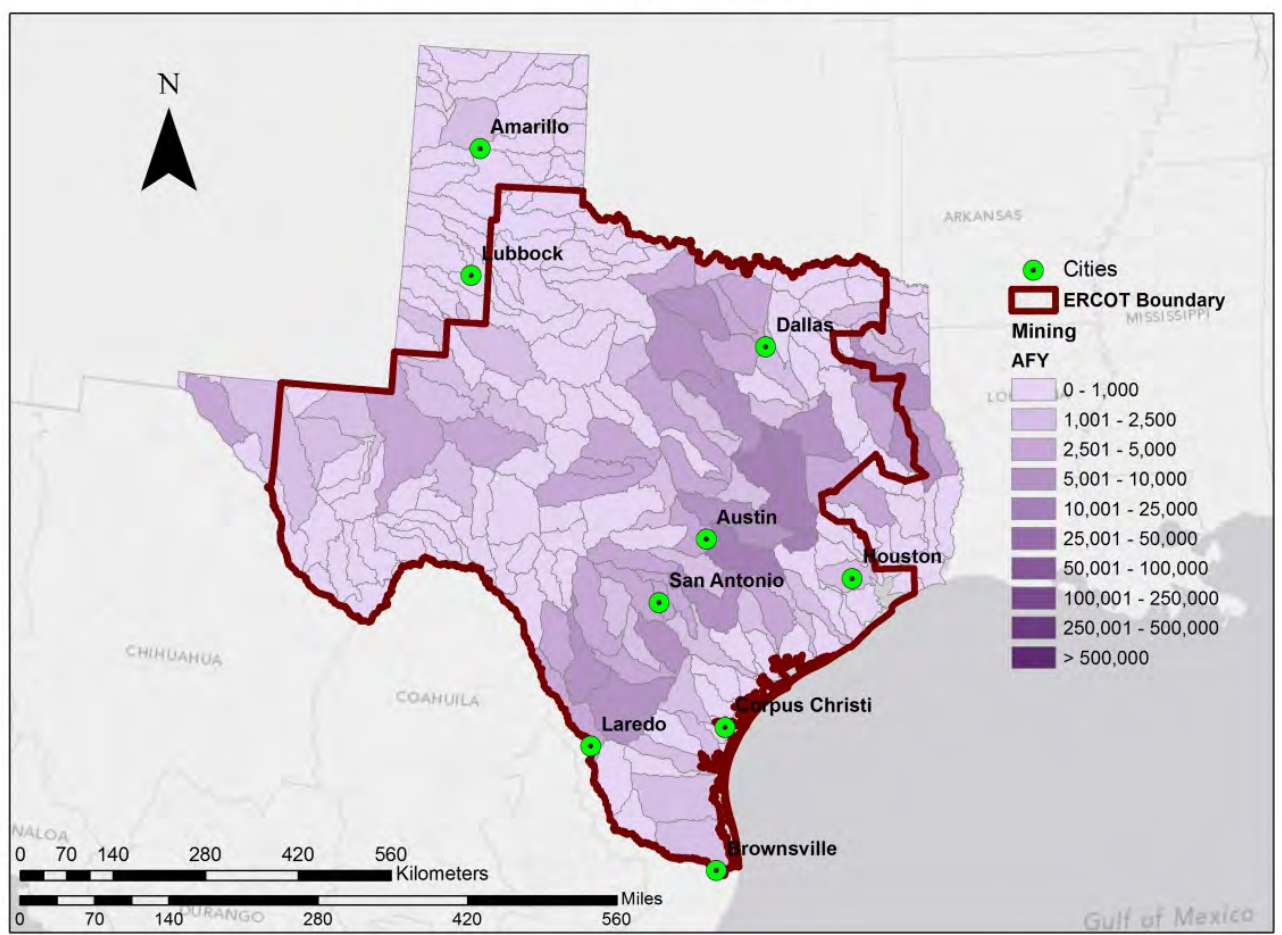

Figure 16. The estimated water consumption for Texas mining demand in 2030 is $296,000 \mathrm{ac}-\mathrm{ft}$. 


\section{Climate Model Data Generation for Scenarios to 2030}

The meteorological forcing data for hydrologic modeling were developed and evaluated for HUC8 basins in the Texas-Gulf water resource region for two future climate data sets: (1) the USGS CASCaDE data set, which contains downscaled Global Circulation Model (GCM) daily projections at the 1/8thdegree ( $12 \mathrm{~km} \times 12 \mathrm{~km}$ ) spatial scale without bias correction, and (2) the U.S. Bureau of Reclamation (USBoR) data set, which contains bias-corrected, downscaled GCM daily projections at the 1/8thdegree spatial scale. After download, these data sets were subjected to a quality assurance/quality control (QA/QC) process and checked for missing or anomalous data; identified errors were removed and corrected. The CASCaDE data set contains meteorological parameters of minimum temperature, maximum temperature, and precipitation. The USBoR data set contains meteorological parameters of minimum temperature, maximum temperature, precipitation, and wind. With the available GCM parameters, we used physics-based algorithms to estimate additional meteorological parameters required by the hydrologic and effluent temperature regression models. The data were then mapped from the 1/8th-degree grid to the HUC8 basins.

The two future climate data sets and processing steps are described below. For each data set, future temperature and precipitation projections from the GCM under three (A1B, A2, and B1) of greenhouse gas (GHG) emission scenarios were considered. The emission scenarios are defined in the Special Report on Emissions Scenarios (SRES) by the Intergovernmental Panel on Climate Change (IPCC 2000). Each emission scenario family has a particular theme that characterizes future technological and economic development, which in turn affects GHG emissions and climate. For example, the A2 family is characterized by continuously increasing population, regionally oriented economic development, and slow technological change, while the B1 family characterizes a more ecologically friendly world, population decline after 2050, and cleaner technological advancements. The A1B family reflects a balanced emphasis on all energy sources, providing a relatively neutral characterization of future climate. The projections for 2020-2030 from one scenario were selected to represent the worst simulated drought. This worst case was then incorporated as climate input to the hydrologic model built for the Texas-Gulf river basin. The potential for the worst-case scenario to impact water availability and power generation is evaluated in Sections 4 and 7.

\subsection{CASCaDE-Based Climate Data Set}

The first climate data set was based on climate projections from the USGS CASCaDE project. The CASCaDE downscaled climate scenarios are available online in a generic binary format. ${ }^{1}$ These data are derived from gridded observed fields from the University of Washington Land Surface Hydrology Research Group, from GCM simulations of historical climate conditions (scenario $20 \mathrm{c} 3 \mathrm{~m}$ in IPCC4 studies), and from future emissions scenarios including A1B, A2, and B1. The GCMs represented are (1) the National Center for Atmospheric Research Parallel Climate Model 1 (PCM) and (2) the National Oceanic and Atmospheric Administration (NOAA) Geophysical Fluid Dynamics Laboratory (GFDL) CM2.1 model. All data, except the gridded historical observation data (from the University of Washington) were downscaled by using the constructed analog method of Hidalgo et al. (2008). The climate fields downscaled for inclusion here are daily minimum and maximum air temperature and daily precipitation, on a 1/8th-degree $(\sim 12 \mathrm{~km} \times 12 \mathrm{~km})$ grid over the conterminous United States,

1 See this location: http://cascade.wr.usgs.gov/data/Task1-climate/index.shtm 
plus parts of the Columbia River basin in Canada. In addition, long-term monthly mean wind speed was calculated from the Maurer et al. (2002) data set.

\subsubsection{Data Preprocessing}

For maximum temperature, minimum temperature, and precipitation, QA/QC was performed on the CASCaDE downscaled data sets. The purpose was to check against the original data and to verify that the binary files, which were translated from the generic binary format to netCDF format, were completed properly, particularly as there were inconsistencies in byte-swapping methods (i.e., big versus little endian). The QA/QC method implemented corresponds to the method the United States Historical Climatology Network uses for data review. The QA/QC methods, implemented in Matlab, cycled through all days and all grid cells in the 100-yr time series (2000-2099). For temperature, data were evaluated for instances of (1) daily minimum temperature > maximum temperature for that day; (2) identical values occurring on successive days; and (3) daily temperature outside an extreme value (less than $-100^{\circ} \mathrm{C}$ and greater than $70^{\circ} \mathrm{C}$ ). For precipitation, data were checked for (1) daily precipitation $>$ the world extreme $24-\mathrm{h}$ precipitation amount $(1,825 \mathrm{~mm})$ and $(2)$ values with negative precipitation.

Different methods were used to assign values for any days determined to be incorrect. For temperature, the values for 10 days before and after the incorrect day were taken from surrounding grid points and used to develop a statistical relationship. The regression coefficients from this statistical relationship were then applied to the day of interest, and a new value was computed and written back into the gridded data set at the proper time step. For erroneous daily precipitation data, the gridded precipitation values surrounding the incorrect cell(s) for the day of interest were interpolated and - as with temperature $Q A / Q C$ - written back to the gridded data set at the proper time step.

\subsubsection{Climate Data Preparation}

The meteorological parameters prepared for the hydrologic and effluent temperature regression models include precipitation; incoming long- and shortwave radiation; wind speed; vapor pressure; relative humidity; dew point temperature; and minimum, maximum, and average air temperatures. We used the physics-based algorithms (Thornton and Running 1999, Kimball et al. 1997) implemented in the Variable Infiltration Capacity (VIC) Macroscale Hydrologic Model to derive incoming long- and shortwave radiation and vapor pressure. VIC was run for each model (PCM and GFDL) and scenario (A1B, A2, and B1).

Dew point temperature was then computed from vapor pressure as in Rogers and Yau (1989), as follows:

$$
\text { Tdew }=B * \ln [A * e]-273.16
$$

Here Tdew is the dew point temperature in degree Celsius; $A=2.53 * 10^{8}(\mathrm{kPa}), B=5.42 * 10^{3}(\mathrm{kPa})$, and $e$ is the vapor pressure $(\mathrm{kPa})$. Relative humidity was calculated from air temperature and vapor pressure as in Bolton (1980), as follows:

$$
R H=\left(e * 10^{3}\right) / 6.112^{\left(\frac{17.67 * T}{243.5+T}\right)}
$$

Here $R H$ is relative humidity (\%); $e$ and $T$ are vapor pressure $(\mathrm{kPa})$ and air temperature (degree Celsius), respectively. 
A simple QC method was used to ensure that data values remained within world extreme minimum and maximum observations. The 1/8th-degree scale data were then aggregated to the HUC 8 basins by using an area-weighted average method for each model (PCM and GFDL) and scenario (A1B, A2, and B1).

\subsection{U.S. Bureau of Reclamation Climate Data Set}

\subsubsection{Data Preprocessing}

The second climate input data set was based on USBoR climate projections, available online in netCDF format. $^{2}$

For consistency in GCMs and emission scenarios between the USBoR and USGS CASCaDE data sets, the $A 1 B, A 2$, and $B 1$ future emissions scenarios from the PCM and GFDL models were retrieved and processed. These data were bias-corrected and spatially downscaled to the $1 / 8$ th-degree spatial scale by the USBoR on the basis of methods described by Wood et al. $(2002,2004)$ and Maurer (2007).

\subsubsection{Climate Data Preparation}

A simple QC method was used to ensure that the data from the USBoR climate projections remained within world extreme minimum and maximum observations. Because no data conversion issues or concerns arose for the USBoR netCDF files, a less stringent QA/QC method was employed. The input parameters for hydrologic and effluent temperature regression models were generated by using the method employed for the CASCaDE data set (Section 3.1.2).

2 See this location: http://gdo-dcp.ucllnl.org/downscaled_cmip_projections/dcpInterface.html\#About 


\section{Hydrologic Model Description and Results of Drought Simulation}

\subsection{Hydrologic Model Construction}

A hydrologic model for the Texas-Gulf river basin was constructed with the Soil and Water Assessment Tool (SWAT) (Neitsch et al. 2011) to simulate dynamic hydrologic processes and calculate stream flows and reservoir storages at the HUC8 basin level. The constructed Texas-Gulf SWAT model includes 122 subbasins that coincide with the HUC8 basins. The main data sources used to construct the model include the USGS National Map Seamless Server for 30-m digital elevation; the USGS National Water Information System for observed discharge data used for calibration; the U.S. Environmental Protection Agency (EPA) Reach File 1 (RF1) for the predefined stream network; NOAA National Climatic Data Centers (NCDC) historical weather data; and the U.S. Department of Agriculture (USDA) National Agricultural Statistics Service for land use and soil data. The model was calibrated by using historical records measured for stream flow and reservoir storage. In addition to the basic elements of hydrologic model construction, key components for the Texas-Gulf river basin that were incorporated into the model are discussed below.

\subsubsection{Water Use}

The historical water use data generated for each HUC8 basin (Section 2) was incorporated into the model. Five water sources (river, reservoir, pond, shallow groundwater, and deep groundwater) were assigned on the basis of the USGS water use survey, TWDB water use survey, distance to water sources, and power plant water use information. For projected future water use, similar proportions among the five water sources were applied. Water usage assumed that all future power plants use surface water sources (even though a small amount comes from groundwater). The projected increase in water consumption from surface water sources from 2010 to 2030 is shown in Figure 6.

\subsubsection{Texas-Gulf Basin Reservoirs}

The reservoir data were collected from the dam database of the U.S. Army Corp of Engineers and the TWDB reservoir database (Appendix A). To include the major reservoirs that have significant storage capacity and/or provide cooling water for power plants, we used three selection criteria: (1) volume > 20,000 ac-ft, (2) located close to power plants that use the surface water or unknown sources of water, or (3) monitored by the TWDB.

A total number of 125 reservoirs, distributed in 63 HUC8 basins as shown in Figure 17, were included in the model. For each HUC8 basin containing multiple reservoirs, a combined reservoir aggregating parameter for all reservoirs in the basin was assigned in the model. This simplification might not address the differences among reservoirs within the basin, but the model still characterizes the overall water availability and change in storage capacity at the HUC8 basin level. The model output for the combined reservoirs in each HUC8 basin was further analyzed for the individual reservoirs providing cooling water for power plants. 


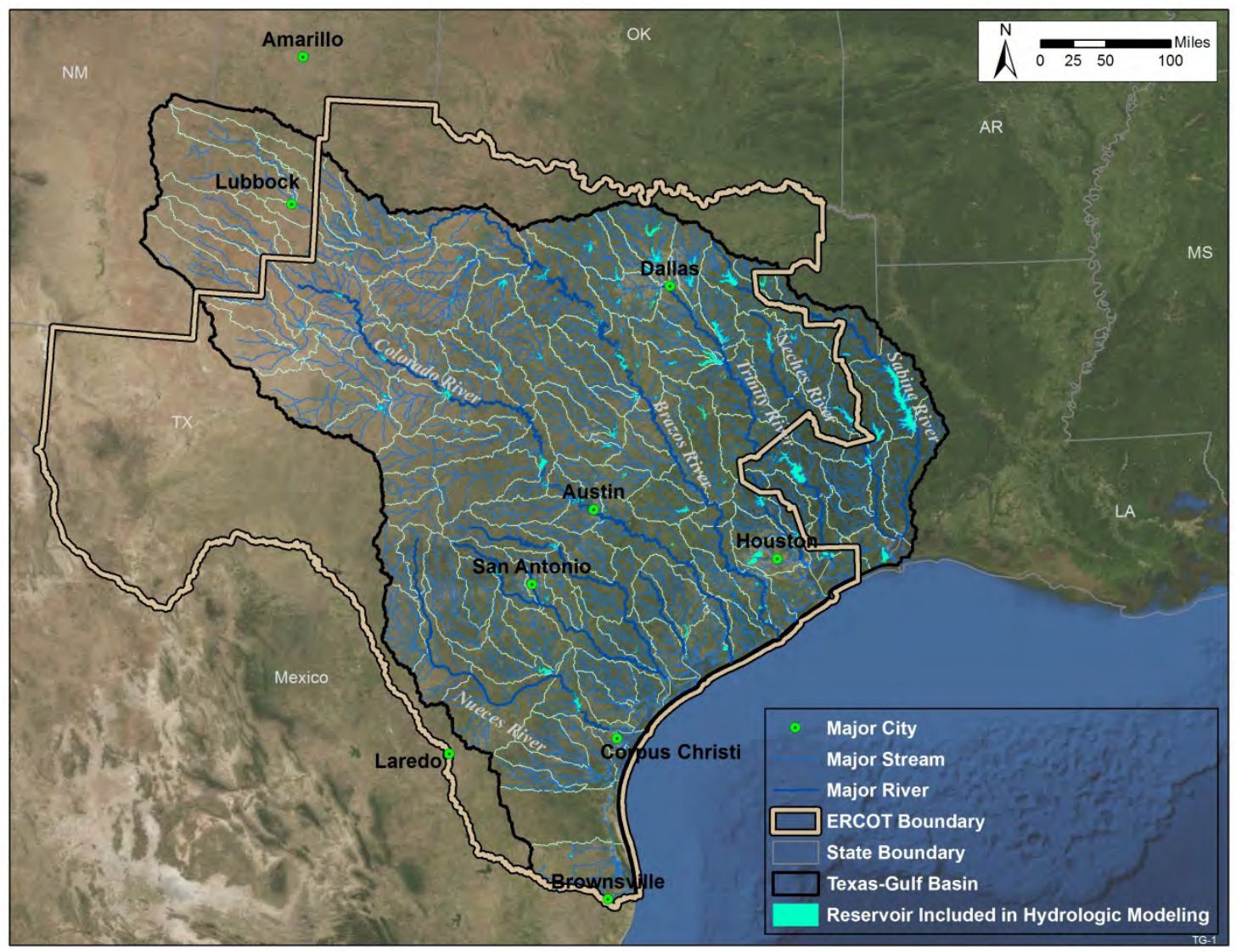

Figure 17. Locations of 125 reservoirs included in the Texas-Gulf SWAT hydrologic model.

\subsubsection{Climate Forcing Data}

The historical climate data were collected from the Global Historical Climatology Network (GHCN) database maintained by the NCDC. The climate data were interpolated on the basis of distance and elevation by using an algorithm that searches records from the desired number of nearest weather stations at a daily time step (Demissie et al. 2012). This procedure eliminated data gaps for the surrounding stations by increasing the search distance as needed at each time step. The interpolation was based on observed records from 2,855 stations in and around the Texas-Gulf river basin. Figure 18 shows the distribution of meteorological stations (for weather data points).

Two data sets of projected climate change were evaluated. Each data set included six sets of output from two GCMs (GFDL and PCM) for three scenarios: A1B, A2, and B1. The USBoR data set (which projects less precipitation and warmer conditions) was downscaled with the bias correction/spatial downscaling (BCSD) method, and the CASCaDE data set was downscaled without bias correction. The data sets were processed as discussed in Section 3. Figure 19 shows six sets of projections (GFDL A1B, GFDL A2, GFDL B1, PCM A1B, PCM A2, and PCM B1) for mean and standard deviation of annual precipitation and annual average daily maximum and minimum temperatures in 2021-2030. The GFDL A2 projection appears to represent drier and warmer climate conditions. To simulate the worst scenario for drought conditions, USBoR climate data downscaled by the BCSD method from GFDL model output under the A2 scenario were used in the simulation for 2021-2030. 


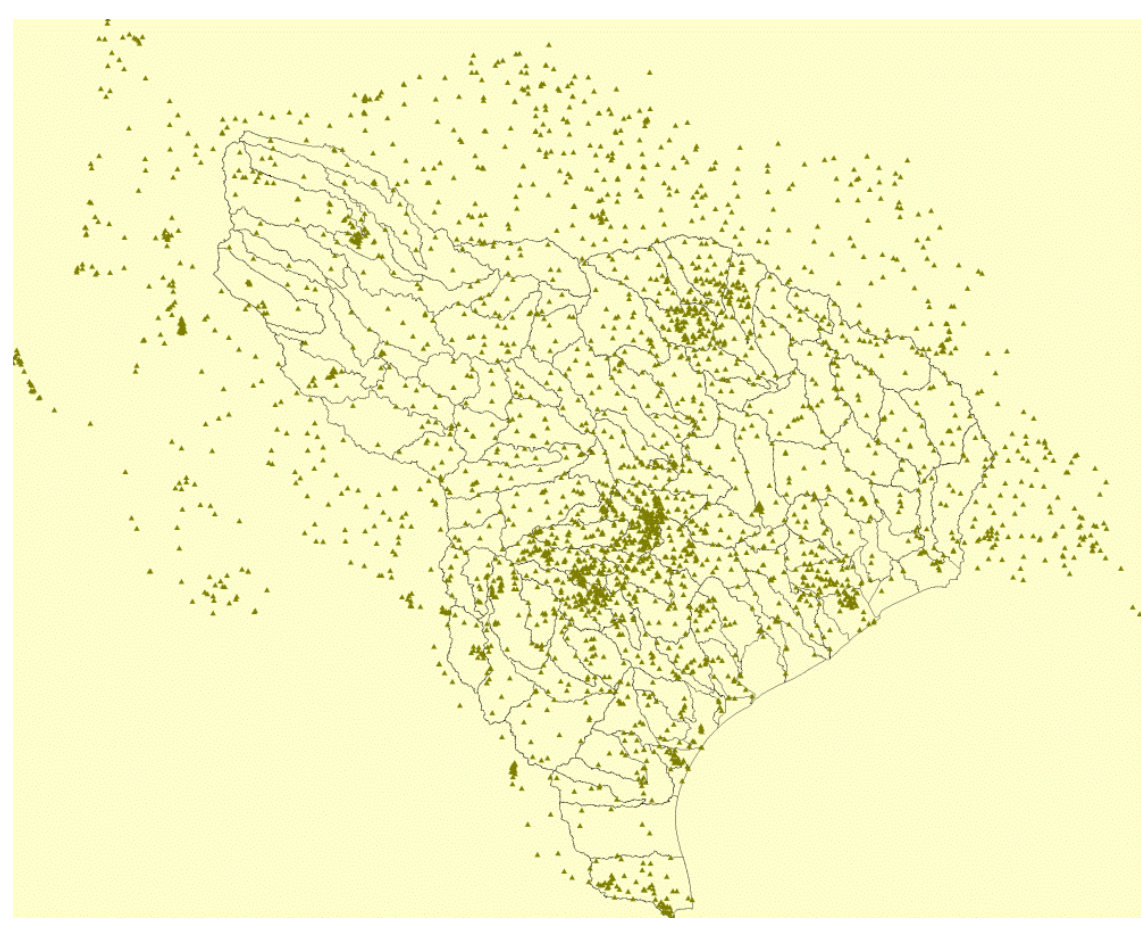

Figure 18. Locations of historical climate stations used for generating climate daily data for HUC8 basins.

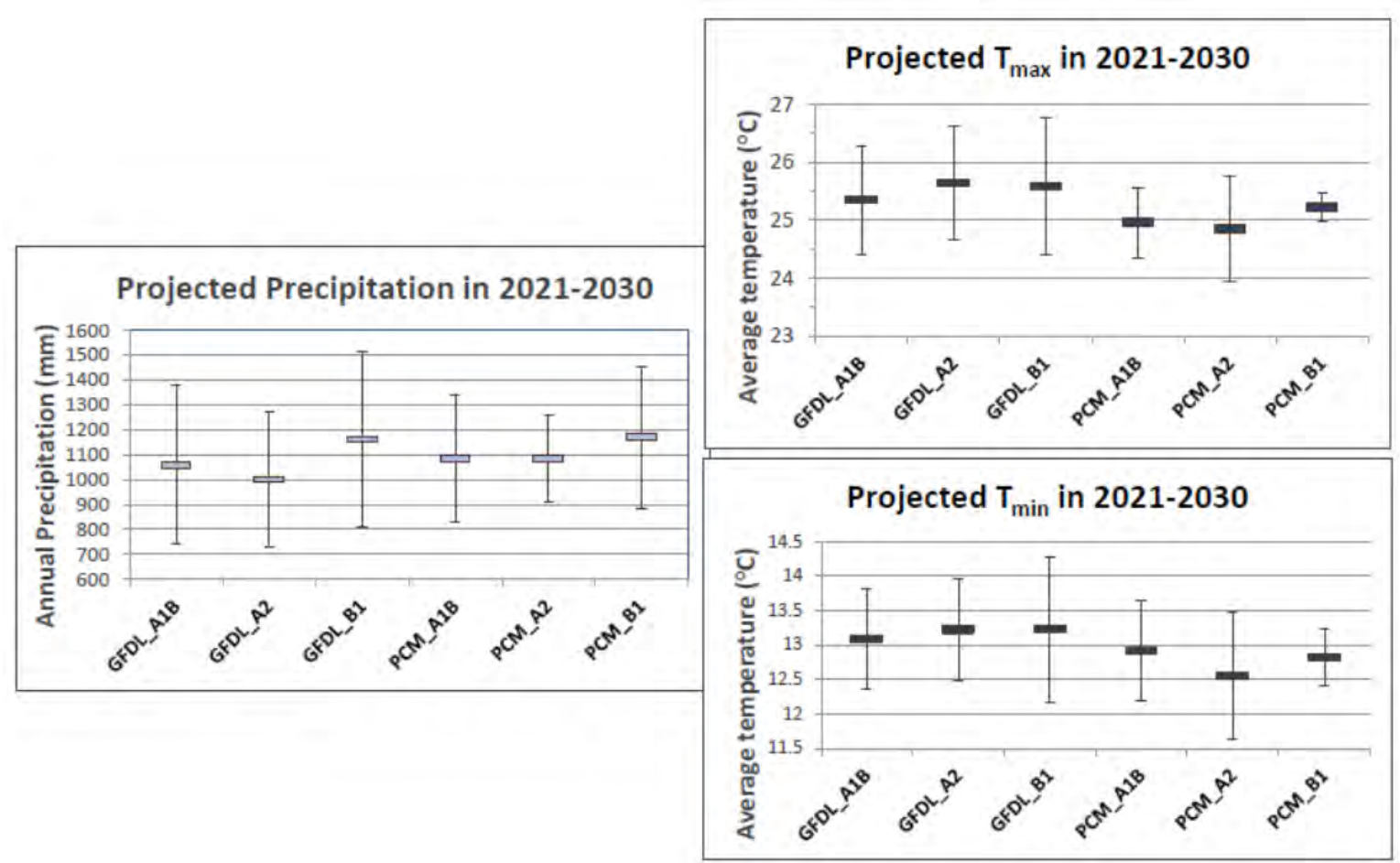

Figure 19. Mean and standard deviation of projected annual precipitation and annual minimum and maximum temperatures in 2021-2030 for the Texas-Gulf river basin. The six sets of projections were downscaled with the BCSD method from the GFDL and PCM models for scenarios A1B, A2, and B1. 


\subsection{Model Calibration}

The hydrologic model was calibrated with observed monthly flow data from nine selected USGS stream gauges. The selected stream gauges are distributed along seven major rivers in Texas-Gulf river basin: Sabine, Neches, Trinity, Brazos, Colorado, Guadalupe, and Nueces. Figure 20 displays the locations of the stream gauges used to calibrate the SWAT model.

In general, the calibrated model reached good agreement between observed and simulated flows. Figures 21-23 show a series of plots that represent the results of the calibration procedure for the Texas-Gulf SWAT model. In each plot showing a time series of stream flow, the blue lines represent the model predictions, and the pink lines represent historical observations measured from USGS stream gauges. The coefficient of determination $\left(R^{2}\right)$ was used to evaluate the goodness of fit of the model. For the final calibrated model, $\mathrm{R}^{2}$ estimated for nine stream gauges along seven major rivers ranged from 0.82 to 0.92 .

To predict dynamic changes in reservoir storage, an additional calibration was conducted for reservoirs with available data (reservoir water level and storage) from their monitoring gauges in 1999-2011. Figure 24 shows simulated and observed reservoir storage for three of the HUC8 basins with the largest reservoir storage. For reservoirs in these HUC8 basins, $R^{2}$ ranged from 0.62 to 0.75 . The calibrated Texas-Gulf SWAT model reasonably predicted the general pattern of changes in reservoir storage.

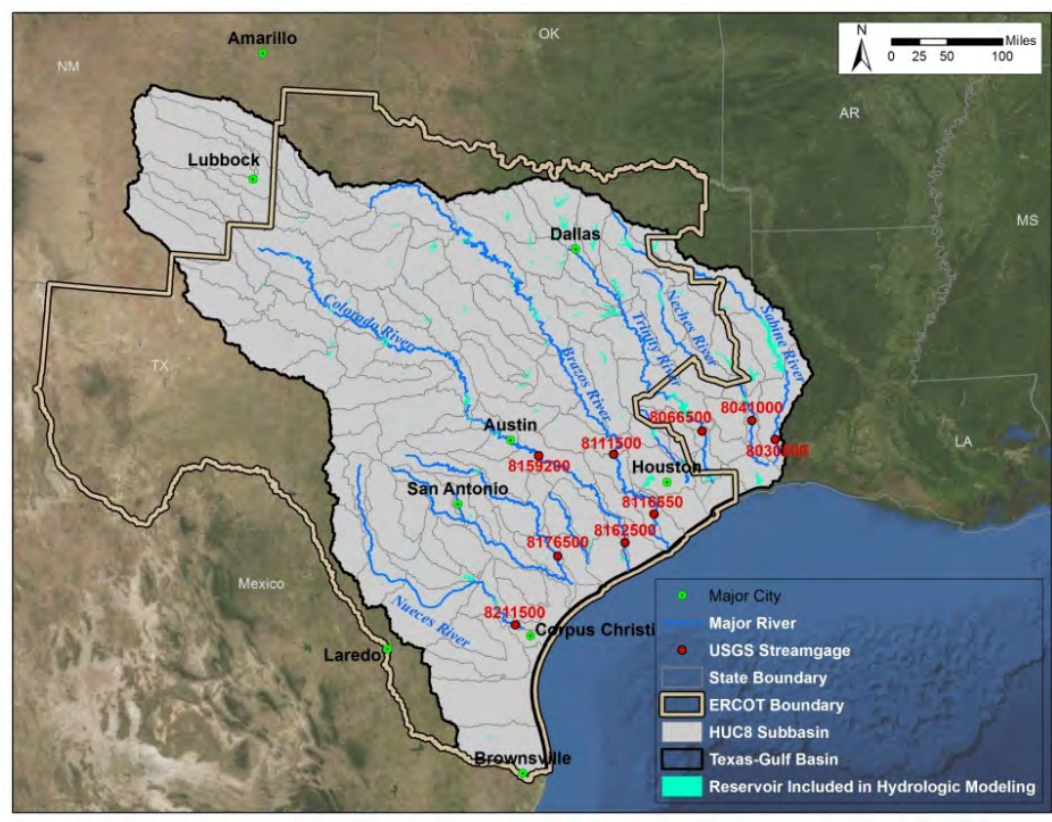

Figure 20. The Texas-Gulf (HUC2 $=12$ ) basin map, indicating the underlying HUC8 level watersheds and the nine stream gauges along seven major river basins used for calibrating the Texas-Gulf SWAT model. 

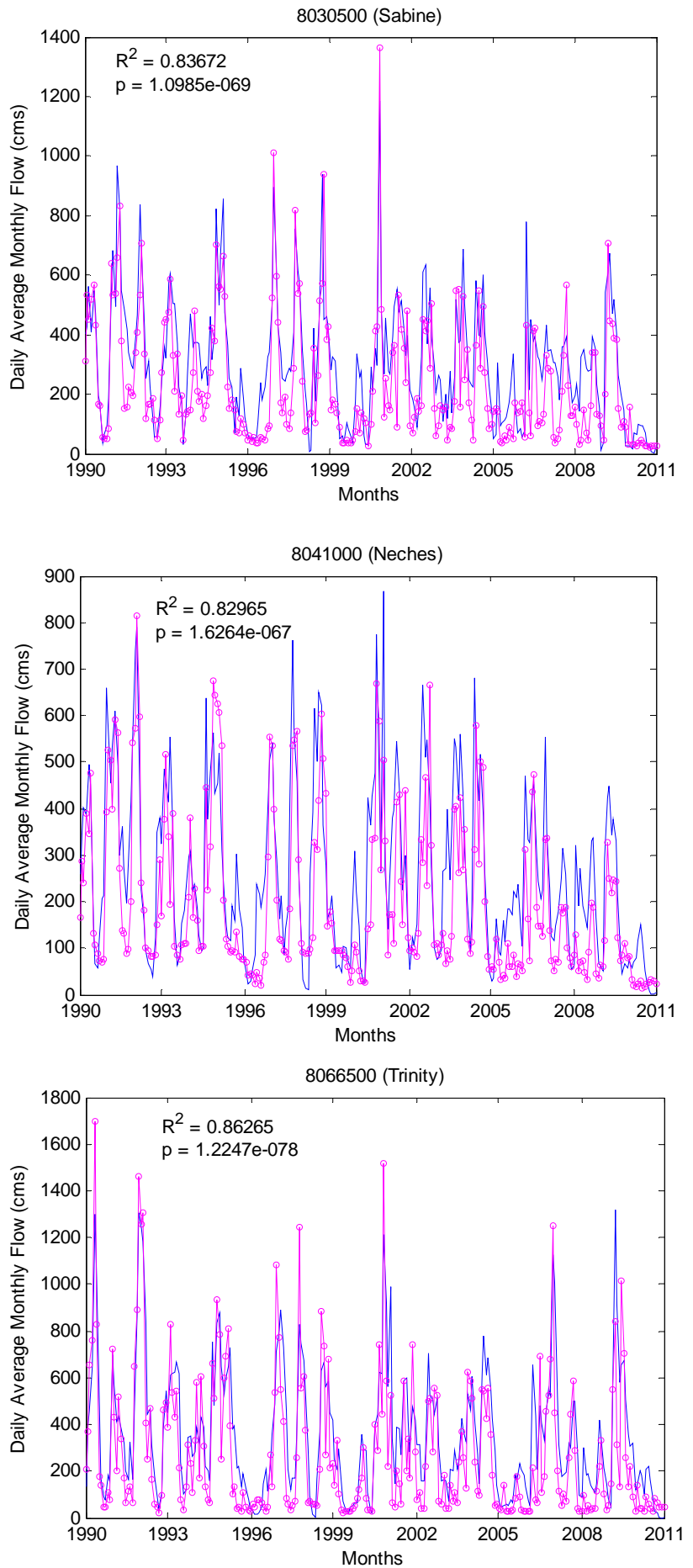

Figure 21. Calibration results for the Sabine, Neches, and Trinity River basins, with flow data at stream gauges 8030500, 8041000, and 8066560, respectively. The Texas-Gulf SWAT model predictions are in blue, and historical observations are in pink (with circles). 

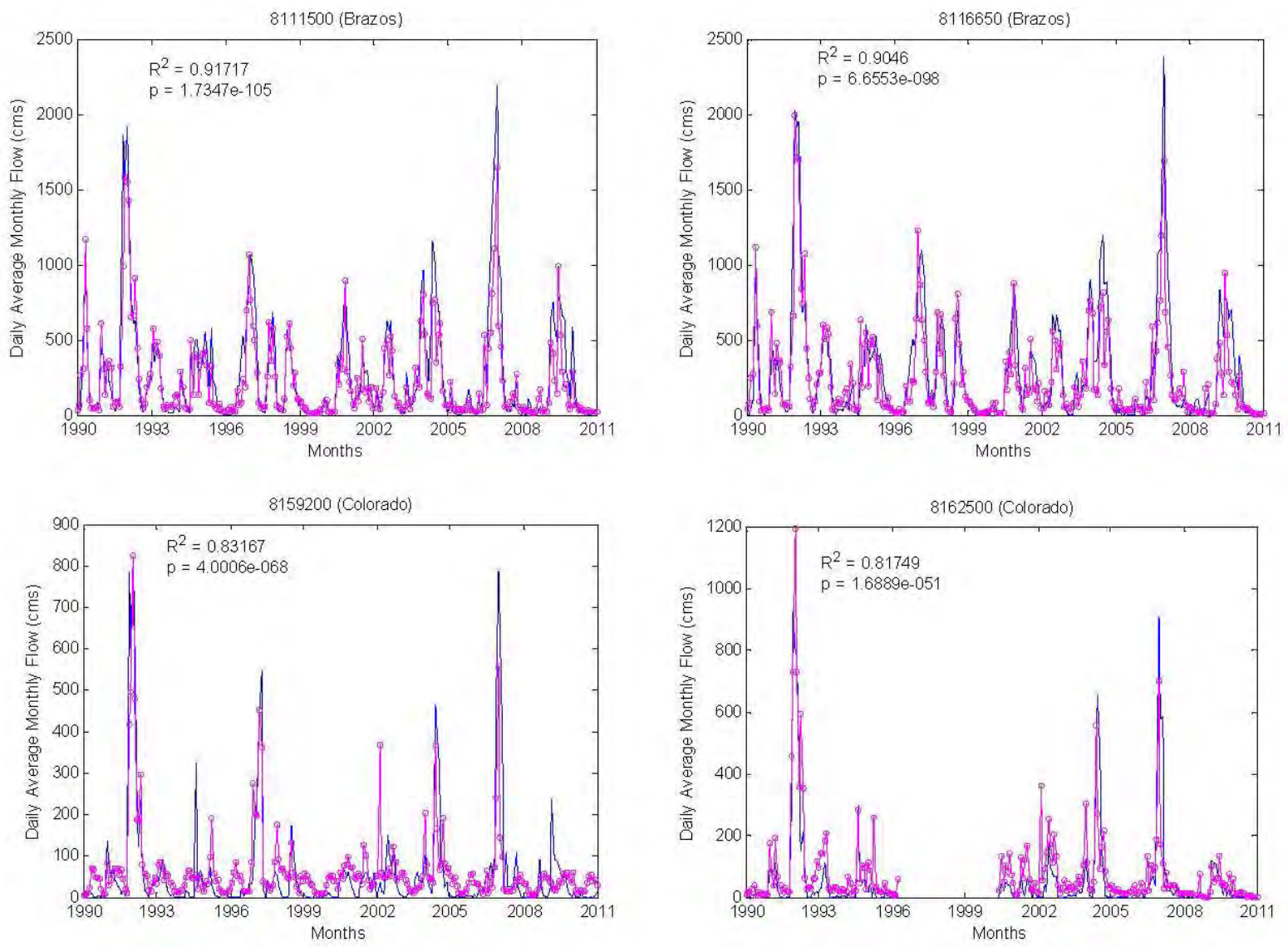

Figure 22. Calibration results for the Brazos River basin and Colorado River basin, with flow data at stream gauges $8111500,8116650,8159200$, and 8162500 , respectively. The Texas-Gulf SWAT model predictions are in blue, and historical observations are in pink (with circles).
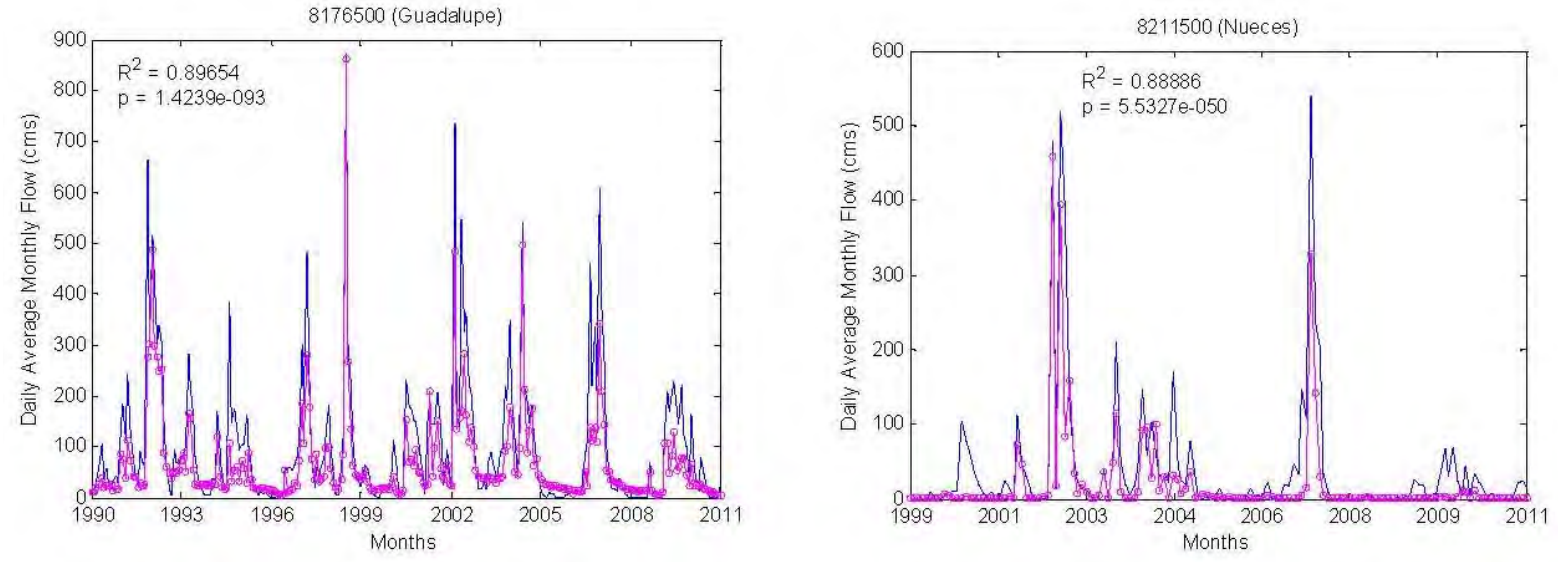

Figure 23. Calibration results for the Guadalupe and Nueces River basins, with flow data at stream gauges 8176500 and 8211500 , respectively. The Texas-Gulf SWAT model predictions are in blue, and historical observations are in pink (with circles). 

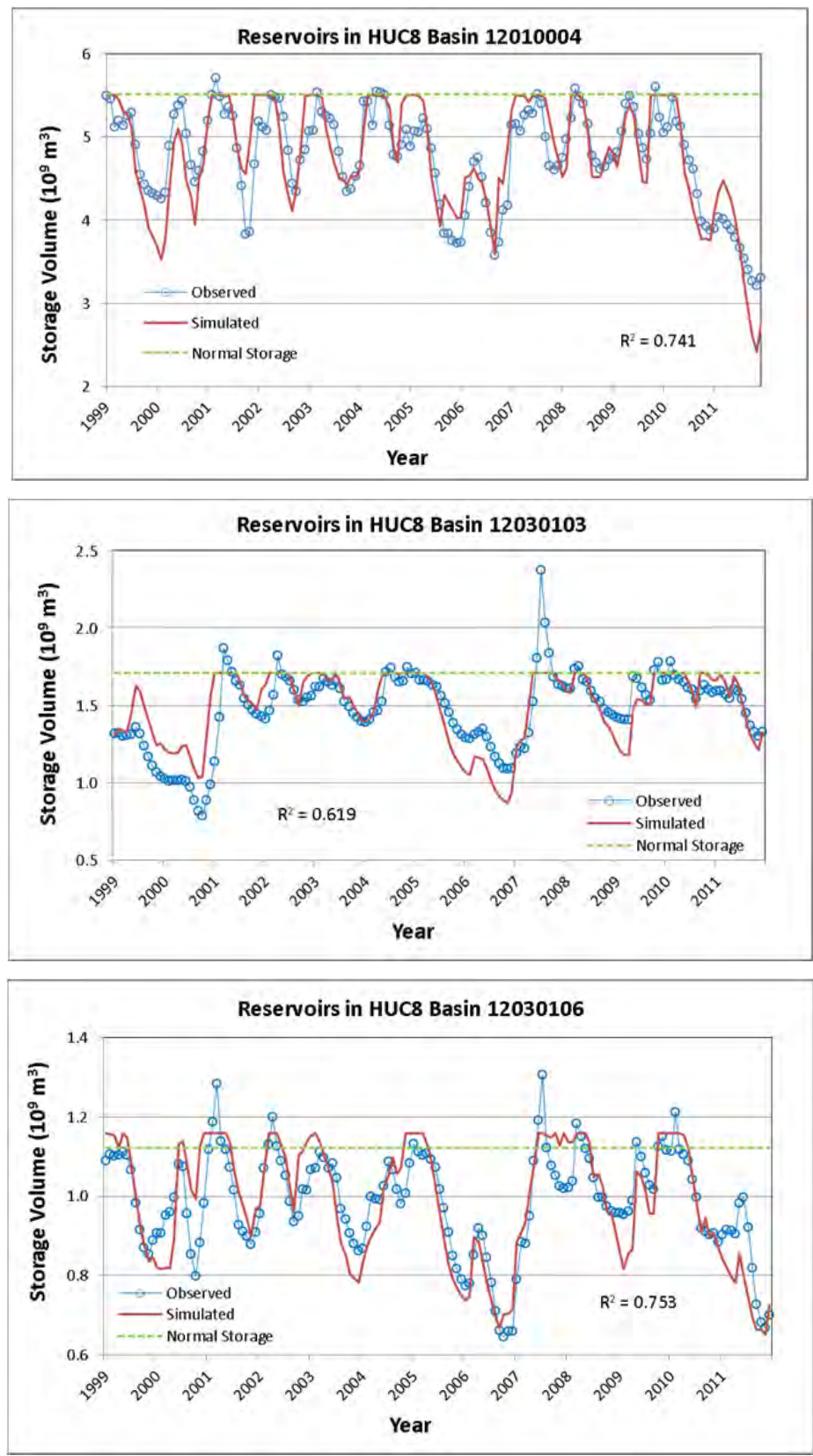

Figure 24. Calibration results for the large-storage reservoirs in three HUC8 basins (12010004, 12030103, and 12030106).

\subsection{Hydrologic Model Results}

To simulate hydrologic responses to future climate variability and increased competition among water users, the calibrated Texas-Gulf SWAT model was used to project stream flow and reservoir storage by incorporating projected future climate change and water demand in 2030. The simulations were performed by using climate variation information (e.g., temperature and precipitation) relating to potential single-year and multiple-year droughts. The results provide quantitative estimates for water availability at the HUC8 basin level under various drought scenarios. 


\subsubsection{Drought Scenarios}

Future drought scenarios were selected for this study on the basis of climate change projections for 2021-2030 and historical drought events. As discussed in Section 4.1.3, the climate data projected by GFDL, one of the GCM models, for GHG emission scenario A2 appear to represent drier and warmer climate conditions compared to other scenarios. The A2 scenario is defined by the IPCC as a possible future development characterized by continuously increasing population, regionally oriented economic development, and slow technological change, resulting in higher emissions. The precipitation and temperature data for the 10-yr period 2021-2030 indicate that 2030 reflects a year of average climate conditions, while 2022 represents the driest year for the period.

Figure 25 shows the pattern of precipitation projected for 2030. All HUC8 subbasins in the Texas-Gulf river basin would receive annual precipitation $>30 \mathrm{in}$. - most of them $>35 \mathrm{in}$. In 2022, projected precipitation significantly decreases to $<30 \mathrm{in}$. in all HUC8 basins and to $<25 \mathrm{in}$. in the northeastern Texas-Gulf basin (Figure 26).

The historical drought events in 1954-1956 and 2011 showed significantly different precipitation $<25$ in. in all HUC8 subbasins in the western Texas-Gulf river basin. The annual precipitation in 19541956, during the long-term drought event (1950-1957), has a pattern similar to that of the 2011 drought (Figure 27). However, the extent of low precipitation (< 25 in.) varied from the western threequarters of Texas-Gulf basin area (west of the Brazos River) in 1954 and 1956 to the western half of the basin area (west of the Colorado River) in 1955 (Figure -30).

The results of running the Texas-Gulf SWAT model with the climate input data projected for 20202030 indicate that the year 2022 represents the driest condition projected for this time period. Year 2030 represents an average year, on the basis of overall precipitation, temperature, and predicted stream flow. No other simulated year of future climate seems to indicate a reduction in overall precipitation comparable to that of 2011.

On the basis of historical and projected precipitation, temperature, and stream flow data, we defined the following drought and normal scenarios for simulation:

- A normal year with an average precipitation for the future climate scenario represented by year 2030, with the projected level of water use in 2030.

- A baseline drought year for comparison: the recent drought in 2011 with the current level of water use.

- A single-year drought in 2022, with the assumed projected water use level for 2030.

- A multiple-year drought constructed by repeating the climate of 1950-1957 and assuming the water demand projected for 2030. (None of the climate simulations produced a multiyear drought, so the 1950s data were used to explore such a future event.)

The drought scenarios selected for evaluation represent (1) two precipitation patterns during the drought (2022 versus 1954-56 and 2011) and (2) two drought durations (single year versus multiple years). The calibrated SWAT model was used to simulate these scenarios, as discussed below. 


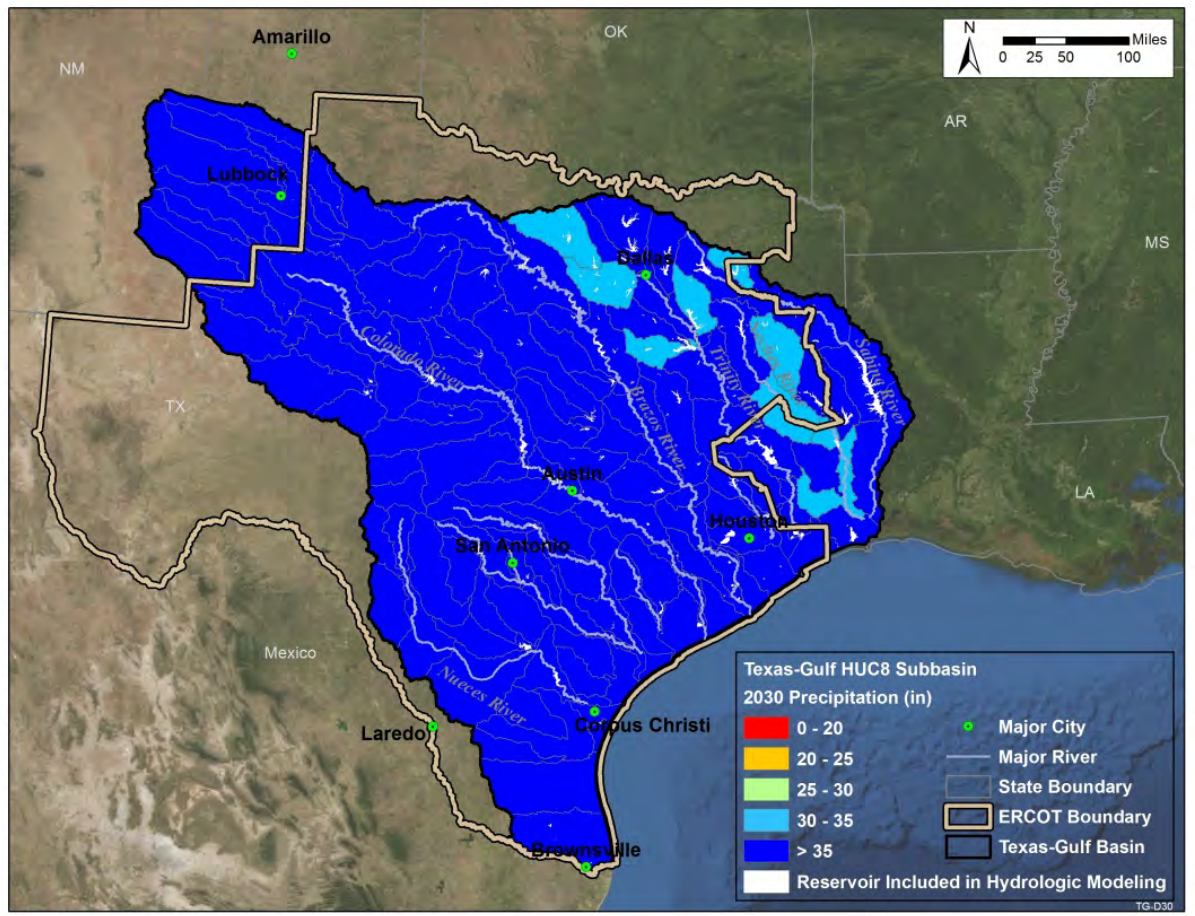

Figure 25. Projected 2030 precipitation for each HUC8 subbasin, based on the data set downscaled with the BCSD method from the GFDL models for the SRES scenario A2.

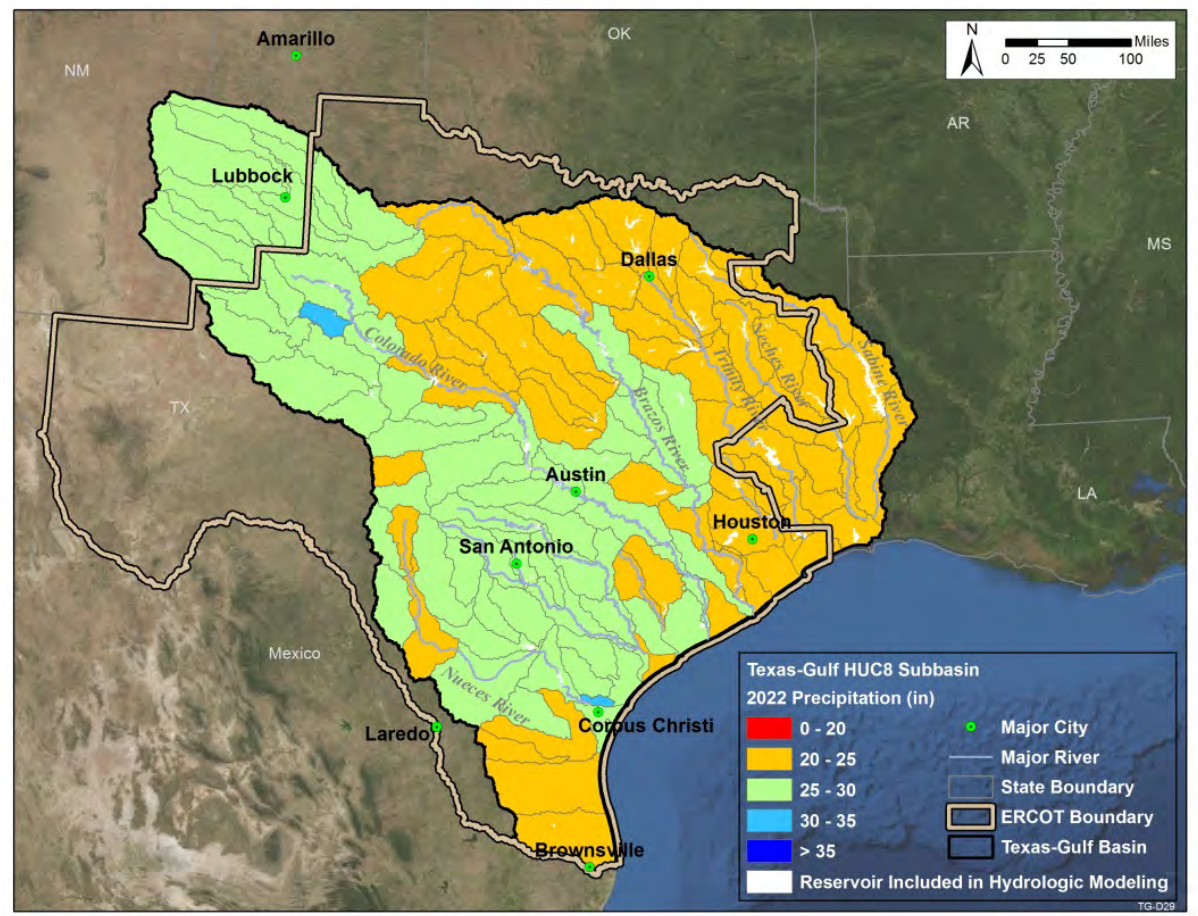

Figure 26. Projected 2022 precipitations for each HUC8 subbasin, based on the data set downscaled with the BCSD method from the GFDL models for the SRES scenario A2. 


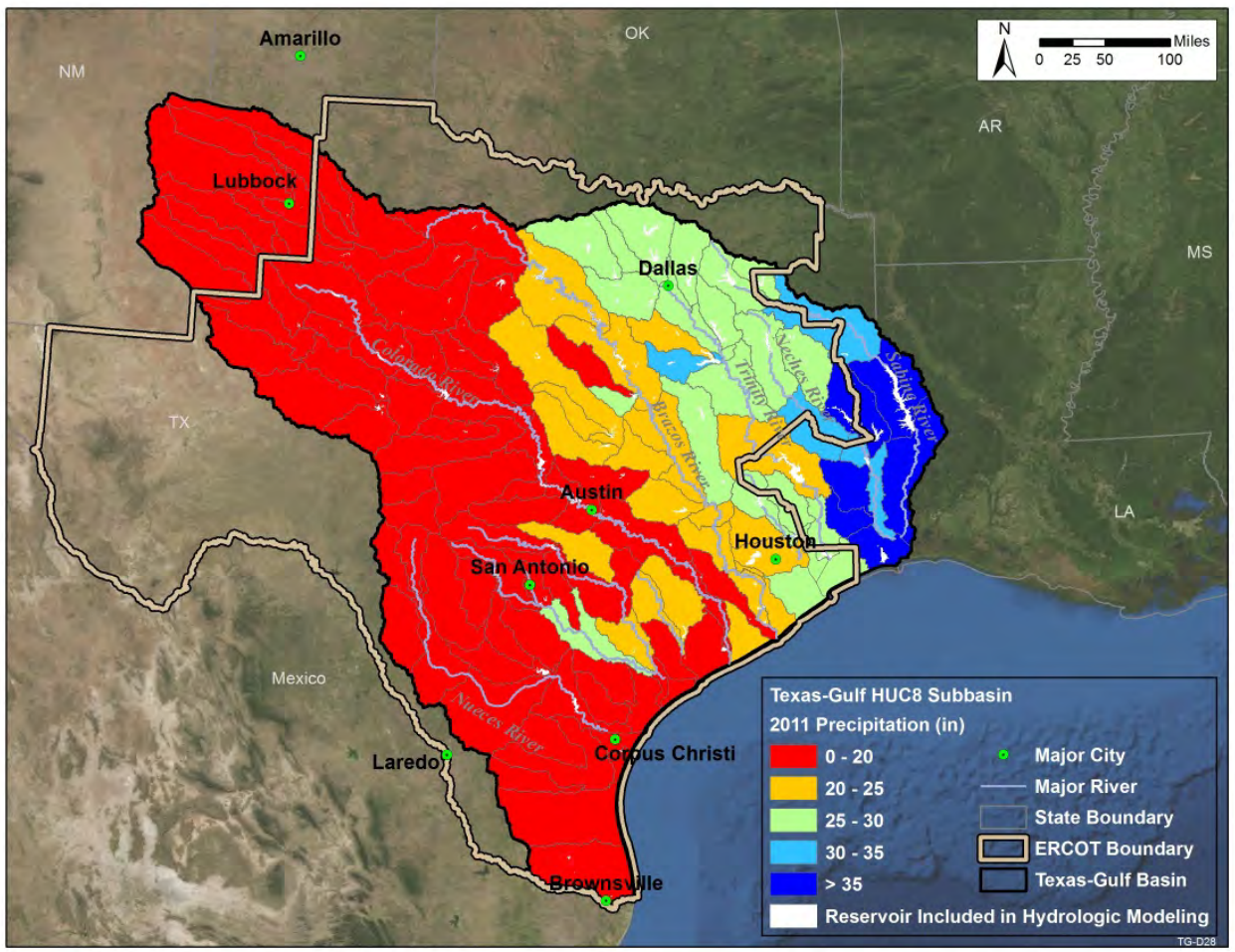

Figure 27. 2011 precipitation at each HUC8 subbasin, based on data interpolated from the GHCN database maintained by the NCDC.

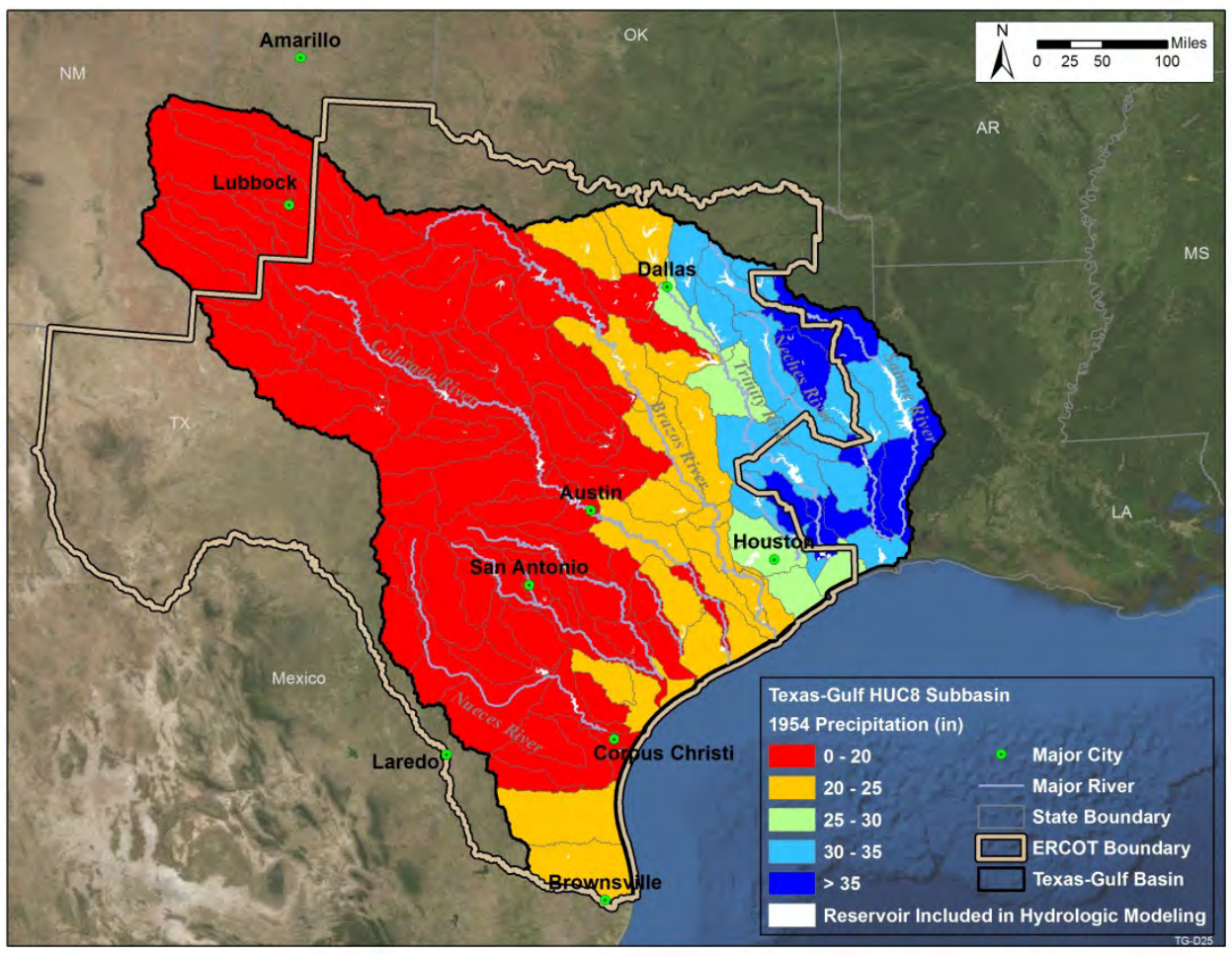

Figure 28. 1954 precipitation at each HUC8 subbasin, based on data interpolated from the GHCN database maintained by the NCDC. 


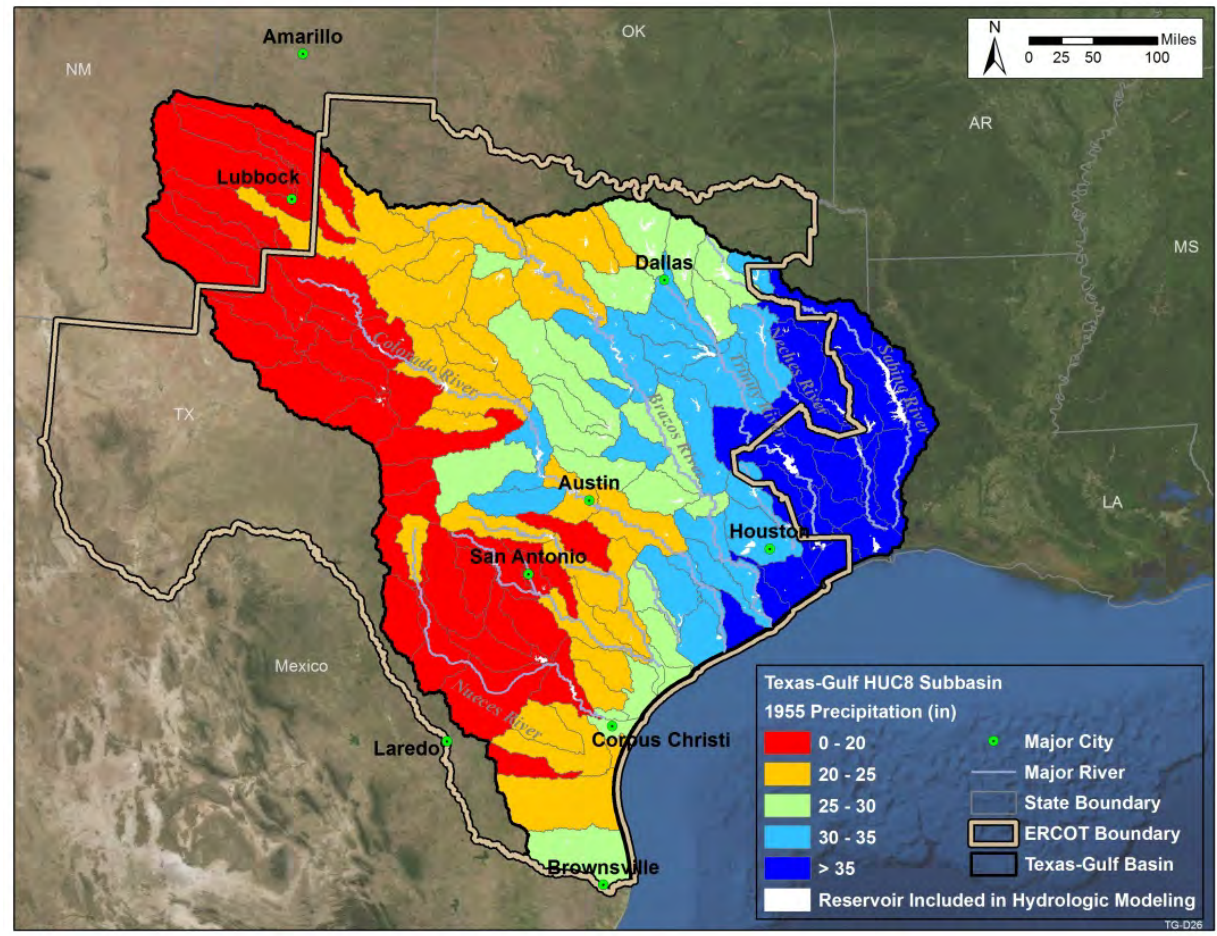

Figure 29. 1955 precipitation at each HUC8 subbasin, based on data interpolated from the GHCN database maintained by the NCDC.

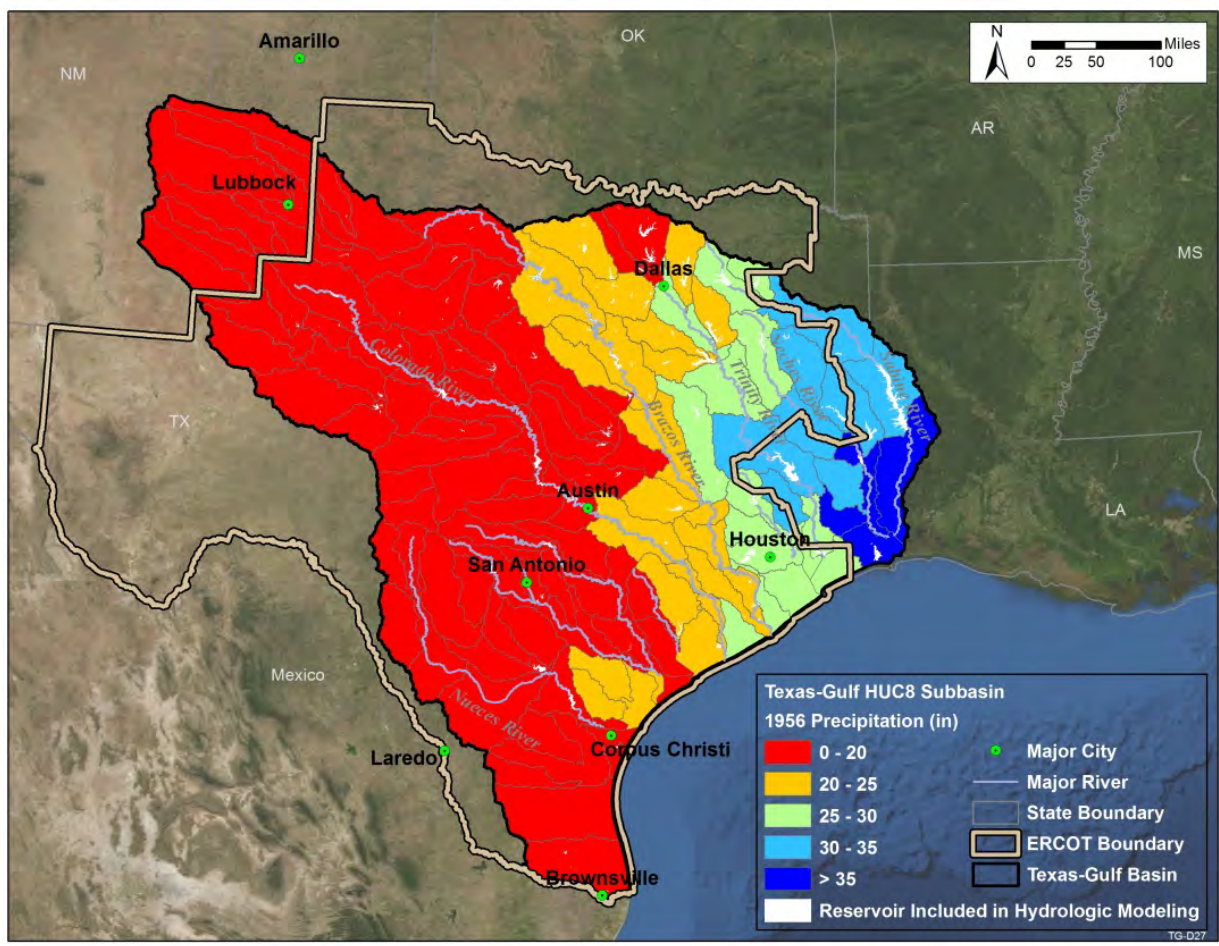

Figure 30. 1956 precipitation at each HUC8 subbasin, based on data interpolated from the GHCN database maintained by the NCDC. 


\subsubsection{Reservoir Storage}

As discussed in Section 4.1.2, the Texas-Gulf SWAT model incorporates 125 reservoirs distributed in 63 HUC8 basins. On the basis of available information on water sources, 43 power plants were identified as using fresh reservoir water. In addition, our power plant database includes nine power plants that receive water from municipal water supply, for which the source of water is unknown. As an initial screening, we assumed that the municipal water supply system would withdraw water from a reservoir if a power plant is within $3 \mathrm{~km}$ of any reservoir. With this assumption, we identified four additional power plants that might be using water from nearby reservoirs. The total number of 37 reservoirs that support the 47 power plants were located by using a geographic information system and analyzed for their storage response to drought events.

The 37 identified reservoirs are distributed over 25 HUC8 basins. For each HUC8 basin with multiple reservoirs, the SWAT model results, which represent the total reservoir storage at the HUC8 basin level, were further divided into a number of storage units corresponding to all of the reservoirs in the basin. A few HUC8 basins have multiple reservoirs. In these HUC8 basins, the monthly storage for each reservoir was calculated on the basis of (1) the simulated total reservoir storage and evaporation at the HUC8 basin level and (2) individual reservoir data relating to reservoir volume, surface area, and water use. The estimate for reservoir storage over time is reasonable for initial screening, although some uncertainties remain regarding detailed reservoir operation and water management, as well as the current scale of the model. Further improvement can be achieved by increasing the model resolution to incorporate detailed reservoir parameters and management data for each of reservoirs, when the information becomes available.

\subsubsection{Validation of Reservoir Results}

To validate the reservoir storage volumes predicted by the model under drought conditions, we collected reservoir storage records provided by the TWDB for 22 of the 37 reservoirs that support power plants. On the basis of reservoir normal storage (or conservative storage) data from the TWDB, the percent of normal storage was calculated for each reservoir. The average and minimum monthly percent of normal storage in drought year 2011 are listed in Table 1. The coefficient of determination $\left(R^{2}\right)$ was also used to evaluate the agreement between the observed and simulated results for 22 reservoirs. The calculated $R^{2}$ values are 0.81 and 0.72 for average and minimum monthly percent of normal storage, respectively. In general, the agreement is reasonable, considering uncertainty in reservoir operations, variation in actual water use in each reservoir, and aggregated effects in model construction at the regional scale.

\subsubsection{Analysis of Drought Year 2011}

Among 22 monitored reservoirs that have reservoir storage data (USGS gauge data), most were impacted by the 2011 drought - resulting in reduced storage in 2011, even though the impact level varied. During 2011, the records show that 7 reservoirs dropped below 55\% of normal storage, 12 reservoirs had storage between $55 \%$ and $75 \%$ of normal, and only 3 reservoirs stayed above $75 \%$ of normal storage. The widely spread reduction of reservoir storage suggests a regional effect of the 2011 drought.

By comparing model output with observation data, we found that the model results can reasonably predict the low-storage reservoirs. Table 2 confirms that all reservoirs ( 7 total) that fell below $50 \%$ of 
normal storage in 2011 (on the basis of observation data), were predicted as below $55 \%$ of normal storage by the model. These reservoirs were most sensitive to the 2011 drought event; had the drought persisted, they might have been at risk for having enough water to support the 7 associated power plants. By examining 11 low-storage reservoirs having both observed and predicted storage data for 2011, we found that the storage reductions were overestimated by the model for 4 out of 11 reservoirs. These 4 reservoirs are not included in Table 2.

In addition to the reservoirs for which we have historical monitoring data, the model predicted that 8 reservoirs had low-storage conditions in 2011. However, because local reservoir management and control tend to mitigate drought effects, these 8 reservoirs need to be evaluated further to confirm their sensitivity to the 2011 drought event.

Figure 31 shows the geographic distribution of the low-storage reservoirs in 2011, with colors representing the minimum monthly percentage of normal storage during 2011. More specifically,

Table 1. Comparison of observed and predicted reservoir data in $2011 .{ }^{a}$

\begin{tabular}{|c|c|c|c|c|c|c|}
\hline \multirow[b]{3}{*}{ Reservoir Name } & \multirow[b]{3}{*}{ HUC8 } & \multirow[b]{3}{*}{ Subbasin } & \multicolumn{4}{|c|}{ Monthly Percent of Normal Storage in 2011} \\
\hline & & & \multicolumn{2}{|c|}{ Average } & \multicolumn{2}{|c|}{ Minimum } \\
\hline & & & Observed & Simulated & Observed & Simulated \\
\hline Addicks Reservoir & 12040104 & 28 & 0 & 5 & 0 & 0 \\
\hline Colorado City, Lake & 12080002 & 99 & 39 & 16 & 32 & 0 \\
\hline Texana, Lake & 12100102 & 66 & 57 & 65 & 36 & 53 \\
\hline Martin Lake & 12010002 & 2 & 56 & 84 & 44 & 47 \\
\hline Lavon Lake & 12030106 & 18 & 67 & 64 & 46 & 55 \\
\hline Whitney, Lake & 12060202 & 40 & 59 & 71 & 50 & 52 \\
\hline Limestone, Lake & 12070103 & 45 & 71 & 71 & 50 & 44 \\
\hline Austin, Lake & 12090205 & 59 & 96 & 77 & 57 & 56 \\
\hline Palo Pinto, Lake & 12060201 & 39 & 77 & 80 & 59 & 60 \\
\hline Arlington, Lake & 12030102 & 14 & 80 & 89 & 62 & 74 \\
\hline Bridgeport, Lake & 12030101 & 13 & 76 & 60 & 62 & 43 \\
\hline Lewisville Lake & 12030103 & 15 & 75 & 85 & 62 & 69 \\
\hline Richland-Chambers Reservoir & 12030108 & 20 & 80 & 78 & 67 & 59 \\
\hline Bardwell Lake & 12030109 & 21 & 85 & 86 & 67 & 66 \\
\hline Graham, Lake & 12060201 & 39 & 83 & 81 & 68 & 60 \\
\hline Granbury, Lake & 12060201 & 39 & 85 & 80 & 69 & 60 \\
\hline Eagle Mountain Lake & 12030101 & 13 & 82 & 59 & 71 & 43 \\
\hline Ray Hubbard, Lake & 12030106 & 18 & 84 & 70 & 73 & 61 \\
\hline Coleto Creek Reservoir & 12100204 & 70 & 86 & 90 & 73 & 68 \\
\hline Mountain Creek Lake & 12030102 & 14 & 93 & 94 & 77 & 79 \\
\hline Lyndon B Johnson, Lake & 12090201 & 57 & 84 & 61 & 83 & 49 \\
\hline Squaw Creek Reservoir & 12060202 & 40 & 100 & 80 & 99 & 61 \\
\hline \multicolumn{3}{|c|}{ Coefficient of Determination $\left(R^{2}\right)$} & \multicolumn{2}{|c|}{$R^{2}=0.81$} & \multicolumn{2}{|c|}{$R^{2}=0.72$} \\
\hline
\end{tabular}

${ }^{a}$ Reservoirs highlighted in red were identified by ERCOT as vulnerable to water supply if the 2011 drought persisted. 
Table 2. Low-storage reservoirs with minimum monthly storage in 2011 below $50 \%$ by observation and 55\% by model prediction. "Oct" stands for "October."

\begin{tabular}{|ll|ccc|cc|}
\hline \multirow{2}{*}{} & & \multicolumn{3}{|c|}{ Monthly Percent of Normal Storage in 2011} \\
\cline { 3 - 7 } Reservoir Name & HUC8 & Oct & Avg. & Min. & Simulated \\
\hline Addicks Reservoir & 12040104 & 0 & 0 & 0 & 5 & Min. \\
Colorado City, Lake & 12080002 & 33 & 39 & 32 & 16 & 0 \\
Texana, Lake & 12100102 & 42 & 57 & 36 & 65 & 53 \\
Martin Lake & 12010002 & 44 & 56 & 44 & 84 & 47 \\
Lavon Lake & 12030106 & 48 & 67 & 46 & 64 & 55 \\
Whitney, Lake & 12060202 & 51 & 59 & 50 & 71 & 52 \\
Limestone, Lake & 12070103 & 54 & 71 & 50 & 71 & 44 \\
\hline
\end{tabular}

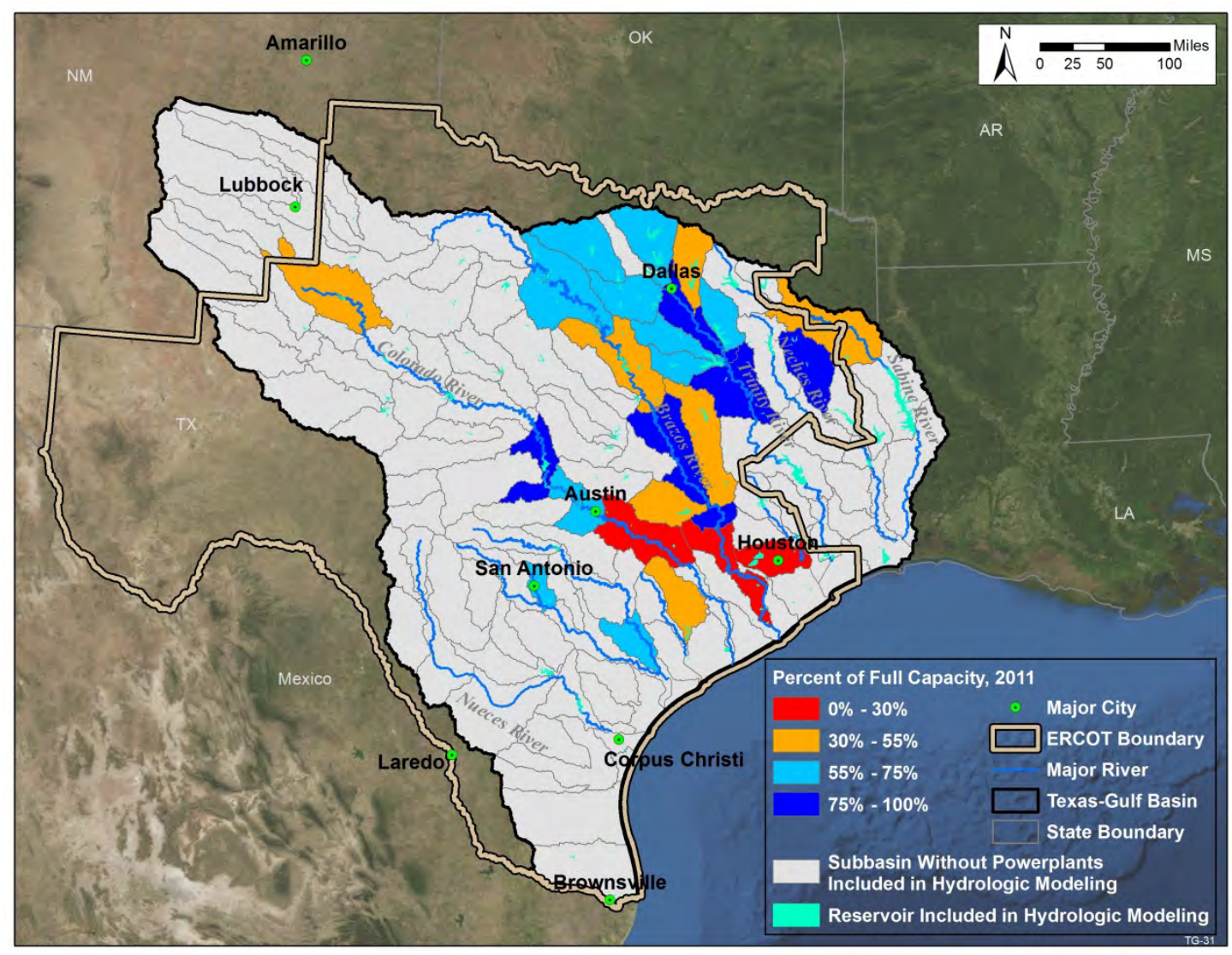

Figure 31. The distribution of reservoir storage supporting power plants in HUC8 basins. Percentage at each HUC8 basin represents the reservoir with the lowest storage in 2011.

when multiple reservoirs occur in an HUC8 basin, Figure 31 indicates the minimum monthly percentage of normal storage for the reservoir that had the lowest percentage storage. The lowstorage reservoirs are located mainly in HUC8 basins near Houston and Austin.

In all, 15 low-storage reservoirs were identified on the basis of observed and predicted reservoir storage in 2011. These reservoirs provide water supply for 18 power plants, with generation capacity of $16,898 \mathrm{MW}$. 


\subsubsection{Analysis of Drought Year 2022}

The 10 predicted low-storage reservoirs in 2022 (Table 3) are identified as sensitive to the projected 2022 drought pattern, which is characterized by significant reduction in precipitation in the eastern part of the Texas-Gulf river basin and increased precipitation in the western part of the basin (Figure 26). Because of the change in climate pattern in 2022 compared to 2011, the reservoirs that are sensitive in 2022 are different from those in 2011 . The identified low-storage reservoirs support 11 power plants with generation capacity of 10,169 MW - less than the affected capacity in the 2011 drought. Figure 32 displays the geographic distribution of the low-storage reservoirs for the simulated drought for 2022. The potentially affected reservoirs are located in areas near Dallas and surrounding Houston.

Table 3. Reservoirs predicted to be at low-storage levels ( $<55 \%$ normal storage) during the 2022 drought scenario.

\begin{tabular}{|c|c|c|c|}
\hline \multirow[b]{2}{*}{ Reservoir Name } & \multirow[b]{2}{*}{ HUC8 } & \multicolumn{2}{|c|}{$\begin{array}{c}\text { Simulated Monthly Percent of } \\
\text { Normal Storage in } 2022\end{array}$} \\
\hline & & Average & Lowest \\
\hline Addicks Reservoir & 12040104 & 3 & 0 \\
\hline Martin Lake & 12010002 & 47 & 12 \\
\hline Eagle Mountain Lake & 12030101 & 38 & 15 \\
\hline Bridgeport, Lake & 12030101 & 39 & 16 \\
\hline Trinidad Lake & 12030105 & 85 & 20 \\
\hline Richland-Chambers Reservoir & 12030108 & 52 & 35 \\
\hline Smithers Lake & 12070104 & 85 & 44 \\
\hline Texana, Lake & 12100102 & 70 & 51 \\
\hline Bardwell Lake & 12030109 & 73 & 52 \\
\hline Lewisville Lake & 12030103 & 64 & 52 \\
\hline
\end{tabular}

\subsubsection{Analysis of Multiple-Year Drought Years (1950-1957)}

For the multiple-year drought (1950-1957) scenario, the drought started in September 1950 and ended in May 1957. This represents Texas' "drought of record" used for state water planning. To explore impacts of the future scenario under 1950-1957 climate conditions, we incorporated estimated future water demand (Section 2) into the model for the scenario. As shown in Figure 33, the reservoir storage projected by the model declines gradually, with a few minor recoveries, because of the slightly increased precipitation in spring 1952, 1953, and 1955. The overall reservoir storage reaches the lowest level in the last year (1956) of the multiyear drought scenario. The gradual decrease in reservoir storage over several years during the drought event demonstrates that reservoir storage prevents immediate water shortage from a short-term drought and mitigates the impact of drought effectively. However, in a prolonged drought, the reservoirs' effectiveness in drought mitigation gradually diminishes with time. The model predicts (on the basis of minimum monthly storage) that 20 reservoirs would have storage less than 55\% of normal in 1956, after $5 \mathrm{yr}$ of drought. Among these 20 reservoirs, 8 were also found to be sensitive to the 2011 drought. As an initial screening for potential impacts of long-term drought on water availability in reservoirs, these lowstorage reservoirs are listed in Table 4. The shaded rows indicate reservoirs that were also at less than $55 \%$ of full storage for 2011, as predicted (and/or observed). 


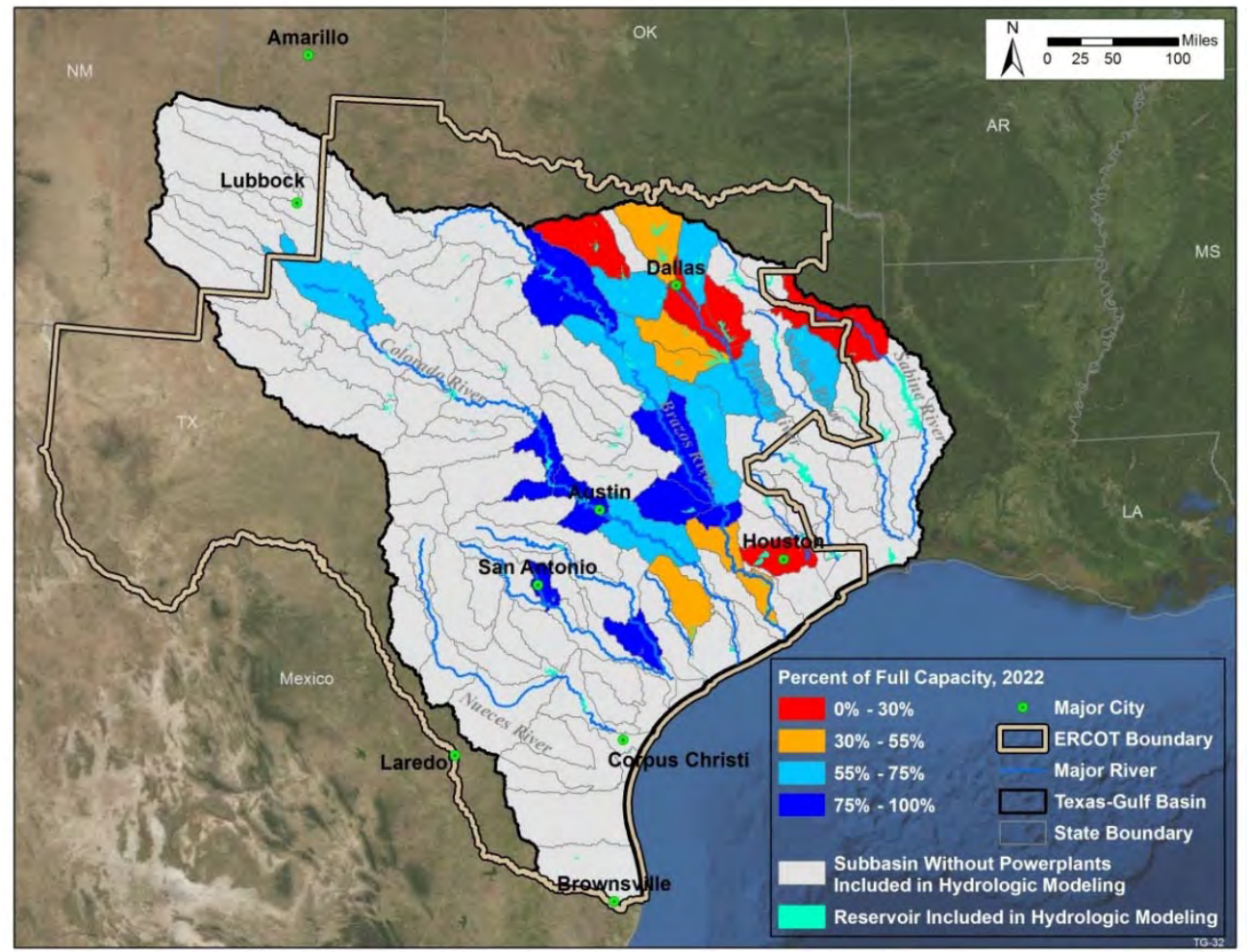

Figure 32. The distribution of reservoir storage supporting power plants in HUC8 basins. The percentage at each HUC8 basin represents the reservoir with the lowest storage in 2022.

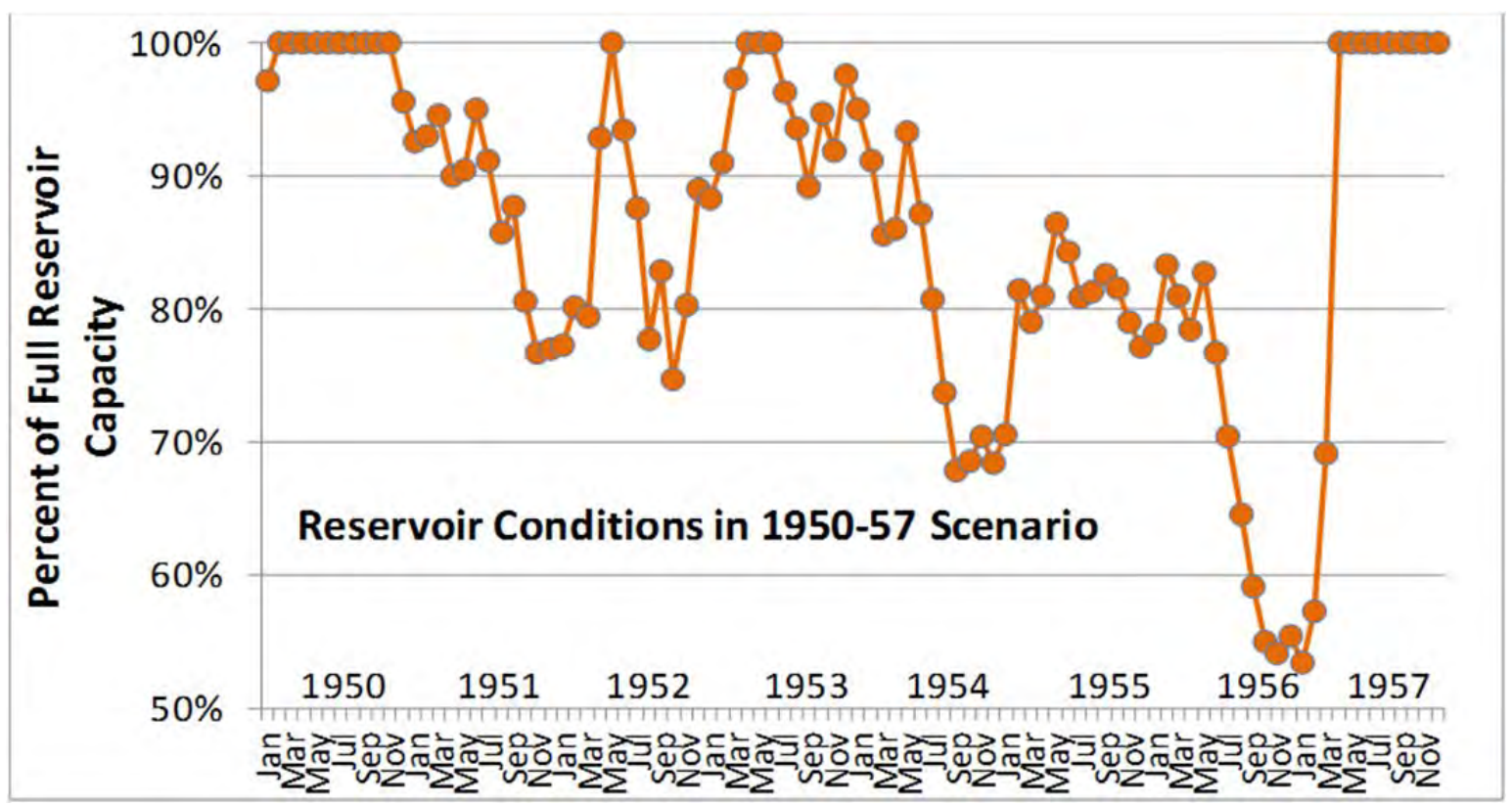

Figure 33. Monthly overall reservoir capacity simulated for multiple-year drought under the 1950-1957 scenario. The overall reservoir capacity aggregates capacities for all reservoirs in the Texas-Gulf river basin. 
Table 4. Reservoirs with minimum monthly storage below 55\%, as predicted for 1956 scenario during the multiple-year drought event (1950-1957) in the Texas-Gulf river basin. The shaded rows indicate reservoirs that were also at less than $55 \%$ of full storage for 2011 , as predicted (and/or observed).

\begin{tabular}{|c|c|c|c|}
\hline \multirow[b]{2}{*}{ Reservoir Name } & \multirow[b]{2}{*}{ HUC8 } & \multicolumn{2}{|c|}{$\begin{array}{c}\text { Simulated Monthly Percent of } \\
\text { Normal Storage in } 1956 \text { (1950- } \\
1957 \text { scenario) }\end{array}$} \\
\hline & & Average & Lowest \\
\hline Calaveras Lake & 12100301 & 1 & 0 \\
\hline Colorado City, Lake & 12080002 & 1 & 0 \\
\hline Victor Braunig Lake & 12100301 & 1 & 0 \\
\hline Eagle Mountain Lake & 12030101 & 1 & 0 \\
\hline Bridgeport, Lake & 12030101 & 1 & 0 \\
\hline Addicks Reservoir & 12040104 & 6 & 0 \\
\hline Austin, Lake & 12090205 & 32 & 19 \\
\hline Richland-Chambers Reservoir & 12030108 & 32 & 26 \\
\hline Lewisville Lake & 12030103 & 45 & 35 \\
\hline Smithers Lake & 12070104 & 81 & 36 \\
\hline Trinidad Lake & 12030105 & 90 & 38 \\
\hline Lavon Lake & 12030106 & 53 & 44 \\
\hline Arlington, Lake & 12030102 & 52 & 46 \\
\hline $\begin{array}{l}\text { Cedar Creek Reservoir } \\
\text { Colorado }\end{array}$ & 12090301 & 74 & 46 \\
\hline Bastrop, Lake & 12090301 & 78 & 50 \\
\hline Ray Hubbard, Lake & 12030106 & 59 & 51 \\
\hline Mountain Creek Lake & 12030102 & 58 & 52 \\
\hline Texana, Lake & 12100102 & 66 & 53 \\
\hline Martin Lake & 12010002 & 86 & 54 \\
\hline Walter E Long, Lake & 12090301 & 81 & 54 \\
\hline
\end{tabular}

Near the end of multiyear drought event (1956), more reservoirs were predicted to fall into the lowstorage category than in the 2011 drought. The 26 power plants currently supported by these reservoirs have generation capacity of $21,734 \mathrm{MW}$. Figure 34 shows the locations of HUC8 basins that host the reservoirs with storage levels below $55 \%$ of normal during 1956 . These low-storage reservoirs are distributed widely in several areas near Dallas, Houston, Austin, San Antonio, and south of Lubbock. As shown in Figure 6, most of these areas are expected to experience a significant increase in water consumptive use from 2010 to 2030. The increased future water demand incorporated in this long-term drought scenario intensifies the drought effect.

In considerations of the ability of the Texas-Gulf SWAT model to mimic observations for the 2011 drought, the predicted results for the 1950-1957 multiple-year drought should identify most of the reservoirs at risk for low storage. However, for some reservoirs modeled as having low (<55\%) storage, the reduction in reservoir storage in response to the drought might have been overestimated. Therefore, these simulated results for 1956 can be used as a screening tool for subsequent evaluation. 


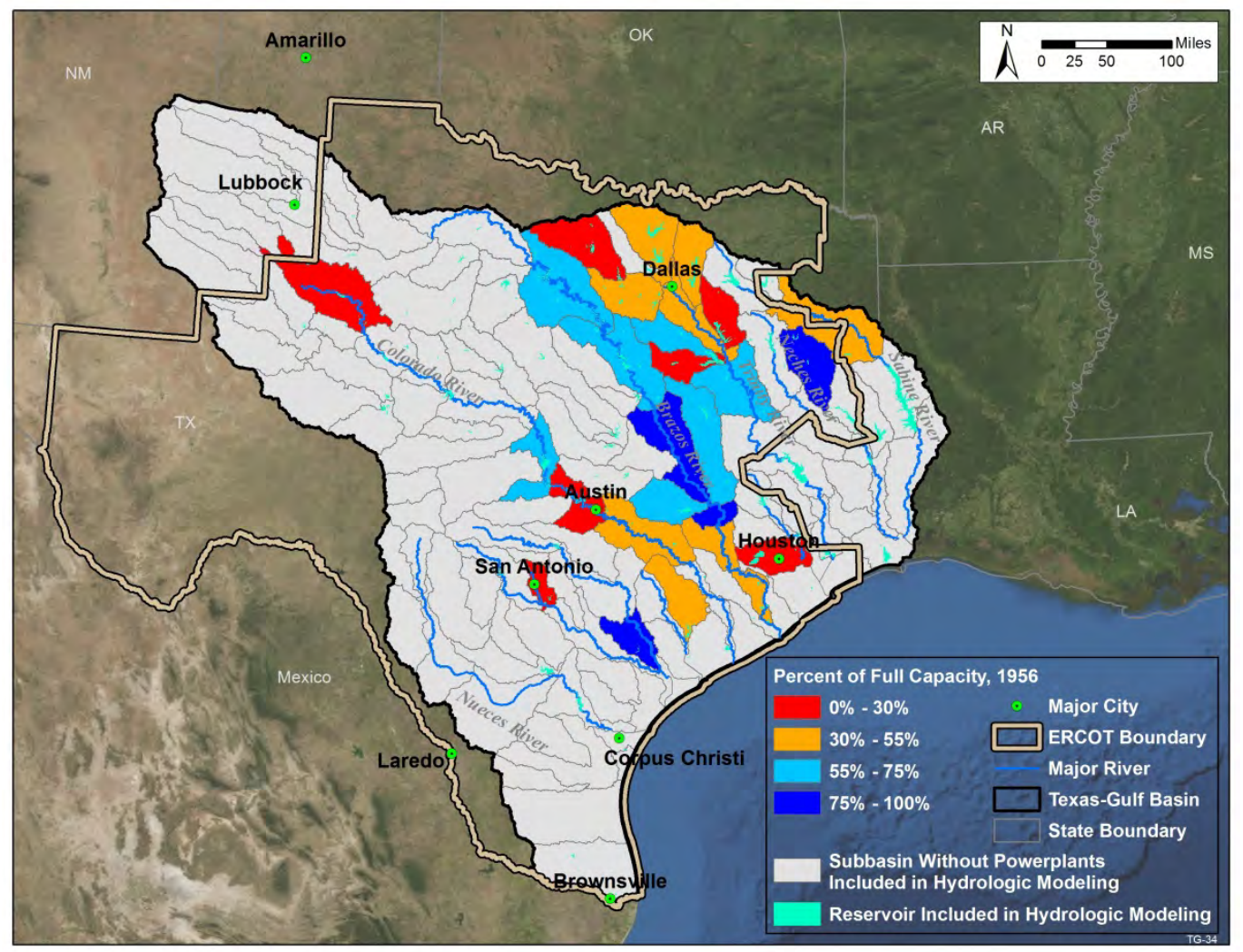

Figure 34. The distribution of predicted reservoir storage that would provide water supply to power plants in HUC8 basins under a long-term drought with assumed 2030 water use. Percentage for each HUC8 basin represents the reservoir with the lowest storage in 1956, for the multiple-year drought (1950-1957).

\subsection{Water Availability}

The simulated results provide two measures for water availability: (1) the amount of water contributing to streams (water yield) through surface runoff, interflow, and shallow groundwater seepage in each HUC8 subbasin and (2) stream flow at the outlet of each HUC8 subbasin, resulting from flow accumulated from all upstream HUC8 subbasins, plus abstraction of surface water in the subbasin for various purposes of water supply. The former reflects the ability of the given watershed to generate water to streams, while the latter represents water availability in a stream at a given location, after accumulation of stream flows and water withdrawals for all uses.

Figure 35 shows dynamic changes in precipitation as the model input and evapotranspiration, water yield, and stream flow predicted by the Texas-Gulf SWAT model in 2020-2030. The precipitation varies from 26 in. to 62 in., while evapotranspiration is less variable - within a range of 23-31 in., resulting in relative high variation in water yield and stream flow. The overall stream flow in the Texas-Gulf river basin is consistently lower than water yield because of water withdrawal for human activities, as well as transmission loss to groundwater through stream routing. Under the 2022 drought scenario, the Texas-Gulf river basin would receive the lowest precipitation (25.6 in.), resulting in the least water available in streams, water yield (4.1 in.), and flow (2.0 in.) in 2020-2030 (Figure 35). 


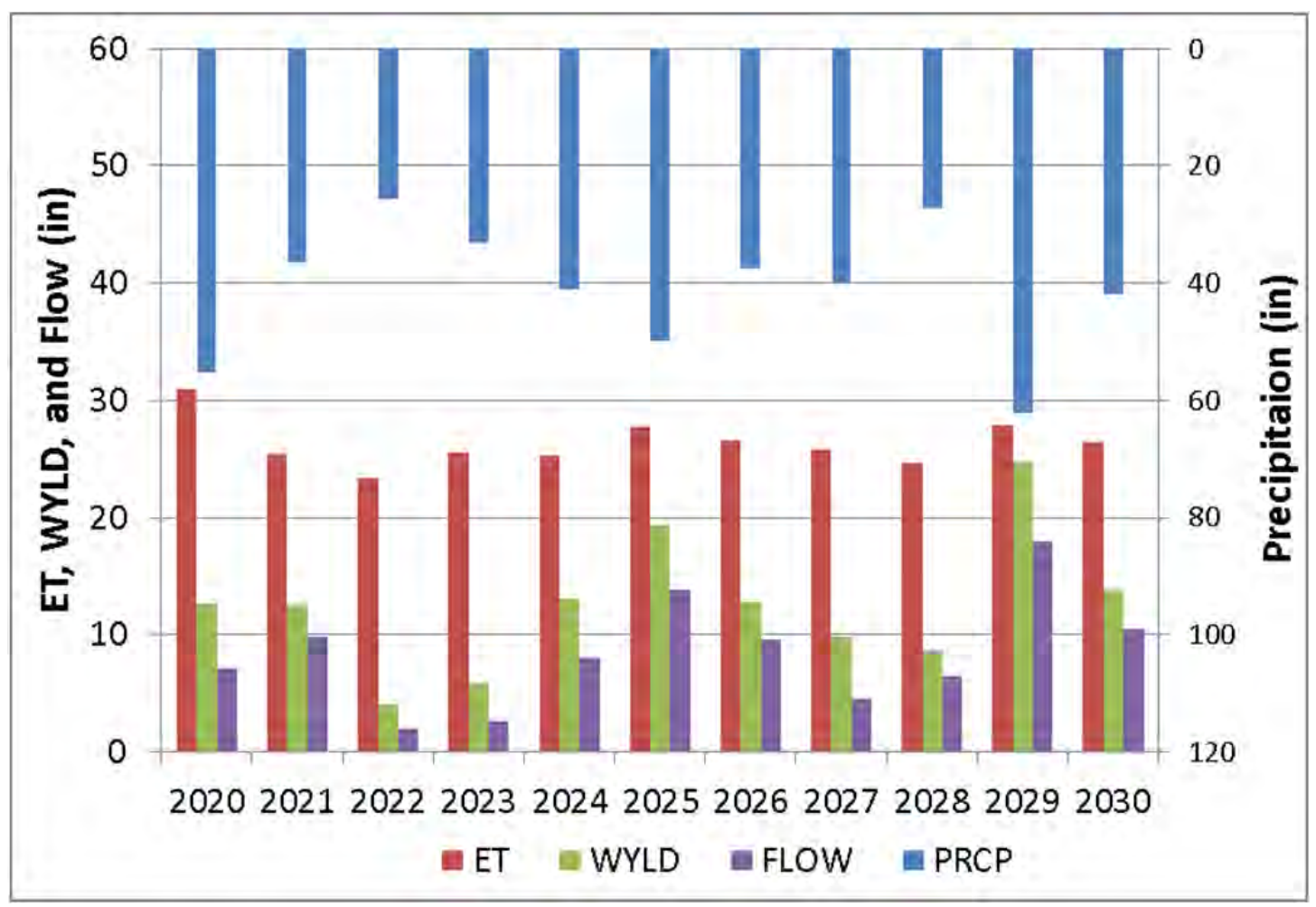

Figure 35. Predicted evapotranspiration (ET), water yield (WYLD), stream flow (FLOW) by the TexasGulf SWAT model, with precipitation (PRCP) projected by the GFDL model for the SRES A2 emission scenario in 2020-2030 for the Texas-Gulf river basin.

It is useful to compare water availability in the 2011 baseline drought event with both the projected water availability in the single-year drought (2022) during the time span 2020-2030 and the potential multiple-year drought (1950-1957). Figure 36 shows the percent change in the amount of water "produced" in each HUC8 basin that contributes to streams in the projected 2022 drought year, versus the SWAT model results for 2011. Water "produced" (water yield) is roughly equal to precipitation minus evapotranspiration; it also reflects net changes caused by change in soil moisture and contributions to groundwater (aquifers). Figure $\mathbf{3 7}$ indicates the percentage change in stream flow at the HUC8 basin outlet from drought year 2011 to drought year 2022.

As discussed in Section 4.3.1, potential drought year 2022 (projected during 2021-2030 under the SRES A2 emission scenario) represents a different precipitation pattern from past drought events (including 2011 and 1954-1956). The 2022 pattern is characterized by low precipitation (< 25 in.) in the eastern half of the Texas-Gulf river basin and moderate precipitation (25-30 in.) in the western half (Figure 26), while past severe drought events demonstrated extremely low precipitation ( $<20$ in.) in the western Texas-Gulf river basin and high precipitation (>30 in.) in the southeastern basin (Figure $\mathbf{2 7}$ and Figure 30). The difference in the drought pattern results in significant reduction in water yield and stream flow in the eastern basin from 2011 to 2022 (Figure 36 and Figure 37). The decrease in water availability in the eastern Texas-Gulf river basin could affect reservoirs and associated ERCOT thermal power generation units in the area. The most affected reservoirs, as predicted by the model, are in a few HUC8 basins near Dallas, with one in Houston (Figure 32). Although the eastern Texas-Gulf river basin, where many reservoirs are located, would be greatly affected by this projected drought pattern in 2022, the overall number of resulting low-storage reservoirs is less in 2022 than in the 2011 and 1956 droughts. The impact of extremely low 
precipitation in the western Texas-Gulf river basin could be evaluated for the drought pattern on the basis of past drought events.

For the multiple-year drought, water availability decreases in later years (1954, 1955, and 1956). Figure 38, Figure 39, and Figure 40 illustrate the percent change in the amount of surface water produced from HUC8 basins in 1954, 1955, and 1956, respectively, compared to the 2011 drought year. Figure 41, Figure 42, and Figure $\mathbf{4 3}$ show the percent change in stream flow at each HUC8 basin outlet in 1954, 1955, and 1956, respectively, versus the baseline drought in 2011. Although the precipitation pattern is similar in 2011 and 1954-1956, some variation in extent and severity of drought are apparent. The model predictions indicate that more HUC8 basins have less water availability and that low-availability basins are more widely spread in 1956 than in 2011. The reductions of water availability may result from accumulated effects of multiple years of drought and increased level of water use, as projected for 2030. The areas with decreasing water availability are mainly located in the southern (near Corpus Christi and San Antonio), northwestern (south of Lubbock), and northern (Dallas) portions of the Texas-Gulf river basin (Figure $\mathbf{4 0}$ and Figure 43).

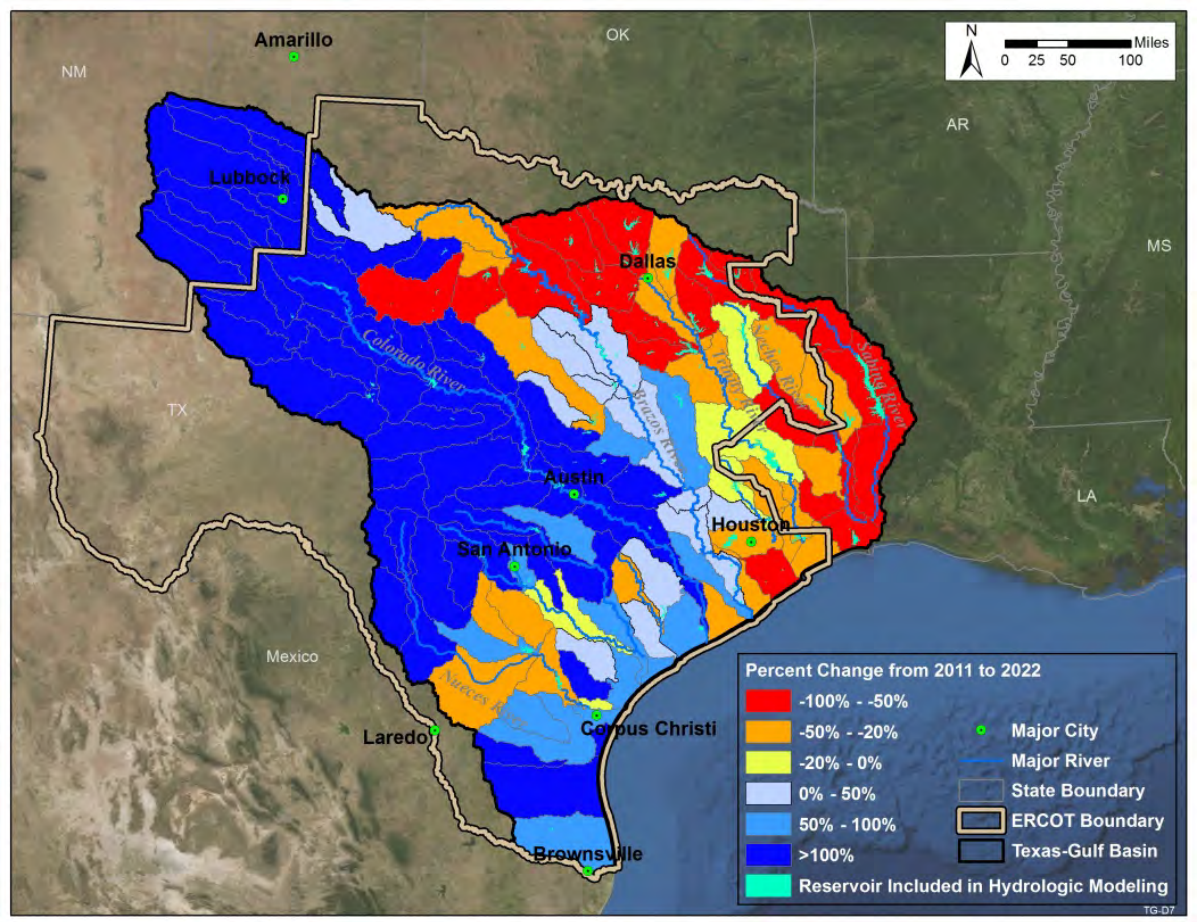

Figure 36. Projected change in amount of surface water yield from HUC8 basins for 2011 versus the single-year drought scenario in 2022. A negative value indicates that an HUC8 basin contributes less water to stream flow in 2022 than in 2011, and vice versa. 


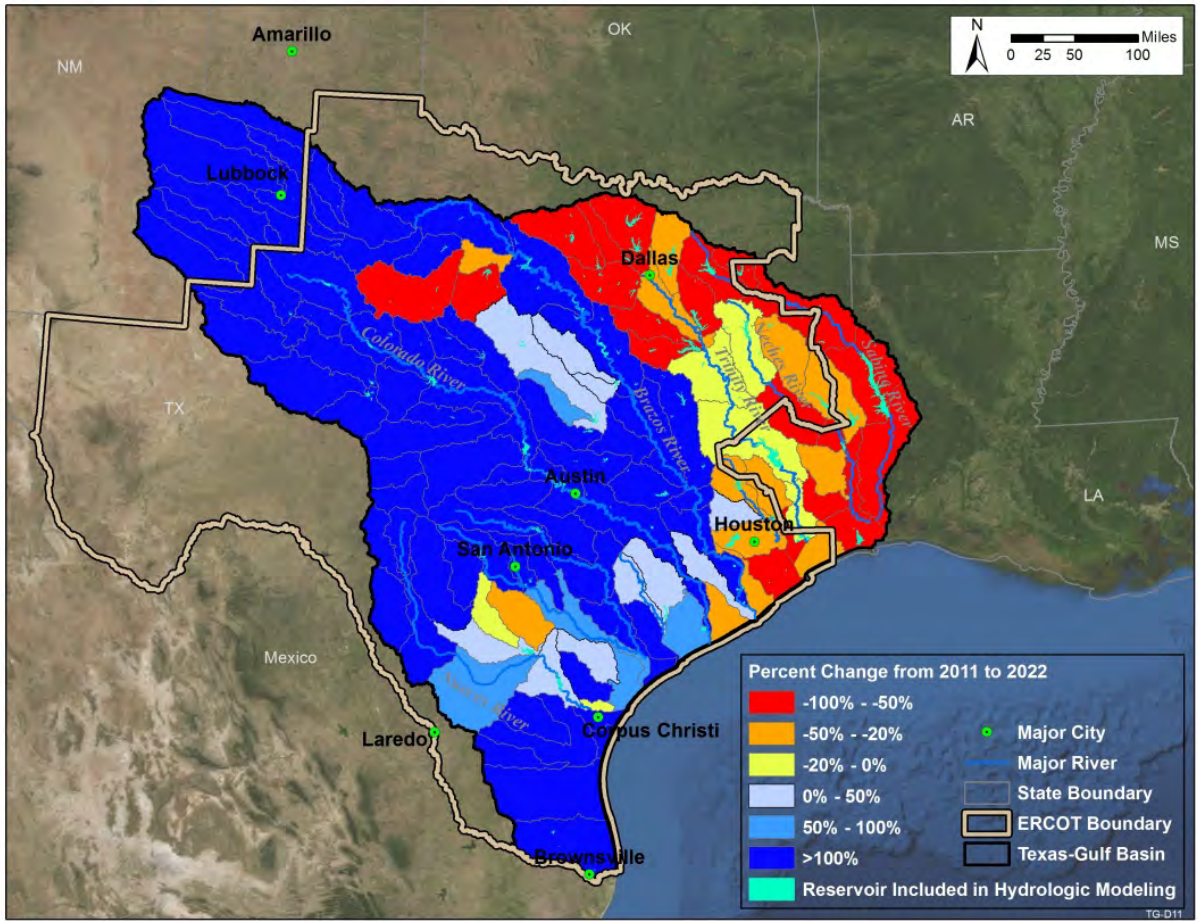

Figure 37. Projected change in stream flow in HUC8 basins from 2011 to the single-year drought scenario in 2022. A negative value indicates that 2022 has less stream flow (at the end of the HUC8 basin) than 2011, and vice versa.

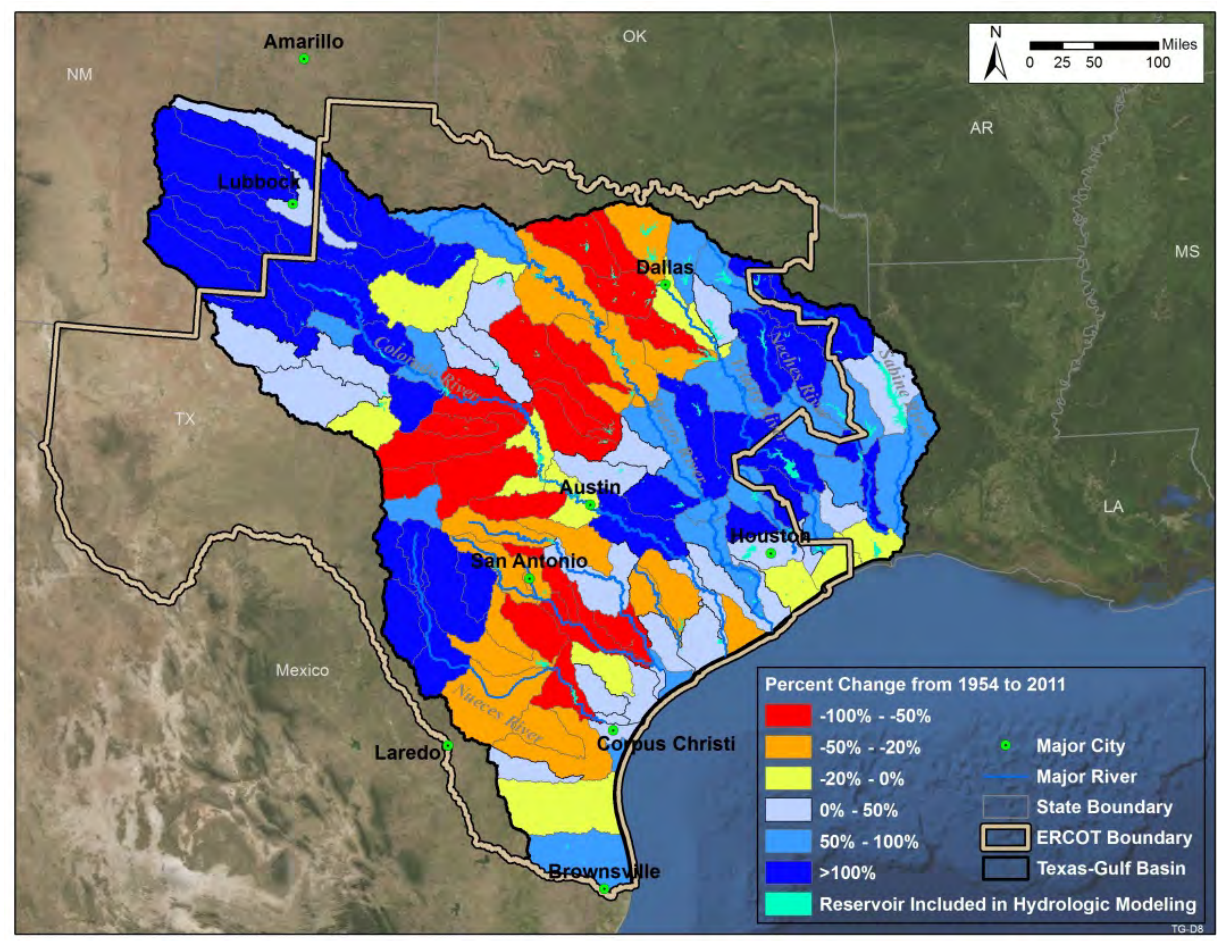

Figure 38. Projected change in amount of surface water generated in HUC8 basins from 2011 to 1954, for the multiple-year drought (1950-1957). A negative value indicates that an HUC8 basin contributes less water to stream flow in 1954 than in 2011, and vice versa. 


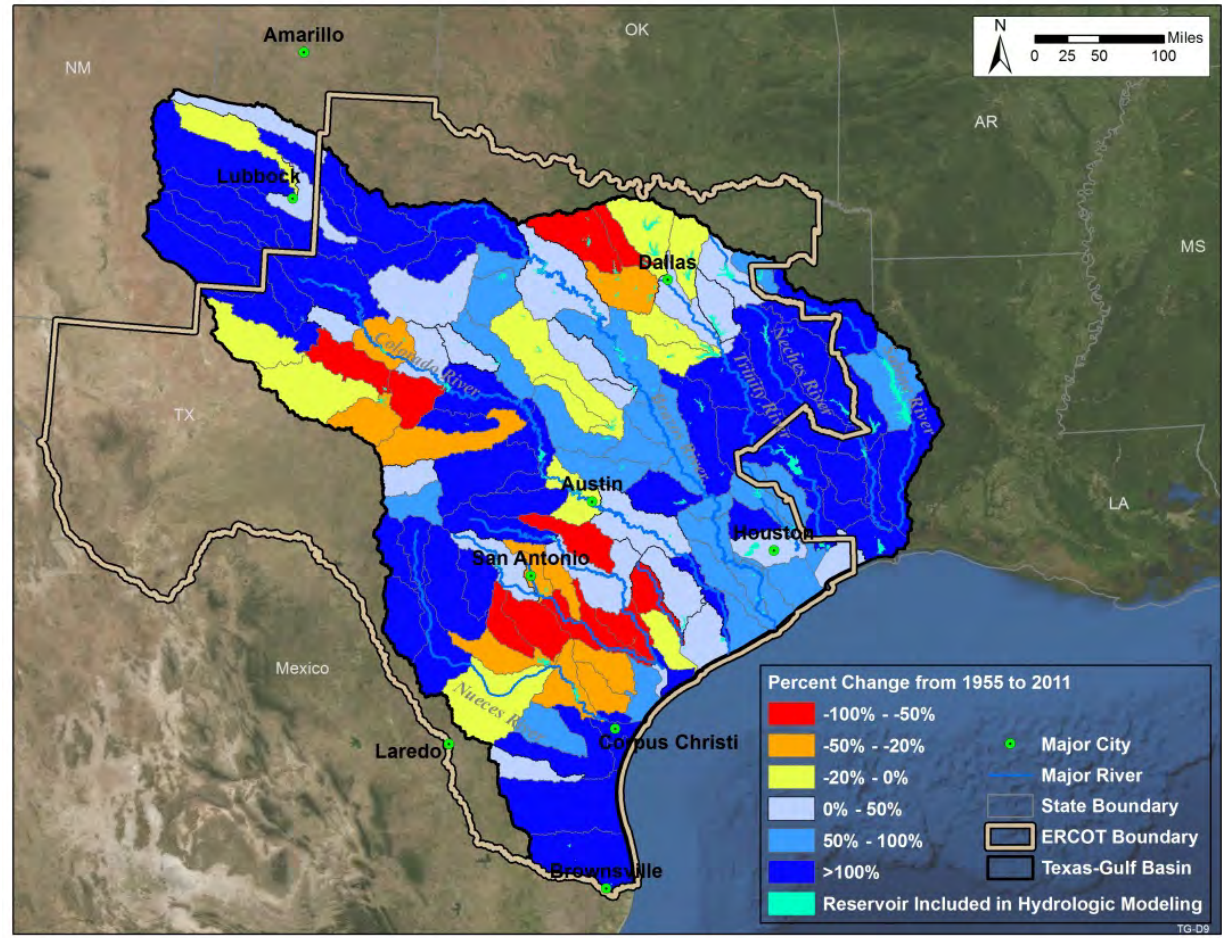

Figure 39. Projected change in amount of surface water generated in HUC8 basins from 2011 to 1955, for the multiple-year drought (1950-1957). A negative value indicates that a HUC8 basin contributes less water to stream flow in 1955 than in 2011, and vice versa.

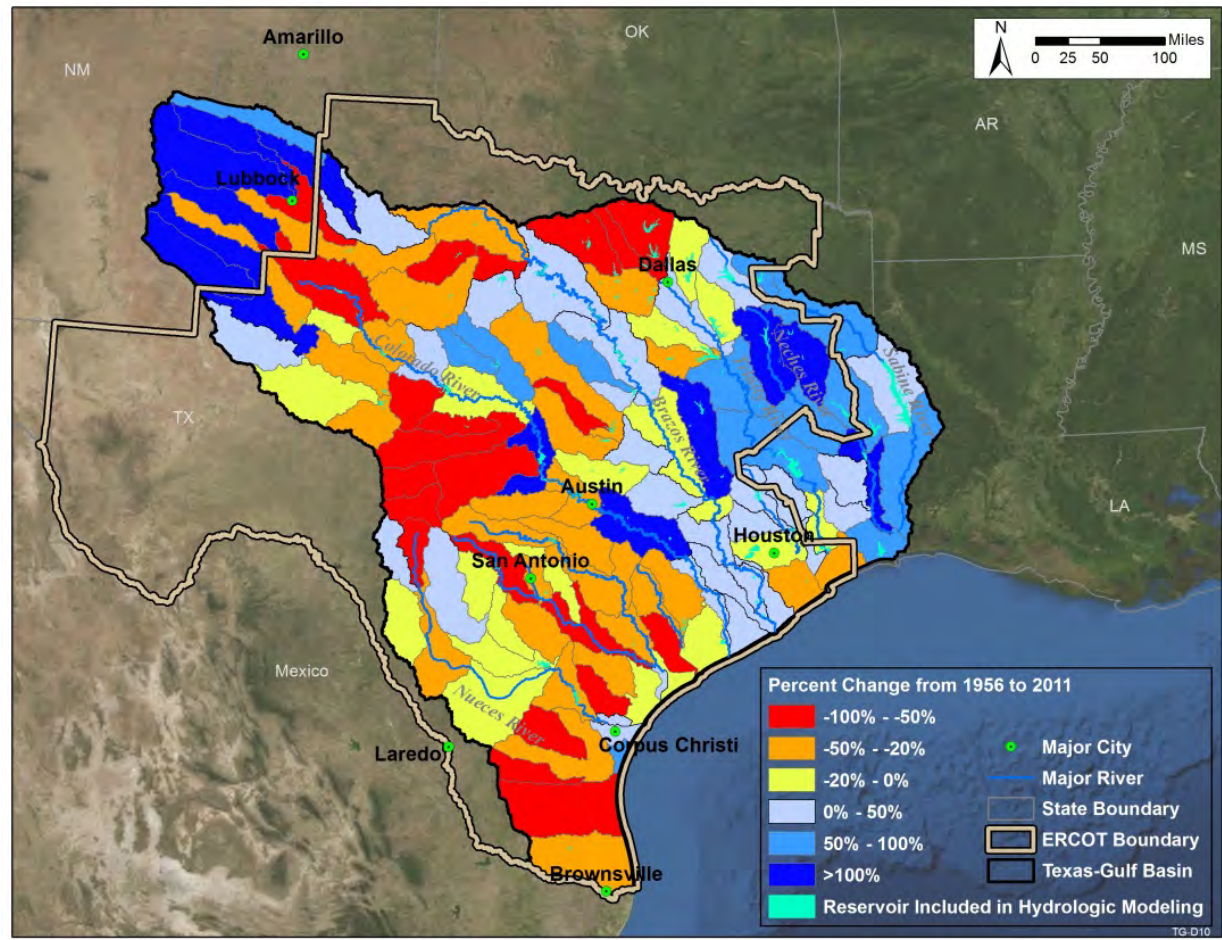

Figure 40. Projected change in amount of surface water generated in HUC8 basins from 2011 to 1956, for the multiple-year drought (1950-1957). A negative value indicates that an HUC8 basin contributes less water to stream flow in 1956 than in 2011 , and vice versa. 


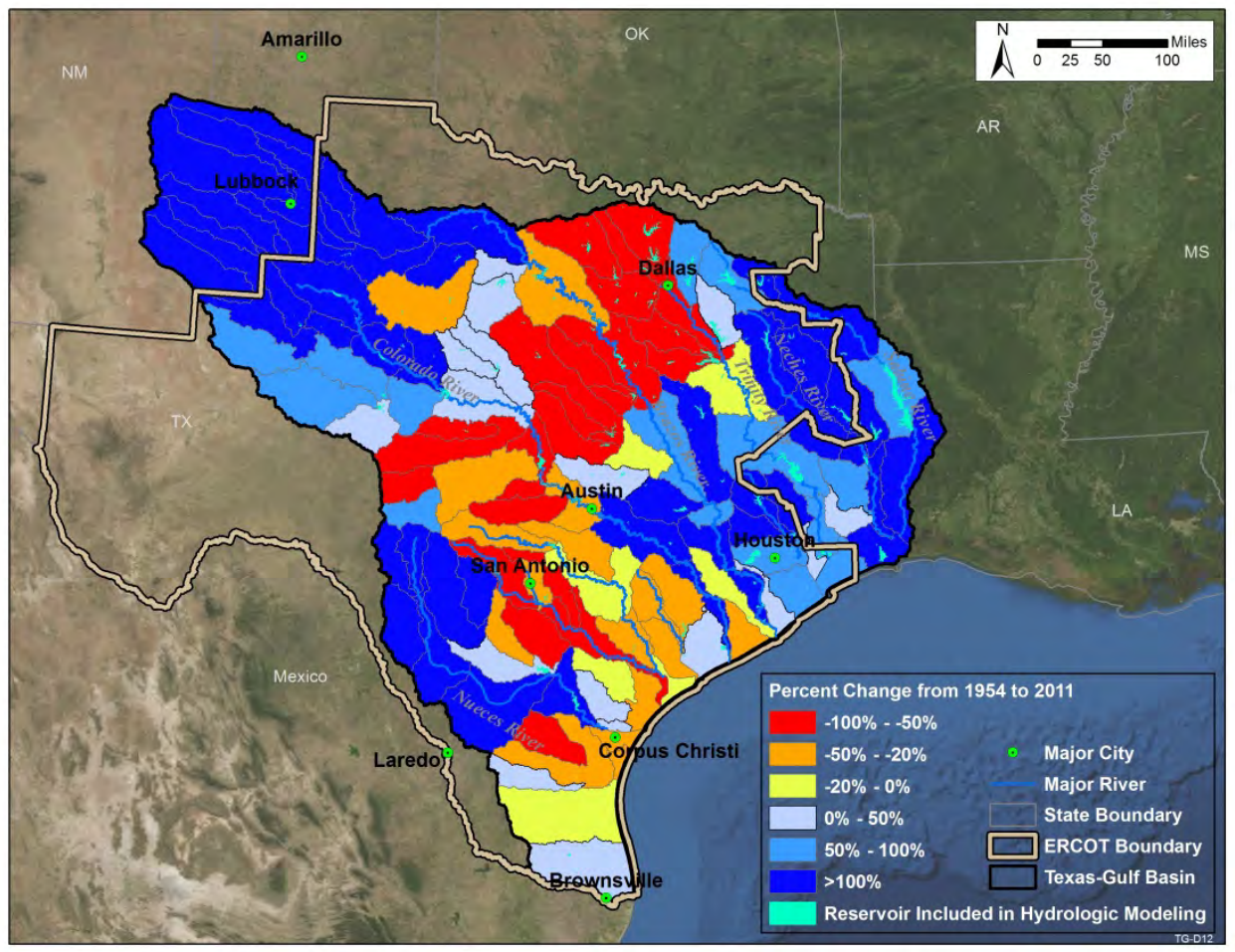

Figure 41. Projected change in amount of stream flow at the HUC8 basin outlets from 2011 to 1954, for the multiple-year drought (1950-1957). A negative value indicates less stream flow at an HUC8 basin in 1954 than in 2011, and vice versa.

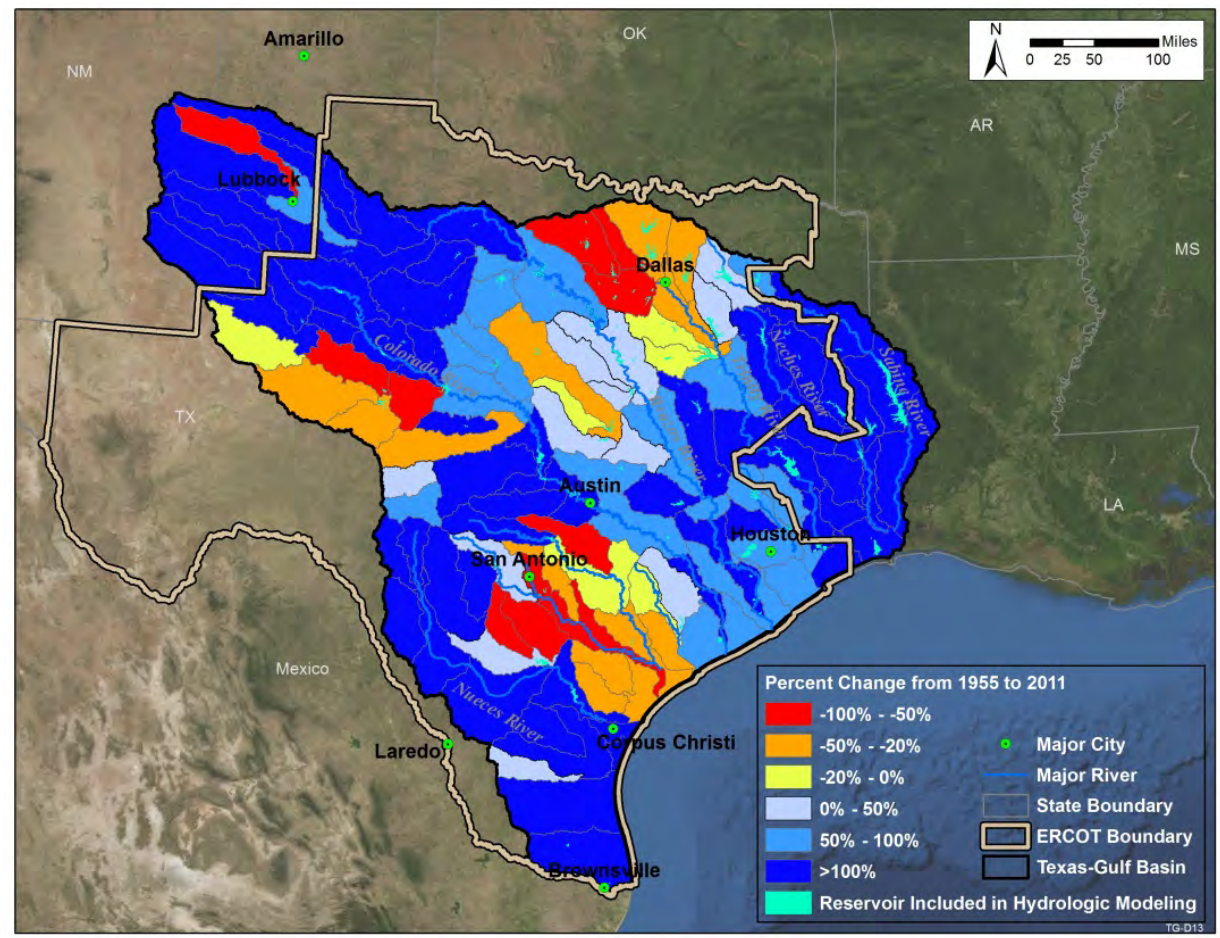

Figure 42. Projected change in amount of stream flow at the HUC8 basin outlets from 2011 to 1955, for the multiple-year drought (1950-1957). A negative value indicates less stream flow at an HUC8 basin in 1955 than in 2011, and vice versa. 


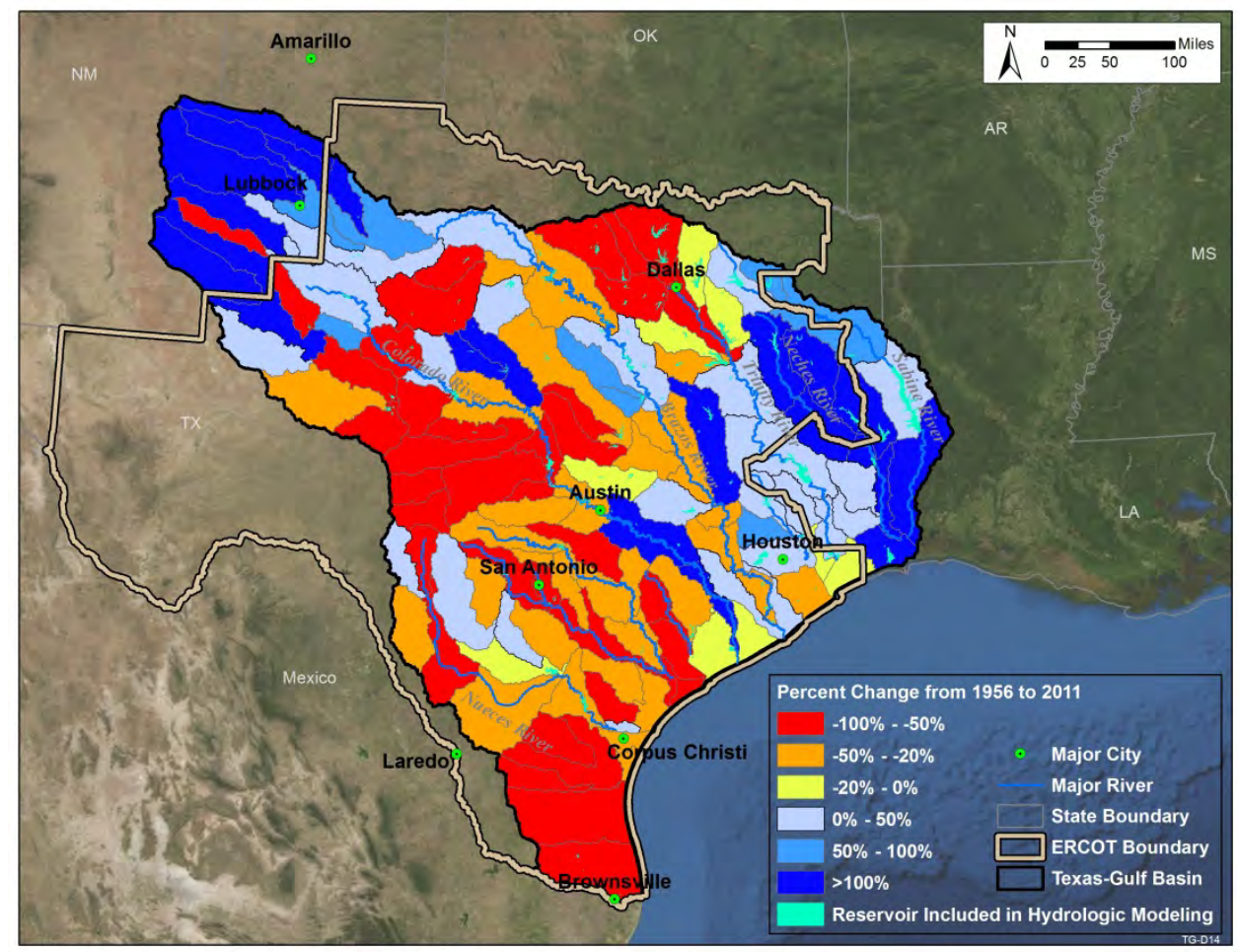

Figure 43. Projected change in amount of stream flow at the HUC8 basin outlets from 2011 to 1956, for the multiple-year drought (1950-1957). A negative value indicates less stream flow at an HUC8 basin in 1956 than in 2011, and vice versa.

\subsection{Water Use versus Water Availability}

We roughly evaluated the drought vulnerability of the HUC8 basins by using the following two metrics:

$$
\begin{gathered}
\text { M1 }(\%)=\frac{\text { Water uses from the source of surface water }}{\text { Amount of water contributing to streams }} \\
\text { Water uses from the source of surface water }
\end{gathered}
$$

If $\mathrm{M} 1$ or $\mathrm{M} 2$ is greater than $50 \%$, these HUC8 basins will be potentially vulnerable to drought. Figure 44 and Figure 45 plot M1 and M2, respectively, for each HUC8 basin for the 2022 single-year drought. These two figures indicate that several basins near Dallas and Houston would have potential vulnerabilities in 2022.

To evaluate the potential impacts of mutiple-year drought, M1 and M2 were estimated for the worst year (1956) of the long-term drought (1950-1957). The spatial distributions of M1 and M2 are shown in Figure 46 and Figure 47, respectively. Toward the last year (1956) of the long-term drought (19501957), more HUC8 basins are projected to be vulnerable than for the single-year drought (2022; Figure 44 and Figure 45). The vulnerable HUC8 basins are near Dallas, Houston, Austin, San Antonio, Brownsville, and Lubbock. Most of these areas are projected to have significantly increased water demand in 2030, except for Brownsville and Lubbock (Figure 6). The distribution of low-storage reservoirs predicted for 1956 (Figure 34) is also consistent with these vulnerable HUC8 basins. 


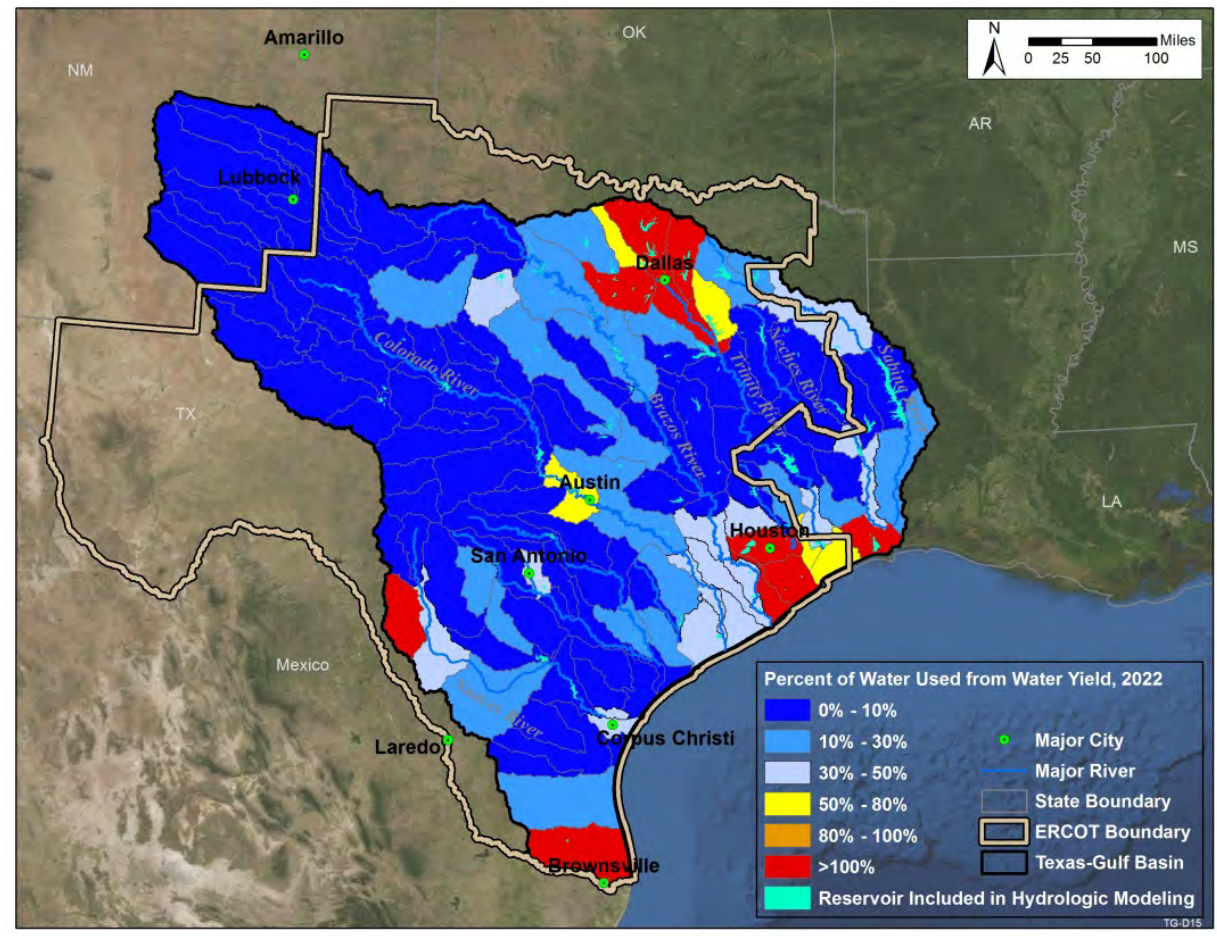

Figure 44. Indication of the M1 criterion of water use versus the amount of surface water generated from HUC8 basins in the single-year drought scenario (2022) of the time span 2021-2030. Basins with M1 > 50\%, as indicated here, could be vulnerable to drought.

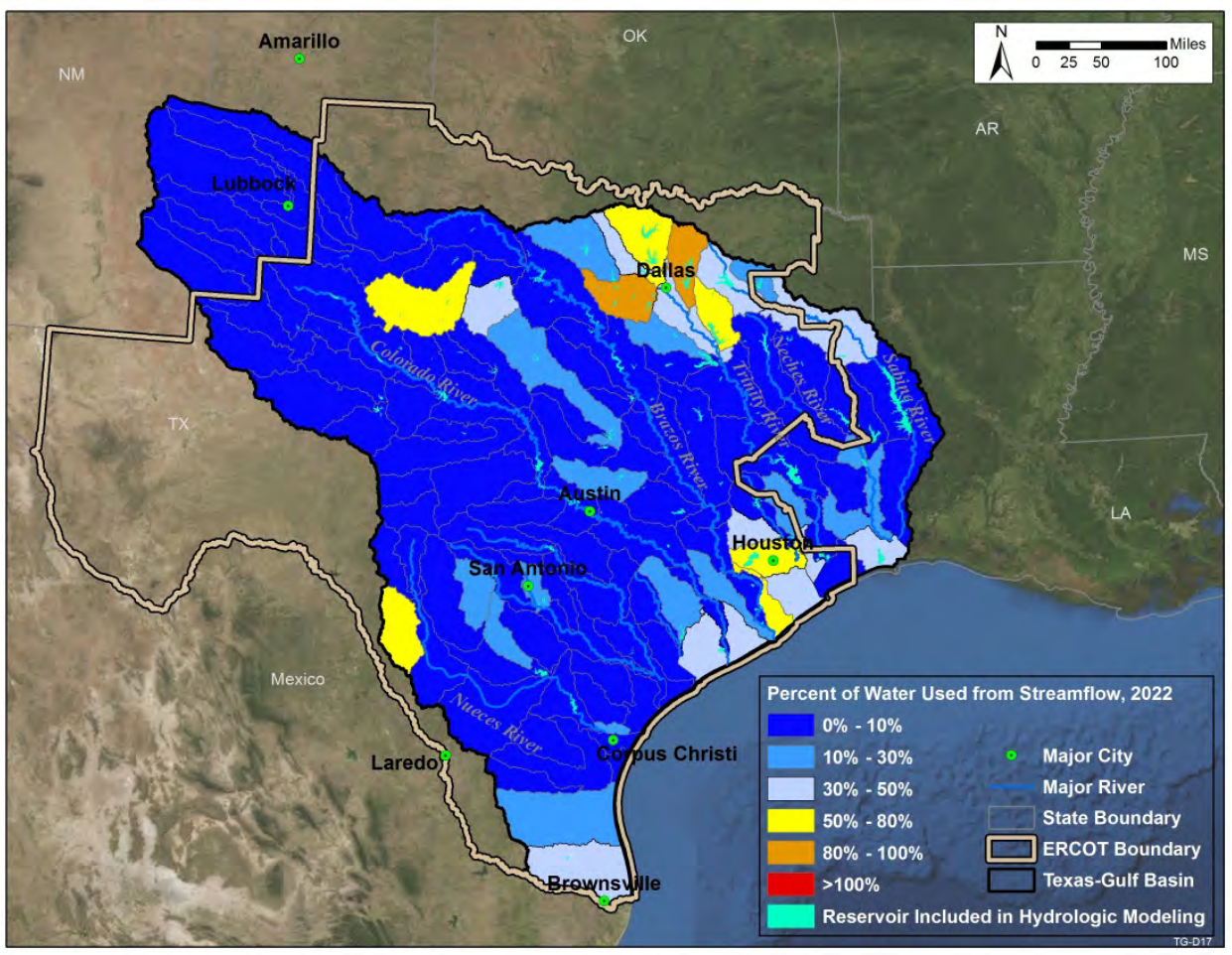

Figure 45. Indication of the $M 2$ criterion of water use versus stream flow in HUC8 basins in the single-year drought scenario (2022) of the time span 2021-2030. Basins with $\mathrm{M} 2>50 \%$, as indicated here, could be vulnerable to drought. 


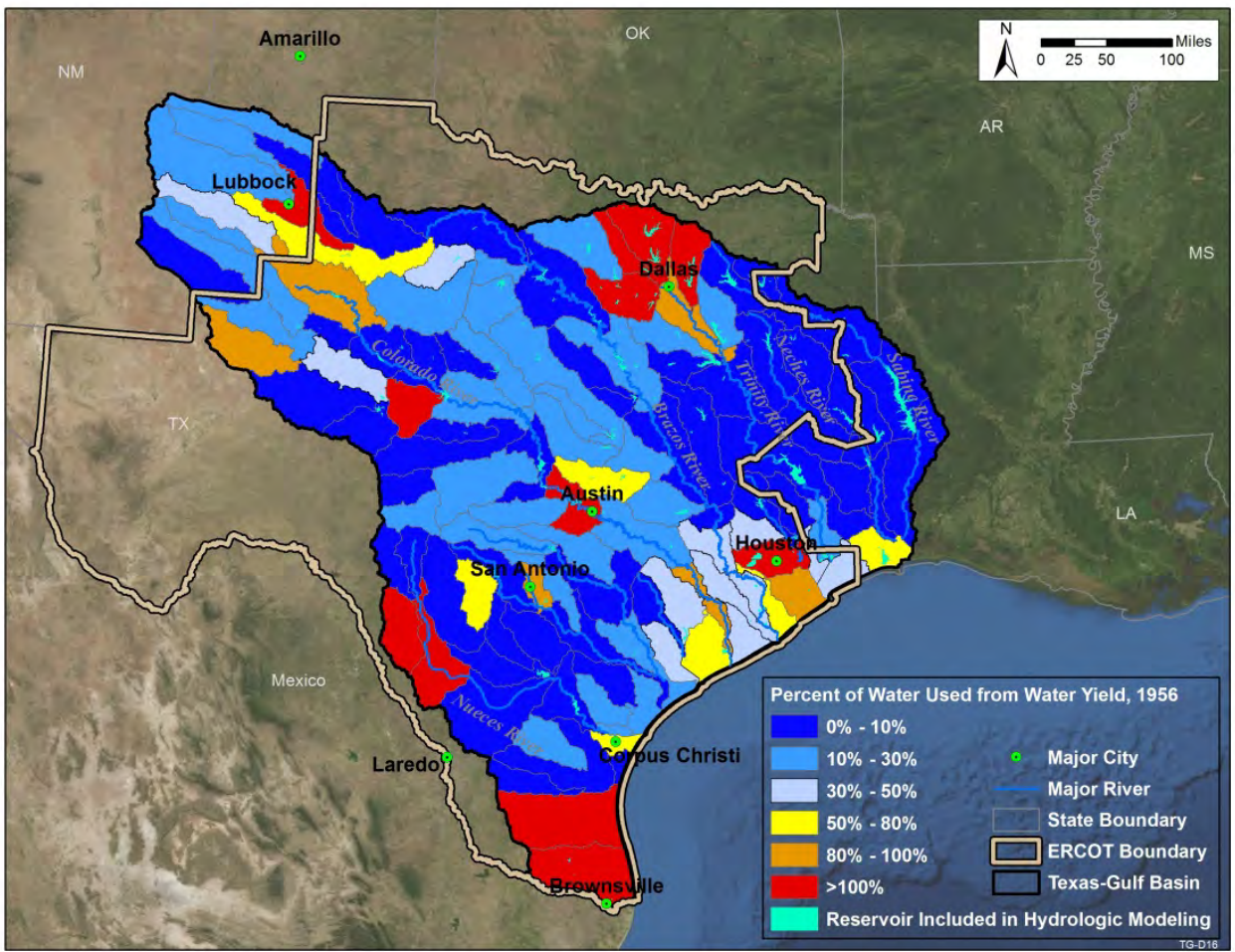

Figure 46. Indication of the M1 criterion of water use versus the amount of surface water generated from HUC8 basins in the last year (1956) of the multiple-year drought (1950-1957). Basins with $\mathrm{M} 1>50 \%$, as indicated here, could be vulnerable to drought.

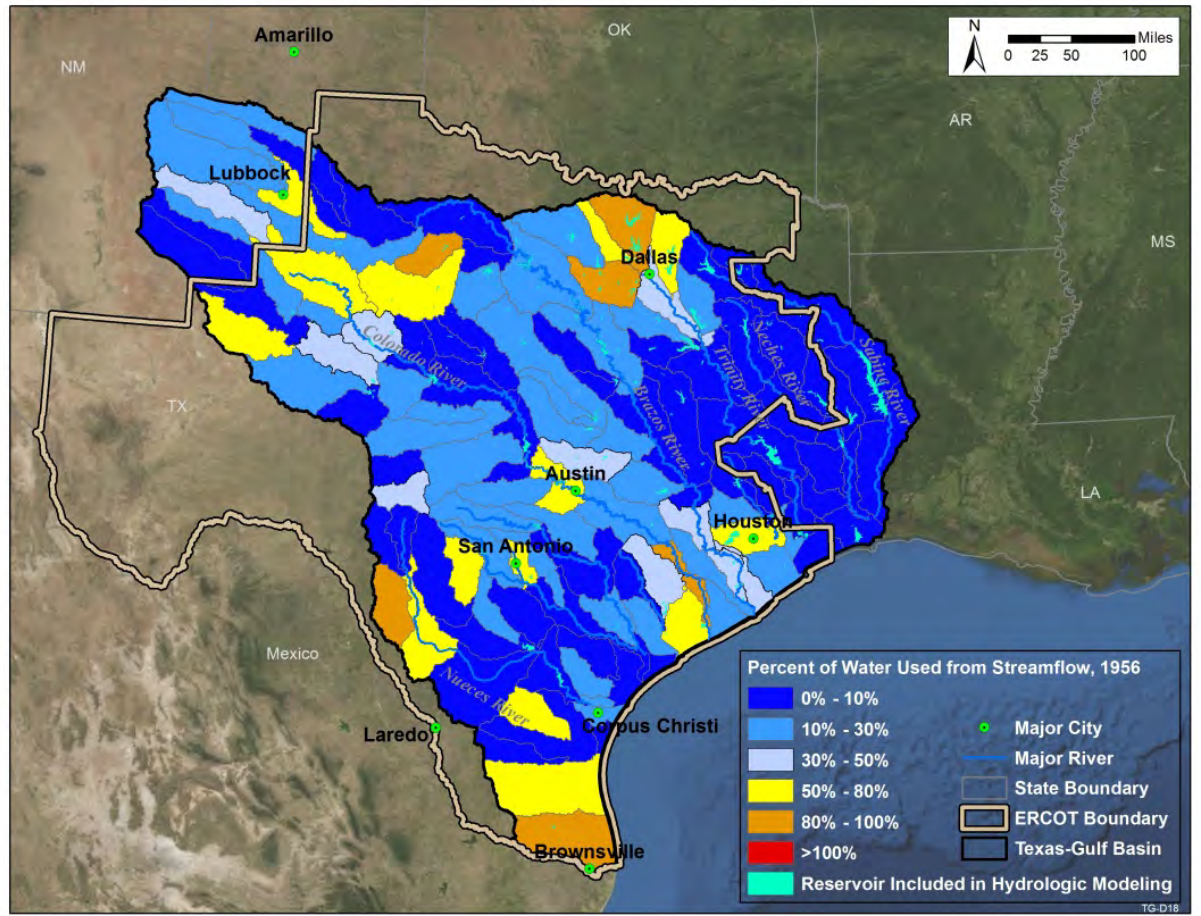

Figure 47. Indication of the $M 2$ criterion of water use versus stream flow at HUC8 basins in the last year (1956) of the multiple-year drought (1950-1957). Basins with $\mathrm{M} 2>50 \%$, as indicated here, could be vulnerable to drought. 
As shown in Figures 44-47 under both drought scenarios (2022 and 1956), the model predicts that HUC8 basins might be more vulnerable in the Dallas area. This prediction is also consistent with projected lower reservoir storage in the area, as shown in Figure $\mathbf{3 2}$ for 2022 and Figure $\mathbf{3 4}$ for 1956. The reduction of water availability in the Dallas area during these two drought scenarios could result because the Dallas area would experience (1) the most increased future water demand projected for 2030 in Texas, as shown in Figure 6, and (2) locally more severe drought than the 2011 drought under the 2022 scenario and the 1956 scenario, on the basis of the spatial distribution of precipitation as shown in Figure 26 (2022), Figure 30 (1956), and Figure 27 (2011). In the 2011 drought, the reservoirs in the Dallas area provided a good mitigation mechnism, with local precipitation of 25-30 in. (Figure 27), and most of them maintained more than $55 \%$ of normal storage (Figure 31). However, in 2022 and 1956, the local precipitation is 20-25 in. (2022) and 0-25 in. (1956), lower than in 2011. The model results suggest that the reservoirs incorporated into the model in the Dallas area have limited capacity to mitigate drought effects. Many of them would fall below $55 \%$ of normal storage (and some would be below 30\%) (Figure 32 and Figure 34). Thus, the drought impact would be significant in the Dallas area if the 2022 drought pattern occurred or the 1950-1957 climate was repeated in the near future at a water use level projected for 2030.

To evaluate potential risk of reduction or curtailment of power generation for future siting, Figure $\mathbf{4 8}$ and Figure 49 show locations of vulnerable HUC8 basins, existing power plants that possibly use surface water for cooling and generation, and all future power plants. As shown in Figures 48-49, most of the future power plants are not located in the vulnerable HUC8 basins, except for a few in areas near Brownsville, south of Lubbock, near Dallas, and on the Gulf coast near the Colorado River. In some area, such as Dallas, exploring possible water sources other than fresh surface water might help to mitigate the impacts of severe drought. The availability of various other water resources is discussed in Section 5.

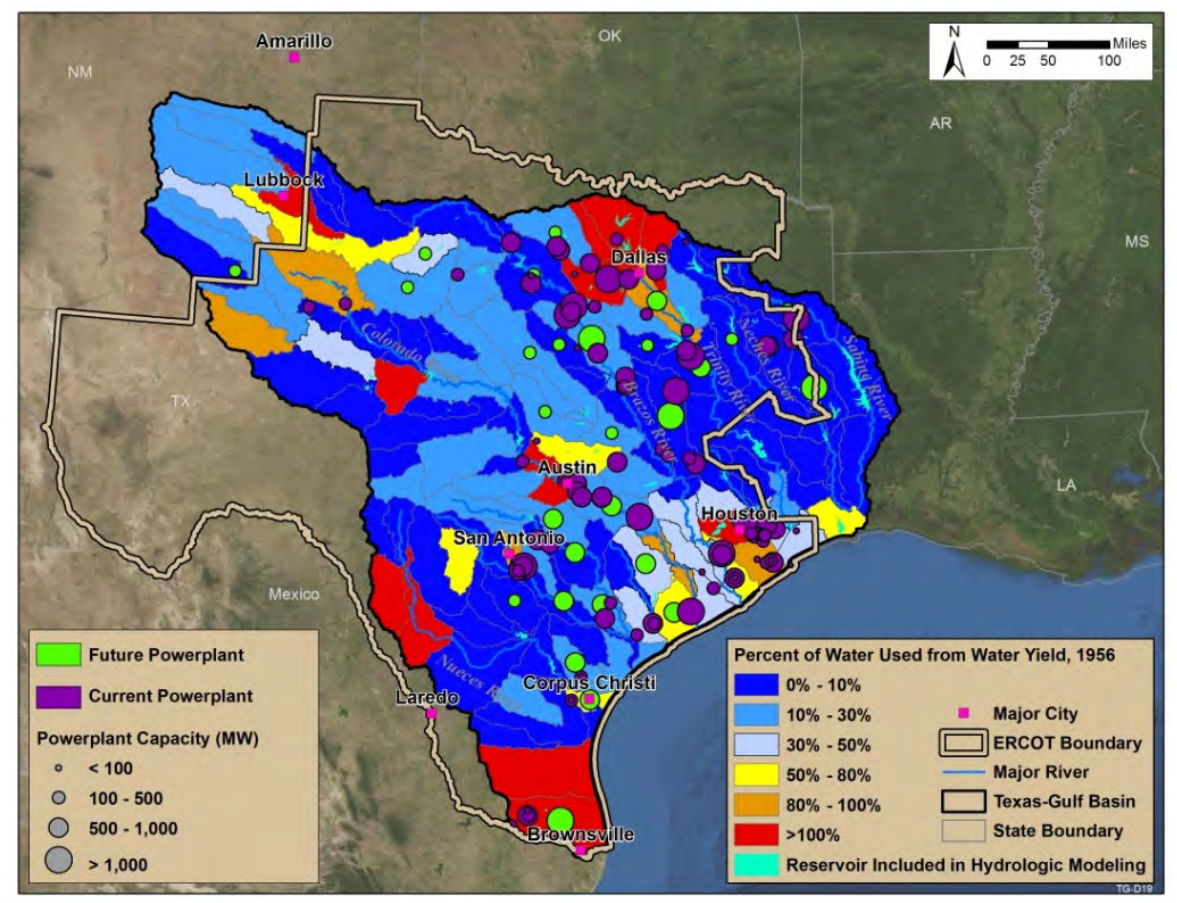

Figure 48. Locations of current and future power plants that are likely to use surface water for cooling or generation, with vulnerable HUC8 basins predicted for the 1956 drought on the basis of the M1 criterion. 


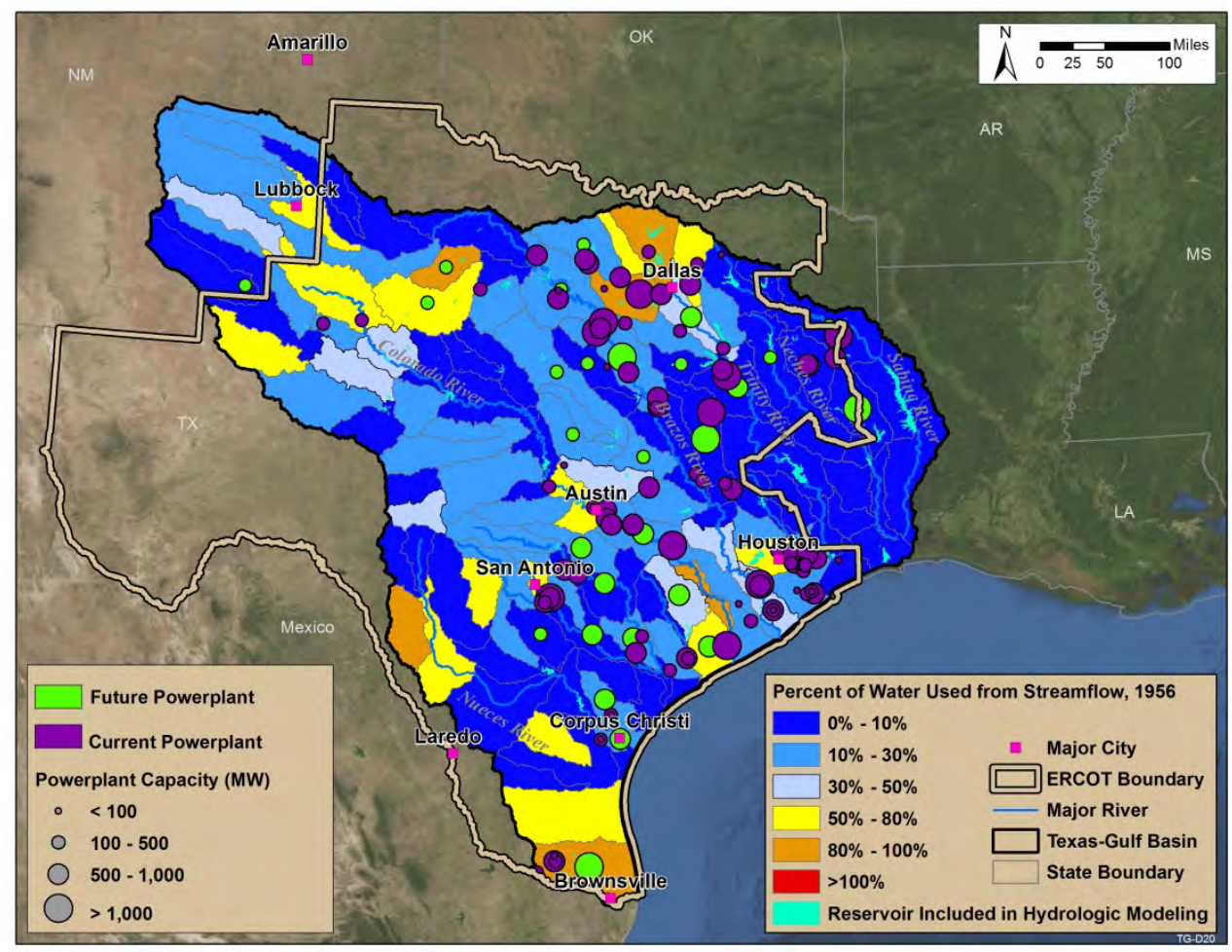

Figure 49. Locations of current and future power plants that are likely to use surface water for cooling or generation, with vulnerable HUC8 basins predicted for the 1956 drought on the basis of the M2 criterion.

\subsection{Summary}

- Drought simulations were performed for single-year drought (2011 as baseline and 2022) and multiple-year drought (1950-1957) scenarios by a using calibrated hydrologic model for the Texas-Gulf water resource region.

- The projected drought scenario in 2022 and the historical drought years in 2011 and 19541956 represent two different precipitation patterns in the Texas-Gulf river basin. The 2022 pattern is characterized by low precipitation ( $<25$ in.) in the eastern basin and moderate precipitation (25-30 in.) in the western basin, while the 2011 and 1954-1956 patterns show extremely low precipitation ( $<20$ in.) in western basin and high precipitation (>30 in.) in the southeastern basin only.

- The model predictions for average and minimum monthly reservoir storage during the 2011 drought year were validated with R2 $=0.81$ and 0.72 , respectively, for 22 reservoirs of the 37 that provide water supply to 47 power plants.

- Vulnerable HUC8 basins, identified by two matrices based on water use versus water availability in three drought scenarios, should be evaluated carefully for future power plant siting. The predictions suggest more vulnerable HUC8 basins near Dallas, Houston, Austin, San Antonio, Brownsville, and Lubbock for the 1956 scenario than for other scenarios.

- For the 2011 single-year drought (baseline) scenario:

- All but 3 of the monitored reservoirs that support power plants have minimum monthly storage $<75 \%$ of normal storage, indicating a severe regional drought effect. 
- The analysis identified 7 low-storage reservoirs with minimum monthly storage of $<50 \%$ by observation and $<55 \%$ by model prediction.

- $\quad$ The analysis identified 8 low-storage reservoirs with minimum monthly storage $<55 \%$ by model prediction only.

- In total, 15 low-storage reservoirs that support power plants were predicted for the 2011 drought. These reservoirs are mainly located in HUC8 basins near Houston and Austin.

- For the 2022 single-year drought scenario:

- Drought effects among HUC8 basins are distributed differently than for the 2011 drought.

- The results show a significant reduction in water availability (water yield and stream flow) in the eastern parts of the Texas-Gulf river basin, where many of reservoirs are located.

- The analysis identified 11 low-storage (<55\% storage) reservoirs that support power plants - fewer than for the 2011 drought. The potentially affected reservoirs are located in areas near Dallas and surrounding Houston.

- $\quad$ For the 1950-1957 multiple-year drought scenario:

- Reservoir water storage declined gradually over the period.

- The drought was more severe and widespread in the final year of the multi-year drought than in 2011. The reduction of water availability occurred mainly in the southern and north-central parts of the Texas-Gulf river basin for the multiple-year drought (1950-1957) with the assumed level of water use for 2030.

- The model predicted that low storage would affect 20 reservoirs that support power plants. The predicted low-storage reservoirs are located mainly in areas near Dallas, Houston, Austin, and San Antonio, as well as south of Lubbock. 


\section{Texas Water Availability and Costs of Water Supply}

The demand for electricity is expected to grow over the next $20 \mathrm{yr}$. This growth is likely to require new supplies of water to support expanded operations. Here we provide water availability information to assist in planning the future build-out of the power plant fleet. For this analysis, we defined the water available for new development, along with the cost to access and treat (if necessary) that water. The intent was not to support detailed power plant siting but rather to provide a relative and comparative measure of water availability and cost across the entire state of Texas.

Estimates of water availability and cost were developed at an HUC8 level for the entire state of Texas. These metrics were developed for five sources of water: shallow brackish water, municipal wastewater, appropriated surface/groundwater (which would need to be purchased from another user), unappropriated surface water (available by simply obtaining a permit), and unappropriated groundwater. These metrics were developed in cooperation with selected water managers representing the Western States Water Council. Also considered in the analysis was the projected future demand for water (Figure 6) that will compete with the thermoelectric sector and planned future water supply projects.

\subsection{Competing Demands for Water Supplies}

Where any water source (brackish water, wastewater, etc.) is available for development, its supply is reduced according to competing demands by other water use sectors. This competition was calculated as the total projected new consumptive demand for water across all use sectors (except thermoelectric) in 2010-2030, $\Delta W U$. As this competition targets all available water sources, it was divided across the five water sources, according to the strength of their availability and price. Specifically, $\triangle W U$ was apportioned from the least expensive source of water first, until $90 \%$ of that source of available water was exhausted. If water demand remained, the next cheapest source of water was used up to $90 \%$ of the available water. This continued until the new demand was met or it was determined that demand exceeded supply - in which case all available water sources were set equal to zero in that watershed. Sections 5.2-5.6 describe the water availability metrics for each of the five modeled water supplies.

\subsection{Shallow Brackish Groundwater}

\subsubsection{Water Availability}

Estimates of brackish water resources are documented in a report by LBG-Guyton Associates (2003). The estimates are in terms of total source volume, and thus an allowable depletion rule is used to protect the resource. The analysis assumed that only $25 \%$ of the resource can be depleted over in 100 $\mathrm{yr}$; annual available water was determined by multiplying estimated total volume of brackish water by 0.0025 . To avoid brackish water that is in communication with potable stream flow, brackish water availability was assumed zero when the average depth to brackish water was less than $50 \mathrm{ft}$ and salinity was $<3,000 \mathrm{mg} / \mathrm{L}$ total dissolved solids (TDS).

Where brackish water was available for development, its amount was reduced according to competing demands by other water use sectors, as discussed in Section 5.1 . 
The brackish water constraint metric $Q_{b w}^{j}$ (annual brackish water available for thermoelectric use after competing uses) takes the following form:

$$
Q_{b w}^{j}=\left\{\begin{array}{lr}
\text { if well }<50 f t \text { deep or } T D S<3000 & Q_{b w}=0 \\
\text { else } & Q_{b w}=V_{b w} * 0.0025
\end{array}\right\}-\Delta W U_{b w}^{j}
$$

Here $V_{b w}$ is the volume estimate of available brackish water, $Q_{b w}$ is the annual water availability of brackish water (volume per year), $j$ is an index designating the HUC8 watershed, and $\Delta W U_{b w}^{j}$ is interpreted as the additional water demand in 2030 relative to 2010 in HUC8 watershed $j$ that is calculated to be served by brackish water.

\subsubsection{Cost Estimate}

Estimated costs considered both capital and operation and maintenance (O\&M) costs to capture and treat the groundwater (Watson et al. 2003). Capture included costs to drill the necessary wells and the electricity to pump the water. Treatment costs included capital costs for the plant and O\&M costs for electricity, membranes, and brine disposal. All capital costs were amortized over a 30-yr horizon with a discount rate of $3 \%$. The number of wells and treatment plant capital costs were based on the treated volume of water, which was assumed at 5 MGD (million gallons per day), or 5,600 ac-ft/yr for an average-size thermoelectric plant (e.g., 500-MW power generation consuming $420 \mathrm{gal} / \mathrm{MW}-\mathrm{h}$ ). Key design parameters included the average depth of the brackish water and average TDS. These data were estimated from the USGS brackish groundwater well logs, available from the National Water Information System. ${ }^{3}$

\subsection{Municipal Wastewater}

\subsubsection{Water Availability}

Municipal wastewater discharge data are relatively consistently available throughout the United States. The EPA publishes the Permit Compliance System (PCS) database ${ }^{4}$ and the Clean Watershed Needs Survey (CWNS) database, ${ }^{5}$ which provide information on the location, discharge, and level of treatment for most wastewater treatment plants in the nation. The USGS (Kenny et al. 2009) also publishes municipal wastewater discharge values aggregated at the county level. These three sources of information were combined to provide a comprehensive view of wastewater discharge across Texas. To the current discharge, we added the projected growth in municipal withdrawal, less the projected consumption in 2030.

However, some of the discharge is unavailable for future use. A considerable fraction of the water is currently reused for industry, agriculture, and thermoelectric generation. Reuse estimates were determined both from USGS (Kenny et al. 2009) data and the EPA PCS and CWNS databases, which record the point of discharge (e.g., stream, agriculture, power plant). These reuse estimates were subtracted from the projected discharge values.

\footnotetext{
Online at this location: http://water.usgs.gov/nwis

Online at this location: http://www.epa.gov/enviro/facts/pcs-icis/index.html

Online at this location: http://water.epa.gov/scitech/datait/databases/cwns/index.cfm
} 
Finally, much municipal wastewater discharge is used to offset a city's consumptive use. That is, downstream water users are dependent on and "own" the wastewater discharged upstream of them. In such cases, the discharged wastewater does not represent a new source of water. Unfortunately, there are no comprehensive data on wastewater treatment plant permitting with respect to water right offsets. In efforts to identify plants that are unlikely to have offset requirements, we identified the plants that do not discharge directly to a perennial stream.

Where wastewater was available for development, its amount was reduced according to competing demands by other water use sectors, as discussed in Section 5.1.

The wastewater constraint metric $Q_{w w}^{j}$ (annual wastewater available for thermoelectric use after competing uses) takes the following form:

$$
Q_{w w}^{j}=\sum_{i=1}^{n}\left\{\begin{array}{lr}
\text { if discharge to perennial stream } & Q_{w w t p}^{i}=0 \\
\text { else } & Q_{w w t p}^{i}=W W T P_{\text {out }}^{i}-W W T P_{\text {reuse }}^{i}
\end{array}\right\}-\Delta W U_{w w}^{j}
$$

Here $i$ designates the wastewater treatment plant, $n$ is the number of plants in a given watershed, $j$ designates the watershed, $W W T P_{\text {out }}$ is the plant discharge, and $W W P T_{\text {reuse }}$ is the quantity reused.

\subsubsection{Cost Estimate}

Estimated costs considered both capital and O\&M costs to capture and treat wastewater (M. Pirnie via Woods, personal communication 2011). Capture considered conveyance costs based on the likely separation distance between a power plant and a wastewater treatment plant, which, in turn, was based on land use density around the treatment plant. Treatment costs addressed polishing likely to be required beyond that associated with the treatment plant, including capital costs for the plant and O\&M costs for electricity, chemicals, labor, and concentrate disposal. All capital costs were amortized over a 30-yr horizon.

\subsection{Potable Groundwater}

\subsubsection{Water Availability}

For availability of potable groundwater, a simple water balance was constructed to identify potable groundwater that is potentially available for development. A safe yield approach was used, in which total pumping should not exceed average recharge. Recharge values were based on USGS estimates (derived from stream base flow statistics), while pumping values were taken from state data.

Groundwater availability was further restricted in watersheds realizing significant groundwater depletions (historical groundwater declines exceeding $40 \mathrm{ft}$, as given by Reilly et al. [2008]) or located within groundwater protection zones (data acquired directly from the state). These watersheds were treated as having no available groundwater for development.

Where groundwater was available for development, its amount was reduced according to competing demands by other water use sectors, as discussed in Section 5.1. 
To facilitate comparison across all five water availability metrics, potable groundwater was mapped according to HUC8 watersheds, though presenting groundwater data according to principal aquifers would have merit if only groundwater were of interest. However, to maintain consistency across metrics and because of the nature of the available data (by county or watershed and not by principal aquifer), mapping is presented by HUC8 watershed. As a point of reference, maps of major and minor aquifers in Texas are available online. ${ }^{6}$

The groundwater constraint metric $Q_{g w}^{j}$ (annual groundwater available for thermoelectric use after competing uses) takes the following form:

$$
Q_{g w}^{j}=\left\{\begin{array}{lc}
\text { if } g w \text { depletion or control area } & Q_{g w}^{j}=0 \\
\text { else } & Q_{g w}^{j}=\text { Recharge } e_{\text {current }}^{j}-\text { Pumping } \\
\text { current }
\end{array}\right\}-\Delta W U_{g w}^{j}
$$

\subsubsection{Cost Estimate}

Estimated costs considered both capital and O\&M costs to lift water for use. Capital costs for drilling were estimated along with electricity costs to lift the water. Average depths to groundwater were taken from USGS well log data (USGS 2011). All capital costs were amortized over a 30-yr horizon.

\subsection{Unappropriated Surface Water}

\subsubsection{Water Availability}

The unappropriated surface water source addresses potable stream flow that would be available for use, requiring only the acquisition of a permitted water right from the state agency. In other words, the water would not have to be purchased and transferred from another use. Estimates of unappropriated water were taken directly from Texas Water Availability Model simulations, by using water availability for the "Drought of Record." The areas of unappropriated water were then narrowed by consulting the maps found on the web site of the Texas Commission of Environmental Quality, Water Availability Models (WAM). ${ }^{7}$ The maps show the areas of Texas in which unappropriated water is available, $0-100 \%$ of the time during the year. The areas of $75-100 \%$ availability were used here to represent constantly available water. The Rio Grande, not depicted in these maps, has such a low volume of unappropriated water that it has been given a zero value for this study.

Where surface water was available for development, its amount was reduced according to competing demands by other water use sectors, as discussed in Section 5.1.

The unappropriated surface water constraint metric $Q_{u s w}^{j}$ (annual unappropriated surface water available for thermoelectric use after competing uses) takes the following form:

\footnotetext{
See this location: http://www.twdb.state.tx.us/mapping/gisdata.asp

7 See this location: http://www.tceq.texas.gov/permitting/water supply/water rights/wam.html
} 


$$
Q_{u s w}^{j}=\left\{\begin{array}{cc}
\text { if water available }<75 \% \text { of time } & Q_{u s w}^{j}=0 \\
\text { else } & Q_{u s w}^{j}=Q_{\text {state }}^{j}
\end{array}\right\}-\Delta W U_{u s w}^{j}
$$

Here $j$ designates the watershed, and $Q_{\text {state }}^{j}$ is state-estimated legally available water in the watershed.

\subsubsection{Cost Estimate}

No costs are associated with use of this water source.

\subsection{Appropriated Water}

\subsubsection{Water Availability}

The appropriated water source addresses potable stream flow and groundwater that would require transfer from another use. Such transfers have traditionally involved sales of water rights from irrigated farmland. The potential for such transfers was estimated on the basis of the irrigated acreage in a given watershed that is devoted to low-value agricultural products - specifically, irrigated hay and alfalfa. Data (irrigated acreage and volume applied) were taken from the USDA (2007) Agricultural Census. ${ }^{8}$ There is often resistance to abandonment of large agricultural areas. Thus, the abandonment was limited to $5 \%$ of the total irrigated acreage in the watershed. This limit was based on the average projected decline in irrigation across the western United States.

For watersheds experiencing significant groundwater depletions (see Section 5.4), the available appropriated water was reduced by $50 \%$ to account for the portion of future water rights abandonment that will be used to offset the groundwater depletion.

Where appropriated water was available for development, its amount was reduced according to competing demands by other water use sectors, as discussed in the Section 5.1.

The appropriated surface water constraint metric $Q_{a p p}^{j}$ (annual appropriated surface water available for thermoelectric use after competing uses) takes the following form:

$$
Q_{\text {app }}^{j}=\left\{\begin{array}{ll}
\text { if no groundwater depletions } \quad \operatorname{Irr}_{\text {pasture }}^{j} \times\left(\frac{\operatorname{Min}\left(A_{\text {total }}^{j} \times b_{\text {app }}^{j}, A_{\text {pasture }}^{j}\right)}{A_{\text {pasture }}^{j}}\right) \\
\text { else } \quad\left(\operatorname{Ir} r_{\text {pasture }}^{j} \times\left(\frac{\operatorname{Min}\left(A_{\text {total }}^{j} \times b_{\text {app }}^{j}, A_{\text {pasture }}^{j}\right)}{A_{\text {pasture }}^{j}}\right)-(0.5 \times \text { depletion })\right)
\end{array}\right\}-\Delta W U_{\text {app }}^{j}(9)
$$

Here $j$ designates the watershed, $I r r_{\text {pasture }}$ is volume of water used to irrigate pasture, $A_{\text {total }}$ is the total irrigated acreage, $A_{\text {pasture }}$ is the acreage in irrigated pasture, and $b_{a p p}$ is the allowable percent of abandoned farmland.

8 See the following location: http://www.agcensus.usda.gov/ 


\subsubsection{Cost Estimate}

Water rights transfer costs were based on historic data collected by the Water Strategist and its predecessor the Water Intelligence Monthly, published by Stratecon, Inc., of Claremont, California. ${ }^{9}$ Costs were estimated by state from the information for agriculture-to-urban sales.

\subsection{Results of Water Availability and Cost Analysis}

The least expensive water is unappropriated surface water that requires only a permit for access. However, availability is very limited (Figure 50), occurring only along the coast. We limited unappropriated water to what was available at least $75 \%$ of the time for the drought of record. This water would be quite dependable under the worst of conditions.

Appropriated water (Figure 51), both surface and groundwater, is available at approximately $\$ 12-19 / a c-f t$ (amortized cost). Best availability is in the panhandle and in far southern and central Texas, where most of the state's irrigation occurs.

Potable groundwater costs $\$ 10-100 / a c-f t$ throughout much of Texas, depending on depth to water (Figure 52). Best availability is in east and central Texas. The panhandle and regions near urban centers are typically experiencing groundwater depletion, and thus they do not have dependable groundwater availability for long-term development.

Municipal wastewater also represents a good future source of water in Texas (Figure 53). Best availability is in east and south-central Texas, corresponding to the areas with highest population density. Associated costs tend to be between those for freshwater and brackish water resources. The advantage of wastewater is that it is one source that is likely to continue to grow along with the urban centers.

Brackish groundwater represents one of the best sources for future development (Figure 54). Relatively abundant supplies are available throughout much of the state; only the north-central and panhandle regions are limited with respect to this water source. The primary issue with this source is the cost for access and treatment. In general, costs are higher by a factor of 10 or more than the costs for freshwater sources.

Figure 55 presents the overall new demand for water (municipal, industrial, mining, and agriculture) projected out to 2030. Here, "new demand" means the increase in water demand between 2010 and 2030. Data were derived directly from the state water plan. Highest growth is associated with urban areas. The white areas in Figure $\mathbf{5 5}$ denote regions with declining water use, largely because of reductions in agricultural irrigation.

Also shown in Figure $\mathbf{5 5}$ (bottom) is the difference between the aggregate water availability (sum of the five water sources presented in Figures 50-54) and projected new demand for water. This bottom image of Figure 55 represents the estimated water available for thermoelectric power. Areas in white are those where future demand for new water exceeds our best estimates of total available water. These water-challenged regions are largely in the panhandle and north-central Texas. More importantly, 14 of these water-challenged basins are the locations of planned future thermoelectric expansion.

9 See the following location: www.waterstrategist.com 


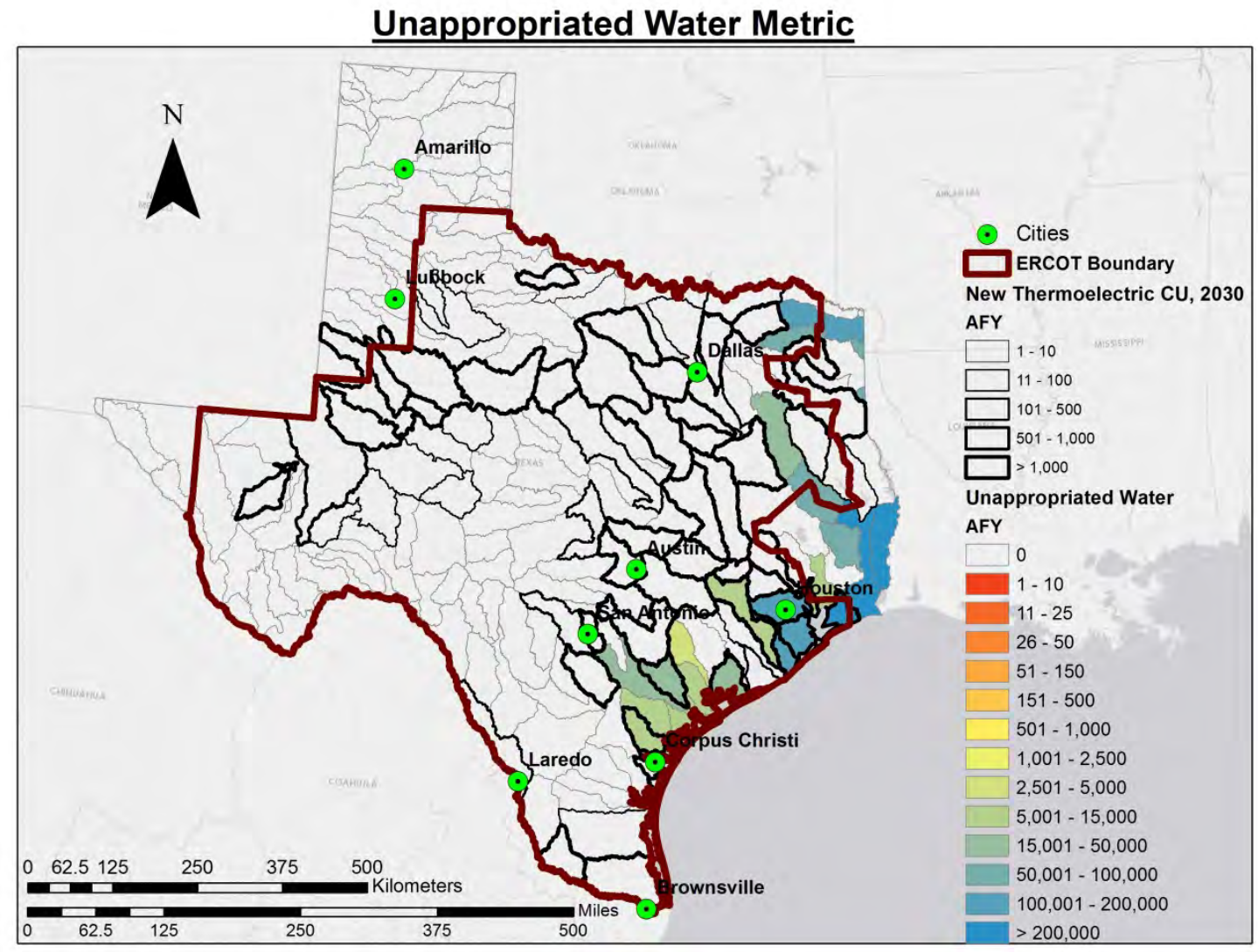

Figure 50. Availability for unappropriated water (data from TWDB 2012). No costs are associated with this supply. Watersheds with black outlines are projected sites for future thermoelectric expansion. The weight of the outline designates the degree of potential water demand.

To address potential water stress, Texas plans a number of water supply augmentation measures (TWDB 2012), including water conservation measures (e.g., improved irrigation efficiency, low-wateruse appliances), seawater desalination, and conveyance (interbasin transfers) projects. Figure $\mathbf{5 6}$ shows the planned improvements to water supply by HUC8 basin. Some have negative values, because water is being transferred to supply an adjoining basin. The sum of Figure $\mathbf{5 5}$ (bottom) and Figure 56 (top) provide a measure of total available water (Figure $\mathbf{5 6}$ bottom). These supply augmentation projects will improve water availability in 12 of the 14 water-challenged basins with planned thermoelectric expansion (white basins with dark outlines in Figure 55). 


\section{Appropriated Water Metric}

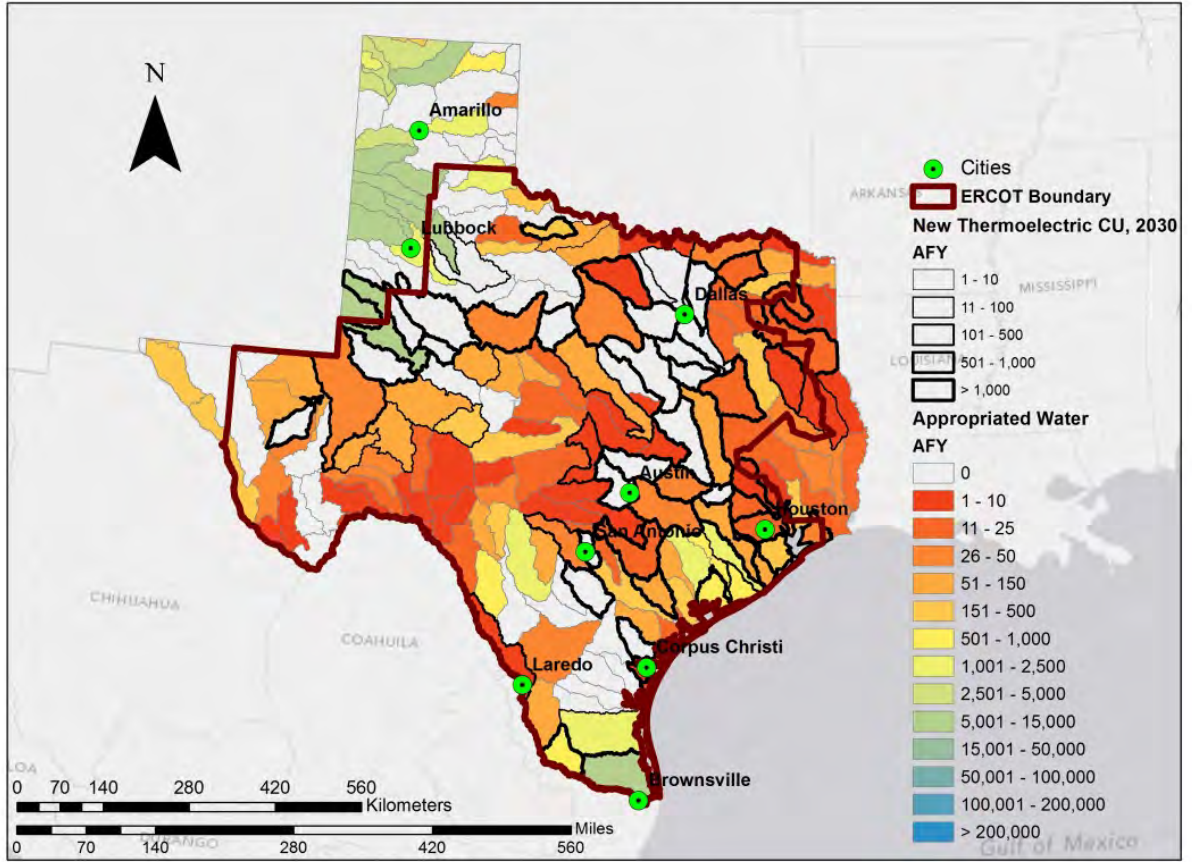

Appropriated Water Cost

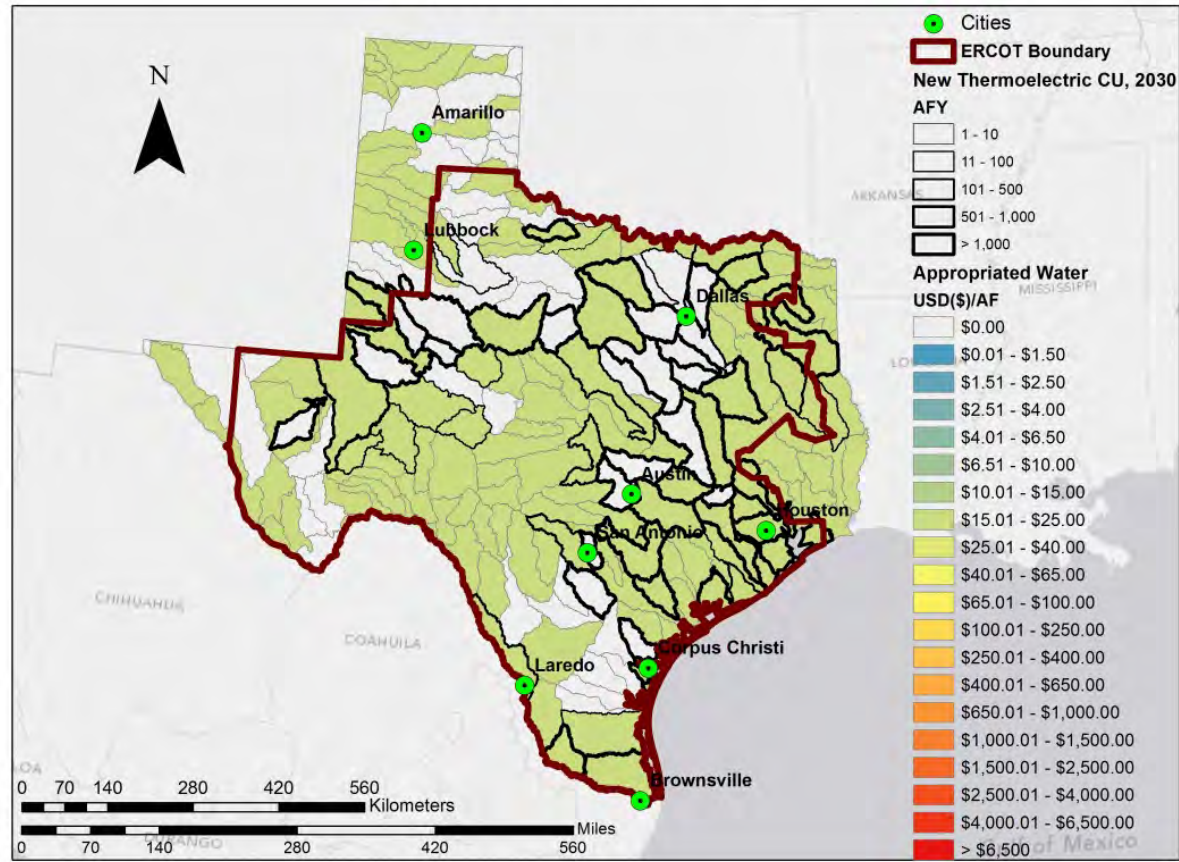

Figure 51. Availability (top) and cost (bottom) for appropriated water. Watersheds with black outlines are projected sites for future thermoelectric expansion. The weight of the outline designates the degree of potential water demand. 

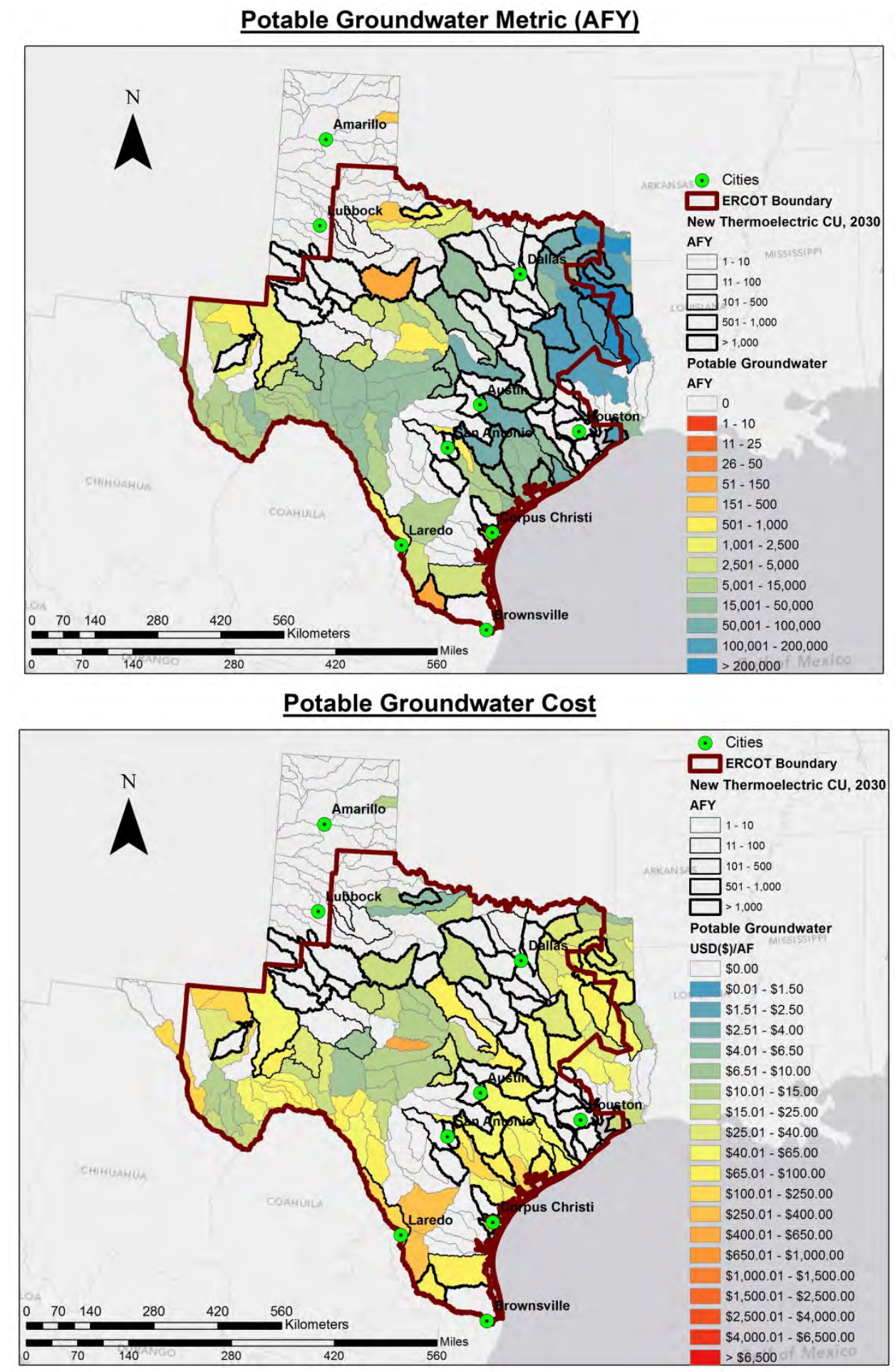

Figure 52. Availability (top) and cost (bottom) for potable groundwater. Watersheds with black outlines are projected sites for future thermoelectric expansion. The weight of the outline designates the degree of potential water demand. 


\section{Wastewater Metric (AFY)}

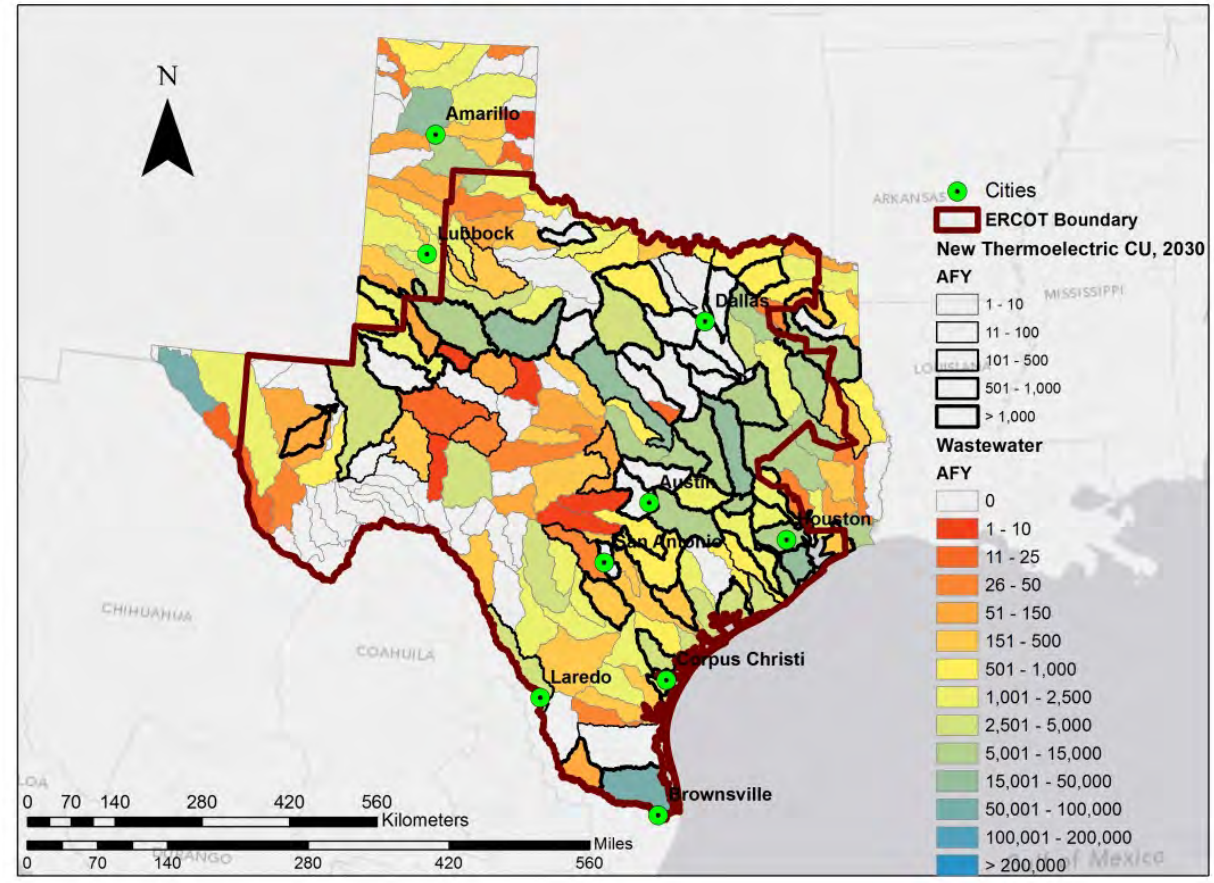

Wastewater Cost

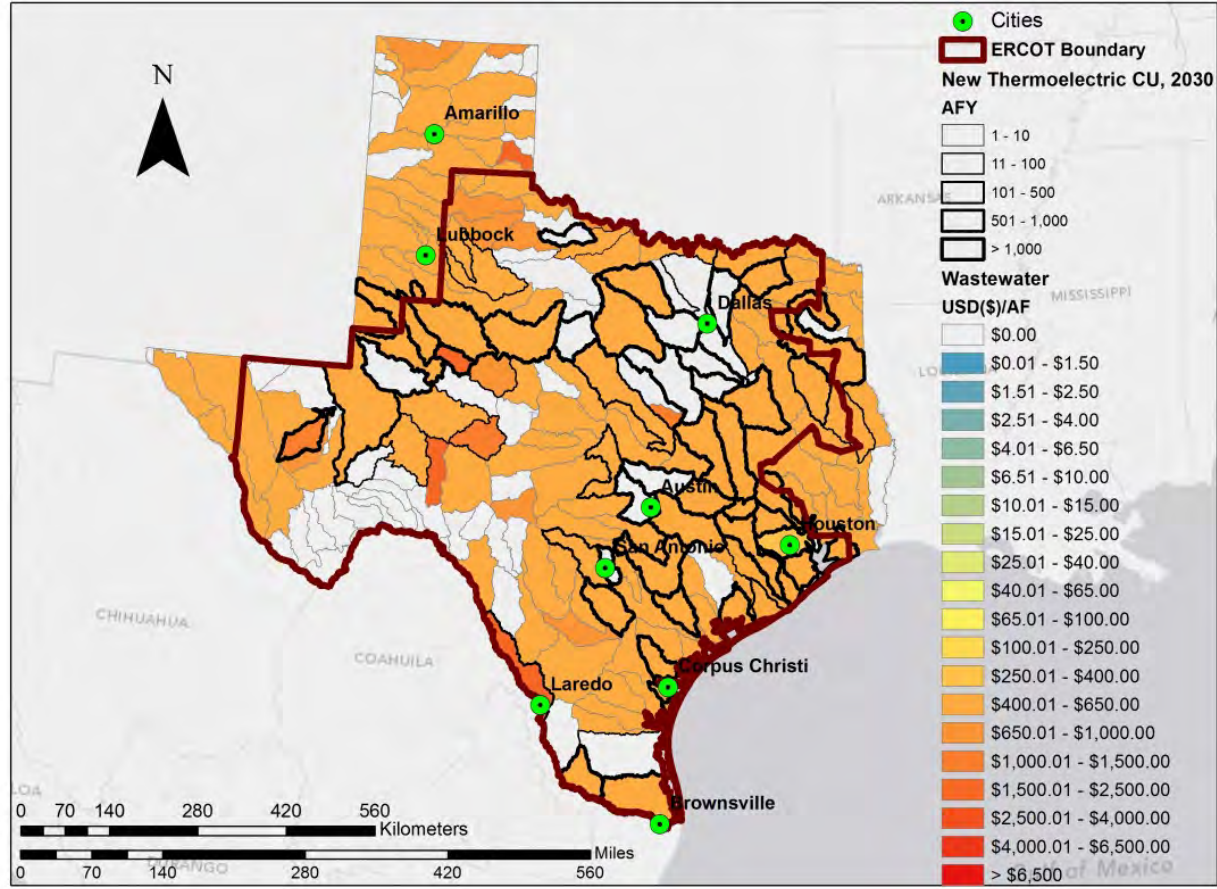

Figure 53. Availability (top) and cost (bottom) for municipal wastewater. Watersheds with black outlines are projected sites for future thermoelectric expansion. The weight of the outline designates the degree of potential water demand. 


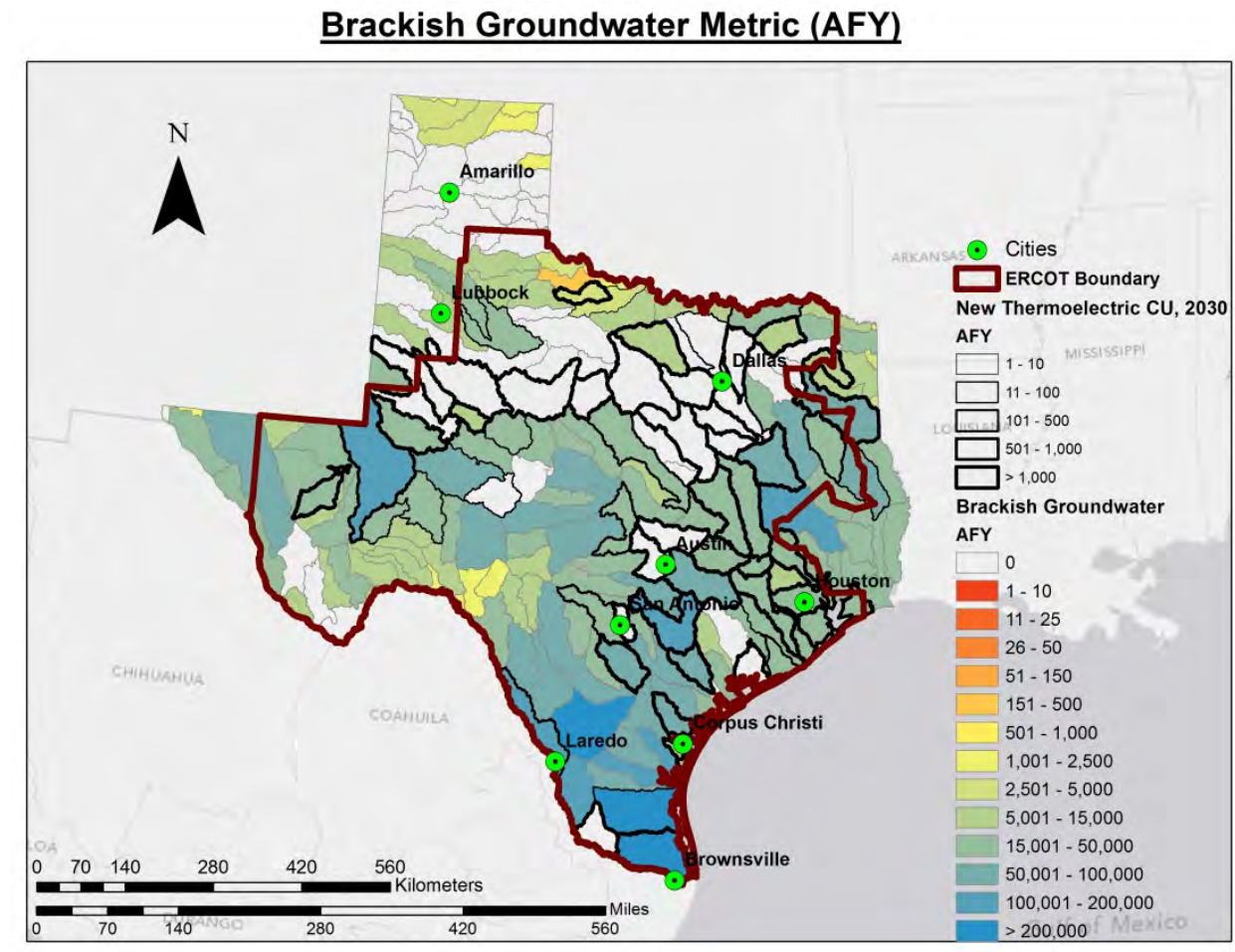

Brackish Groundwater Cost

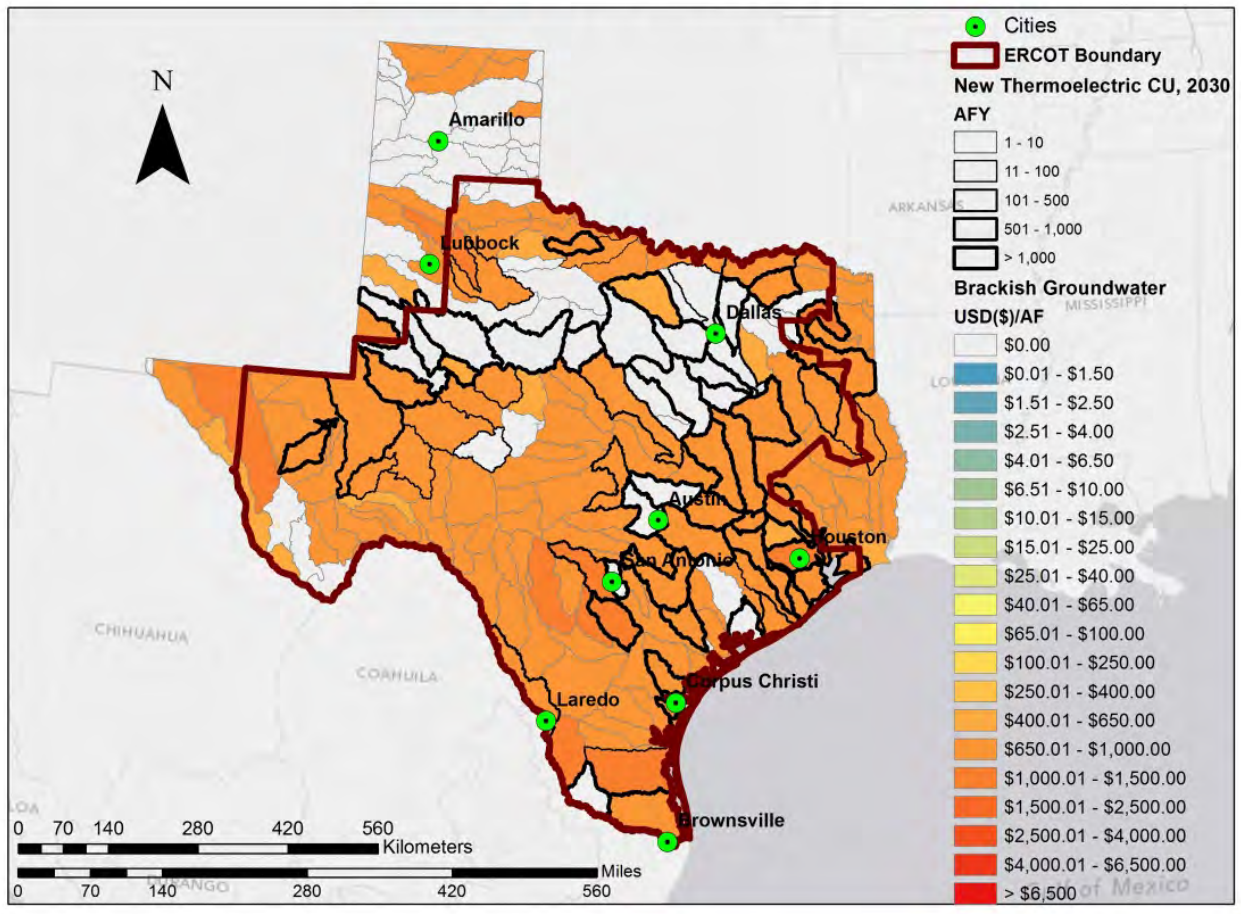

Figure 54. Availability (top) and cost (bottom) for brackish groundwater. Watersheds with black outlines are projected sites for future thermoelectric expansion. The weight of the outline designates the degree of potential water demand. 


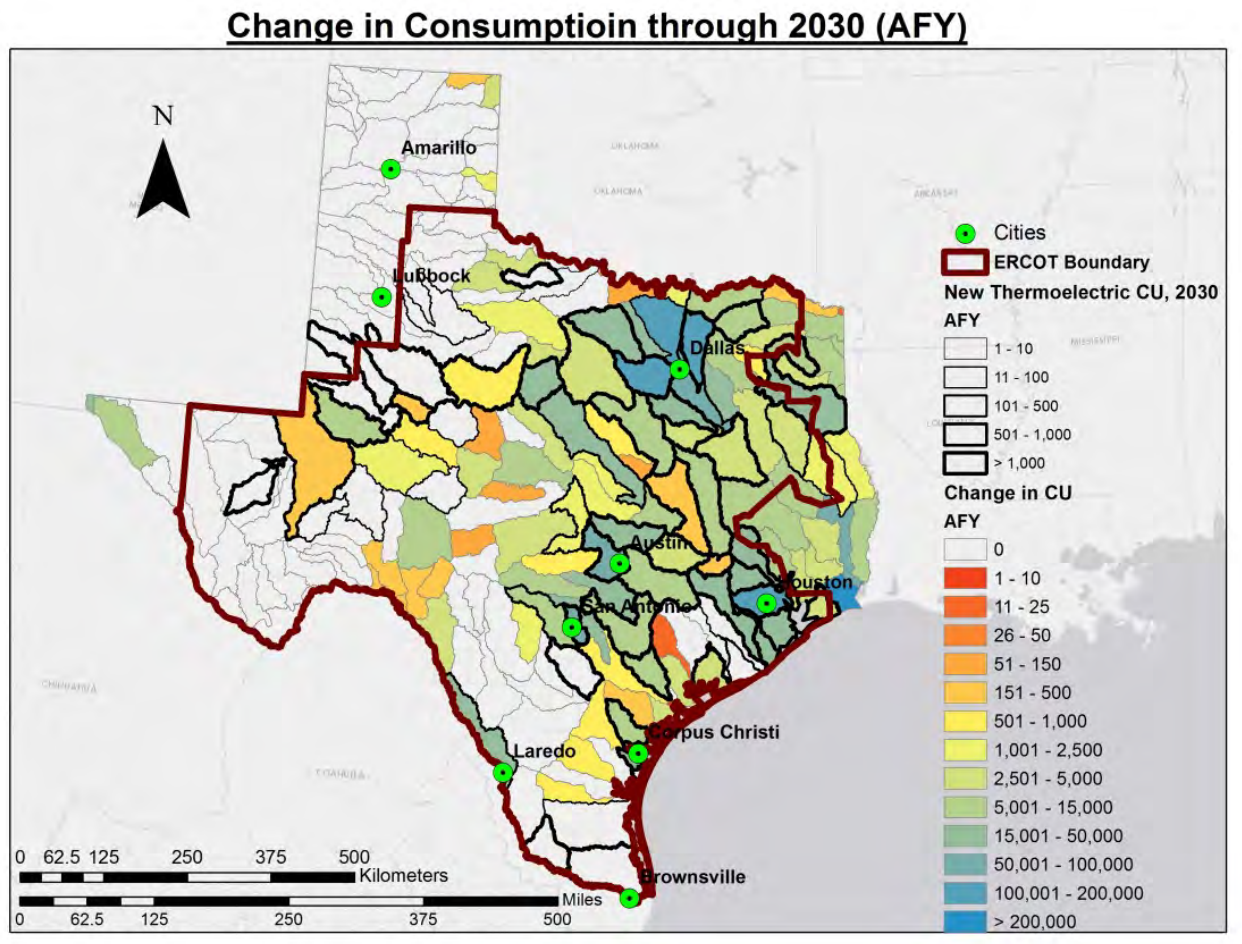

Availability - Demand 2030 (AFY)

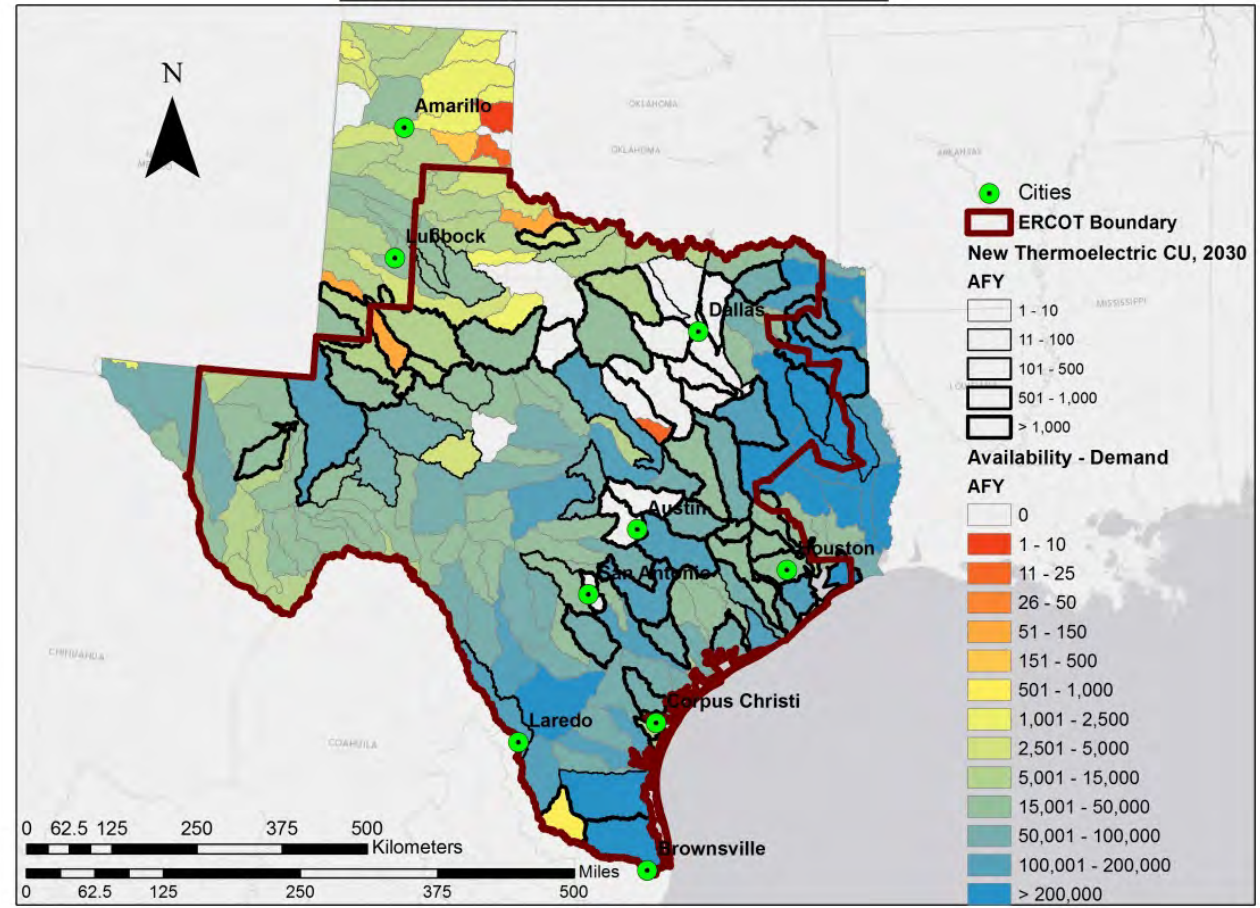

Figure 55. Change in consumptive water use between 2010 and 2030 (top), with difference between total available water supply (sum of water availability measures for all five sources) and change in consumptive water use (bottom). Watersheds with black outlines are projected sites for future thermoelectric expansion. The weight of the outline designates the degree of potential water demand. 


\section{New Water 2030}

Conveyance + Conservation + Seawater Desalination

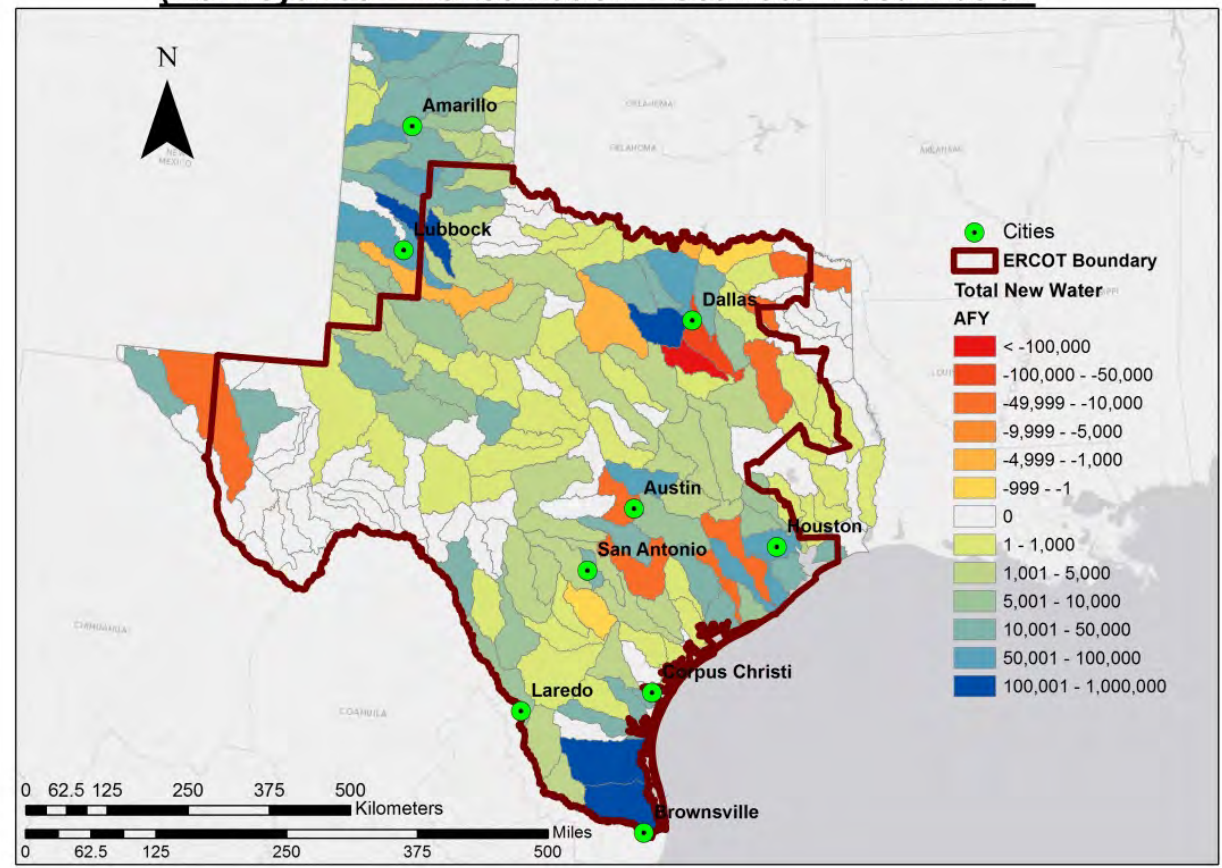

\section{Availability - Demand + New Water 2030}

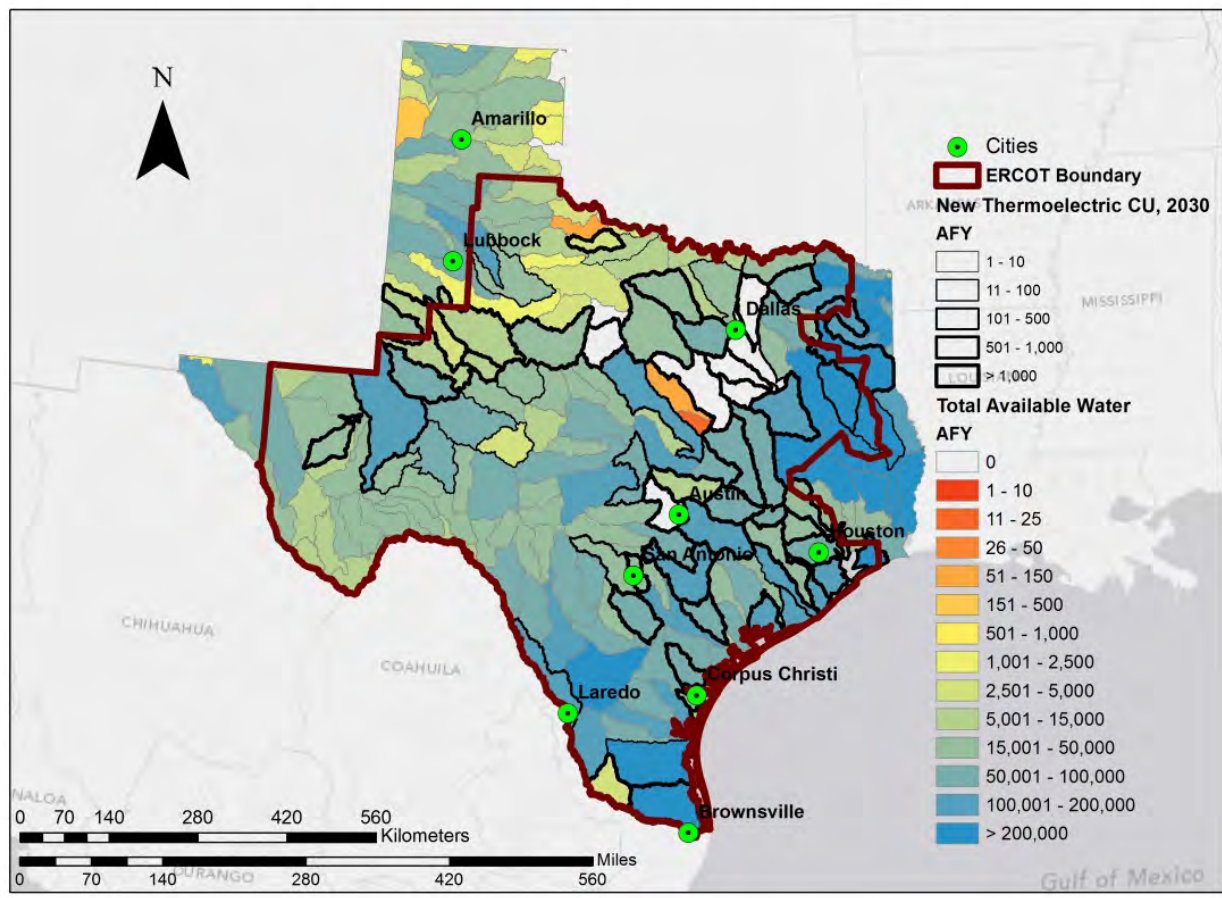

Figure 56. Planned water supply augmentation projects in the state of Texas (data from TWDB 2012) (top). This map shows where new water supply, created through conservation, seawater desalination, or interbasin transfer, will be available for development by 2030. Where transfers are planned, the basin losing water is also shown (resulting in negative values for some basins). The sum of this figure and the bottom image in Figure $\mathbf{5 5}$ provide a measure of the total water available for thermoelectric development in 2030 (assuming that the state accomplishes its planned augmentation projects) (bottom). 


\section{Electricity Production and Associated Water Consumption for 2030}

For the projection of the quantity of electricity generation in ERCOT for 2030, ERCOT provided results from an internal simulation of hourly load (see Table 5) based on the weather for year 2011 (the hottest year on record). The total assumed generation in 2030 is $489,700,000 \mathrm{MW}$-h.

Table 5. Monthly generation estimate for 2030, based on 2011 weather data.

\begin{tabular}{|lcccccccccccc|}
\hline & $\underline{\text { Jan }}$ & $\underline{\text { Feb }}$ & $\underline{\text { Mar }}$ & $\underline{\text { Apr }}$ & $\underline{\text { May }}$ & $\underline{\text { Jun }}$ & $\underline{\text { Jul }}$ & $\underline{\text { Aug }}$ & $\underline{\text { Sep }}$ & $\underline{\text { Oct }}$ & $\underline{\text { Nov }}$ & $\underline{\text { Dec }}$ \\
$\begin{array}{l}\text { Monthly Generation in } \\
2030 \text { (million MW-h) }\end{array}$ & 37.2 & 34.3 & 32.8 & 36.8 & 40.9 & 49.3 & 53.8 & 56.3 & 44.0 & 35.6 & 32.7 & 36.0 \\
\hline
\end{tabular}

The business-as-usual scenario for modeling the electric generation units added between 2011 and 2030 (as provided by ERCOT) estimated 18,100 MW of new natural gas generation (10,400 MW for combined cycle and 7,700 MW for combustion turbines). We also modeled wind generation and zero wind generation scenarios to understand the role of wind power in reducing water consumption for power generation in ERCOT. Although this approach does not necessarily encompass the full realm of future possibilities, it does give an indication of the significant water consumption potentially avoided with wind power. The scenario with zero wind generation is close to an upper bound for water consumption (given the scope of total power generation). The scenario with wind generation presents a nominal case with approximately 2.5 times more electricity generated from wind than in 2011 .

The water consumption factors (gal/MW-h) for each power plant are based primarily on a report for the TWDB (King et al., 2008). The total generation values (MW-h) for each power plant are based upon 2011 electricity generation data from the Energy Information Administration (EIA) form 932. For comparison to the 2030 estimates, the estimated water consumption for 2011 electricity generation in ERCOT is 392,000 ac-ft. Figure $\mathbf{5 7}$ shows the estimated annual water consumption in ERCOT, disaggregated by HUC8 river basin.

\subsection{Wind Scenario (Baseline Water Consumption for Power Generation)}

The "wind" generation scenario assumed that all wind farms present in 2011 continue to operate in 2030 with the same monthly generation. We also assumed that new wind farms to be constructed will increase the total wind generation to $64,850,000 \mathrm{MW}-\mathrm{h}$ in 2030 , to $13.2 \%$ of annual generation. More wind power could be generated in ERCOT in 2030, but this quantity corresponds to wind farms achieving the targets for the Competitive Renewable Energy Zones, plus double to triple the currently installed capacity of wind farms in coastal regions.

The new wind farms are assumed to be composed of two types: 5,500 MW of additional wind capacity that follows the wind pattern of west Texas and 2,600 MW of additional wind capacity that follows Texas coastal wind patterns (generation in Kennedy and San Patricio Counties). This distinction is made to estimate monthly water consumption for Texas power generation; the assumed monthly capacity factors for new wind farms are based on the typical west Texas and coastal monthly capacity factors in 2011. This use of 2011 data heuristically matches the assumed 2011 weather year that ERCOT used to project hourly generation, and the results did not appear to show significantly different water distributions. Thus, we do not illustrate monthly estimates for water consumption for power generation. 


\section{Current Thermoelectric Consumptive Use}

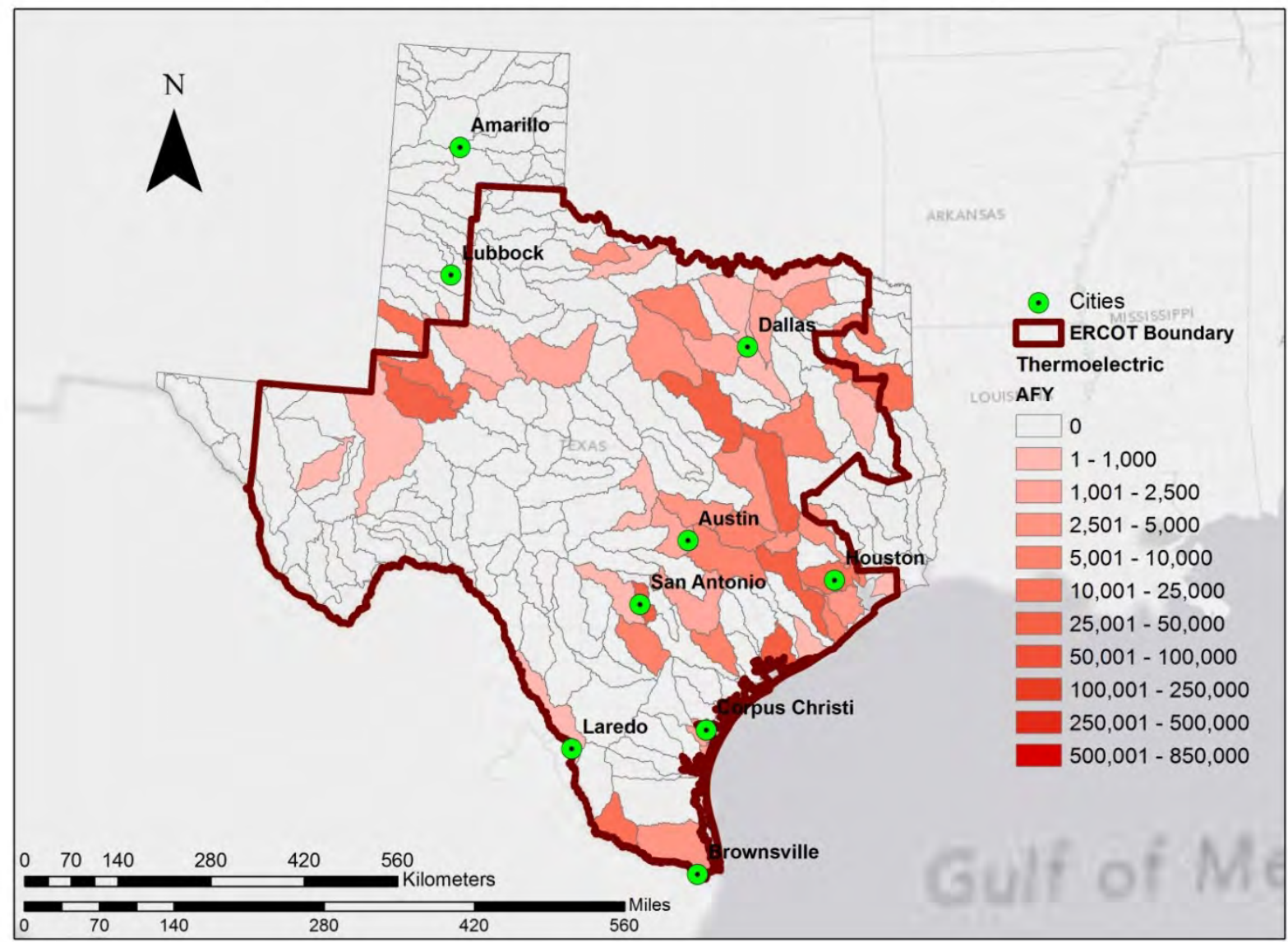

Figure 57. The water consumption estimate for 2011 power generation (AFY = ac-ft/yr), which is primarily associated with cooling of thermal power plants in the eastern half of Texas.

We estimated 450,000 ac-ft of water consumption for power generation in ERCOT in 2030, assuming that $13.2 \%$ of generation is from wind. Figure $\mathbf{5 8}$ indicates the annual distribution of water consumption per HUC8 river basin for 2030.

\subsection{No-Wind Scenario (Baseline Water Consumption for Power Generation)}

The no-wind generation scenario assumed that no new wind farms will be built and that all existing wind farms will be decommissioned by 2030 . This was not meant to represent a realistic scenario, but it provides an indication of the potential water consumption distribution throughout ERCOT in the absence of wind (or solar photovoltaic) power. We estimated 510,000 ac-ft of water consumption for power generation in ERCOT in 2030 with no wind power generation. Figure 59 illustrates the distribution of water consumption per HUC8 river basin. All other assumptions are the same as in the scenario with wind generation (Section 6.1). 


\section{Total Water Consumption in Acre-Feet for $\mathbf{2 0 3 0}$}

Hi Wind Scenario

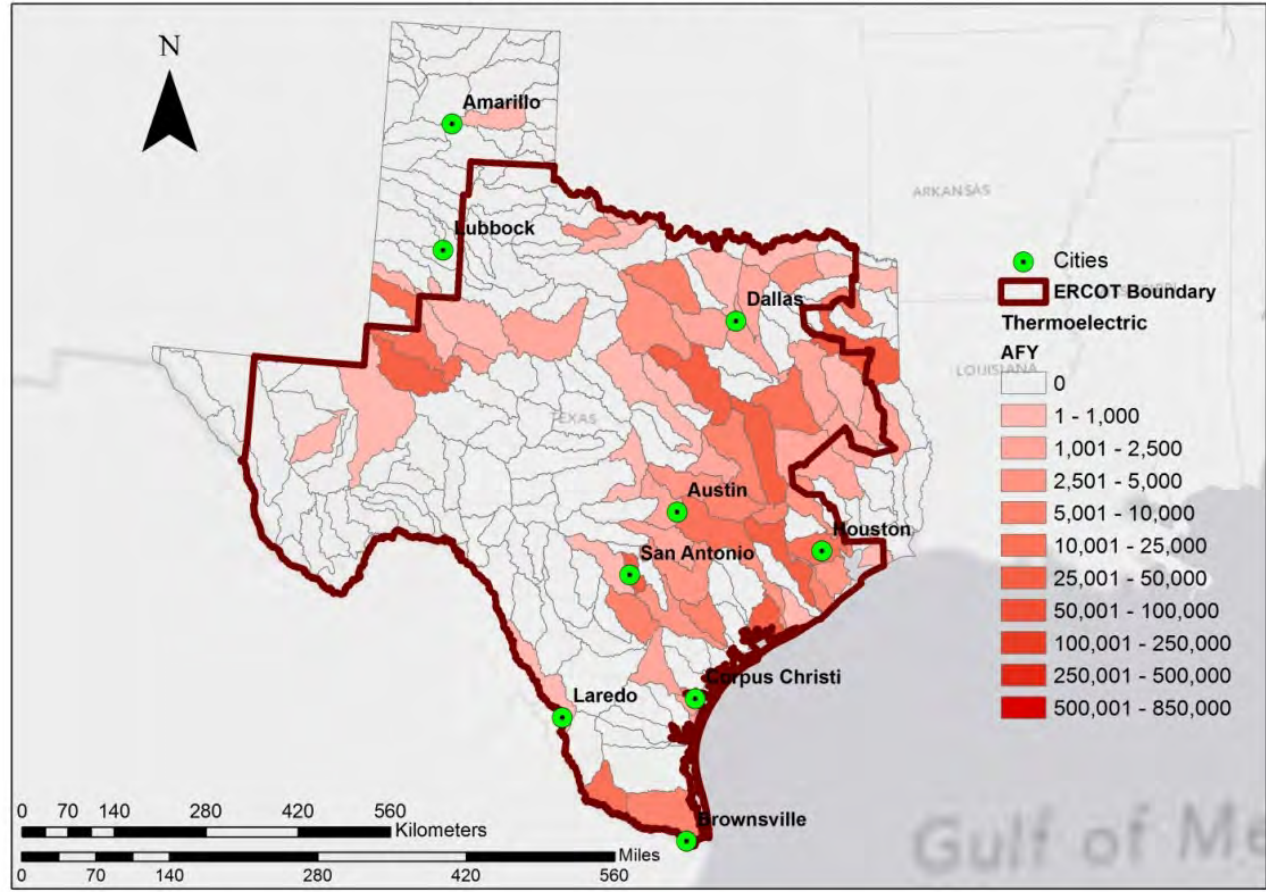

Figure 58. The water consumption estimate for 2030 power generation (AFY $=\mathrm{ac}-\mathrm{ft} / \mathrm{yr}$ ), totaling $450,000 \mathrm{ac}-\mathrm{ft}$, if $13.2 \%$ of generation comes from wind power and requires zero water consumption.

\section{Total Water Consumption in Acre-Feet for 2030} No Wind Scenario

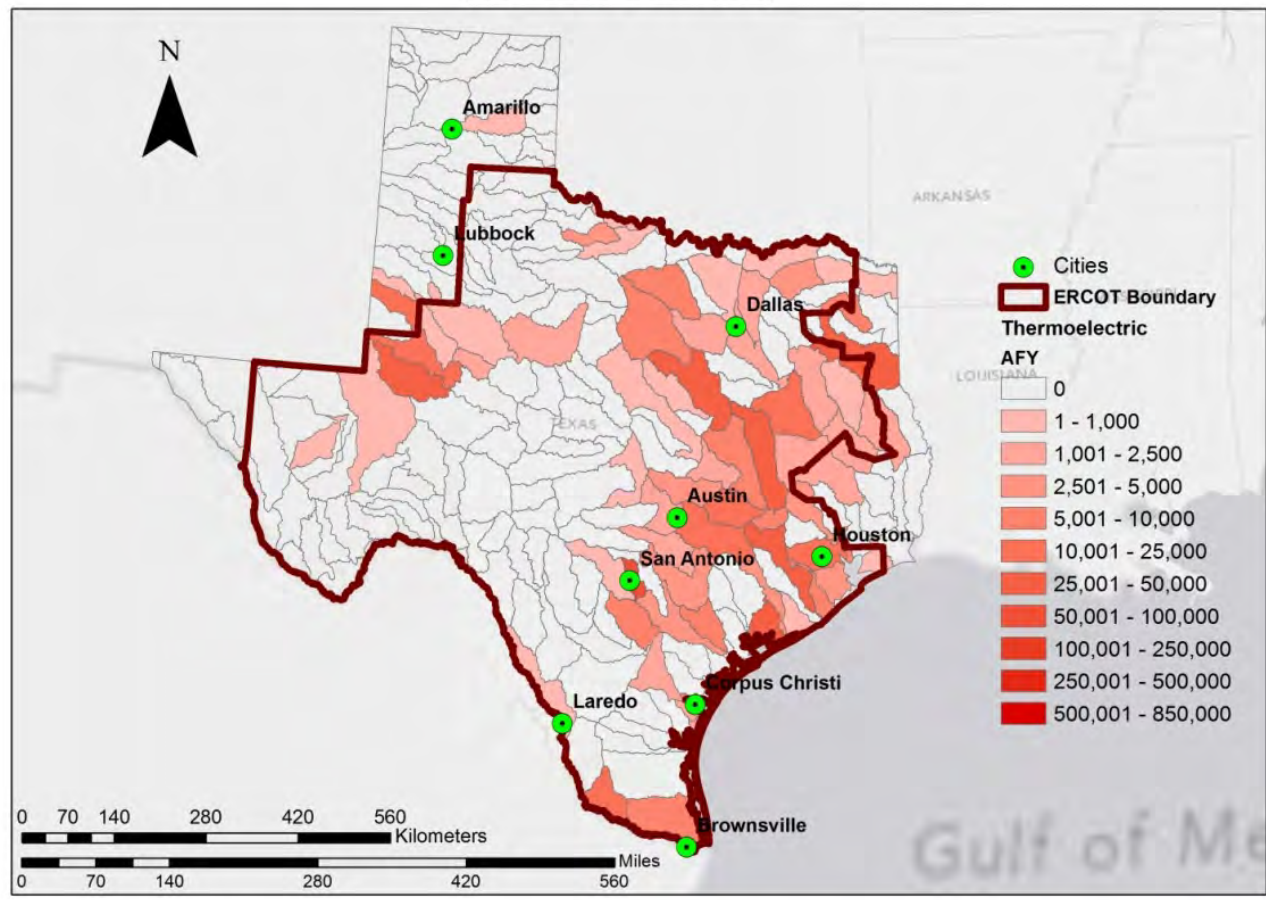

Figure 59 The water consumption estimate for 2030 power generation (AFY = ac-ft/yr), totaling 510,000 ac-ft, if no generation comes from wind power. 


\section{Assessment of Water-Related Risk to ERCOT Power Generation for 2030 Scenarios}

\subsection{Power Plants at Risk of Curtailment due to Low Water Levels in Cooling Reservoirs}

A very direct consequence of low water levels in reservoirs and streams (e.g., during drought) is the potential for the water surface to fall below the elevation of a cooling water intake at a power plant. This section summarizes the available data from the EIA (via Form 860 , Schedule 6, Part F) ${ }^{10}$ describing water intake levels at ERCOT power plants. The form asks for "average distance below water surface (feet)" of the cooling water intake location. Unfortunately, the data are sparse and often appear inaccurate. As noted by the National Energy Technology Laboratory (NETL 2009), many power plants report water intake levels as exactly $10 \mathrm{ft}$ below average lake level. However, this is the only data set available for our analysis.

Of the ERCOT power plants, only 33 (in the 2010 EIA Form 860 data [Table 6]) reported average cooling water intake levels relative to the water surface (see Table 7 and Appendix A). We converted the relative measures of intake elevation reported to the EIA via Form 860 to absolute elevation above mean sea level where possible. Figure $\mathbf{6 0}$ shows data for the Coleto Creek power plant and reservoir, as an example of estimation of the absolute elevation of the cooling water intake through use of data from EIA Form 860 and historical reservoir storage information. We used the information in EIA Form 860 to infer an absolute elevation (e.g., feet above sea level) for the cooling water intake.

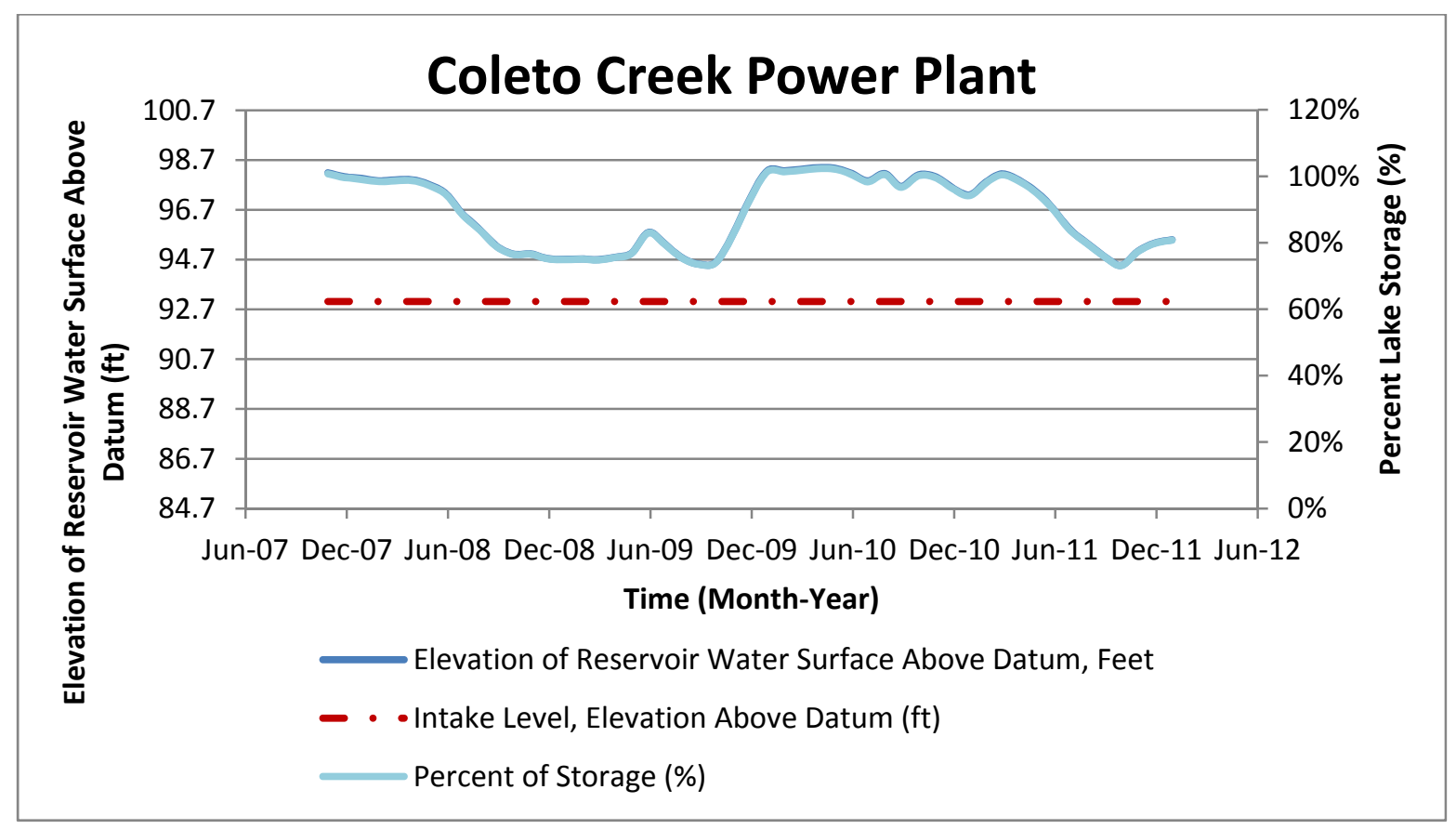

Figure 60. The estimated elevation of the lake at the Coleto Creek power plant on Coleto Creek Reservoir, fitted to total reservoir storage by the equation, water elevation $(\mathrm{ft})=\left(0.000431\right.$ acre $\left.^{-1}\right) \times$ [reservoir storage (acre-feet)] + $84.69 \mathrm{ft}$. The data point in EIA-860 that indicates that distance below the average water surface for the cooling water intake is $5 \mathrm{ft}$. For the "average lake level" at $98 \mathrm{ft}$ and the data in this figure, we estimated that the cooling water intake is at $93 \mathrm{ft}$ above sea level.

10 See this location: $\underline{\text { http://www.eia.gov/electricity/data/eia860/index.html }}$ 
Unfortunately, the data available from the TWDB and USGS do not include historical data for the elevation levels of many of the cooling ponds associated with power plants (e.g., Smithers Lake associated with the W A Parish plant and the cooling pond associated with South Texas Nuclear Project). Some of these reservoirs or cooling ponds are privately controlled and divert water from nearby rivers and streams as needed. Thus, accurate modeling of the storage of these reservoirs over time is difficult, because the levels are not controlled purely on the basis of natural hydrologic processes, but are subject to considerable human intervention. For example, consider the South Texas Nuclear Project (STP). If the cooling reservoir level is too low for normal operations, water is pumped from the Colorado River to fill the reservoir. Thus, the level of this reservoir is not linked directly to the average water storage in its HUC8 basin or to the stream flow. As long as water is legally available to STP and enough water resides in the nearby Colorado River, water can be pumped to keep the cooling reservoir at appropriate levels.

With the limited available data, we assessed the risk that a power plant would be unable to take in water from a water source for cooling. For this assessment, we estimated the elevation of the water surface level in reservoirs and determined whether that elevation is below the water intake elevation for a power plant (data from EIA Form 860). Reservoir surface water levels were inferred from the SWAT results by applying a relation that correlates historical water storage to water surface elevation (data from TWDB). Results are as follows:

- Table 6 presents the information from EIA form 860 for relevant ERCOT power plants and their respective reservoirs.

- Table 7 compares simulated and observed information for 2011 reservoir levels.

- Table 8 presents simulated reservoir storage for 2022 and 1950-1957 (displaying information for the lowest-storage year of 1956).

Although only nine power plants had the full set of information for assessing whether they could take in water during these simulated droughts, the simulations indicated that only two of these power plants (in 1956) would be unable to take in cooling water. For the multiyear analysis showing results for 1956, both Lake Calaveras and Victor Braunig Lake were simulated to become empty in 1956. However, CPS Energy of San Antonio operates these lakes and fills them with treated municipal wastewater from San Antonio, so that they are usually at a constant level. Thus, the results for Lake Calaveras and Victor Braunig Lake must be considered incomplete with respect to the city of San Antonio and CPS operations.

Two power plants (Coleto Creek and Ray Olinger) were simulated to have lake elevations less than or close to our estimates of their intake levels. These two power plants normally have $5 \mathrm{ft}$ and $15 \mathrm{ft}$ of water above the intake levels, respectively (values from EIA Form 860). For Coleto Creek, 2011 data indicate that the lake level declined to within $1.5 \mathrm{ft}$ of the intake level; the simulation estimated a lower level at $0.8 \mathrm{ft}$ above the intake. For Ray Olinger on Lake Lavon, the observed data for 2011 indicate that the reservoir level declined to within $1.8 \mathrm{ft}$ of the intake, while the simulation estimated a lake level $3.9 \mathrm{ft}$ above intake. However, the 1950 s drought simulation estimated the surface level of Lake Lavon within $1.8 \mathrm{ft}$ of the intake, indicating that Ray Olinger could be at much higher risk of drought if the 1950s drought was repeated; the model predicted more storage than was observed for the 2011 drought, and thus it might also be slightly overestimating storage for 1956.

A more complete set of data for water intakes would enable a fuller analysis. If intake water level data become available, a future analysis focusing on all of the low-storage reservoirs can evaluate the derating potential. 
Table 6. Parameters for reservoirs used for power plant cooling, including size and reservoir storage data from the TWDB and water intake information from the EIA Form 860.

\begin{tabular}{|c|c|c|c|c|c|c|c|c|c|c|c|}
\hline Power Plant & HUC_8 & Reservoir & $\begin{array}{l}\text { Surface area } \\
\text { at normal } \\
\text { storage (10^4 } \\
\text { m2) (TWDB) }\end{array}$ & $\begin{array}{c}\text { Normal } \\
\text { Storage } \\
\text { (10^4 m3) } \\
\text { (TWDB) }\end{array}$ & $\begin{array}{c}\text { Reservoir } \\
\text { Elevation } \\
\text { (ft) } \\
\text { (TWDB) }\end{array}$ & $\begin{array}{c}\text { Storage } \\
\text { (acre-feet) } \\
\text { (TWDB) }\end{array}$ & $\begin{array}{c}\text { Intake } \\
\text { Distance } \\
\text { From Shore } \\
\text { (ft) (EIA 860) }\end{array}$ & $\begin{array}{c}\text { Outlet } \\
\text { Distance } \\
\text { from Shore } \\
\text { (ft) (EIA 860) }\end{array}$ & $\begin{array}{l}\text { Intake } \\
\text { Distance } \\
\text { from } \\
\text { Surface (ft) } \\
\text { (EIA 860) }\end{array}$ & $\begin{array}{c}\text { Intake } \\
\text { Elevation } \\
\text { (ft) }\end{array}$ & $\begin{array}{c}\text { Outlet } \\
\text { Distance from } \\
\text { Surface (ft) } \\
\text { (EIA 860) }\end{array}$ \\
\hline Barney M. Davis Power Station & 12110203 & Laguna Madre & -- & -- & -- & -- & 3,824 & 492 & 24 & -- & 0 \\
\hline Bastrop Energy Center & 12090301 & Municipal, Colorado River & -- & -- & -- & -- & -- & -- & 6 & -- & 0 \\
\hline Big Brown & 12030201 & Fairfield Lake & 874 & 5,448 & -- & -- & 0 & 0 & 12 & -- & 0 \\
\hline Bosque County & 12060202 & Whitney, Lake & 9,534 & 68,360 & -- & -- & 175 & -- & 10 & -- & -- \\
\hline Brazos Valley & 12070104 & Brazos River & -- & -- & -- & -- & 84 & 20 & 7 & -- & -- \\
\hline Cedar Bayou & 12040104 & Cedar Bayou & -- & -- & -- & -- & 0 & 0 & 0 & -- & 10 \\
\hline Coleto Creek & 12100204 & Coleto Creek Reservoir & 1,255 & 3,829 & 98 & 31,040 & 20 & 5,300 & 5 & 93 & 0 \\
\hline Colorado Bend Energy Center & 12090302 & Wells & -- & -- & -- & -- & -- & -- & -- & -- & 10 \\
\hline Comanche Peak & 12060202 & Squaw Creek Reservoir & 1,334 & 18,677 & 775 & 151,367 & -- & -- & -- & -- & 10 \\
\hline Corpus Christi Plant & 12110202 & Corpus Christi Ship Channe & -- & -- & -- & -- & 50 & 2,000 & 10 & -- & 0 \\
\hline Dansby & 12070101 & Bryan Utilities Lake & 335 & 1,878 & -- & -- & 28 & 30 & 27 & -- & -- \\
\hline Decker Creek & 12090301 & Walter E Long, Lake & 514 & 4,186 & -- & -- & 360 & 830 & 10 & -- & -- \\
\hline Deer Park & 12040101 & Municipal-CIWA & -- & -- & -- & -- & -- & -- & -- & -- & 0 \\
\hline Fayette Power Plant & 12090301 & Fayette County Lake, or Ced; & -- & -- & -- & -- & 8 & 70 & 9 & -- & 0 \\
\hline Formosa & 12100102 & Texana, Lake & 3,916 & 19,870 & 44 & 159,640 & 350 & -- & 29 & 15 & -- \\
\hline Gibbons Creek SES & 12070103 & Gibbons Creek Reservoir & 1,121 & 3,958 & -- & -- & 0 & -- & 16 & -- & -- \\
\hline Graham & 12060201 & Graham, Lake & 989 & 5,588 & 1,075 & 45,260 & 0 & 150 & 15 & 1,060 & 0 \\
\hline Handley & 12030102 & Arlington, Lake & 779 & 4,784 & 550 & 40,156 & 0 & 4,691 & 15 & 535 & 0 \\
\hline JK Spruce, JT Deely & 12100301 & Calaveras Lake & 1,467 & 7,796 & 436 & 452,040 & 0 & 0 & 18 & 418 & 14 \\
\hline Lake Hubbard & 12030106 & Ray Hubbard, Lake & 9,205 & 55,758 & -- & -- & -- & -- & -- & -- & -- \\
\hline Martin Lake & 12010002 & Martin Lake & 2,016 & 9,265 & 306 & 75,116 & 0 & 0 & 32 & 274 & 0 \\
\hline Mountain Creek & 12030102 & Mountain Creek Lake & 1,008 & 2,817 & 457 & 22,840 & 0 & 5,808 & 20 & 437 & 0 \\
\hline North Texas & 12030102 & Lake Weatherford & -- & -- & 896 & 17,789 & -- & -- & -- & -- & 5 \\
\hline Nueces Bay Power Station WWTP & 12110201 & Nueces Bay & -- & -- & -- & -- & 0 & 415 & 20 & -- & -- \\
\hline Optim Energy & 12040101 & San Jacinto River Basin & -- & -- & -- & -- & 3,000 & -- & 6 & -- & 15 \\
\hline Ray Olinger & 12030106 & Lavon Lake & 8,643 & 56,312 & 492 & 443,844 & 20 & 300 & 15 & 477 & 15 \\
\hline Sabine & 12010002 & Sabine Lake & -- & -- & -- & -- & 0 & 0 & 15 & -- & 2 \\
\hline Sam Bertron & 12040101 & Houston Ship Channel & -- & -- & -- & -- & 75 & 0 & 33 & -- & 8 \\
\hline Sam Rayburn & 12100204 & Guadalupe River & -- & -- & 164 & $2,857,076$ & -- & -- & -- & -- & 12 \\
\hline Sandy Creek & 12060202 & WMARSS & -- & -- & -- & -- & -- & 0 & -- & -- & 2 \\
\hline Sim Gideon & 12090301 & Bastrop, Lake & 367 & 2,046 & -- & -- & 34 & 400 & 12 & -- & -- \\
\hline Stryker Creek & 12020004 & Striker, Lake & 754 & 2,820 & -- & -- & 0 & 0 & 17 & -- & -- \\
\hline Thomas C. Ferguson & 12090201 & Lyndon B Johnson, Lake & 2,631 & 16,416 & 825 & 113,323 & 0 & 0 & 25 & 800 & -- \\
\hline Tradinghouse & 12060202 & Tradinghouse Creek Reservc & 813 & 4,663 & -- & -- & 0 & 0 & 17 & -- & 2 \\
\hline Trinidad & 12030105 & Trinidad Lake & 299 & 765 & -- & -- & 0 & 0 & 17 & -- & -- \\
\hline VH Braunig, Arthur Von Rosenburg & 12100301 & Victor Braunig Lake & 546 & 3,269 & -- & -- & 0 & -- & 6 & -- & -- \\
\hline Valero & 12110202 & Unknown & -- & -- & -- & -- & -- & -- & -- & -- & 5 \\
\hline Victoria Power Station & 12100204 & Guadalupe River & -- & -- & -- & -- & 30 & 12 & 8 & -- & 0 \\
\hline W A Parish & 12070104 & Smithers Lake & 1,004 & 2,307 & -- & -- & 0 & 0 & 0 & -- & -- \\
\hline Wolf Hollow & 12060201 & Granbury, Lake & 3,363 & 15,913 & 693 & 128,046 & 140 & 150 & 55 & 638 & 2 \\
\hline
\end{tabular}


Table 7. Comparison of the available reservoir data and the SWAT model simulation for the 2011 meteorological year, indicating that most reservoirs were modeled relatively well. The water intake level data on EIA Form 860 confirmed that nine power plants can take in cooling water at the lowest simulated water levels.

\begin{tabular}{|c|c|c|c|c|c|c|c|c|c|c|c|c|}
\hline \multicolumn{3}{|c|}{ Power Plant Specific Information } & \multicolumn{5}{|c|}{ Observed 2011} & \multicolumn{5}{|c|}{ Simulated 2011} \\
\hline Power Plant & HUC_8 & Reservoir & $\begin{array}{c}\text { Average } \\
\% \text { storage }\end{array}$ & $\begin{array}{l}\text { Lowest } \% \\
\text { storage }\end{array}$ & $\begin{array}{l}\text { Reservoir } \\
\text { Storage } \\
\text { (acre-feet) } \\
2011\end{array}$ & $\begin{array}{l}\text { Reservoir } \\
\text { Elevation } \\
\text { (ft) } 2011\end{array}$ & $\begin{array}{l}\text { Intake Below } \\
\text { Reservoir } \\
\text { Surface } 2011 \\
(\mathrm{Y} / \mathrm{N}) ?\end{array}$ & $\begin{array}{c}\text { Average \% } \\
\text { storage }\end{array}$ & $\begin{array}{l}\text { Lowest \% } \\
\text { storage }\end{array}$ & $\begin{array}{c}\text { Reservoir } \\
\text { Storage (acre- } \\
\text { feet) } 2011\end{array}$ & $\begin{array}{l}\text { Reservoir } \\
\text { Elevation } \\
\text { (ft) } 2011\end{array}$ & $\begin{array}{l}\text { Intake Below } \\
\text { Reservoir } \\
\text { Surface } 2011 \\
(\mathrm{Y} / \mathrm{N}) ?\end{array}$ \\
\hline Barney M. Davis Power Station & 12110203 & Laguna Madre & -- & -- & -- & -- & -- & -- & -- & -- & -- & -- \\
\hline Bastrop Energy Center & 12090301 & Municipal, Colorado River & -- & -- & -- & -- & -- & -- & -- & -- & -- & -- \\
\hline Big Brown & 12030201 & Fairfield Lake & -- & -- & -- & -- & -- & $94 \%$ & $76 \%$ & -- & -- & -- \\
\hline Bosque County & 12060202 & Whitney, Lake & $59 \%$ & $50 \%$ & -- & -- & -- & $71 \%$ & $52 \%$ & -- & -- & -- \\
\hline Brazos Valley & 12070104 & Brazos River & -- & -- & -- & -- & -- & -- & -- & -- & -- & -- \\
\hline Cedar Bayou & 12040104 & Cedar Bayou & -- & -- & -- & -- & -- & -- & -- & -- & -- & -- \\
\hline Coleto Creek & 12100204 & Coleto Creek Reservoir & $86 \%$ & $73 \%$ & 22,767 & 95 & $\mathrm{~N}$ & $90 \%$ & $68 \%$ & 21,079 & 94 & $\mathrm{~N}$ \\
\hline Colorado Bend Energy Center & 12090302 & Wells & -- & -- & - & -- & -- & -- & -- & -- & -- & -- \\
\hline Comanche Peak & 12060202 & Squaw Creek Reservoir & $100 \%$ & $99 \%$ & 149,590 & 774 & -- & $80 \%$ & $61 \%$ & 92,843 & 733 & -- \\
\hline Corpus Christi Plant & 12110202 & Corpus Christi Ship Channel & -- & -- & -- & -- & -- & -- & -- & -- & -- & -- \\
\hline Dansby & 12070101 & Bryan Utilities Lake & - & -- & -- & -- & -- & $98 \%$ & $83 \%$ & -- & -- & -- \\
\hline Decker Creek & 12090301 & Walter E Long, Lake & -- & -- & -- & -- & -- & $52 \%$ & $25 \%$ & -- & -- & -- \\
\hline Deer Park & 12040101 & Municipal-CIWA & -- & -- & -- & -- & -- & -- & -- & -- & -- & -- \\
\hline Fayette Power Plant & 12090301 & Fayette County Lake, or Cedar Creel & -- & -- & -- & -- & -- & $52 \%$ & $25 \%$ & -- & -- & -- \\
\hline Formosa & 12100102 & Texana, Lake & $57 \%$ & $36 \%$ & 57,546 & -- & -- & $65 \%$ & $53 \%$ & 84,628 & -- & -- \\
\hline Gibbons Creek SES & 12070103 & Gibbons Creek Reservoir & -- & -- & -- & -- & -- & $70 \%$ & $43 \%$ & -- & -- & -- \\
\hline Graham & 12060201 & Graham, Lake & $83 \%$ & $68 \%$ & 30,864 & 1,069 & $\mathrm{~N}$ & $81 \%$ & $60 \%$ & 27,316 & 1,067 & $\mathrm{~N}$ \\
\hline Handley & 12030102 & Arlington, Lake & $80 \%$ & $62 \%$ & 24,757 & 542 & $\mathrm{~N}$ & $89 \%$ & $74 \%$ & 29,671 & 544 & $\mathrm{~N}$ \\
\hline JK Spruce, JT Deely & 12100301 & Calaveras Lake & -- & -- & -- & -- & -- & $79 \%$ & $57 \%$ & 256,596 & 426 & $\mathrm{~N}$ \\
\hline Lake Hubbard & 12030106 & Ray Hubbard, Lake & $84 \%$ & $73 \%$ & -- & -- & -- & $70 \%$ & $61 \%$ & -- & -- & -- \\
\hline Martin Lake & 12010002 & Martin Lake & $56 \%$ & $44 \%$ & 33,145 & 295 & $\mathrm{~N}$ & $84 \%$ & $47 \%$ & 35,046 & 296 & $\mathrm{~N}$ \\
\hline Mountain Creek & 12030102 & Mountain Creek Lake & $93 \%$ & $77 \%$ & 17,602 & 454 & $\mathrm{~N}$ & $94 \%$ & $79 \%$ & 18,125 & 454 & $\mathrm{~N}$ \\
\hline North Texas & 12030102 & Lake Weatherford & -- & -- & -- & -- & -- & -- & -- & -- & -- & -- \\
\hline Nueces Bay Power Station WWTP & 12110201 & Nueces Bay & -- & -- & -- & -- & -- & -- & -- & -- & -- & -- \\
\hline Optim Energy & 12040101 & San Jacinto River Basin & -- & -- & -- & -- & -- & -- & -- & -- & -- & -- \\
\hline Ray Olinger & 12030106 & Lavon Lake & $67 \%$ & $46 \%$ & 206,348 & 479 & $\mathrm{~N}$ & $64 \%$ & $55 \%$ & 243,524 & 481 & $\mathrm{~N}$ \\
\hline Sabine & 12010002 & Sabine Lake & -- & -- & -- & -- & -- & -- & -- & -- & -- & -- \\
\hline Sam Bertron & 12040101 & Houston Ship Channel & -- & -- & -- & -- & -- & -- & -- & -- & -- & -- \\
\hline Sam Rayburn & 12100204 & Guadalupe River & -- & -- & -- & -- & -- & -- & -- & -- & -- & -- \\
\hline Sandy Creek & 12060202 & WMARSS & -- & -- & -- & -- & -- & -- & -- & -- & -- & -- \\
\hline Sim Gideon & 12090301 & Bastrop, Lake & - & -- & -- & -- & -- & $56 \%$ & $30 \%$ & -- & -- & -- \\
\hline Stryker Creek & 12020004 & Striker, Lake & -- & -- & -- & -- & -- & $92 \%$ & $75 \%$ & -- & -- & -- \\
\hline Thomas C. Ferguson & 12090201 & Lyndon B Johnson, Lake & $84 \%$ & $83 \%$ & 94,393 & 823 & $\mathrm{~N}$ & $61 \%$ & $49 \%$ & 55,053 & 820 & $\mathrm{~N}$ \\
\hline Tradinghouse & 12060202 & Tradinghouse Creek Reservoir & -- & -- & -- & -- & -- & $75 \%$ & $56 \%$ & -- & -- & -- \\
\hline Trinidad & 12030105 & Trinidad Lake & -- & -- & -- & -- & -- & $100 \%$ & $100 \%$ & -- & -- & -- \\
\hline VH Braunig, Arthur Von Rosenburg & 12100301 & Victor Braunig Lake & -- & -- & -- & -- & -- & $79 \%$ & $57 \%$ & -- & -- & -- \\
\hline Valero & 12110202 & Unknown & & & -- & -- & -- & & & -- & -- & -- \\
\hline Victoria Power Station & 12100204 & Guadalupe River & -- & -- & -- & -- & -- & -- & -- & -- & -- & -- \\
\hline WAParish & 12070104 & Smithers Lake & -- & -- & -- & -- & -- & $73 \%$ & $25 \%$ & -- & -- & -- \\
\hline Wolf Hollow & 12060201 & Granbury, Lake & $85 \%$ & $69 \%$ & 88,834 & 687 & $\mathrm{~N}$ & $80 \%$ & $60 \%$ & 76,459 & 685 & $\mathrm{~N}$ \\
\hline
\end{tabular}


Table 8. The reservoir storage values from the SWAT simulation output for the 2022 drought scenario, the $1950-1957$ (1956 results shown) meteorological years, and the data in EIA Form 860 confirmed that eight existing power plants can take in cooling water at the lowest simulated water levels. One of those reservoirs (Calaveras) and one additional reservoir (Braunig Lake) were simulated at $0 \%$ storage in 1956, although in practice CPS Energy operates these reservoirs to maintain a nearly constant level.

\begin{tabular}{|c|c|c|c|c|c|c|c|c|c|c|c|c|}
\hline \multicolumn{3}{|c|}{ Power Plant Specific Information } & \multicolumn{5}{|c|}{ Simulated 2022} & \multicolumn{5}{|c|}{ Simulated 1956} \\
\hline Power Plant & HUC_8 & Reservoir & $\begin{array}{c}\text { Average \% } \\
\text { storage }\end{array}$ & $\begin{array}{l}\text { Lowest \% } \\
\text { storage }\end{array}$ & $\begin{array}{l}\text { Reservoir } \\
\text { Storage (acre- } \\
\text { feet) } 2022\end{array}$ & $\begin{array}{l}\text { Reservoir } \\
\text { Elevation } \\
\text { (ft) } 2022\end{array}$ & $\begin{array}{l}\text { Intake Below } \\
\text { Reservoir } \\
\text { Surface } 2022 \\
(\mathrm{Y} / \mathrm{N}) ?\end{array}$ & $\begin{array}{c}\text { Average \% } \\
\text { storage }\end{array}$ & $\begin{array}{l}\text { Lowest \% } \\
\text { storage }\end{array}$ & $\begin{array}{c}\text { Reservoir } \\
\text { Storage (acre- } \\
\text { feet) } 1956\end{array}$ & $\begin{array}{c}\text { Reservoir } \\
\text { Elevation (ft) } \\
1956\end{array}$ & $\begin{array}{l}\text { Intake Below } \\
\text { Reservoir } \\
\text { Surface } 1956 \\
(\mathrm{Y} / \mathrm{N}) ?\end{array}$ \\
\hline Barney M. Davis Power Station & 12110203 & Laguna Madre & -- & -- & -- & -- & -- & -- & -- & -- & -- & -- \\
\hline Bastrop Energy Center & 12090301 & Municipal, Colorado River & -- & -- & -- & -- & -- & -- & -- & -- & -- & -- \\
\hline Big Brown & 12030201 & Fairfield Lake & $85 \%$ & $57 \%$ & -- & -- & -- & $95 \%$ & $72 \%$ & -- & -- & -- \\
\hline Bosque County & 12060202 & Whitney, Lake & $81 \%$ & $60 \%$ & -- & -- & -- & $85 \%$ & $69 \%$ & -- & -- & -- \\
\hline Brazos Valley & 12070104 & Brazos River & -- & -- & -- & -- & -- & -- & -- & -- & -- & -- \\
\hline Cedar Bayou & 12040104 & Cedar Bayou & -- & -- & -- & -- & -- & -- & -- & -- & -- & -- \\
\hline Coleto Creek & 12100204 & Coleto Creek Reservoir & $94 \%$ & $77 \%$ & 23,778 & 95 & $\mathrm{~N}$ & $90 \%$ & $81 \%$ & 22,767 & 95 & $\mathrm{~N}$ \\
\hline Colorado Bend Energy Center & 12090302 & Wells & -- & -- & -- & -- & -- & -- & -- & -- & -- & -- \\
\hline Comanche Peak & 12060202 & Squaw Creek Reservoir & $88 \%$ & $69 \%$ & 105,186 & 742 & -- & $81 \%$ & $64 \%$ & 149,590 & 774 & -- \\
\hline Corpus Christi Plant & 12110202 & Corpus Christi Ship Channel & -- & -- & -- & -- & -- & -- & -- & -- & -- & -- \\
\hline Dansby & 12070101 & Bryan Utilities Lake & $99 \%$ & $94 \%$ & -- & -- & -- & $100 \%$ & $100 \%$ & -- & -- & -- \\
\hline Decker Creek & 12090301 & Walter E Long, Lake & $93 \%$ & $67 \%$ & -- & -- & -- & $81 \%$ & $54 \%$ & -- & -- & -- \\
\hline Deer Park & 12040101 & Municipal-CIWA & -- & -- & -- & -- & -- & -- & -- & -- & -- & -- \\
\hline Fayette Power Plant & 12090301 & Fayette County Lake, or Cedar Creel & $93 \%$ & $67 \%$ & -- & -- & -- & $81 \%$ & $54 \%$ & -- & -- & -- \\
\hline Formosa & 12100102 & Texana, Lake & $70 \%$ & $51 \%$ & 82,057 & -- & -- & $66 \%$ & $53 \%$ & 57,546 & -- & -- \\
\hline Gibbons Creek SES & 12070103 & Gibbons Creek Reservoir & $87 \%$ & $65 \%$ & -- & -- & -- & $85 \%$ & $55 \%$ & -- & -- & -- \\
\hline Graham & 12060201 & Graham, Lake & $90 \%$ & $78 \%$ & 35,234 & 1,071 & $\mathrm{~N}$ & $83 \%$ & $67 \%$ & 30,864 & 1,069 & $\mathrm{~N}$ \\
\hline Handley & 12030102 & Arlington, Lake & $83 \%$ & $71 \%$ & 28,623 & 544 & $\mathrm{~N}$ & $52 \%$ & $46 \%$ & 24,757 & 542 & $\mathrm{~N}$ \\
\hline JK Spruce, JT Deely & 12100301 & Calaveras Lake & $97 \%$ & $87 \%$ & 392,274 & 433 & $\mathrm{~N}$ & $1 \%$ & $0 \%$ & 0 & 412 & Y \\
\hline Lake Hubbard & 12030106 & Ray Hubbard, Lake & $71 \%$ & $62 \%$ & -- & -- & -- & $59 \%$ & $51 \%$ & -- & -- & -- \\
\hline Martin Lake & 12010002 & Martin Lake & $47 \%$ & $12 \%$ & 8,722 & 288 & $\mathrm{~N}$ & $86 \%$ & $54 \%$ & 33,145 & 295 & $\mathrm{~N}$ \\
\hline Mountain Creek & 12030102 & Mountain Creek Lake & $88 \%$ & $77 \%$ & 17,514 & 454 & $\mathrm{~N}$ & $58 \%$ & $52 \%$ & 17,602 & 454 & $\mathrm{~N}$ \\
\hline North Texas & 12030102 & Lake Weatherford & -- & -- & -- & -- & -- & -- & -- & -- & -- & -- \\
\hline Nueces Bay Power Station WWTP & 12110201 & Nueces Bay & -- & -- & -- & -- & -- & -- & -- & -- & -- & -- \\
\hline Optim Energy & 12040101 & San Jacinto River Basin & -- & -- & -- & -- & -- & -- & -- & -- & -- & -- \\
\hline Ray Olinger & 12030106 & Lavon Lake & $65 \%$ & $55 \%$ & 246,053 & 481 & $\mathrm{~N}$ & $53 \%$ & $44 \%$ & 206,348 & 479 & $\mathrm{~N}$ \\
\hline Sabine & 12010002 & Sabine Lake & -- & -- & -- & -- & -- & -- & -- & -- & -- & -- \\
\hline Sam Bertron & 12040101 & Houston Ship Channel & -- & -- & -- & -- & -- & -- & -- & -- & -- & -- \\
\hline Sam Rayburn & 12100204 & Guadalupe River & -- & -- & -- & -- & -- & -- & -- & -- & -- & -- \\
\hline Sandy Creek & 12060202 & WMARSS & -- & -- & -- & -- & -- & -- & -- & -- & -- & -- \\
\hline Sim Gideon & 12090301 & Bastrop, Lake & $94 \%$ & $71 \%$ & -- & -- & -- & $78 \%$ & $50 \%$ & -- & -- & -- \\
\hline Stryker Creek & 12020004 & Striker, Lake & $91 \%$ & $72 \%$ & -- & -- & -- & $96 \%$ & $79 \%$ & -- & -- & -- \\
\hline Thomas C. Ferguson & 12090201 & Lyndon B Johnson, Lake & $91 \%$ & $79 \%$ & 89,356 & 823 & $\mathrm{~N}$ & $75 \%$ & $58 \%$ & 94,393 & 823 & $\mathrm{~N}$ \\
\hline Tradinghouse & 12060202 & Tradinghouse Creek Reservoir & $84 \%$ & $64 \%$ & -- & -- & -- & $89 \%$ & $73 \%$ & -- & -- & -- \\
\hline Trinidad & 12030105 & Trinidad Lake & $85 \%$ & $20 \%$ & -- & -- & -- & $90 \%$ & $38 \%$ & -- & -- & -- \\
\hline VH Braunig, Arthur Von Rosenburg & 12100301 & Victor Braunig Lake & $97 \%$ & $87 \%$ & -- & -- & -- & $1 \%$ & $0 \%$ & -- & -- & -- \\
\hline Valero & 12110202 & Unknown & - &.- & -- & -- & -- & -- & -- & -- & -- & -- \\
\hline Victoria Power Station & 12100204 & Guadalupe River & -- & -- & -- & -- & -- & -- & -- & -- & -- & -- \\
\hline W A Parish & 12070104 & Smithers Lake & $85 \%$ & $44 \%$ & -- & -- & -- & $81 \%$ & $36 \%$ & -- & -- & -- \\
\hline Wolf Hollow & 12060201 & Granbury, Lake & $90 \%$ & $77 \%$ & 98,792 & 689 & $\mathrm{~N}$ & $83 \%$ & $67 \%$ & 88,834 & 687 & $\mathrm{~N}$ \\
\hline
\end{tabular}




\subsection{Power Plants at Risk of Curtailment due to High Effluent Temperatures}

To analyze the risk of power plant curtailment due to high effluent discharge temperatures, we used publicly available information from the USGS (lake levels), EIA (monthly power generation from Form 923), EPA (thermal effluent discharge temperatures and limits) in the form of Enforcement and Compliance History Online (ECHO) data, ${ }^{11}$ and the TWDB (lake levels), as well as climate information (air temperature, wind speed, wet-bulb temperature) provided by Pacific Northwest National Laboratory and Argonne National Laboratory for the Texas-Gulf river basin. We then used historical data to create linear multiple regression models to estimate cooling water effluent discharge temperatures. We created regression models for each power plant having sufficient historical data (usually limited to power plants not lacking reported discharge temperatures). These regression models were then used with future simulated climate data to estimate the chance that a power plant could be curtailed in summer months because it exceeded a limit on the effluent discharge temperature.

We are able to create effluent temperature regression models for 31 of the power plants in ERCOT (Table 9). Plants were modeled if the type of cooling used (RC, OC, OF, OS) ${ }^{12}$ was known and effluent temperature data were available from the EPA database. Although some power plants that use cooling towers have data on EPA-permitted effluent discharge temperatures, we did not create regressions for these plants, because the cooling is dominated by evaporation of water in the cooling tower. Thus, the effluent water does not contain a sufficient quantity and proportion of the dissipated heat for easy correlation with power generation.

For each power plant with estimated effluent discharge temperatures, Appendix B (1) compares the historical (January 2007-August 2011) effluent temperature data to the regression estimates and the effluent temperature maximum limit as set by the water permit (if applicable and available from the EPA ECHO database) and (2) displays the predicted effluent temperatures for simulated climate data for 2027-2032 (see Section 3). The future effluent temperature estimates are based on four different climate simulations of the "A2" scenario as defined by the IPCC. ${ }^{13}$ The A2 scenario represents very little mitigation for future climate impacts; it is characterized by these general guidelines:

- Relatively slow demographic transition and relatively slow convergence in regional fertility patterns.

- Relatively slow convergence of differences in values for gross domestic product between regions.

- Relatively slow end-use and supply-side energy efficiency improvements (compared to other scenarios).

- Delayed development of renewable energy.

- No barriers to the use of nuclear energy.

The regressions focus on estimating summer effluent discharge temperatures, as thermal pollution levels have the potential to reach regulatory limits only during the summer. In addition, optimizing regressions for only summer months maximizes the accuracy for the time period of concern. To find the most accurate prediction of average monthly summer effluent temperature discharged from a power

11 See this location: http://www.epa-echo.gov/echo/

12 The EIA designates cooling types as follows: OC, OF = once through using fresh water; OS = once through using saline water; $\mathrm{RC}=$ recirculating cooling system using cooling pond; $\mathrm{RI}=$ induced-draft cooling tower; $\mathrm{RF}=$ forced-draft cooling tower.

13 See this location: http://www.ipcc.ch/ipccreports/sres/emission/index.php?idp=98. 
plant, we performed 25 different multiple regressions for 6 power plants by using some or all of the following 8 variables:

1. Ambient air (dry bulb) temperature $\left({ }^{\circ} \mathrm{F}\right)$.

2. Heat dissipated to environment:

a. Estimated as (MW-h per month)/[(1 - 3.41/heat rate (MMBtu/MW-h)] (MMBtu output as electricity)/(1 - efficiency).

b. The factor 3.41 represents $3.41 \mathrm{MMBtu}=1 \mathrm{MW}$-h conversion factor.

3. Lag of the ambient air temperature by one month $\left({ }^{\circ} \mathrm{F}\right)$.

4. Percent storage in the cooling pond or lake (\% of capacity).

5. A proxy for heat radiation to the night sky: (percent of night sky hours) $\times$ (air temperature).

6. Wet bulb temperature $\left({ }^{\circ} \mathrm{F}\right)$.

7. Dew point $\left({ }^{\circ} \mathrm{F}\right)$.

8. Wind speed $(\mathrm{m} / \mathrm{s})$.

Each of the 8 variables used in our regression models had to be averaged to single monthly values to match the EPA data on average monthly effluent water discharge temperatures. This is highly limiting, as additional data measured at daily or hourly time scales could enable future regressions to be more accurate. To determine the best linear regression for modeling power plant cooling effluent discharge temperature, we performed 25 different regression tests to determine the relative accuracy and feasibility for modeling any given power plant. These different regression tests represented different combinations of the listed 8 variables.

Ambient air temperature and heat dissipated are the most important of the 8 variables, as expected. All other variables can add some accuracy in matching the monthly historical effluent temperature data, but the accuracy varies by month and for each power plant, so that no particular regression model was superior, overall. The test numbers and descriptions of the 25 different multiple regression tests are shown in Table 10. The shaded column represents the regression chosen to model cooling water effluent discharge temperatures for ERCOT power plants. By including variables for dew point (or potentially another measure of humidity) and wind speed, we can theoretically account for some effect of multiple reservoir cooling mechanisms (e.g., convection from wind). For some reservoirs, these variables increased the accuracy of modeling effluent temperatures during summer.

Although we created regression equations for many power plants, only a subset of those power plants have configurations - a large water body absorbing a relatively large flow rate of cooling water with elevated temperatures - suitable for modeling. These power plants are configured with once-through (OS, OC, OF) cooling systems and recirculating cooling systems using ponds (RC). Not all power plants with these cooling configurations are subject to EPA permits that limit discharge temperatures, and not all of these power plants have available effluent discharge temperature data. Table 9 lists the power plants for which multiple regression linear coefficients were estimated for feasible prediction of effluent temperatures. After applying the regression model to all 31 power plants, we screened the set of regression coefficients to ensure that they have the correct sign to indicate physical reality. Specifically, the regression equation coefficients should be correlated to the dependent variable, effluent temperature, as follows:

1. Air dry bulb temperature should have a positive coefficient, as hotter ambient air means hotter water bodies.

2. Heat dissipated should have a positive coefficient, as more heat dissipated should raise effluent temperatures.

3. Wind speed should have a negative coefficient, as more wind should result in more convective cooling. 
Table 9. The coefficients of regression equation 25 (see Table 10) that are multiplied by the data variable indicated in the column headings to estimate the effluent discharge temperatures of power plants using cooling ponds or once-through systems on lakes or bays. Grayed rows indicate regressions that are not considered accurate, because the sign of one or more coefficients is incorrect.

\begin{tabular}{|c|c|c|c|c|c|c|}
\hline \multirow[b]{2}{*}{ Plant } & \multicolumn{6}{|c|}{ Coefficient for Regression Equation } \\
\hline & $\begin{array}{l}\text { Wind Speed } \\
\qquad(\mathrm{m} / \mathrm{s})\end{array}$ & $\begin{array}{c}\text { Dew } \\
\text { Point } \\
\left({ }^{\circ} \mathrm{F}\right)\end{array}$ & $\begin{array}{c}\text { Air } \\
\text { Temperature } \\
\text { 1-Month Lag } \\
\left({ }^{\circ} \mathrm{F}\right)\end{array}$ & $\begin{array}{c}\text { Air } \\
\text { Temperature } \\
\left({ }^{\circ} \mathrm{F}\right)\end{array}$ & $\begin{array}{c}\text { Heat } \\
\text { Dissipated } \\
\text { (MMBtu) }\end{array}$ & Constant \\
\hline Arthur Von Rosenberg & -1.75 & 0.11 & 0.32 & 0.60 & $1.32 \mathrm{E}-05$ & 10.92 \\
\hline Barney M Davis & -0.13 & 0.20 & 0.10 & 0.81 & $-1.35 \mathrm{E}-06$ & -3.20 \\
\hline Big Brown & 0.19 & 0.05 & 0.22 & 0.56 & $5.02 \mathrm{E}-06$ & 30.32 \\
\hline Cedar Bayou & 0.76 & 0.09 & 0.08 & 0.88 & $-2.42 \mathrm{E}-08$ & -0.70 \\
\hline Coleto Creek & -1.44 & -0.12 & -0.12 & 0.83 & 3.27E-05 & 33.64 \\
\hline Comanche Peak & -1.93 & 0.29 & 0.16 & 0.21 & $9.12 \mathrm{E}-06$ & 41.07 \\
\hline $\begin{array}{l}\text { Corpus Christi (Equistar } \\
\text { Chemicals) }\end{array}$ & -1.60 & 0.09 & -0.05 & 0.71 & $-2.95 \mathrm{E}-06$ & 37.24 \\
\hline Decker Creek & -0.81 & 0.37 & 0.10 & 0.55 & $1.97 \mathrm{E}-05$ & 12.76 \\
\hline Fayette Power Project & -1.01 & 0.13 & 0.06 & 0.48 & 7.70E-06 & 42.85 \\
\hline Gibbons Creek & -1.10 & 0.05 & 0.05 & 0.70 & 2.99E-05 & 18.83 \\
\hline Graham & -1.49 & 0.45 & 0.26 & 0.37 & $1.95 \mathrm{E}-05$ & 9.40 \\
\hline Handley & -0.74 & 0.16 & 0.33 & 0.51 & $3.18 \mathrm{E}-05$ & 10.60 \\
\hline J K Spruce $1 \& 2$ & -6.05 & -0.06 & -0.01 & 0.76 & $9.35 \mathrm{E}-06$ & 46.13 \\
\hline J T Deely & -6.27 & -0.21 & -0.08 & 0.96 & 8.69E-06 & 46.50 \\
\hline Lake Hubbard & 0.15 & 0.29 & 0.33 & 0.41 & $2.66 \mathrm{E}-05$ & 3.89 \\
\hline Martin Lake & -0.17 & 0.08 & 0.11 & 0.68 & $2.57 \mathrm{E}-06$ & 30.72 \\
\hline Mountain Creek & -1.14 & 0.15 & 0.00 & 0.80 & $3.72 \mathrm{E}-05$ & 12.44 \\
\hline Nueces Bay & -1.18 & 0.22 & -0.06 & 0.78 & $2.27 \mathrm{E}-05$ & 14.26 \\
\hline Ray Olinger & -3.07 & 0.17 & 0.01 & 0.83 & $1.02 \mathrm{E}-05$ & 16.66 \\
\hline $\begin{array}{l}\text { Roland C Dansby (City of } \\
\text { Bryan) }\end{array}$ & 0.61 & -0.03 & 0.25 & 0.98 & $-4.91 \mathrm{E}-05$ & -3.93 \\
\hline Sam R Bertron & -1.92 & -0.08 & 0.10 & 1.23 & $-2.78 \mathrm{E}-05$ & -2.61 \\
\hline Sam Rayburn & -0.96 & 0.56 & -0.16 & 0.54 & $-3.09 E-05$ & 21.20 \\
\hline Sim Gideon & -1.14 & 0.16 & 0.28 & 0.50 & $4.94 \mathrm{E}-06$ & 25.75 \\
\hline Stryker Creek & 0.60 & 0.11 & -0.08 & 0.97 & $3.79 \mathrm{E}-05$ & 1.13 \\
\hline Thomas C Ferguson & -1.58 & 0.14 & 0.23 & 0.54 & $3.27 \mathrm{E}-05$ & 19.62 \\
\hline Tradinghouse & -0.60 & 0.07 & 0.06 & 0.77 & $4.02 \mathrm{E}-05$ & 14.40 \\
\hline
\end{tabular}


Table 9. (Cont.)

\begin{tabular}{|c|c|c|c|c|c|c|}
\hline \multirow[b]{2}{*}{ Plant } & \multicolumn{6}{|c|}{ Coefficient for Regression Equation } \\
\hline & $\begin{array}{l}\text { Wind Speed } \\
\qquad(\mathrm{m} / \mathrm{s})\end{array}$ & $\begin{array}{c}\text { Dew } \\
\text { Point } \\
\left({ }^{\circ} \mathrm{F}\right)\end{array}$ & $\begin{array}{c}\text { Air } \\
\text { Temperature } \\
\text { 1-Month Lag } \\
\left({ }^{\circ} \mathrm{F}\right)\end{array}$ & $\begin{array}{c}\text { Air } \\
\text { Temperature } \\
\left({ }^{\circ} \mathrm{F}\right)\end{array}$ & $\begin{array}{c}\text { Heat } \\
\text { Dissipated } \\
\text { (MMBtu) }\end{array}$ & Constant \\
\hline Trinidad (TX) & 1.09 & 0.13 & 0.46 & 0.41 & $-1.16 \mathrm{E}-05$ & 2.98 \\
\hline V H Braunig & -0.84 & 0.03 & 0.42 & 0.54 & $3.49 \mathrm{E}-05$ & 8.03 \\
\hline $\begin{array}{l}\text { Victoria Power Station } 5 \text { \& } \\
7\end{array}$ & -0.06 & 0.03 & -0.07 & 0.76 & $-4.32 \mathrm{E}-05$ & 27.94 \\
\hline W A Parish & -1.37 & 0.08 & -0.08 & 0.79 & $4.10 \mathrm{E}-06$ & 34.18 \\
\hline Wolf Hollow & 0.33 & 0.28 & 0.17 & -0.04 & 8.17E-06 & 51.69 \\
\hline
\end{tabular}


Table 10. The multiple regressions evaluated to select a regression to use for all power plants. Regression 25 was used to model each power plant with sufficient data.

\begin{tabular}{|c|c|c|c|c|c|c|c|c|c|c|c|c|c|c|c|c|c|c|c|c|c|c|c|c|c|}
\hline & \multicolumn{25}{|c|}{ Regression Test } \\
\hline $\begin{array}{l}\text { Regression } \\
\text { Variables }\end{array}$ & 1 & 2 & 3 & 4 & 5 & 6 & 7 & 8 & 9 & 10 & 11 & 12 & 13 & 14 & 15 & 16 & 17 & 18 & 19 & 20 & 21 & 22 & 23 & 24 & 25 \\
\hline Air Temp. & $x$ & $X$ & $X$ & $X$ & $X$ & $X$ & $X$ & $X$ & $X$ & $X$ & $X$ & $X$ & $X$ & $X$ & $X$ & $X$ & $X$ & $X$ & $X$ & $X$ & $X$ & $X$ & $X$ & $X$ & $\mathrm{X}$ \\
\hline $\begin{array}{l}\text { Heat } \\
\text { dissipated } \\
\text { to } \\
\text { environ. }\end{array}$ & $\mathrm{X}$ & $x$ & $X$ & $\mathrm{X}$ & $\mathrm{X}$ & $X$ & $x$ & $x$ & $X$ & $X$ & $X$ & $\mathrm{X}$ & $\mathrm{X}$ & $\mathrm{X}$ & $\mathrm{X}$ & $\mathrm{X}$ & $X$ & $x$ & $\mathrm{X}$ & $X$ & $\mathrm{X}$ & $\mathrm{X}$ & $\mathrm{X}$ & $X$ & $x$ \\
\hline $\begin{array}{l}\text { 1-month } \\
\text { lag of air } \\
\text { temp. }\end{array}$ & & $\mathrm{X}$ & $\mathrm{X}$ & $\mathrm{X}$ & $\mathrm{X}$ & $X$ & & & & & & $\mathrm{X}$ & $\mathrm{X}$ & $\mathrm{X}$ & $X$ & $X$ & $X$ & $X$ & $\mathrm{X}$ & $\mathrm{X}$ & $\mathrm{X}$ & & & & $\mathrm{X}$ \\
\hline $\begin{array}{l}\% \text { of } \\
\text { reservoir } \\
\text { storage }\end{array}$ & & & $\mathrm{X}$ & $\mathrm{X}$ & $\mathrm{X}$ & $\mathrm{X}$ & $X$ & $X$ & $X$ & $X$ & $X$ & & & & & & $X$ & $X$ & $x$ & $X$ & $X$ & & & & \\
\hline $\begin{array}{l}\text { Heat } \\
\text { radiation } \\
\text { to night } \\
\text { sky ("night } \\
\text { hours } \times \\
T^{\wedge} 4 \text { ") }\end{array}$ & & & $X$ & $X$ & $X$ & $X$ & $X$ & $X$ & $X$ & $X$ & $X$ & $X$ & $X$ & $X$ & $X$ & $x$ & & & & & & & & & \\
\hline $\begin{array}{l}\text { Wet bulb } \\
\text { temp. }\end{array}$ & & & & $X$ & & $X$ & & & & $X$ & $X$ & & & & $x$ & $X$ & & & & $x$ & $X$ & & $X$ & $X$ & \\
\hline Dew point & & & & & $X$ & & & & $X$ & & & & $X$ & $X$ & & & & $X$ & $X$ & & & $X$ & & & $X$ \\
\hline $\begin{array}{l}\text { Wind } \\
\text { speed }\end{array}$ & & & & & & $X$ & & & $X$ & & $X$ & & & $X$ & & $X$ & & & $X$ & & $x$ & & & $x$ & $x$ \\
\hline
\end{tabular}


For power plants that did not produce regressions of the correct sign for important coefficients, we did not consider the regression accurate enough to project water effluent temperature.

Appendix B shows plots the EPA effluent temperature data for 2007-2011, the modeled effluent temperatures for 2007-2011, and the future effluent temperature predictions for 2027-2032 for each applicable power plant. As example results in Appendix B, Figure 61 shows the average monthly historical cooling effluent discharge temperature for Leon Creek Steam Electric Station, and Figure 62 shows the same data for Martin Lake Steam Electric Station. Leon Creek clearly operates well below its thermal discharge temperature limit, operating much as a peaking facility, whereas Martin Lake Steam Electric Station has operated at or near its thermal discharge temperature limit during at least two summers (2007 and 2011).

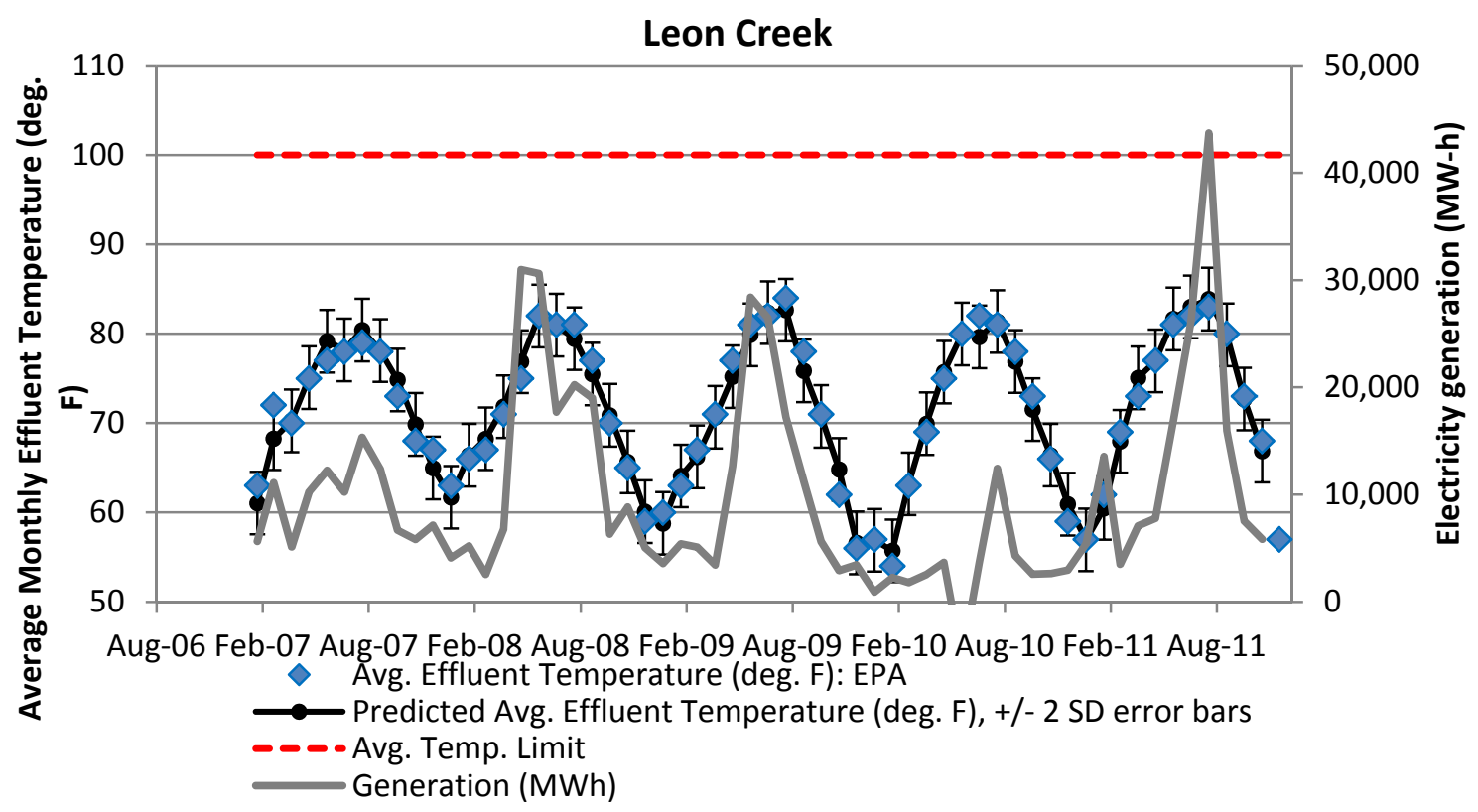

Figure 61. The historical regression for Leon Creek Steam Electric Station, indicating that it does not operate close to its $100^{\circ} \mathrm{F}$ discharge temperature limit. 


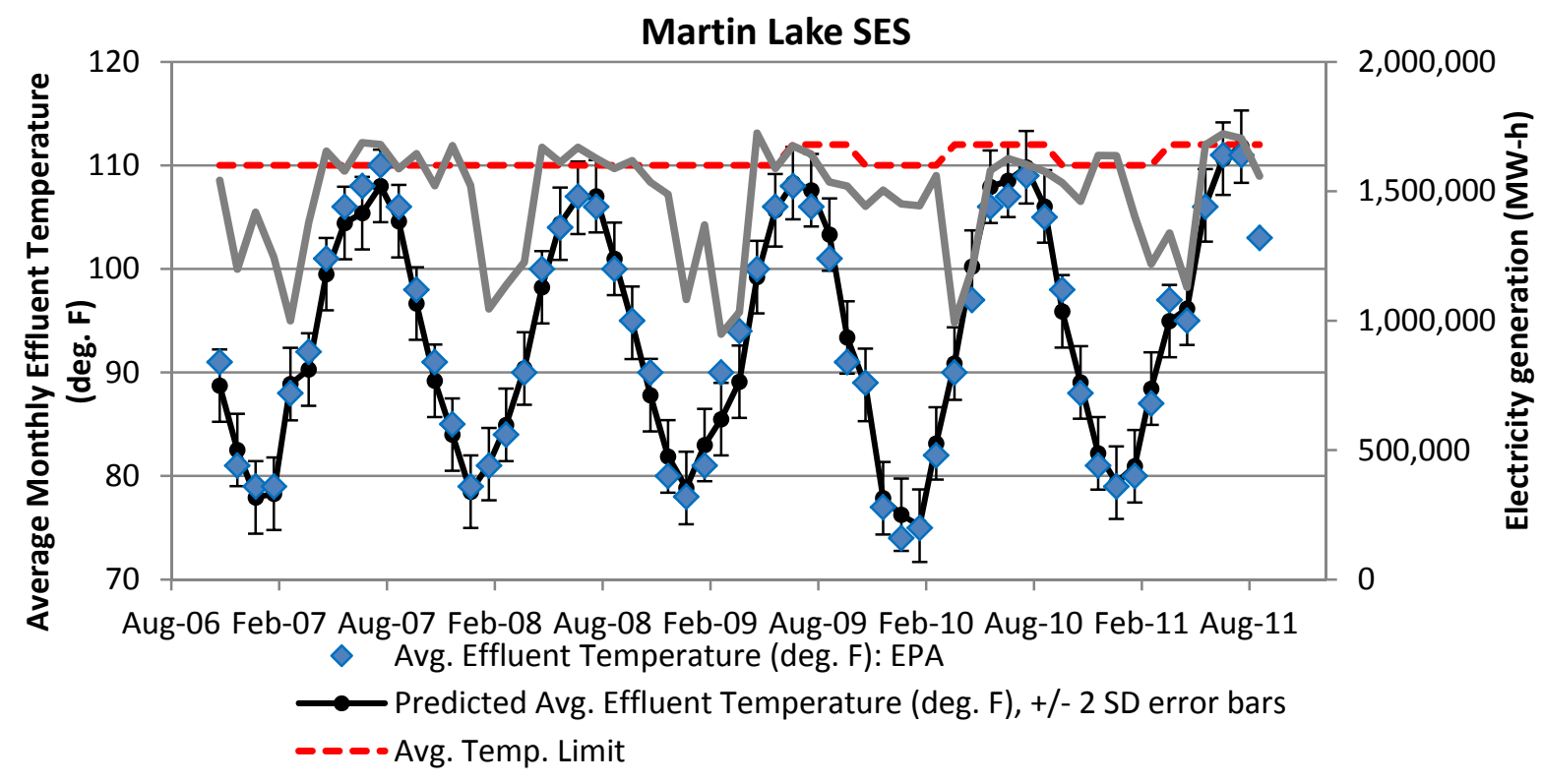

Figure 62. The historical regression for Martin Lake Steam Electric Station, indicating that it operated very near its discharge temperature limit of $110^{\circ} \mathrm{F}$ during the summers of 2007 and 2011 . The change in the regulated temperature limit indicates that the operating company for Martin Lake is aware that the temperature limit is the restriction on the amount of power it can generate in the summer.

The regression model for each power plant can be used to estimate future effluent temperatures, given predicted climate data. These estimates of future effluent temperatures can then be used to estimate whether a plant will breach its EPA-permitted thermal limit for an assumed amount of future monthly electricity generation. Appendix B, Table B1, identifies the two plants that breached their average temperature effluent discharge limits during 2007-2011: Martin Lake and Coleto Creek.

Tables B2 and B3 show the plants predicted to breach their thermal limits between 2027 and 2032 under two different assumptions: 2011 monthly generation and 100\% capacity factor (May-August), respectively. If each power plant attempted to operate at historical monthly generation (e.g., generation in 2011) under the future climate of 2027-2032 projected from the climate models and A1 scenarios, we estimate that 6 power plants (Coleto Creek, Comanche Peak, JK Spruce, Martin Lake, Nueces Bay, and WA Parish) will be exposed to some degree of curtailment due to thermal discharge limits (see Table B4). An estimated average of 25,000-210,000 MW-h/month in the summer months (May-August) of 2027-2032 could be curtailed if these power plants attempted to operate at 2011 monthly generation (see Table B5).

If power plants attempted to operate at $100 \%$ summer (May-August) capacity factor for 2027-2032, up to 13 power plants (Coleto Creek, Comanche Peak, Graham, Handley, JK Spruce, Lake Hubbard, Martin Lake, Mountain Creek, Nueces Bay, Sim Gideon, Stryker Creek, Thomas C. Ferguson, and WA Parish) could be exposed to curtailment due to effluent temperature limits (see Table B3). About 1,000,000$1,400,000 \mathrm{MW}$-h/month more could be generated in the summer months in 2027-2032 if power plants could operate at $100 \%$ capacity factor and there were no effluent temperature limits (see Table B6).

We can interpret the potential future (2027-2032) electricity curtailment in terms of a "worst-case" scenario, where all generation curtailment occurs from 12 noon to 8 p.m., during peak demand hours. If we assume that the electricity curtailments projected for power plants operating at 2011 monthly generation in 2027-2032 (Table B4) occur equally for all hours from 12 noon to 8 p.m., then the curtailed 
capacity is 100-850 MW (see Table B5). If we assume that electricity curtailments projected for power plants operating at $100 \%$ monthly capacity factor in 2027-2032 (Table B6) occur equally for all hours from 12 noon to 8 p.m., then the curtailed capacity is 3,900-5,500 MW (see Table B7).

Instead of considering how much electricity cannot be generated in the future because EROCT power plants might breach their permitted average monthly effluent temperatures, we can also consider how much electricity could be generated if power plants generate as much as possible without reaching their average monthly effluent temperature limits. That is to say, most power plants do not operate at $100 \%$ capacity factor in the summer, but some power plants could operate at $100 \%$ capacity factor without reaching their permitted effluent temperature limits. Additionally, some power plants could perhaps operate at a higher capacity factor than they have in the past, but they cannot reach $100 \%$ capacity factor without breaching effluent temperature limits. Thus, by considering additional electricity generation potential up to effluent temperature limits, we estimated that an additional 7,500,000 MW$\mathrm{h} /$ month could have been generated in 2011 (Table B10). Further, if we consider the baseline electricity generation in 2011, we estimate that the existing power plants could generate an additional 6,400,0006,800,000 MW-h/month in the 2027-2032 summer months (Table B8) without breaching temperature limits. In short, the effluent temperature regression modeling indicates that - when only EPA effluent temperature limits are considered - approximately 5 to 6 million $\mathrm{MW}$-h generation is available from existing generators than might be curtailed.

\subsection{Summary of Analysis of Drought and Future Climate Risk to ERCOT Power Plant Curtailment}

Sections 7.1 and 7.2 describe the approach to estimating future climate and drought impacts on power generation in ERCOT. This subsection briefly summarizes the findings. Table 11 lists each power plant considered, its prime mover type, its cooling system type, and whether the drought analysis of this report indicates that the power plant is at risk of having to reduce power generation because of either thermal effluent temperature limits or water levels potentially falling below intake elevations. As discussed in Section 7.1, nine power plants under the modeled drought scenarios have a full set of indicators for water intake levels. These power plants show no difficulty with water intake, although in the 1950s drought scenario, JT Deely, JK Spruce, and VH Braunig, operating on Lakes Calaveras and Victor Braunig, were highly managed by CPS to maintain near-constant water levels. 
Table 11. Summary of drought (2011, 1950-1957, and 2022 estimated drought) and future (2030 temperatures) climate analysis of impacts on ERCOT thermal generation. Cooling system types are identified by EIA designations: $\mathrm{OC}, \mathrm{OF}=$ once-through using fresh water; $\mathrm{OS}=$ once-through using saline water; $\mathrm{RC}=$ recirculating cooling system using cooling pond; $\mathrm{RI}$ = induced draft cooling tower; $\mathrm{RF}$ = forced draft cooling tower.

\begin{tabular}{|c|c|c|c|c|}
\hline Plant Name & $\begin{array}{l}\text { Fuel and } \\
\text { Prime } \\
\text { Mover }\end{array}$ & $\begin{array}{l}\text { Cooling System } \\
\text { Type }\end{array}$ & $\begin{array}{l}\text { At Risk of Current or } \\
\text { Future Curtailment } \\
\text { Because of Water } \\
\text { Effluent Thermal } \\
\text { Discharge Limits? }\end{array}$ & $\begin{array}{l}\text { Does Water Basin } \\
\text { Drought Analysis Indicate } \\
\text { Risk of Current or Future } \\
\text { Curtailment due to } \\
\text { Inability to Take in Water } \\
\text { (e.g., low reservoir } \\
\text { condition)? }\end{array}$ \\
\hline Barney M. Davis & $\begin{array}{l}\text { NG, steam } \\
\text { turbine }\end{array}$ & $\begin{array}{l}\text { Once-through (OS) } \\
\text { using saline water } \\
\text { from Laguna Madre }\end{array}$ & $\begin{array}{c}\text { No } \\
\text { (not likely to reach EPA } \\
\text { thermal limit) }\end{array}$ & $-{ }^{a}$ \\
\hline Bastrop & $\begin{array}{l}\text { NG, steam } \\
\text { turbine }\end{array}$ & Cooling tower (RI) & $\begin{array}{c}\text { No } \\
\text { (no EPA thermal limit) }\end{array}$ & - \\
\hline Big Brown & $\begin{array}{l}\text { Coal, steam } \\
\text { turbine }\end{array}$ & $\begin{array}{l}\text { Once-through (OC) } \\
\text { using Fairfield Lake }\end{array}$ & $\begin{array}{c}\text { No } \\
\text { (no EPA thermal limit) }\end{array}$ & - \\
\hline Bosque County & $\begin{array}{c}\text { NG } \\
\text { combined } \\
\text { cycle }\end{array}$ & $\begin{array}{l}\text { Cooling tower (RF) } \\
\text { sourced from Brazos } \\
\text { River below Lake } \\
\text { Whitney }\end{array}$ & $\begin{array}{c}\text { No } \\
\text { (no EPA thermal limit) }\end{array}$ & - \\
\hline $\begin{array}{l}\text { Brazos Valley } \\
\text { Generating } \\
\text { Station }\end{array}$ & NGCC & $\begin{array}{l}\text { Cooling tower (RF) } \\
\text { next to WA Parish } \\
\text { and Smithers Lake }\end{array}$ & $\begin{array}{c}\text { No } \\
\text { (no EPA thermal limit) }\end{array}$ & - \\
\hline Cedar Bayou & NG Steam & Once-through (OC) & $\begin{array}{c}\text { No } \\
\text { (not likely to reach EPA } \\
\text { thermal limit) }\end{array}$ & - \\
\hline Coleto Creek & $\begin{array}{l}\text { Coal, RC } \\
\text { (pond) }\end{array}$ & $\begin{array}{l}\text { Cooling pond/lake } \\
\text { (RC) }\end{array}$ & $\begin{array}{c}\text { Yes } \\
\text { (has operated at or very } \\
\text { near EPA thermal limit) }\end{array}$ & No \\
\hline $\begin{array}{l}\text { Colorado Bend } \\
\text { Energy Center }\end{array}$ & $\begin{array}{c}\text { NG } \\
\text { combined } \\
\text { cycle }\end{array}$ & Cooling tower (RF) & $\begin{array}{c}\text { No } \\
\text { (not likely to reach EPA } \\
\text { thermal limit) }\end{array}$ & $\begin{array}{c}- \\
\text { (water from wells) }\end{array}$ \\
\hline Comanche Peak & $\begin{array}{l}\text { Nuclear } \\
\text { steam }\end{array}$ & $\begin{array}{l}\text { Once-through (OC) } \\
\text { on Lake Somerville }\end{array}$ & $\begin{array}{c}\text { Yes } \\
\text { (has operated at or very } \\
\text { near EPA thermal limit) }\end{array}$ & - \\
\hline $\begin{array}{l}\text { Corpus Christi } \\
\text { Energy Center }\end{array}$ & NG steam & $\begin{array}{c}\text { Cooling tower (RI), } \\
\text { discharges to ship } \\
\text { channel }\end{array}$ & $\begin{array}{c}\text { No } \\
\text { (not likely to reach EPA } \\
\text { thermal limit) }\end{array}$ & - \\
\hline Decker Creek & $\begin{array}{l}\text { NG steam } \\
\text { and } \\
\text { combustion } \\
\text { turbines }\end{array}$ & $\begin{array}{l}\text { Once-through (OF) } \\
\text { on Lake Long }\end{array}$ & $\begin{array}{c}\text { No } \\
\text { (no EPA thermal limit) }\end{array}$ & - \\
\hline $\begin{array}{c}\text { Deer Park } \\
\text { Energy Center }\end{array}$ & NG steam & Cooling tower (RI) & $\begin{array}{c}\text { No } \\
\text { (no EPA thermal limit) }\end{array}$ & - \\
\hline $\begin{array}{l}\text { Fayette Power } \\
\text { Project }\end{array}$ & Coal steam & Once-through (OC) & $\begin{array}{c}\text { No } \\
\text { (no EPA thermal limit) }\end{array}$ & - \\
\hline
\end{tabular}


Table 11 (Cont.)

\begin{tabular}{|c|c|c|c|c|}
\hline Plant Name & $\begin{array}{l}\text { Fuel and } \\
\text { Prime } \\
\text { Mover }\end{array}$ & $\begin{array}{c}\text { Cooling System } \\
\text { Type }\end{array}$ & $\begin{array}{l}\text { At Risk of Current Or } \\
\text { Future Curtailment } \\
\text { Because of Water } \\
\text { Effluent Thermal } \\
\text { Discharge Limits? }\end{array}$ & $\begin{array}{l}\text { Does Water Basin } \\
\text { Drought Analysis Indicate } \\
\text { Risk of Current or Future } \\
\text { Curtailment due to } \\
\text { Inability to Take in Water } \\
\text { (e.g., low reservoir } \\
\text { condition)? }\end{array}$ \\
\hline $\begin{array}{c}\text { Formosa Energy } \\
\text { Center }\end{array}$ & NG steam & Cooling tower (RI) & $\begin{array}{l}\text { Yes } \\
\text { (has operated at or very } \\
\text { near EPA thermal limit, } \\
\text { but likely linked to } \\
\text { industrial activity rather } \\
\text { than electric generation) }\end{array}$ & No \\
\hline Gibbons Creek & Coal & $\begin{array}{l}\text { Cooling pond/lake } \\
\text { (RC) }\end{array}$ & $\begin{array}{c}\text { No } \\
\text { (not likely to reach EPA } \\
\text { thermal limit) }\end{array}$ & - \\
\hline Graham SES & NG steam & Once-through (OC) & $\begin{array}{l}\text { No } \\
\text { (not likely to reach EPA } \\
\text { thermal limit unless } \\
\text { generation increases to } \\
100 \% \text { capacity) }\end{array}$ & No \\
\hline $\begin{array}{l}\text { JT Deely, JK } \\
\text { Spruce }\end{array}$ & Coal & $\begin{array}{l}\text { Once-through (OC); } \\
\text { Cooling pond/lake } \\
\text { (RC) }\end{array}$ & $\begin{array}{c}\text { No } \\
\text { (not likely to reach EPA } \\
\text { thermal limit) }\end{array}$ & $\begin{array}{c}\text { No } \\
\text { (but simulation for 1950s } \\
\text { drought indicates } \\
\text { extremely low storage } \\
\text { without water transfers) }\end{array}$ \\
\hline Lake Hubbard & NG steam & Once-through (OC) & $\begin{array}{c}\text { No } \\
\text { (not likely to reach EPA } \\
\text { thermal limit unless } \\
\text { generation increases to } \\
100 \% \text { capacity) }\end{array}$ & - \\
\hline Leon Creek & $\begin{array}{l}\text { NG steam } \\
\text { and } \\
\text { combustion } \\
\text { turbine }\end{array}$ & Cooling tower (RF) & $\begin{array}{c}\text { No } \\
\text { (not likely to reach EPA } \\
\text { thermal limit) }\end{array}$ & - \\
\hline Martin Lake & Coal & Once-through (OC) & $\begin{array}{c}\text { Yes } \\
\text { (has operated at or very } \\
\text { near EPA thermal limit) }\end{array}$ & No \\
\hline Mountain Creek & NG steam & Once-through (OC) & $\begin{array}{l}\text { No } \\
\text { (not likely to reach EPA } \\
\text { thermal limit unless } \\
\text { generation increases to } \\
100 \% \text { capacity) }\end{array}$ & No \\
\hline Nueces Bay & $\begin{array}{c}\text { NG } \\
\text { combined } \\
\text { cycle }\end{array}$ & Once-through (OS) & $\begin{array}{c}\text { Yes } \\
\text { (could operate at EPA } \\
\text { thermal limit at higher } \\
\text { summer capacity factor } \\
\text { today and in future) }\end{array}$ & - \\
\hline
\end{tabular}


Table 11 (Cont.)

\begin{tabular}{|c|c|c|c|c|}
\hline Plant Name & $\begin{array}{l}\text { Fuel and } \\
\text { Prime } \\
\text { Mover }\end{array}$ & $\begin{array}{l}\text { Cooling System } \\
\text { Type }\end{array}$ & $\begin{array}{l}\text { At Risk of Current Or } \\
\text { Future Curtailment } \\
\text { Because of Water } \\
\text { Effluent Thermal } \\
\text { Discharge Limits? }\end{array}$ & $\begin{array}{l}\text { Does Water Basin } \\
\text { Drought Analysis Indicate } \\
\text { Risk of Current or Future } \\
\text { Curtailment due to } \\
\text { Inability to Take in Water } \\
\text { (e.g., low reservoir } \\
\text { condition)? }\end{array}$ \\
\hline $\begin{array}{l}\text { Optim Energy } \\
\text { Altura }\end{array}$ & NG steam & Cooling tower (RF) & $\begin{array}{c}\text { No } \\
\text { (not likely to reach EPA } \\
\text { thermal limit) }\end{array}$ & - \\
\hline Ray Olinger & NG steam & Once-through (OF) & $\begin{array}{c}\text { No } \\
\text { (not likely to reach EPA } \\
\text { thermal limit) }\end{array}$ & No \\
\hline Sam Bertron & NG steam & Once-through (OS) & $\begin{array}{c}\text { No } \\
\text { (not likely to reach EPA } \\
\text { thermal limit) }\end{array}$ & - \\
\hline Sam Rayburn & $\begin{array}{l}\text { NG } \\
\text { combined } \\
\text { cycle }\end{array}$ & $\begin{array}{c}\text { Cooling tower (RF) } \\
\text { and Once-through } \\
\text { (OC) on Guadalupe } \\
\text { River }\end{array}$ & $\begin{array}{c}\text { No } \\
\text { (not likely to reach EPA } \\
\text { thermal limit) }\end{array}$ & - \\
\hline Sim Gideon & NG steam & Cooling pond (RC) & $\begin{array}{l}\text { No } \\
\text { (not likely to reach EPA } \\
\text { thermal limit unless } \\
\text { generation increases to } \\
100 \% \text { capacity) }\end{array}$ & - \\
\hline $\begin{array}{l}\text { South Texas } \\
\text { Project }\end{array}$ & Nuclear & Cooling Pond (RC) & $\begin{array}{c}\text { Not known (no EPA } \\
\text { historical data available) }\end{array}$ & - \\
\hline Stryker Creek & NG steam & Once-through (OC) & $\begin{array}{c}\text { No } \\
\text { (not likely to reach EPA } \\
\text { thermal limit unless } \\
\text { generation increases to } \\
100 \% \text { capacity) }\end{array}$ & - \\
\hline $\begin{array}{l}\text { Thomas C. } \\
\text { Ferguson }\end{array}$ & NG steam & Once-through (OF) & $\begin{array}{l}\text { No } \\
\text { (not likely to reach EPA } \\
\text { thermal limit unless } \\
\text { generation increases to } \\
100 \% \text { capacity) }\end{array}$ & No \\
\hline Tradinghouse & NG steam & Once-through (OC) & $\begin{array}{c}\text { No } \\
\text { (no EPA thermal limit) }\end{array}$ & - \\
\hline Trinidad & NG steam & Once-through (OC) & $\begin{array}{c}\text { No } \\
\text { (no EPA thermal limit) }\end{array}$ & - \\
\hline
\end{tabular}


Table 11 (Cont.)

\begin{tabular}{|c|c|c|c|c|}
\hline Plant Name & $\begin{array}{c}\text { Fuel and } \\
\text { Prime } \\
\text { Mover }\end{array}$ & $\begin{array}{l}\text { Cooling System } \\
\text { Type }\end{array}$ & $\begin{array}{l}\text { At Risk of Current Or } \\
\text { Future Curtailment } \\
\text { Because of Water } \\
\text { Effluent Thermal } \\
\text { Discharge Limits? }\end{array}$ & $\begin{array}{c}\text { Does Water Basin } \\
\text { Drought Analysis Indicate } \\
\text { Risk of Current or Future } \\
\text { Curtailment due to } \\
\text { Inability to Take in Water } \\
\text { (e.g., low reservoir } \\
\text { condition)? }\end{array}$ \\
\hline V H Braunig & NG steam & Cooling pond (RC) & $\begin{array}{c}\text { No } \\
\text { (no EPA thermal limit) }\end{array}$ & $\begin{array}{l}- \\
\text { (but simulation for 1950s } \\
\text { drought indicates } \\
\text { extremely low storage } \\
\text { without water transfers) }\end{array}$ \\
\hline WA Parish & $\begin{array}{l}\text { Coal and } \\
\mathrm{NG} \text {, multiple } \\
\text { steam and } \\
\text { combustion } \\
\text { turbine } \\
\end{array}$ & Cooling pond (RC) & $\begin{array}{c}\text { Yes } \\
\text { (not likely to reach EPA } \\
\text { thermal limit unless } \\
\text { generation increases to } \\
100 \% \text { capacity) }\end{array}$ & - \\
\hline Wolf Hollow & $\begin{array}{c}\text { NG } \\
\text { combined } \\
\text { cycle }\end{array}$ & Cooling tower (RF) & $\begin{array}{c}\text { No } \\
\text { (no EPA thermal limit) }\end{array}$ & No \\
\hline
\end{tabular}

No intake data. 


\section{Conclusions}

\subsection{Water Availability}

Water is projected to be available for ERCOT thermoelectric power plant operations out to 2030. However, water for new development will probably need to come from sources other than unappropriated surface water. This conclusion largely means that future water supplies for thermoelectric power will be more expensive than historical supplies, for the following reasons:

- In general, very little unappropriated surface water is available for any use, including thermoelectric power

- Water availability from appropriated water supplies, specifically "low-value" agriculture, is present at $>5,000 \mathrm{ac}-\mathrm{ft} / \mathrm{yr}$, but only in a few HUC8 basins.

- Several HUC8 basins have wastewater, potable groundwater, and brackish groundwater availability at over 10,000 ac-ft/yr (enough for a large power plant).

- A number of basins (14) with severely limited water supplies are targeted for siting of new electric power production.

\subsection{Water Supply Costs}

- The cheapest water supply (at $\$ 18 / \mathrm{ac}-\mathrm{ft}$ ) that has enough water (roughly $>5,000 \mathrm{ac}$-ft/yr) to supply wet cooling at a medium to large-sized thermal power plant is from low-value agriculture.

- Estimated costs for brackish water availability per HUC8 basin vary widely, from tens to more than thousands of dollars per acre-foot, with most in the range of $\$ 500-900 / a c-f t$ (or about $\$ 1.7-2.7 / 1,000$ gal). This price for water is close to but below some estimates for the cost of water needed to incentivize the use of dry cooling systems at $>\$ 3 / 1,000$ gal.

\subsection{Potential Derating of Thermoelectric Cooling during Drought due to Lack of Water Supply}

- Hydrologic modeling results indicate significant impact on water availability (water yield, stream flow, and reservoir storage) in single-year drought (2011 and 2022) and multiple-year drought (1950-1957) scenarios.

- The model predictions for average and minimum monthly reservoir storage during the 2011 drought year were validated with R2 $=0.81$ and 0.72 , respectively, for 22 reservoirs out of 37 that provide water supply to 47 power plants.

- With a criterion based on observed and predicted reservoir data, we identified 15 low-storage reservoirs in 2011, 10 in 2022, and 20 in 1956 (the last year for the multiple-year drought scenario). Among them, 4 reservoirs (Addicks Reservoir, Texana Lake, Martin Lake, and Smithers Lake) would be under the low-storage condition in all three drought scenarios.

- Reservoir water storage declined gradually over the period of the multiple-year drought duration, suggesting that the reservoirs would be more vulnerable in a long-term drought than in a single-year drought.

- Analysis of available water intake levels found that none of the 9 power plants considered would be unable to take in cooling water because of low reservoir water levels in the three drought scenarios. Such an analysis is recommended for all reservoirs, especially low-storage reservoirs as predicted for the drought scenarios, if water intake level data for other reservoirs with power plants become available. 
- The predicted low-storage reservoirs in 2011,2022 , and 1956 would potentially affect 18,11 , and 26 power plants, respectively. The total generation capacity for those power plants is 16,898 MW in 2011, 10,169 MW in 2022, and 21,734 MW in 1956.

- The different drought scenarios (such as 2011, 2022, and 1950-1957) have different drought effects in terms of spatial distribution of water availability and reservoir storage reduction, because of variations in the climate pattern.

- Vulnerable HUC8 basins, identified by two matrices based on water use versus water availability in three drought scenarios, need to be evaluated carefully for future power plant siting to avoid basins with high water demand and limited water availability. The predictions for the 1956 scenario suggest more vulnerable HUC8 basins near Dallas, Houston, Austin, San Antonio, Brownsville, and Lubbock than do other scenarios.

- Future work on potential derating due to low reservoir storage should involve analysis for the individual reservoirs with low storage, as predicted in this study for the three drought scenarios. A full analysis of water intake level at each reservoir should be performed for all power plants if the intake level data become available. This information can be used to quantify the direct impact of drought on electricity generation.

\subsection{Potential Derating of Thermoelectric Cooling during Drought due to Effluent Discharge Temperature Limits}

The assessment of ERCOT thermal power plants potentially operating above EPA limits for temperature of effluent discharges indicated that a few power plants and a significant quantity of generation capacity have operated at or near these temperature limits in the past. In addition, because of expected warming from climate change, the major factor affecting effluent temperatures - ambient temperature - can be expected to result in even greater future derating potential (near 1,000,000 MW-h per summer month) under limitations by cooling water effluent temperatures. However, while some power plants are projected to be exposed to curtailment because of these EPA temperature limits, we estimate that six times more electricity generation potential ( 6,000,000 MW-h per summer month) can occur from other existing generators where power plants will not reach thermal effluent temperature limits. The specific findings are as follows:

- The regression models derived for this study reasonably simulated average monthly effluent temperatures for most of the open-loop and recirculating cooling pond systems in ERCOT.

- The data on effluent water thermal discharges from power plants revealed that at least two power plants (Martin Lake, Coleto Creek) operated above their average temperature effluent discharge limits in 2007-2011.

- By 2030, up to 6 power plants could have effluent discharge thermally limiting their generation at $20,000-200,000 \mathrm{MW}$-h per month if they attempt to operate at 2011 capacity factors.

- By 2030, up to 13 power plants could have effluent discharge thermally limiting their generation at $1,000,000 \mathrm{MW}$-h per month if they attempt to operate at $100 \%$ summer capacity factors.

- Approximately $6,000,000 \mathrm{MW}$-h of electricity is available (up to $100 \%$ capacity factor in summer months) from thermal generators that would not be limited by effluent temperature limits. 


\section{References}

Bolton, D., 1980, "The Computation of Equivalent Potential Temperature," Monthly Weather Review 108:1046-1053.

Demissie, Y., E. Yan, M. Wu, and Z. Zhang, 2012, Watershed Modeling for Evaluation of Biofuel Feedstock Production in the Upper Mississippi River Basin, ANL/EVS/AGEM/TR-12-07, Argonne National Laboratory, Argonne, IL, http://www.ipd.anl.gov/anlpubs/2012/08/73898.pdf.

Hidalgo, H.G., M.D. Dettinger, and D.R. Cayan, 2008, Downscaling with Constructed Analogues: Daily Precipitation and Temperature Fields over the United States, CEC-500-2007-123, Public Interest Energy Research Program, California Energy Commission, Sacramento, California.

IPCC SRES, 2000, Special Report on Emissions Scenarios: A Special Report of Working Group III of the Intergovernmental Panel on Climate Change, N. Nakićenović and R. Swart, eds., Cambridge University Press.

Kenny, R.F., N.L. Barber, S.S. Hutson, K.S. Linsey, J.K. Lovelace, and M.A. Maupin, 2009, Estimated Use of Water in the United States in 2005, Circular 1344, U.S. Geological Survey, Washington, D.C.

Kimball, J.S., S.W. Running, and R. Nemani, 1997, "An Improved Method for Estimating Surface Humidity from Daily Minimum Temperature," Agricultural and Forest Meteorology 85(1-2):87-98, DOI: 10.1016/S0168-1923(96)02366-0.

King, C.W., I.J. Duncan, and M.E. Webber, 2008, Water Demand Projections for Power Generation in Texas, prepared for the Texas Water Development Board, contract No. 0704830756.

LBG-Guyton Associates, 2003, Brackish Groundwater Manual for Texas Regional Water Planning Groups, prepared for the Texas Water Development Board, available at www.twdb.state.tx.us.

Maurer, E.P., A.W. Wood, J.C. Adam, D.P. Lettenmaier, and B. Nijssen, 2002, "A Long-Term Hydrologically Based Data Set of Land Surface Fluxes and States for the Conterminous United States," Journal of Climate 15:3237-3251.

Maurer, E.P., 2007, "Uncertainty in Hydrologic Impacts of Climate Change in the Sierra Nevada, California, under Two Emissions Scenarios," Climatic Change 82, 10.1007/s10584-006-9180-9.

Neitsch, S.L., J.G. Arnold, J.R. Kiniry, and J.R. Williams, 2011, Soil and Water Assessment Tool: Theoretical Documentation Version 2009, Grassland Soil and Water Research Laboratory Agricultural Research Service, Temple, Texas.

NETL, 2009, Impact of Drought on U.S. Steam Electric Power Plant Cooling Water Intakes and Related Water Resource Management Issues, DOE/NETL-2009/1364, National Energy Technology Laboratory, U.S. Department of Energy, Washington, D.C.

Reilly, T.E., K.F. Dennehey, W.M. Alley, and W.L. Cunningham, 2008, Ground-Water Availability in the United States in 2008, Circular 1323, U.S. Geological Survey, Washington, D.C.

Rogers, R.R., and M.K. Yau, 1989, A Short Course in Cloud Physics, 3rd ed., Vol. 113, International Series in Natural Philosophy, Butterworth-Heinemann.

TWDB, 2012, 2012 State Water Plan, Texas Water Development Board, http://www.twdb.state.tx.us/wrpi/swp/swp.asp.

Thornton, P.E., and S.W. Running, 1999, "An Improved Algorithm for Estimating Incident Daily Solar Radiation from Measurements of Temperature, Humidity, and Precipitation," Agricultural and Forest Meteorology 93:211-228. 
Watson, I.C., O. Morin, and L. Henthorne, 2003, Desalting Handbook for Planners, 3rd ed., Bureau of Reclamation, U.S. Department of the Interior, Washington, D.C.

Wood, A.W., E.P. Maurer, A. Kumar, and D.P. Lettenmaier, 2002, "Long-Range Experimental Hydrologic Forecasting for the Eastern United States," Journal of Geophysical Research-Atmospheres 107(D20):4429.

Wood, A.W., Leung, L.R., Sridhar, V., and D.P. Lettenmaier, 2004, "Hydrologic Implications of Dynamical and Statistical Approaches to Downscaling Climate Model Outputs," Climatic Change 62:189-216. 
This page intentionally left blank. 
Appendix A:

Historical Data for Reservoirs and Cooling Ponds Associated with Power Plants within ERCOT and the Gulf Coast Basin 
This page intentionally left blank. 


\section{Appendix A:}

\section{Historical Data for Reservoirs and Cooling Ponds Associated with Power Plants within ERCOT and the Gulf Coast Basin}

This appendix includes historical storage and elevation data for cooling ponds and reservoirs (from the TWDB and USGS) and cooling water intake levels (from EIA Form 860) associated with power plants within ERCOT and the Gulf Coast Basin.

Except for Lake Ray Hubbard and Lake Arlington, the USGS surface elevation data and TWDB reservoir storage and elevation data were combined to form a full representation of elevation and storage for each cooling pond or reservoir. Because TWDB data date back one year, while USGS data date back to 2007, reservoir storage was calculated from USGS historical elevation values and the recent TWDB elevation and storage data.

For Lake Hubbard, the USGS and TWDB data did not match, so no calculation was possible. For Lake Arlington, both storage and elevation data were available from the USGS.

Data are presented for the following power plants:

- Coleto Creek

- Comanche Peak

- Formosa

- Graham

- Handley

- Lake Hubbard

- Martin Lake

- Mountain Creek

- North Texas

- Ray Olinger

- Sam Rayburn

- Thomas C. Ferguson

- Wolf Hollow 


\section{Coleto Creek}

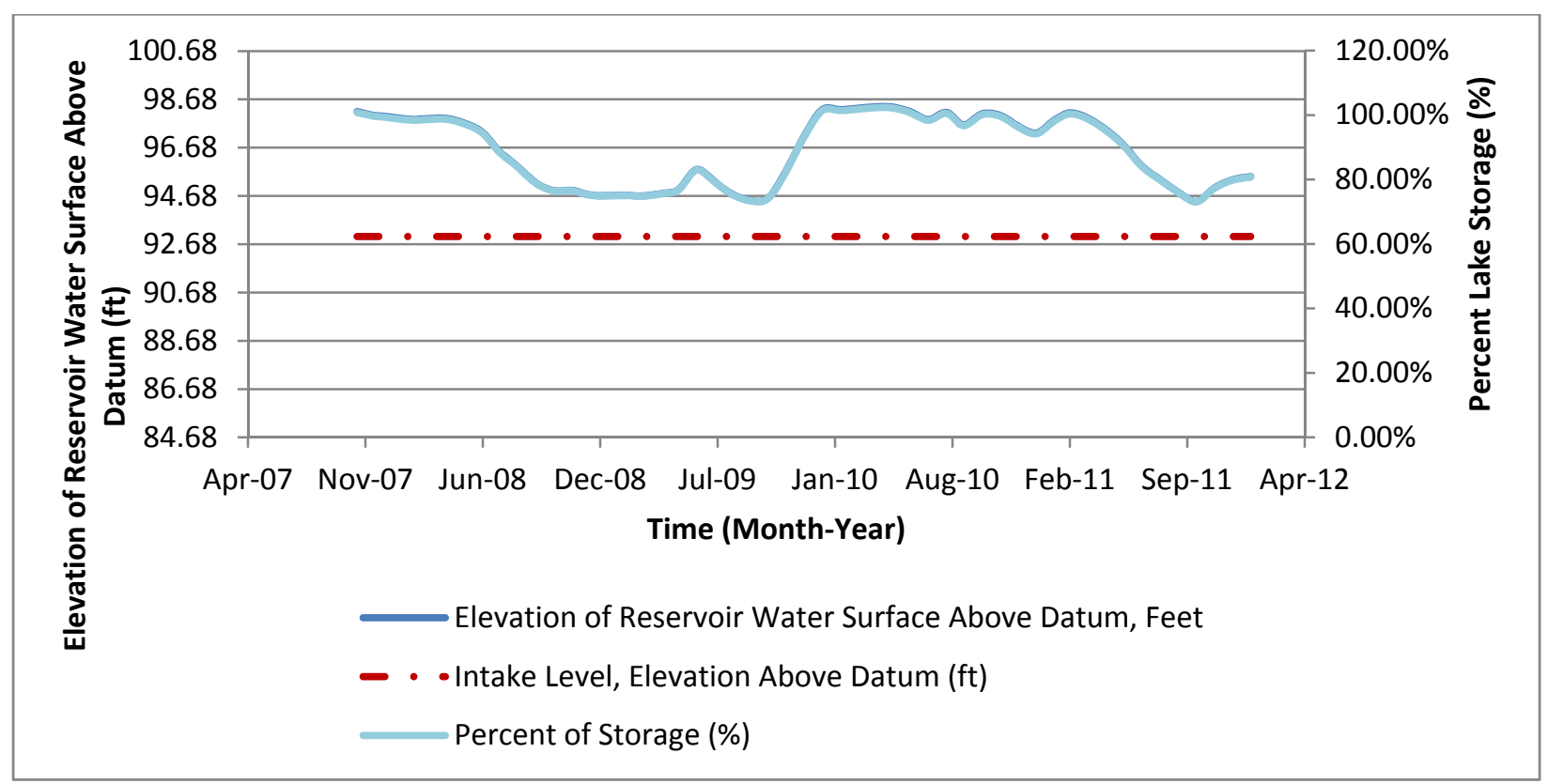

The water level in Coleto Creek Reservoir (USGS, TWDB) remains $\sim 2 \mathrm{ft}$ above the estimated intake level for the power plant. Under extended 2011 drought conditions, the reservoir surface level might have declined beneath the intake.

Storage $(\mathrm{ac}-\mathrm{ft})=2306.612(\mathrm{ac}-\mathrm{ft} / \mathrm{ft}) *$ Elevation $(\mathrm{ft})-195166(\mathrm{ac}-\mathrm{ft})$ 


\section{Comanche Peak SES}

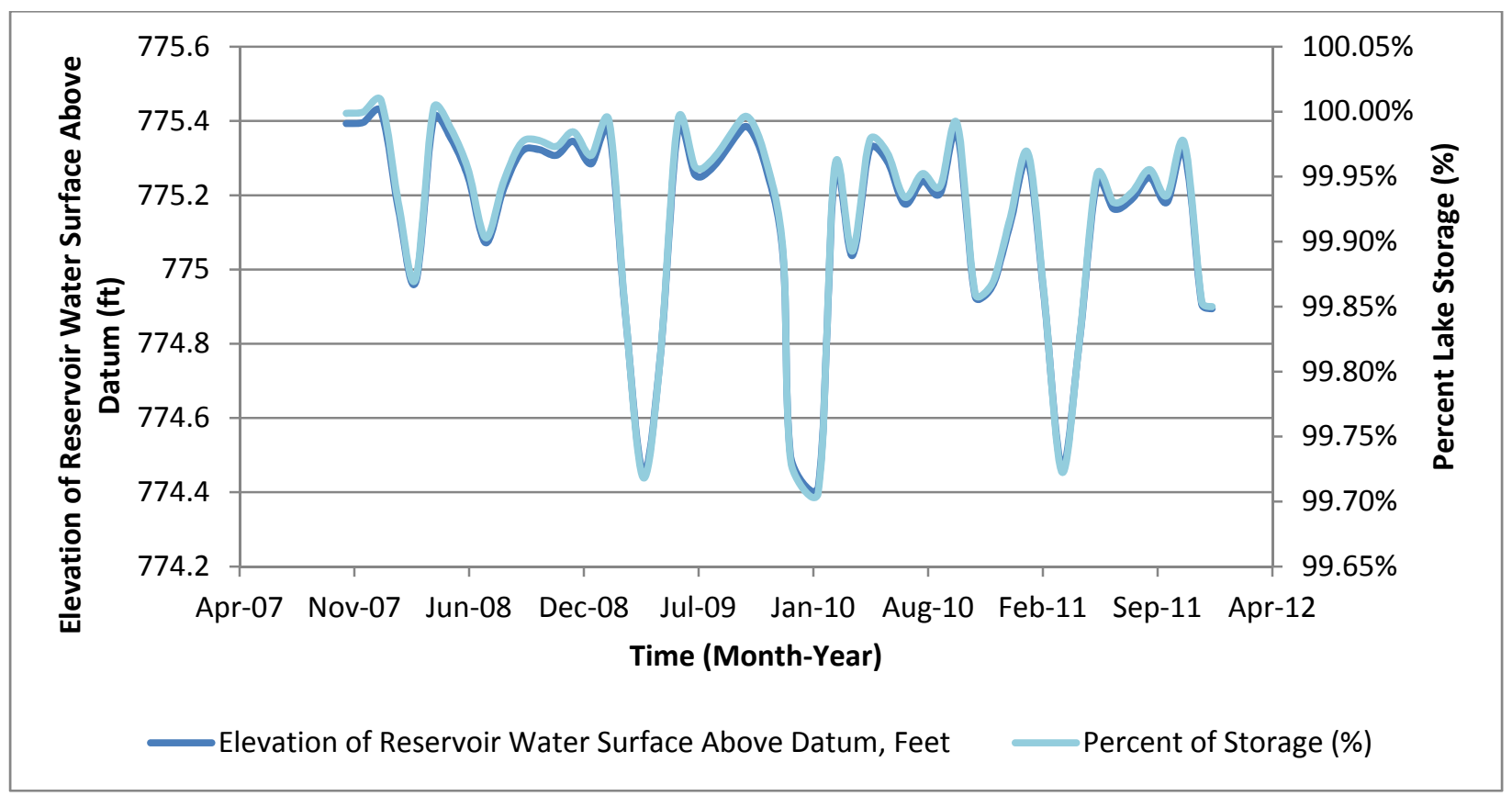

The water level for Squaw Creek Reservoir (USGS, TWDB) remains close to the 775-ft conservation elevation, at more than $99 \%$ full. The intake level is not known.

Storage $(\mathrm{ac}-\mathrm{ft})=415.796(\mathrm{ac}-\mathrm{ft} / \mathrm{ft}) *$ Elevation $(\mathrm{ft})-198954.17(\mathrm{ac}-\mathrm{ft})$ 


\section{Formosa}

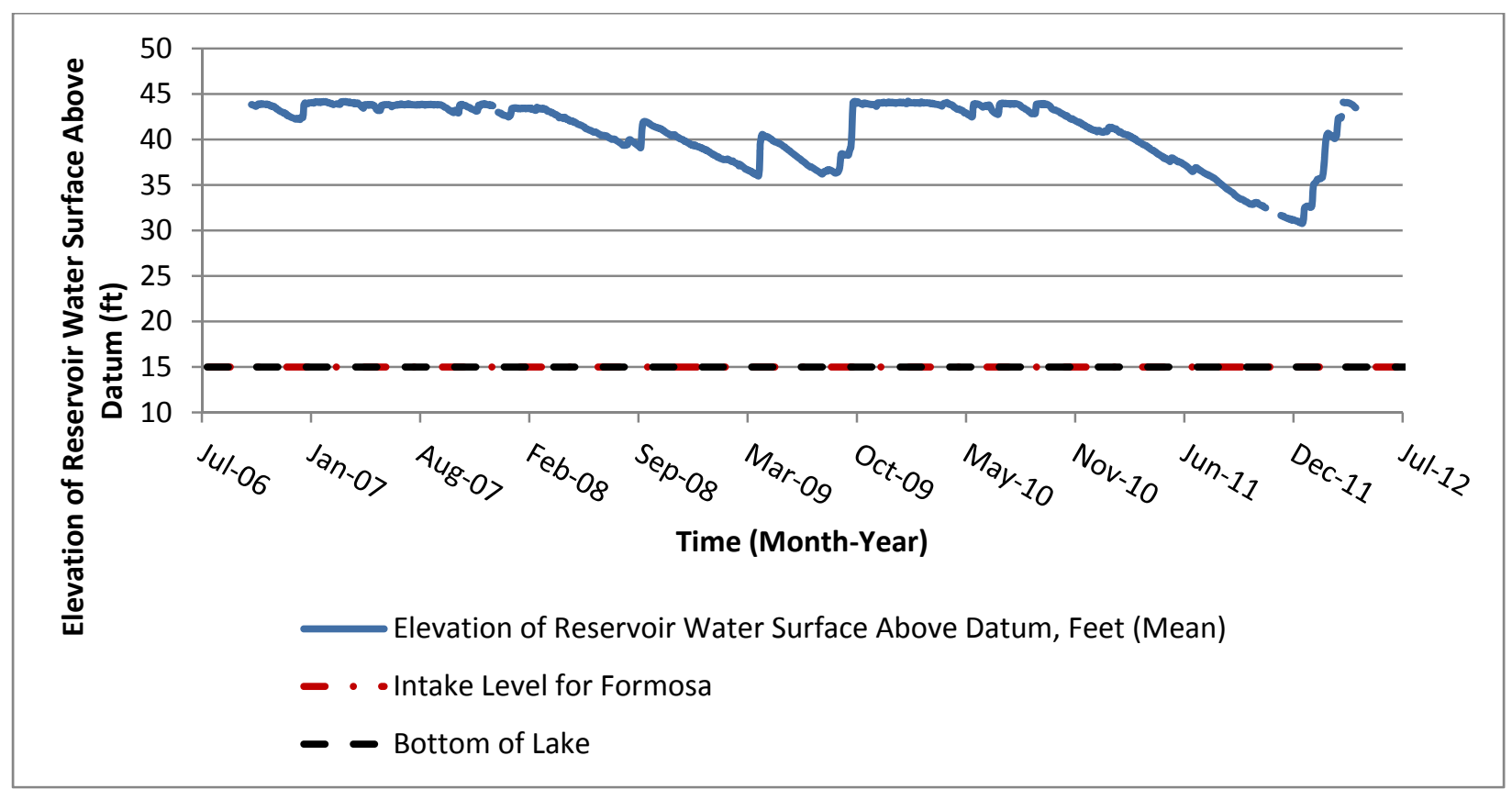

The water level for Lake Texana (USGS, TWDB) remains more than $15 \mathrm{ft}$ above the estimated intake level for the power plant. Formosa does not appear to be at risk due to the effects of drought on Lake Texana.

\begin{tabular}{|c|c|c|}
\hline \multicolumn{3}{|c|}{ Storage $=\mathrm{m}^{*}$ Elevation $(\mathrm{ft})+\mathrm{b}$} \\
\hline Elevation Range $(\mathrm{ft})$ & Slope, $\mathrm{m}(\mathrm{ft} / \mathrm{ac}-\mathrm{ft})$ & Intercept, $\mathrm{b}$ (ac-ft) \\
\hline 30 to 35 & 5832 & -123893 \\
\hline 35 to 40 & 7409 & -179043 \\
\hline 40 to 44 & 10868 & -317573 \\
\hline$>44$ & 0 & 159640 \\
\hline
\end{tabular}




\section{Graham SES}

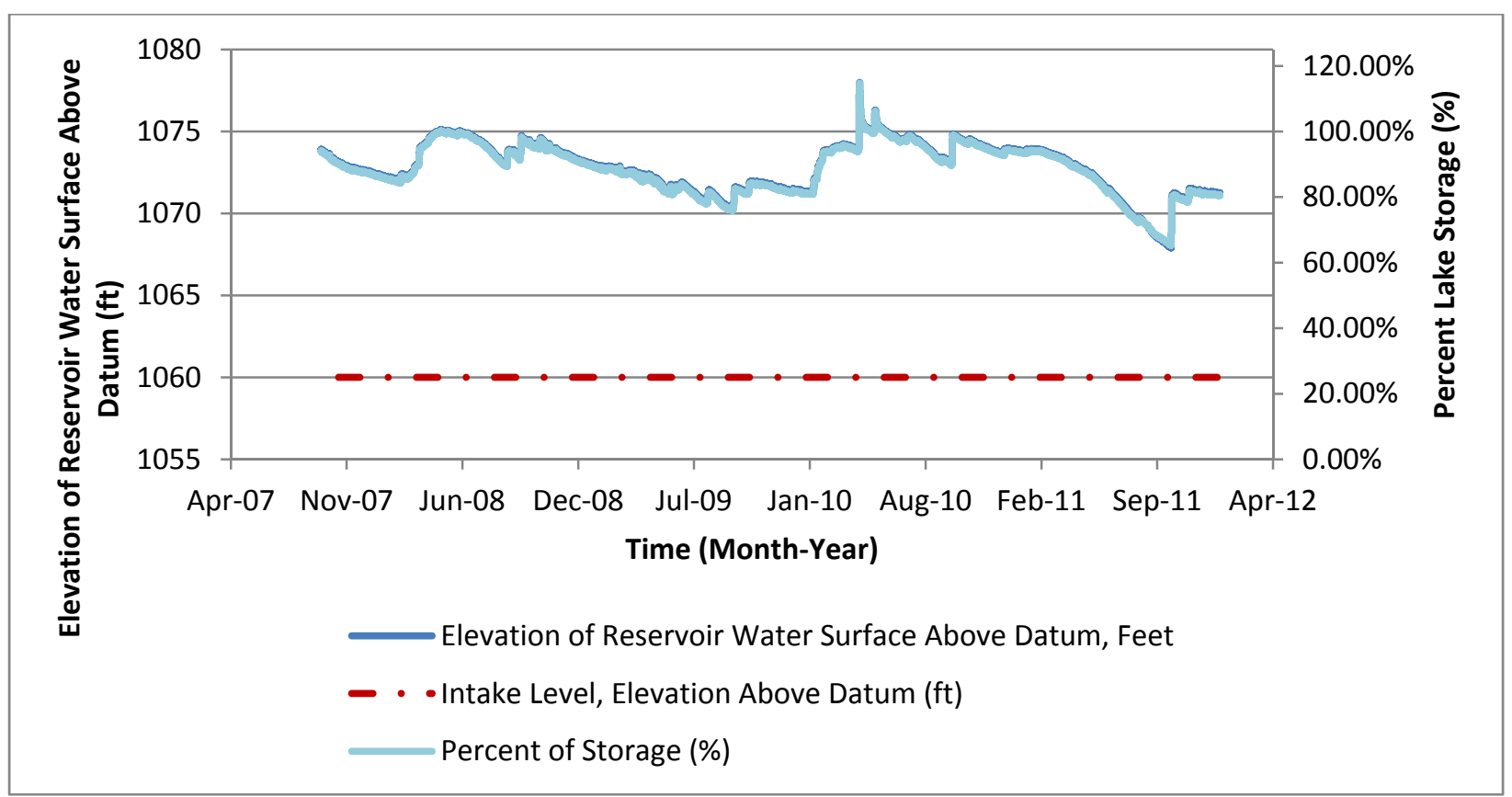

The water level in Lake Graham (USGS, TWDB) remains $\sim 8 \mathrm{ft}$ above the estimated intake level for the power plant. Graham SES does not appear to be at risk due to the effects of drought on Lake Graham.

\begin{tabular}{|c|c|c|}
\hline \multicolumn{3}{|c|}{ Storage $=\mathrm{m}$ *Elevation $(\mathrm{ft})+\mathrm{b}$} \\
\hline Elevation Range $(\mathrm{ft})$ & Slope, $\mathrm{m}(\mathrm{ft} / \mathrm{ac}-\mathrm{ft})$ & Intercept, $\mathrm{b}$ (ac-ft) \\
\hline 1067.5 to 1070 & 2000 & -2105857 \\
\hline$>1070$ & 2288 & -2414753 \\
\hline
\end{tabular}




\section{Handley SES}

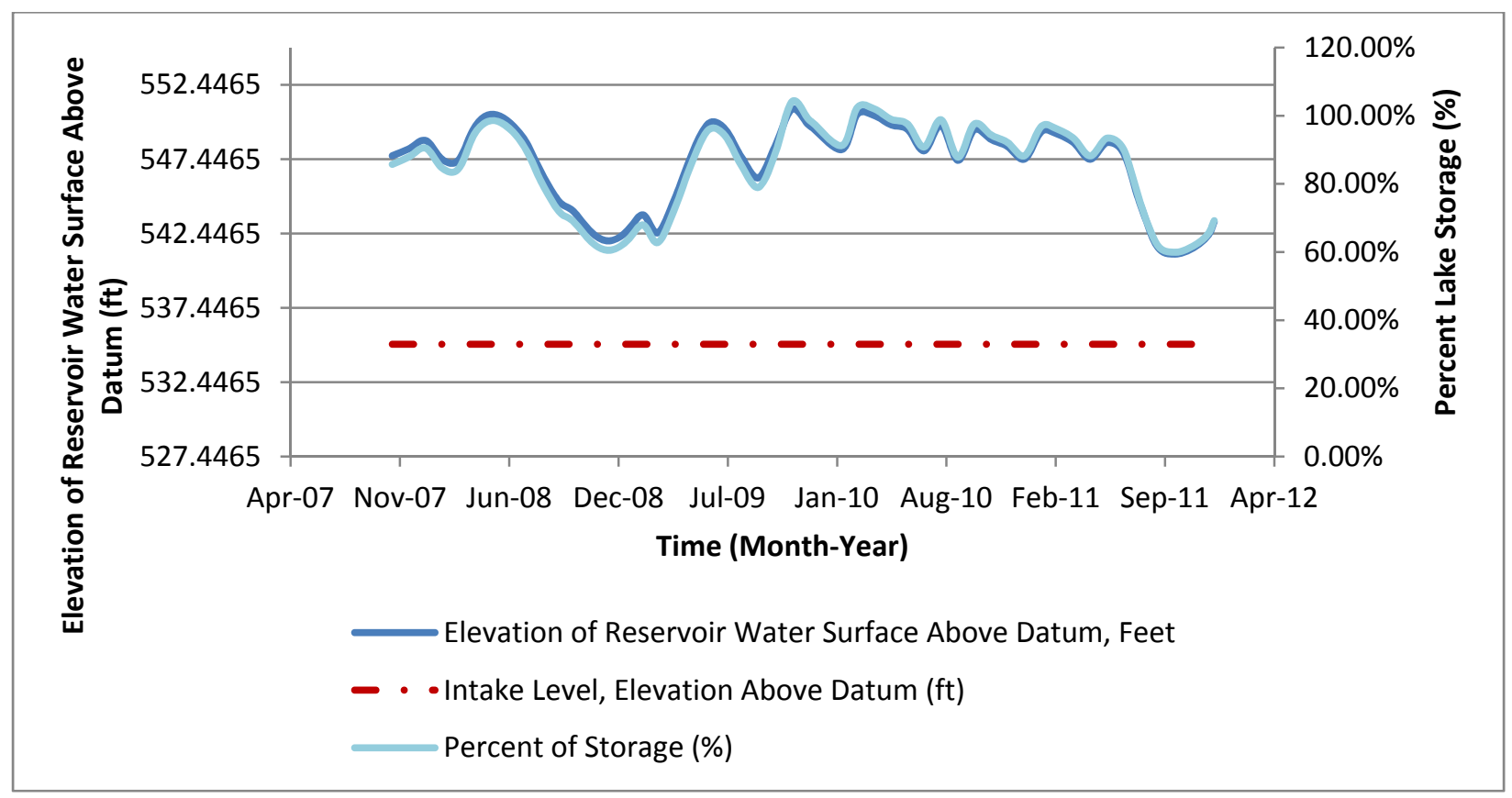

The water level in Lake Arlington (USGS) remains $5 \mathrm{ft}$ above the estimated intake level for the power plant. Under extended 2011 drought conditions, the reservoir surface level might have declined beneath the intake.

\begin{tabular}{|c|c|c|}
\hline \multicolumn{3}{|c|}{ Storage $=\mathrm{m}$ *Elevation $(\mathrm{ft})+\mathrm{b}$} \\
\hline Elevation Range $(\mathrm{ft})$ & Slope, $\mathrm{m}(\mathrm{ft} / \mathrm{ac}-\mathrm{ft})$ & Intercept, $\mathrm{b}$ (ac-ft) \\
\hline 538 to 541 & 1581 & -831621 \\
\hline 541 to 544 & 1739 & -917304 \\
\hline 544 to 547 & 1836 & -969590 \\
\hline 547 to 550 & 2231 & -1187277 \\
\hline$>550$ & 0 & 40156 \\
\hline
\end{tabular}


Lake Hubbard

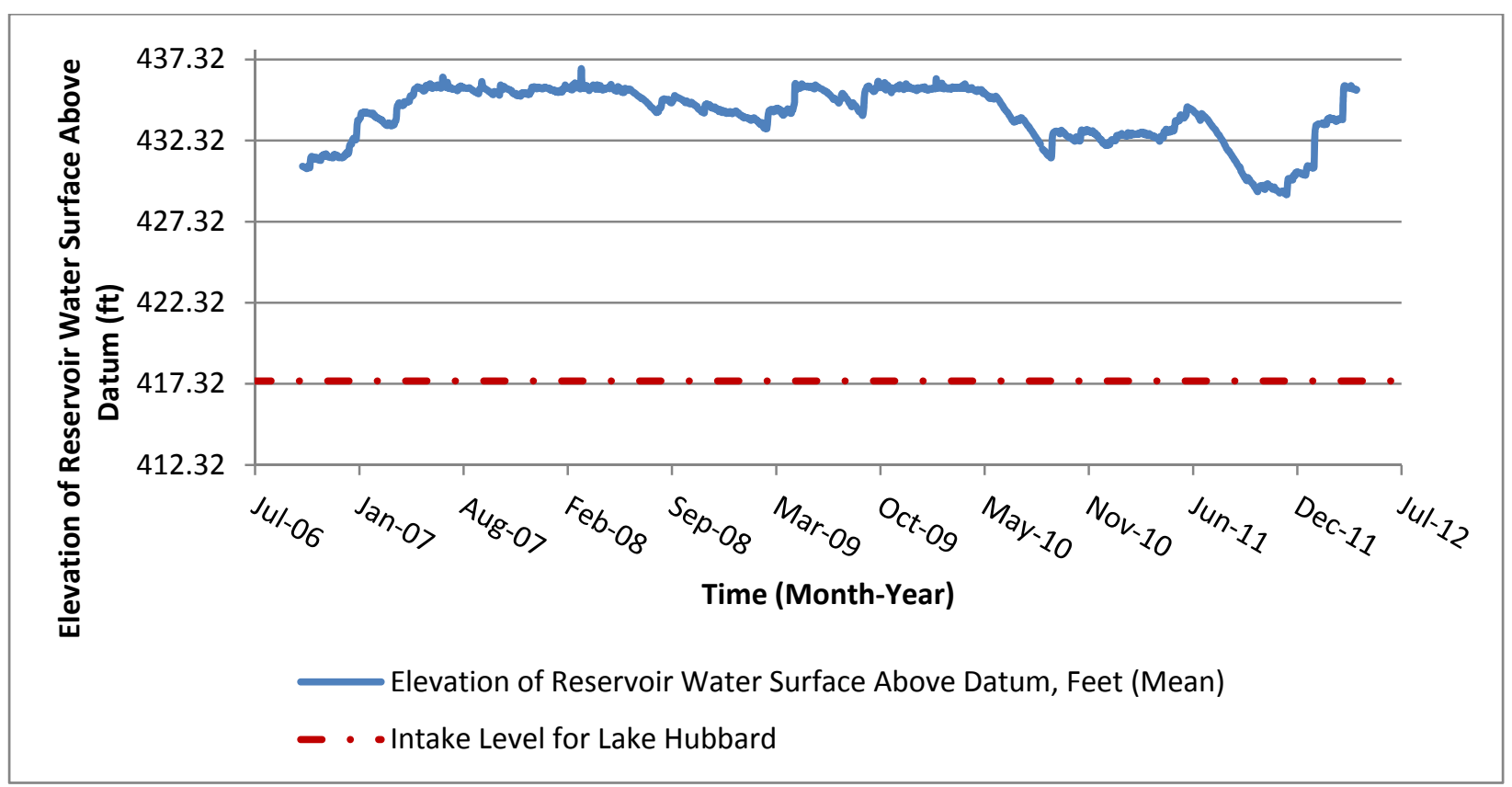

The water level in Lake Ray Hubbard (USGS) remains $\sim 12 \mathrm{ft}$ above the estimated intake level for the power plant. Lake Hubbard does not appear to be at risk due to the effects of drought on Lake Ray Hubbard.

\begin{tabular}{|c|c|c|}
\hline \multicolumn{3}{|c|}{ Storage $=\mathrm{m}^{*}$ Elevation $(\mathrm{ft})+\mathrm{b}$} \\
\hline Elevation Range $(\mathrm{ft})$ & Slope, $\mathrm{m}(\mathrm{ft} / \mathrm{ac}-\mathrm{ft})$ & Intercept, $\mathrm{b}$ (ac-ft) \\
\hline 427.5 to 430 & 18047 & -7417020 \\
\hline 430 to 432.5 & 20964 & -8688142 \\
\hline 432.5 to 435.5 & 10004 & -3942140 \\
\hline$>435.5$ & 3920 & -1277409 \\
\hline
\end{tabular}




\section{Martin Lake SES}

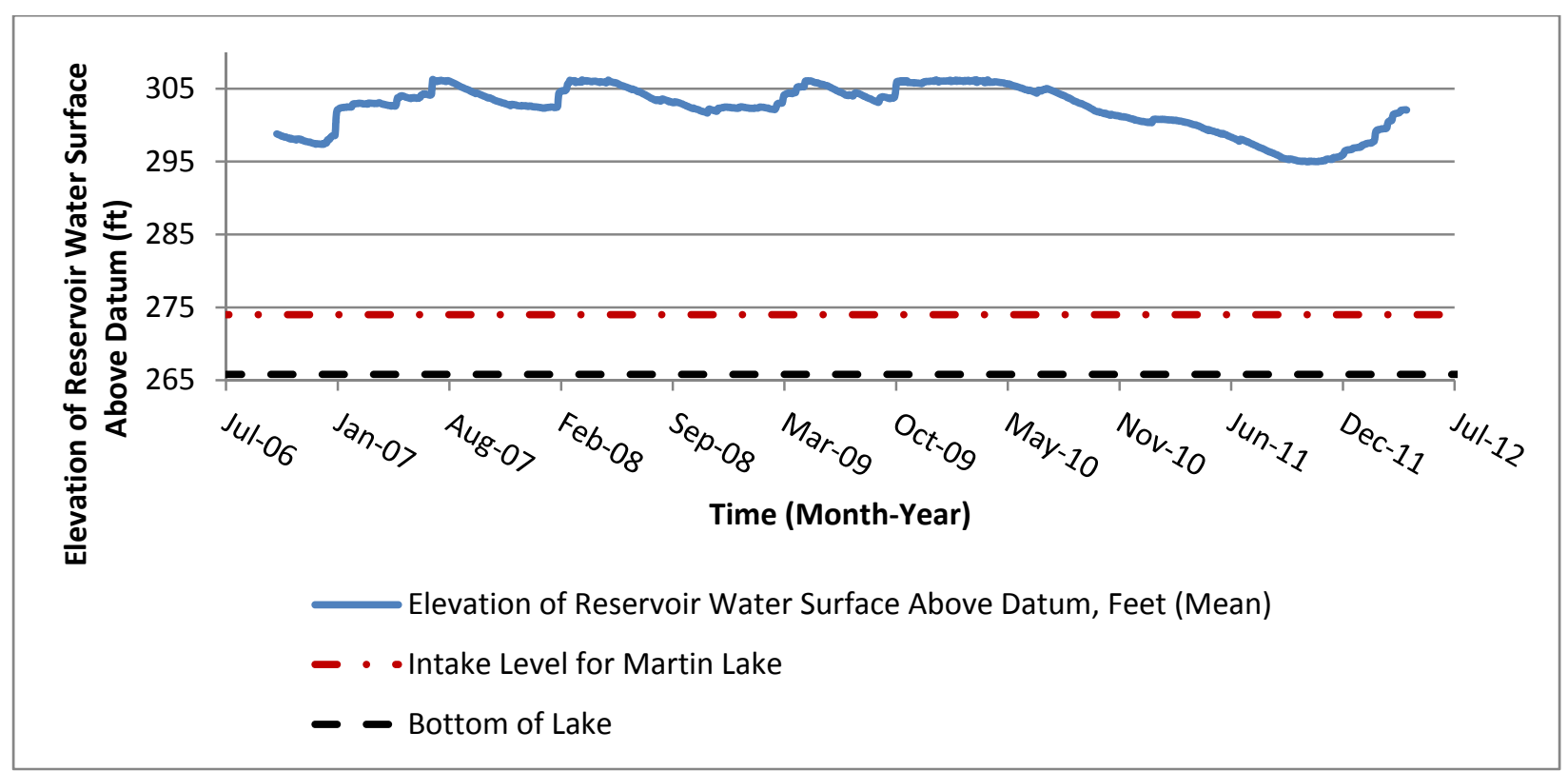

The water level in Martin Lake (USGS, TWDB) remains $\sim 20 \mathrm{ft}$ above the estimated intake level for the power plant. Martin Lake SES does not appear to be at risk due to the effects of drought on Martin Lake.

\begin{tabular}{|c|c|c|}
\hline \multicolumn{3}{|c|}{ Storage $=\mathrm{m}$ *Elevation $(\mathrm{ft})+\mathrm{b}$} \\
\hline Elevation Range (ft) & Slope, $\mathrm{m}$ (ft/ac-ft) & Intercept, b (ac-ft) \\
\hline 294 to 295 & 2939 & -834123 \\
\hline 295 to 296 & 2954 & -838549 \\
\hline 296 to 297 & 3108 & -883968 \\
\hline 297 to 298 & 3260 & -928998 \\
\hline 298 to 299 & 3412 & -974139 \\
\hline 299 to 300 & 3579 & -1024136 \\
\hline 300 to 301 & 3783 & -1085254 \\
\hline 301 to 302 & 3966 & -1140265 \\
\hline 302 to 303 & 4096 & -1179461 \\
\hline 303 to 304 & 4410 & -1272673 \\
\hline 304 to 305 & 4605 & -1331854 \\
\hline$>305$ & 4810 & -1394276 \\
\hline
\end{tabular}




\section{Mountain Creek}

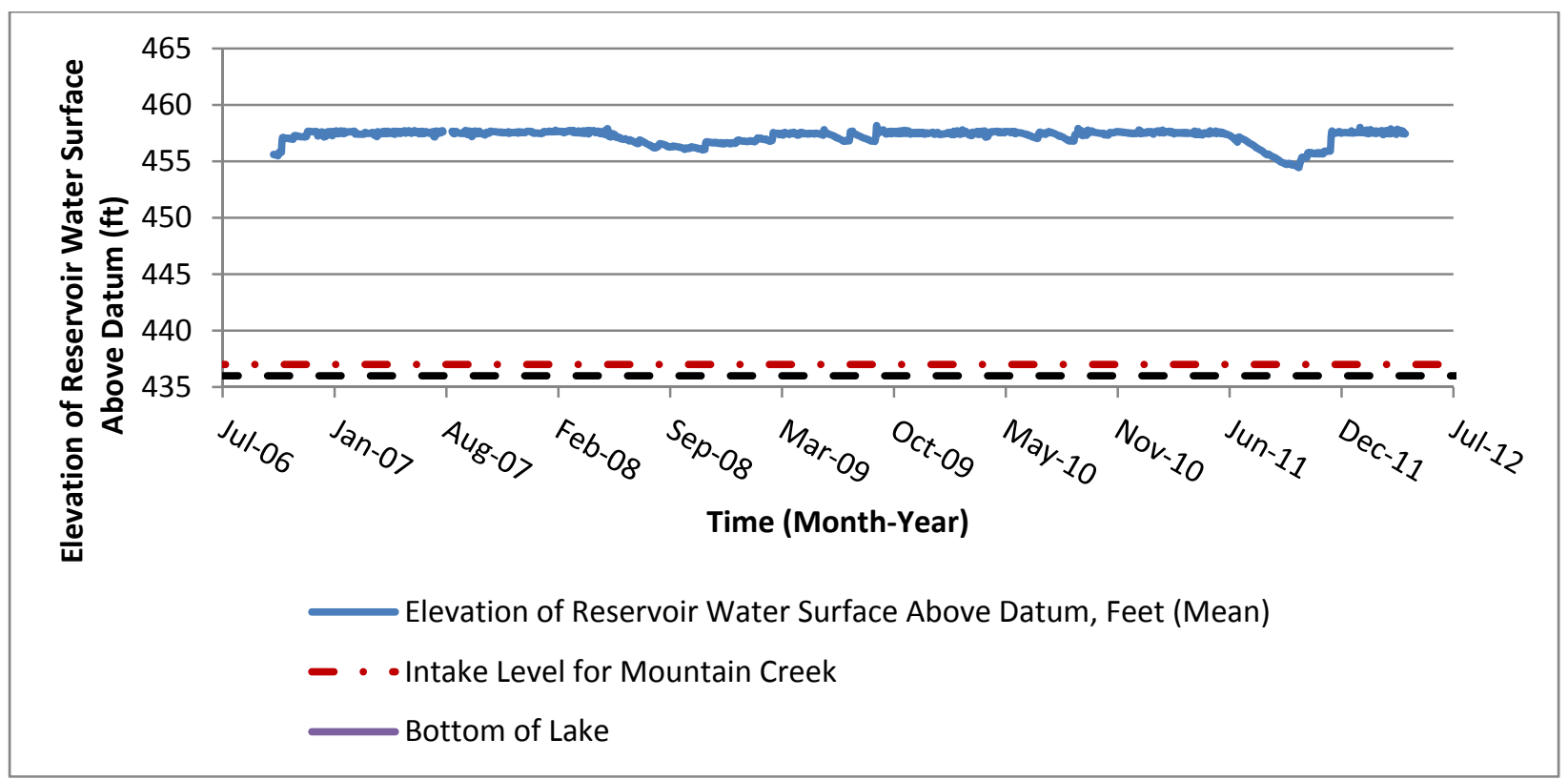

The water level in Mountain Creek (USGS, TWDB) remains $17 \mathrm{ft}$ above the estimated intake level for the power plant. Mountain Creek does not appear to be at risk due to the effects of drought on Mountain Creek Reservoir.

\begin{tabular}{|c|c|c|}
\hline \multicolumn{3}{|c|}{ Storage $=\mathrm{m}^{*}$ Elevation $(\mathrm{ft})+\mathrm{b}$} \\
\hline Elevation Range $(\mathrm{ft})$ & Slope, $\mathrm{m}(\mathrm{ft} / \mathrm{ac}-\mathrm{ft})$ & Intercept, $\mathrm{b}$ (ac-ft) \\
\hline 454 to 456 & 2350 & -1051200 \\
\hline 456 to 457 & 1223 & -536805 \\
\hline 457 to 458 & 0 & 22840 \\
\hline$>458$ & 0 & 22840 \\
\hline
\end{tabular}




\section{North Texas Power Plant}

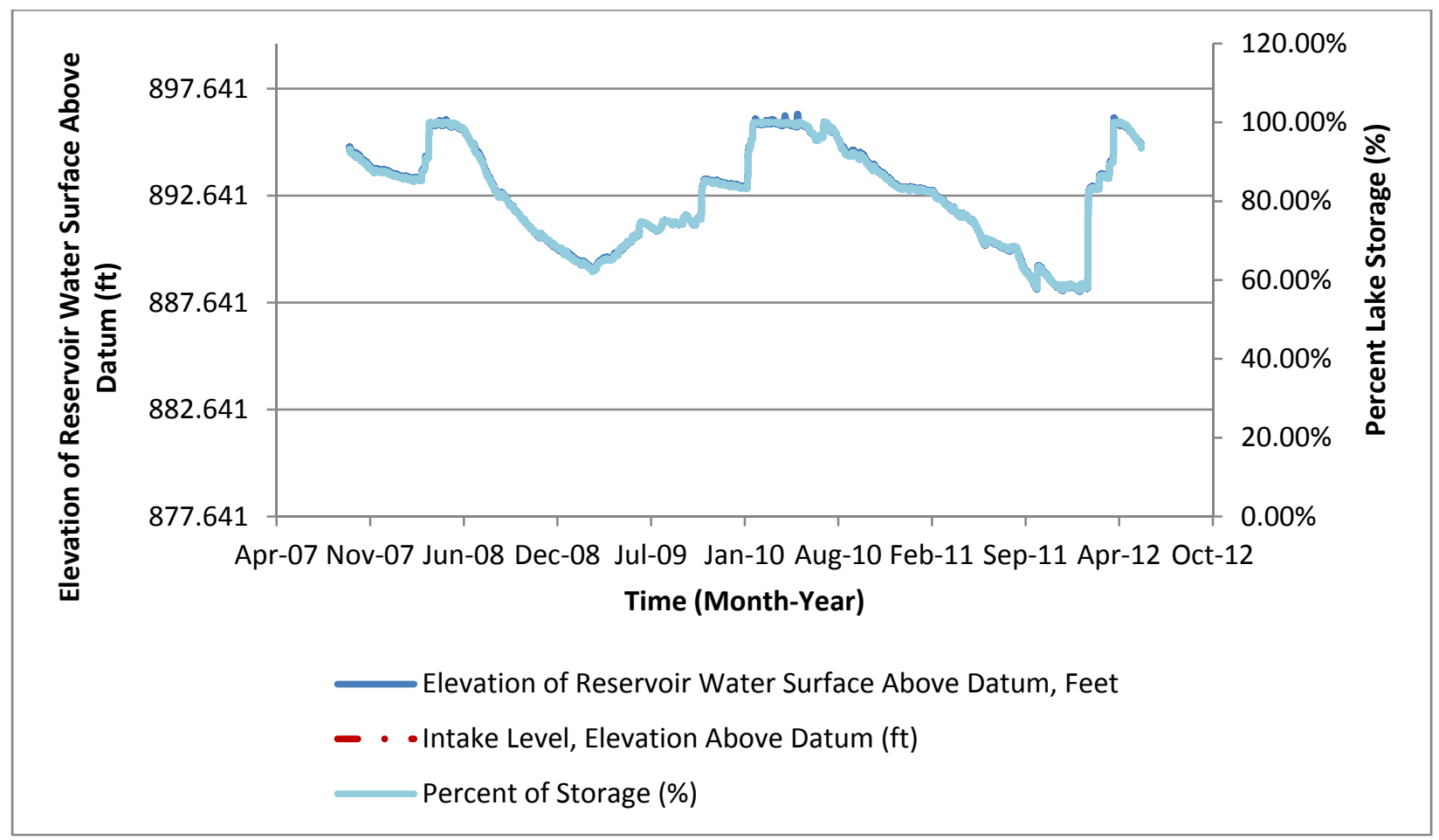

The water level in Lake Weatherford (USGS, TWDB) remains above 60\%. The intake level is not known.

\begin{tabular}{|c|c|c|}
\hline \multicolumn{3}{|c|}{ Storage $=\mathrm{m}^{*}$ Elevation $(\mathrm{ft})+\mathrm{b}$} \\
\hline Elevation Range $(\mathrm{ft})$ & Slope, $\mathrm{m}(\mathrm{ft} / \mathrm{ac}-\mathrm{ft})$ & Intercept, $\mathrm{b}$ (ac-ft) \\
\hline 885 to 890 & 887 & -777613 \\
\hline 890 to 895 & 933 & -818663 \\
\hline 895 to 896 & 1073 & -943412 \\
\hline$>896$ & 0 & 17789 \\
\hline
\end{tabular}


Ray Olinger

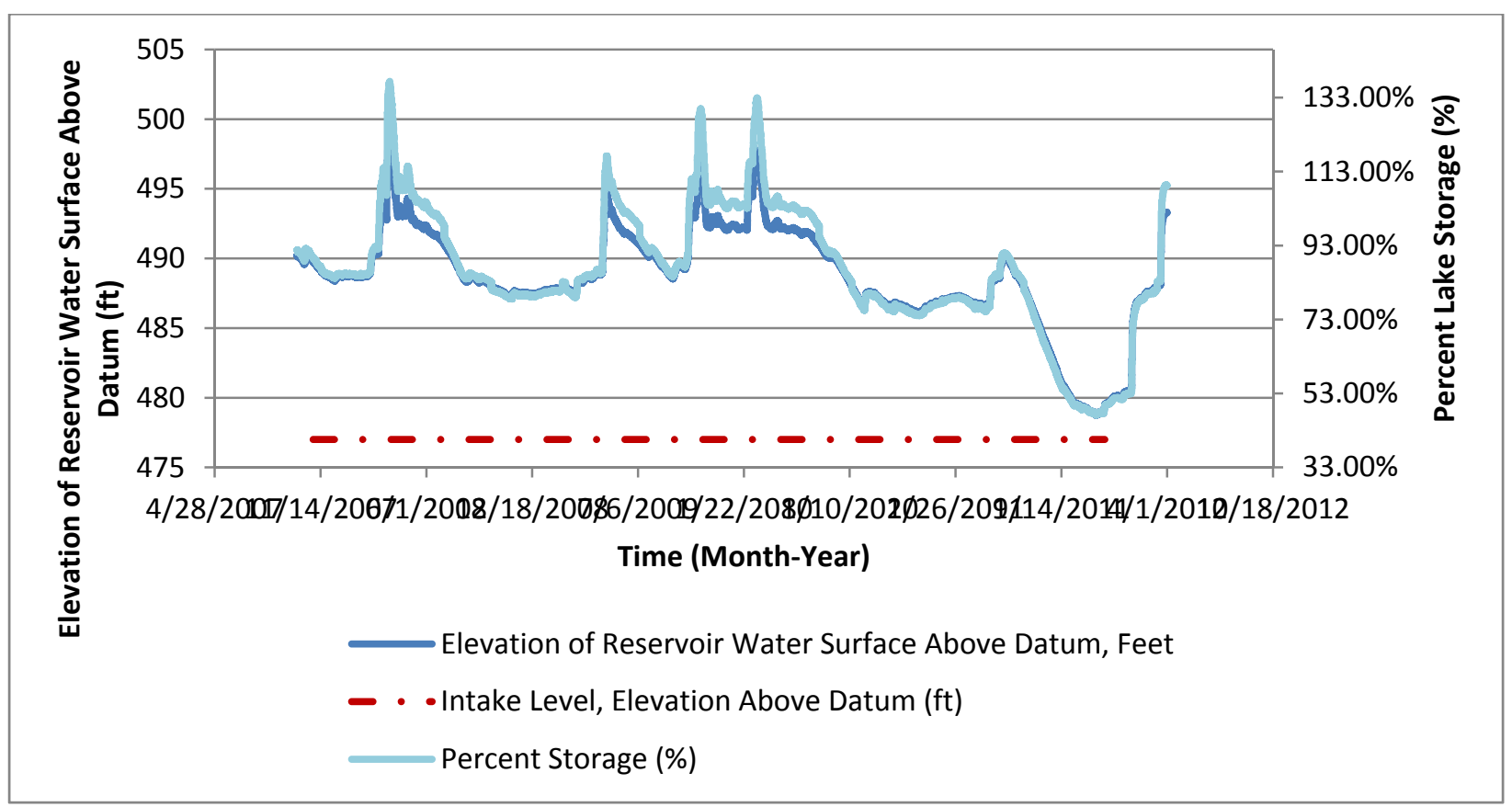

The water level in Lake Lavon (USGS, TWDB) remains more than $1.5 \mathrm{ft}$ above the estimated intake level for the power plant. Under extended 2011 drought conditions, the reservoir surface level might have declined beneath the intake. The bottom of the lake is at $433 \mathrm{ft}$. The approximation from elevation to storage is most accurate at elevations below $492 \mathrm{ft}$.

\begin{tabular}{|c|c|c|}
\hline \multicolumn{3}{|c|}{ Storage $=\mathrm{m}^{*}$ Elevation $(\mathrm{ft})+\mathrm{b}$} \\
\hline Elevation Range $(\mathrm{ft})$ & Slope, $\mathrm{m}$ (ft/ac-ft) & Intercept, $\mathrm{b}$ (ac-ft) \\
\hline 479 to 480 & 14193 & -6585365 \\
\hline 480 to 481 & 14697 & -6826802 \\
\hline 481 to 482 & 15204 & -7070158 \\
\hline 482 to 483 & 15706 & -7311626 \\
\hline 483 to 484 & 16209 & -7554081 \\
\hline 484 to 485 & 16712 & -7797013 \\
\hline 485 to 486 & 17223 & -8044352 \\
\hline 486 to 487 & 17736 & -8293143 \\
\hline 487 to 488 & 18238 & -8537103 \\
\hline 488 to 489 & 14685 & -6805280 \\
\hline 489 to 490 & 12845 & -5899947 \\
\hline 490 to 491 & 19738 & -9269134 \\
\hline
\end{tabular}




\begin{tabular}{|c|l|c|}
\hline 491 to 492 & 20330 & -9559192 \\
\hline 492 to 493 & 20650 & -9703417 \\
\hline 493 to 494 & 21350 & -10047467 \\
\hline 494 to 495 & 22050 & -10392217 \\
\hline 495 to 496 & 22750 & -10737667 \\
\hline 496 to 497 & 23400 & -11059100 \\
\hline$>497$ & 24100 & -11405933 \\
\hline
\end{tabular}


Sam Rayburn

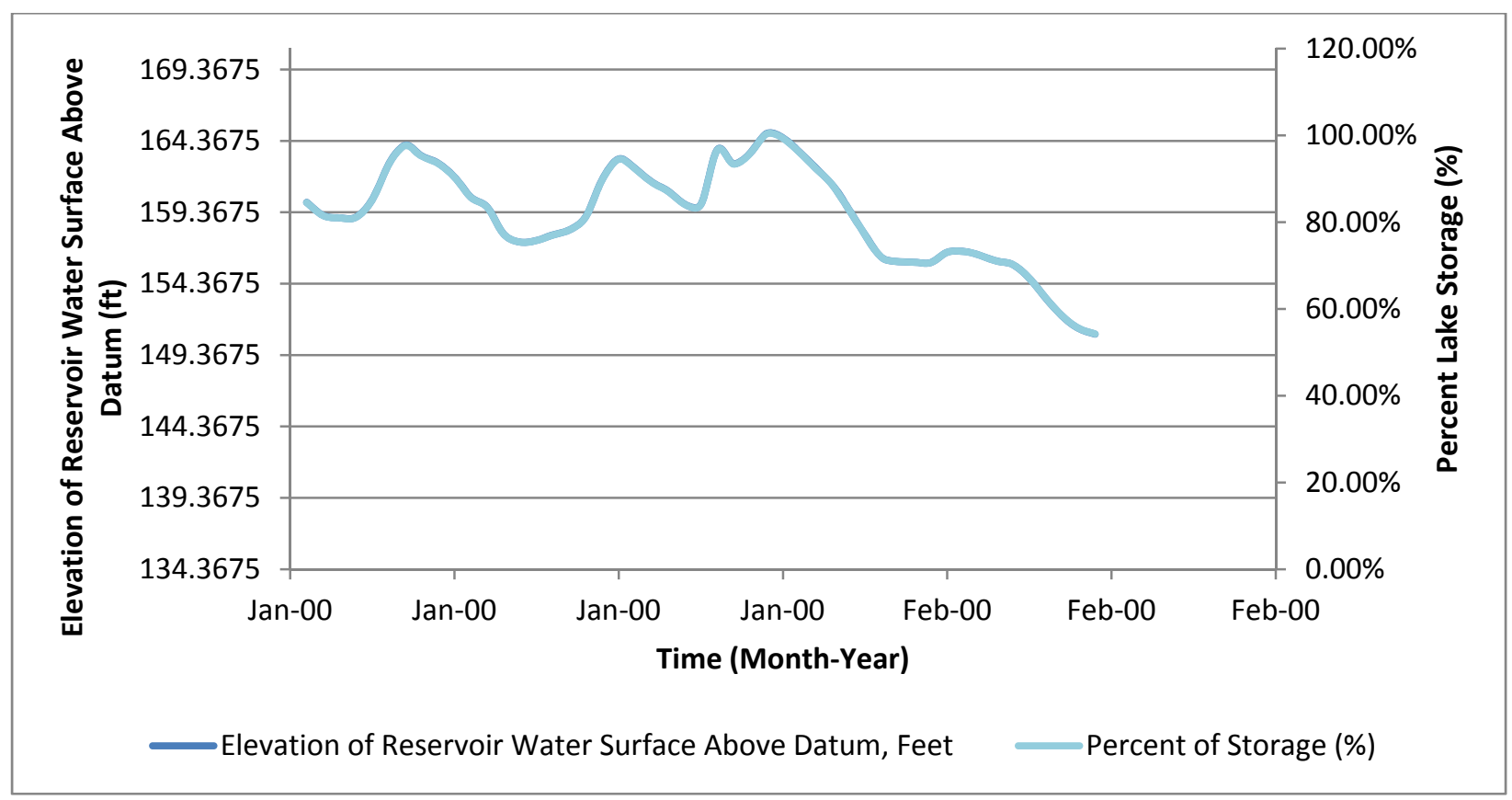

The water level in Sam Rayburn Reservoir (USGS, TWDB) remains above $60 \%$. The intake level is not known.

\begin{tabular}{|c|c|c|}
\hline \multicolumn{3}{|c|}{ Storage $=\mathrm{m}^{*}$ Elevation $(\mathrm{ft})+\mathrm{b}$} \\
\hline Elevation Range $(\mathrm{ft})$ & Slope, $\mathrm{m}(\mathrm{ft} / \mathrm{ac}-\mathrm{ft})$ & Intercept, $\mathrm{b}$ (ac-ft) \\
\hline 149 to 152 & 77492 & $-1 \mathrm{E}+07$ \\
\hline 152 to 155 & 82236 & $-1.1 \mathrm{E}+07$ \\
\hline 155 to 157 & 88676 & $-1.2 \mathrm{E}+07$ \\
\hline 157 to 160 & 96338 & $-1.3 \mathrm{E}+07$ \\
\hline 160 to 164 & 107259 & $-1.5 \mathrm{E}+07$ \\
\hline$>164$ & 112405 & $-1.6 \mathrm{E}+07$ \\
\hline
\end{tabular}


Thomas C. Ferguson

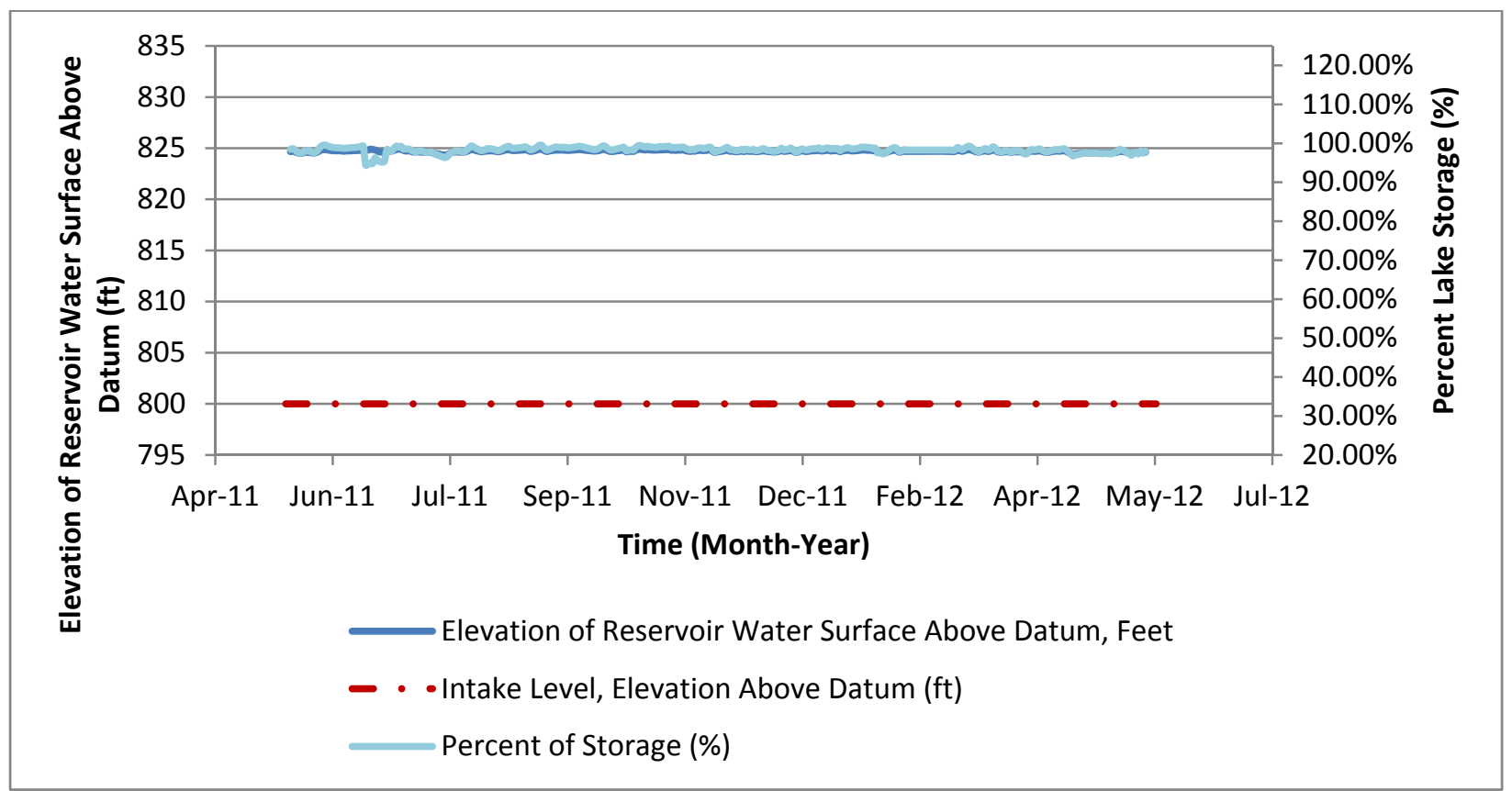

The water level in Lake LBJ (USGS, TWDB) remains above $90 \%$. The intake level resides at 33\% storage. Thomas C. Ferguson does not appear to be at risk due to the effects of drought on Lake LBJ.

Storage $(\mathrm{ac}-\mathrm{ft})=5405.944(\mathrm{ac}-\mathrm{ft} / \mathrm{ft}) *$ Elevation $(\mathrm{ft})-4346883(\mathrm{ac}-\mathrm{ft})$ 


\section{Wolf Hollow}

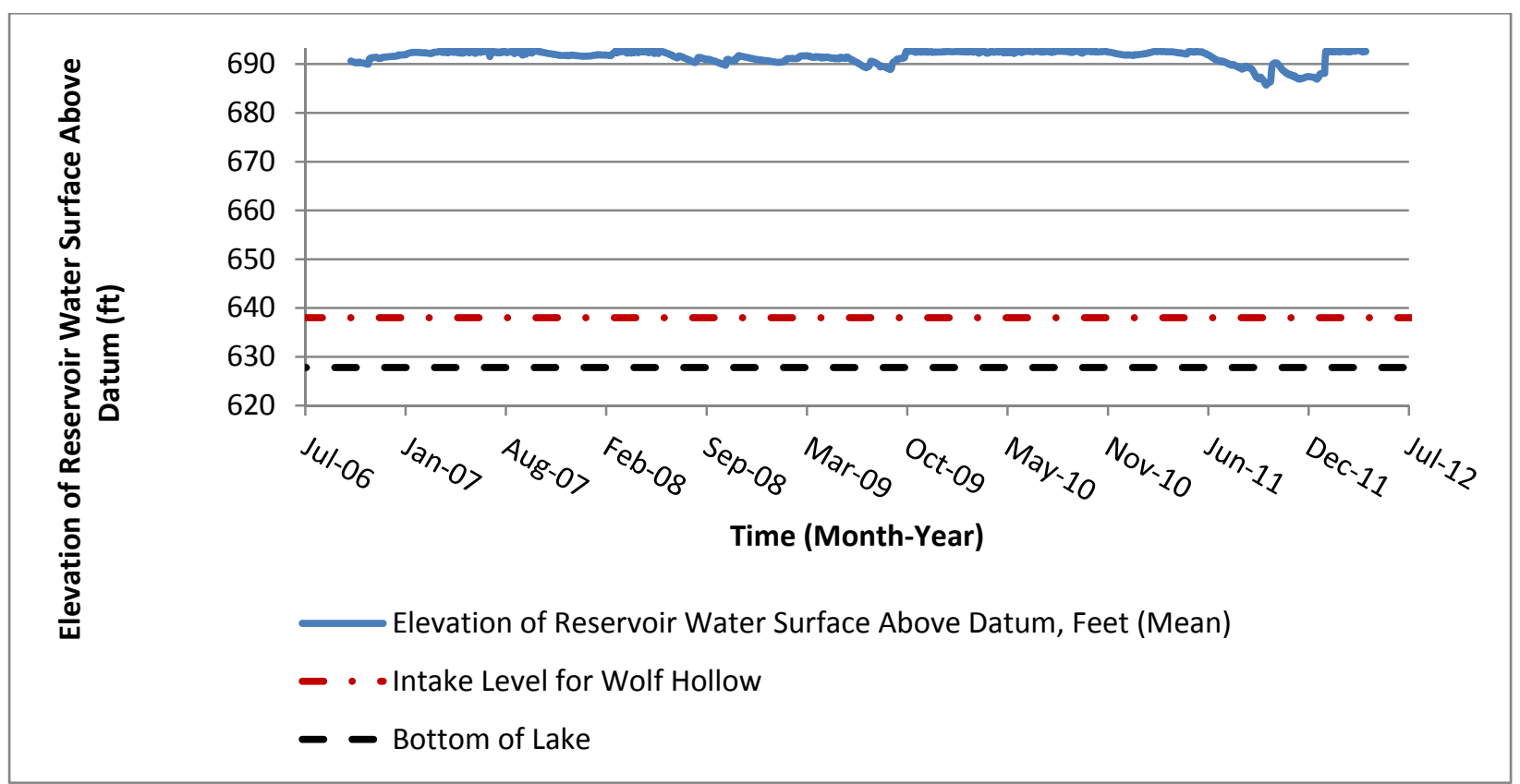

The water level in Lake Granbury (USGS, TWDB) remains more than $40 \mathrm{ft}$ above the estimated intake level. Wolf Hollow is not estimated to be at risk from the effects of drought in Lake Granbury.

\begin{tabular}{|c|c|c|}
\hline \multicolumn{3}{|c|}{ Storage $=\mathrm{m}$ *Elevation $(\mathrm{ft})+\mathrm{b}$} \\
\hline Elevation Range $(\mathrm{ft})$ & Slope, $\mathrm{m}(\mathrm{ft} / \mathrm{ac}-\mathrm{ft})$ & Intercept, b (ac-ft) \\
\hline 683 to 688 & 53867 & -3612415 \\
\hline$>688$ & 6977 & -4707577 \\
\hline
\end{tabular}


This page intentionally left blank. 
Appendix B:

Regression Analysis Results for Estimates of Cooling Water Effluent Discharge Temperatures for Applicable Power Plants in ERCOT 
This page intentionally left blank. 


\section{Appendix B:}

\section{Regression Analysis Results for Estimates of Cooling Water Effluent Discharge Temperatures for Applicable Power Plants in ERCOT}

This appendix describes efforts to model average monthly temperatures for power plant cooling water effluent. In some cases, an EPA permit requires the average monthly effluent temperature to be below a threshold value. That threshold limit is determined on a plant-specific basis.

This appendix presents the following information, where available and where applicable for a given power plant:

- Tables B1-B3 summarize the results of multiple-factor linear regressions to estimate effluent temperatures as a function of power generation at the power plants. The goal is to project the potential for power plants to be limited (by breaching effluent temperature limits) in future power generation. The information is presented as follows:

o Table B1 indicates whether power plants reached their effluent temperature limits during 2007-2011.

o Table B2 indicates which power plants could reach their effluent temperature limits in 2030 if they operate at their 2011 capacity factors.

o Table B3 indicates which power plants could reach their effluent temperature limits in 2030 if they operate at $100 \%$ capacity factors in the summer.

- Tables B4-B7 summarize estimates of the amount of future (2027-2032) electricity generation that could be curtailed because of thermal effluent discharge limits, in light of future climate impacts (e.g., higher temperatures). The information is presented as follows:

o Table B4 summarizes future curtailments for 2011 capacity factors (MW-h per summer month).

o Table B5 summarizes future curtailments for 2011 capacity factors (MW, with all curtailments from 12 noon to 8 p.m.).

o Table B6 summarizes future curtailments for $100 \%$ capacity factors ( $\mathrm{MW}$-h per summer month).

o Table B7 summarizes future curtailments for $100 \%$ capacity factors (MW, with all curtailments from 12 noon to 8 p.m.).

- Tables B8-B10 summarize estimates of the amount of electricity generation that is or could still be available, over 2011 capacity factors, without curtailment due to thermal effluent discharge limits (e.g., higher temperatures).

o Table B8 summarizes estimates of electricity generation that could still be available in 2027-2032 (MW-h per summer month).

- Table B9 summarizes estimates of electricity capacity that could still be available in 2027-2032 (MW, assuming that all excess power occurs from 12 noon to 8 p.m.).

o Table B10 summarizes estimates of electricity generation available in 2007-2011 (MW-h per summer month). 
Table B1. An indication of whether ERCOT power plants have exceeded their permitted temperature limits for average monthly effluent temperatures (for cooling water) in any year, 2007-2011. The symbol "-" indicates that the power plant does not have an EPA effluent thermal discharge limit.

\begin{tabular}{|l|c|}
\hline \multicolumn{1}{|c|}{ Plant } & Was the thermal limit reached in 2007-2011? \\
\hline Arthur Von Rosenberg & - \\
\hline Barney M Davis & No \\
\hline Big Brown & Yes \\
\hline Cedar Bayou & No \\
\hline Coleto Creek & No \\
\hline Comanche Peak & - \\
\hline Corpus Christi (Equistar Chemicals) & - \\
\hline Decker Creek & No \\
\hline Fayette Power Project & No \\
\hline Gibbons Creek & No \\
\hline Graham & No \\
\hline Handley & No \\
\hline J K Spruce 1 \& & No \\
\hline J Deely & Yes \\
\hline Lake Hubbard & No \\
\hline Martin Lake & No \\
\hline Mountain Creek & No \\
\hline Nueces Bay & No \\
\hline Ray Olinger & No \\
\hline Roland C Dansby (City of Bryan) & No \\
\hline Sam R Bertron & No \\
\hline Sam Rayburn & No \\
\hline Sim Gideon & No \\
\hline Stryker Creek & - \\
\hline Thomas C Ferguson & - \\
\hline Tradinghouse & - \\
\hline Trinidad (TX) & No \\
\hline V H Braunig & No \\
\hline Victoria Power Station 5 \& 7 & - \\
\hline W A Parish & \\
\hline Wolf Hollow & - \\
\hline
\end{tabular}


Table B2. With assumed historical generation data (2011 data, usually) and the downscaled future climate data (temperature, wind speed, and dew point) for 2027-2032, additional power plants are expected to exceed their average monthly effluent temperature limits. The symbol "-" indicates that the power plant does not have an EPA effluent thermal discharge limit. Results are shown for input climate from four climate models.

\begin{tabular}{|c|c|c|c|c|}
\hline \multirow[b]{2}{*}{ Plant } & \multicolumn{4}{|c|}{$\begin{array}{l}\text { Is the thermal limit likely to be reached at historical } \\
\text { generation in } 2027-2032 ?\end{array}$} \\
\hline & PCMA2 & GFDLA2 & BCSDPCMA2 & BCSDGFDLA2 \\
\hline Arthur Von Rosenberg & - & - & - & - \\
\hline Barney M Davis & No & No & No & No \\
\hline Big Brown & - & - & - & - \\
\hline Cedar Bayou & No & No & No & No \\
\hline Coleto Creek & Yes & Yes & Yes & Yes \\
\hline Comanche Peak & Yes & Yes & No & Yes \\
\hline Corpus Christi (Equistar Chemicals) & No & No & No & No \\
\hline Decker Creek & - & - & - & - \\
\hline Fayette Power Project & - & - & - & - \\
\hline Gibbons Creek & No & No & No & No \\
\hline Graham & No & No & No & No \\
\hline Handley & No & No & No & No \\
\hline J K Spruce 1 \& 2 & No & No & Yes & Yes \\
\hline J T Deely & No & No & No & No \\
\hline Lake Hubbard & No & No & No & No \\
\hline Martin Lake & No & Yes & No & Yes \\
\hline Mountain Creek & No & No & No & No \\
\hline Nueces Bay & Yes & No & No & Yes \\
\hline Ray Olinger & No & No & No & No \\
\hline Roland C Dansby (City of Bryan) & No & No & No & No \\
\hline Sam R Bertron & No & No & No & No \\
\hline Sam Rayburn & No & No & No & No \\
\hline Sim Gideon & No & No & No & No \\
\hline Stryker Creek & No & No & No & No \\
\hline Thomas C Ferguson & No & No & No & No \\
\hline Tradinghouse & - & - & - & - \\
\hline Trinidad (TX) & - & - & - & - \\
\hline V H Braunig & - & - & - & - \\
\hline Victoria Power Station 5 \& 7 & No & No & No & No \\
\hline W A Parish & No & Yes & Yes & Yes \\
\hline Wolf Hollow & - & - & - & - \\
\hline
\end{tabular}

${ }^{a}$ Historical generation is what occurred from December 2010 to November 2011. If no generation occurred in that period, the latest year's generation was used in calculations. 
Table B3. With assumed power plant operation at $100 \%$ capacity factor for May-August in each future year and the downscaled future climate data (temperature, wind speed, and dew point) for 2027-2032, many power plants are expected to exceed their average monthly effluent temperature limits. The climate models project different climate and thus imply slightly different outcomes.

\begin{tabular}{|c|c|c|c|c|}
\hline \multirow[b]{2}{*}{ Plant } & \multicolumn{4}{|c|}{$\begin{array}{l}\text { Is the thermal limit likely to be reached at } 100 \% \text { summer } \\
\text { capacity factor }{ }^{a} \text { in } 2027-2032 ?\end{array}$} \\
\hline & PCMA2 & GFDLA2 & BCSDPCMA2 & BCSDGFDLA2 \\
\hline Arthur Von Rosenberg & - & - & - & - \\
\hline Barney M Davis & - & - & - & - \\
\hline Big Brown & - & - & - & - \\
\hline Cedar Bayou & - & - & - & - \\
\hline Coleto Creek & Yes & Yes & Yes & Yes \\
\hline Comanche Peak & Yes & Yes & Yes & Yes \\
\hline Corpus Christi (Equistar Chemicals) & - & - & - & - \\
\hline Decker Creek & - & - & - & - \\
\hline Fayette Power Project & - & - & - & - \\
\hline Gibbons Creek & No & No & No & No \\
\hline Graham & No & No & No & Yes \\
\hline Handley & Yes & Yes & Yes & Yes \\
\hline J K Spruce 1 \& 2 & No & No & Yes & Yes \\
\hline J T Deely & No & No & No & No \\
\hline Lake Hubbard & Yes & Yes & Yes & Yes \\
\hline Martin Lake & Yes & Yes & Yes & Yes \\
\hline Mountain Creek & Yes & Yes & Yes & Yes \\
\hline Nueces Bay & Yes & Yes & Yes & Yes \\
\hline Ray Olinger & No & No & No & No \\
\hline Roland C Dansby (City of Bryan) & - & - & - & - \\
\hline Sam R Bertron & - & - & - & - \\
\hline Sam Rayburn & - & - & - & - \\
\hline Sim Gideon & No & Yes & No & Yes \\
\hline Stryker Creek & Yes & Yes & Yes & Yes \\
\hline Thomas C Ferguson & Yes & Yes & Yes & Yes \\
\hline Tradinghouse & - & - & - & - \\
\hline Trinidad (TX) & - & - & - & - \\
\hline V H Braunig & - & - & - & - \\
\hline Victoria Power Station 5 \& 7 & - & - & - & - \\
\hline W A Parish & Yes & Yes & Yes & Yes \\
\hline Wolf Hollow & - & - & - & - \\
\hline
\end{tabular}

a 100\% capacity factor includes the historical energy generation levels in December 2010-April 2011 and September-November 2011. For May-August 2011, generation is at $100 \%$ of each plant's capacity. 
Table B4. Estimated electricity generation curtailment (MW-h per month) due to exceeding average monthly effluent temperature limits, for 2011 monthly generation and years 2027-2032. Each column represents results for input climate from one of the four climate models.

\begin{tabular}{|c|c|c|c|c|}
\hline & PCMA2 & BCSDPCMA2 & GFDLA2 & BSCDGFDLA2 \\
\hline $\begin{array}{l}\text { May through August } \\
\text { Average (2027-2032) }\end{array}$ & 25,000 & 25,000 & 210,000 & 93,000 \\
\hline Jan- 27 & 0 & 0 & 0 & 0 \\
\hline Feb-27 & 0 & 0 & 0 & 0 \\
\hline Mar-27 & 0 & 0 & 0 & 0 \\
\hline Apr-27 & 0 & 0 & 0 & 0 \\
\hline May-27 & 0 & 0 & 0 & 0 \\
\hline Jun-27 & 41841 & 0 & 0 & 0 \\
\hline Jul-27 & 5602 & 25928 & 955579 & 602058 \\
\hline Aug-27 & 3101 & 0 & 605044 & 520104 \\
\hline Sep-27 & 0 & 0 & 0 & 0 \\
\hline Oct-27 & 0 & 0 & 0 & 0 \\
\hline Nov-27 & 0 & 0 & 0 & 0 \\
\hline Dec-27 & 0 & 0 & 0 & 0 \\
\hline Jan-28 & 0 & 0 & 0 & 0 \\
\hline Feb-28 & 0 & 0 & 0 & 0 \\
\hline Mar-28 & 0 & 0 & 0 & 0 \\
\hline Apr-28 & 0 & 0 & 0 & 0 \\
\hline May-28 & 0 & 0 & 0 & 0 \\
\hline Jun-28 & 0 & 0 & 22800 & 32730 \\
\hline Jul-28 & 5569 & 8211 & 557808 & 108514 \\
\hline Aug-28 & 0 & 0 & 158383 & 44725 \\
\hline Sep-28 & 0 & 0 & 0 & 0 \\
\hline Oct-28 & 0 & 0 & 0 & 0 \\
\hline Nov-28 & 0 & 0 & 0 & 0 \\
\hline Dec-28 & 0 & 0 & 0 & 0 \\
\hline Jan-29 & 0 & 0 & 0 & 0 \\
\hline Feb-29 & 0 & 0 & 0 & 0 \\
\hline Mar-29 & 0 & 0 & 0 & 0 \\
\hline Apr-29 & 0 & 0 & 0 & 0 \\
\hline May-29 & 0 & 0 & 0 & 0 \\
\hline Jun-29 & 0 & 0 & 0 & 0 \\
\hline Jul-29 & 27042 & 201090 & 5569 & 5569 \\
\hline Aug-29 & 0 & 3613 & 5501 & 0 \\
\hline Sep-29 & 0 & 0 & 0 & 0 \\
\hline Oct-29 & 0 & 0 & 0 & 0 \\
\hline Nov-29 & 0 & 0 & 0 & 0 \\
\hline Dec-29 & 0 & 0 & 0 & 0 \\
\hline Jan-30 & 0 & 0 & 0 & 0 \\
\hline Feb-30 & 0 & 0 & 0 & 0 \\
\hline Mar-30 & 0 & 0 & 0 & 0 \\
\hline Apr-30 & 0 & 0 & 0 & 0 \\
\hline May-30 & 0 & 0 & 0 & 0 \\
\hline Jun-30 & 13493 & 0 & 0 & 0 \\
\hline
\end{tabular}


Table B4. (Cont.)

\begin{tabular}{|c|c|c|c|c|}
\hline & PCMA2 & BCSDPCMA2 & GFDLA2 & BSCDGFDLA2 \\
\hline $\begin{array}{l}\text { May through August } \\
\text { Average (2027-2032) }\end{array}$ & 25,000 & 25,000 & 210,000 & 93,000 \\
\hline Jul-30 & 165049 & 39357 & 44900 & 8960 \\
\hline Aug-30 & 0 & 0 & 0 & 0 \\
\hline Sep-30 & 0 & 0 & 0 & 0 \\
\hline Oct-30 & 0 & 0 & 0 & 0 \\
\hline Nov-30 & 0 & 0 & 0 & 0 \\
\hline Dec-30 & 0 & 0 & 0 & 0 \\
\hline Jan-31 & 0 & 0 & 0 & 0 \\
\hline Feb-31 & 0 & 0 & 0 & 0 \\
\hline Mar-31 & 0 & 0 & 0 & 0 \\
\hline Apr-31 & 0 & 0 & 0 & 0 \\
\hline May-31 & 0 & 0 & 0 & 0 \\
\hline Jun-31 & 0 & 0 & 407894 & 10884 \\
\hline Jul-31 & 64101 & 34477 & 717121 & 7740 \\
\hline Aug-31 & 8278 & 290092 & 6444 & 0 \\
\hline Sep-31 & 0 & 0 & 0 & 0 \\
\hline Oct-31 & 0 & 0 & 0 & 0 \\
\hline Nov-31 & 0 & 0 & 0 & 0 \\
\hline Dec-31 & 0 & 0 & 0 & 0 \\
\hline Jan-32 & 0 & 0 & 0 & 0 \\
\hline Feb-32 & 0 & 0 & 0 & 0 \\
\hline Mar-32 & 0 & 0 & 0 & 0 \\
\hline Apr-32 & 0 & 0 & 0 & 0 \\
\hline May-32 & 0 & 0 & 0 & 0 \\
\hline Jun-32 & 3073 & 0 & 12573 & 65232 \\
\hline Jul-32 & 240004 & 6383 & 1573634 & 833643 \\
\hline Aug-32 & 11101 & 0 & 0 & 0 \\
\hline Sep-32 & 0 & 0 & 0 & 0 \\
\hline Oct-32 & 0 & 0 & 0 & 0 \\
\hline Nov-32 & 0 & 0 & 0 & 0 \\
\hline Dec-32 & 0 & 0 & 0 & 0 \\
\hline
\end{tabular}


Table B5. Estimated electricity generation curtailment (MW) due to exceeding average monthly effluent temperature limits, for 2011 monthly generation and years 2027-2032, with the assumption that all curtailed generation occurs from 12 noon to 8 p.m. Each column represents results for input climate from one of the four climate models.

\begin{tabular}{|c|c|c|c|c|}
\hline & PCMA2 & BCSDPCMA2 & GFDLA2 & BSCDGFDLA2 \\
\hline $\begin{array}{l}\text { May through August } \\
\text { Average (2027-2032) }\end{array}$ & 100 & 100 & 850 & 380 \\
\hline Jan-27 & 0 & 0 & 0 & 0 \\
\hline Feb-27 & 0 & 0 & 0 & 0 \\
\hline Mar-27 & 0 & 0 & 0 & 0 \\
\hline Apr-27 & 0 & 0 & 0 & 0 \\
\hline May-27 & 0 & 0 & 0 & 0 \\
\hline Jun-27 & 174 & 0 & 0 & 0 \\
\hline Jul-27 & 23 & 105 & 3853 & 2428 \\
\hline Aug-27 & 13 & 0 & 2440 & 2097 \\
\hline Sep-27 & 0 & 0 & 0 & 0 \\
\hline Oct-27 & 0 & 0 & 0 & 0 \\
\hline Nov-27 & 0 & 0 & 0 & 0 \\
\hline Dec-27 & 0 & 0 & 0 & 0 \\
\hline Jan-28 & 0 & 0 & 0 & 0 \\
\hline Feb-28 & 0 & 0 & 0 & 0 \\
\hline Mar-28 & 0 & 0 & 0 & 0 \\
\hline Apr-28 & 0 & 0 & 0 & 0 \\
\hline May-28 & 0 & 0 & 0 & 0 \\
\hline Jun-28 & 0 & 0 & 95 & 136 \\
\hline Jul-28 & 22 & 33 & 2249 & 438 \\
\hline Aug-28 & 0 & 0 & 639 & 180 \\
\hline Sep-28 & 0 & 0 & 0 & 0 \\
\hline Oct-28 & 0 & 0 & 0 & 0 \\
\hline Nov-28 & 0 & 0 & 0 & 0 \\
\hline Dec-28 & 0 & 0 & 0 & 0 \\
\hline Jan-29 & 0 & 0 & 0 & 0 \\
\hline Feb-29 & 0 & 0 & 0 & 0 \\
\hline Mar-29 & 0 & 0 & 0 & 0 \\
\hline Apr-29 & 0 & 0 & 0 & 0 \\
\hline May-29 & 0 & 0 & 0 & 0 \\
\hline Jun-29 & 0 & 0 & 0 & 0 \\
\hline Jul-29 & 109 & 811 & 22 & 22 \\
\hline Aug-29 & 0 & 15 & 22 & 0 \\
\hline Sep-29 & 0 & 0 & 0 & 0 \\
\hline Oct-29 & 0 & 0 & 0 & 0 \\
\hline Nov-29 & 0 & 0 & 0 & 0 \\
\hline Dec-29 & 0 & 0 & 0 & 0 \\
\hline Jan-30 & 0 & 0 & 0 & 0 \\
\hline Feb-30 & 0 & 0 & 0 & 0 \\
\hline Mar-30 & 0 & 0 & 0 & 0 \\
\hline Apr-30 & 0 & 0 & 0 & 0 \\
\hline May-30 & 0 & 0 & 0 & 0 \\
\hline
\end{tabular}


Table B5. (Cont.)

\begin{tabular}{|c|c|c|c|c|}
\hline & PCMA2 & BCSDPCMA2 & GFDLA2 & BSCDGFDLA2 \\
\hline $\begin{array}{l}\text { May through August } \\
\text { Average (2027-2032) }\end{array}$ & 100 & 100 & 850 & 380 \\
\hline Jun-30 & 56 & 0 & 0 & 0 \\
\hline Jul-30 & 666 & 159 & 181 & 36 \\
\hline Aug-30 & 0 & 0 & 0 & 0 \\
\hline Sep-30 & 0 & 0 & 0 & 0 \\
\hline Oct-30 & 0 & 0 & 0 & 0 \\
\hline Nov-30 & 0 & 0 & 0 & 0 \\
\hline Dec-30 & 0 & 0 & 0 & 0 \\
\hline Jan-31 & 0 & 0 & 0 & 0 \\
\hline Feb-31 & 0 & 0 & 0 & 0 \\
\hline Mar-31 & 0 & 0 & 0 & 0 \\
\hline Apr-31 & 0 & 0 & 0 & 0 \\
\hline May-31 & 0 & 0 & 0 & 0 \\
\hline Jun-31 & 0 & 0 & 1700 & 45 \\
\hline Jul-31 & 258 & 139 & 2892 & 31 \\
\hline Aug-31 & 33 & 1170 & 26 & 0 \\
\hline Sep-31 & 0 & 0 & 0 & 0 \\
\hline Oct-31 & 0 & 0 & 0 & 0 \\
\hline Nov-31 & 0 & 0 & 0 & 0 \\
\hline Dec-31 & 0 & 0 & 0 & 0 \\
\hline Jan-32 & 0 & 0 & 0 & 0 \\
\hline Feb-32 & 0 & 0 & 0 & 0 \\
\hline Mar-32 & 0 & 0 & 0 & 0 \\
\hline Apr-32 & 0 & 0 & 0 & 0 \\
\hline May-32 & 0 & 0 & 0 & 0 \\
\hline Jun-32 & 13 & 0 & 52 & 272 \\
\hline Jul-32 & 968 & 26 & 6345 & 3361 \\
\hline Aug-32 & 45 & 0 & 0 & 0 \\
\hline Sep-32 & 0 & 0 & 0 & 0 \\
\hline Oct-32 & 0 & 0 & 0 & 0 \\
\hline Nov-32 & 0 & 0 & 0 & 0 \\
\hline Dec-32 & 0 & 0 & 0 & 0 \\
\hline
\end{tabular}


Table B6. Estimated electricity generation curtailment (MW-h per month) due to exceeding average monthly effluent temperature limits, with the assumption that power plants would otherwise operate at $100 \%$ capacity factor in years $2027-2032$. This is an analysis of maximum possible generation curtailment. Each column represents results for input climate from one of the four climate models.

\begin{tabular}{|c|c|c|c|c|}
\hline & PCMA2 & BCSDPCMA2 & GFDLA2 & BSCDGFDLA2 \\
\hline $\begin{array}{l}\text { May through August Average } \\
\qquad(2027-2032)\end{array}$ & $1,000,000$ & $1,000,000$ & $1,400,000$ & $1,000,000$ \\
\hline Jan-27 & 0 & 0 & 0 & 0 \\
\hline Feb-27 & 0 & 0 & 0 & 0 \\
\hline Mar-27 & 0 & 0 & 0 & 0 \\
\hline Apr-27 & 0 & 0 & 0 & 0 \\
\hline May-27 & 76263 & 250089 & 114662 & 154118 \\
\hline Jun-27 & 1090789 & 725747 & 1099903 & 712628 \\
\hline Jul-27 & 1260725 & 1414082 & 2877935 & 2176950 \\
\hline Aug-27 & 1453514 & 1469030 & 2439953 & 2175667 \\
\hline Sep-27 & 0 & 0 & 0 & 0 \\
\hline Oct-27 & 0 & 0 & 0 & 0 \\
\hline Nov-27 & 0 & 0 & 0 & 0 \\
\hline Dec-27 & 0 & 0 & 0 & 0 \\
\hline Jan-28 & 0 & 0 & 0 & 0 \\
\hline Feb-28 & 0 & 0 & 0 & 0 \\
\hline Mar-28 & 0 & 0 & 0 & 0 \\
\hline Apr-28 & 0 & 0 & 0 & 0 \\
\hline May-28 & 70882 & 66727 & 574119 & 271128 \\
\hline Jun-28 & 492370 & 491749 & 1753780 & 977655 \\
\hline Jul-28 & 1114803 & 1320722 & 2333293 & 1282182 \\
\hline Aug-28 & 837280 & 986770 & 1811879 & 1072255 \\
\hline Sep-28 & 0 & 0 & 0 & 0 \\
\hline Oct-28 & 0 & 0 & 0 & 0 \\
\hline Nov-28 & 0 & 0 & 0 & 0 \\
\hline Dec-28 & 0 & 0 & 0 & 0 \\
\hline Jan-29 & 0 & 0 & 0 & 0 \\
\hline Feb-29 & 0 & 0 & 0 & 0 \\
\hline Mar-29 & 0 & 0 & 0 & 0 \\
\hline Apr-29 & 0 & 0 & 0 & 0 \\
\hline May-29 & 134252 & 315830 & 1825 & 24937 \\
\hline Jun-29 & 511098 & 1115969 & 385326 & 570729 \\
\hline Jul-29 & 1569729 & 1941075 & 494629 & 1078773 \\
\hline Aug-29 & 1270026 & 1439551 & 1513125 & 1172891 \\
\hline Sep-29 & 0 & 0 & 0 & 0 \\
\hline Oct-29 & 0 & 0 & 0 & 0 \\
\hline Nov-29 & 0 & 0 & 0 & 0 \\
\hline Dec-29 & 0 & 0 & 0 & 0 \\
\hline Jan-30 & 0 & 0 & 0 & 0 \\
\hline Feb-30 & 0 & 0 & 0 & 0 \\
\hline Mar-30 & 0 & 0 & 0 & 0 \\
\hline Apr-30 & 0 & 0 & 0 & 0 \\
\hline May-30 & 47136 & 61333 & 167948 & 164081 \\
\hline
\end{tabular}


Table B6. (Cont.)

\begin{tabular}{|c|c|c|c|c|}
\hline & PCMA2 & BCSDPCMA2 & GFDLA2 & BSCDGFDLA2 \\
\hline $\begin{array}{l}\text { May through August Average } \\
(2027-2032)\end{array}$ & $1,000,000$ & $1,000,000$ & $1,400,000$ & $1,000,000$ \\
\hline Jun-30 & 1313348 & 649934 & 761775 & 849025 \\
\hline Jul-30 & 1937904 & 1714159 & 1688125 & 1068212 \\
\hline Aug-30 & 1528666 & 1531626 & 1473569 & 1476159 \\
\hline Sep-30 & 0 & 0 & 0 & 0 \\
\hline Oct-30 & 0 & 0 & 0 & 0 \\
\hline Nov-30 & 0 & 0 & 0 & 0 \\
\hline Dec-30 & 0 & 0 & 0 & 0 \\
\hline Jan-31 & 0 & 0 & 0 & 0 \\
\hline Feb-31 & 0 & 0 & 0 & 0 \\
\hline Mar-31 & 0 & 0 & 0 & 0 \\
\hline Apr-31 & 0 & 0 & 0 & 0 \\
\hline May-31 & 85271 & 164123 & 430484 & 212218 \\
\hline Jun-31 & 833072 & 572808 & 2388277 & 971430 \\
\hline Jul-31 & 1770777 & 1221479 & 2572861 & 1191634 \\
\hline Aug-31 & 1703871 & 2101677 & 1462804 & 1460231 \\
\hline Sep-31 & 0 & 0 & 0 & 0 \\
\hline Oct-31 & 0 & 0 & 0 & 0 \\
\hline Nov-31 & 0 & 0 & 0 & 0 \\
\hline Dec-31 & 0 & 0 & 0 & 0 \\
\hline Jan-32 & 0 & 0 & 0 & 0 \\
\hline Feb-32 & 0 & 0 & 0 & 0 \\
\hline Mar-32 & 0 & 0 & 0 & 0 \\
\hline Apr-32 & 0 & 0 & 0 & 0 \\
\hline May-32 & 59203 & 57300 & 65512 & 69494 \\
\hline Jun-32 & 1372885 & 506452 & 1700436 & 1948745 \\
\hline Jul-32 & 2108626 & 1544614 & 3674518 & 2742305 \\
\hline Aug-32 & 1528340 & 1418342 & 656310 & 778986 \\
\hline Sep-32 & 0 & 0 & 0 & 0 \\
\hline Oct-32 & 0 & 0 & 0 & 0 \\
\hline Nov-32 & 0 & 0 & 0 & 0 \\
\hline Dec-32 & 0 & 0 & 0 & 0 \\
\hline
\end{tabular}


Table B7. Estimated electricity generation curtailment (MW) due to exceeding average monthly effluent temperature limits, with the assumption of operation at $100 \%$ capacity factor for all months in years 2027-2032 and the assumption that all curtailed generation occurs from 12 noon to 8 p.m. Each column represents results for input climate from one of the four climate models.

\begin{tabular}{|c|c|c|c|c|}
\hline & PCMA2 & BCSDPCMA2 & GFDLA2 & BSCDGFDLA2 \\
\hline $\begin{array}{l}\text { May through August } \\
\text { Average (2027-2032) }\end{array}$ & 4,100 & 3,900 & 5,500 & 4,200 \\
\hline Jan-27 & 0 & 0 & 0 & 0 \\
\hline Feb-27 & 0 & 0 & 0 & 0 \\
\hline Mar-27 & 0 & 0 & 0 & 0 \\
\hline Apr-27 & 0 & 0 & 0 & 0 \\
\hline May-27 & 308 & 1008 & 462 & 621 \\
\hline Jun-27 & 4545 & 3024 & 4583 & 2969 \\
\hline Jul-27 & 5084 & 5702 & 11605 & 8778 \\
\hline Aug-27 & 5861 & 5924 & 9839 & 8773 \\
\hline Sep-27 & 0 & 0 & 0 & 0 \\
\hline Oct-27 & 0 & 0 & 0 & 0 \\
\hline Nov-27 & 0 & 0 & 0 & 0 \\
\hline Dec-27 & 0 & 0 & 0 & 0 \\
\hline Jan-28 & 0 & 0 & 0 & 0 \\
\hline Feb-28 & 0 & 0 & 0 & 0 \\
\hline Mar-28 & 0 & 0 & 0 & 0 \\
\hline Apr-28 & 0 & 0 & 0 & 0 \\
\hline May-28 & 286 & 269 & 2315 & 1093 \\
\hline Jun-28 & 2052 & 2049 & 7307 & 4074 \\
\hline Jul-28 & 4495 & 5325 & 9408 & 5170 \\
\hline Aug-28 & 3376 & 3979 & 7306 & 4324 \\
\hline Sep-28 & 0 & 0 & 0 & 0 \\
\hline Oct-28 & 0 & 0 & 0 & 0 \\
\hline Nov-28 & 0 & 0 & 0 & 0 \\
\hline Dec-28 & 0 & 0 & 0 & 0 \\
\hline Jan-29 & 0 & 0 & 0 & 0 \\
\hline Feb-29 & 0 & 0 & 0 & 0 \\
\hline Mar-29 & 0 & 0 & 0 & 0 \\
\hline Apr-29 & 0 & 0 & 0 & 0 \\
\hline May-29 & 541 & 1274 & 7 & 101 \\
\hline Jun-29 & 2130 & 4650 & 1606 & 2378 \\
\hline Jul-29 & 6330 & 7827 & 1994 & 4350 \\
\hline Aug-29 & 5121 & 5805 & 6101 & 4729 \\
\hline Sep-29 & 0 & 0 & 0 & 0 \\
\hline Oct-29 & 0 & 0 & 0 & 0 \\
\hline Nov-29 & 0 & 0 & 0 & 0 \\
\hline Dec-29 & 0 & 0 & 0 & 0 \\
\hline Jan-30 & 0 & 0 & 0 & 0 \\
\hline Feb-30 & 0 & 0 & 0 & 0 \\
\hline Mar-30 & 0 & 0 & 0 & 0 \\
\hline Apr-30 & 0 & 0 & 0 & 0 \\
\hline May-30 & 190 & 247 & 677 & 662 \\
\hline
\end{tabular}


Table B7. (Cont.)

\begin{tabular}{|c|c|c|c|c|}
\hline & PCMA2 & BCSDPCMA2 & GFDLA2 & BSCDGFDLA2 \\
\hline $\begin{array}{l}\text { May through August } \\
\text { Average (2027-2032) }\end{array}$ & 4,100 & 3,900 & 5,500 & 4,200 \\
\hline & & & & \\
\hline Jun-30 & 5472 & 2708 & 3174 & 3538 \\
\hline Jul-30 & 7814 & 6912 & 6807 & 4307 \\
\hline Aug-30 & 6164 & 6176 & 5942 & 5952 \\
\hline Sep-30 & 0 & 0 & 0 & 0 \\
\hline Oct-30 & 0 & 0 & 0 & 0 \\
\hline Nov-30 & 0 & 0 & 0 & 0 \\
\hline Dec-30 & 0 & 0 & 0 & 0 \\
\hline Jan-31 & 0 & 0 & 0 & 0 \\
\hline Feb-31 & 0 & 0 & 0 & 0 \\
\hline Mar-31 & 0 & 0 & 0 & 0 \\
\hline Apr-31 & 0 & 0 & 0 & 0 \\
\hline May-31 & 344 & 662 & 1736 & 856 \\
\hline Jun-31 & 3471 & 2387 & 9951 & 4048 \\
\hline Jul-31 & 7140 & 4925 & 10374 & 4805 \\
\hline Aug-31 & 6870 & 8475 & 5898 & 5888 \\
\hline Sep-31 & 0 & 0 & 0 & 0 \\
\hline Oct-31 & 0 & 0 & 0 & 0 \\
\hline Nov-31 & 0 & 0 & 0 & 0 \\
\hline Dec-31 & 0 & 0 & 0 & 0 \\
\hline Jan-32 & 0 & 0 & 0 & 0 \\
\hline Feb-32 & 0 & 0 & 0 & 0 \\
\hline Mar-32 & 0 & 0 & 0 & 0 \\
\hline Apr-32 & 0 & 0 & 0 & 0 \\
\hline May-32 & 239 & 231 & 264 & 280 \\
\hline Jun-32 & 5720 & 2110 & 7085 & 8120 \\
\hline Jul-32 & 8503 & 6228 & 14817 & 11058 \\
\hline Aug-32 & 6163 & 5719 & 2646 & 3141 \\
\hline Sep-32 & 0 & 0 & 0 & 0 \\
\hline Oct-32 & 0 & 0 & 0 & 0 \\
\hline Nov-32 & 0 & 0 & 0 & 0 \\
\hline Dec-32 & 0 & 0 & 0 & 0 \\
\hline
\end{tabular}


Table B8. Estimated possible increase in electricity generation from normal (2011) generation levels in all months in years 2027-2032 (MW-h). This increased generation is approximated as the difference of normal (2011) generation from the calculated maximum possible energy generation without breaching the EPA average monthly effluent temperature limit. Each column represents results for input climate from one of the four climate models.

\begin{tabular}{|c|c|c|c|c|}
\hline & PCMA2 & BCSDPCMA2 & GFDLA2 & BSCDGFDLA2 \\
\hline $\begin{array}{l}\text { May through August } \\
\text { Average (2027-2032) }\end{array}$ & $6,800,000$ & $6,700,000$ & $6,400,000$ & $6,700,000$ \\
\hline Jan- 27 & 0 & 0 & 0 & 0 \\
\hline Feb-27 & 0 & 0 & 0 & 0 \\
\hline Mar-27 & 0 & 0 & 0 & 0 \\
\hline Apr-27 & 0 & 0 & 0 & 0 \\
\hline May-27 & 7772306 & 7598480 & 7733907 & 7694451 \\
\hline Jun-27 & 6809190 & 7260932 & 6860854 & 7238404 \\
\hline Jul-27 & 6021313 & 5900897 & 5116691 & 5425078 \\
\hline Aug-27 & 5048176 & 5022055 & 4432376 & 4587842 \\
\hline Sep-27 & 0 & 0 & 0 & 0 \\
\hline Oct-27 & 0 & 0 & 0 & 0 \\
\hline Nov-27 & 0 & 0 & 0 & 0 \\
\hline Dec-27 & 0 & 0 & 0 & 0 \\
\hline Jan-28 & 0 & 0 & 0 & 0 \\
\hline Feb-28 & 0 & 0 & 0 & 0 \\
\hline Mar-28 & 0 & 0 & 0 & 0 \\
\hline Apr-28 & 0 & 0 & 0 & 0 \\
\hline May-28 & 9993125 & 9997280 & 9489888 & 9792879 \\
\hline Jun-28 & 7554159 & 7560402 & 6056291 & 6871206 \\
\hline Jul-28 & 6212914 & 5993576 & 5306149 & 5942064 \\
\hline Aug-28 & 10541178 & 7910883 & 6258564 & 7295265 \\
\hline Sep-28 & 0 & 0 & 0 & 0 \\
\hline Oct-28 & 0 & 0 & 0 & 0 \\
\hline Nov-28 & 0 & 0 & 0 & 0 \\
\hline Dec-28 & 0 & 0 & 0 & 0 \\
\hline Jan-29 & 0 & 0 & 0 & 0 \\
\hline Feb-29 & 0 & 0 & 0 & 0 \\
\hline Mar-29 & 0 & 0 & 0 & 0 \\
\hline Apr-29 & 0 & 0 & 0 & 0 \\
\hline May-29 & 7714317 & 7532739 & 7846744 & 7823632 \\
\hline Jun-29 & 7532657 & 6808321 & 7666825 & 7481422 \\
\hline Jul-29 & 5693148 & 5358045 & 6991752 & 6243935 \\
\hline Aug-29 & 5221546 & 5052201 & 5014767 & 5369989 \\
\hline Sep-29 & 0 & 0 & 0 & 0 \\
\hline Oct-29 & 0 & 0 & 0 & 0 \\
\hline Nov-29 & 0 & 0 & 0 & 0 \\
\hline Dec-29 & 0 & 0 & 0 & 0 \\
\hline Jan-30 & 0 & 0 & 0 & 0 \\
\hline Feb-30 & 0 & 0 & 0 & 0 \\
\hline Mar-30 & 0 & 0 & 0 & 0 \\
\hline Apr-30 & 0 & 0 & 0 & 0 \\
\hline
\end{tabular}


Table B8. (Cont.)

\begin{tabular}{|c|c|c|c|c|}
\hline & PCMA2 & BCSDPCMA2 & GFDLA2 & BSCDGFDLA2 \\
\hline $\begin{array}{l}\text { May through August } \\
\text { Average (2027-2032) }\end{array}$ & $6,800,000$ & $6,700,000$ & $6,400,000$ & $6,700,000$ \\
\hline May-30 & 7801432 & 7787235 & 7680621 & 7684488 \\
\hline Jun-30 & 6643893 & 7383023 & 7221527 & 7072053 \\
\hline Jul-30 & 5401003 & 5511870 & 5568651 & 6150672 \\
\hline Aug-30 & 4933488 & 4930474 & 4979302 & 4994973 \\
\hline Sep-30 & 0 & 0 & 0 & 0 \\
\hline Oct-30 & 0 & 0 & 0 & 0 \\
\hline Nov-30 & 0 & 0 & 0 & 0 \\
\hline Dec-30 & 0 & 0 & 0 & 0 \\
\hline Jan-31 & 0 & 0 & 0 & 0 \\
\hline Feb-31 & 0 & 0 & 0 & 0 \\
\hline Mar-31 & 0 & 0 & 0 & 0 \\
\hline Apr-31 & 0 & 0 & 0 & 0 \\
\hline May-31 & 9978736 & 9899884 & 9633523 & 9851789 \\
\hline Jun-31 & 7181750 & 7459294 & 5635829 & 6845674 \\
\hline Jul-31 & 5466777 & 6169467 & 5165468 & 5983530 \\
\hline Aug-31 & 4720000 & 4645659 & 5008748 & 5073699 \\
\hline Sep-31 & 0 & 0 & 0 & 0 \\
\hline Oct-31 & 0 & 0 & 0 & 0 \\
\hline Nov-31 & 0 & 0 & 0 & 0 \\
\hline Dec-31 & 0 & 0 & 0 & 0 \\
\hline Jan-32 & 0 & 0 & 0 & 0 \\
\hline Feb-32 & 0 & 0 & 0 & 0 \\
\hline Mar-32 & 0 & 0 & 0 & 0 \\
\hline Apr-32 & 0 & 0 & 0 & 0 \\
\hline May-32 & 7789365 & 7791269 & 7783057 & 7779075 \\
\hline Jun-32 & 6544553 & 7545699 & 6167840 & 5921576 \\
\hline Jul-32 & 5242059 & 5690973 & 4843222 & 5117352 \\
\hline Aug-32 & 4943914 & 5070125 & 5929166 & 5823938 \\
\hline Sep-32 & 0 & 0 & 0 & 0 \\
\hline Oct-32 & 0 & 0 & 0 & 0 \\
\hline Nov-32 & 0 & 0 & 0 & 0 \\
\hline Dec-32 & 0 & 0 & 0 & 0 \\
\hline
\end{tabular}


Table B9. Estimated possible increase in electricity generation from normal (2011) generation levels for all months in years 2027-2032 (MW-h), under the assumption that all curtailed generation occurs from 12 noon to 8 p.m. The values were approximated as the difference of normal (2011) generation from the calculated maximum possible energy generation without breaching the thermal limit. Each column represents results for input climate from one of the four climate models.

\begin{tabular}{|c|c|c|c|c|}
\hline & PCMA2 & BCSDPCMA2 & GFDLA2 & BSCDGFDLA2 \\
\hline $\begin{array}{l}\text { May through August } \\
\text { Average (2027-2032) }\end{array}$ & 28,000 & 27,000 & 26,000 & 27,000 \\
\hline Jan- 27 & 0 & 0 & 0 & 0 \\
\hline Feb-27 & 0 & 0 & 0 & 0 \\
\hline Mar-27 & 0 & 0 & 0 & 0 \\
\hline Apr-27 & 0 & 0 & 0 & 0 \\
\hline May-27 & 31340 & 30639 & 31185 & 31026 \\
\hline Jun-27 & 28372 & 30254 & 28587 & 30160 \\
\hline Jul-27 & 24279 & 23794 & 20632 & 21875 \\
\hline Aug-27 & 20356 & 20250 & 17872 & 18499 \\
\hline Sep-27 & 0 & 0 & 0 & 0 \\
\hline Oct-27 & 0 & 0 & 0 & 0 \\
\hline Nov-27 & 0 & 0 & 0 & 0 \\
\hline Dec-27 & 0 & 0 & 0 & 0 \\
\hline Jan-28 & 0 & 0 & 0 & 0 \\
\hline Feb-28 & 0 & 0 & 0 & 0 \\
\hline Mar-28 & 0 & 0 & 0 & 0 \\
\hline Apr-28 & 0 & 0 & 0 & 0 \\
\hline May-28 & 40295 & 40312 & 38266 & 39487 \\
\hline Jun-28 & 31476 & 31502 & 25235 & 28630 \\
\hline Jul-28 & 25052 & 24168 & 21396 & 23960 \\
\hline Aug-28 & 42505 & 31899 & 25236 & 29416 \\
\hline Sep-28 & 0 & 0 & 0 & 0 \\
\hline Oct-28 & 0 & 0 & 0 & 0 \\
\hline Nov-28 & 0 & 0 & 0 & 0 \\
\hline Dec-28 & 0 & 0 & 0 & 0 \\
\hline Jan-29 & 0 & 0 & 0 & 0 \\
\hline Feb-29 & 0 & 0 & 0 & 0 \\
\hline Mar-29 & 0 & 0 & 0 & 0 \\
\hline Apr-29 & 0 & 0 & 0 & 0 \\
\hline May-29 & 31106 & 30374 & 31640 & 31547 \\
\hline Jun-29 & 31386 & 28368 & 31945 & 31173 \\
\hline Jul-29 & 22956 & 21605 & 28193 & 25177 \\
\hline Aug-29 & 21055 & 20372 & 20221 & 21653 \\
\hline Sep-29 & 0 & 0 & 0 & 0 \\
\hline Oct-29 & 0 & 0 & 0 & 0 \\
\hline Nov-29 & 0 & 0 & 0 & 0 \\
\hline Dec-29 & 0 & 0 & 0 & 0 \\
\hline Jan-30 & 0 & 0 & 0 & 0 \\
\hline Feb-30 & 0 & 0 & 0 & 0 \\
\hline Mar-30 & 0 & 0 & 0 & 0 \\
\hline Apr-30 & 0 & 0 & 0 & 0 \\
\hline
\end{tabular}


Table B9. (Cont.)

\begin{tabular}{|c|c|c|c|c|}
\hline & PCMA2 & BCSDPCMA2 & GFDLA2 & BSCDGFDLA2 \\
\hline $\begin{array}{l}\text { May through August } \\
\text { Average (2027-2032) }\end{array}$ & 28,000 & 27,000 & 26,000 & 27,000 \\
\hline May-30 & 31457 & 31400 & 30970 & 30986 \\
\hline Jun-30 & 27683 & 30763 & 30090 & 29467 \\
\hline Jul-30 & 21778 & 22225 & 22454 & 24801 \\
\hline Aug-30 & 19893 & 19881 & 20078 & 20141 \\
\hline Sep-30 & 0 & 0 & 0 & 0 \\
\hline Oct-30 & 0 & 0 & 0 & 0 \\
\hline Nov-30 & 0 & 0 & 0 & 0 \\
\hline Dec-30 & 0 & 0 & 0 & 0 \\
\hline Jan-31 & 0 & 0 & 0 & 0 \\
\hline Feb-31 & 0 & 0 & 0 & 0 \\
\hline Mar-31 & 0 & 0 & 0 & 0 \\
\hline Apr-31 & 0 & 0 & 0 & 0 \\
\hline May-31 & 40237 & 39919 & 38845 & 39725 \\
\hline Jun-31 & 29924 & 31080 & 23483 & 28524 \\
\hline Jul-31 & 22043 & 24877 & 20828 & 24127 \\
\hline Aug-31 & 19032 & 18732 & 20197 & 20458 \\
\hline Sep-31 & 0 & 0 & 0 & 0 \\
\hline Oct-31 & 0 & 0 & 0 & 0 \\
\hline Nov-31 & 0 & 0 & 0 & 0 \\
\hline Dec-31 & 0 & 0 & 0 & 0 \\
\hline Jan-32 & 0 & 0 & 0 & 0 \\
\hline Feb-32 & 0 & 0 & 0 & 0 \\
\hline Mar-32 & 0 & 0 & 0 & 0 \\
\hline Apr-32 & 0 & 0 & 0 & 0 \\
\hline May-32 & 31409 & 31416 & 31383 & 31367 \\
\hline Jun-32 & 27269 & 31440 & 25699 & 24673 \\
\hline Jul-32 & 21137 & 22947 & 19529 & 20634 \\
\hline Aug-32 & 19935 & 20444 & 23908 & 23484 \\
\hline Sep-32 & 0 & 0 & 0 & 0 \\
\hline Oct-32 & 0 & 0 & 0 & 0 \\
\hline Nov-32 & 0 & 0 & 0 & 0 \\
\hline Dec-32 & 0 & 0 & 0 & 0 \\
\hline
\end{tabular}


Table B10. Estimated possible increase in electricity generation from recorded electricity generation (MW-h). This increased generation is approximated as the difference of historical generation (20072011) from the calculated maximum possible energy generation without breaching the EPA average monthly effluent temperature limit.

\begin{tabular}{|c|c|}
\hline & $\begin{array}{l}\text { Total Monthly Electricity } \\
\text { Generation above } \\
\text { Normal (2011) } \\
\text { Generation in 2007-2011 } \\
\text { (MW-h) }\end{array}$ \\
\hline $\begin{array}{l}\text { May through August } \\
\text { Average (2007-2011) }\end{array}$ & $7,500,000$ \\
\hline Jan-07 & 0 \\
\hline Feb-07 & 0 \\
\hline Mar-07 & 0 \\
\hline Apr-07 & 0 \\
\hline May-07 & 8954340 \\
\hline Jun-07 & 8272082 \\
\hline Jul-07 & 7801125 \\
\hline Aug-07 & 6279473 \\
\hline Sep-07 & 0 \\
\hline Oct-07 & 0 \\
\hline Nov-07 & 0 \\
\hline Dec-07 & 0 \\
\hline Jan-08 & 0 \\
\hline Feb-08 & 0 \\
\hline Mar-08 & 0 \\
\hline Apr-08 & 0 \\
\hline May-08 & 8778521 \\
\hline Jun-08 & 7857341 \\
\hline Jul-08 & 7079905 \\
\hline Aug-08 & 7499495 \\
\hline Sep-08 & 0 \\
\hline Oct-08 & 0 \\
\hline Nov-08 & 0 \\
\hline Dec-08 & 0 \\
\hline Jan-09 & 0 \\
\hline Feb-09 & 0 \\
\hline Mar-09 & 0 \\
\hline Apr-09 & 0 \\
\hline May-09 & 8484506 \\
\hline Jun-09 & 7615577 \\
\hline Jul-09 & 6391604 \\
\hline Aug-09 & 6367596 \\
\hline Sep-09 & 0 \\
\hline Oct-09 & 0 \\
\hline
\end{tabular}


Table B10. (Cont.)

\begin{tabular}{|c|c|}
\hline & $\begin{array}{l}\text { Total Monthly Electricity } \\
\text { Generation above } \\
\text { Normal (2011) } \\
\text { Generation in 2007-2011 } \\
\text { (MW-h) } \\
\end{array}$ \\
\hline $\begin{array}{l}\text { May through August } \\
\text { Average (2007-2011) }\end{array}$ & $7,500,000$ \\
\hline Nov-09 & 0 \\
\hline Dec-09 & 0 \\
\hline Jan-10 & 0 \\
\hline Feb-10 & 0 \\
\hline Mar-10 & 0 \\
\hline Apr-10 & 0 \\
\hline May-10 & 10005177 \\
\hline Jun-10 & 7903703 \\
\hline Jul-10 & 7296307 \\
\hline Aug-10 & 5798003 \\
\hline Sep-10 & 0 \\
\hline Oct-10 & 0 \\
\hline Nov-10 & 0 \\
\hline Dec-10 & 0 \\
\hline Jan-11 & 0 \\
\hline Feb-11 & 0 \\
\hline Mar-11 & 0 \\
\hline Apr-11 & 0 \\
\hline May-11 & 9984701 \\
\hline Jun-11 & 7291052 \\
\hline Jul-11 & 6091749 \\
\hline Aug-11 & 4740279 \\
\hline Sep-11 & 0 \\
\hline Oct-11 & 0 \\
\hline Nov-11 & 0 \\
\hline Dec-11 & 0 \\
\hline
\end{tabular}




\section{Estimate of Future Summer Power Generation without Violation of Effluent Temperature Limits}

Given future climate projections of higher air temperatures, we wish to understand the effects of these higher temperatures on power plant effluent water temperatures. All other factors being equal, a higher air temperature leads to higher intake water temperatures and higher effluent water temperatures. Thus, future higher air temperatures could cause power plants to reach their permitted effluent temperature limits more often than today. We use the year 2011 - the hottest and driest single year on record for Texas - as our baseline year for comparison.

For each power plant, some increase in monthly generation relative to 2011, in MW-h, is possible before the effluent temperature, $T_{\text {eff }}$, breaches the permitted monthly average maximum effluent temperature limit, $T_{\text {eff,limit. }}$. This section describes the calculation used to estimate this increase in power plant monthly electricity generation, as compared to actual power plant generation during calendar year 2011.

Figure B1 (a) shows an example of effluent temperatures that would result from increasing power plant generation to $100 \%$ of capacity factor during the summer. In some years, the effluent temperature would breach the maximum effluent temperature limit. Figure B1 (b) shows an example of the effluent temperature that would result if we impose the constraint of permitted maximum effluent temperature limit. The implications are that, in some years, less monthly power generation might be allowed in future years than in 2011 (e.g., year 2027 and 2032). Below, we describe our method for approximating the reduction in power generation. 


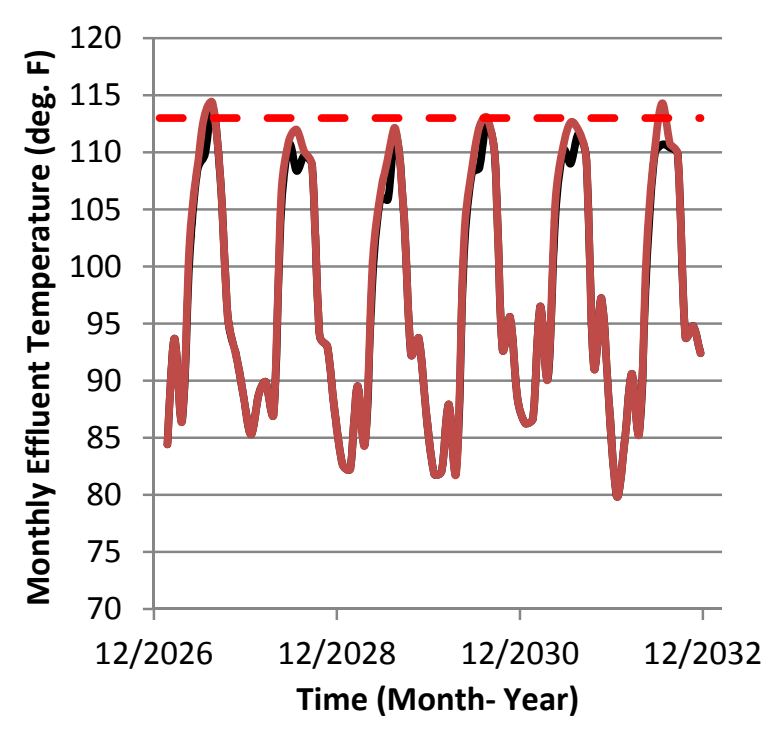

(a)

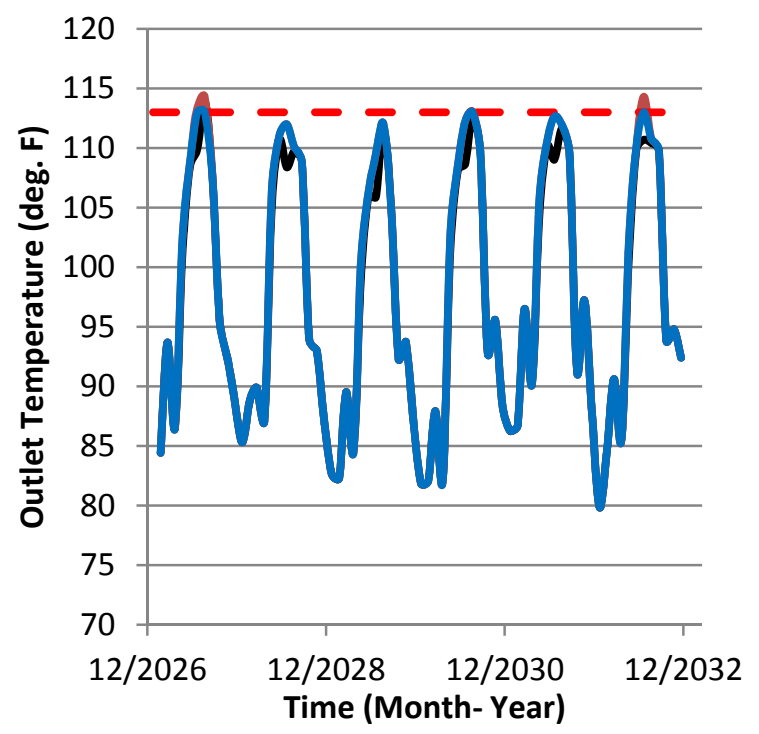

(b)

- Predicted Avg. Effluent Temperature (deg. F), 2011 Monthly Generation Predicted Avg. Effluent Temperature (deg. F), 100\% Capacity in Summer

- - Avg. Temp. Limit: EPA

Predicted Avg. Effluent Temperature (deg. F) at Max Capacity without Breaching Permit Limit

Figure B1. Modeled average effluent temperature for 2011 electric generation profiles, with a horizontal dashed line marking the average effluent temperature limit set by the EPA. Plot (a) indicates the average effluent temperature for $100 \%$ summer capacity factor. Plot (b) indicates the average effluent temperature assuming an increase in electricity generated to the maximum allowable without breaching the effluent temperature limit.

Figures B2 and B3 provide a more detailed graphic explanation of the effluent temperature and related power generation analysis. Figure B2 shows the predicted effluent temperature, $T_{\text {eff, }}$, that a power plant would reach under 2011 electricity generation levels in a future year and the predicted effluent

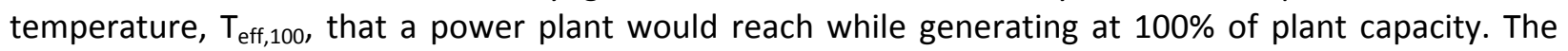

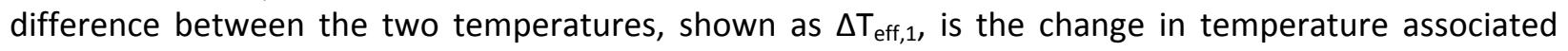
with increasing summer electricity generation to $100 \%$ of capacity - an increase that might need to occur because of future increases in electricity demand. Calculations for each of the values are shown as Equations B1-B3. 


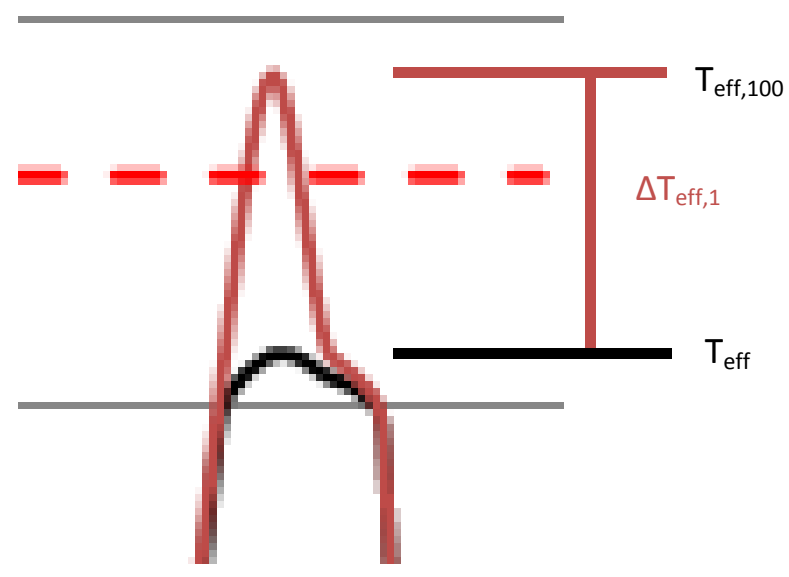

—_Predicted Avg. Effluent Temperature (deg. F), 2011 Monthly Generation _ Predicted Avg. Effluent Temperature (deg. F), 100\% Capacity in Summer - - Avg. Temp. Limit: EPA

Figure B2. The temperature, $\mathrm{T}_{\text {eff, }}$, that a power plant would reach under 2011 electricity generation levels; the predicted effluent temperature,

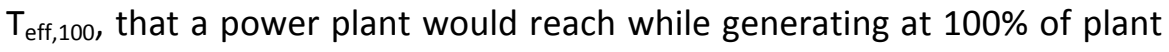
capacity for the same weather conditions; the change in effluent temperature, $\Delta \mathrm{T}_{\mathrm{eff}, 1}$, associated with increasing summer electricity generation to $100 \%$ of capacity; and a horizontal dashed line indicating the average effluent temperature limit set by the EPA.

For the estimated effluent temperature, $T_{\text {eff, }}$

$$
\mathrm{T}_{\text {eff }}=\mathrm{a}_{5} \mathrm{~W}+\mathrm{a}_{4} \mathrm{~T}_{D P}+\mathrm{a}_{3} \mathrm{~T}_{\mathrm{DB}, \operatorname{lag} 1}+\mathrm{a}_{2} \mathrm{~T}_{\mathrm{DB}}+\mathrm{a}_{1} \mathrm{Q}+\mathrm{a}_{0} .
$$

For estimated effluent temperature at $100 \%$ electricity generation capacity, $T_{\text {eff,100, }}$

$$
\mathrm{T}_{\text {eff }, 100}=\mathrm{a}_{5} \mathrm{~W}+\mathrm{a}_{4} \mathrm{~T}_{D P}+\mathrm{a}_{3} \mathrm{~T}_{\mathrm{DB}, \text { lag } 1}+\mathrm{a}_{2} \mathrm{~T}_{\mathrm{DB}}+\mathrm{a}_{1} \mathrm{Q}^{\prime}+\mathrm{a}_{0} \text {. }
$$

For change in temperature, $\Delta \mathrm{T}_{\text {eff,1, }}$

$$
\begin{aligned}
& \text { In summer months (May-August), } \Delta \mathrm{T}_{\text {eff, } 1}=\mathrm{T}_{\text {eff, } 100}-\mathrm{T}_{\text {eff }}=a_{1}\left(Q^{\prime}-Q\right) \text {, and } \\
& \text { In all other months, } \Delta \mathrm{T}_{\text {eff, } 1}=\mathrm{T}_{\text {eff, } 100}-\mathrm{T}_{\text {eff }}=0 .
\end{aligned}
$$

Here

Constants $a_{0}, a_{1}, a_{2}, a_{3}, a_{4}$, and $a_{5}$ were determined via linear regression.

$\mathrm{W}=$ wind speed in $\mathrm{m} / \mathrm{s}$.

$\mathrm{T}_{\mathrm{DP}}=$ dew point in ${ }^{\circ} \mathrm{F}$.

$\mathrm{T}_{\mathrm{DB}, \mathrm{lag} 1}=$ dry-bulb temperature lagged by 1 month in ${ }^{\circ} \mathrm{F}$.

$\mathrm{T}_{\mathrm{DB}}=$ dry-bulb temperature in ${ }^{\circ} \mathrm{F}$.

$Q=$ heat dissipated in MMBtu at 2011 levels. 
$\mathrm{Q}^{\prime}=$ heat dissipated in MMBtu for $100 \%$ electricity generation capacity in summer months or at 2011 generation capacity for all other months.

Figure B3 graphically demonstrates a reduction in effluent temperature from operation at $100 \%$ capacity factor to a lower monthly summer capacity factor. We back-calculate this lower summer capacity factor, so that the predicted average monthly effluent temperature, $T_{\text {eff, }}$ is equal to the

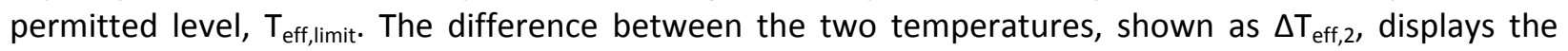
change in temperature associated with increasing summer electricity generation to the maximum allowable - an increase that might need to occur because of future increases in electricity demand without violating EPA-permitted effluent temperature restrictions. Calculations for each of the values are shown as Equations B4-B5.

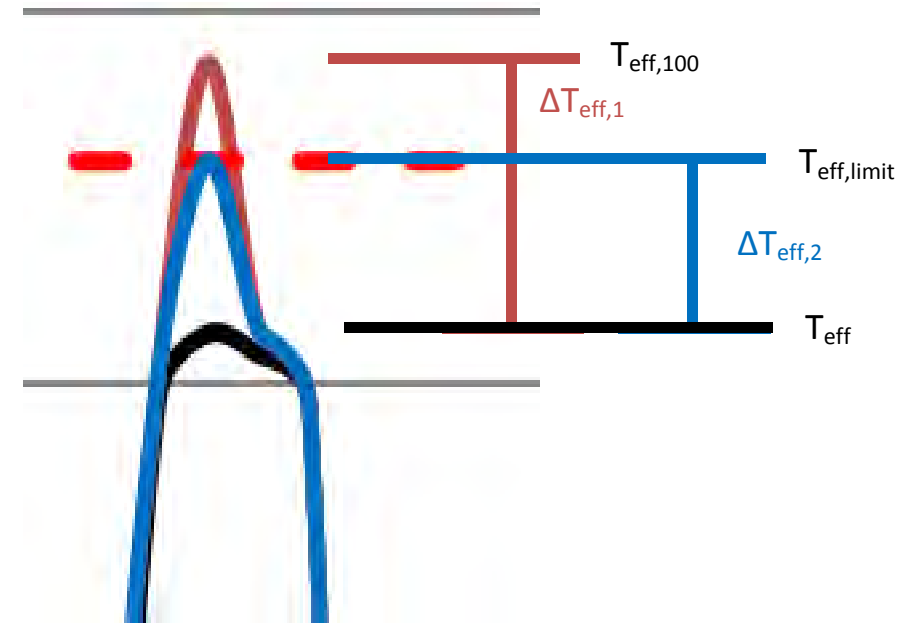

Predicted Avg. Effluent Temperature (deg. F), 2011 Monthly Generation Predicted Avg. Effluent Temperature (deg. F), 100\% Capacity in Summer

- - Avg. Temp. Limit: EPA

Predicted Avg. Effluent Temperature (deg. F) at Max Capacity without Breaching Permit Limit

Figure B3. The temperature, $T_{\text {eff, }}$ that a power plant would reach under 2011 electricity generation levels between 2026 and 2030; the EPA effluent temperature limit, $T_{\text {eff,limit, }}$ which is equivalent to the effluent temperature a power plant would reach while generating at the maximum allowable electricity generation without breaching the EPA limit; the change in temperature, $\Delta \mathrm{T}_{\text {eff,1, }}$, associated with increasing summer electricity generation to $100 \%$ of capacity; and a horizontal dashed line indicating the average effluent temperature limit set by the EPA.

For estimated effluent temperature at maximum allowable generation without breaching the temperature effluent limit, $T_{\text {eff,limit, }}$

$$
\mathrm{T}_{\text {eff,limit }}=\mathrm{a}_{5} \mathrm{~W}+\mathrm{a}_{4} \mathrm{~T}_{\mathrm{DP}}+\mathrm{a}_{3} \mathrm{~T}_{\mathrm{DB}, \text { lag1 }}+\mathrm{a}_{2} \mathrm{~T}_{\mathrm{DB}}+\mathrm{a}_{1} \mathrm{Q}^{\prime \prime}+\mathrm{a}_{0}
$$


For change in temperature, $\Delta \mathrm{T}_{\text {eff,2, }}$

$$
\begin{aligned}
& \text { In summer months, } \Delta \mathrm{T}_{\text {eff, } 2}=\mathrm{T}_{\text {eff,limit }}-\mathrm{T}_{\text {eff }}=a_{1} \times\left(Q^{\prime \prime}-Q\right) \text {, and } \\
& \text { In all other months, } \Delta \mathrm{T}_{\text {eff, }, 2}=\mathrm{T}_{\text {eff,limit }}-\mathrm{T}_{\text {eff }}=0 .
\end{aligned}
$$

Here

$Q^{\prime \prime}$ (summer months) = heat dissipated in MMBtu, as determined for the maximum possible generation capacity in summer months without exceeding the thermal discharge limit.

$Q^{\prime \prime}$ (non-summer months) $=Q$ of 2011.

The assumed heat dissipation, Q", for months May, June, July, and August were back-calculated from the effluent temperature limit and electricity generation capacity as shown below in Equations B6-B7.

For maximum electricity generation capacity factor allowable in a summer month, Ef,plant,s,

$$
\mathrm{Ef}_{\text {plant }, \mathrm{s}}=\left(\mathrm{L}-\left(\mathrm{a}_{5} \mathrm{~W}+\mathrm{a}_{4} \mathrm{~T}_{\mathrm{DP}}+\mathrm{a}_{3} \mathrm{~T}_{\mathrm{DB}, \text { lag1 }}+\mathrm{a}_{2} \mathrm{~T}_{\mathrm{DB}}+\mathrm{a}_{0}\right)\right) \times\left(\frac{\mathrm{a}_{1} \mathrm{t}_{\text {hours }} \mathrm{E}_{\text {plant }}}{1-\frac{3.41}{\mathrm{C}}}\right) \leq 1 .
$$

Here

$$
\begin{aligned}
& \mathrm{L}=\text { effluent thermal limit }\left({ }^{\circ} \mathrm{F}\right) . \\
& \mathrm{C}=\text { Heat rate of aggregate plant in 2011, EIA } 923 \text { (million Btu/MW-h). } \\
& t_{\text {hours }}=\text { number of hours in the month. } \\
& 3.41=\text { conversion factor (million Btu/MW-h). } \\
& \mathrm{E}_{\text {plant }}=\text { electricity capacity for the power plant in } 1 \mathrm{~h}(\mathrm{MW} / \mathrm{h}) . \\
& \mathrm{Ef}_{\text {plant, } \mathrm{s}}=\text { electricity capacity factor in summer }(-) .
\end{aligned}
$$

Thus, the heat that can be dissipated at maximum allowable electricity generation, $Q^{\prime \prime}$, is

$$
\mathrm{Q}^{\prime \prime}=\frac{\mathrm{t}_{\text {hours }} \mathrm{E}_{\text {plant }} \mathrm{E}_{\text {plant,s }} \mathrm{C}}{(1-3.40951)} \text {. }
$$

\section{Reduction or Increase in Electricity Generation from 2011 in Future Scenarios}

We are particularly interested in potential reductions in monthly electricity generation due to thermal effluent limits and potential increases in monthly electricity generation. The estimate for reduction or increase in monthly electricity generation is the difference in electricity generation at normal (2011) levels and the maximum amount of electricity generation possible without breaching the EPA discharge temperature limit, where reduction is a negative change in electricity generation, and increase is a positive change in electricity generation, as follows:

$$
\Delta \mathrm{G}=\frac{\left(\mathrm{Q}-\mathrm{Q}^{\prime \prime}\right) \times(1-3.40951)}{\mathrm{C}},
$$

Or, conversely, 


$$
\Delta \mathrm{G}=\mathrm{t}_{\text {hours }} \mathrm{E}_{\text {plant }}\left(\mathrm{Ef}_{\text {plant,2011 }}-\mathrm{Ef}_{\text {plant,s }}\right) .
$$

Here

$$
\mathrm{Ef}_{\text {plant }, 2011}=\text { electricity capacity factor (-). }
$$

The estimate for reduced monthly electricity generation from $100 \%$ capacity is the negative change in electricity generation at $100 \%$ capacity levels and the maximum amount of electricity generation possible without breaching the EPA discharge temperature limit, as follows:

$$
\Delta \mathrm{G}=\frac{\left(\mathrm{Q}^{\prime}-\mathrm{Q}^{\prime}\right) \times(1-3.40951)}{\mathrm{C}},
$$

Or, conversely,

$$
\Delta \mathrm{G}=\mathrm{t}_{\text {hours }} \mathrm{E}_{\text {plant }}\left(\mathrm{Ef}_{\text {plant,max }}-\mathrm{Ef}_{\text {plant,s }}\right) .
$$

Here

$$
\mathrm{Ef}_{\text {plant, } \max }=\text { electricity capacity factor }(-)=1
$$

\section{Results of Estimated Cooling Water Effluent Temperatures for Power Plants}

- $\quad$ Figures B4-B59 present the following information for each power plant for which a meaningful regression equation was estimated:

o One figure for each plant (e.g., Figure B4 for the Arthur Von Rosenburg plant) displays the following (where applicable):

- Historical (2007-2011) cooling water effluent average monthly discharge temperatures, as reported by the EPA.

- Historical (2007-2011) cooling water effluent maximum monthly discharge temperatures, as reported by the EPA.

- Regression results for estimates of the historical cooling water effluent discharge temperature data.

- The EPA thermal discharge temperature limits for average monthly discharge temperature.

- The EPA thermal discharge temperature limits for maximum monthly discharge temperature.

- Historical (2007-2011) power generation (MW-h per month)

- For each power plant for which the regressions are accurate, a figure with four panels (e.g., Figure B5 for the Arthur Von Rosenburg power plant) estimates the future (20272032) cooling water effluent temperatures for the power plant by using the regression fit from historical (2007-2011) data. Each of the four panels uses downscaled climate data (scenario A2 data) from a different global climate model. 


\section{Arthur Von Rosenburg}

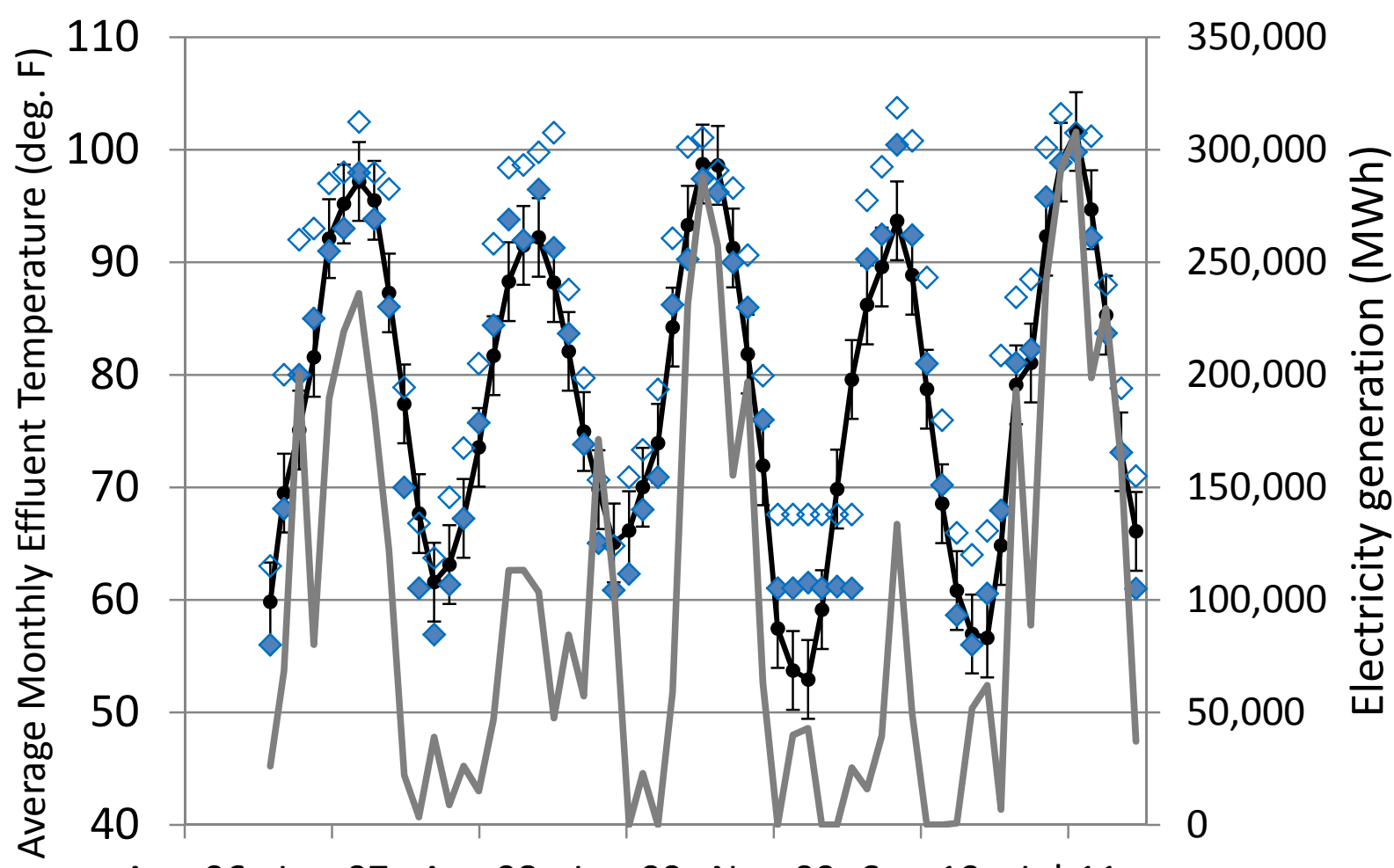

Aug-06 Jun-07 Apr-08 Jan-09 Nov-09 Sep-10 Jul-11

$\diamond$ Avg. Effluent Temperature (deg. F): EPA

$\diamond$ Max. Effluent Temperature (deg. F): EPA

$\rightarrow$ Predicted Avg. Effluent Temperature (deg. F), +/- 2 SD error bars

-.--Avg. Temp. Limit

Max. Temp. Limit

Figure B4. Average effluent temperature, maximum effluent temperature, predicted average effluent temperature from regression test, average effluent temperature limit, maximum effluent temperature limit for the Arthur Von Rosenburg plant. 


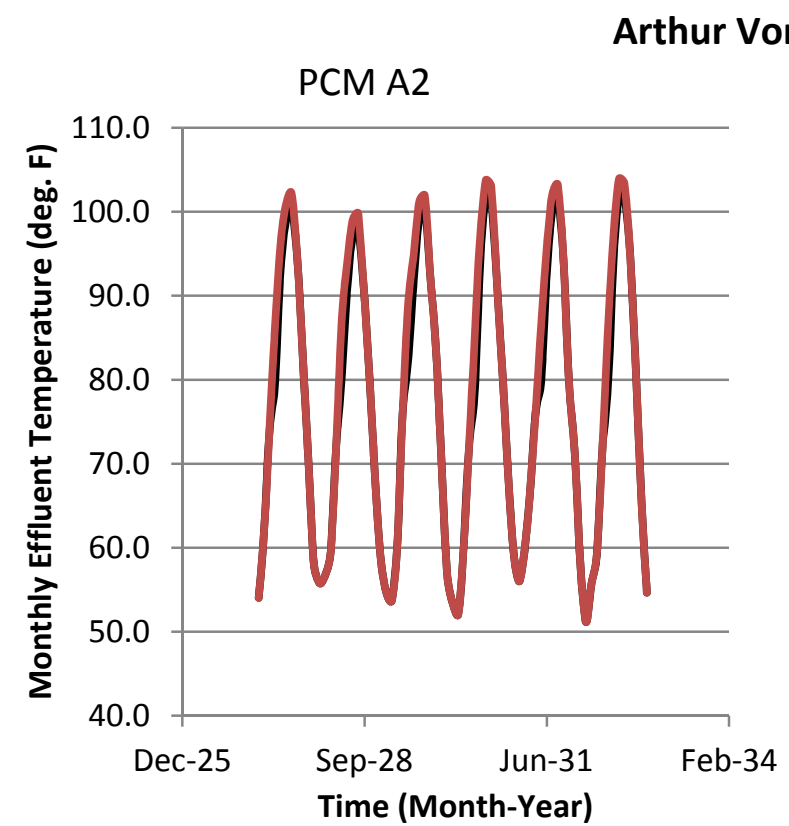

(a)

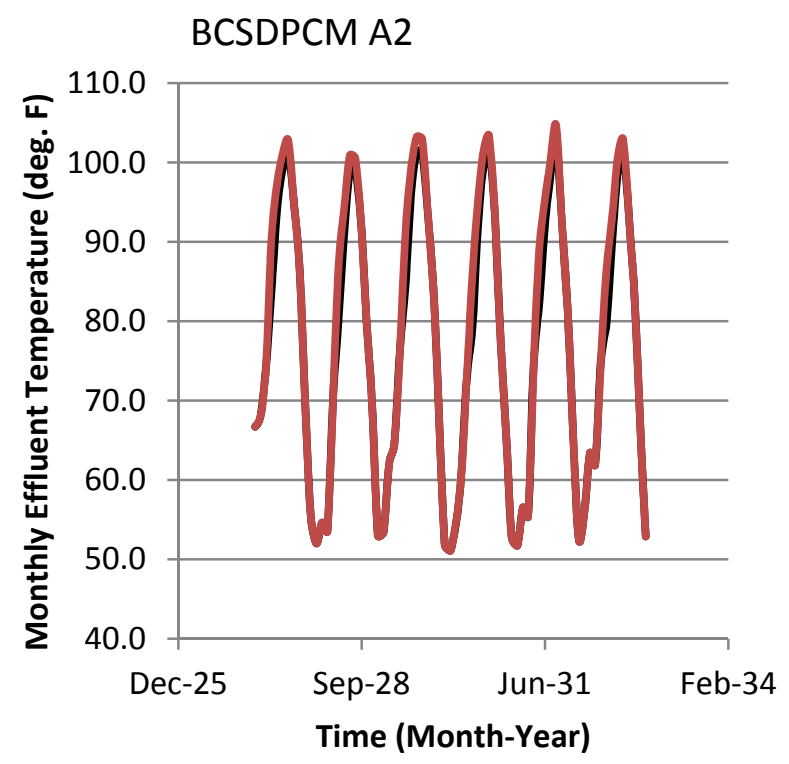

(c)
GFDL A2

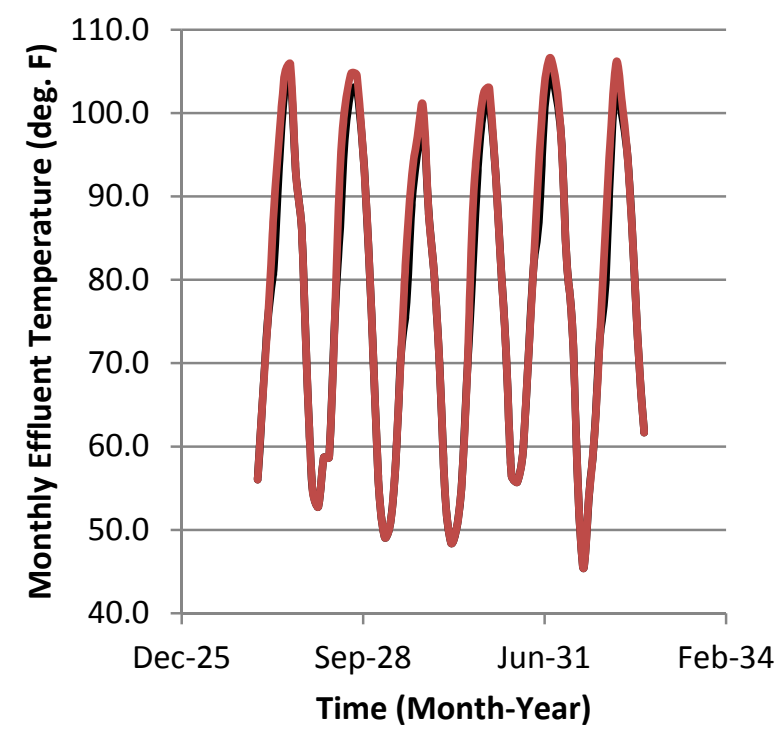

(b)

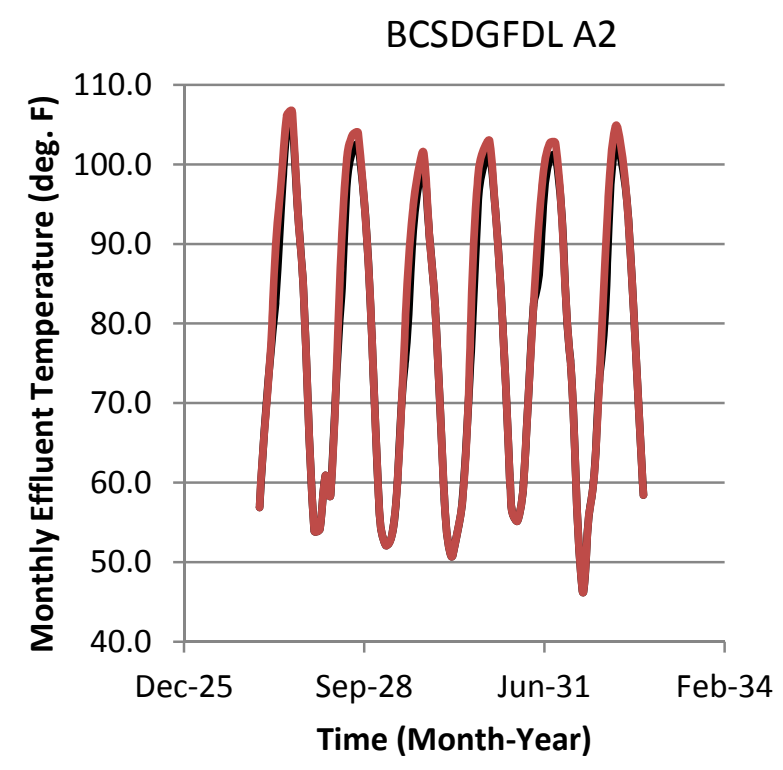

(d)

— Predicted Avg. Effluent Temperature (deg. F)

—Predicted Avg. Effluent Temperature (deg. F), 100\% Capacity in Summer

- - Avg. Temp. Limit: EPA

Figure B5. For the Arthur Von Rosenburg plant and four different simulated future climates (a) PCM, (b) GFDL, (c) BCSDPCM, (d) BCSDGFDL - of the A2 emissions scenario, average effluent temperature assuming 2011 electric generation profiles, average effluent temperature assuming $100 \%$ summer capacity factor, and (if applicable) a horizontal dashed line indicating the average effluent temperature limit set by the EPA. 


\section{Barney M Davis}

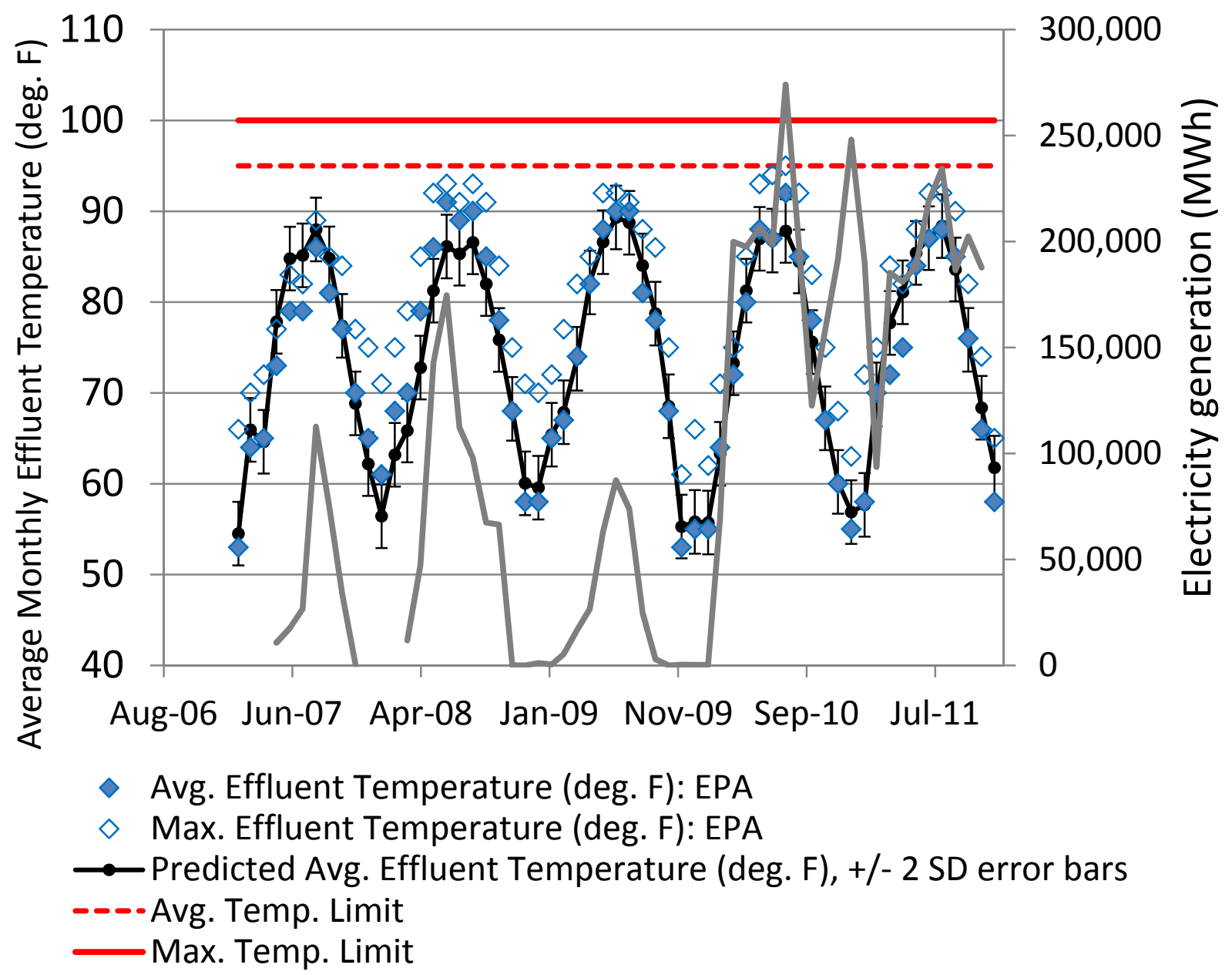

Figure B6. Average effluent temperature, maximum effluent temperature, predicted average effluent temperature from regression test, average effluent temperature limit, maximum effluent temperature limit for the Barney M Davis plant. 


\section{Big Brown}

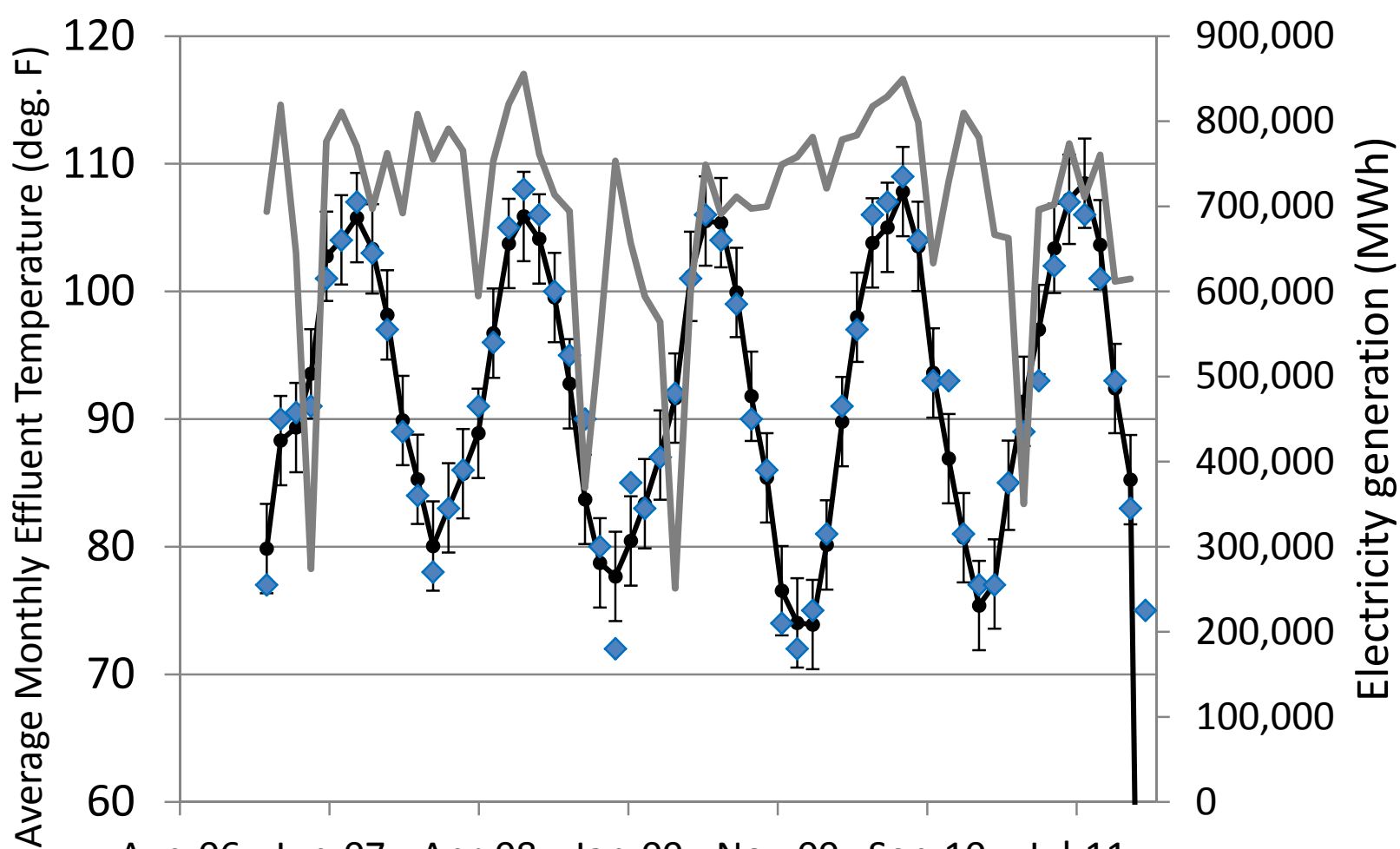

Aug-06 Jun-07 Apr-08 Jan-09 Nov-09 Sep-10 Jul-11

$\diamond$ Avg. Effluent Temperature (deg. F): EPA

$\diamond$ Max. Effluent Temperature (deg. F): EPA

$\longrightarrow$ Predicted Avg. Effluent Temperature (deg. F), +/- 2 SD error bars

---Avg. Temp. Limit

Max. Temp. Limit

Figure B7. Average effluent temperature, maximum effluent temperature, predicted average effluent temperature from regression test, average effluent temperature limit, maximum effluent temperature limit for the Big Brown plant. 
Big Brown

PCM A2

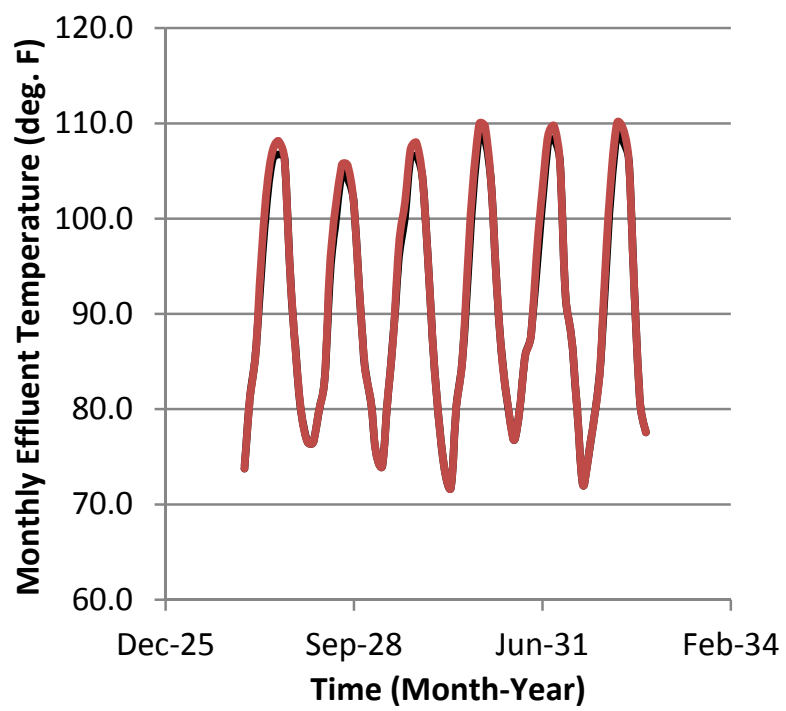

(a)

BCSDPCM A2

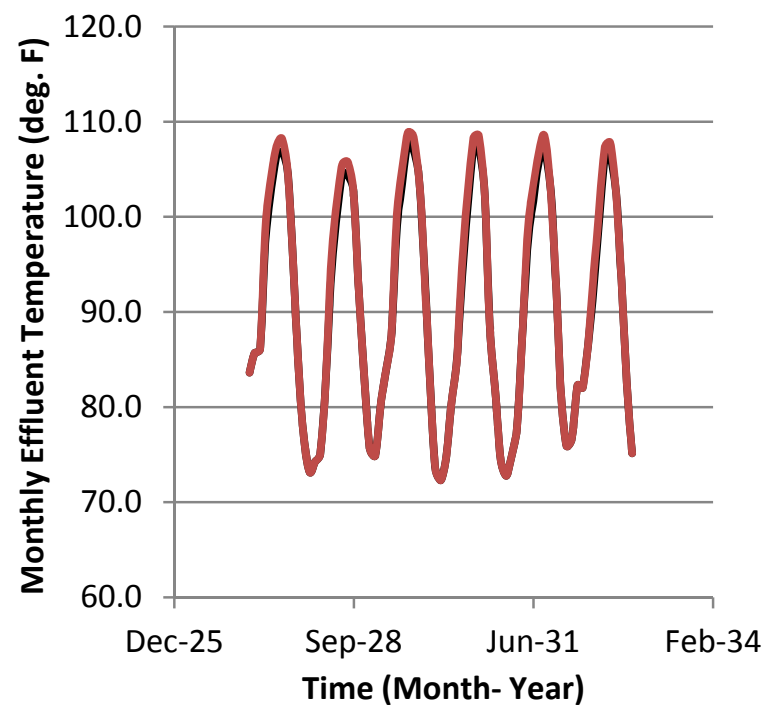

(c)
GFDL A2

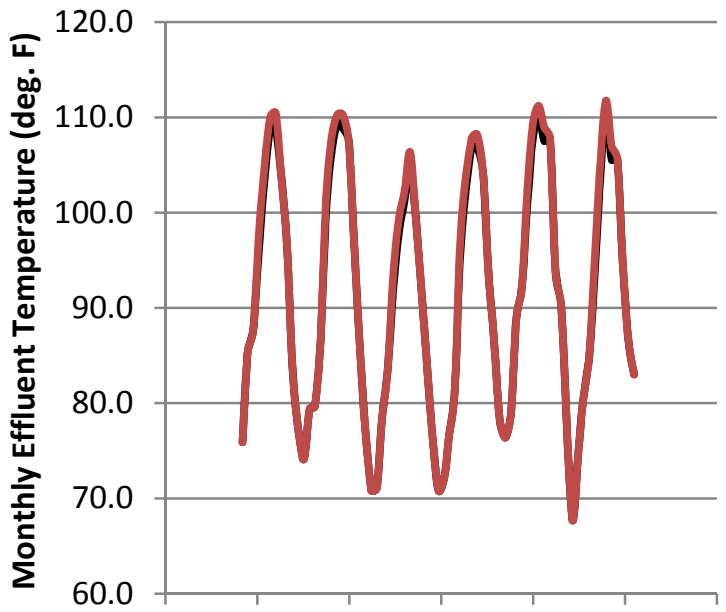

Dec-25Apr-27Sep-28Jan-30Jun-31Oct-32Feb-34 Time (Month- Year)

(b)

BCSDGFDL A2

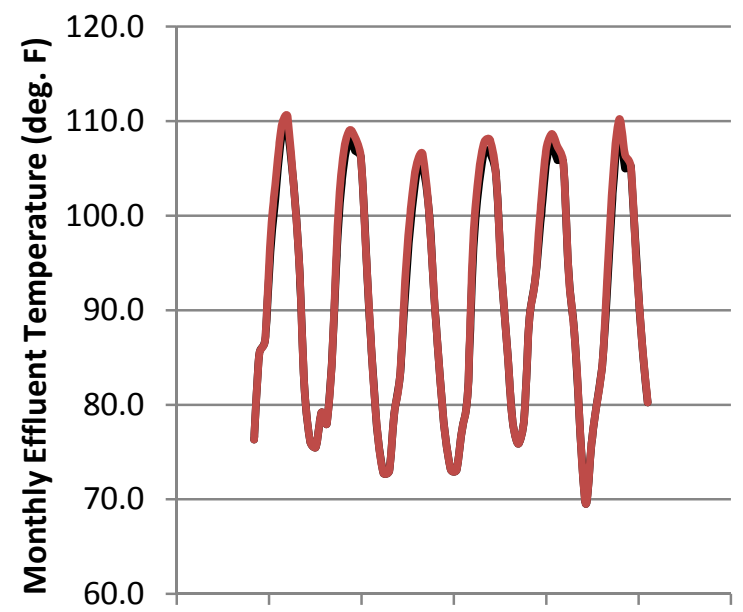

Dec-25Apr-27Sep-28Jan-30Jun-31Oct-32Feb-34

Time (Month- Year)

(d)

—-Predicted Avg. Effluent Temperature (deg. F)

Predicted Avg. Effluent Temperature (deg, F), 100\% Capacity in Summer

- - Avg. Temp. Limit: EPA

Figure B8. For the Big Brown plant and four different simulated future climates - (a) PCM, (b) GFDL, (c) BCSDPCM, (d) BCSDGFDL - of the A2 emissions scenario, average effluent temperature assuming 2011 electric generation profiles, average effluent temperature assuming 100\% summer capacity factor, and (if applicable) a horizontal dashed line indicating the average effluent temperature limit set by the EPA. 


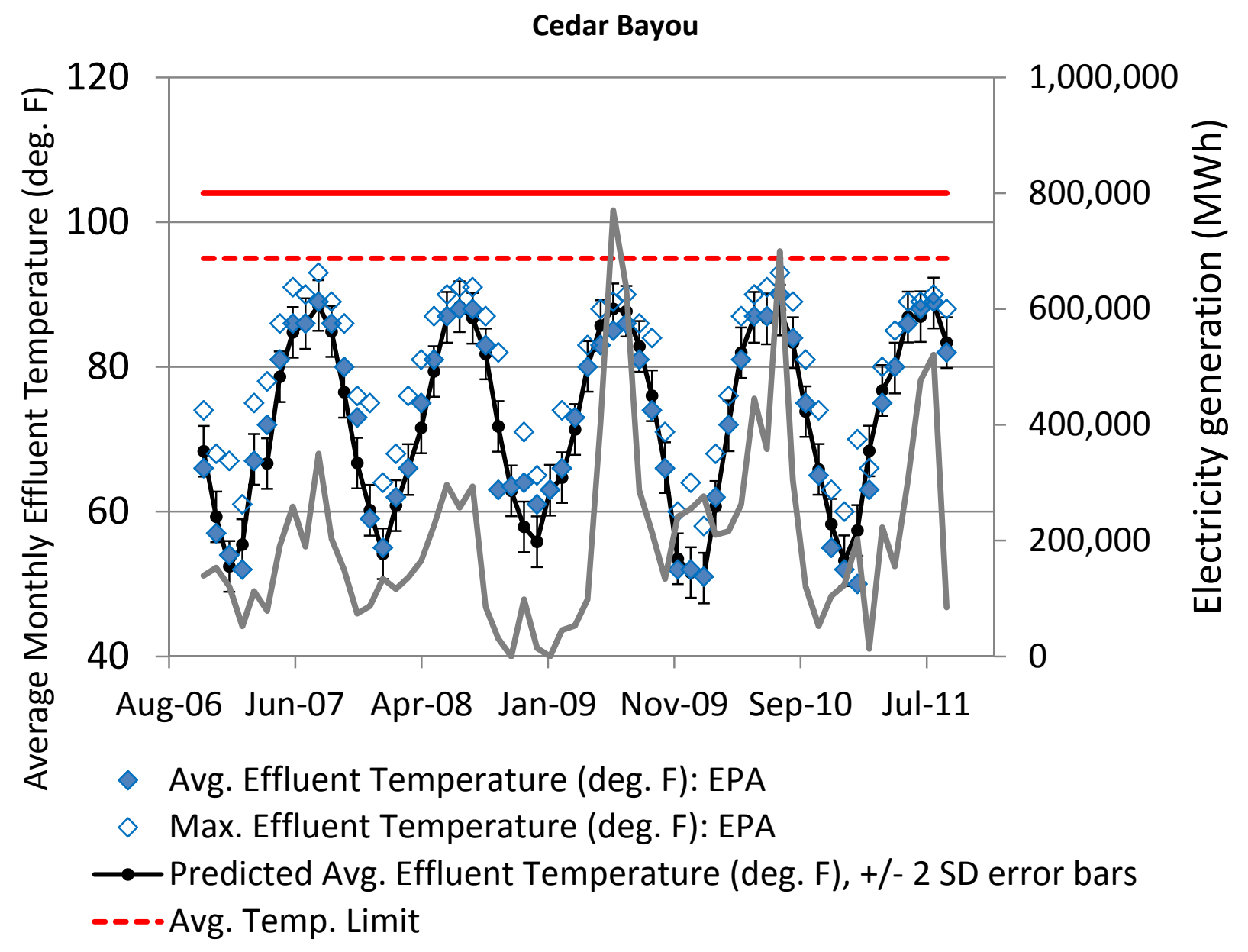

Figure B9. Average effluent temperature, maximum effluent temperature, predicted average effluent temperature from regression test, average effluent temperature limit, maximum effluent temperature limit for the Cedar Bayou plant. 


\section{Coleto Creek}

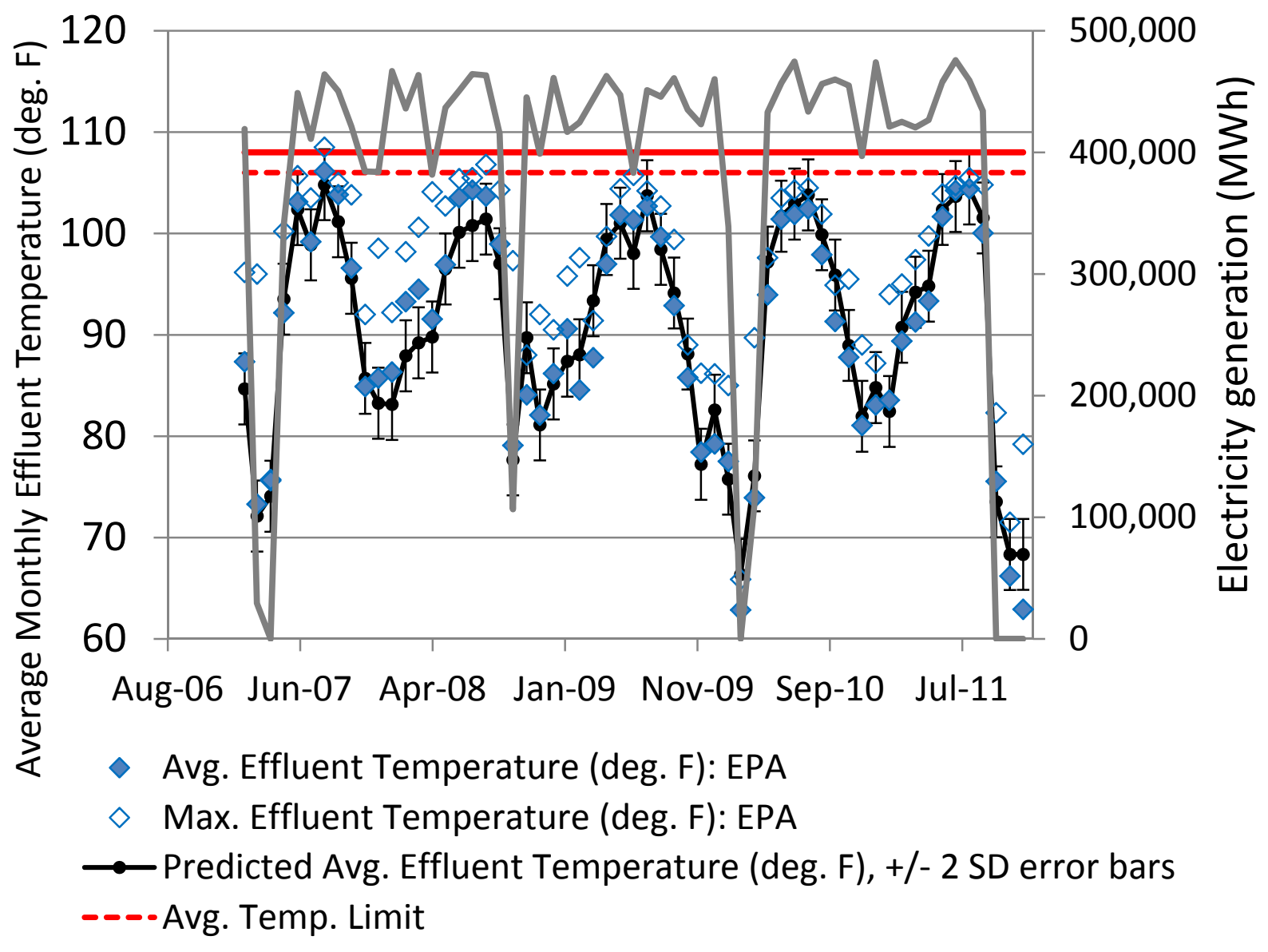

Figure B10. Average effluent temperature, maximum effluent temperature, predicted average effluent temperature from regression test, average effluent temperature limit, maximum effluent temperature limit for the Coleto Creek plant. 


\section{Coleto Creek}

PCM A2

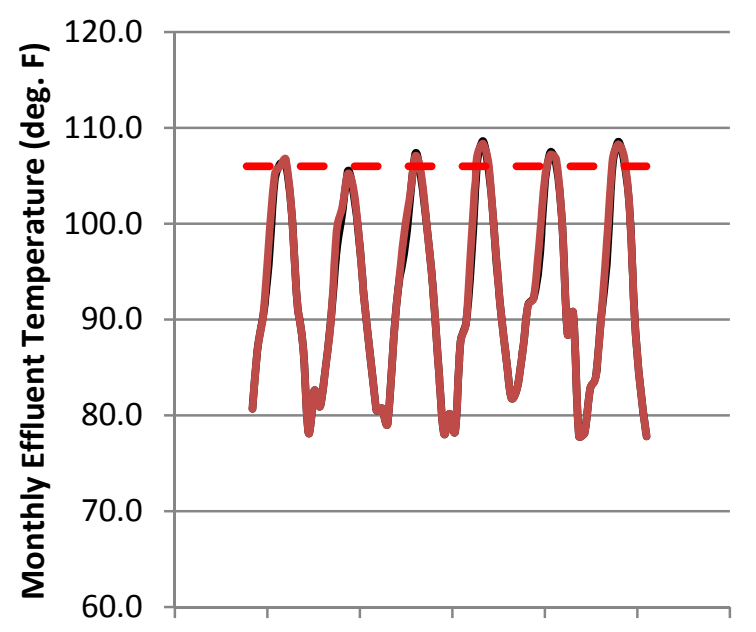

Dec-25Apr-27Sep-28Jan-30Jun-31Oct-32Feb-34 Time (Month-Year)

(a)

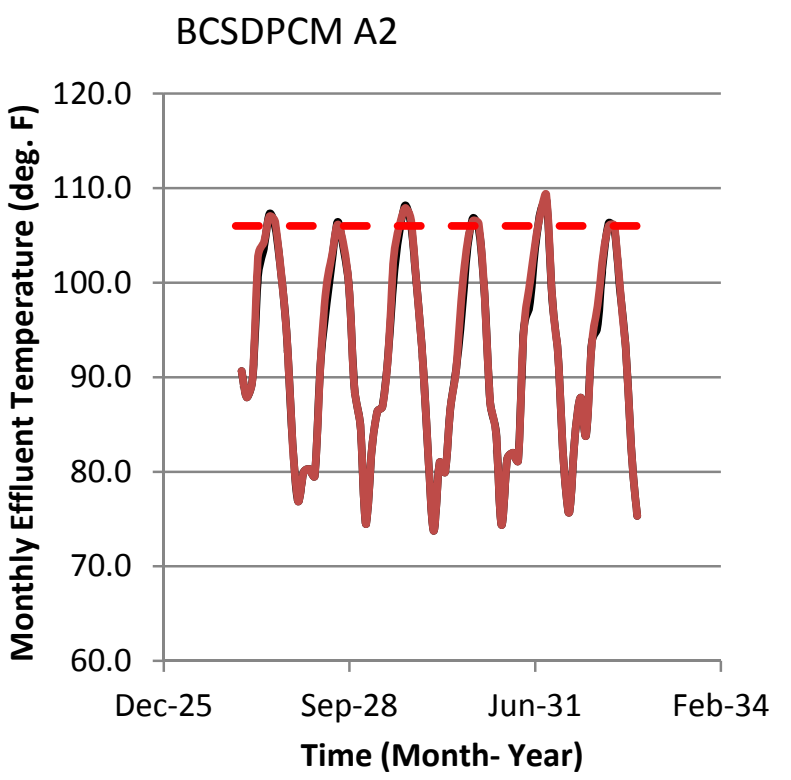

(c)
GFDL A2

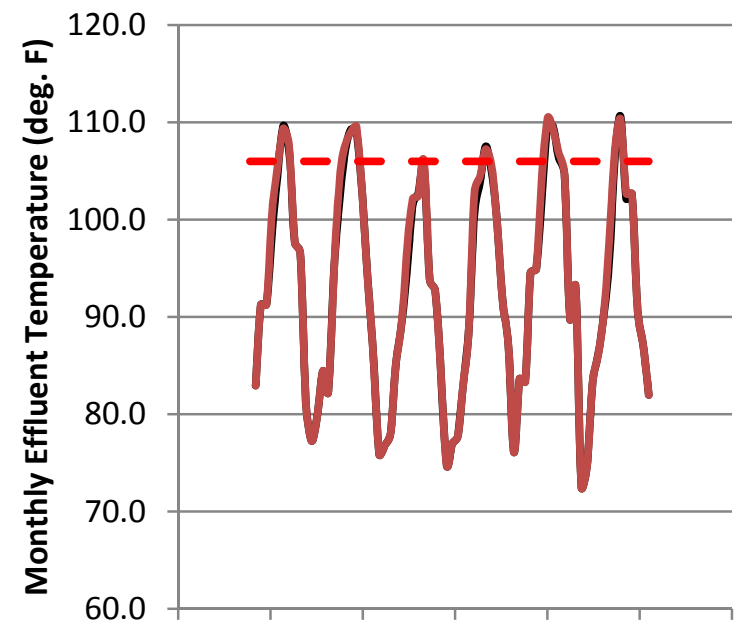

Dec-25Apr-27Sep-28Jan-30Jun-310ct-32Feb-34 Time (Month- Year)

(b)

\section{BCSDGFDL A2}

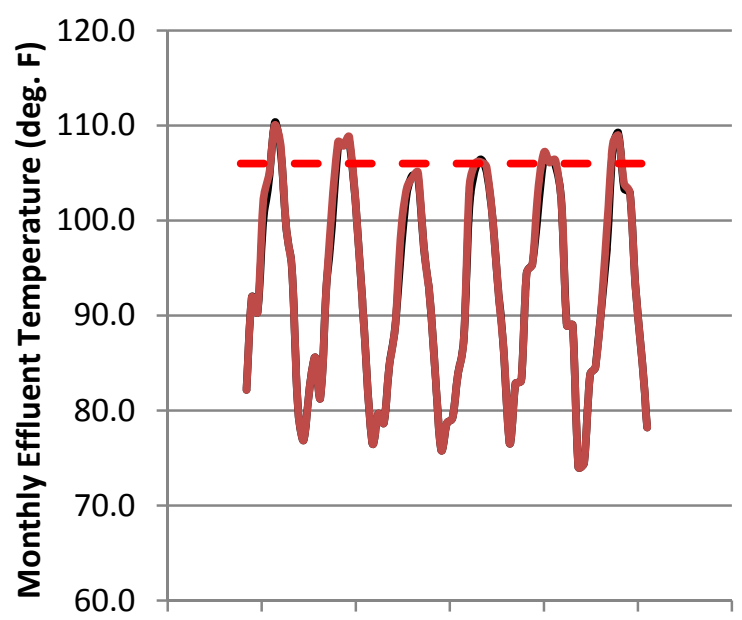

Dec-25Apr-27Sep-28Jan-30Jun-31Oct-32Feb-34

Time (Month- Year)

(d)

- Predicted Avg. Effluent Temperature (deg. F)

—Predicted Avg. Effluent Temperature (deg, F), 100\% Capacity in Summer

- - Avg. Temp. Limit: EPA

Figure B11. For the Coleto Creek plant and four different simulated future climates - (a) PCM, (b) GFDL, (c) BCSDPCM, (d) BCSDGFDL - of the A2 emissions scenario, average effluent temperature assuming 2011 electric generation profiles, average effluent temperature assuming $100 \%$ summer capacity factor, and (if applicable) a horizontal dashed line indicating the average effluent temperature limit set by the EPA. 


\section{Coleto Creek (Additional Generator)}

. PCM A2

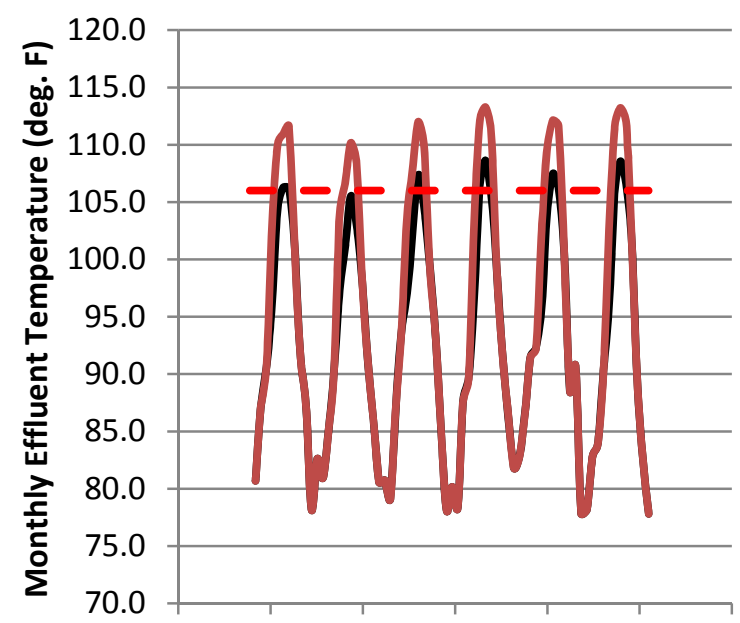

Dec-25Apr-27Sep-28Jan-30Jun-310ct-32Feb-34

Time (Month-Year)

(a)

\section{BCSDPCM A2}

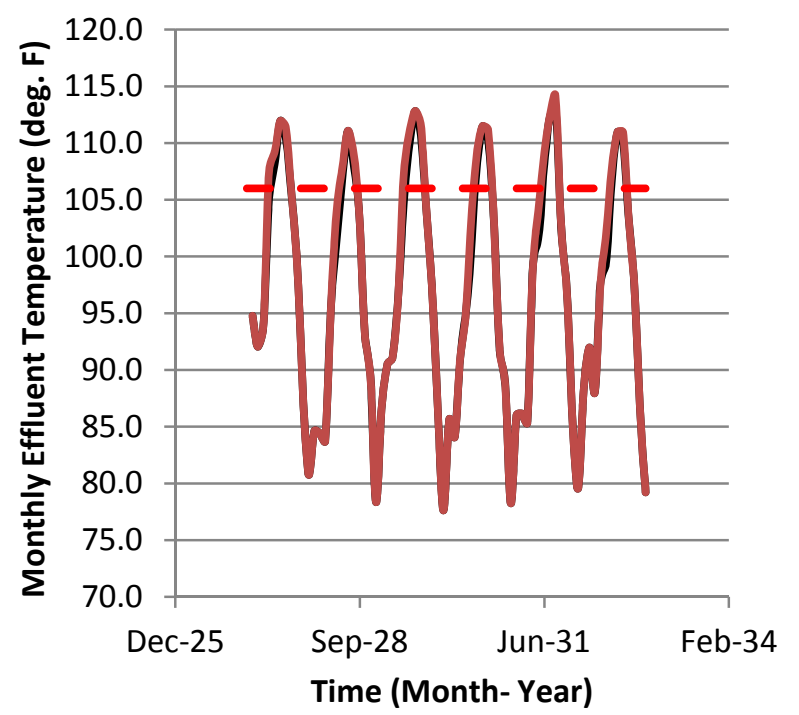

(c)
GFDL A2

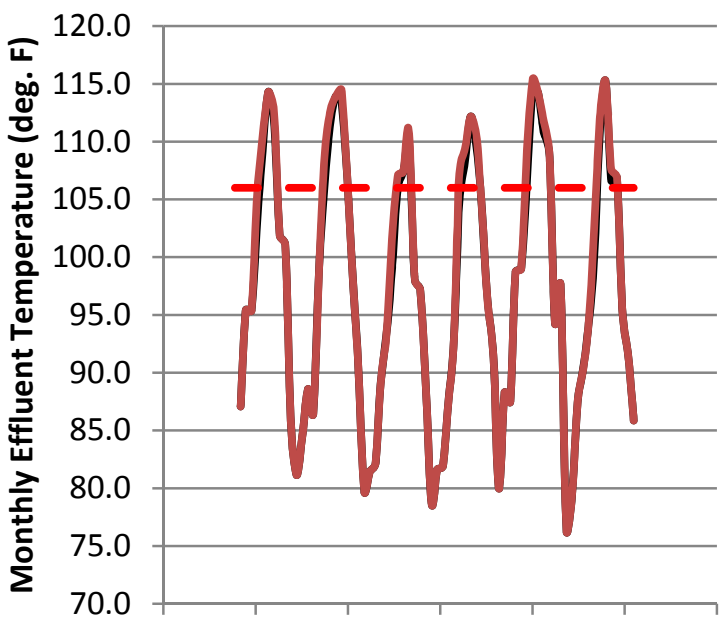

Dec-25Apr-27Sep-28Jan-30Jun-31Oct-32Feb-34 Time (Month- Year)

(b)

BCSDGFDL A2

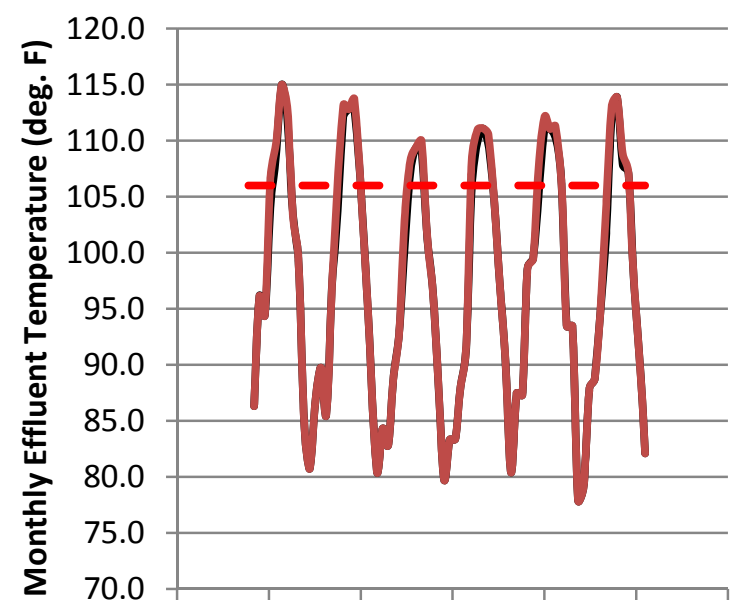

Dec-25Apr-27Sep-28Jan-30Jun-31Oct-32Feb-34

Time (Month- Year)

(d)

—-Predicted Avg. Effluent Temperature (deg. F)

—Predicted Avg. Effluent Temperature (deg, F), 100\% Capacity in Summer

- Avg. Temp. Limit: EPA

Figure B12. For the Coleto Creek plant with an additional generator and four different simulated future climates - (a) PCM, (b) GFDL, (c) BCSDPCM, (d) BCSDGFDL - of the A2 emissions scenario, average effluent temperature assuming 2011 electric generation profiles, average effluent temperature assuming 100\% summer capacity factor, and (if applicable) a horizontal dashed line indicating the average effluent temperature limit set by the EPA. 


\section{Comanche Peak}

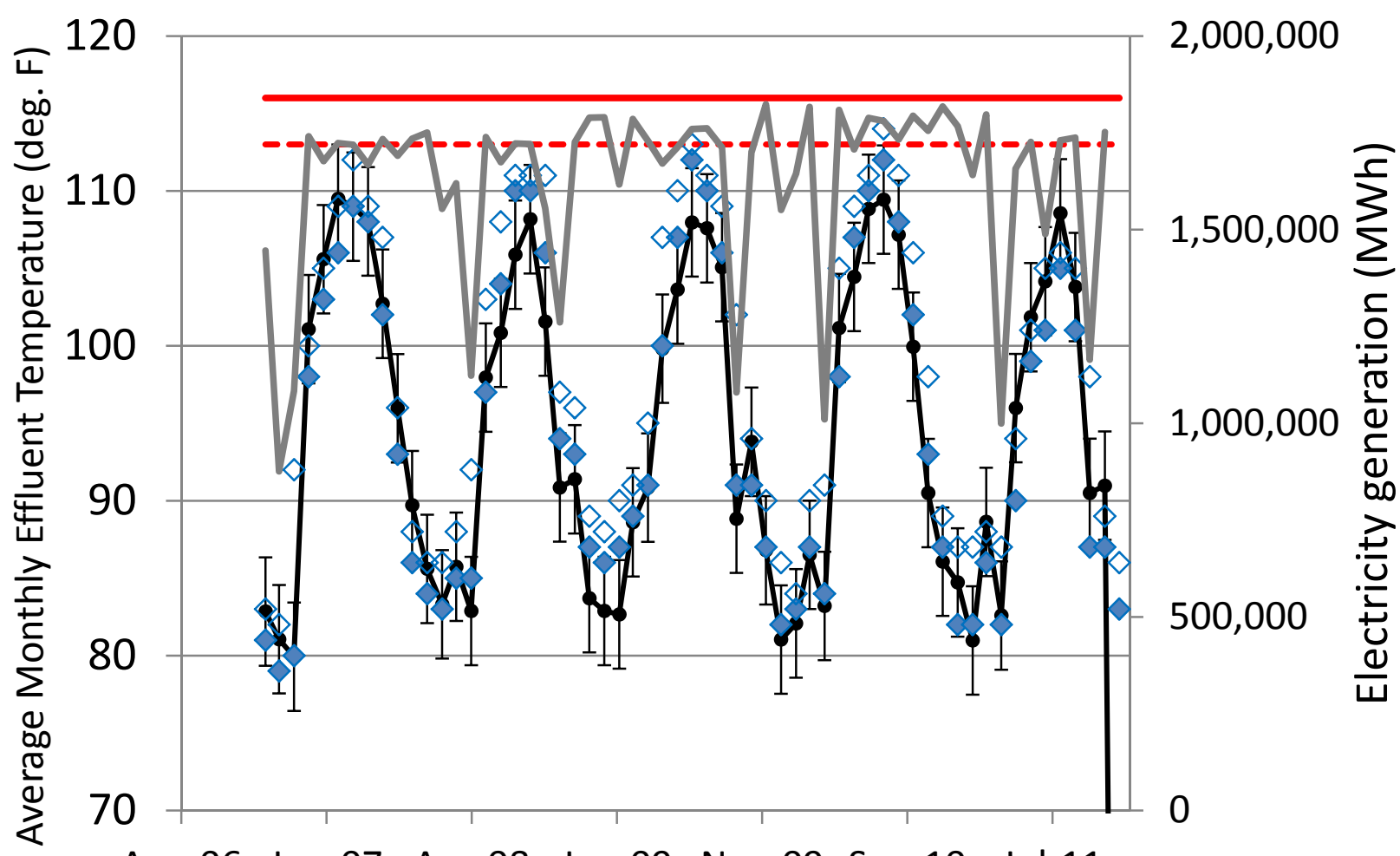

Aug-06 Jun-07 Apr-08 Jan-09 Nov-09 Sep-10 Jul-11

$\diamond$ Avg. Effluent Temperature (deg. F): EPA

$\diamond$ Max. Effluent Temperature (deg. F): EPA

$\rightarrow$ Predicted Avg. Effluent Temperature (deg. F), +/- 2 SD error bars

-.-Avg. Temp. Limit

Max. Temp. Limit

Figure B13. Average effluent temperature, maximum effluent temperature, predicted average effluent temperature from regression test, average effluent temperature limit, maximum effluent temperature limit for the Comanche Peak plant. 


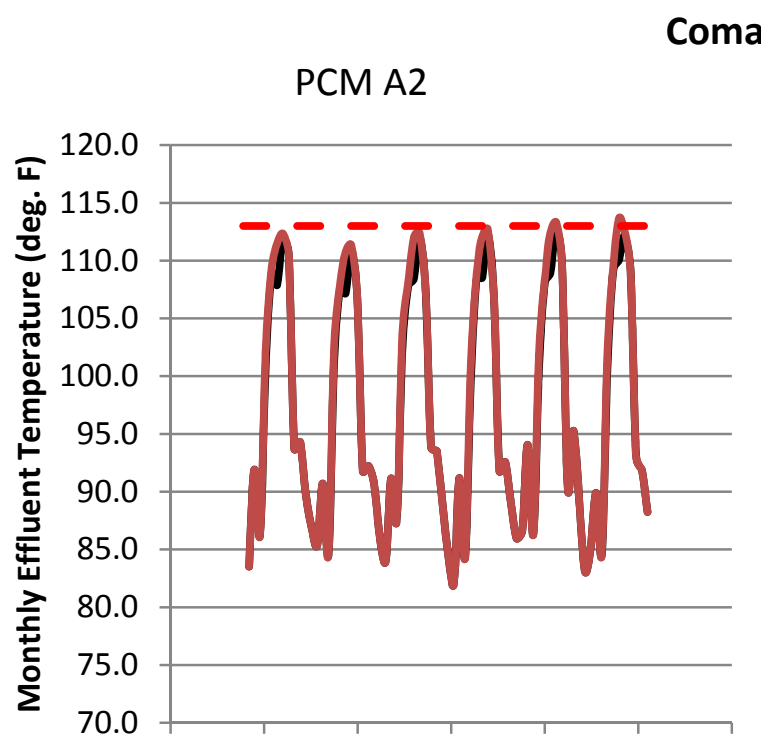

Dec-25Apr-27Sep-28Jan-30Jun-310ct-32Feb-34 Time (Month-Year)

(a)

\section{BCSDPCM A2}

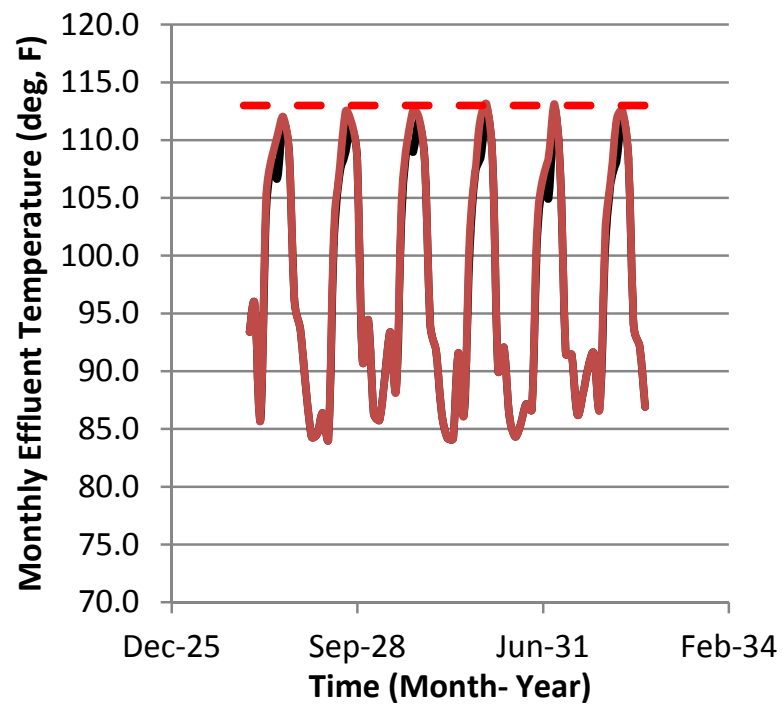

(c)
GFDL A2

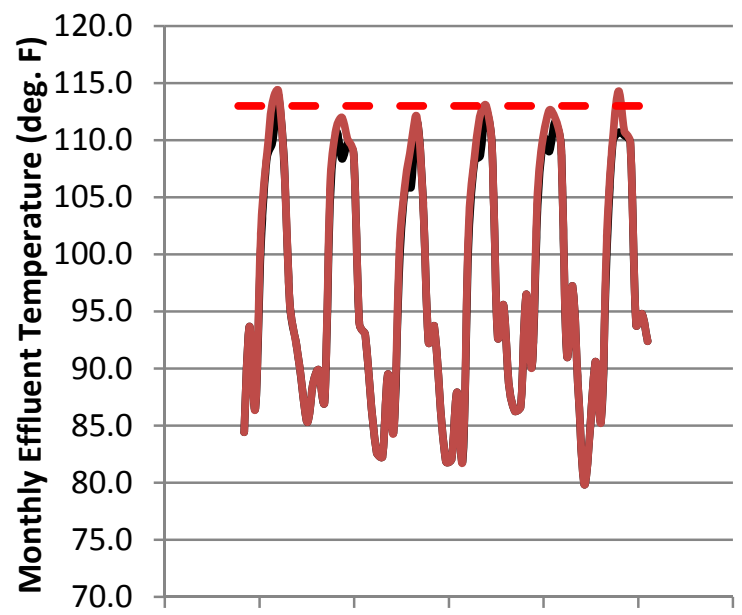

Dec-25Apr-27Sep-28Jan-30Jun-310ct-32Feb-34

Time (Month- Year)

(b)

BCSDGFDL A2

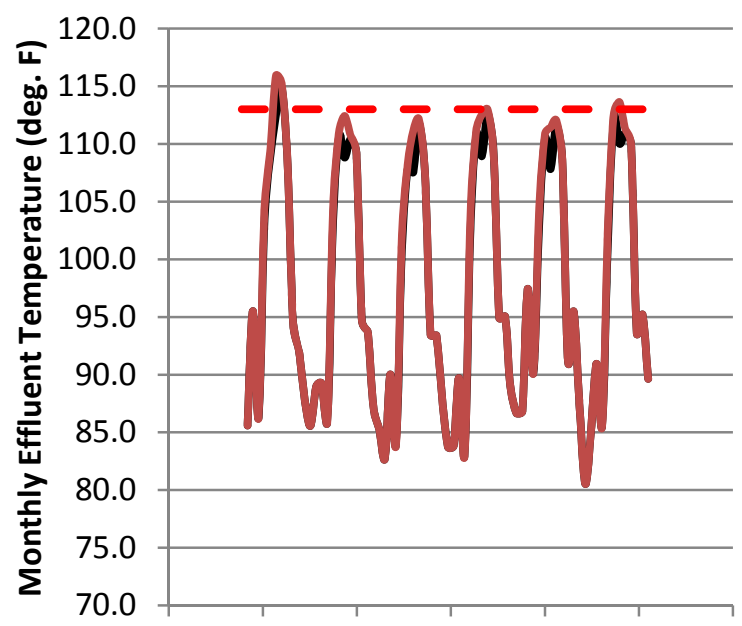

Dec-25Apr-27Sep-28Jan-30Jun-31Oct-32Feb-34 Time (Month- Year)

(d)

—-Predicted Avg. Effluent Temperature (deg. F)

—Predicted Avg. Effluent Temperature (deg, F), 100\% Capacity in Summer

- - Avg. Temp. Limit: EPA

Figure B14. For the Comanche Peak plant and four different simulated future climates - (a) PCM, (b) GFDL, (c) BCSDPCM, (d) BCSDGFDL - of the A2 emissions scenario, average effluent temperature assuming 2011 electric generation profiles, average effluent temperature assuming $100 \%$ summer capacity factor, and (if applicable) a horizontal dashed line indicating the average effluent temperature limit set by the EPA. 


\section{Corpus Christi}

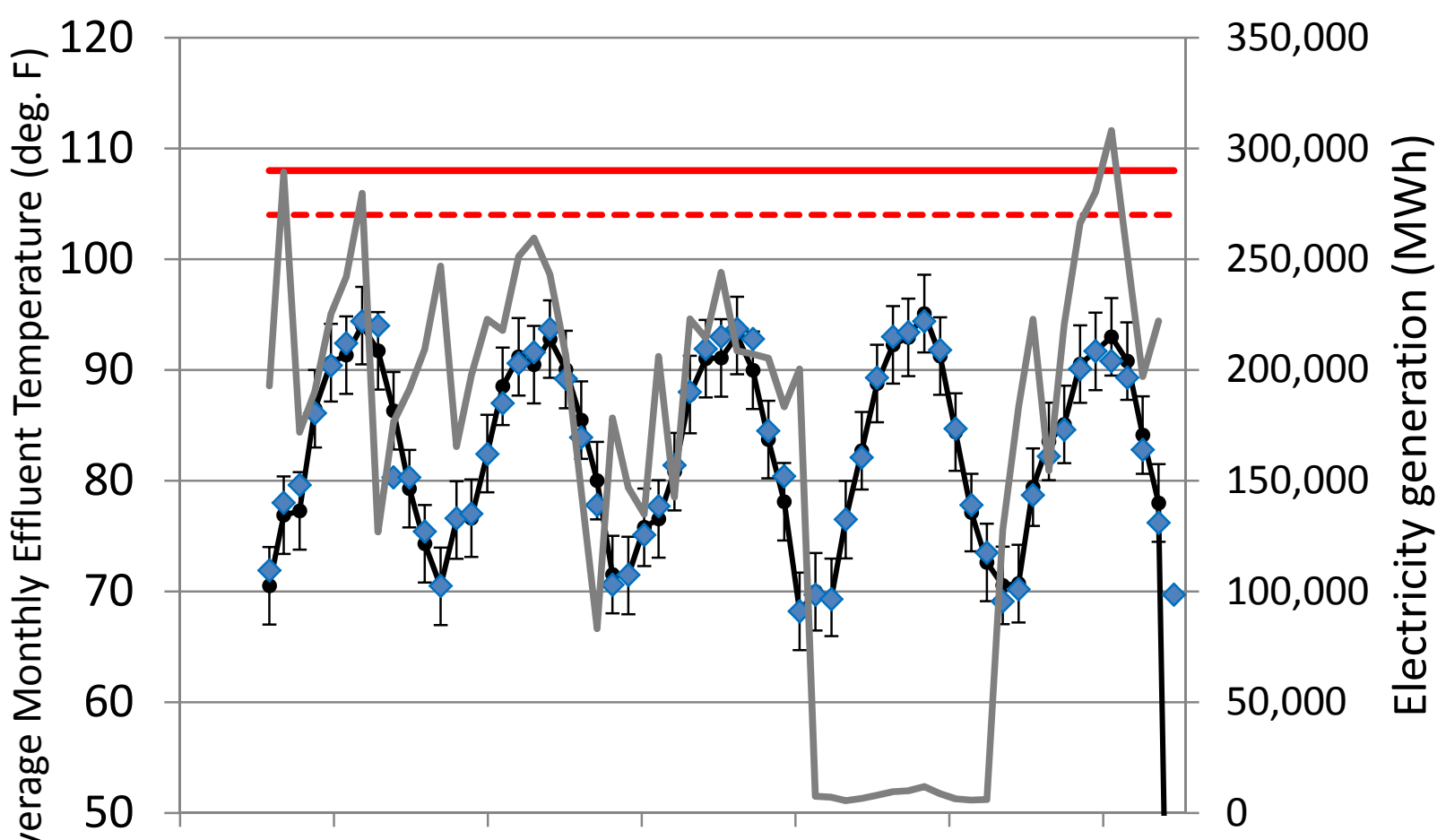

Aug-06 Jun-07 Apr-08 Jan-09 Nov-09 Sep-10 Jul-11

$\checkmark$ Avg. Effluent Temperature (deg. F): EPA

$\diamond$ Max. Effluent Temperature (deg. F): EPA

$\rightarrow$ Predicted Avg. Effluent Temperature (deg. F), +/- 2 SD error bars

----Avg. Temp. Limit

Max. Temp. Limit

Figure B15. Average effluent temperature, maximum effluent temperature, predicted average effluent temperature from regression test, average effluent temperature limit, maximum effluent temperature limit for the Corpus Christi plant. 


\section{Corpus Christi}

PCM A2

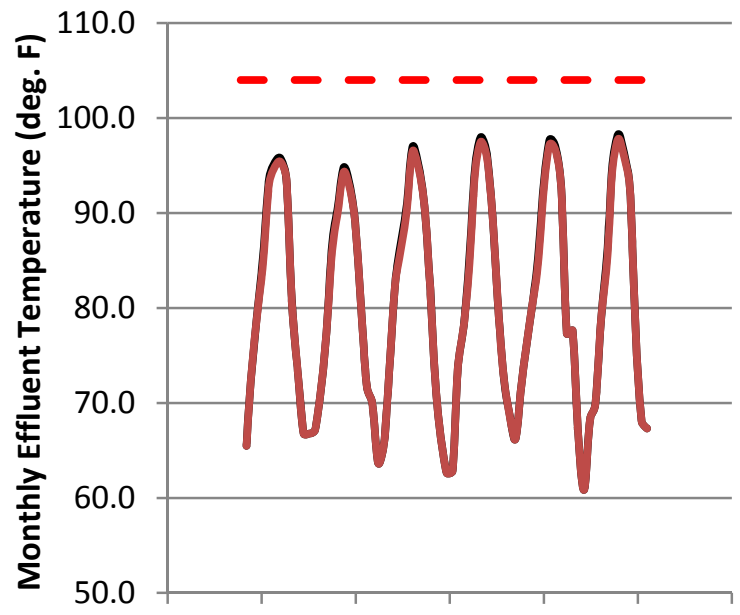

Dec-25Apr-27Sep-28Jan-30Jun-31Oct-32Feb-34

Time (Month-Year)

(a)

BCSDPCM A2

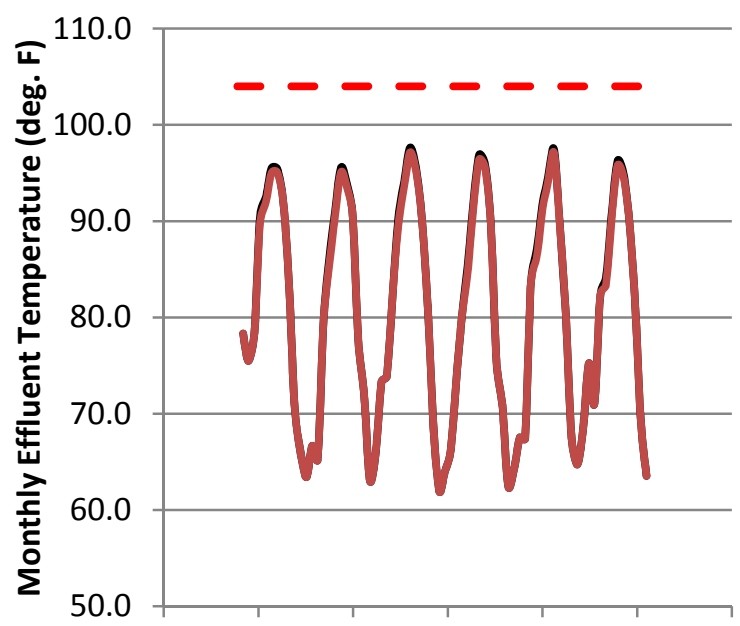

Dec-25Apr-27Sep-28Jan-30Jun-310ct-32Feb-34 Time (Month- Year)

(c)
GFDL A2

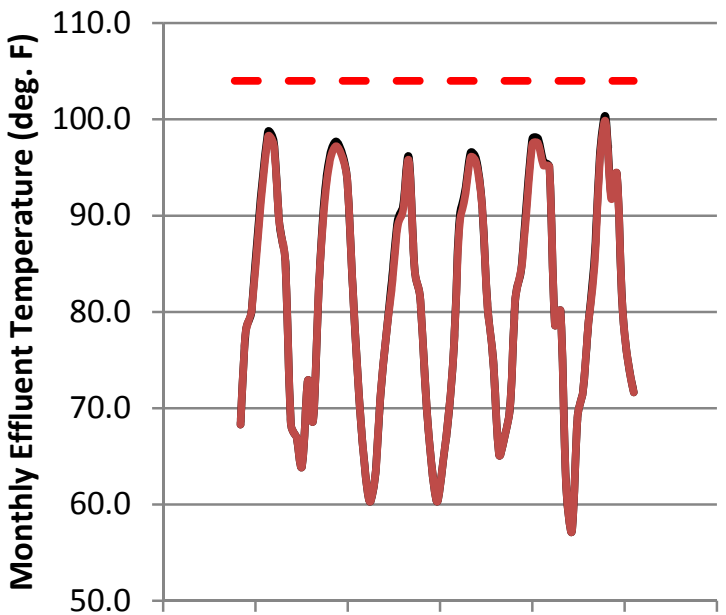

Dec-25Apr-27Sep-28Jan-30Jun-31Oct-32Feb-34 Time (Month- Year)

(b)

BCSDGFDL A2

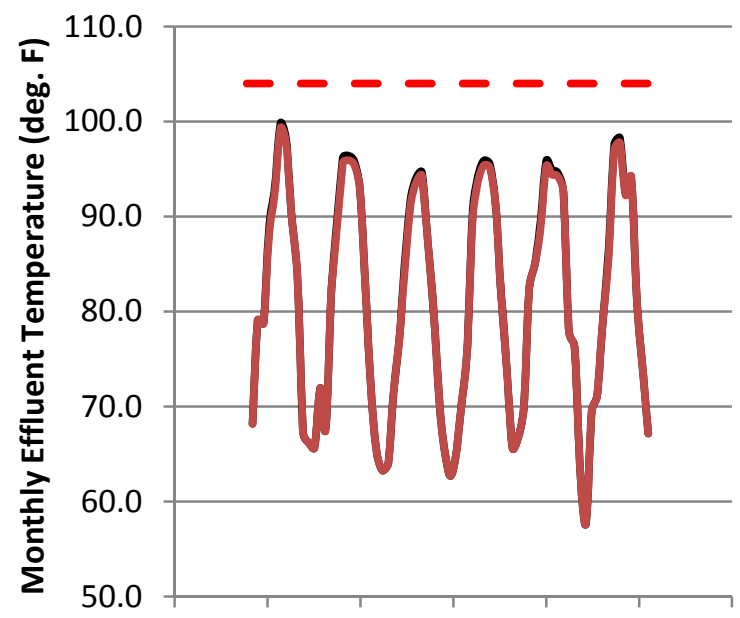

Dec-25Apr-27Sep-28Jan-30Jun-310ct-32Feb-34 Time (Month- Year)

(d)

—Predicted Avg. Effluent Temperature (deg. F)

—Predicted Avg. Effluent Temperature (deg, F), 100\% Capacity in Summer

- - Avg. Temp. Limit: EPA

Figure B16. For the Corpus Christi plant and four different simulated future climates - (a) PCM, (b) GFDL, (c) BCSDPCM, (d) BCSDGFDL - of the A2 emissions scenario, average effluent temperature assuming 2011 electric generation profiles, average effluent temperature assuming $100 \%$ summer capacity factor, and (if applicable) a horizontal dashed line indicating the average effluent temperature limit set by the EPA. 


\section{Decker Creek}

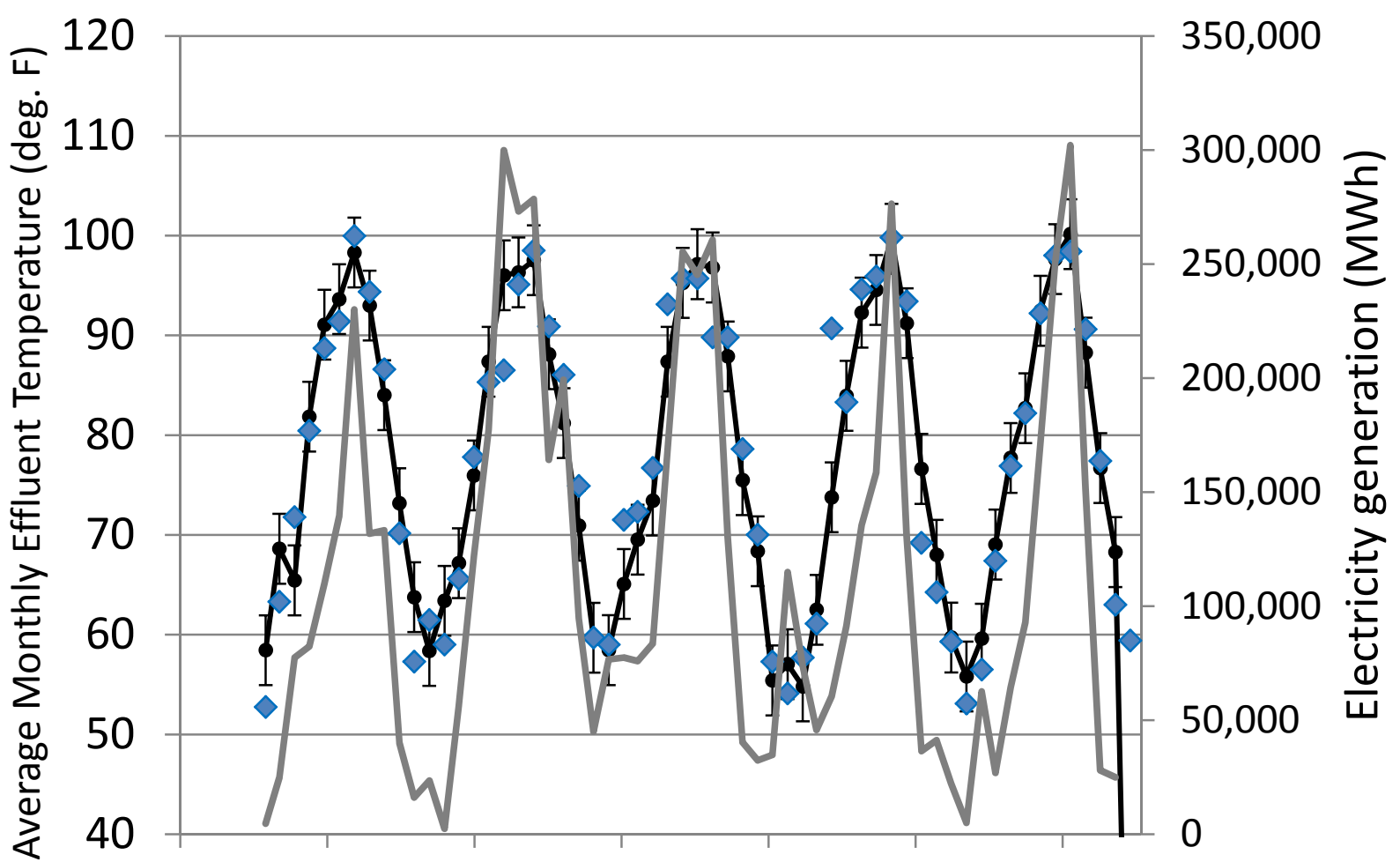

Aug-06 Jun-07 Apr-08 Jan-09 Nov-09 Sep-10 Jul-11

$\diamond$ Avg. Effluent Temperature (deg. F): EPA

$\diamond$ Max. Effluent Temperature (deg. F): EPA

$\rightarrow$ Predicted Avg. Effluent Temperature (deg. F), +/- 2 SD error bars

----Avg. Temp. Limit

Max. Temp. Limit

Figure B17. Average effluent temperature, maximum effluent temperature, predicted average effluent temperature from regression test, average effluent temperature limit, maximum effluent temperature limit for the Decker Creek plant. 


\section{Decker Creek}

PCM A2

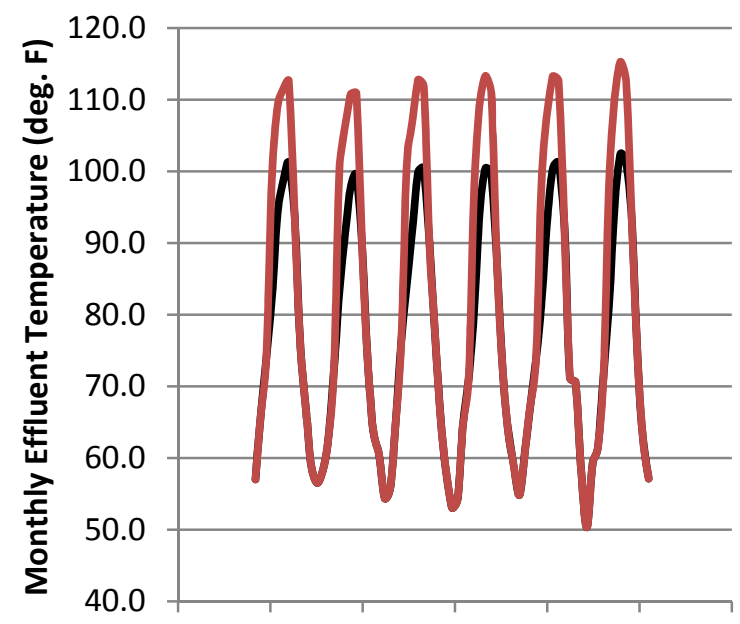

Dec-25Apr-27Sep-28Jan-30Jun-310ct-32Feb-34 Time (Month-Year)

(a)

\section{BCSDPCM A2}

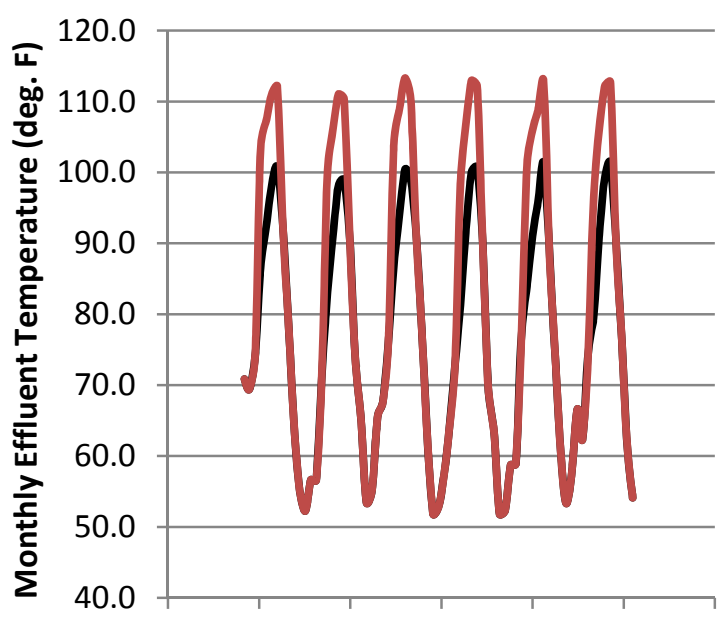

Dec-25Apr-27Sep-28Jan-30Jun-310ct-32Feb-34 Time (Month- Year)

(c)
GFDL A2

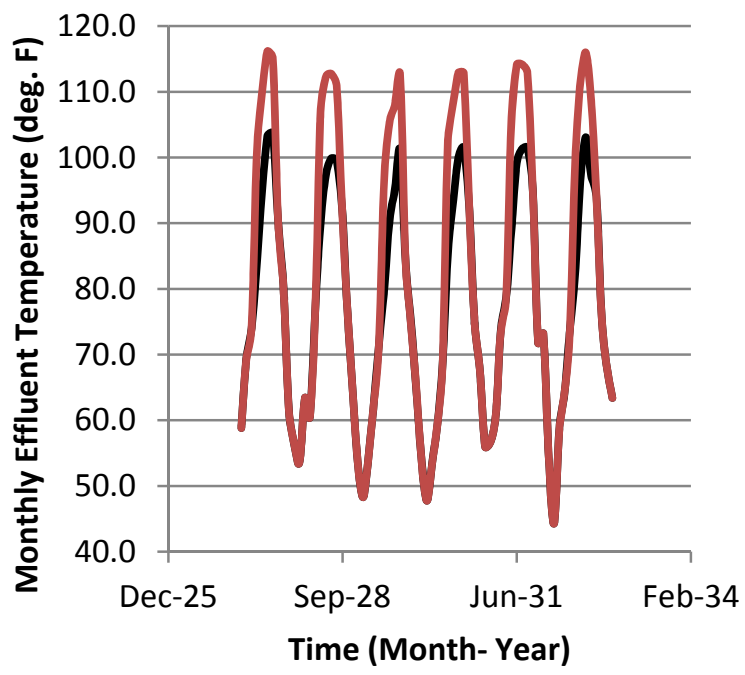

(b)

\section{BCSDGFDL A2}

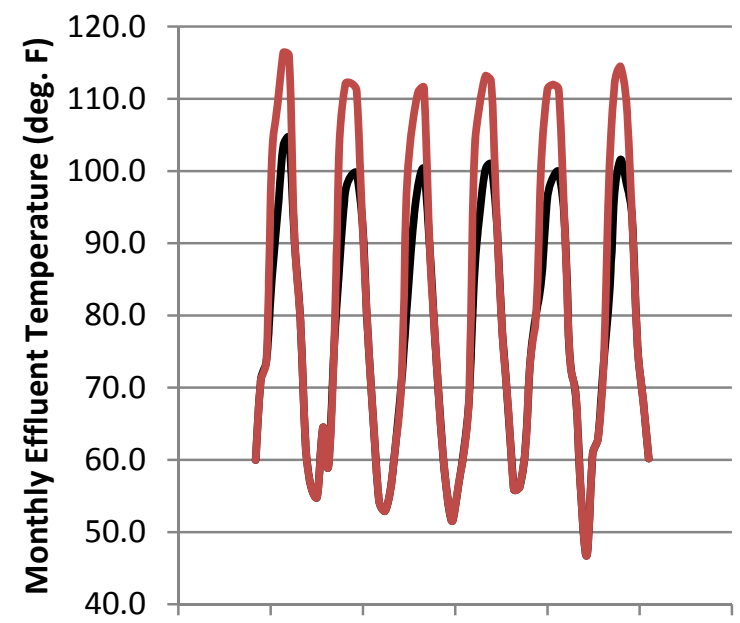

Dec-25Apr-27Sep-28Jan-30Jun-310ct-32Feb-34 Time (Month- Year)

(d)

—Predicted Avg. Effluent Temperature (deg. F)

Predicted Avg. Effluent Temperature (deg, F), 100\% Capacity in Summer

- - Avg. Temp. Limit: EPA

Figure B18. For the Decker Creek plant and four different simulated future climates - (a) PCM, (b) GFDL, (c) BCSDPCM, (d) BCSDGFDL - of the A2 emissions scenario, average effluent temperature assuming 2011 electric generation profiles, average effluent temperature assuming $100 \%$ summer capacity factor, and (if applicable) a horizontal dashed line indicating the average effluent temperature limit set by the EPA. 


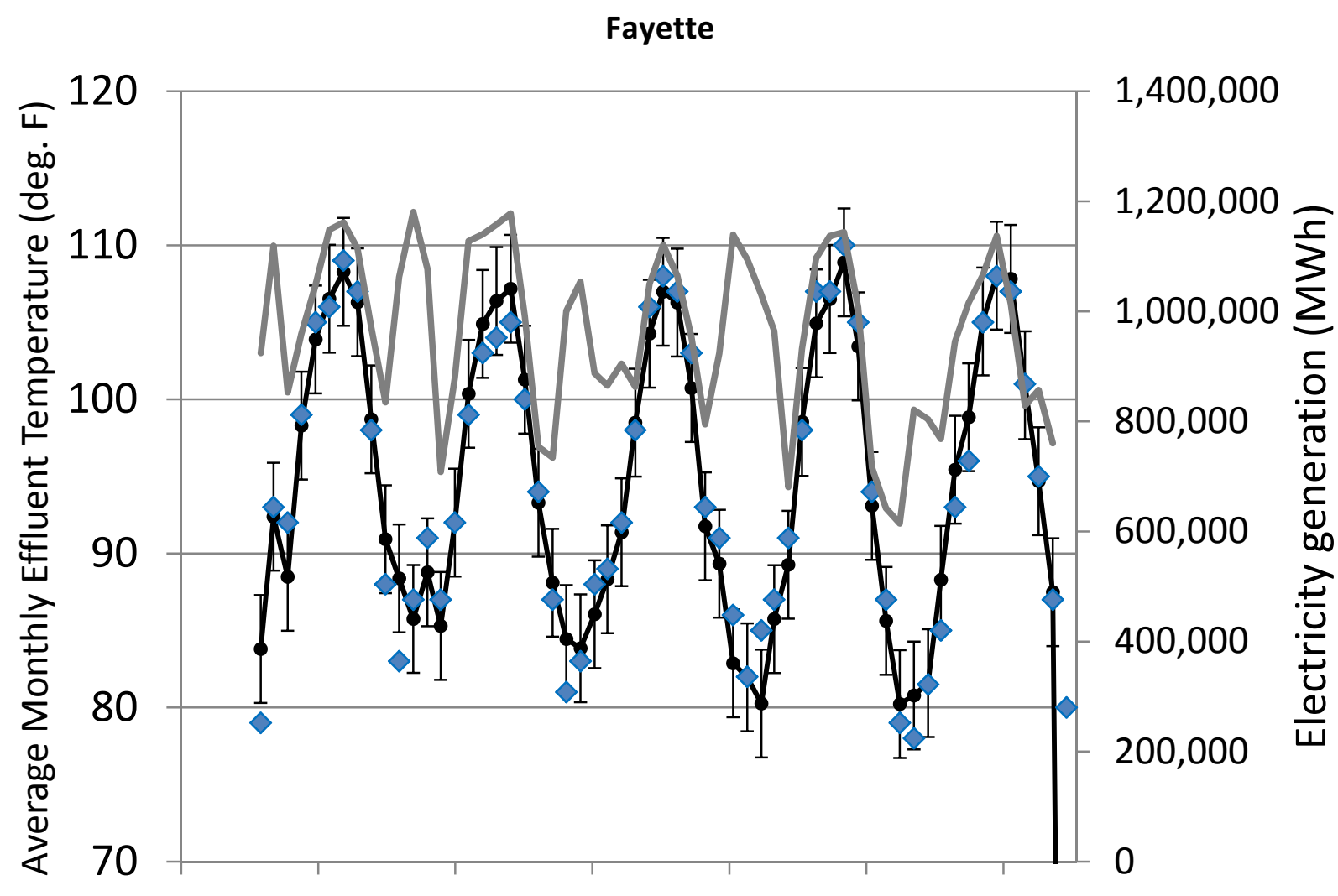

Aug-06 Jun-07 Apr-08 Jan-09 Nov-09 Sep-10 Jul-11

$\checkmark$ Avg. Effluent Temperature (deg. F): EPA

$\diamond$ Max. Effluent Temperature (deg. F): EPA

$\rightarrow$ Predicted Avg. Effluent Temperature (deg. F), +/- 2 SD error bars

-.-Avg. Temp. Limit

Max. Temp. Limit

Figure B19. Average effluent temperature, maximum effluent temperature, predicted average effluent temperature from regression test, average effluent temperature limit, maximum effluent temperature limit for the Fayette plant. 


\section{Fayette}

PCM A2

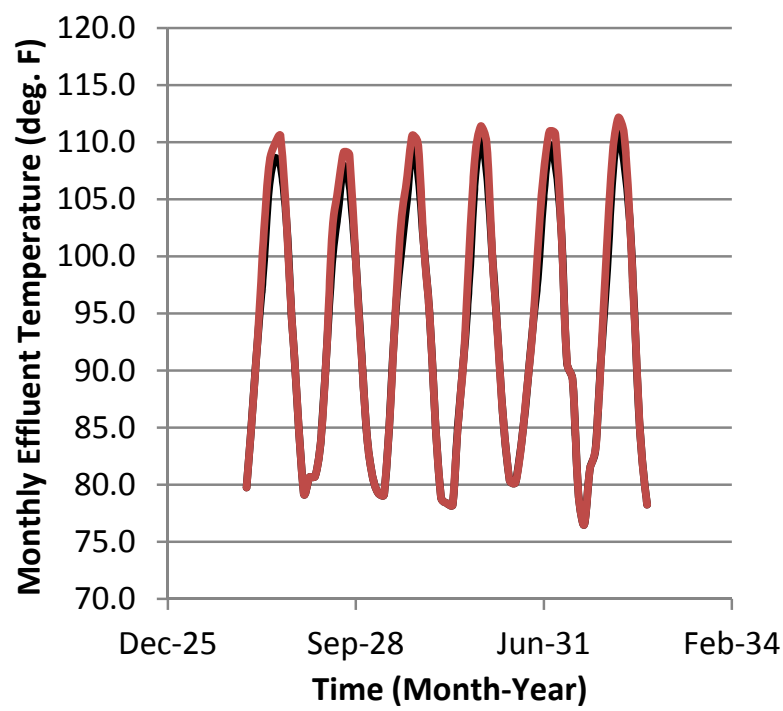

(a)

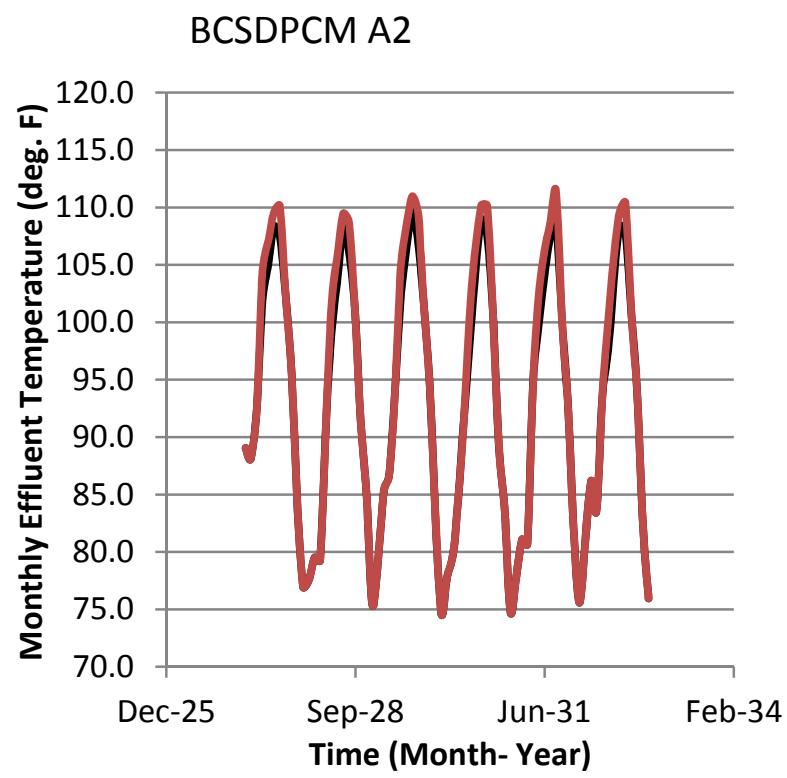

(c)
GFDL A2

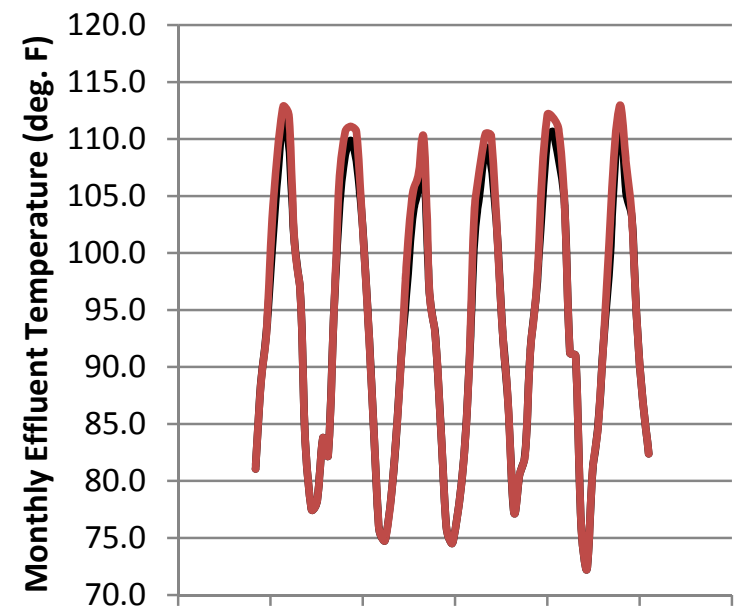

Dec-25Apr-27Sep-28Jan-30Jun-310ct-32Feb-34

Time (Month- Year)

(b)

\section{BCSDGFDL A2}

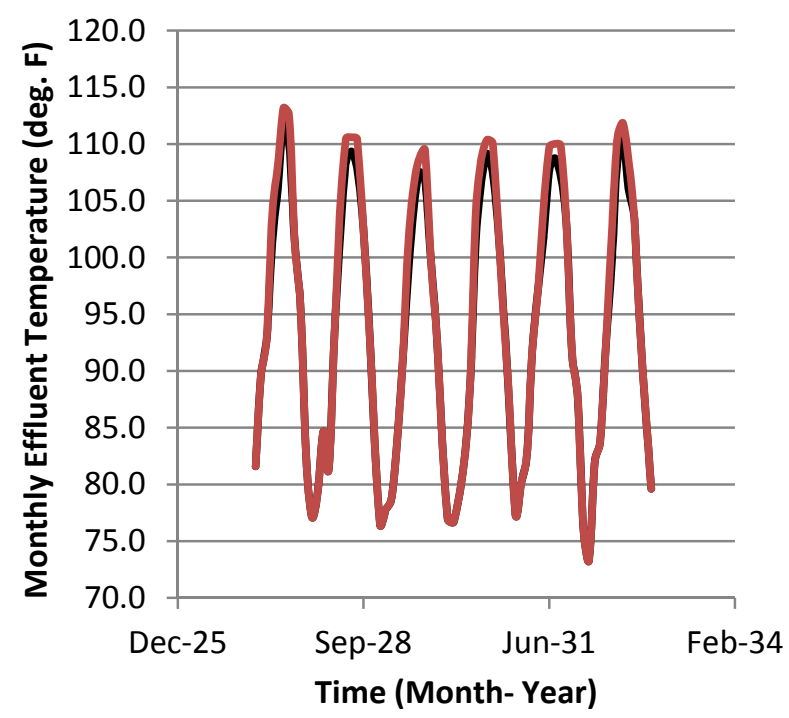

(d)

— Predicted Avg. Effluent Temperature (deg. F)

—Predicted Avg. Effluent Temperature (deg, F), 100\% Capacity in Summer

- - Avg. Temp. Limit: EPA

Figure B20. For the Fayette plant and four different simulated future climates - (a) PCM, (b) GFDL, (c) BCSDPCM, (d) BCSDGFDL - of the A2 emissions scenario, average effluent temperature assuming 2011 electric generation profiles, average effluent temperature assuming 100\% summer capacity factor, and (if applicable) a horizontal dashed line indicating the average effluent temperature limit set by the EPA. 


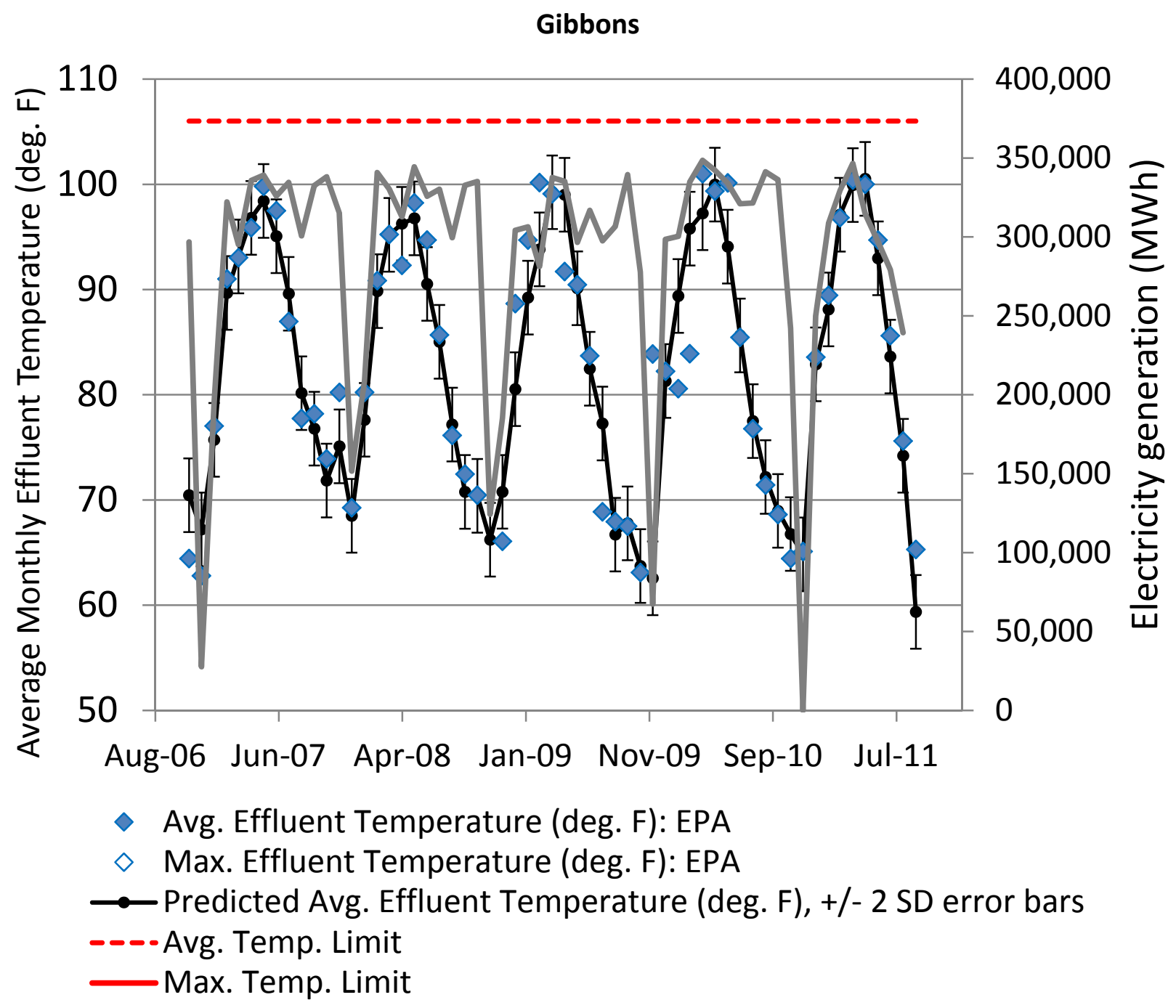

Figure B21. Average effluent temperature, maximum effluent temperature, predicted average effluent temperature from regression test, average effluent temperature limit, maximum effluent temperature limit for the Gibbons plant. 


\section{Gibbons}

PCM A2

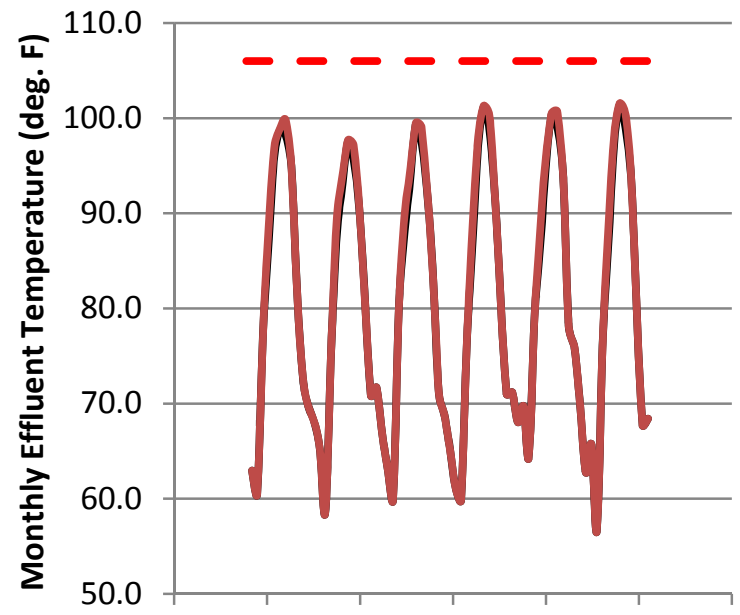

Dec-25Apr-27Sep-28Jan-30Jun-310ct-32Feb-34

Time (Month-Year)

(a)

BCSDPCM A2

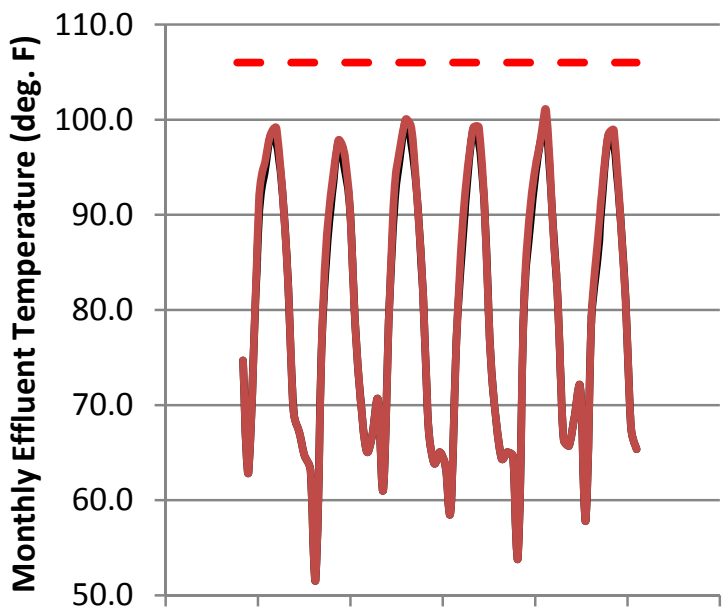

Dec-25Apr-27Sep-28Jan-30Jun-310ct-32Feb-34

Time (Month- Year)

(c)
GFDL A2

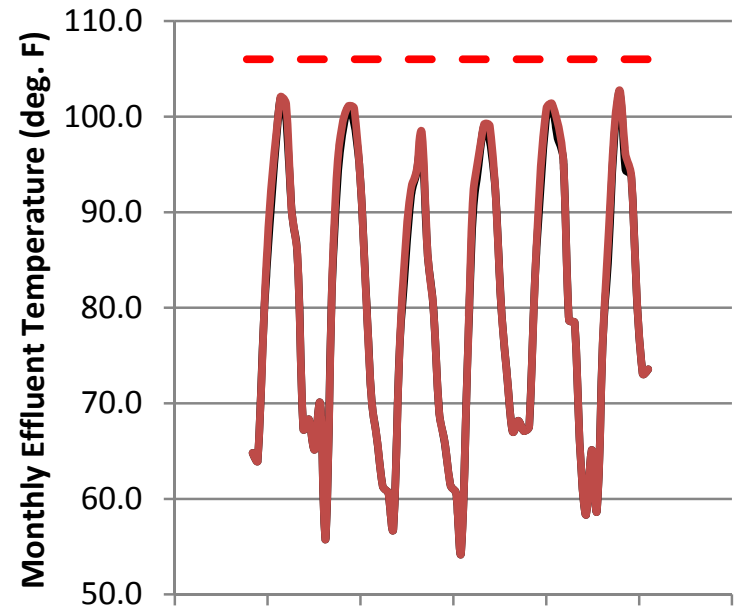

Dec-25Apr-27Sep-28Jan-30Jun-310ct-32Feb-34 Time (Month- Year)

(b)

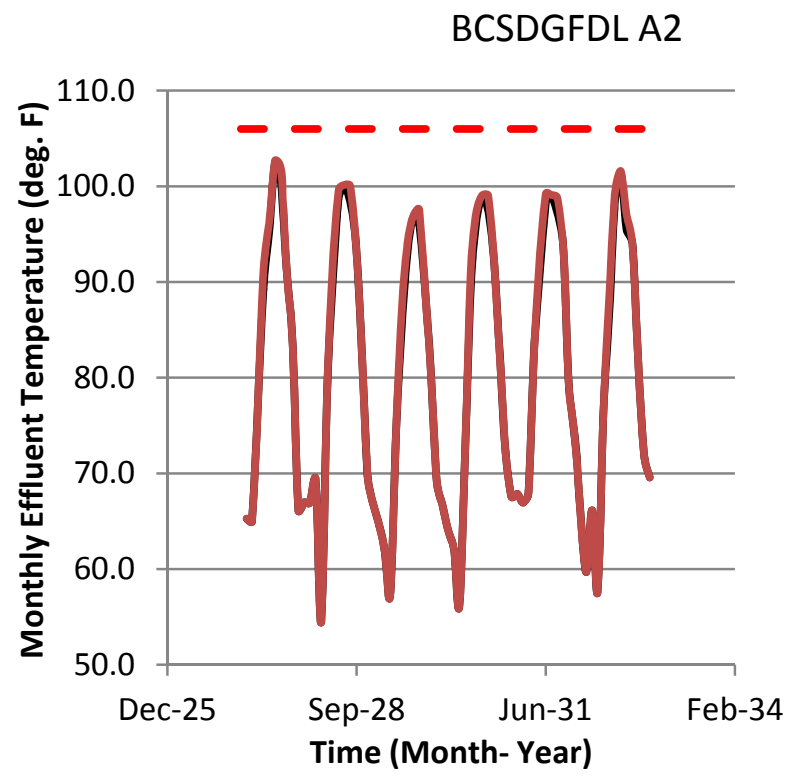

(d)

—Predicted Avg. Effluent Temperature (deg. F)

Predicted Avg. Effluent Temperature (deg, F), 100\% Capacity in Summer

- - Avg. Temp. Limit: EPA

Figure B22. For the Gibbons plant and four different simulated future climates - (a) PCM, (b) GFDL, (c) BCSDPCM, (d) BCSDGFDL - of the A2 emissions scenario, average effluent temperature assuming 2011 electric generation profiles, average effluent temperature assuming $100 \%$ summer capacity factor, and (if applicable) a horizontal dashed line indicating the average effluent temperature limit set by the EPA. 


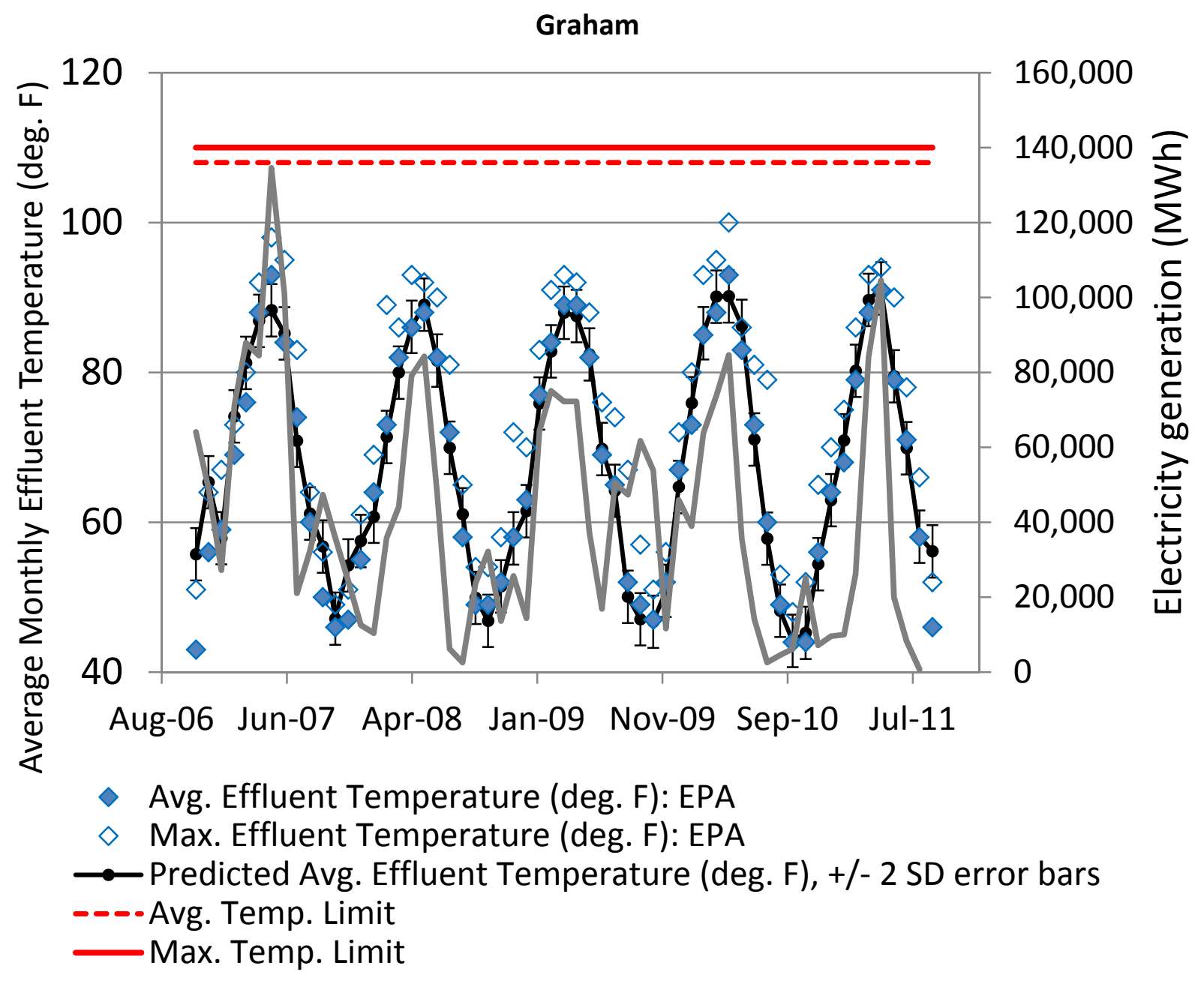

Figure B23. Average effluent temperature, maximum effluent temperature, predicted average effluent temperature from regression test, average effluent temperature limit, maximum effluent temperature limit for the Graham plant. 


\section{Graham}

PCM A2

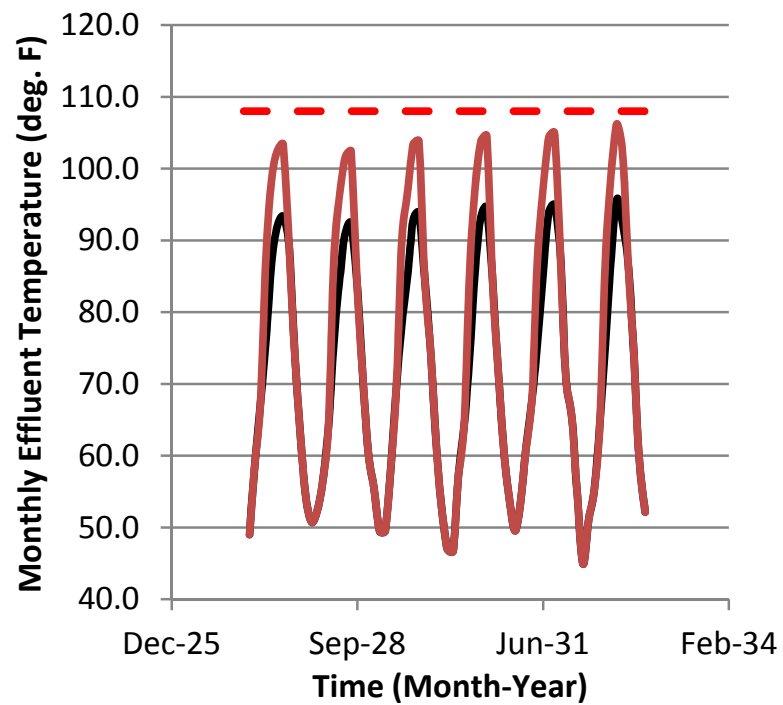

(a)

BCSDPCM A2

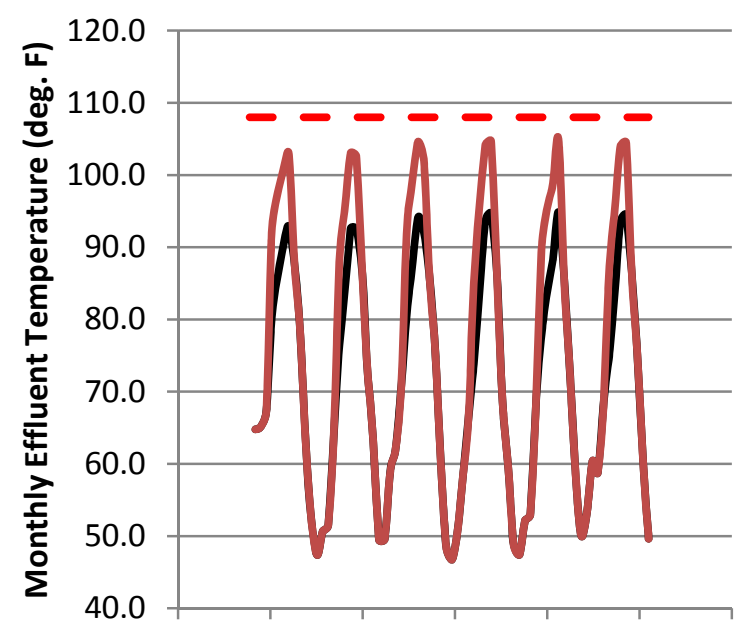

Dec-25Apr-27Sep-28Jan-30Jun-310ct-32Feb-34 Time (Month- Year)

(c)
GFDL A2

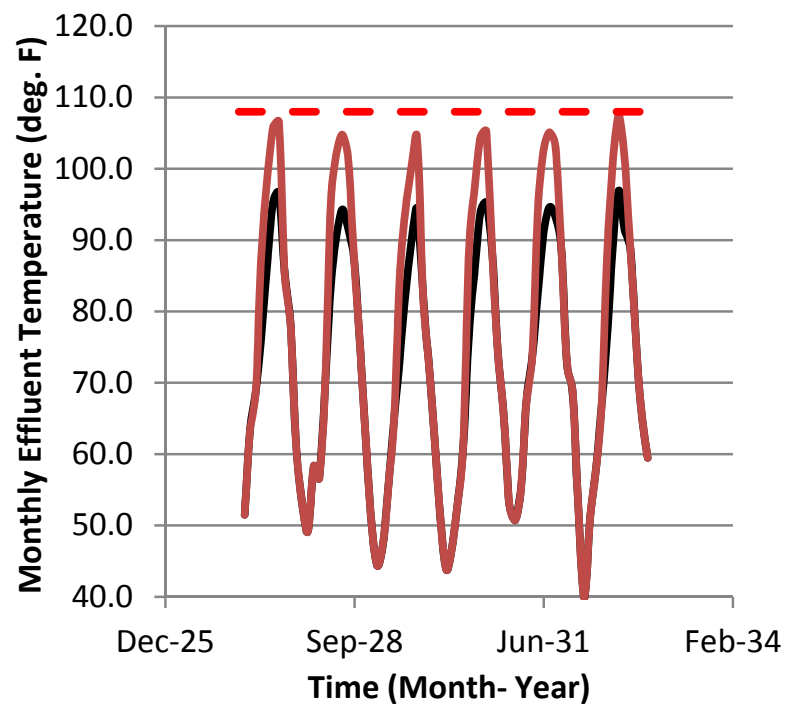

(b)

BCSDGFDL A2

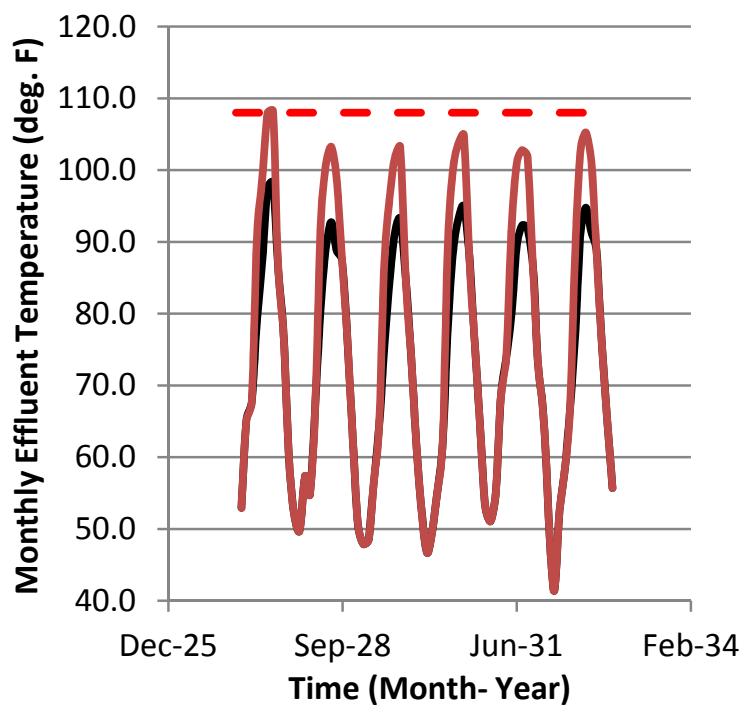

(d)

—Predicted Avg. Effluent Temperature (deg. F)

—Predicted Avg. Effluent Temperature (deg, F), 100\% Capacity in Summer

- - Avg. Temp. Limit: EPA

Figure B24. For the Graham plant and four different simulated future climates - (a) PCM, (b) GFDL, (c) BCSDPCM, (d) BCSDGFDL - of the A2 emissions scenario, average effluent temperature assuming 2011 electric generation profiles, average effluent temperature assuming $100 \%$ summer capacity factor, and (if applicable) a horizontal dashed line indicating the average effluent temperature limit set by the EPA. 


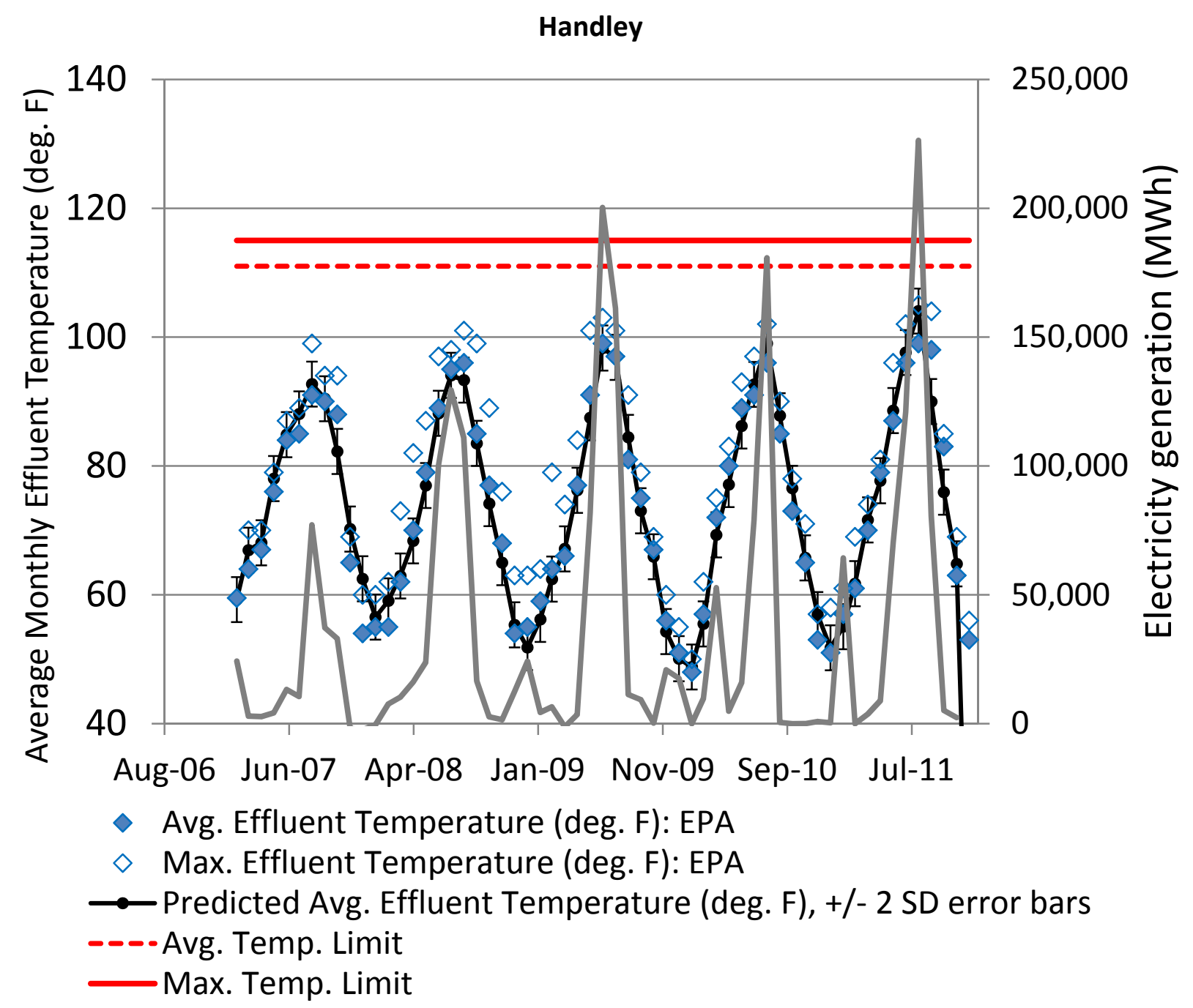

Figure B25. Average effluent temperature, maximum effluent temperature, predicted average effluent temperature from regression test, average effluent temperature limit, maximum effluent temperature limit for the Handley plant. 
Handley

PCM A2

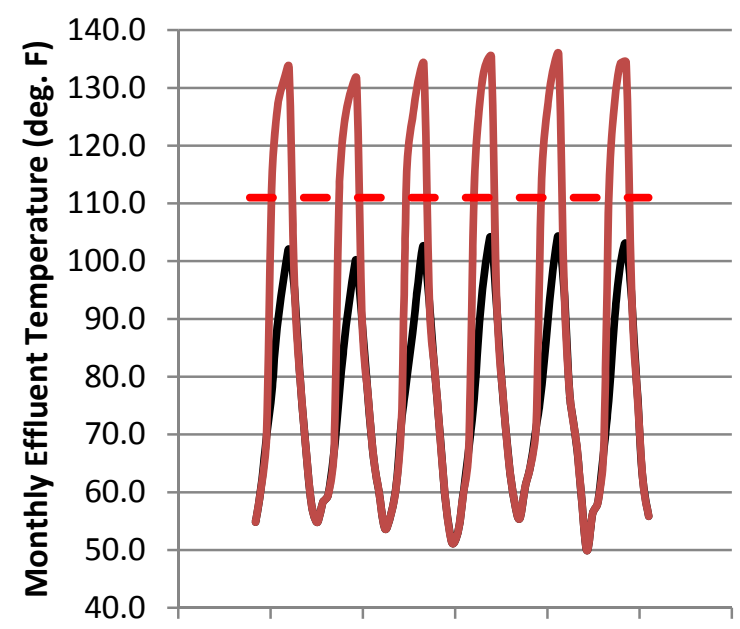

Dec-25Apr-27Sep-28Jan-30Jun-31Oct-32Feb-34 Time (Month-Year)

(a)

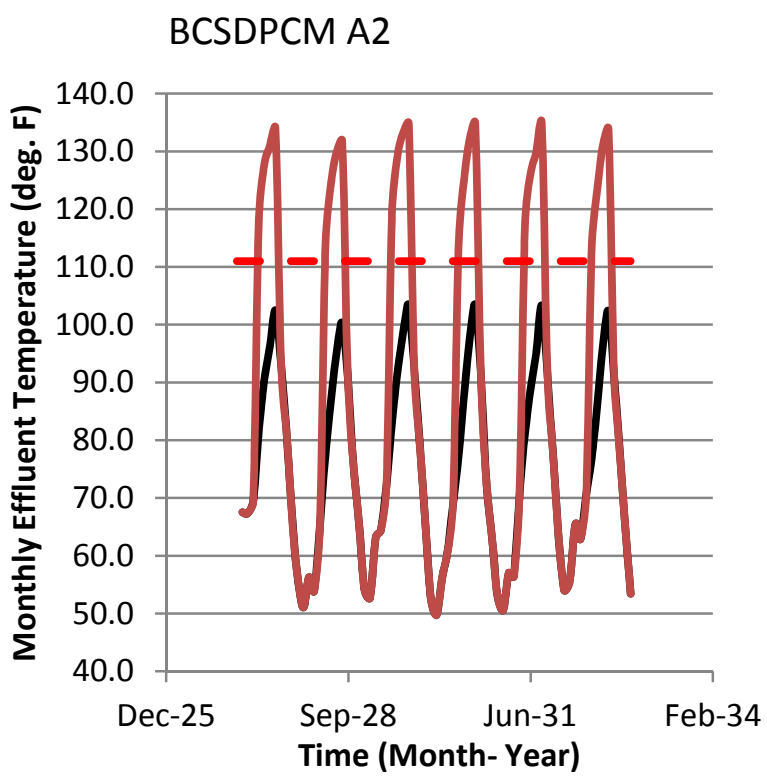

(c)
GFDL A2

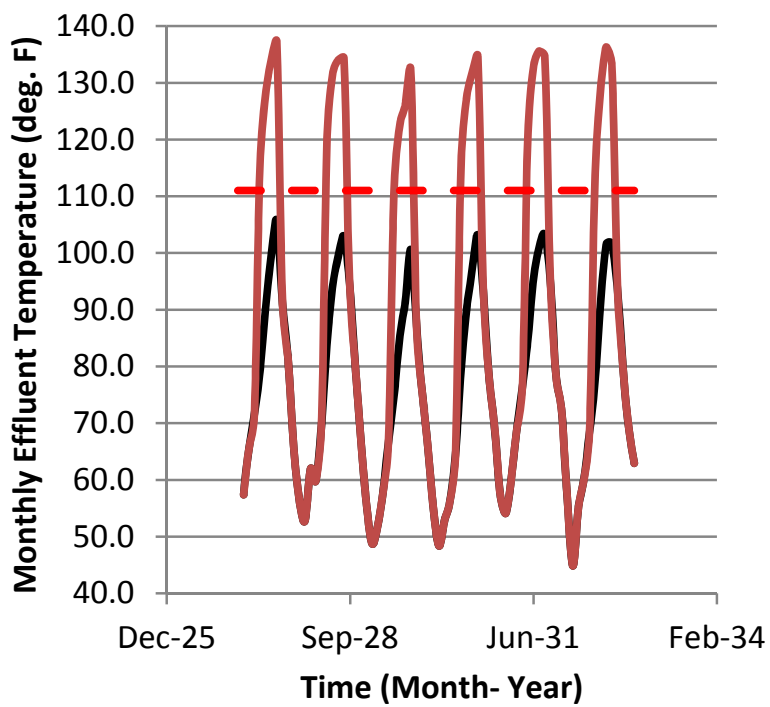

(b)

\section{BCSDGFDL A2}

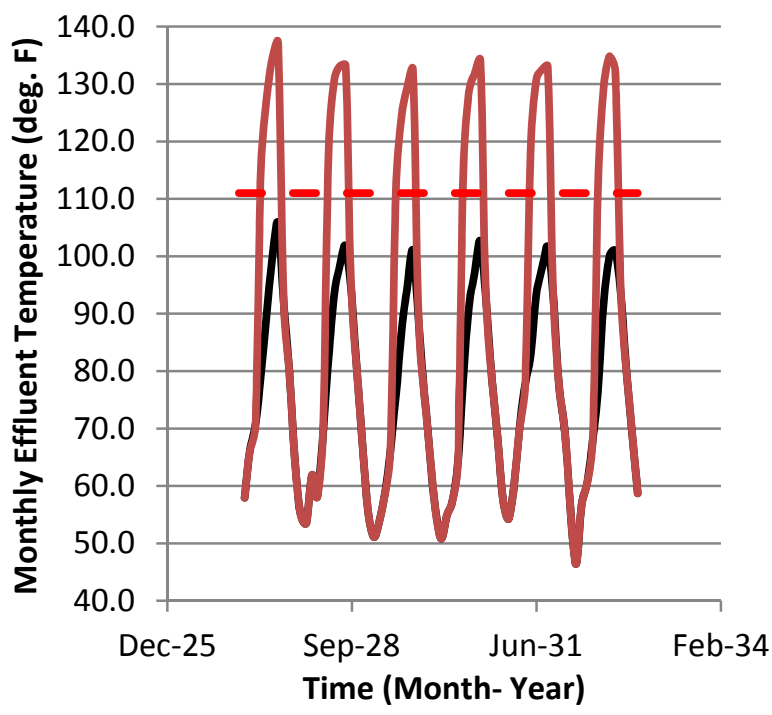

(d)

— Predicted Avg. Effluent Temperature (deg. F)

—Predicted Avg. Effluent Temperature (deg, F), 100\% Capacity in Summer

- - Avg. Temp. Limit: EPA

Figure B26. For the Handley plant and four different simulated future climates - (a) PCM, (b) GFDL, (c) BCSDPCM, (d) BCSDGFDL - of the A2 emissions scenario, average effluent temperature assuming 2011 electric generation profiles, average effluent temperature assuming $100 \%$ summer capacity factor, and (if applicable) a horizontal dashed line indicating the average effluent temperature limit set by the EPA. 


\section{JT Deely}

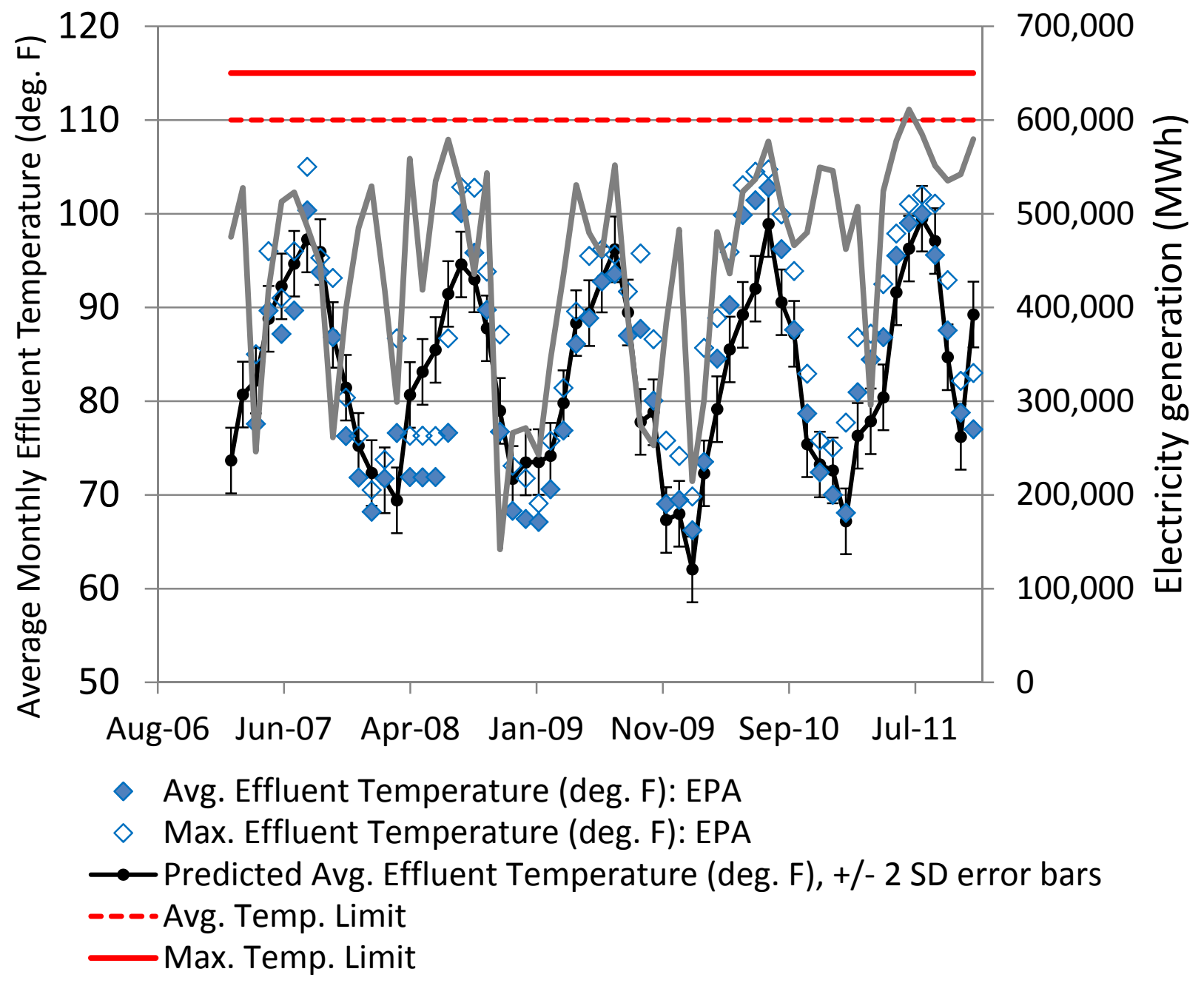

Figure B27. Average effluent temperature, maximum effluent temperature, predicted average effluent temperature from regression test, average effluent temperature limit, maximum effluent temperature limit for the JT Deely plant. 


\section{JT Deely}

PCM A2

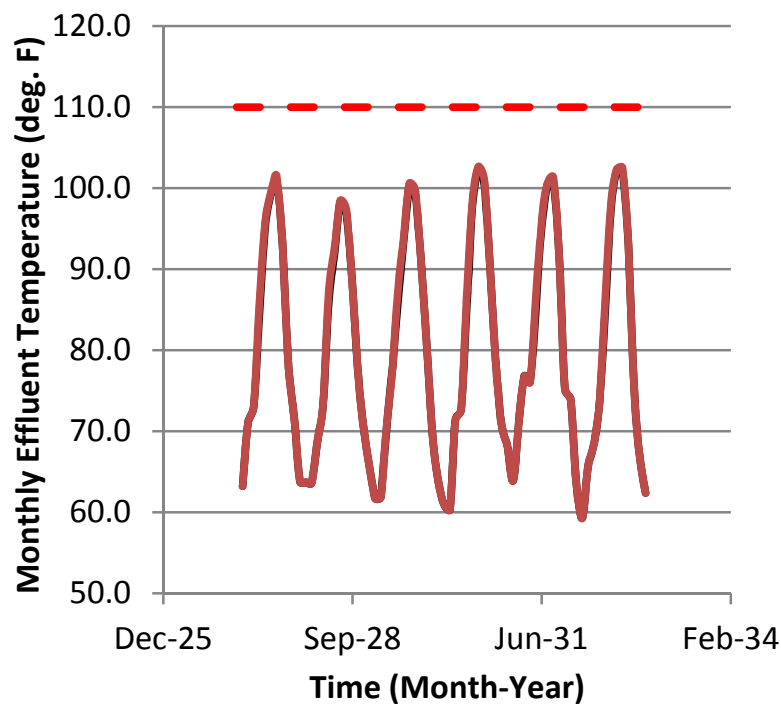

(a)

\section{BCSDPCM A2}

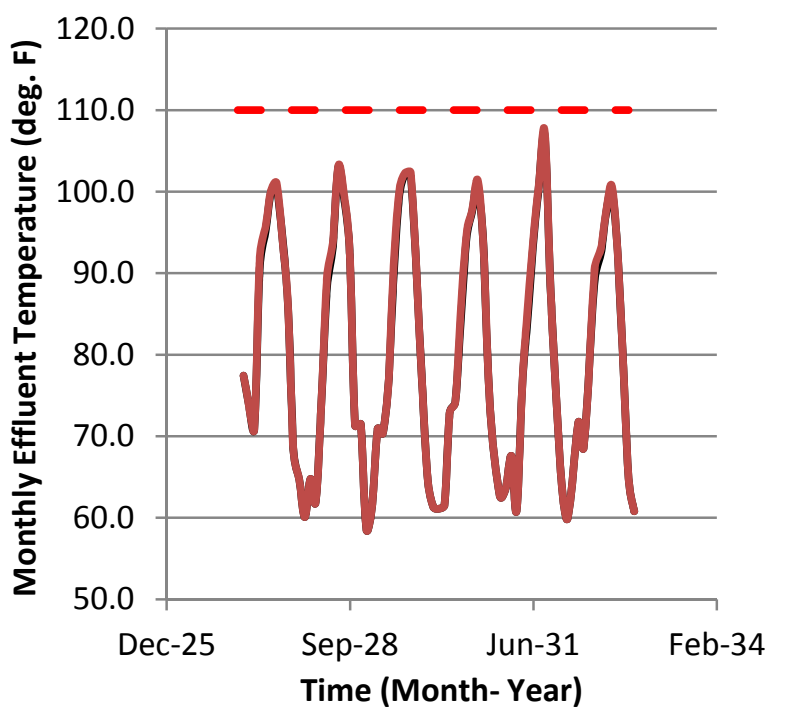

(c)
GFDL A2

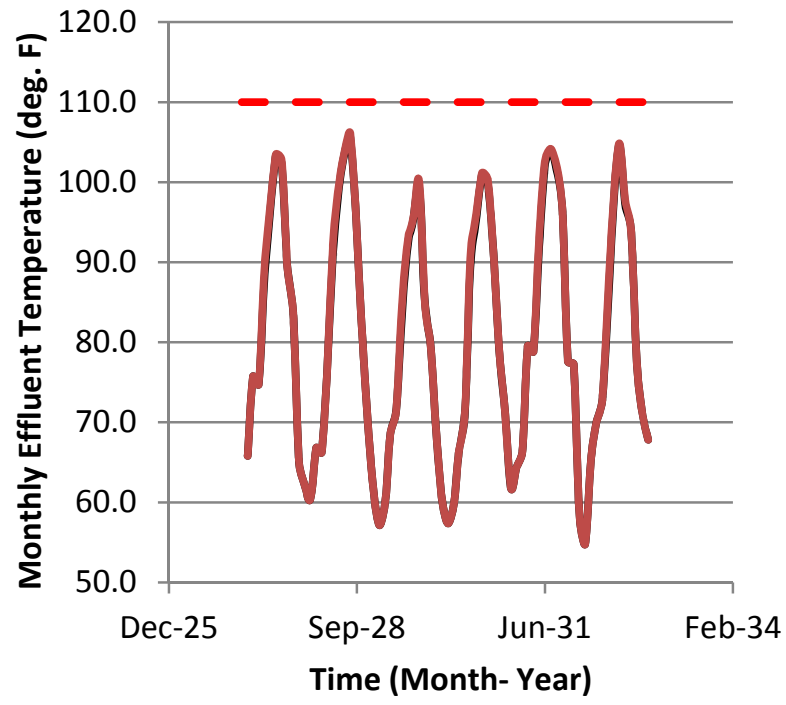

(b)

BCSDGFDL A2

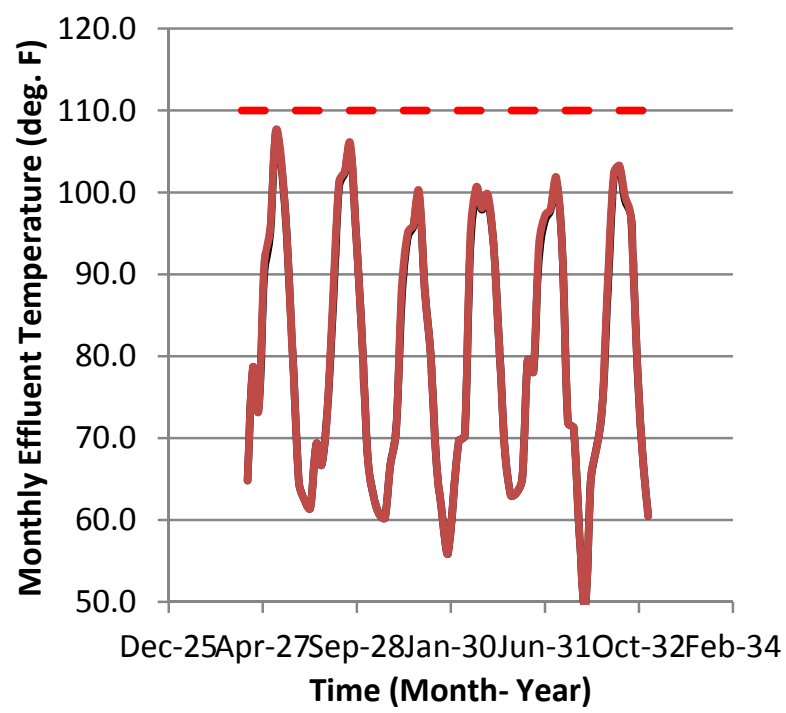

(d)

—Predicted Avg. Effluent Temperature (deg. F)

Predicted Avg. Effluent Temperature (deg, F), 100\% Capacity in Summer

- Avg. Temp. Limit: EPA

Figure B28. For the JT Deely plant and four different simulated future climates - (a) PCM, (b) GFDL, (c) BCSDPCM, (d) BCSDGFDL - of the A2 emissions scenario, average effluent temperature assuming 2011 electric generation profiles, average effluent temperature assuming $100 \%$ summer capacity factor, and (if applicable) a horizontal dashed line indicating the average effluent temperature limit set by the EPA. 


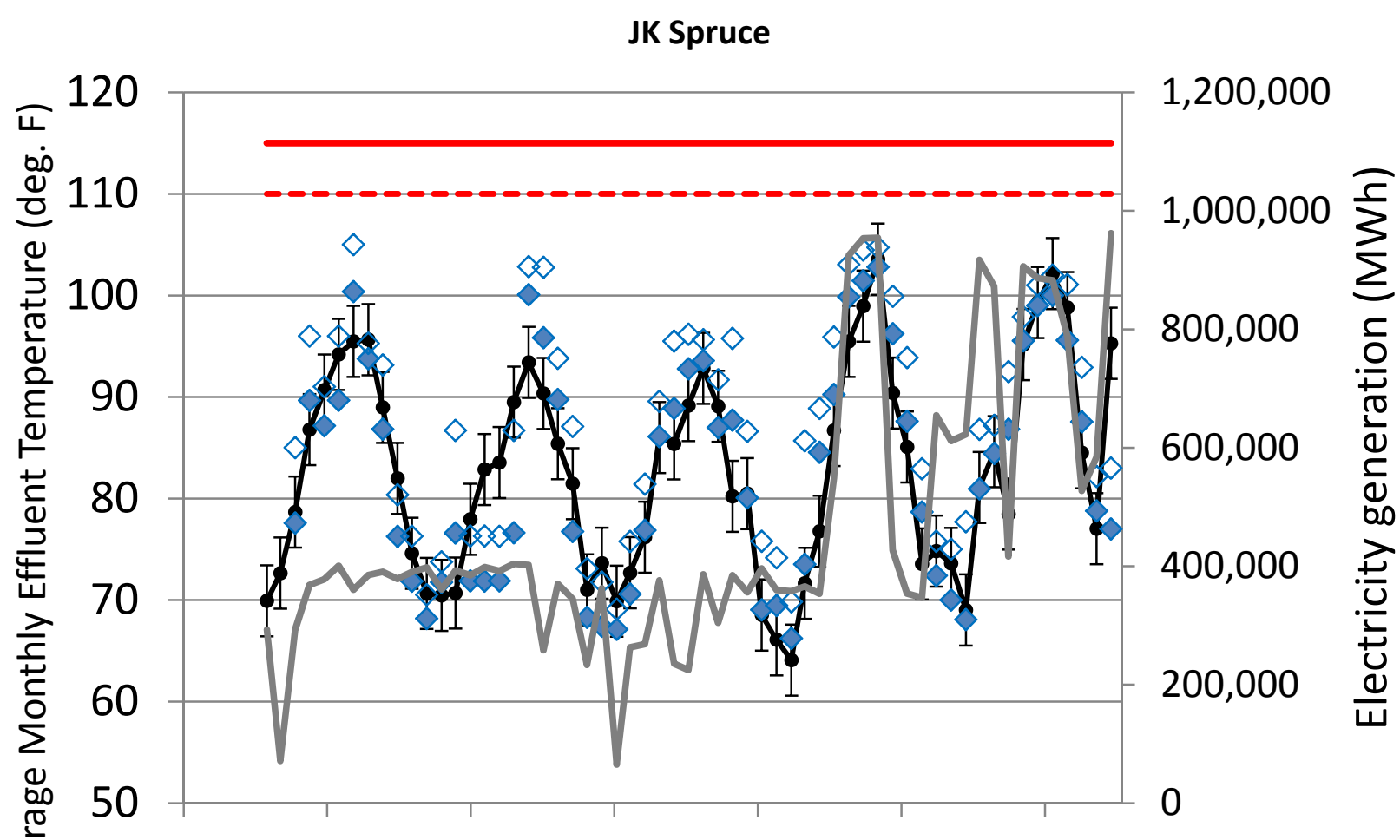

Aug-06 Jun-07 Apr-08 Jan-09 Nov-09 Sep-10 Jul-11

$\diamond$ Avg. Effluent Temperature (deg. F): EPA

$\diamond$ Max. Effluent Temperature (deg. F): EPA

$\longrightarrow$ Predicted Avg. Effluent Temperature (deg. F), +/- 2 SD error bars

---Avg. Temp. Limit

Max. Temp. Limit

Figure B29. Average effluent temperature, maximum effluent temperature, predicted average effluent temperature from regression test, average effluent temperature limit, maximum effluent temperature limit for the JK Spruce plant. 


\section{JK Spruce}

PCM A2

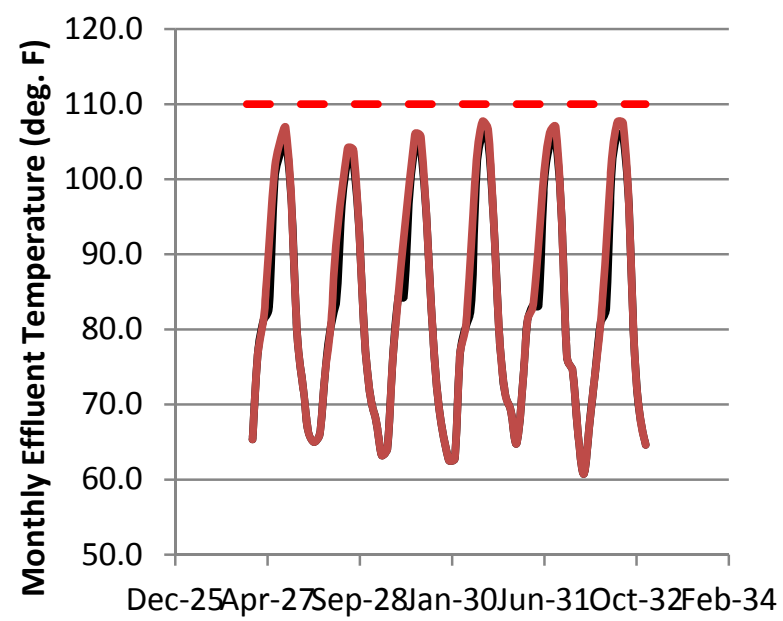

Time (Month-Year)

(a)

BCSDPCM A2

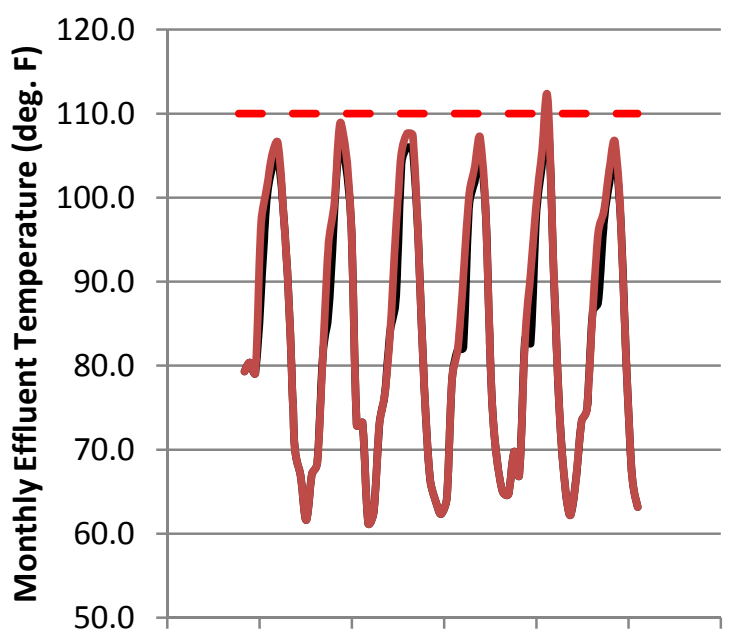

Dec-25Apr-27Sep-28Jan-30Jun-31Oct-32Feb-34 Time (Month- Year)

(c)
GFDL A2

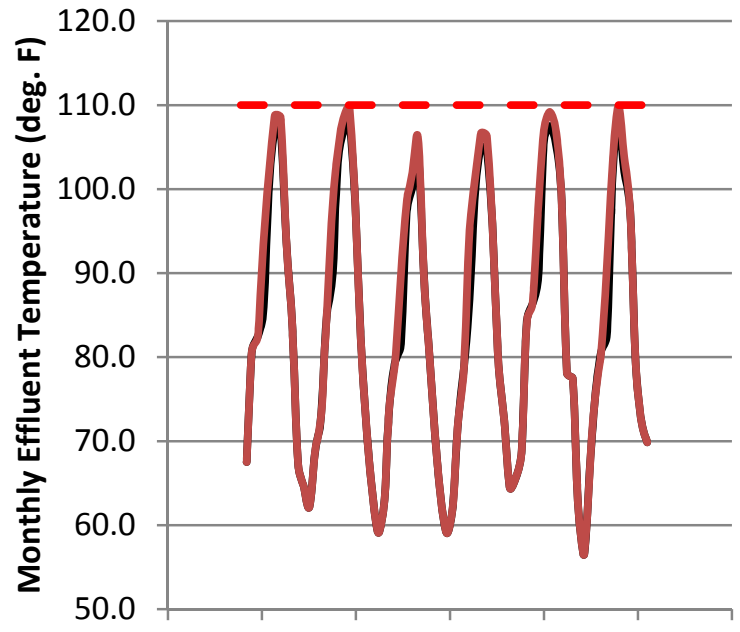

Dec-25Apr-27Sep-28Jan-30Jun-31Oct-32Feb-34 Time (Month- Year)

(b)

BCSDGFDL A2

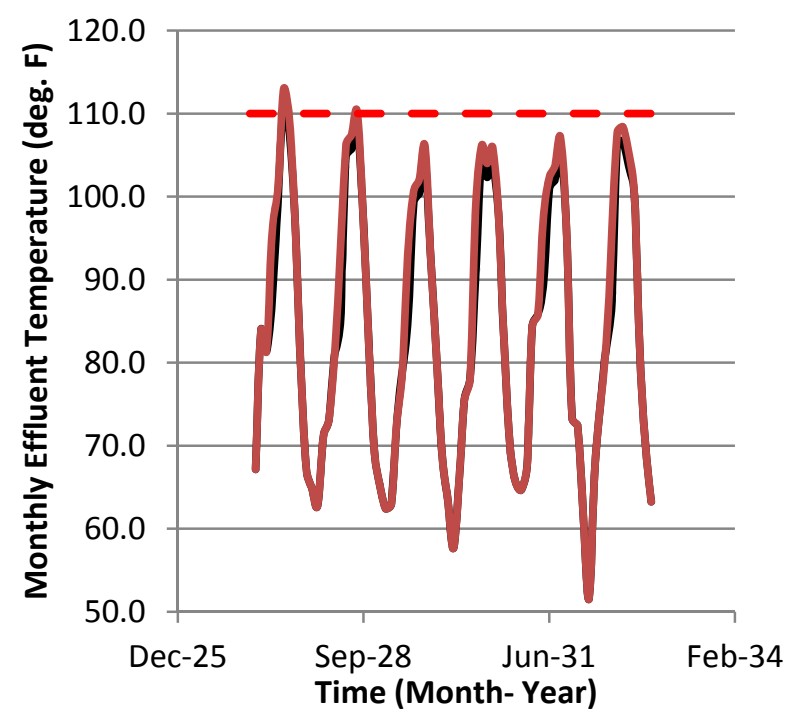

(d)

—Predicted Avg. Effluent Temperature (deg. F)

Predicted Avg. Effluent Temperature (deg, F), 100\% Capacity in Summer

- - Avg. Temp. Limit: EPA

Figure B30. For the JK Spruce plant and four different simulated future climates - (a) PCM, (b) GFDL, (c) BCSDPCM, (d) BCSDGFDL - of the A2 emissions scenario, average effluent temperature assuming 2011 electric generation profiles, average effluent temperature assuming $100 \%$ summer capacity factor, and (if applicable) a horizontal dashed line indicating the average effluent temperature limit set by the EPA. 


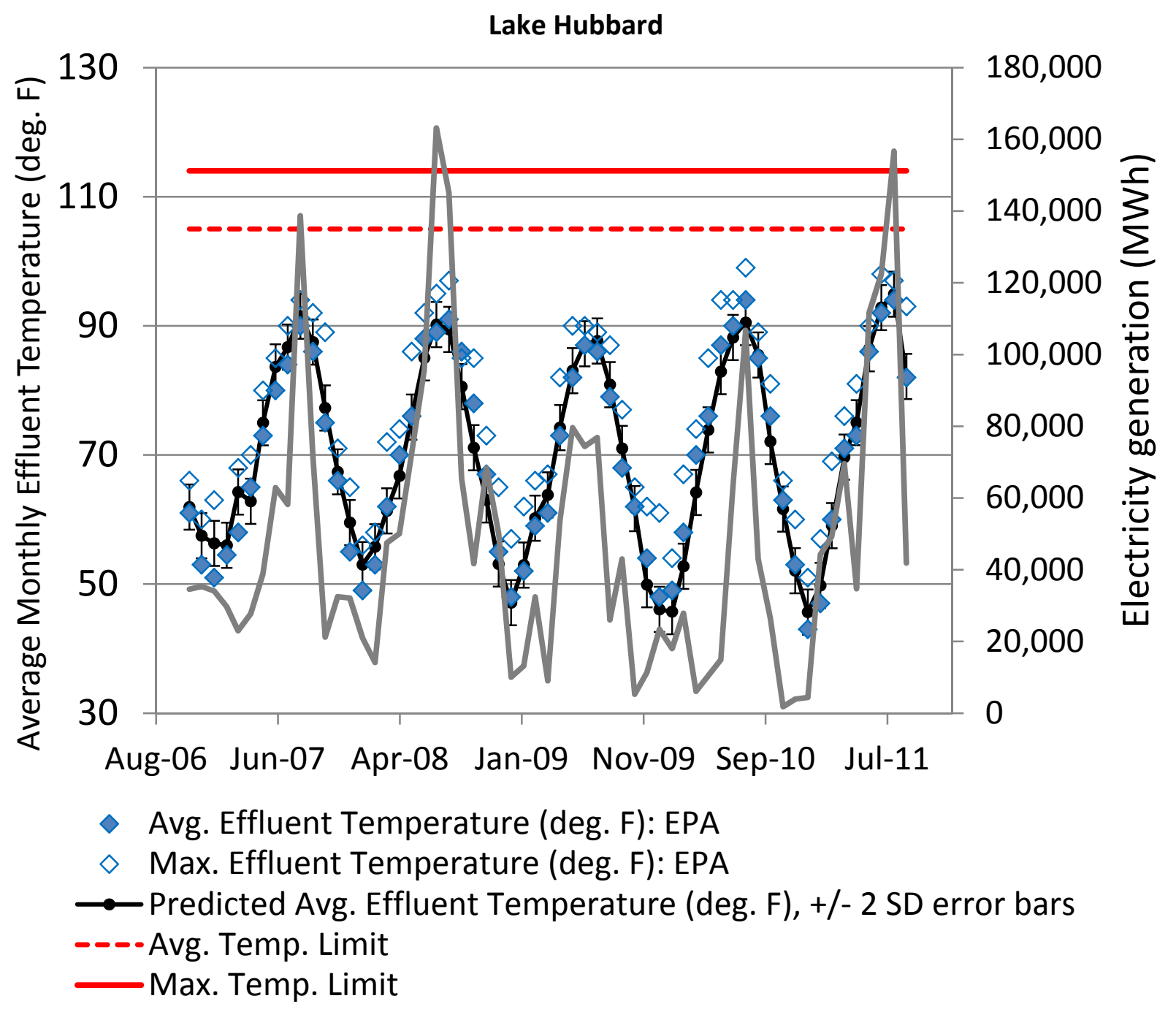

Figure B31. Average effluent temperature, maximum effluent temperature, predicted average effluent temperature from regression test, average effluent temperature limit, maximum effluent temperature limit for the Lake Hubbard plant. 
Lake Hubbard

PCM A2

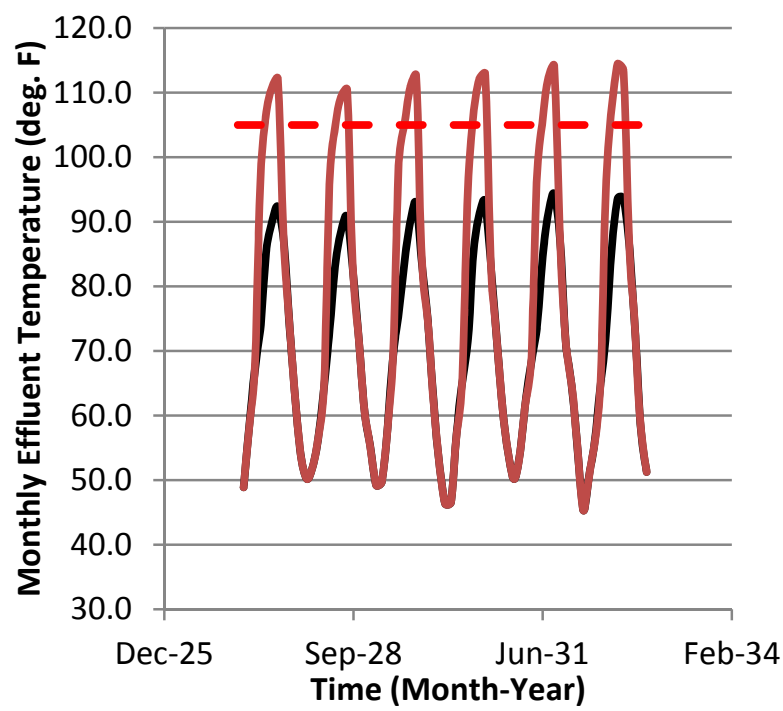

(a)

BCSDPCM A2

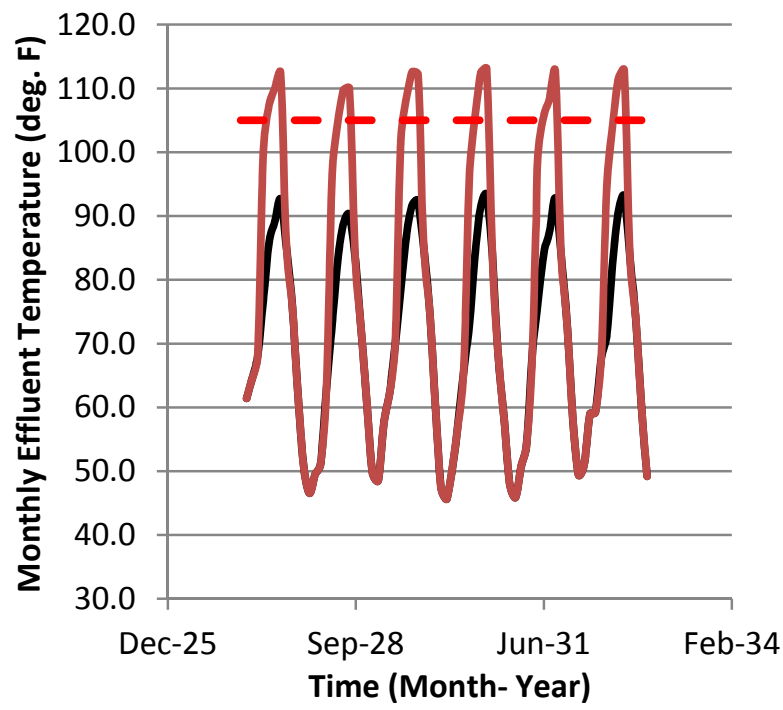

(c)
GFDL A2

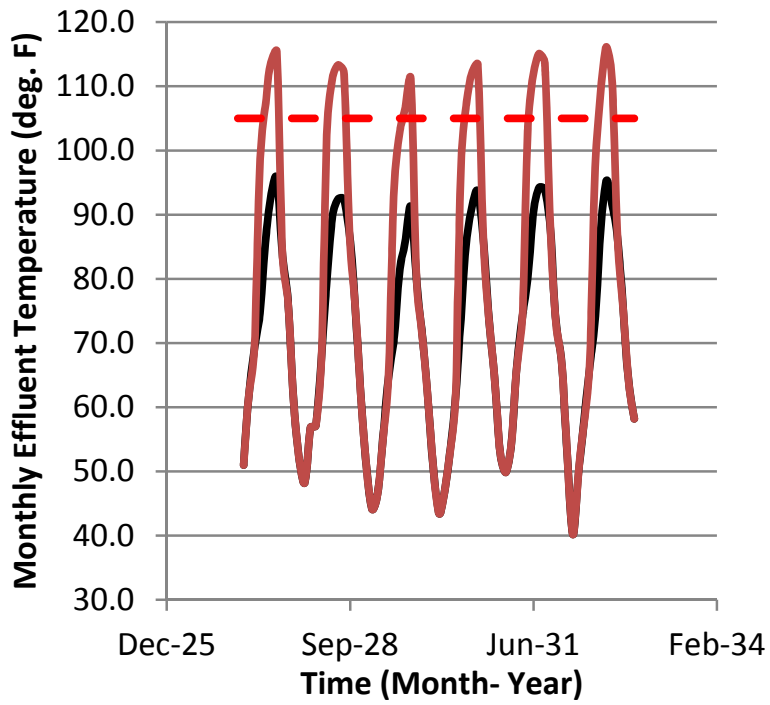

(b)

BCSDGFDL A2

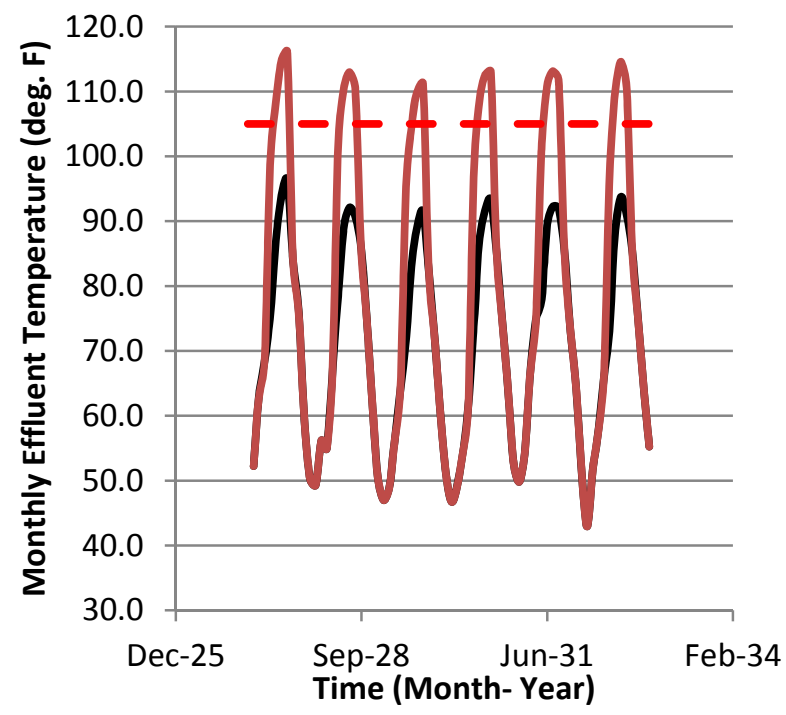

(d)

—Predicted Avg. Effluent Temperature (deg. F)

—Predicted Avg. Effluent Temperature (deg, F), 100\% Capacity in Summer

- - Avg. Temp. Limit: EPA

Figure B32. For the Lake Hubbard plant and four different simulated future climates - (a) PCM, (b) GFDL, (c) BCSDPCM, (d) BCSDGFDL - of the A2 emissions scenario, average effluent temperature assuming 2011 electric generation profiles, average effluent temperature assuming $100 \%$ summer capacity factor, and (if applicable) a horizontal dashed line indicating the average effluent temperature limit set by the EPA. 


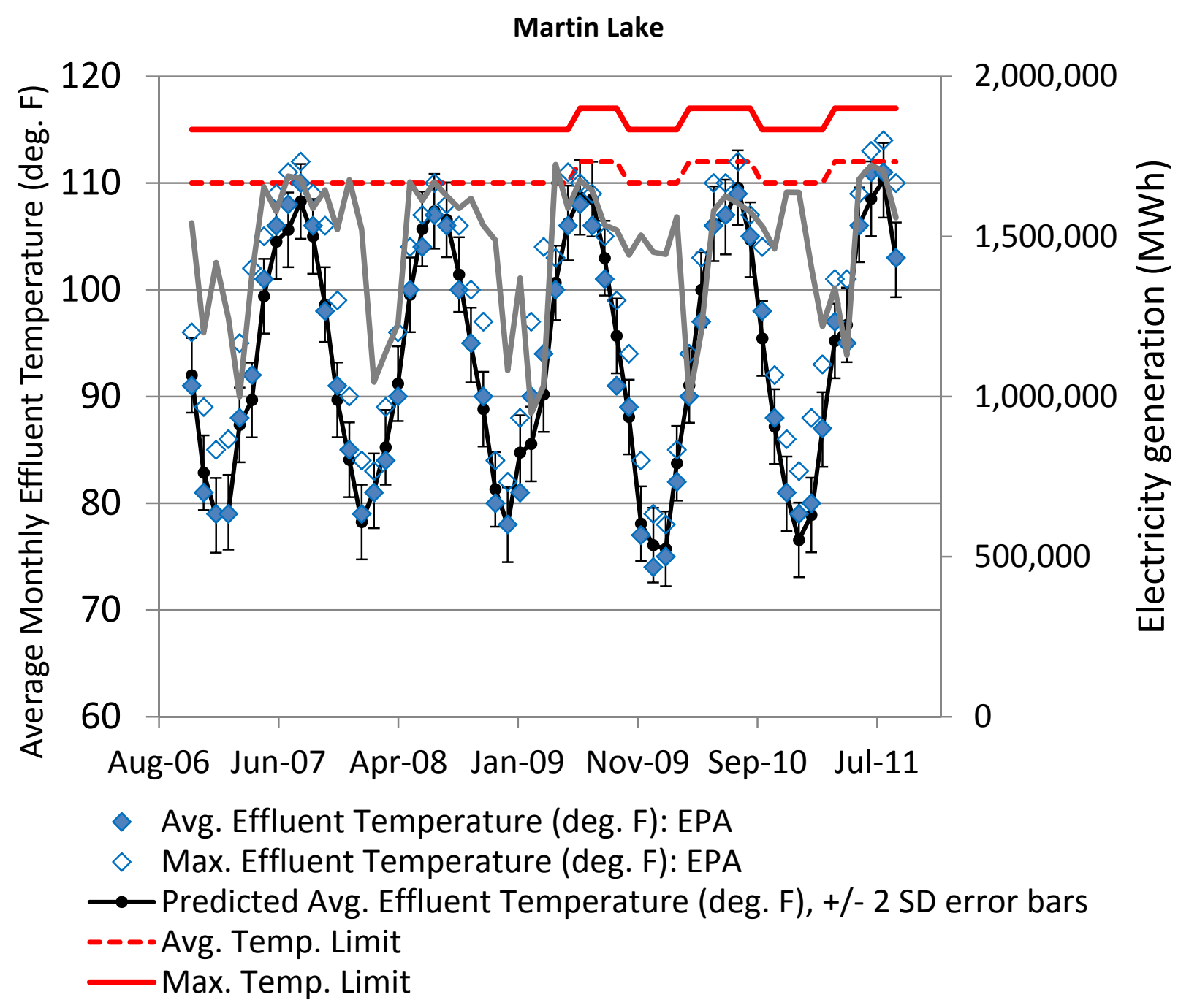

Figure B33. Average effluent temperature, maximum effluent temperature, predicted average effluent temperature from regression test, average effluent temperature limit, maximum effluent temperature limit for the Martin Lake plant. 


\section{Martin Lake}

PCM A2

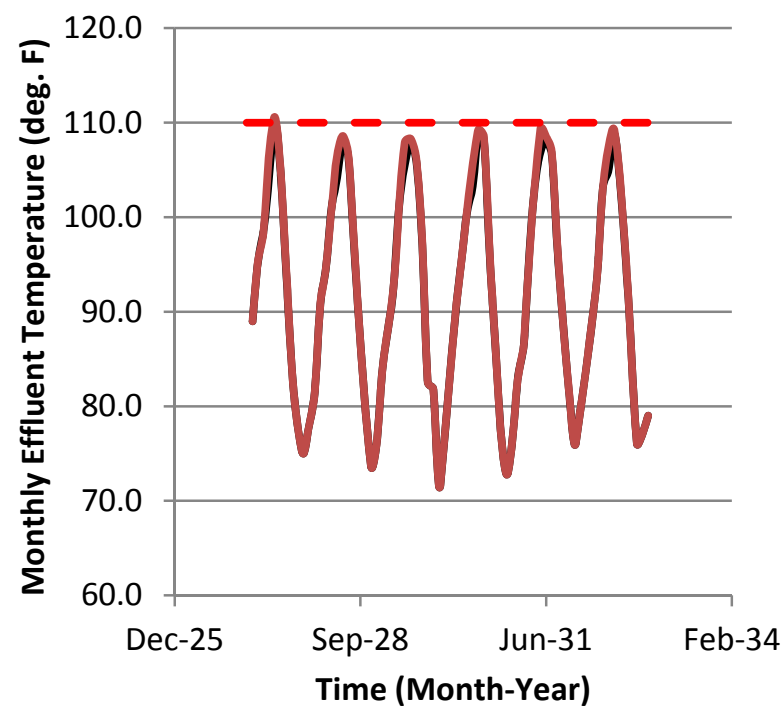

(a)

BCSDPCM A2

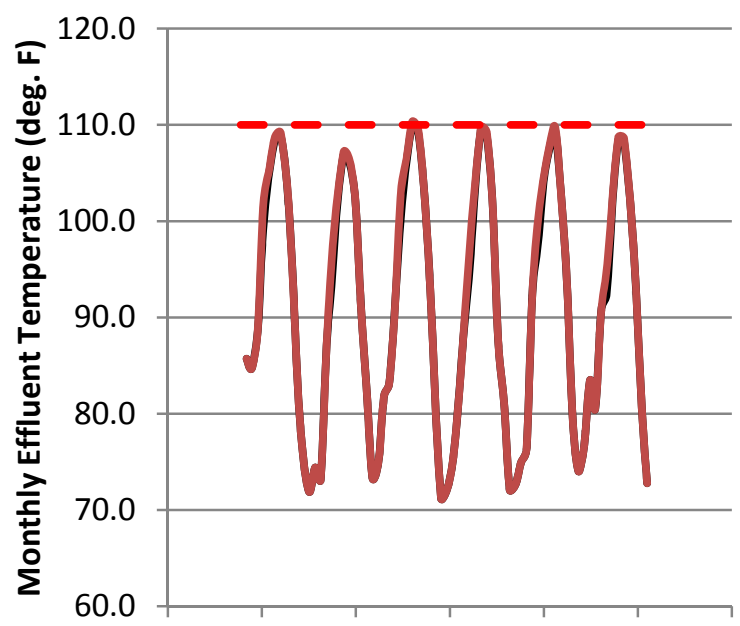

Dec-25Apr-27Sep-28Jan-30Jun-31Oct-32Feb-34 Time (Month- Year)

(c)
GFDL A2

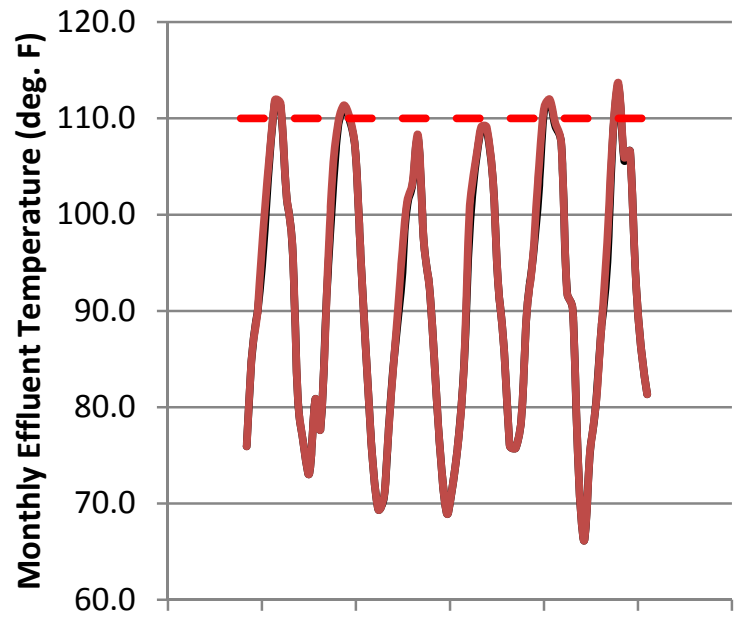

Dec-25Apr-27Sep-28Jan-30Jun-31Oct-32Feb-34 Time (Month- Year)

(b)

BCSDGFDL A2

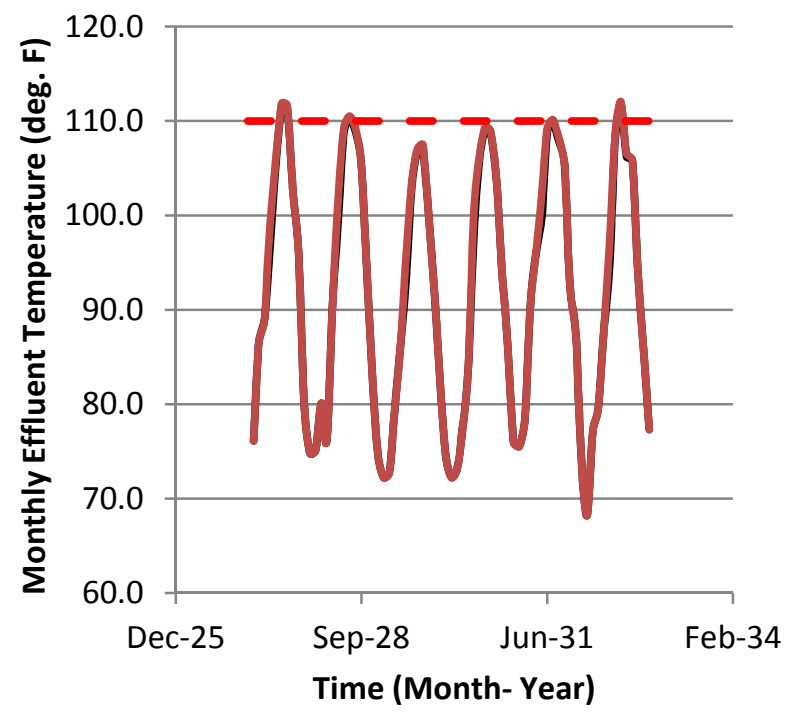

(d)

—Predicted Avg. Effluent Temperature (deg. F)

—Predicted Avg. Effluent Temperature (deg, F), 100\% Capacity in Summer

- - Avg. Temp. Limit: EPA

Figure B34. For the Martin Lake plant and four different simulated future climates - (a) PCM, (b) GFDL, (c) BCSDPCM, (d) BCSDGFDL - of the A2 emissions scenario, average effluent temperature assuming 2011 electric generation profiles, average effluent temperature assuming $100 \%$ summer capacity factor, and (if applicable) a horizontal dashed line indicating the average effluent temperature limit set by the EPA. 


\section{Mountain Creek}

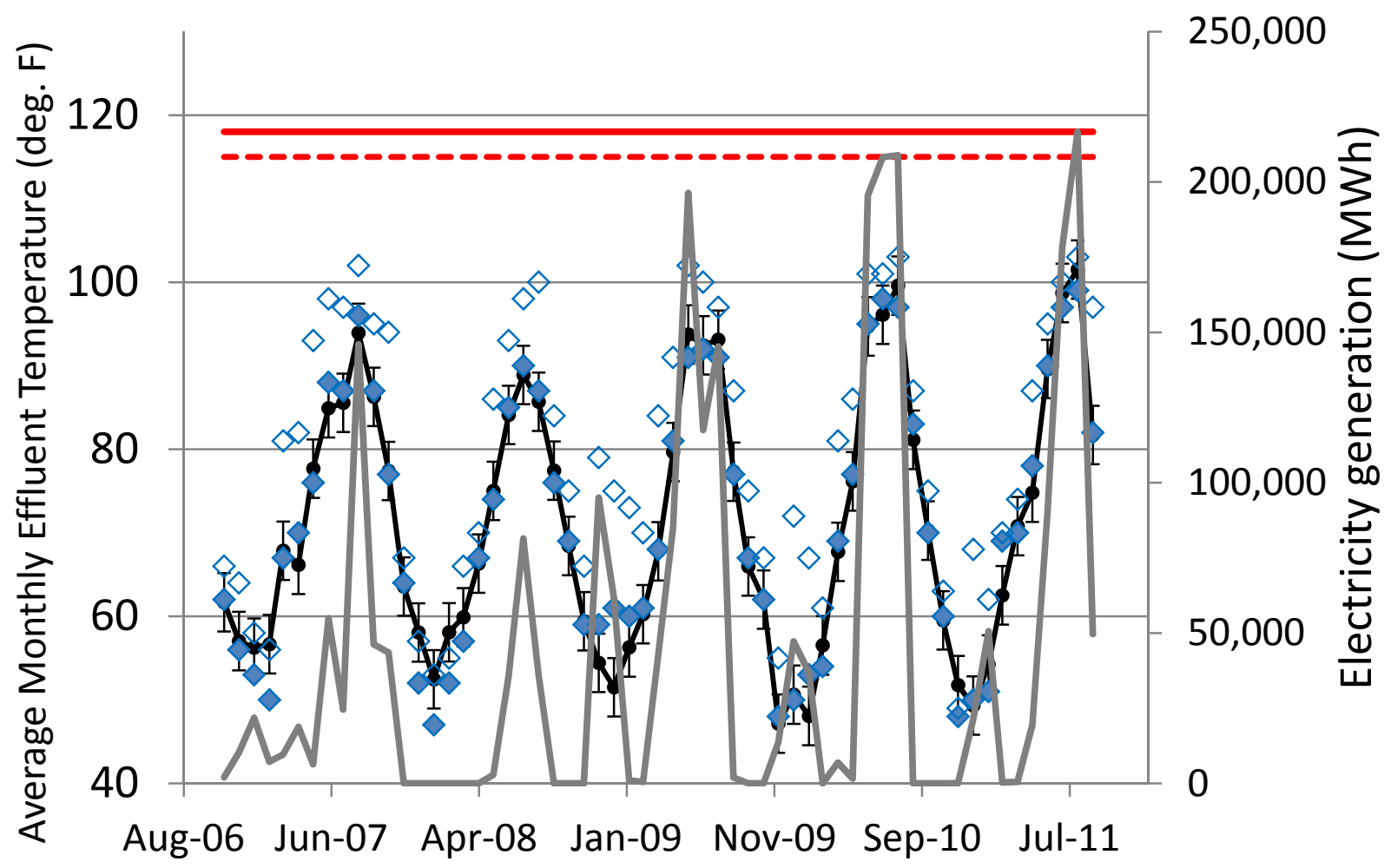

$\diamond$ Avg. Effluent Temperature (deg. F): EPA

$\diamond$ Max. Effluent Temperature (deg. F): EPA

$\longrightarrow$ Predicted Avg. Effluent Temperature (deg. F), +/- 2 SD error bars

---.Avg. Temp. Limit

Max. Temp. Limit

Figure B35. Average effluent temperature, maximum effluent temperature, predicted average effluent temperature from regression test, average effluent temperature limit, maximum effluent temperature limit for the Mountain Creek plant. 
Mountain Creek

PCM A2

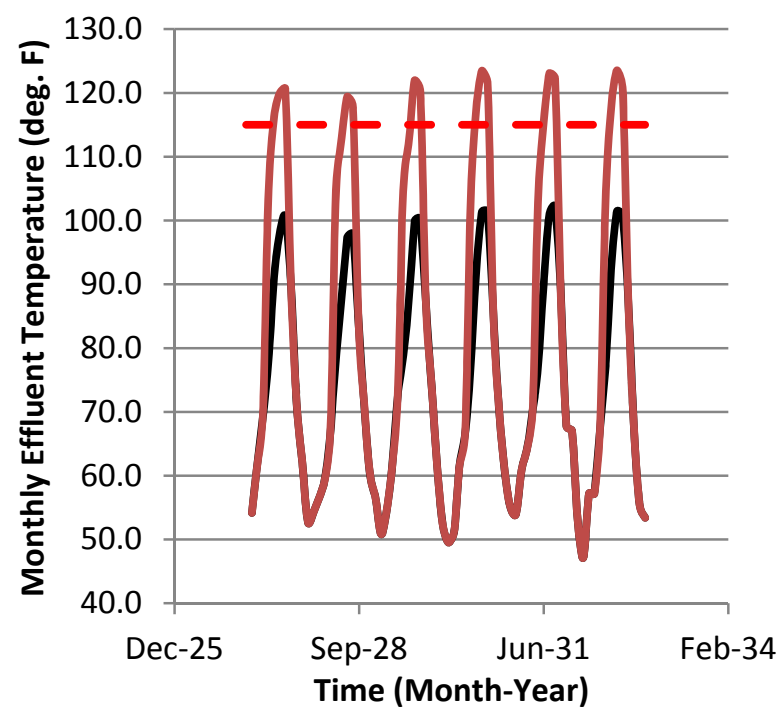

(a)

\section{BCSDPCM A2}

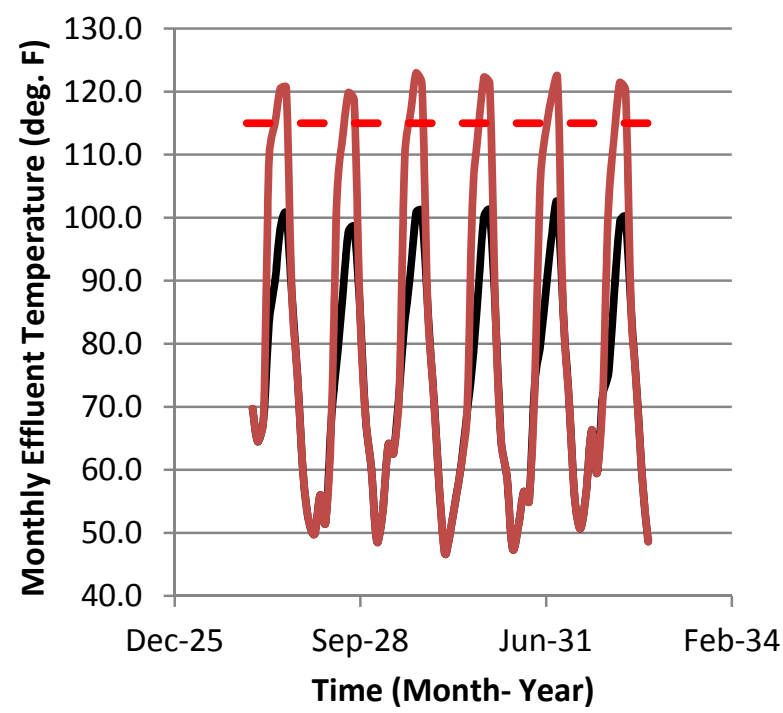

(c)
GFDL A2

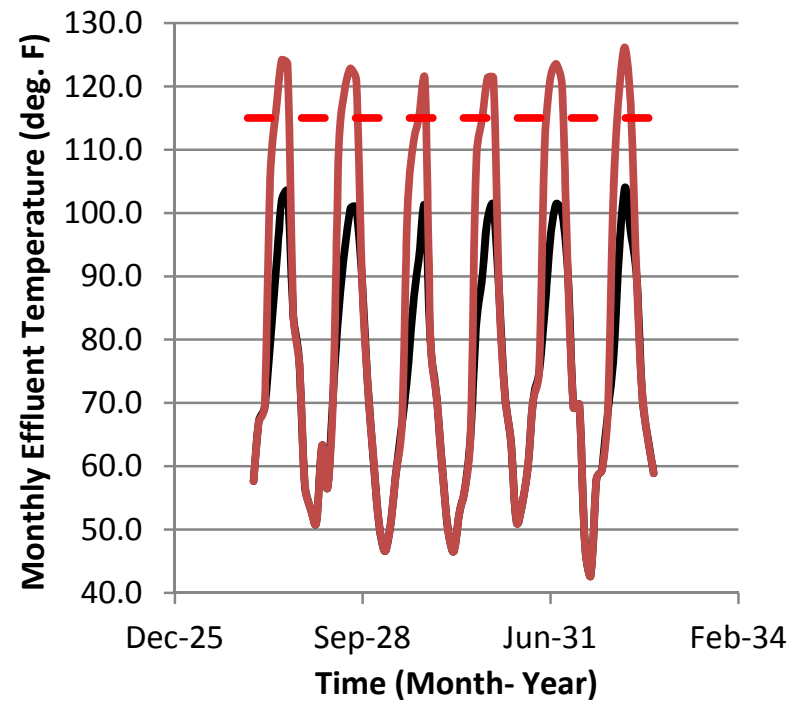

(b)

BCSDGFDL A2

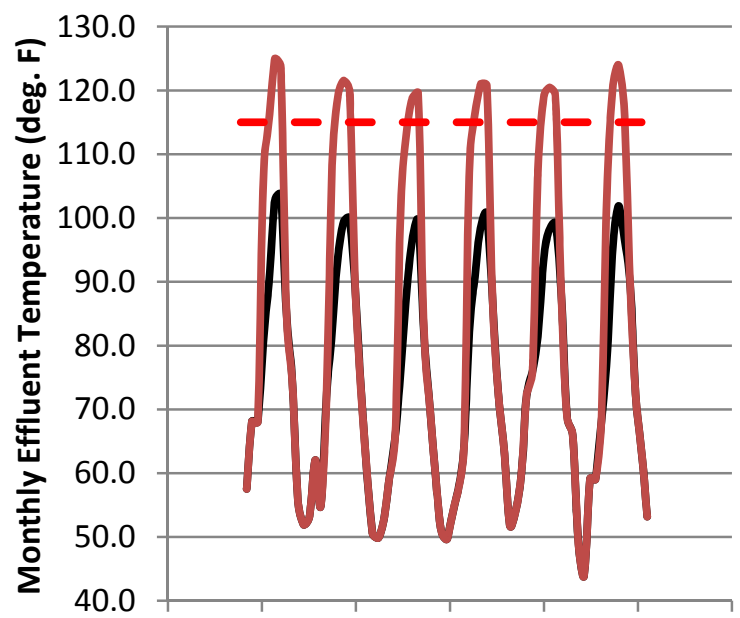

Dec-25Apr-27Sep-28Jan-30Jun-31Oct-32Feb-34 Time (Month- Year)

(d)

—Predicted Avg. Effluent Temperature (deg. F)

—Predicted Avg. Effluent Temperature (deg, F), 100\% Capacity in Summer

- - Avg. Temp. Limit: EPA

Figure B36. For the Mountain Creek plant and four different simulated future climates - (a) PCM, (b) GFDL, (c) BCSDPCM, (d) BCSDGFDL - of the A2 emissions scenario, average effluent temperature assuming 2011 electric generation profiles, average effluent temperature assuming $100 \%$ summer capacity factor, and (if applicable) a horizontal dashed line indicating the average effluent temperature limit set by the EPA. 


\section{Nueces Bay}

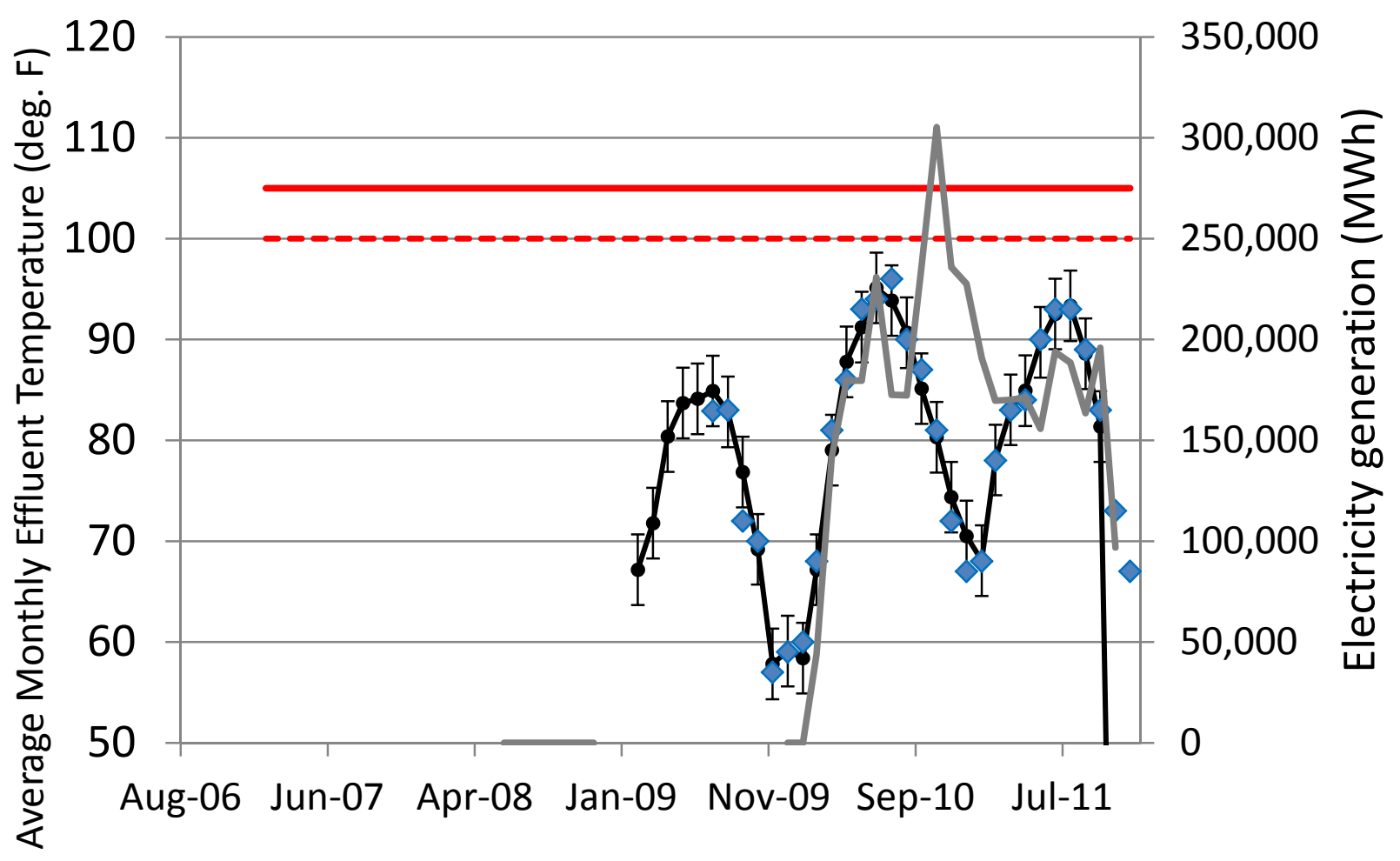

$\diamond \quad$ Avg. Effluent Temperature (deg. F): EPA

$\diamond$ Max. Effluent Temperature (deg. F): EPA

$\rightarrow$ Predicted Avg. Effluent Temperature (deg. F), +/- 2 SD error bars

---Avg. Temp. Limit

Max. Temp. Limit

Figure B37. Average effluent temperature, maximum effluent temperature, predicted average effluent temperature from regression test, average effluent temperature limit, maximum effluent temperature limit for the Nueces Bay plant. 


\section{Nueces Bay}

PCM A2

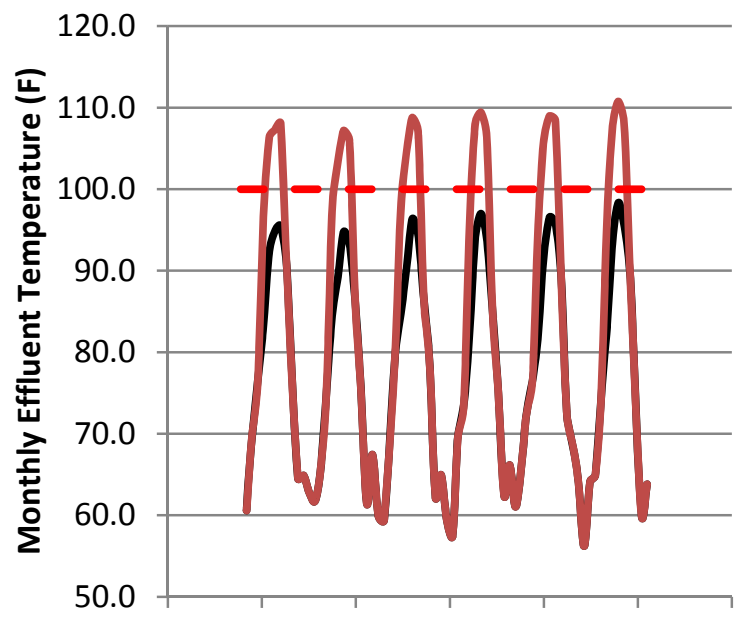

Dec-25Apr-27Sep-28Jan-30Jun-31Oct-32Feb-34

Time (Month-Year)

(a)

\section{BCSDPCM A2}

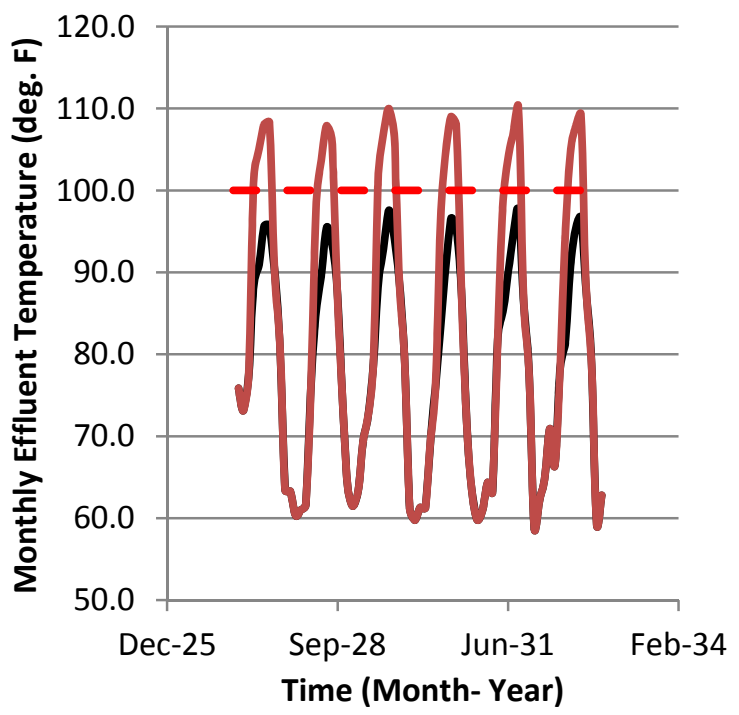

(c)
GFDL A2

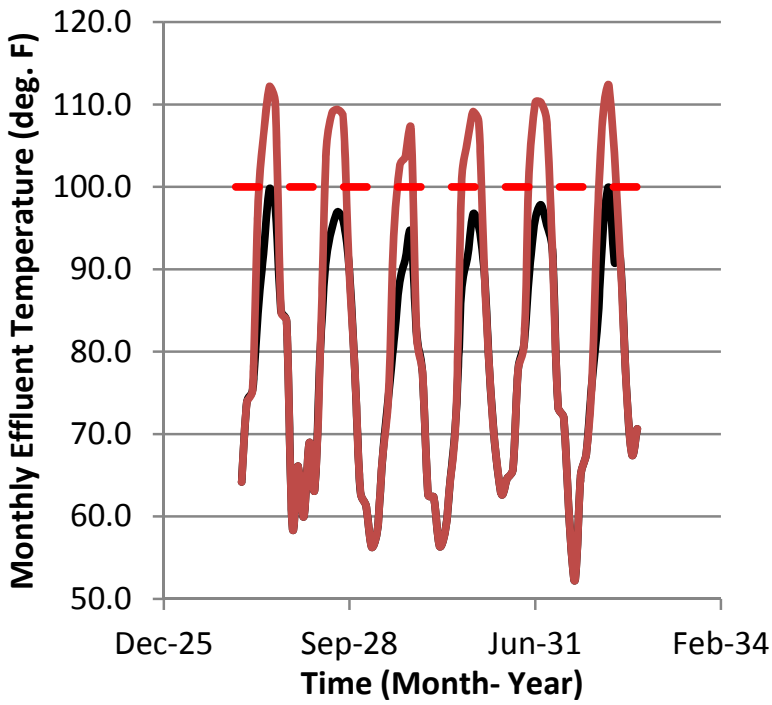

(b)

BCSDGFDL A2

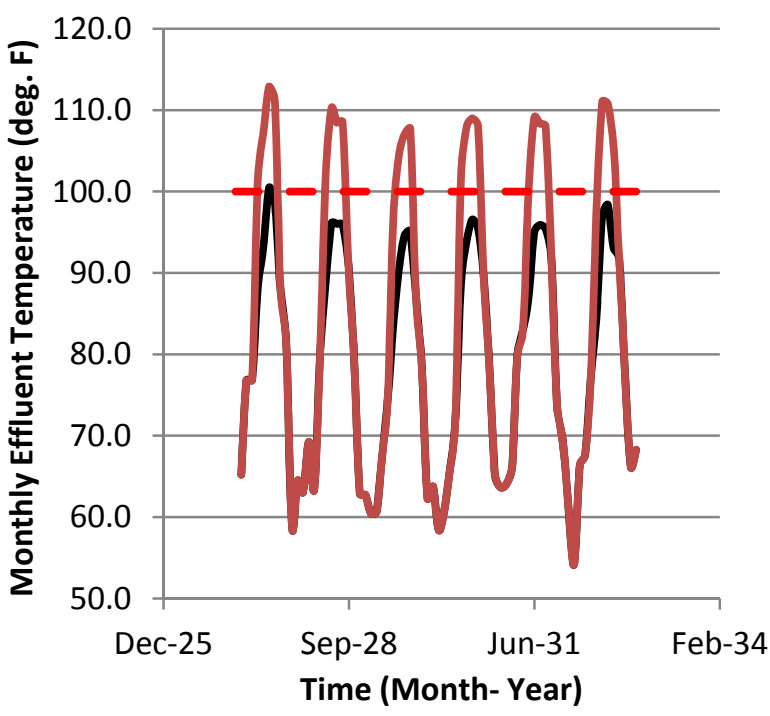

(d)

- Predicted Avg. Effluent Temperature (deg. F)

—Predicted Avg. Effluent Temperature (deg. F), 100\% Capacity in Summer

- -Avg. Temp. Limit: EPA

Figure B38. For the Nueces Bay plant and four different simulated future climates - (a) PCM, (b) GFDL, (c) BCSDPCM, (d) BCSDGFDL - of the A2 emissions scenario, average effluent temperature assuming 2011 electric generation profiles, average effluent temperature assuming $100 \%$ summer capacity factor, and (if applicable) a horizontal dashed line indicating the average effluent temperature limit set by the EPA. 


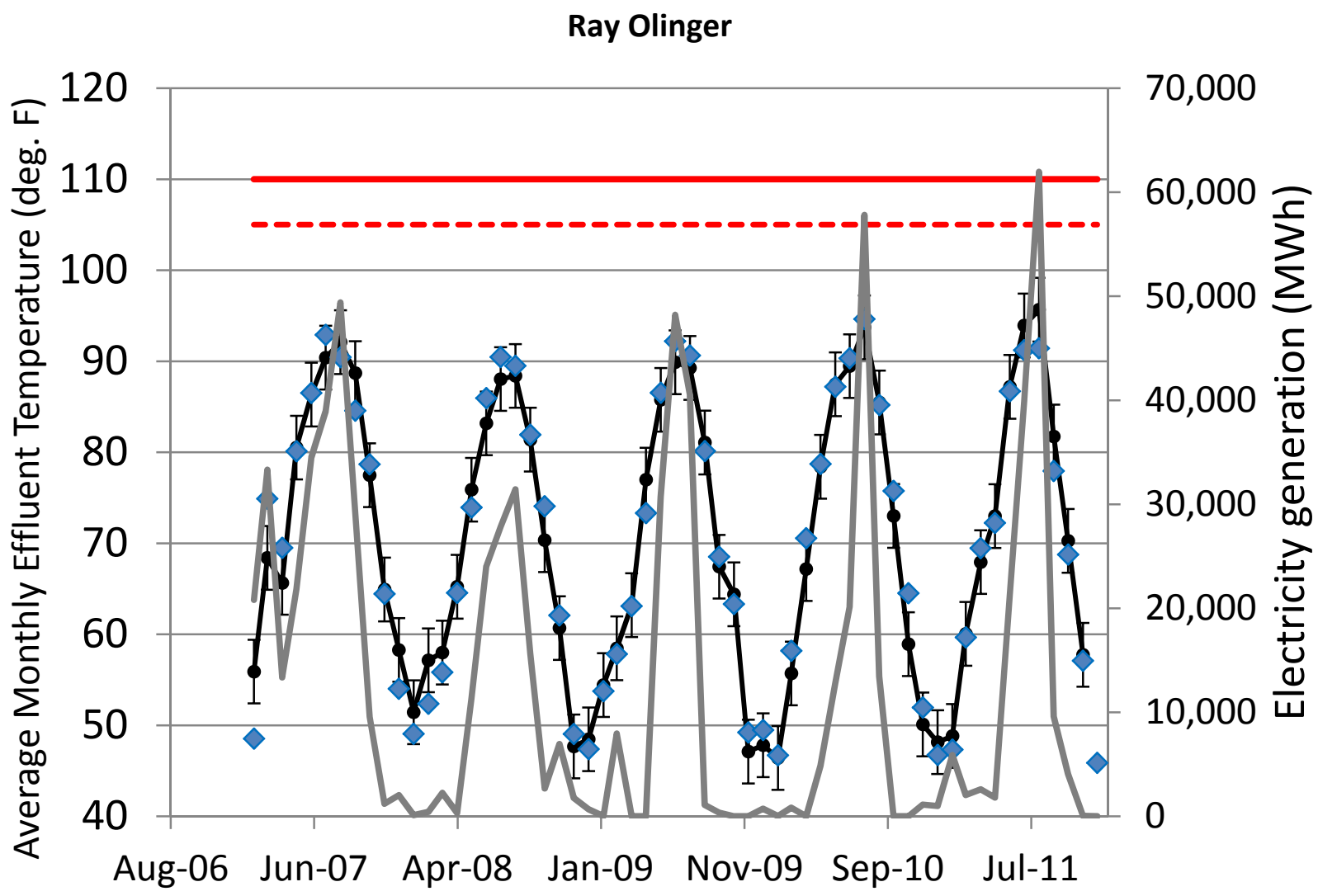

$\diamond$ Avg. Effluent Temperature (deg. F): EPA

$\diamond$ Max. Effluent Temperature (deg. F): EPA

$\rightarrow$ Predicted Avg. Effluent Temperature (deg. F), +/- 2 SD error bars

-.--Avg. Temp. Limit

Max. Temp. Limit

Figure B39. Average effluent temperature, maximum effluent temperature, predicted average effluent temperature from regression test, average effluent temperature limit, maximum effluent temperature limit for the Ray Olinger plant. 
Ray Olinger

PCM A2

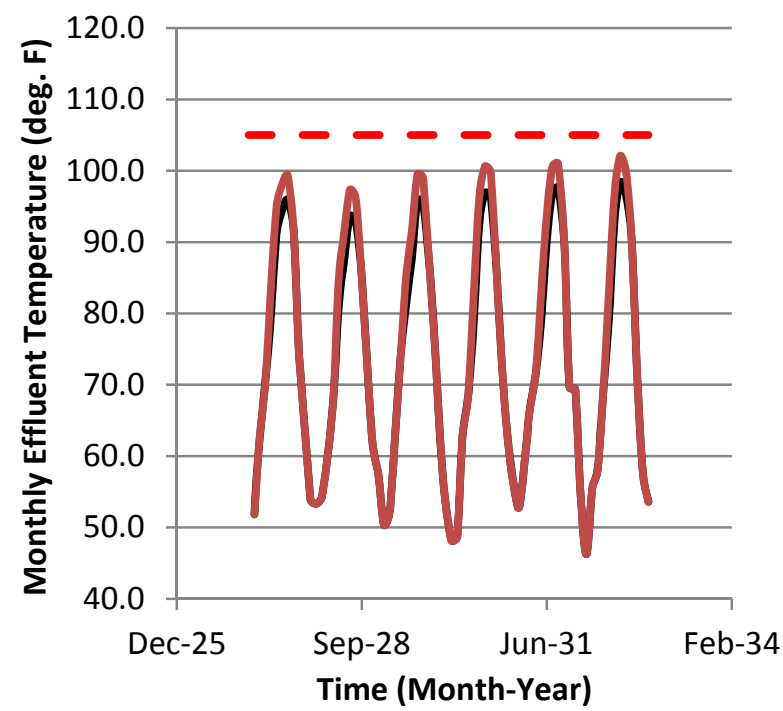

(a)

BCSDPCM A2

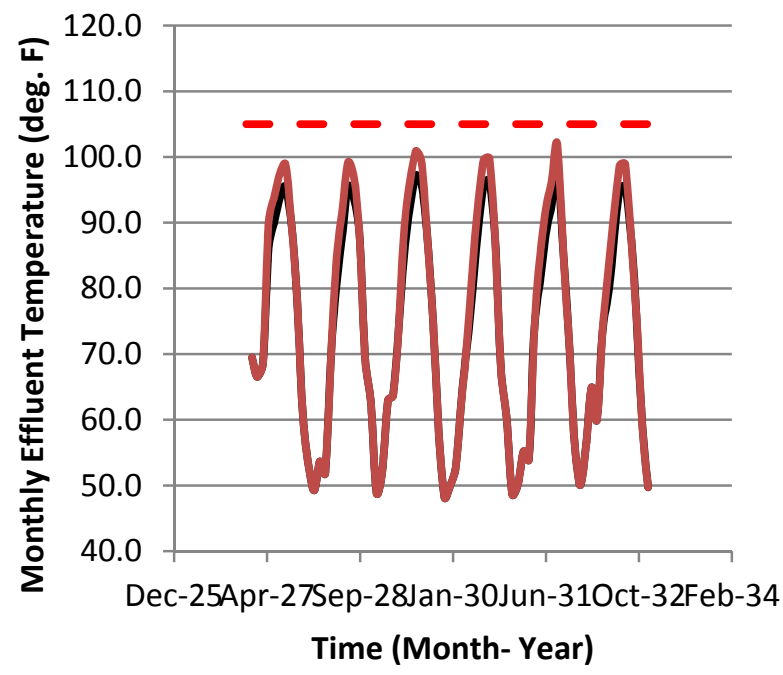

(c)
GFDL A2

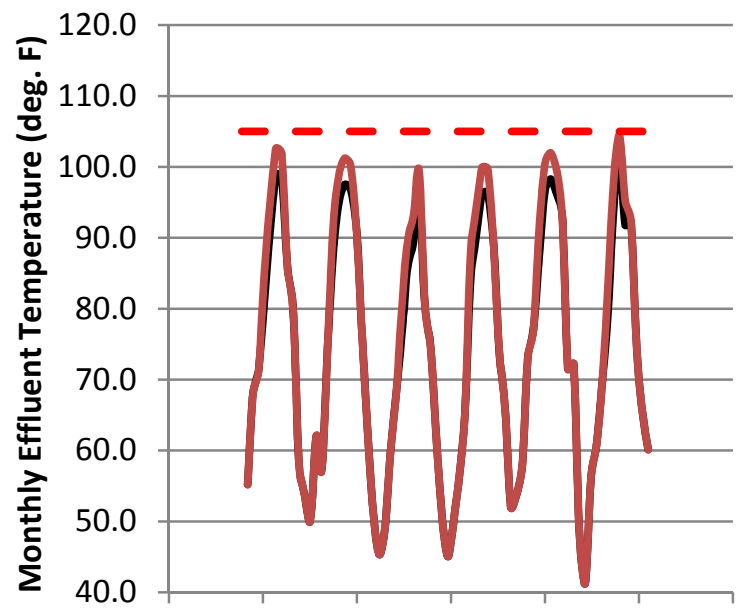

Dec-25Apr-27Sep-28Jan-30Jun-31Oct-32Feb-34

Time (Month- Year)

(b)

BCSDGFDL A2

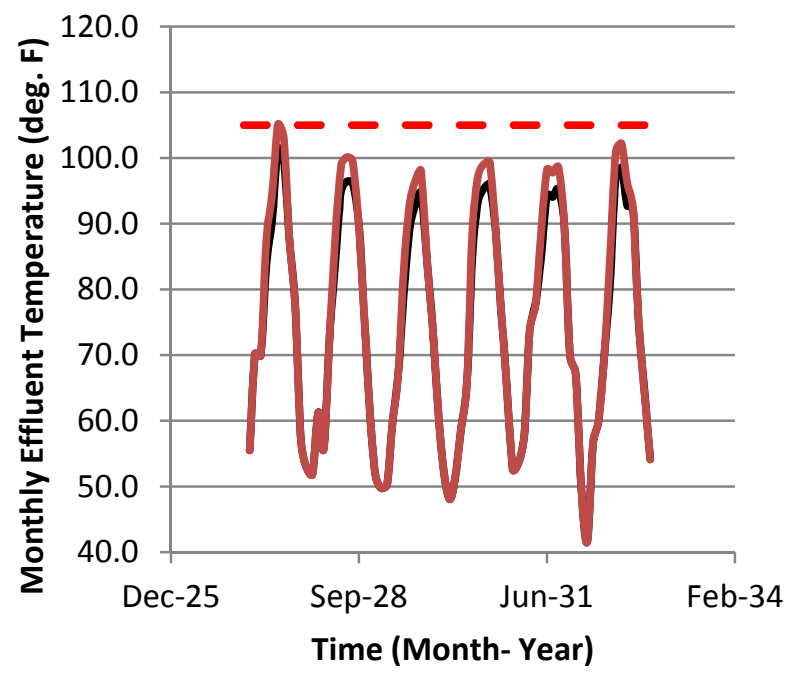

(d)

—Predicted Avg. Effluent Temperature (deg. F)

—Predicted Avg. Effluent Temperature (deg, F), 100\% Capacity in Summer

- - Avg. Temp. Limit: EPA

Figure B40. For the Ray Olinger plant and four different simulated future climates - (a) PCM, (b) GFDL, (c) BCSDPCM, (d) BCSDGFDL - of the A2 emissions scenario, average effluent temperature assuming 2011 electric generation profiles, average effluent temperature assuming $100 \%$ summer capacity factor, and (if applicable) a horizontal dashed line indicating the average effluent temperature limit set by the EPA. 


\section{Roland C. Dansby}

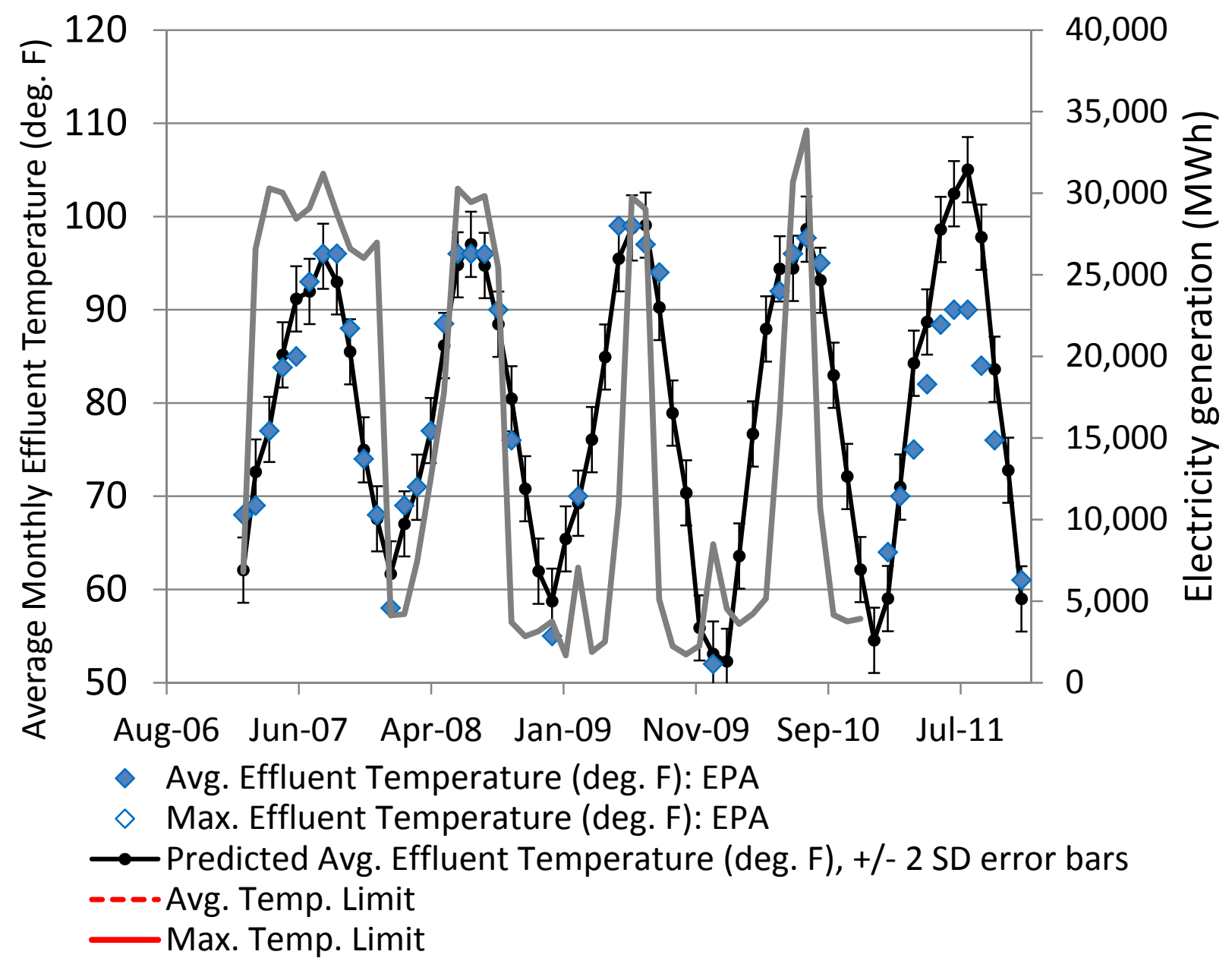

Figure B41. Average effluent temperature, maximum effluent temperature, predicted average effluent temperature from regression test, average effluent temperature limit, maximum effluent temperature limit for the Roland C. Dansby plant. 


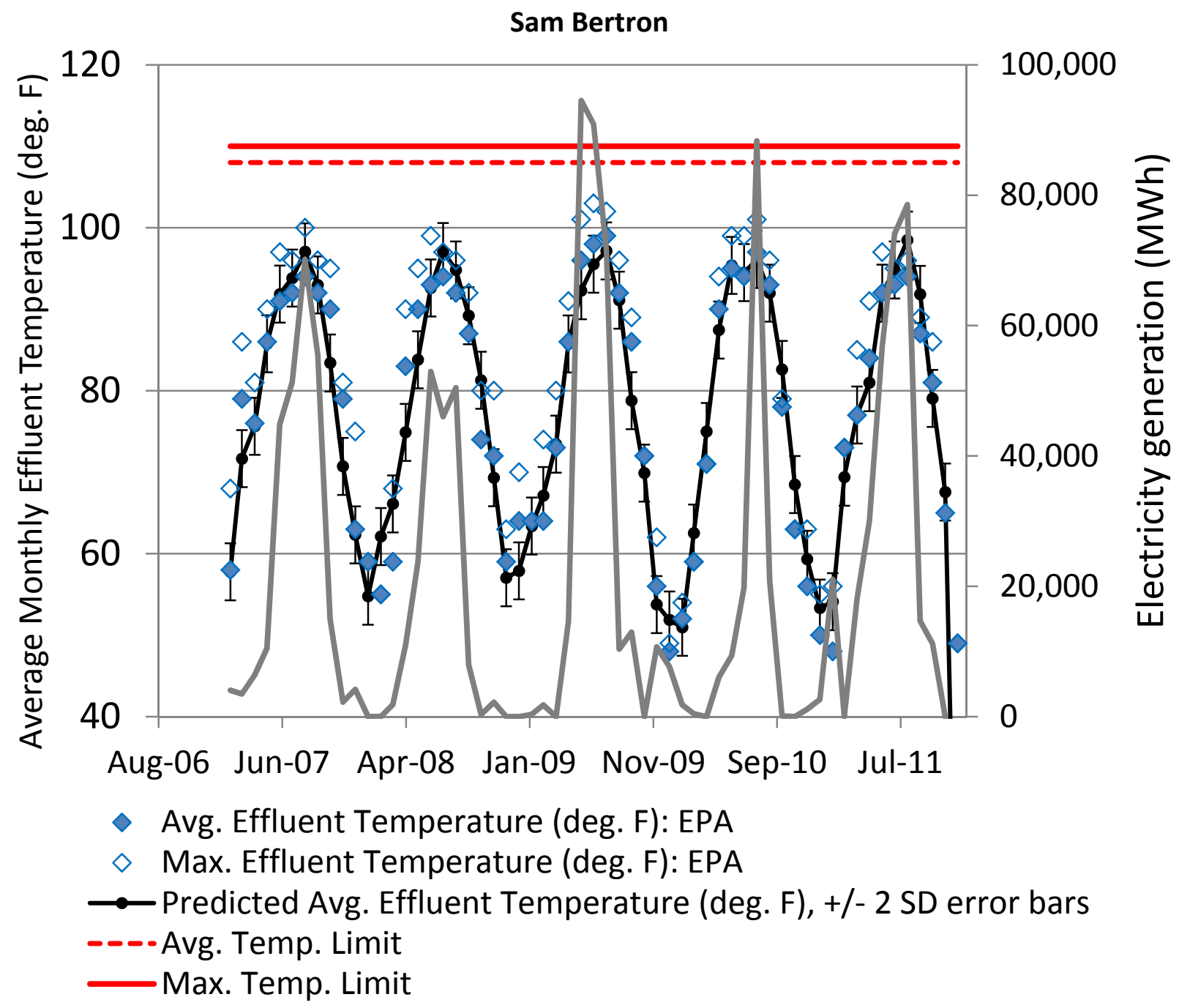

Figure B42. Average effluent temperature, maximum effluent temperature, predicted average effluent temperature from regression test, average effluent temperature limit, maximum effluent temperature limit for the Sam Bertron plant. 


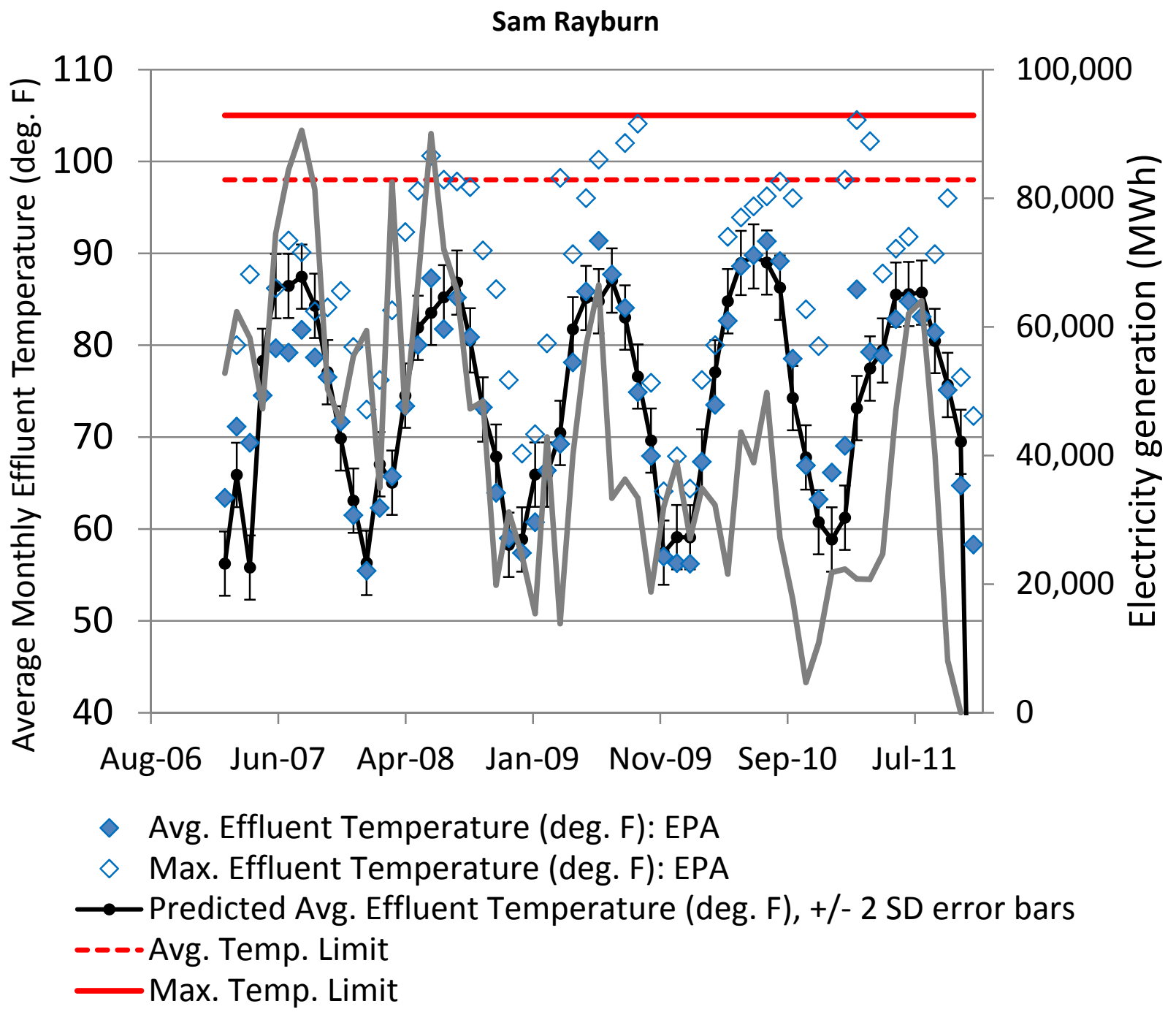

Figure B43. Average effluent temperature, maximum effluent temperature, predicted average effluent temperature from regression test, average effluent temperature limit, maximum effluent temperature limit for the Sam Rayburn plant. 


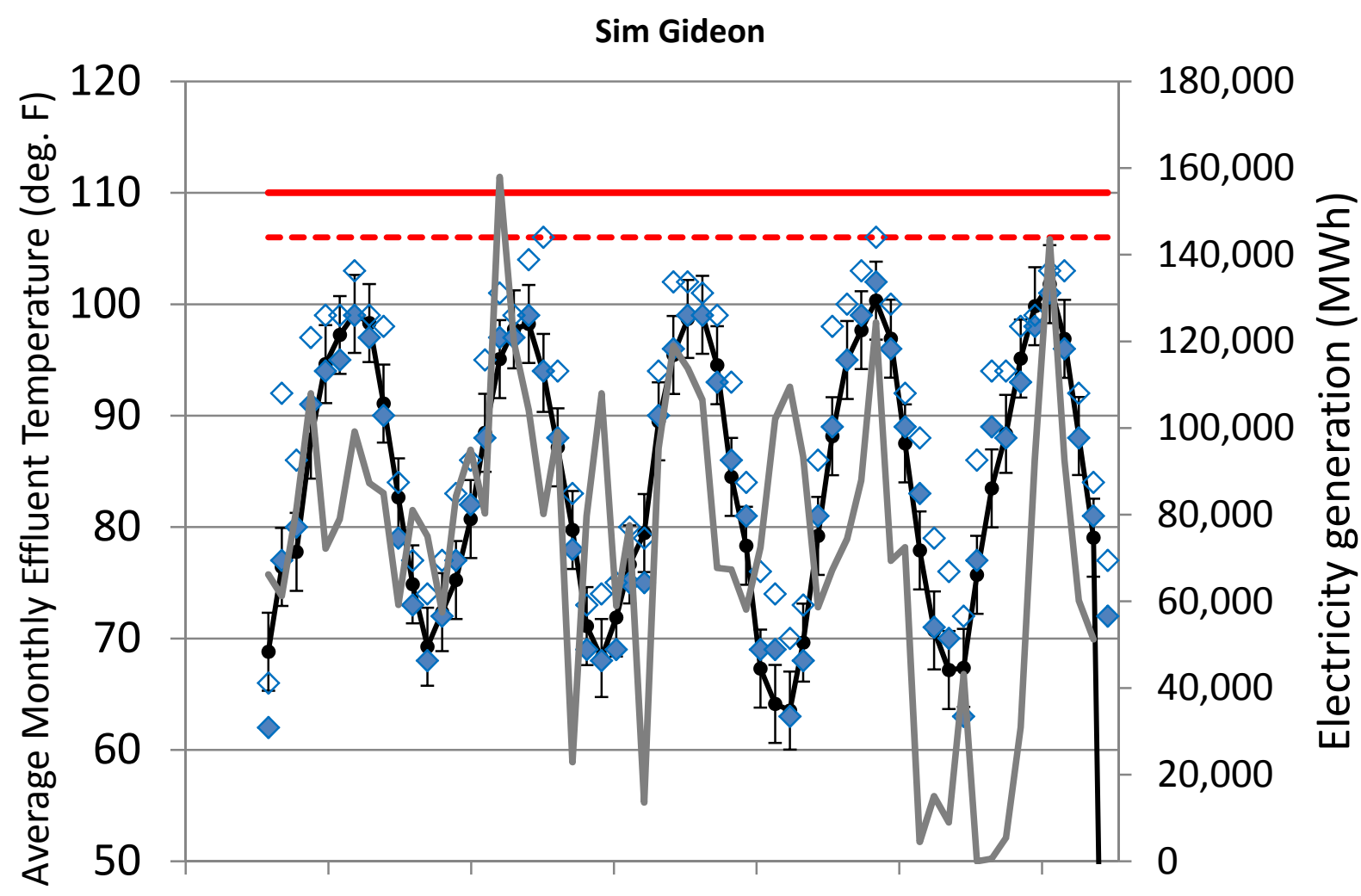

Aug-06 Jun-07 Apr-08 Jan-09 Nov-09 Sep-10 Jul-11

$\diamond$ Avg. Effluent Temperature (deg. F): EPA

$\diamond$ Max. Effluent Temperature (deg. F): EPA

$\rightarrow$ Predicted Avg. Effluent Temperature (deg. F), +/- 2 SD error bars

-.-Avg. Temp. Limit

Max. Temp. Limit

Figure B44. Average effluent temperature, maximum effluent temperature, predicted average effluent temperature from regression test, average effluent temperature limit, maximum effluent temperature limit for the Sim Gideon plant. 


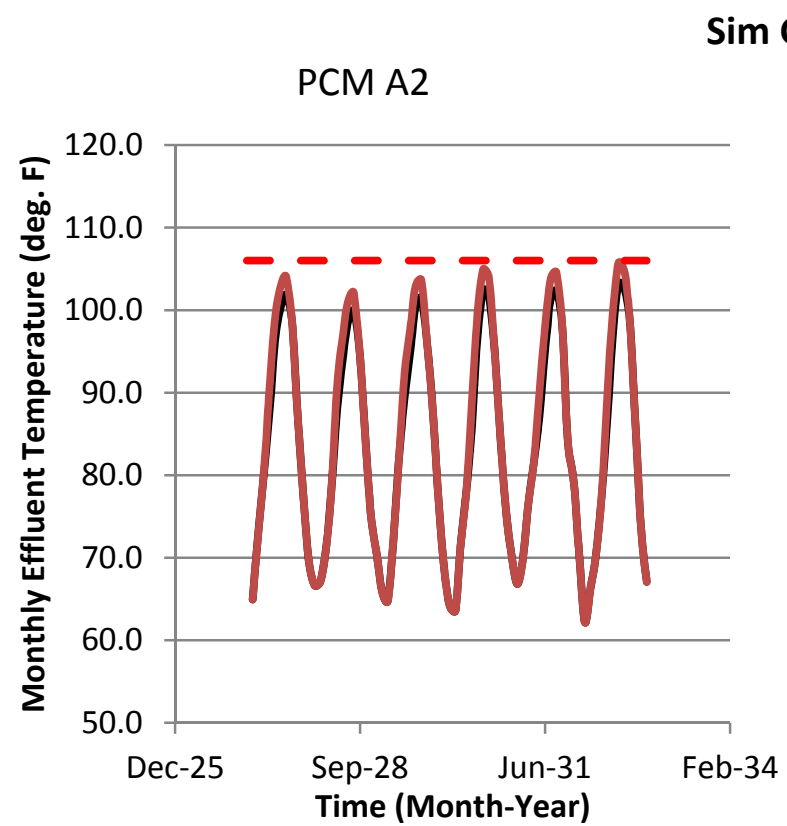

(a)

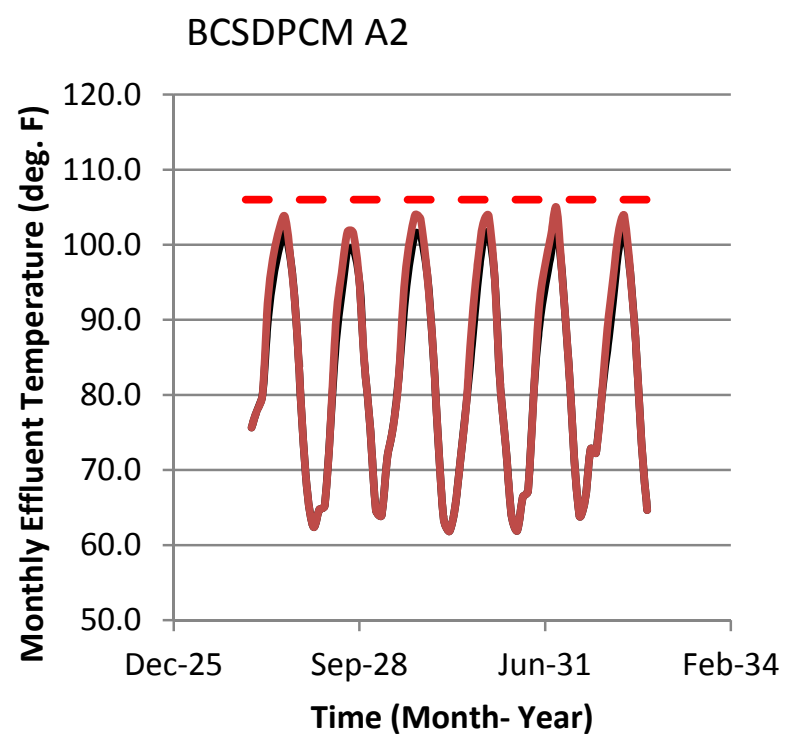

(c)
GFDL A2

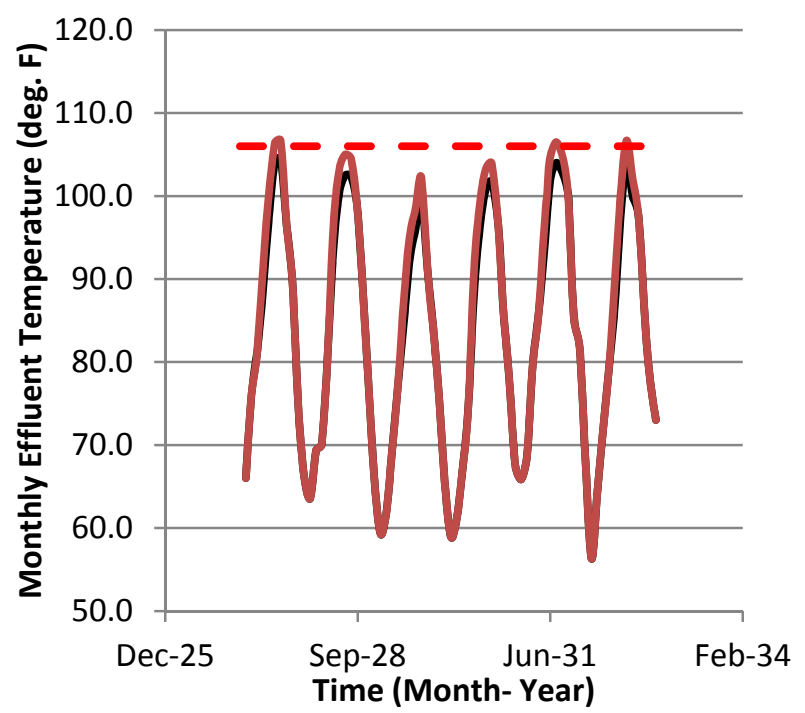

(b)

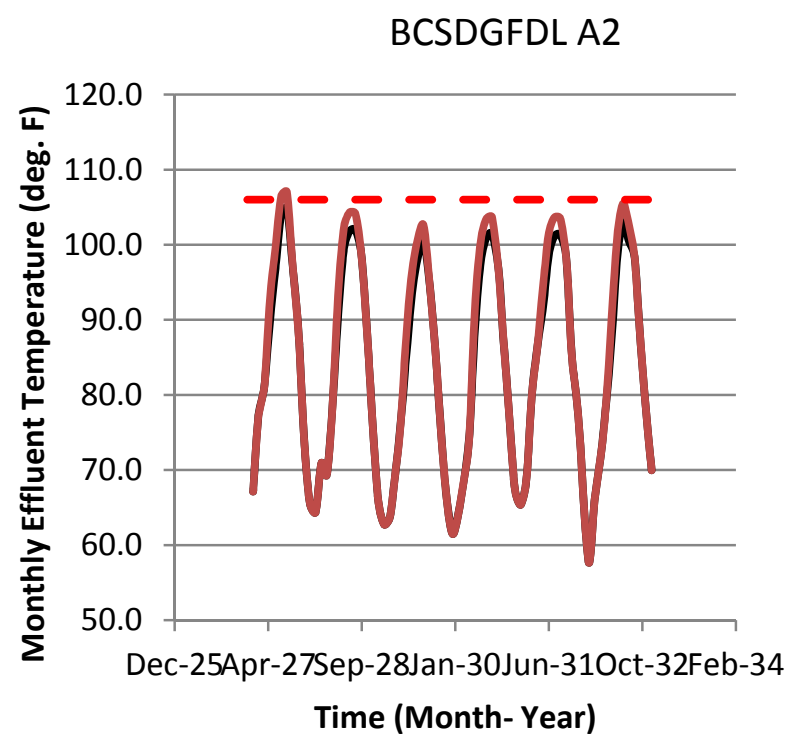

(d)

—Predicted Avg. Effluent Temperature (deg. F)

—Predicted Avg. Effluent Temperature (deg, F), 100\% Capacity in Summer

- - Avg. Temp. Limit: EPA

Figure B45. For the Sim Gideon plant and four different simulated future climates - (a) PCM, (b) GFDL, (c) BCSDPCM, (d) BCSDGFDL - of the A2 emissions scenario, average effluent temperature assuming 2011 electric generation profiles, average effluent temperature assuming $100 \%$ summer capacity factor, and (if applicable) a horizontal dashed line indicating the average effluent temperature limit set by the EPA. 


\section{Stryker Creek}

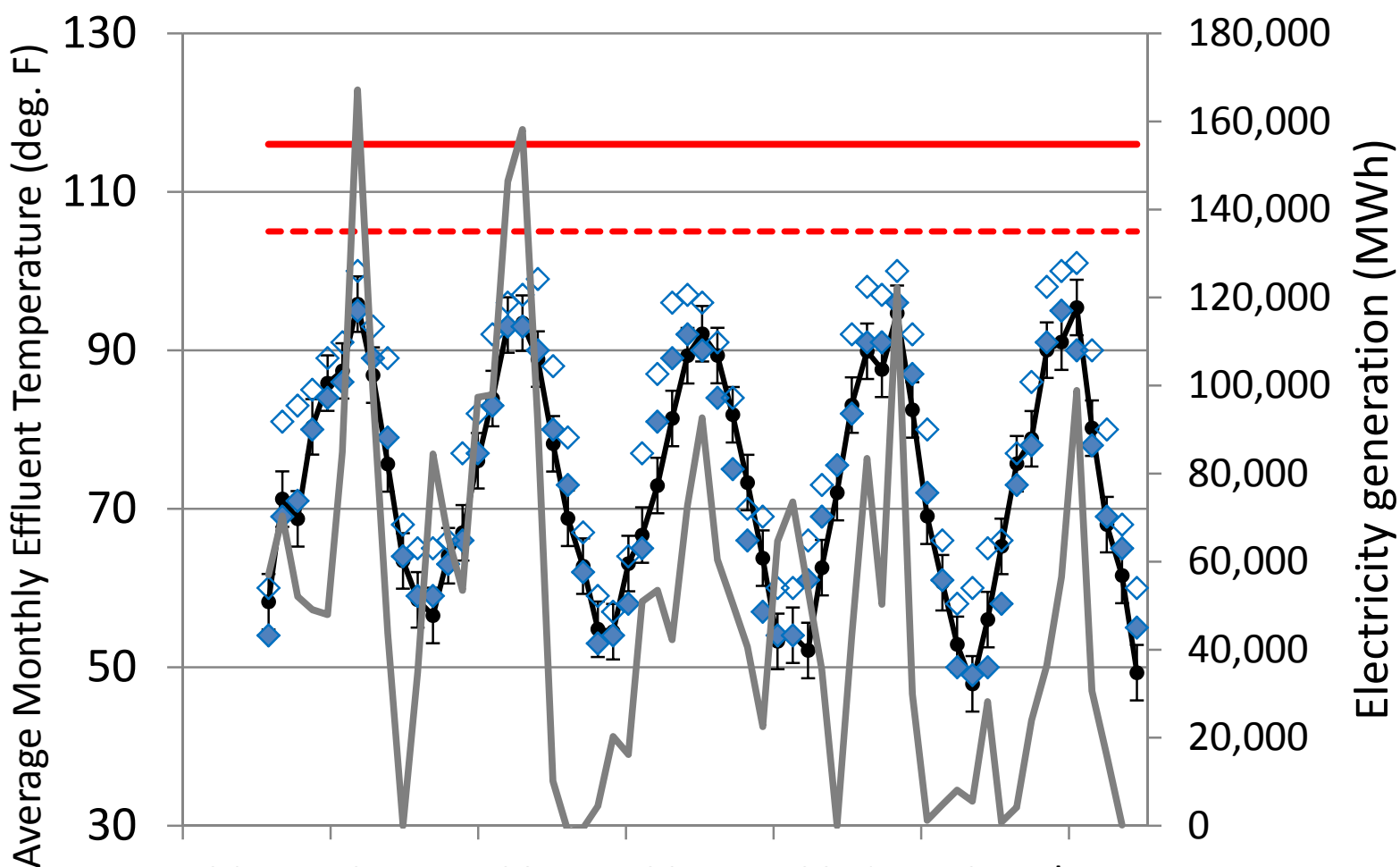

Aug-06 Jun-07 Apr-08 Jan-09 Nov-09 Sep-10 Jul-11

$\diamond$ Avg. Effluent Temperature (deg. F): EPA

$\diamond$ Max. Effluent Temperature (deg. F): EPA

$\rightarrow$ Predicted Avg. Effluent Temperature (deg. F), +/- 2 SD error bars

----Avg. Temp. Limit

Max. Temp. Limit

Figure B46. Average effluent temperature, maximum effluent temperature, predicted average effluent temperature from regression test, average effluent temperature limit, maximum effluent temperature limit for the Stryker Creek plant. 


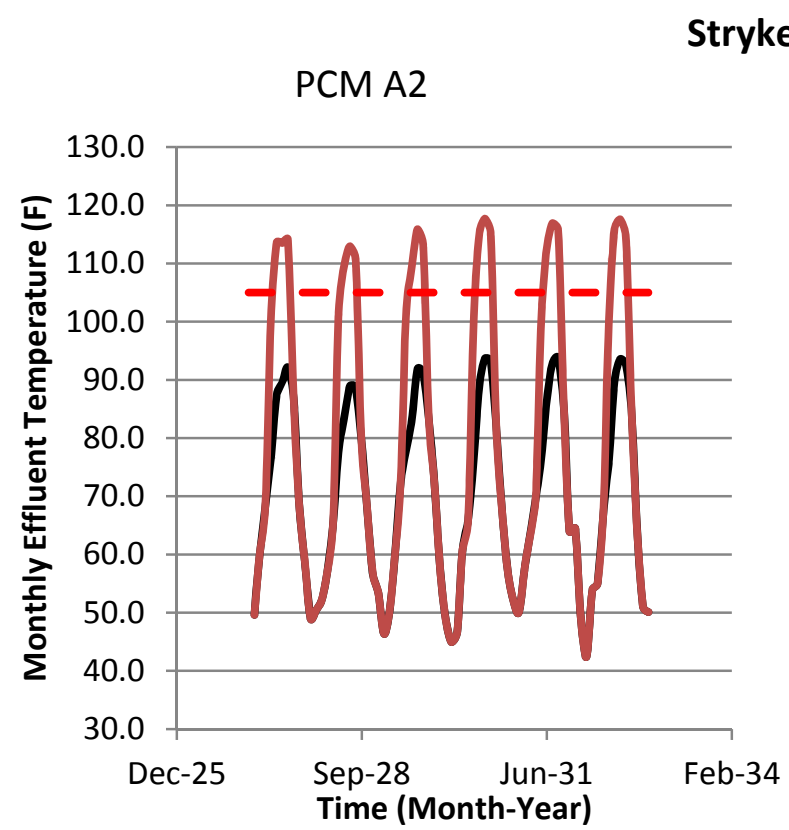

(a)

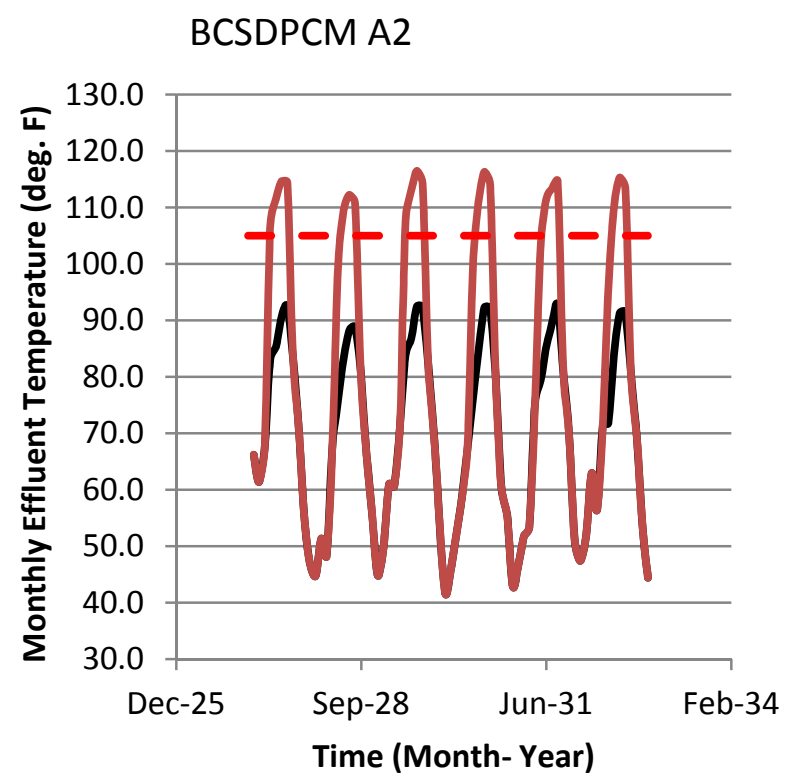

(c)
GFDL A2

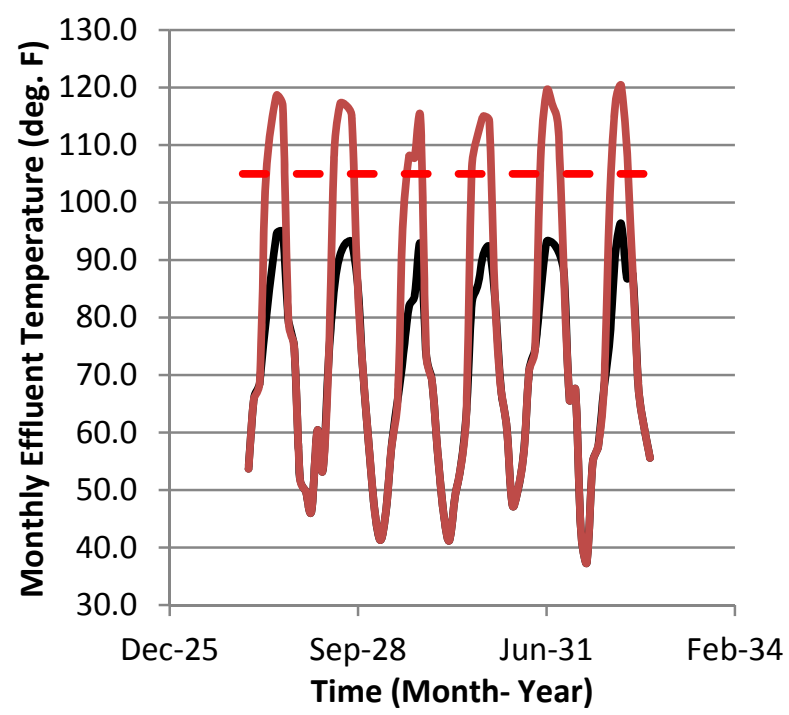

(b)

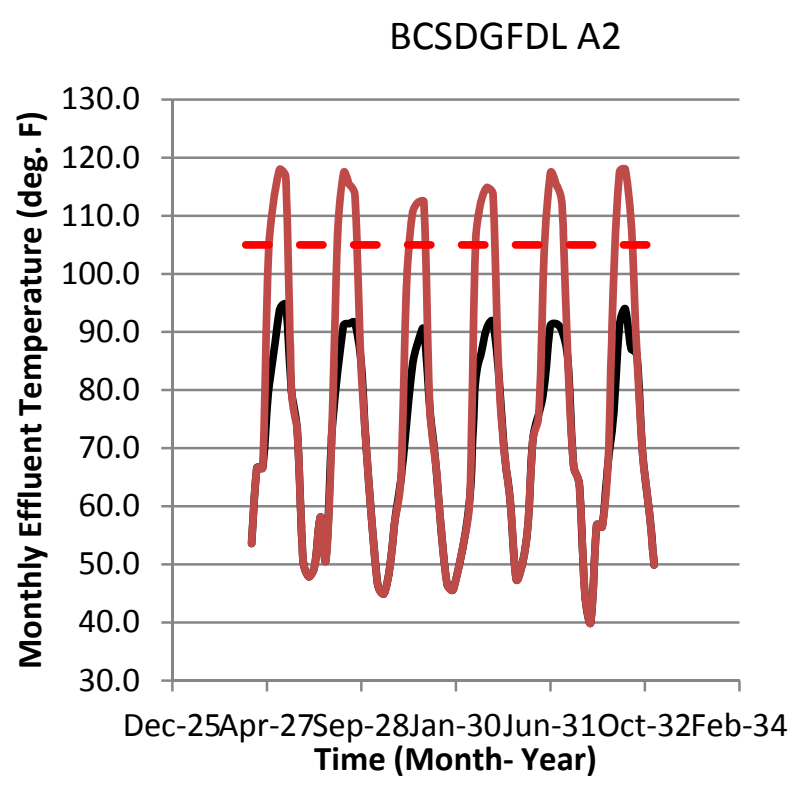

(d)

— Predicted Avg. Effluent Temperature (deg. F)

—Predicted Avg. Effluent Temperature (deg, F), 100\% Capacity in Summer

- - Avg. Temp. Limit: EPA

Figure B47. For the Stryker Creek plant and four different simulated future climates - (a) PCM, (b) GFDL, (c) BCSDPCM, (d) BCSDGFDL - of the A2 emissions scenario, average effluent temperature assuming 2011 electric generation profiles, average effluent temperature assuming $100 \%$ summer capacity factor, and (if applicable) a horizontal dashed line indicating the average effluent temperature limit set by the EPA. 


\section{Thomas C. Ferguson}

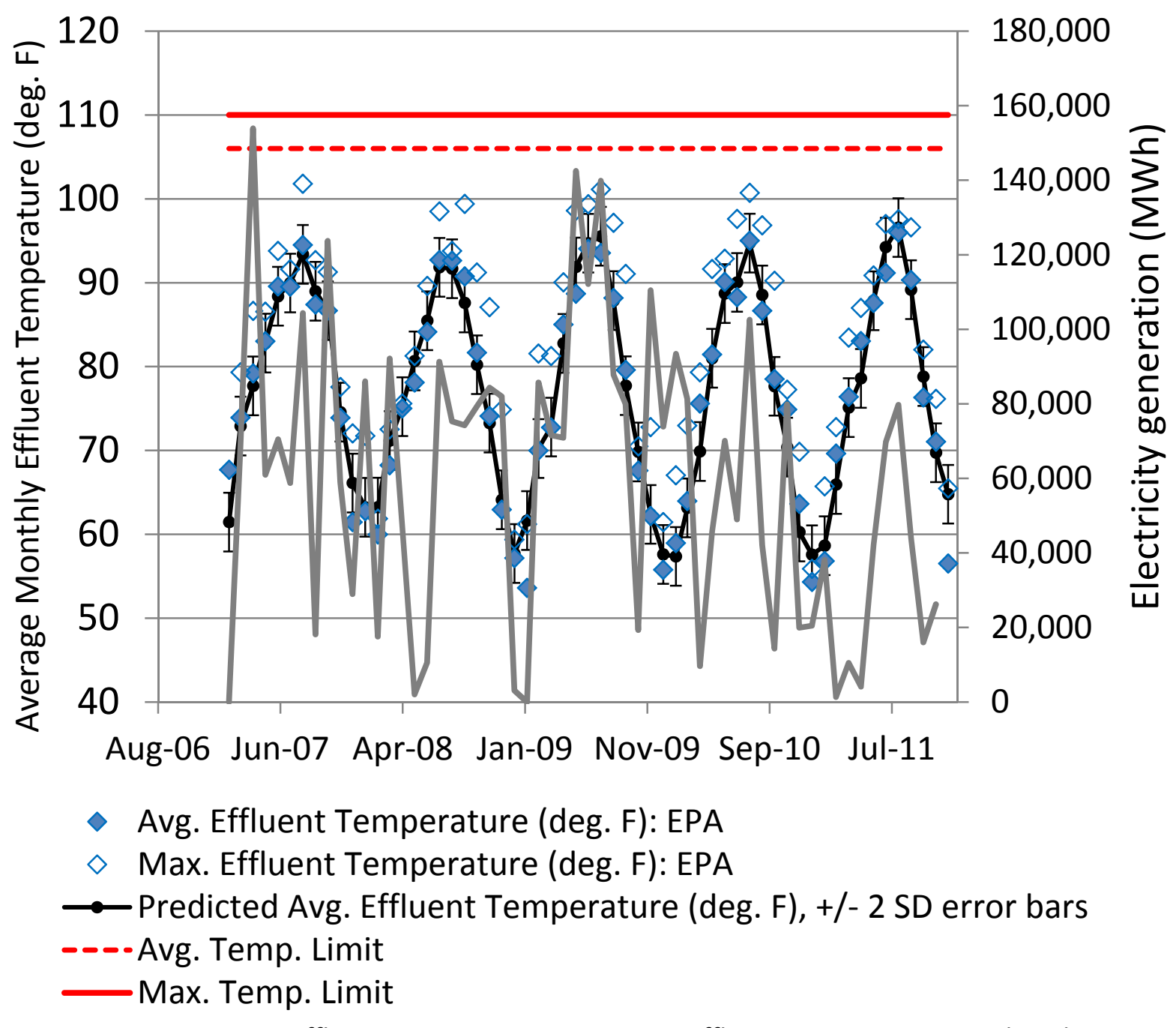

Figure B48. Average effluent temperature, maximum effluent temperature, predicted average effluent temperature from regression test, average effluent temperature limit, maximum effluent temperature limit for the Thomas $\mathrm{C}$. Ferguson plant. 


\section{Thomas C. Ferguson}

PCM A2

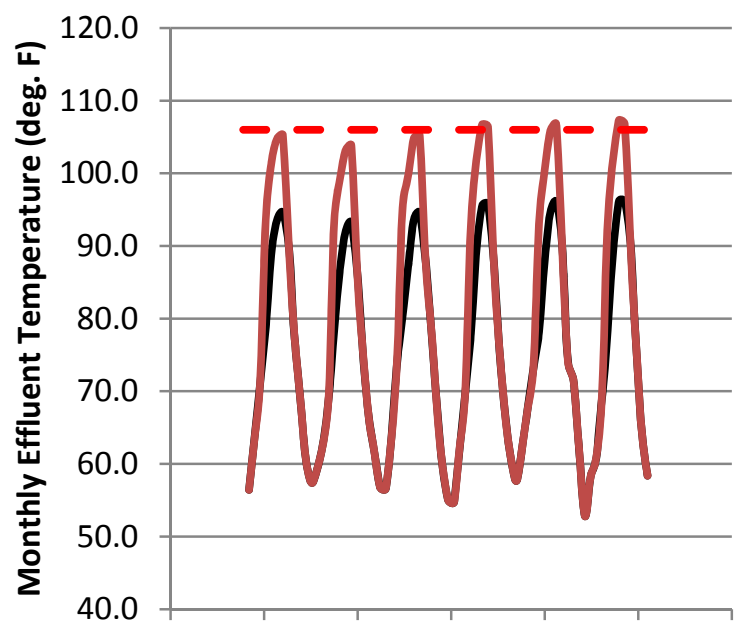

Dec-25Apr-27Sep-28Jan-30Jun-31Oct-32Feb-34 Time (Month-Year)

(a)

BCSDPCM A2

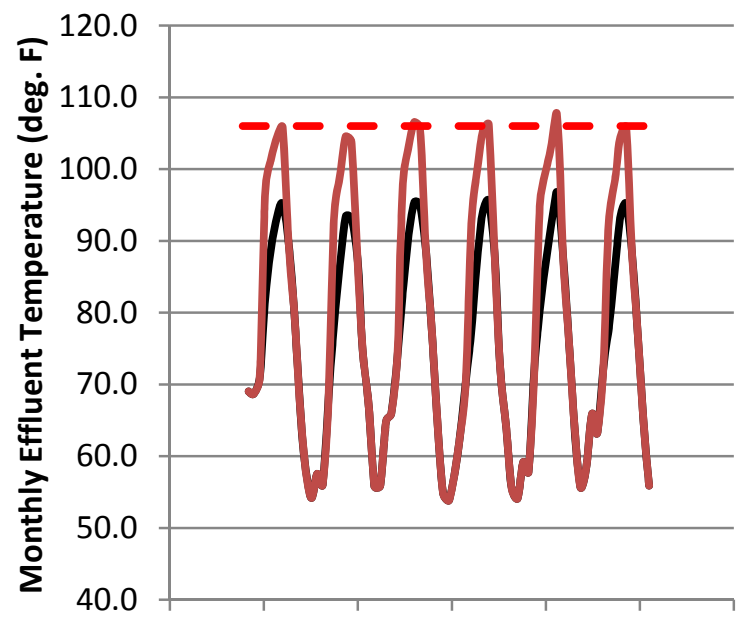

Dec-25Apr-27Sep-28Jan-30Jun-31Oct-32Feb-34 Time (Month- Year)

(c)
GFDL A2

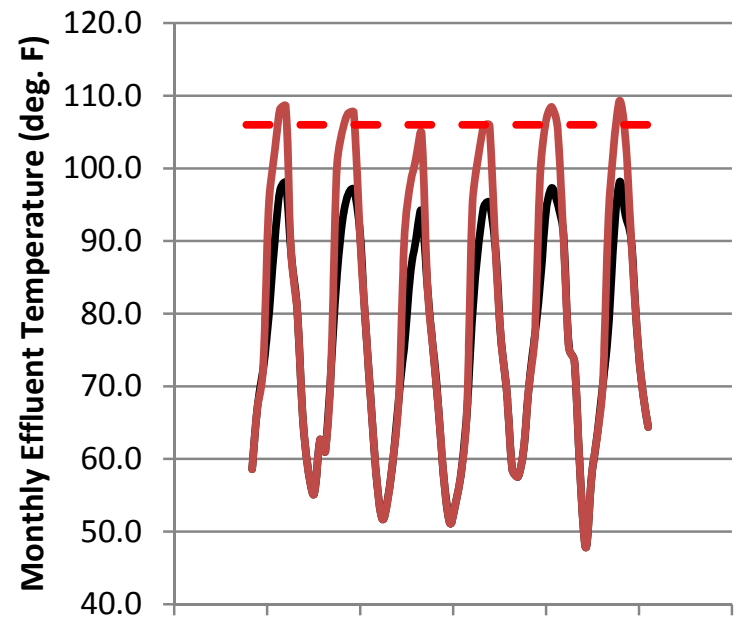

Dec-25Apr-27Sep-28Jan-30Jun-310ct-32Feb-34 Time (Month- Year)

(b)

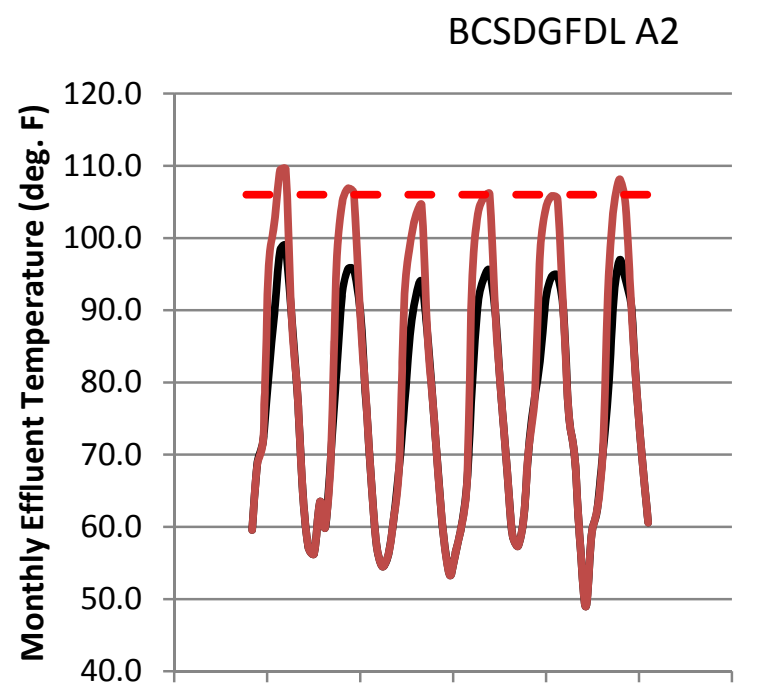

Dec-25Apr-27Sep-28Jan-30Jun-310ct-32Feb-34 Time (Month- Year)

(d)

—Predicted Avg. Effluent Temperature (deg. F)

Predicted Avg. Effluent Temperature (deg, F), 100\% Capacity in Summer

- - Avg. Temp. Limit: EPA

Figure B49. For the Thomas C. Ferguson plant and four different simulated future climates (a) PCM, (b) GFDL, (c) BCSDPCM, (d) BCSDGFDL - of the A2 emissions scenario, average effluent temperature assuming 2011 electric generation profiles, average effluent temperature assuming $100 \%$ summer capacity factor, and (if applicable) a horizontal dashed line indicating the average effluent temperature limit set by the EPA. 


\section{Tradinghouse}

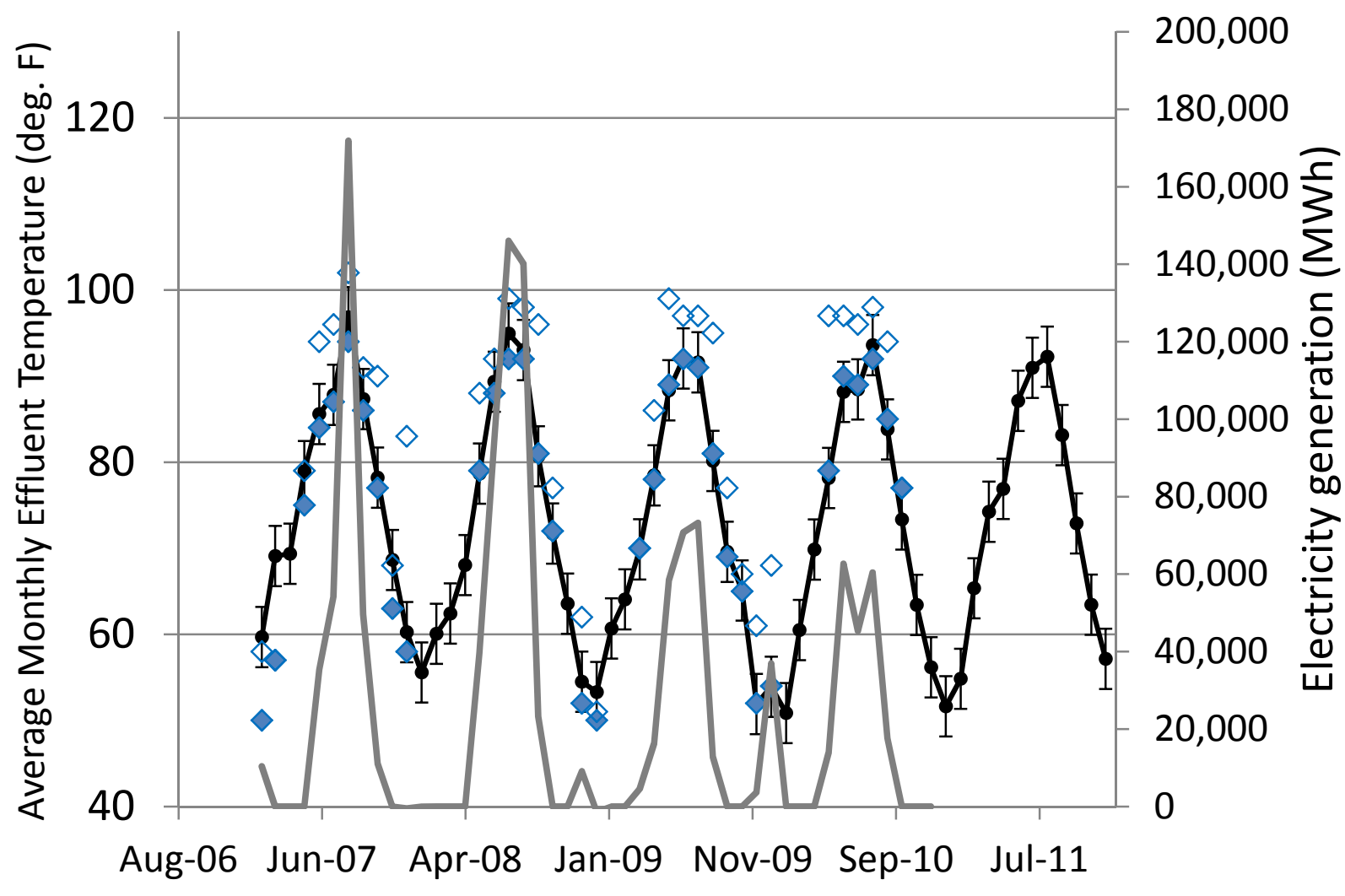

$\checkmark$ Avg. Effluent Temperature (deg. F): EPA

$\diamond$ Max. Effluent Temperature (deg. F): EPA

$\rightarrow$ Predicted Avg. Effluent Temperature (deg. F), +/- 2 SD error bars

----Avg. Temp. Limit

Max. Temp. Limit

Figure B50. Average effluent temperature, maximum effluent temperature, predicted average effluent temperature from regression test, average effluent temperature limit, maximum effluent temperature limit for the Tradinghouse plant. 
Tradinghouse

PCM A2

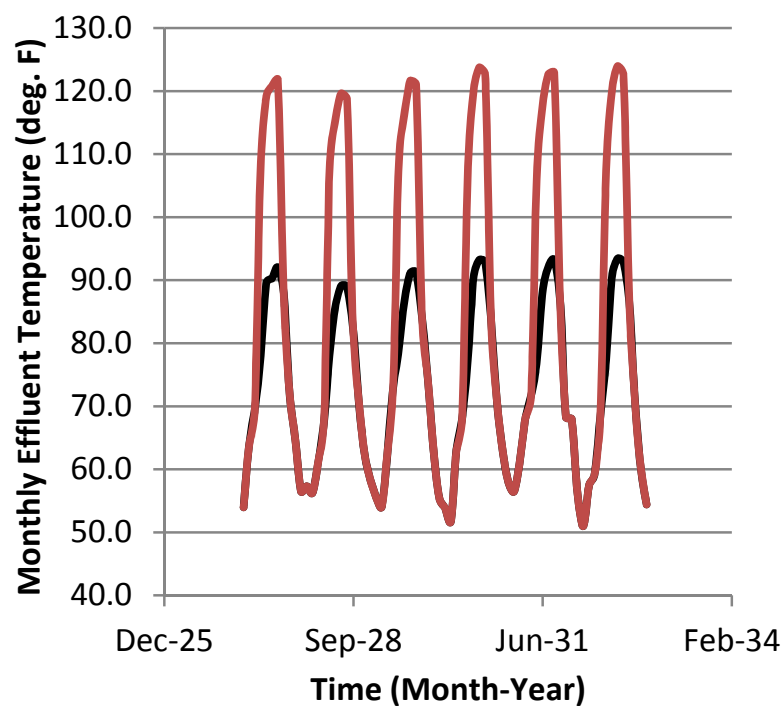

(a)

BCSDPCM A2

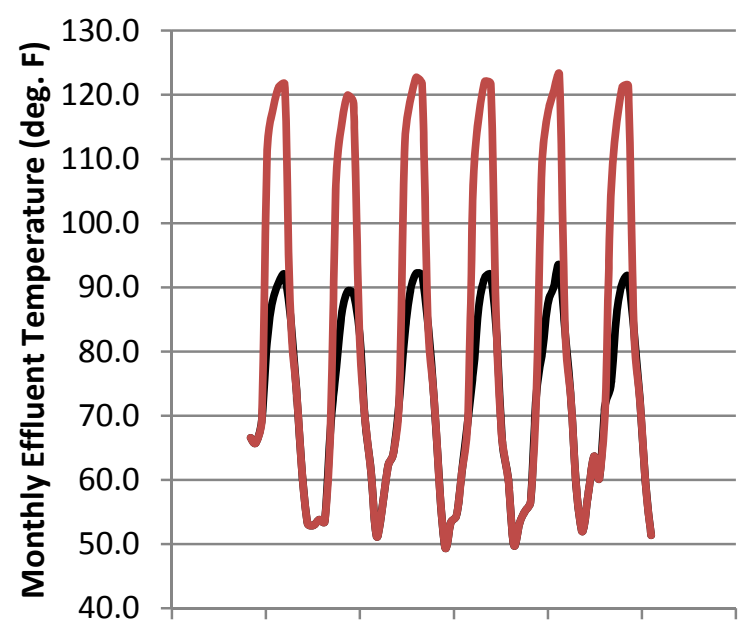

Dec-25Apr-27Sep-28Jan-30Jun-31Oct-32Feb-34 Time (Month- Year)

(c)
GFDL A2

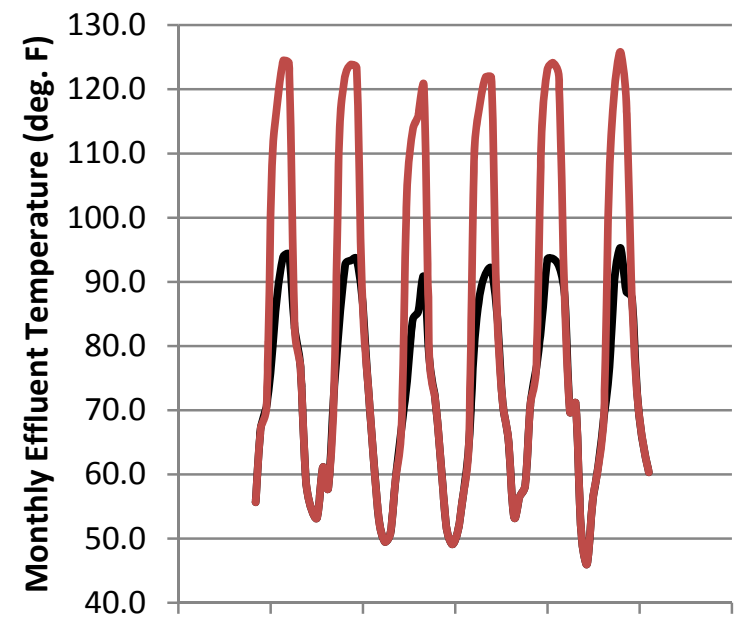

Dec-25Apr-27Sep-28Jan-30Jun-31Oct-32Feb-34 Time (Month- Year)

(b)

\section{BCSDGFDL A2}

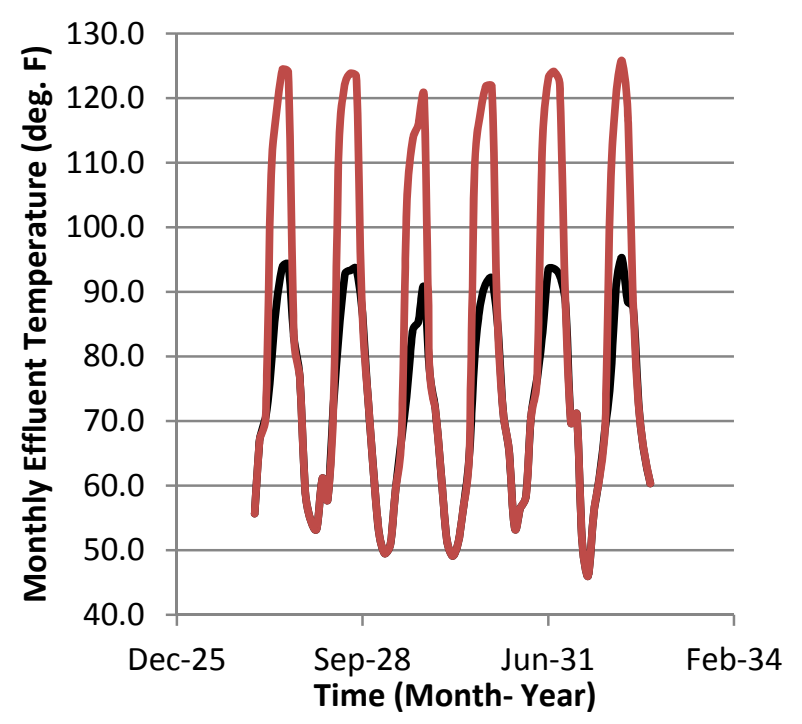

(d)

—Predicted Avg. Effluent Temperature (deg. F)

—Predicted Avg. Effluent Temperature (deg, F), 100\% Capacity in Summer

- - Avg. Temp. Limit: EPA

Figure B51. For the Tradinghouse plant and four different simulated future climates - (a) PCM, (b) GFDL, (c) BCSDPCM, (d) BCSDGFDL - of the A2 emissions scenario, average effluent temperature assuming 2011 electric generation profiles, average effluent temperature assuming $100 \%$ summer capacity factor, and (if applicable) a horizontal dashed line indicating the average effluent temperature limit set by the EPA. 


\section{Trinidad}

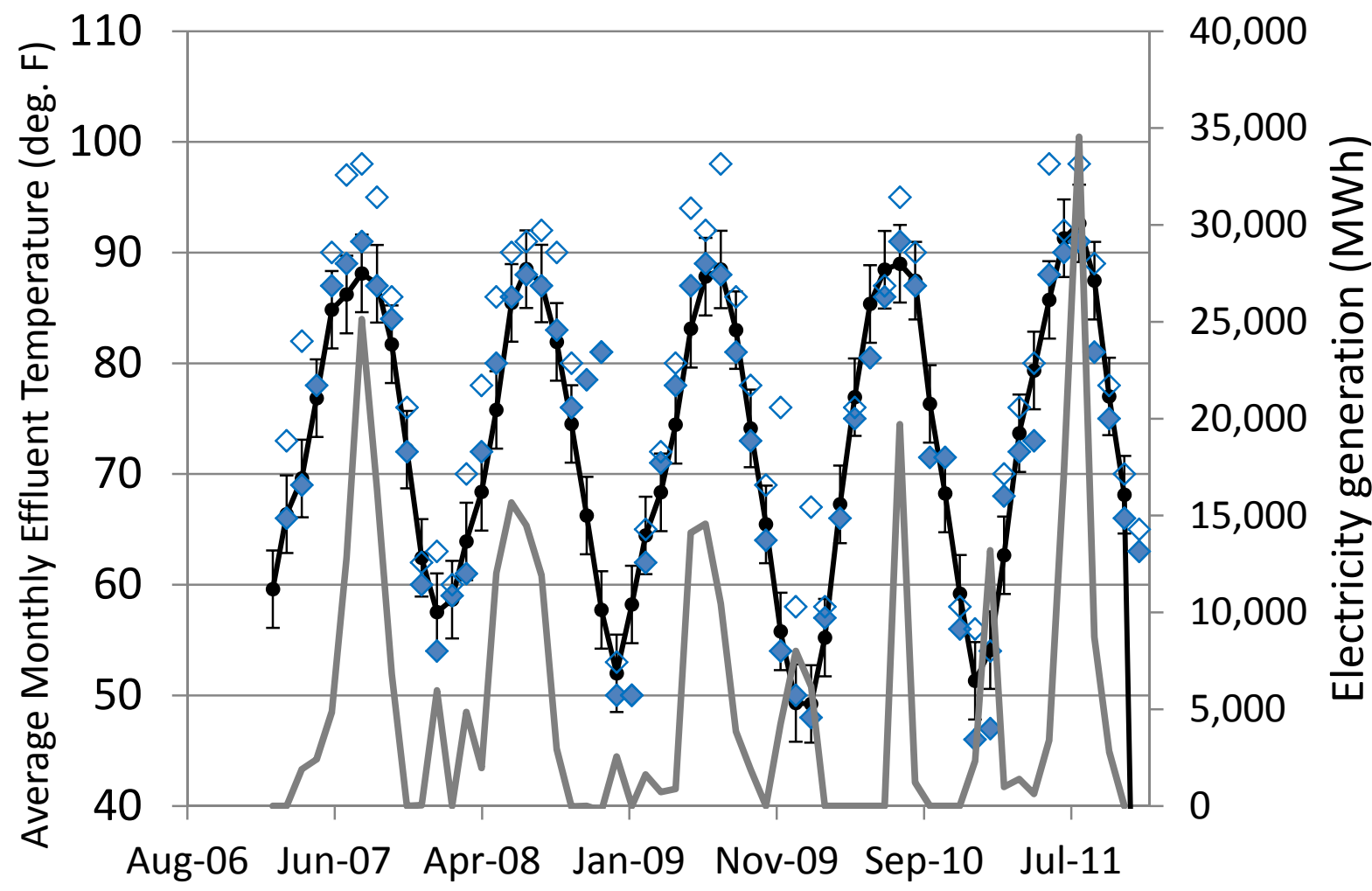

$\diamond \quad$ Avg. Effluent Temperature (deg. F): EPA

$\diamond$ Max. Effluent Temperature (deg. F): EPA

$\rightarrow$ Predicted Avg. Effluent Temperature (deg. F), +/- 2 SD error bars

----Avg. Temp. Limit

Max. Temp. Limit

Figure B52. Average effluent temperature, maximum effluent temperature, predicted average effluent temperature from regression test, average effluent temperature limit, maximum effluent temperature limit for the Trinidad plant. 


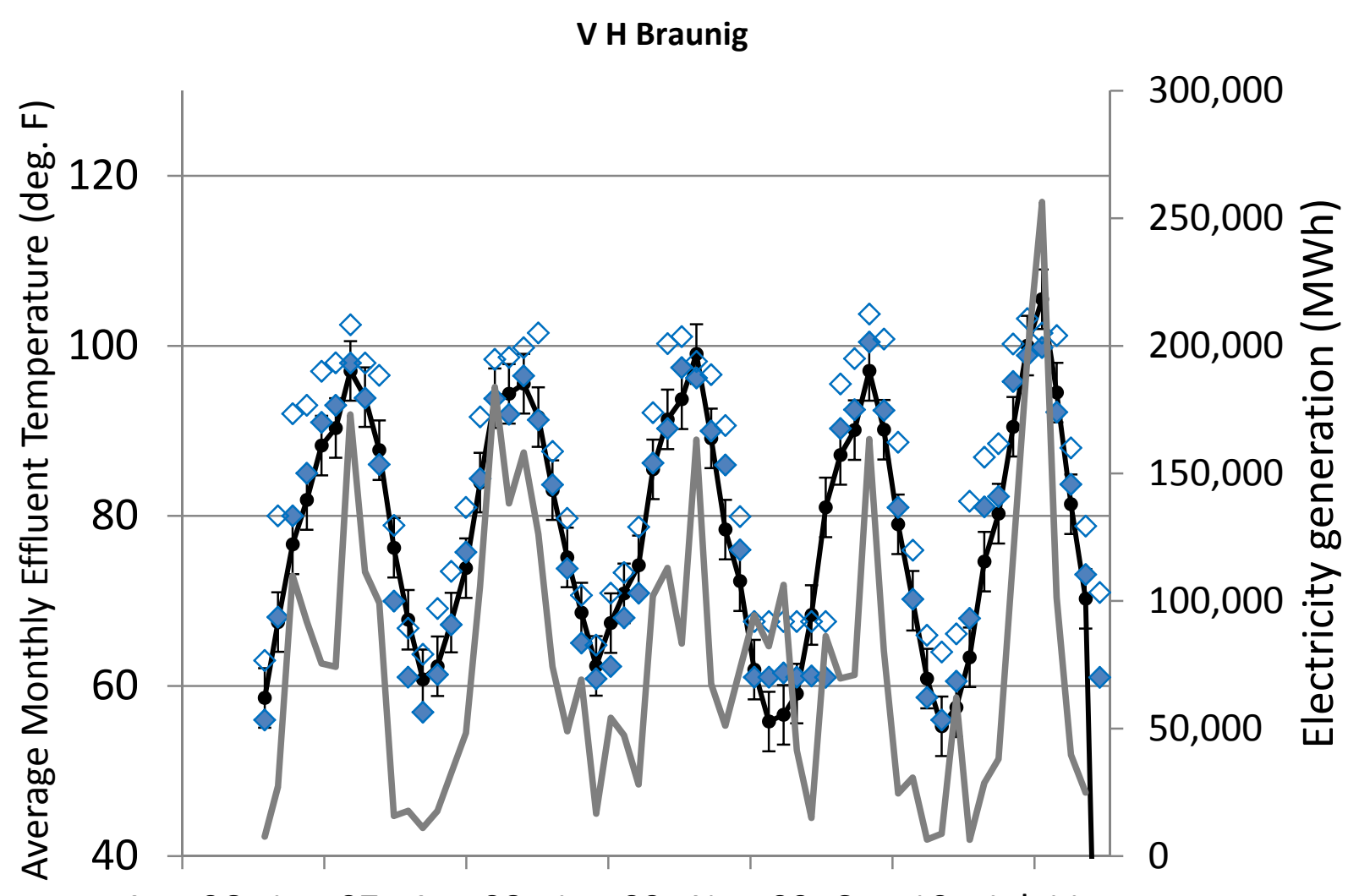

Aug-06 Jun-07 Apr-08 Jan-09 Nov-09 Sep-10 Jul-11

$\checkmark$ Avg. Effluent Temperature (deg. F): EPA

$\diamond$ Max. Effluent Temperature (deg. F): EPA

$\longrightarrow$ Predicted Avg. Effluent Temperature (deg. F), +/- 2 SD error bars

---Avg. Temp. Limit Max. Temp. Limit

Figure B53. Average effluent temperature, maximum effluent temperature, predicted average effluent temperature from regression test, average effluent temperature limit, maximum effluent temperature limit for the $\mathrm{V} \mathrm{H}$ Braunig plant. 


\section{H Braunig}

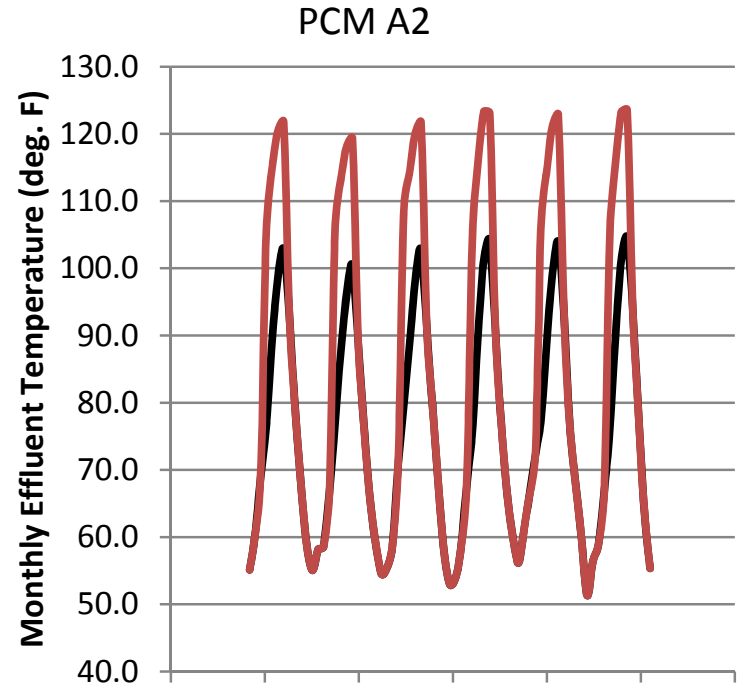

Dec-25Apr-27Sep-28Jan-30Jun-31Oct-32Feb-34 Time (Month-Year)

(a)

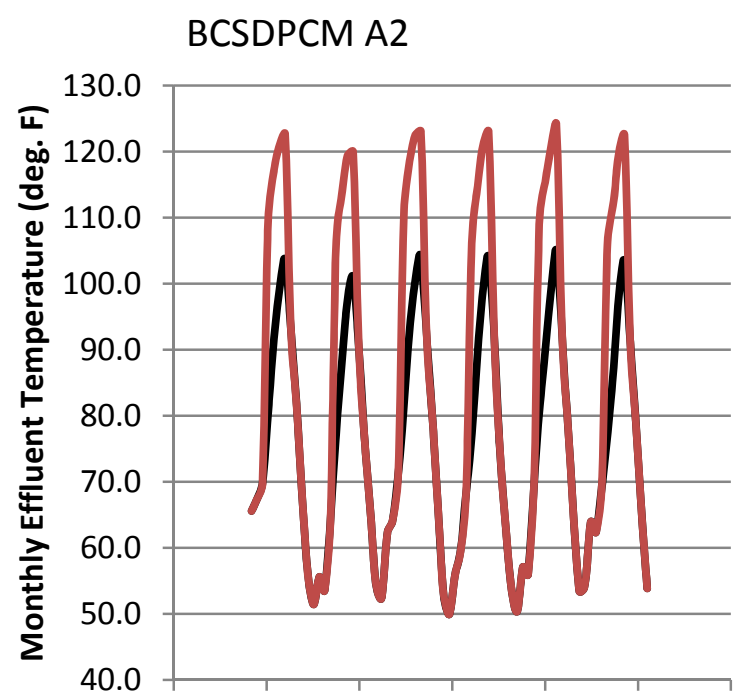

Dec-25Apr-27Sep-28Jan-30Jun-310ct-32Feb-34 Time (Month- Year)

(c)

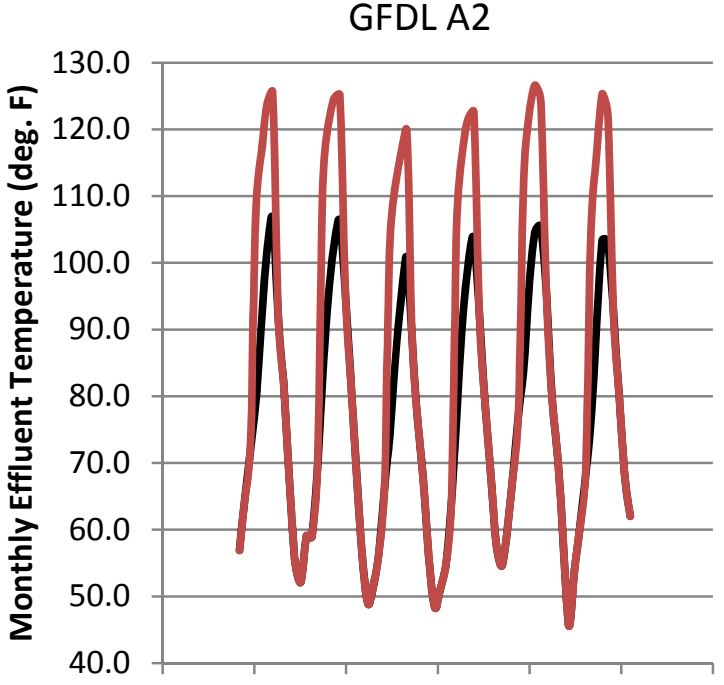

Dec-25Apr-27Sep-28Jan-30Jun-310ct-32Feb-34 Time (Month- Year)

(b)

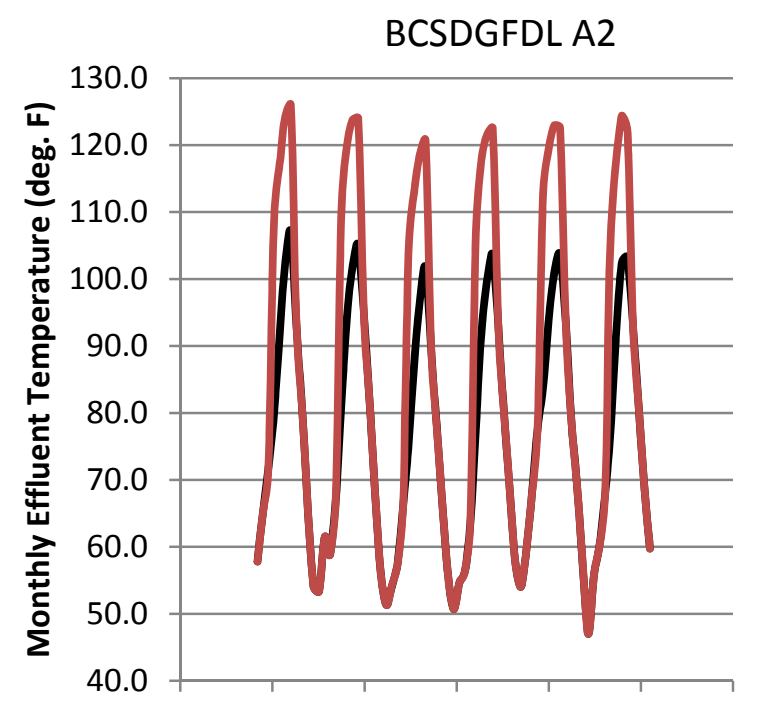

Dec-25Apr-27Sep-28Jan-30Jun-310ct-32Feb-34 Time (Month- Year)

(d)

—Predicted Avg. Effluent Temperature (deg. F)

—Predicted Avg. Effluent Temperature (deg, F), 100\% Capacity in Summer

- - Avg. Temp. Limit: EPA

Figure B54. For the $\mathrm{V} \mathrm{H}$ Braunig plant and four different simulated future climates - (a) PCM, (b) GFDL, (c) BCSDPCM, (d) BCSDGFDL - of the A2 emissions scenario, average effluent temperature assuming 2011 electric generation profiles, average effluent temperature assuming $100 \%$ summer capacity factor, and (if applicable) a horizontal dashed line indicating the average effluent temperature limit set by the EPA. 


\section{Victoria Power Station}
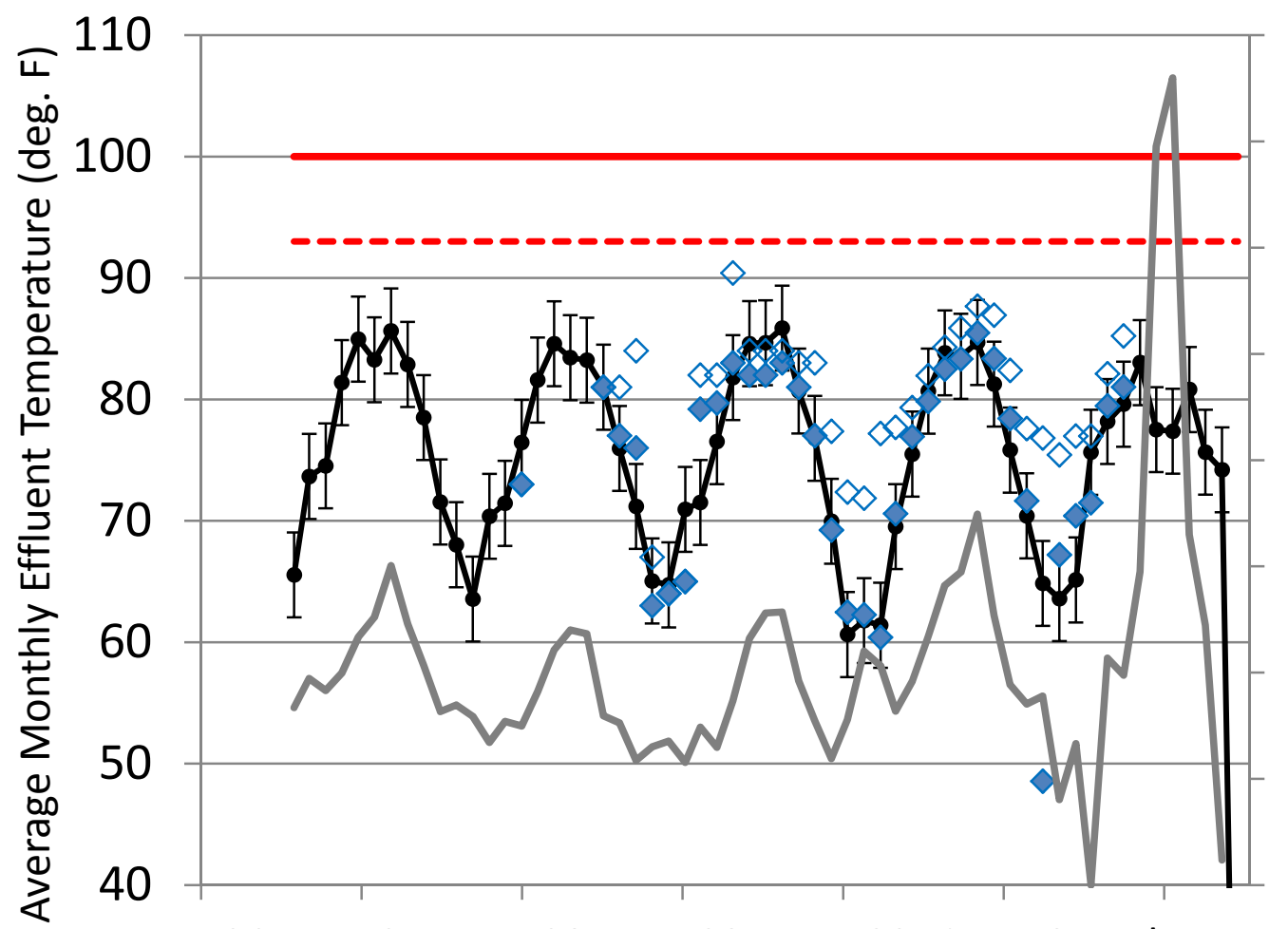

160,000

140,000

0

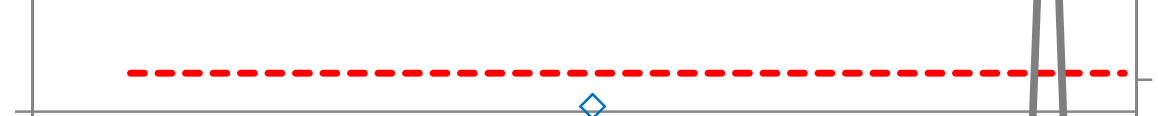

120,000

돌

80

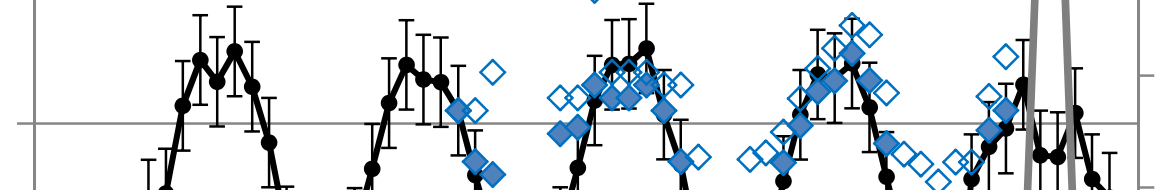

100,000

ᄃ

80,000

70

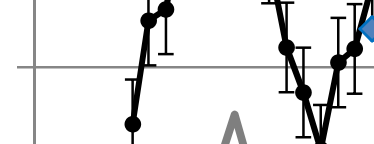

60

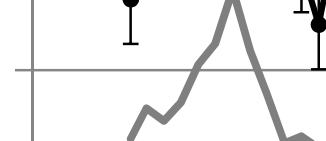

50

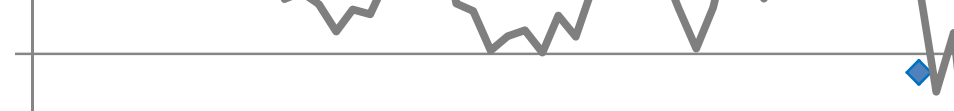

40

Aug-06 Jun-07 Apr-08 Jan-09 Nov-09 Sep-10 Jul-11

60,000

40,000

20,000

0

$\diamond \quad$ Avg. Effluent Temperature (deg. F): EPA

$\diamond$ Max. Effluent Temperature (deg. F): EPA

$\rightarrow$ Predicted Avg. Effluent Temperature (deg. F), +/- 2 SD error bars

----Avg. Temp. Limit

Max. Temp. Limit

Figure B55. Average effluent temperature, maximum effluent temperature, predicted average effluent temperature from regression test, average effluent temperature limit, maximum effluent temperature limit for the Victoria Power Station plant. 
W A Parish

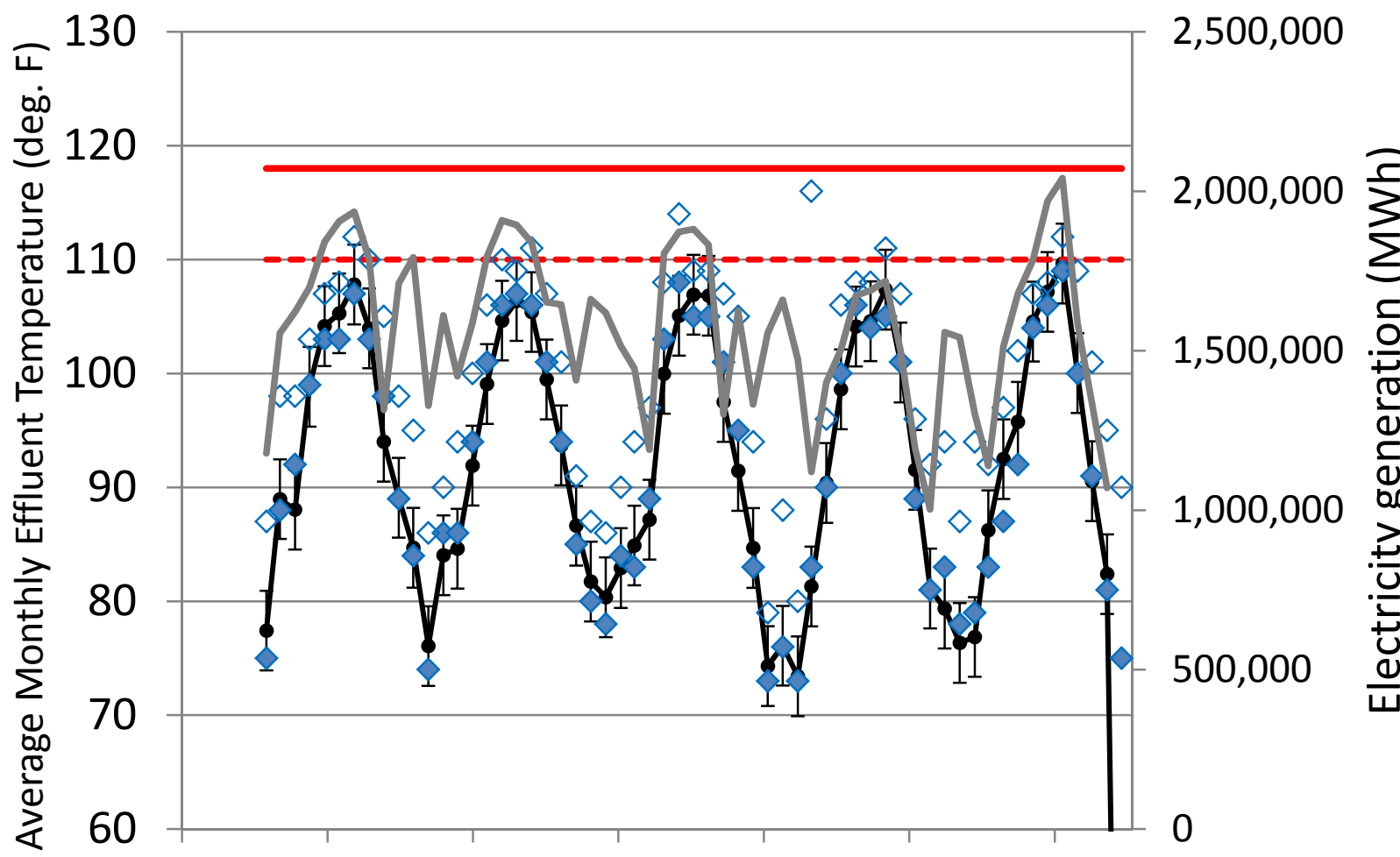

Aug-06 Jun-07 Apr-08 Jan-09 Nov-09 Sep-10 Jul-11

$\diamond$ Avg. Effluent Temperature (deg. F): EPA

$\diamond$ Max. Effluent Temperature (deg. F): EPA

$\rightarrow$ Predicted Avg. Effluent Temperature (deg. F), +/- 2 SD error bars

-.--Avg. Temp. Limit

-Max. Temp. Limit

Figure B56. Average effluent temperature, maximum effluent temperature, predicted average effluent temperature from regression test, average effluent temperature limit, maximum effluent temperature limit for the W A Parish plant. 


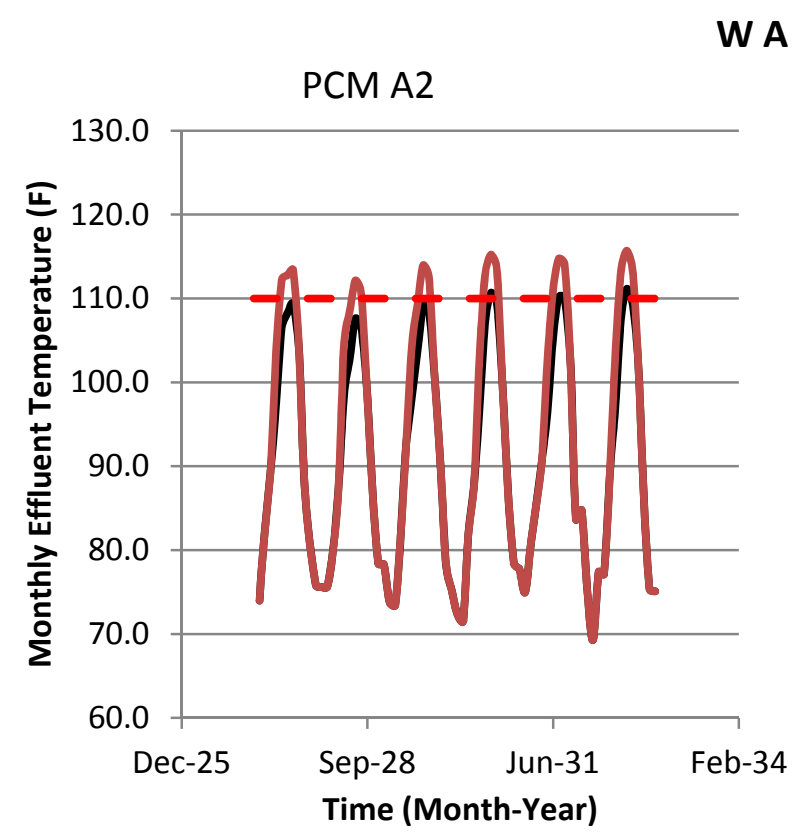

(a)

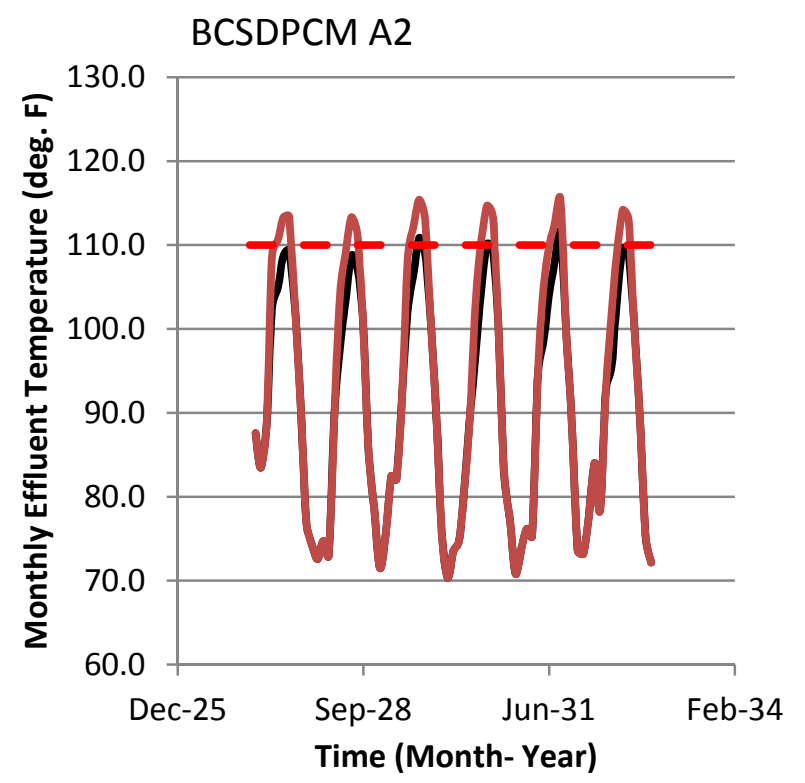

(c)

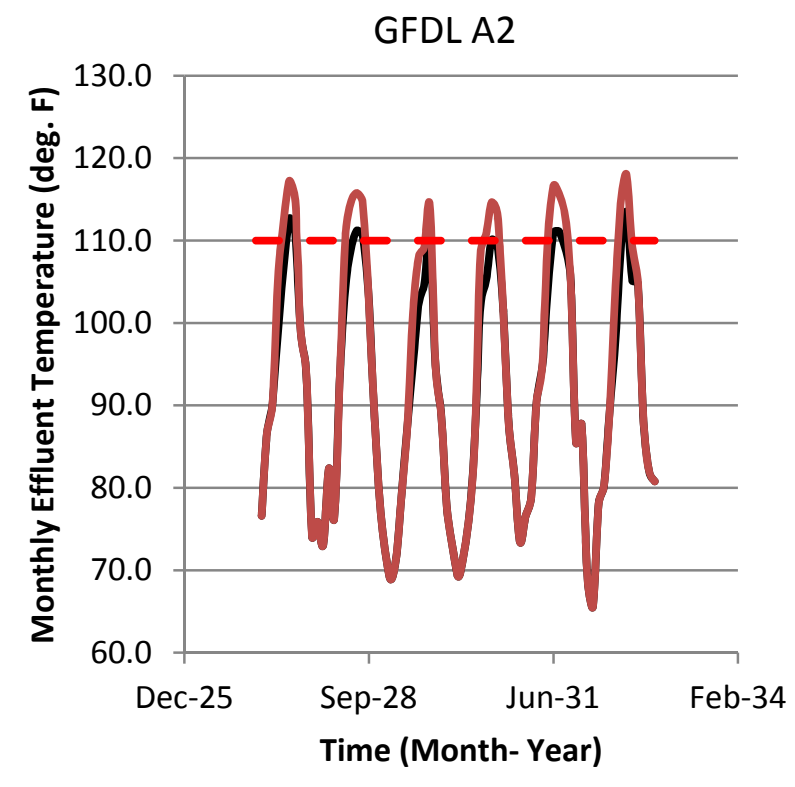

(b)

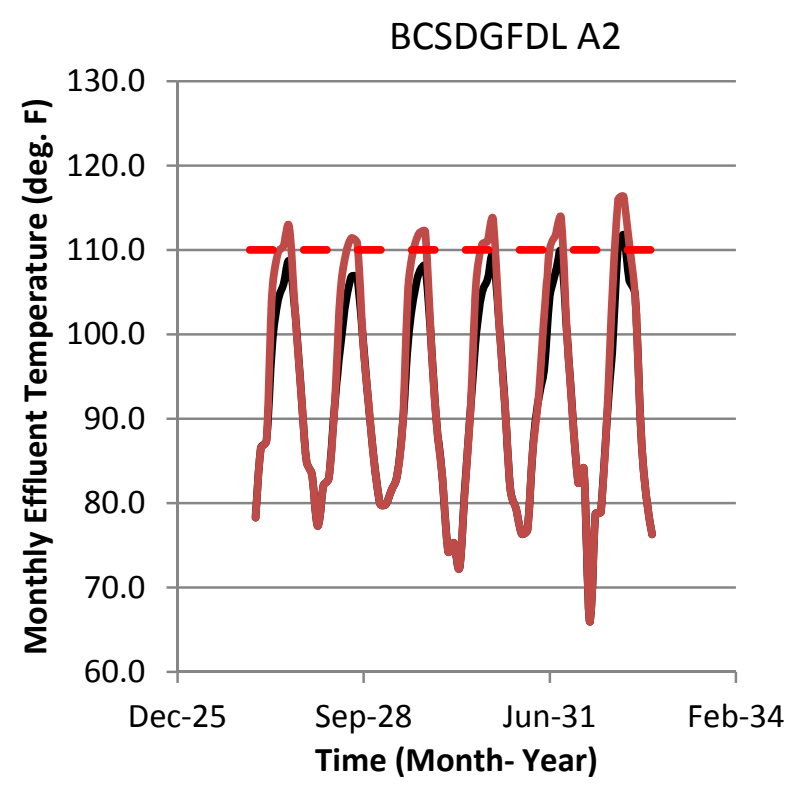

(d)

— Predicted Avg. Effluent Temperature (deg. F)

—Predicted Avg. Effluent Temperature (deg, F), 100\% Capacity in Summer

- - Avg. Temp. Limit: EPA

Figure B57. For the $W$ A Parish plant and four different simulated future climates - (a) PCM, (b) GFDL, (c) BCSDPCM, (d) BCSDGFDL - of the A2 emissions scenario, average effluent temperature assuming 2011 electric generation profiles, average effluent temperature assuming $100 \%$ summer capacity factor, and (if applicable) a horizontal dashed line indicating the average effluent temperature limit set by the EPA. 


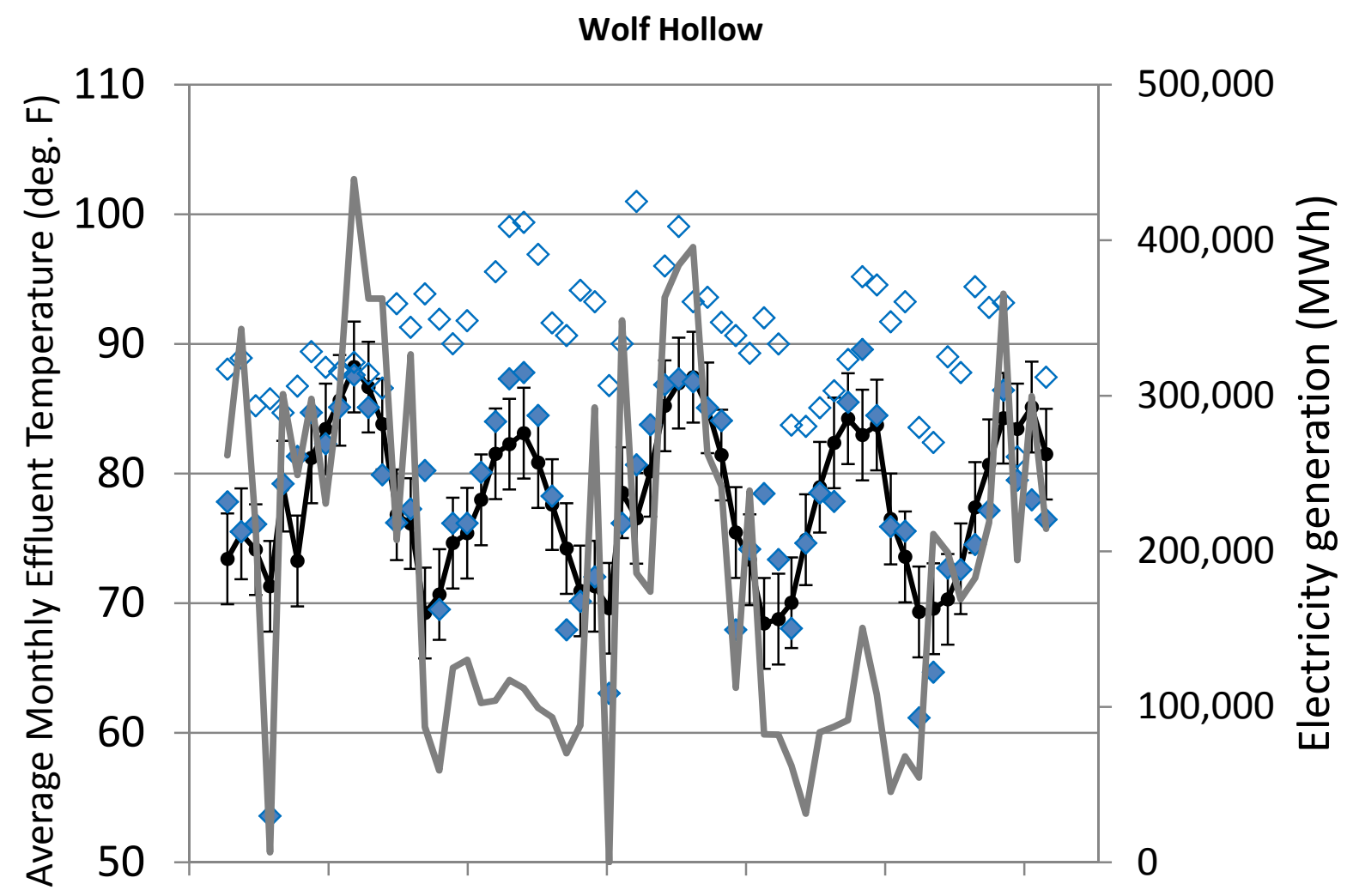

Aug-06 Jun-07 Apr-08 Jan-09 Nov-09 Sep-10 Jul-11

$\diamond$ Avg. Effluent Temperature (deg. F): EPA

$\diamond$ Max. Effluent Temperature (deg. F): EPA

$\rightarrow$ Predicted Avg. Effluent Temperature (deg. F), +/- 2 SD error bars

----Avg. Temp. Limit

Max. Temp. Limit

Figure B58. Average effluent temperature, maximum effluent temperature, predicted average effluent temperature from regression test, average effluent temperature limit, maximum effluent temperature limit for the Wolf Hollow plant. 


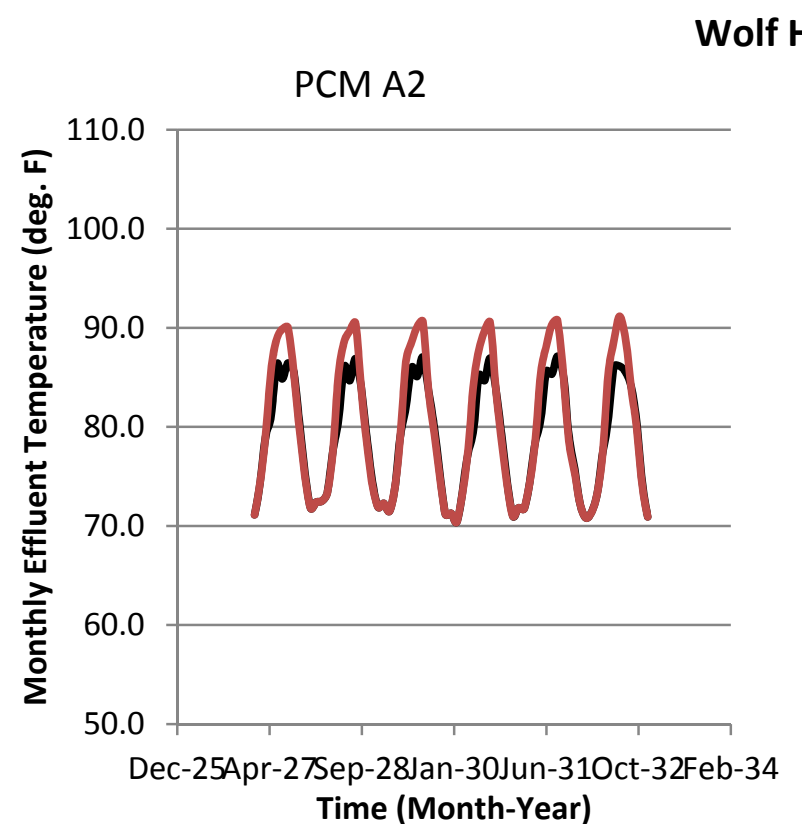

(a)

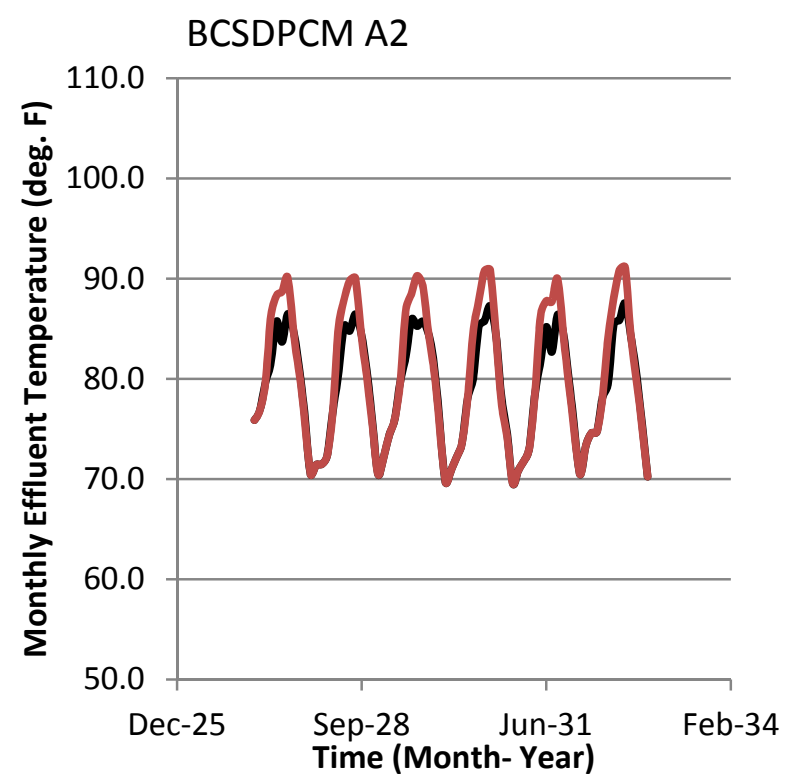

(c)
GFDL A2

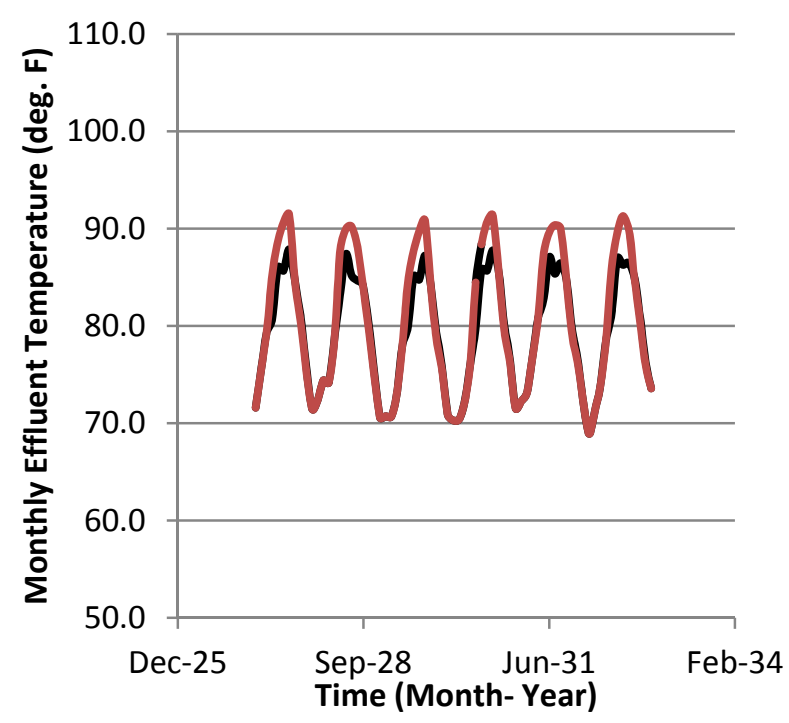

(b)

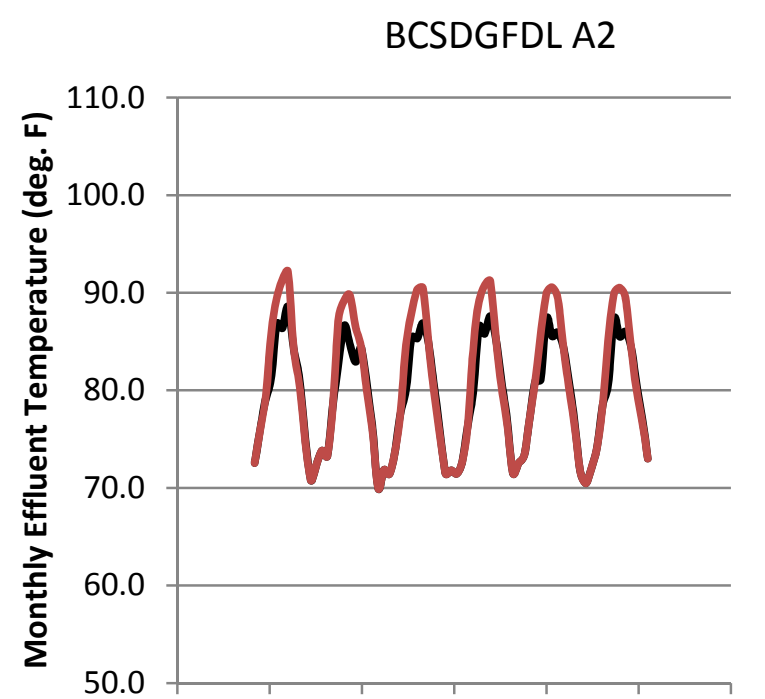

Dec-25Apr-27Sep-28Jan-30Jun-310ct-32Feb-34 Time (Month- Year)

(d)

— Predicted Avg. Effluent Temperature (deg. F)

—Predicted Avg. Effluent Temperature (deg, F), 100\% Capacity in Summer

- - Avg. Temp. Limit: EPA

Figure B59. For the Wolf Hollow plant and four different simulated future climates - (a) PCM, (b) GFDL, (c) BCSDPCM, (d) BCSDGFDL - of the A2 emissions scenario, average effluent temperature assuming 2011 electric generation profiles, average effluent temperature assuming $100 \%$ summer capacity factor, and (if applicable) a horizontal dashed line indicating the average effluent temperature limit set by the EPA. 
Argonne

\section{Environmental Science Division}

Argonne National Laboratory

9700 South Cass Avenue, Bldg. 240

Argonne, IL 60439-4847

www.anl.gov 